\title{
GEOLOGICAL SURVEY RESEARCH 1971 Chapter D
}

\section{GEOLOGICAL SURVEY PROFESSIONAL PAPER 750-D}

Scientific notes and summaries of investigations in geology, hydrology, and related fields

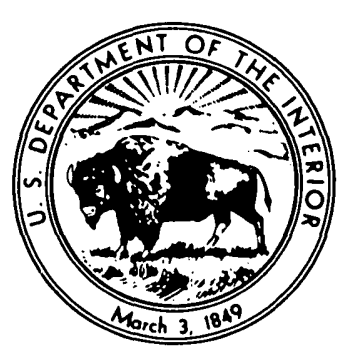

UNITED STATES GOVERNMENT PRINTING OFFICE, WASHINGTON: 1971 


\section{UNITED STATES DEPARTMENT OF THE INTERIOR \\ ROGERS C. B. MORTON, Secretary \\ GEOLOGICAL SURVEY}

W. A. Radlinski, Acting Director 


\section{CONTENTS \\ GEOLOGIC STUDIES}

Economic geology

Geology and geochemistry of the Sinuk River barite deposit, Seward Peninsula, Alaska, by D. A. Brobst, D. M. Pinckney, and C. L.

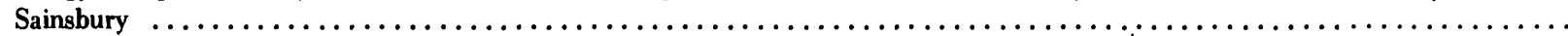

Oil-shale beds in the Green River and Wasatch Formations in the Little Snake River area of northwestern Colorado, by E. J. McKay.

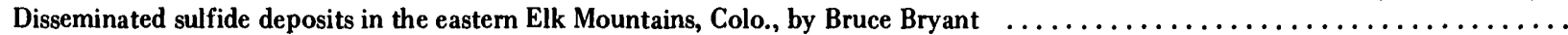

Platiniferous chromitite in the Tocantins complex, Niquelândia, Goiás, Brazil, by R. W. White, Jorge Motta, and V. A. de Araújo ...

D1

9

13

\section{Geochronology}

Potassium-argon ages of plutons in the Skykomish-Stillaguamish areas, North Cascades, Wash., by R. S. Yeats and J. C. Engels .... Late Cretaceous fission-track and potassium-argon ages of the Mount Stuart Granodiorite and Beckler Peak stock, North Cascades,

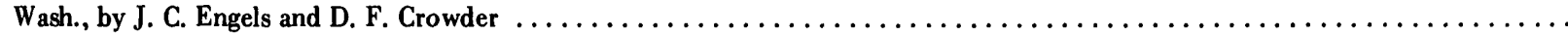

Radiometric ages in the Santander massif, Eastern Cordillera, Colombian Andes, by Richard Goldsmith, R. F. Marvin, and H. H.

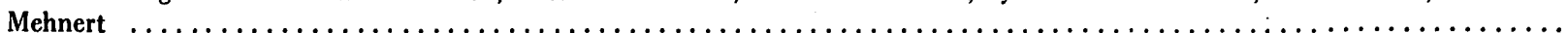

\section{Mineralogy and petrology}

Sodic harmotome in lacustrine Pliocene tuffs near Wikieup, Mohave County, Ariz., by R. A. Sheppard and A. J. Gude 3d . . . . . . .

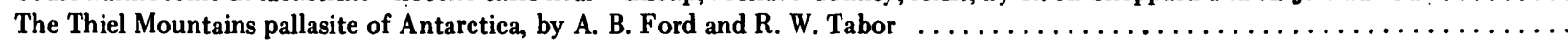

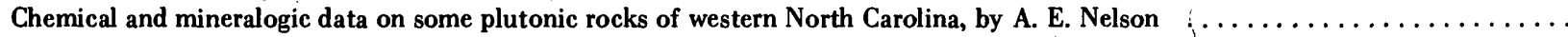
Cretaceous plutonic rocks of St. Lawrence Island, Alaska-A preliminary report, by Béla Csejtey, Jr., W. W. Patton, Jr., and T. P. Miller

\section{Structural geology}

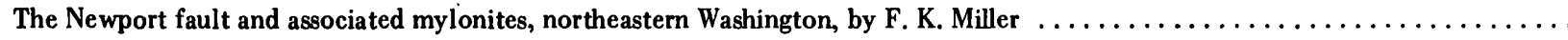

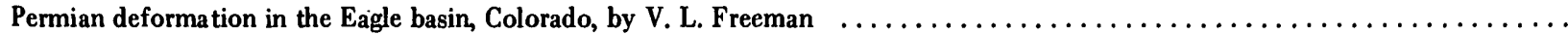

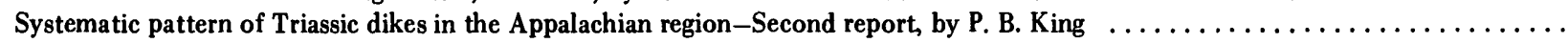

\section{Paleontology and stratigraphy}

Stratigraphic distribution of echinoderm plates in the Antelope Valley Limestone of Nevada and California, by James Sprinkle ..... Geology of the Carter Caves Sandstone (Mississippian) in northeastern Kentucky, by K. J. Englund and J. F. Windolph, Jr. ....... Revised correlation of some Carboniferous rock units in the Causey Dam quadrangle, Weber County, Utah, by T. E. Mullens ......

\section{Sedimentation}

Growth and movement of dunes at White Sands National Monument, N. Mex., by E. D. McKee and J. R. Douglass ........... Paleocurrents in the upper part of the Allegheny Group and Conemaugh Formation, Blandburg quadrangle, central Pennsylvania, by

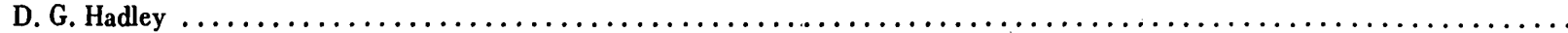

\section{Glacial geology}

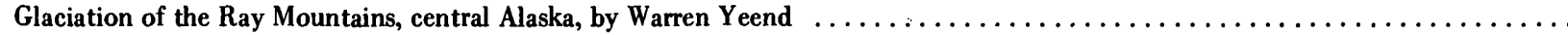

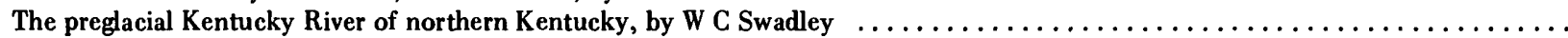

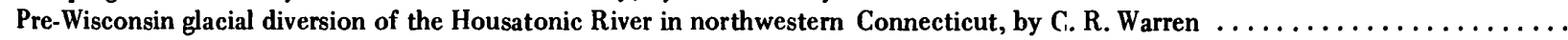

\section{Astrogeology}

Geologic comparison of mare materials in the lunar equatorial belt, including Apollo 11 and Apollo 12 landing sites, by N. J. Trask .. 
Techniques in aerial photography

Solar position diagrams-Solar altitude, azimuth, and time at different latitudes, by M. M. Clark

\section{Geophysics}

A sea trial of the LaCoste-Romberg and Bell Aerosystems surface ship gravimeters, by Alan Cooper and Roland von Huene .......

Isotope studies

$\mathrm{Sr}^{87} / \mathrm{Sr}^{86}$ in mafic rocks of the Troodos massif, Cyprus, by Z. E. Peterman, R. G. Coleman, and R. A. Hildreth

\section{Analytical methods}

A sensitive method for the determination of tellurium in vegetation, by A. E. Hubert

\section{HYDROLOGIC STUDIES}

\section{Estuarine hydrology}

Mathematical model to compute reaeration coefficients for the Connecticut River, by L. A. Weiss

\section{Quality of water}

Preliminary findings on the detergent and phosphate contents of water of southern Nassau County, N.Y., by N. M. Perlmutter and

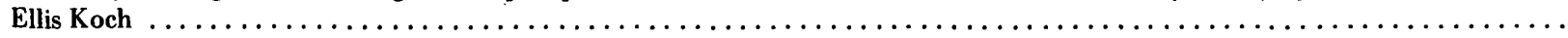
Relationship between ground-water levels and quality in shallow observation wells, Muddy Creek basin, southeastern York County,

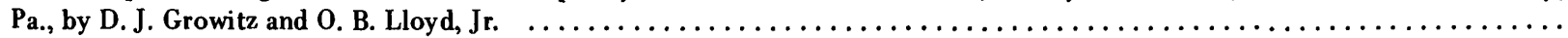
Relation between oxidation potential and the occurrence of iron in ground water from the Chicot aquifer, Lafayette, La., by L. D.

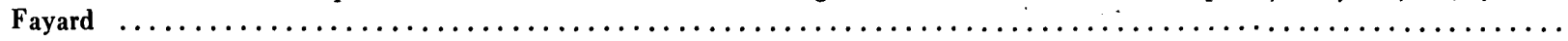

\section{Surface water}

Changes in the elevation of Great Salt Lake caused by man's activities in the drainage basin, by G. L. Whitaker

\section{Ground water}

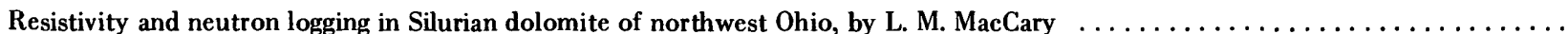

Reconnaissance of ground-water supplies from bedrock in the Metlakatla peninsula, Annette Island, Alaska, by M. V. Marcher .... .

Raised beach deposits and their ground-water potential in the southern part of the Metlakatla peninsula, Annette Island, Alaska, by

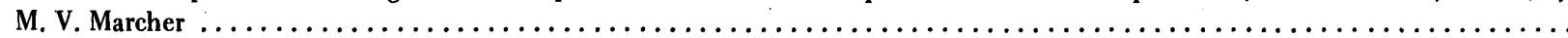

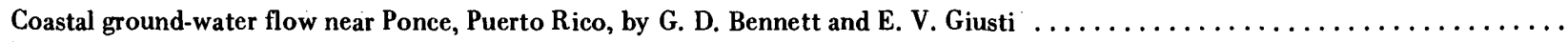

Relation between ground water and surface water

Base flow as an indicator of aquifer characteristics in the Coastal Plain of Delaware, by R. H. Johnston

\section{Geochemistry of water}

Association and dissociation of a humic acid fraction as a function of $\mathrm{pH}$, by R. L. Wershaw and D. J. Pinckney

\section{Hydrologic techniques}

Method of rating flow in a storm sewer, by G. E. Seaburn

\section{INDEXES}




\section{GEOLOGICAL SURVEY RESEARCH 1971}

This collection of 39 short papers is the third published chapter of "Geological Survey Research 1971." The papers report on scientific and economic results of current work by members of the Geologic and Water Resources Divisions of the U.S. Geological Survey.

Chapter A, to be published later in the year, will present a summary of significant results of work done in fiscal year 1971, fogether with lists of investigations in progress, reports published, cooperating agencies, and Geological Survey offices.

"Geological Survey Research 1971" is the twelfth volume of the annual series Geological Survey Research. The eleven volumes already published are listed below, with their series designations.

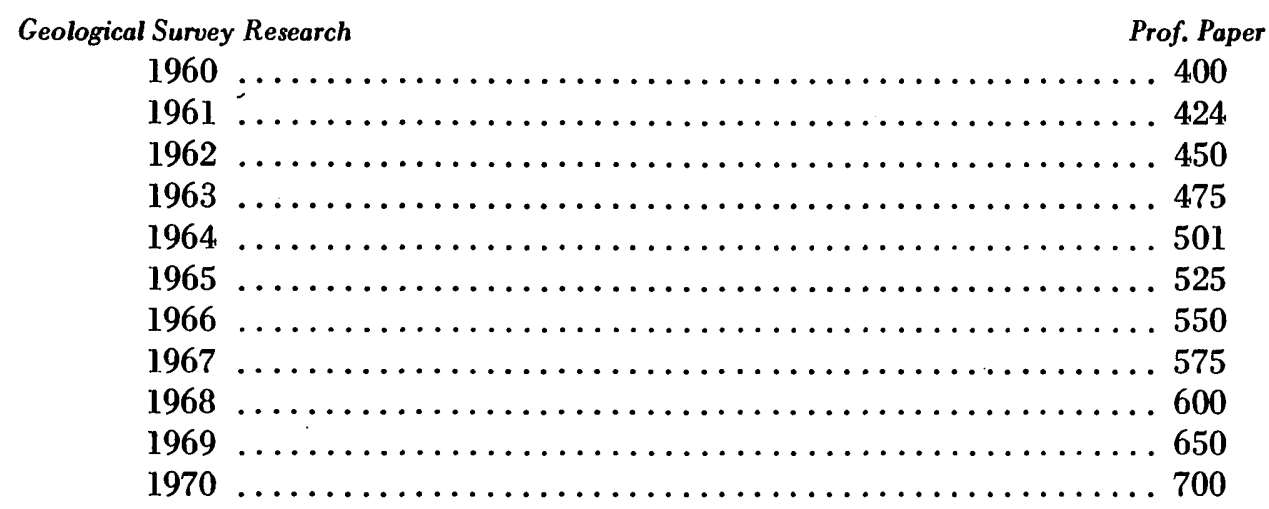




\title{
GEOLOGY AND GEOCHEMISTRY OF THE SINUK RIVER BARITE DEPOSIT, SEWARD PENINSULA, ALASKA
}

\author{
By D. A. BROBST, D. M. PINCKNEY, and \\ C. L. SAINSBURY, Denver, Colo.
}

\begin{abstract}
Barite, fluorite, galena, sphalerite, boulangerite, and associated silver and gold were introduced into thrust sheets of marble and schist of the Nome Group (Precambrian age) in the Sinuk River barite deposit along the Teller Highway about 20 miles north of Nome on the Seward Peninsula, Alaska. Most of the introduced minerals were emplaced pervasively, followed by some later shearing and recrystallization which occurred at a temperature of about $250^{\circ} \mathrm{C}$, as indicated by study of fluid inclusions in the fluorite. Fissure fillings consisting principally of calcite and aragonite with some sulfide minerals and associated gold and silver possibly indicate a second epoch of mineralization in the area. The vertical and lateral extent of the mineralization is unknown, although gossans with base metals are known in the surrounding region. Mineralization might have taken place in shear zones between thrust sheets or might have penetrated favorable host rocks in either the overriding or underlying sheet or both. Further exploration seems warranted.
\end{abstract}

Barite, fluorite, goethite, galena, sphalerite, boulangerite, and associated silver and gold occur in marble and schist in the Sinuk River barite deposit that lies adjacent to the Teller Highway about 20 miles north of Nome on the Seward Peninsula, Alaska (fig. 1). The deposit, also known as the quarry prospect (Herreid, 1966, p. 3), lies on the divide between the Cripple River and Washington Creek, a tributary of the Sinuk River, in the NW/4 sec. 19 (and adjacent sections), T. 9 S., R. 35 W., in the Nome C-2 quadrangle. New observations on the stratigraphic, structural, and mineralogical features of the barite deposit suggest that a large area is worthy of exploration for mineral deposits of commercial value.

In earlier times, the interest of prospectors and geologists has been drawn to the Sinuk River area by gossans. Eakin (1915) first described the gossans and after spending only a day in the area had the general impression (p. 362), "that there had been strong mineralization at certain localities, and that the mineralizing agencies had affected a considerable area." The gossans were examined by A. B. Shallit (unpub. data) in 1942 for the Alaska Territorial Department of Mines and again by Mulligan (1965) and rejected as sources of iron ore. Some geologic and geochemical work was done in the area

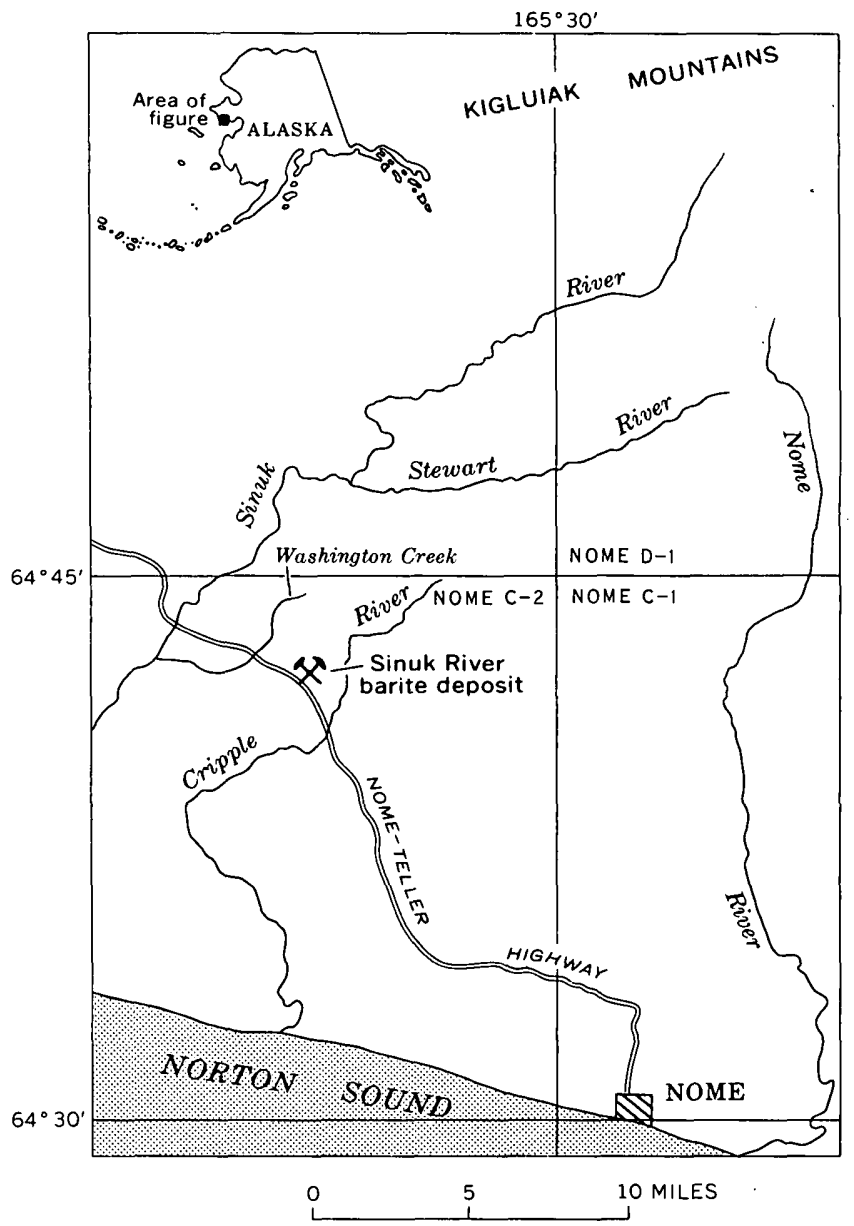

Figure 1.-Index map of the Nome area, Seward Peninsula, showing the location of the Sinuk River barite deposit.

by Herreid (1966, p. 3, figs. 1, 3), who reported a strong geochemical anomaly for lead and zinc in the soil of an area 2,000 by 6,000 feet. This area includes a large borrow pit from which road metal was taken for construction of the Teller Highway. The pit became known as the quarry prospect. Recently Mr. Charles Volkheimer and associates, of Nome, 
found barite in the pit and staked the quarry site and environs as the Sinuk River barite claims.

In August 1970, Brobst spent 2 days examining and sampling the Sinuk River barite deposit after an introduction to the geology of the area by Sainsbury, who has supplied much information on the local stratigraphy and geology of the Seward Peninsula. Studies of the fluid inclusions were contributed by Pinckney. Additional studies of the samples included petrographic examination of thin and polished sections, mineral identifications by X-ray diffraction, spectrographic analyses of rocks and minerals, and fire assays for precious metals. The authors acknowledge the assistance of L. A. Bradley for the spectrographic analyses, J. B. McHugh for the instrumental determinations of mercury, W. D. Goss, A. W. Haubert, J. A. Thomas, and L. B. Riley for the fire assays, J. D. Tucker for the X-ray diffractograms, and Irving Friedman and K. G. Hardcastle for the determination of the carbon dioxide-to-water ratio in the fluid inclusions. The authors also thank Mr. Charles Volkheimer and associates for permission to publish the results of this study.

\section{BARITE-FLUORITE DEPOSIT}

The deposit is exposed in a stripped area about 225 by 1,000 feet, the long dimension of which trends about N. $10^{\circ}$ W. up a gently sloping hill. The cut exposes a sequence of folded interlayered marble and chloritic schist in three benches referred to as the upper, middle, and lower benches. The upper bench is composed mostly of marble, but contains some schist. A shaft and short unroofed crosscut lie in the northwest corner of the middle bench. This bench is composed mostly of schist and some marble. The lower bench occupies the southern third of the cut and also is composed mostly of schist. A geologic map of the cut as it appeared in 1965 was included in a report by Herreid (1966, fig. 3), but the map showed only parts of what are now the upper and middle benches.

A detailed stratigraphic sequence of marble and schist was not worked out, but marble seems to be more abundant in the upper than in the lower part of the sequence in the cut. The rocks are assigned by Sainsbury to the Nome Group, which comprises a thick sequence of interbedded schistose marble and epidote-chlorite-albite-actinolite schists of Precambrian age. Similar rocks crop out over large areas of the Seward Peninsula; they are well described by Moffit (1913), Smith (1910), and Sainsbury, Coleman, and Kachadoorian (1970).

The marble and schist have been deformed, thermally altered and pervasively mineralized to various degrees. The compositional layers and foliation have various attitudes in the exposures, but a general southeasterly dip prevails at the cut. A well-developed lineation trends slightly east of south and generally plunges $15^{\circ}$ to $30^{\circ} \mathrm{SE}$. Steeply dipping veins only a few inches wide, consisting mostly of colloform calcite and aragonite, trend west and transect the earlier structural features. The ore deposits occur principally along the foliation planes of the host rocks, but some veins and veinlets crosscut both the marble and the schist.

At several places in the cut, the marble was replaced by masses of pale-yellowish-orange dolomite. A sample of this rock consists of cloudy grains of dolomite about $0.01 \mathrm{~mm}$ across. The rock is cut by thin veinlets of calcite and sulfide. The sulfide minerals apparently account for the lead, zinc, antimony, and silver shown in the spectrographic analysis (table 1, sample 17).

Some of the dolomite has been brecciated to angular fragments $3 \mathrm{~mm}$ to $3 \mathrm{~cm}$ across and cemented by fine-grained white quartz that is free of inclusions. Some sericite lies in the interstices of both the quartz and the carbonate. X-ray diffraction analysis indicated that some calcite and fluorite also occur in the breccia. The brecciated dolomite also contains some sulfides which probably account for the lead, zinc, and silver shown in the spectrographic analysis (table 1 , sample 22).

\section{COUNTRY ROCKS}

The unmineralized marble exposed at the deposit is gray to bluish white and is composed of more than 95 percent calcite, commonly twinned, with a grain size of 0.1 to $1 \mathrm{~mm}$. The marble is schistose, its foliation accentuated by thin layers of shiny flakes of sericite interstitial to the calcite. Round to subangular grains of quartz 0.02 to $0.2 \mathrm{~mm}$ in diameter are scattered through the rock. Spectrographic analyses of two fresh samples of this marble from the upper and lower benches are shown in table 1 (samples 7 and 18). These analyses indicate the low initial content of barium.

Some of the marble has been altered by bleaching and dolomitization. Bleaching produced streaks and patches of white marble within the unaltered gray marble. Some of the bleached rock is stained by iron oxides.

The least altered schists are silvery to dark greenish gray and consist of various proportions of quartz, muscovite (including sericite), and chlorite associated with smaller amounts of albite, epidote, hornblende, garnet, magnetite-ilmenite, and sulfide minerals. The streaks of micaceous minerals are bent and broken and separated by streaks of quartz in grains 0.1 to $0.2 \mathrm{~mm}$ across. Some muscovite and chlorite are included in the quartz, some sericite occurs interstitially to the quartz, and some grains and patches of calcite are associated with quartz. Some schist contains small grains of high-calcium garnet (andradite) which is pale red and greatly fractured. Elongate streaks of opaque ilmenite-magnetite and sulfide minerals occur with the muscovite. Spectrographic analyses of two samples of this type of schist from the west side of the middle bench are shown in table 1 (samples 20 and 21). The suite and amount of the trace elements, especially the zinc and antimony, certainly suggest that even the freshest appearing schist has been hydrothermally altered.

Because the schist has been altered pervasively, the marble also probably was altered similarly. If so, the streaks and 
patches of either bleached or dolomitized rock mentioned above indicate places where the marble was more intensely altered.

\section{INTRODUCED MINERALS}

The introduced minerals occur chiefly as streaks and pods in the pervasively altered schist and marble and to a much lesser extent as thin veins which trend west across the exposures. The streaks and pods are a few inches to several feet thick and as much as several tens of feet long. They contain various amounts and combinations of barite, fluorite, sulfides of lead, zinc, antimony, and iron, and precious metals, along with their weathering products and a gangue of calcite, dolomite, and quartz. The streaks and pods generally follow the foliation of the host rocks and the contacts of the various layers of marble and schist.

White barite occurs mostly in marble on the upper bench and is especially abundant in a bulldozer cut adjacent to the northwest side of the main cut. The barite (sample 3 ) from the bulldozer cut is sugary grained and has a lineation induced by shear. In thin section the grains of barite are 0.5 to $1.5 \mathrm{~mm}$ across, and many are twinned. The only accessory minerals observed are scattered round grains of quartz and pyrite, the latter surrounded by thin rims of iron oxide. A similar-looking specimen of barite (sample 25) from the north end of the upper bench contains a little calcite. The texture of both samples is sutured, and relict grain boundaries are indicative of at least a partial recrystallization of the barite. Spectrographic analyses of barite samples 3 and 25 (table 1) indicate a good-quality barite. The strontium values are not especially unusual, because barium and strontium freely substitute to several percent in their respective sulfates.

Barite also occurs with other minerals in some of the pods; for example, with fluorite and quartz in the crest of a small fold in marble on the upper bench. In a sample from this locality, grains of barite and fluorite, 0.1 to $0.2 \mathrm{~mm}$ across, are scattered in finer grained quartz. Some small amounts of sericite lie in the interstices of the aforementioned minerals. Some round grains of pyrite only $0.04 \mathrm{~mm}$ in diameter are scattered through the sample. The spectrographic analysis (table 1 , sample 8 ) suggests that most of the material analyzed is barite.

The fluorite occurs in clots and streaks from several inches to several feet across. Most of the fluorite is white or light green and purple, but some is colorless. Most of the fluorite examined under the microscope has been sheared and at least partly recrystallized; relict traces of former grain boundaries are easily visible. Some fractures as wide as $0.1 \mathrm{~mm}$ are filled by quartz or calcite. In some thin sections, hair fractures and cleavage planes are "corroded" by calcite, and the fluorite apparently has been thoroughly penetrated by later solutions. The fluorite regarded as typical of this deposit is nearly pure. Spectrographic analyses of seven samples of fluorite shown in table 1 (samples $4,5,6,9,10,11$, and 19) indicate very little barium or other elements.

The sulfides galena $(\mathrm{PbS})$, sphalerite $(\mathrm{ZnS})$, and boulangerite $\left(\mathrm{Pb}_{5} \mathrm{Sb}_{4} \mathrm{~S}_{11}\right)$ have been identified in polished sections and by $\mathrm{X}$-ray diffraction. They occur as scattered grains or aggregates in the clots and streaks with other introduced minerals and as finely disseminated grains in the calcite and aragonite of the late west-trending veins.

Some of the sulfide minerals are sheared and some are not. Textural relations suggest that at least some of the sulfide minerals were introduced later than the fluorite and barite.

A body of quartz-rich rock on the east side of the middle bench has discontinuous thin streaks of sheared galena. The quartz matrix has been partly recrystallized, and some of the relict boundaries have been preserved. A spectrographic analysis of this rock (table 1 , sample 15) also indicates the presence of anomalous silver and antimony.

Sheared yellow-orange fluorite-calcite-quartz rock with goethite at a marble-schist contact on the east side of the middle bench contains streaks or veins of unsheared quartz, galena, and boulangerite; this veining suggests that the latter minerals perhaps are younger than the enclosing sheared rock. Spectrographic analyses of this material are shown in table 1. Sample $14 \mathrm{~A}$ is the sheared fluorite-rich rock. Sample 14B, the unsheared quartz-sulfide vein, contains $2,000 \mathrm{ppm}$ arsenic, but no specific arsenic minerals were identified. Sample 14 is a composite of the sheared and unsheared material. The traces of tin, molybdenum, and rare earths found in these samples are similar to those known in many altered rocks on the Seward Peninsula.

Herreid (1966) reported some silver and gold in the rocks of this area. The amounts of silver listed in some of the analyses in table 1 of this report warranted further investigation. Fire-assay data for eight samples selected from those collected at the deposit are shown in table 2. The sample numbers and material correspond to those in table 1 . No specific gold or silver minerals were identified in this study.

Trace amounts of mercury were detected in all the samples from the barite deposit (table 1). Background values for the mercury content of rocks on the Seward Peninsula are less than $0.09 \mathrm{ppm}$. Thus, 10 of the samples, mostly those with abundant sulfide minerals, contain anomalous amounts of mercury. The samples of schist and marble in the mineralized area do not contain anomalous amounts of mercury. The anomalous amounts of mercury seem to accompany the lead and zinc minerals and barite, so geochemical prospecting with tests for lead-zinc or even barite could be successful and require less cost as well as less complicated techniques than prospecting with mercury.

Colloform calcite and aragonite with disseminated finegrained galena and sphalerite constitute the principal filling of a group of west-trending veins that attain a maximum thickness of several inches. The veins were fractured and healed during the deposition of the carbonate minerals. Spectrographic analyses of samples from two of these veins are listed in table 1 (samples 13 and 24). 
[Six-step semiquantitative spectrographic analyses by L.A. Bradley. Mercury determinations by J.B. McHugh by instrumental methods. $G$, amount greater than 10 percent; $L$, detected, but below limit of detection; $\mathrm{N}$, not detected at limit of detection; ppm, parts per million (conversion $10,000 \mathrm{ppm}=1$ percent). As terisk $\left({ }^{*}\right)$ indicates sample in which additional elements were found (in ppm):

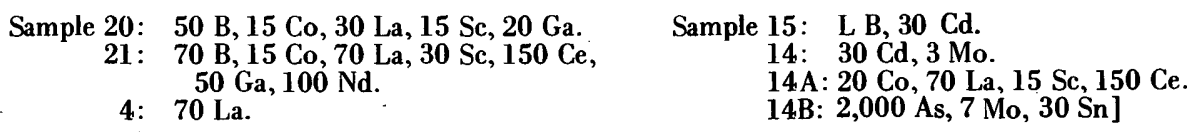

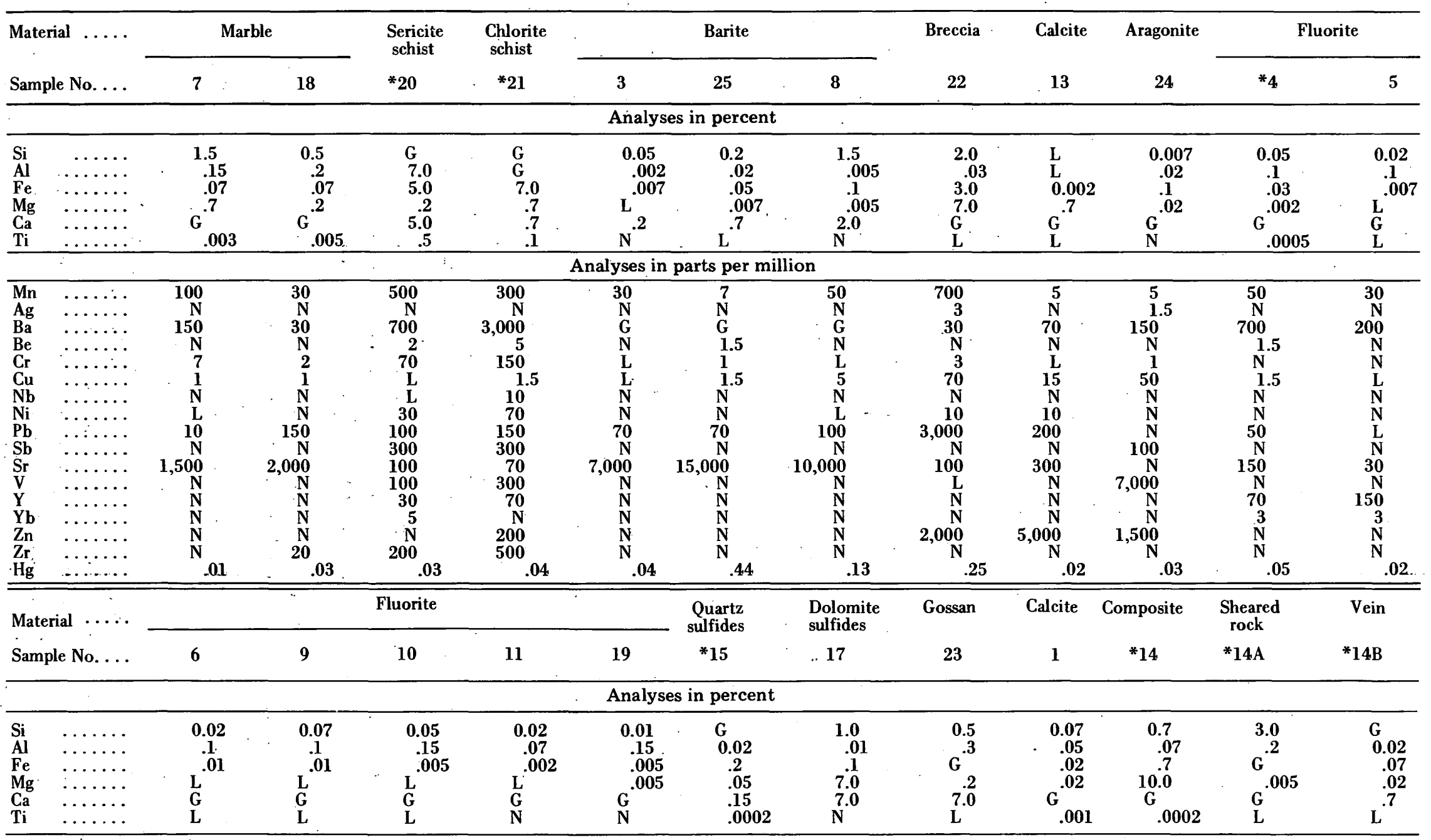




\begin{tabular}{|c|c|c|c|c|c|c|c|c|c|c|c|c|c|}
\hline \multirow{2}{*}{\multicolumn{2}{|c|}{$\begin{array}{l}\text { Material .... } \\
\text { Sample No. ... }\end{array}$}} & \multicolumn{5}{|c|}{ Fluorite } & \multirow{2}{*}{$\begin{array}{c}\text { Quartz } \\
\text { sulfides } \\
* 15\end{array}$} & \multirow{2}{*}{$\begin{array}{c}\text { Dolomite } \\
\text { sulfides } \\
17\end{array}$} & \multirow{2}{*}{$\begin{array}{c}\text { Gossan } \\
23\end{array}$} & \multirow{2}{*}{$\begin{array}{c}\text { Calcite } \\
1\end{array}$} & \multirow{2}{*}{$\begin{array}{l}\text { Composite } \\
{ }^{*} 14\end{array}$} & \multirow{2}{*}{$\begin{array}{l}\text { Sheared } \\
\text { rock } \\
{ }^{*} 14 \mathrm{~A}\end{array}$} & \multirow{2}{*}{$\begin{array}{l}\text { Vein } \\
* 14 B\end{array}$} \\
\hline & & 6 & 9 & 10 & 11 & 19 & & & & & & & \\
\hline \multicolumn{14}{|c|}{ Analyses in parts per million } \\
\hline $\begin{array}{l}\mathrm{Mn} \\
\mathrm{Ag} \\
\mathrm{Ba} \\
\mathrm{Be} \\
\mathrm{Cr} \\
\mathrm{Cu} \\
\mathrm{Nb} \\
\mathrm{Ni} \\
\mathrm{Pb} \\
\mathrm{Sb} \\
\mathrm{Sr} \\
\mathrm{V} \\
\mathrm{Y} \\
\mathrm{Yb} \\
\mathrm{Zn} \\
\mathrm{Zr} \\
\mathrm{Hg}\end{array}$ & 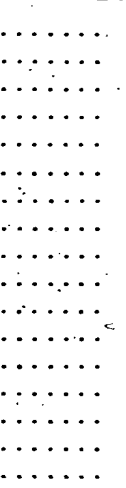 & $\begin{array}{c}20 \\
\mathrm{~N} \\
100 \\
\mathbf{1 . 5} \\
\mathrm{N} \\
\mathrm{L} \\
\mathrm{N} \\
\mathrm{N} \\
\mathbf{1 0} \\
\mathrm{N} \\
\mathbf{3 0} \\
\mathrm{N} \\
\mathbf{3 0 0} \\
\mathbf{3} \\
\mathrm{N} \\
\mathrm{N} \\
.02\end{array}$ & $\begin{array}{r}20 \\
N \\
500 \\
N \\
N \\
L \\
N \\
L \\
20 \\
N \\
50 \\
N \\
70 \\
N \\
N \\
N \\
.02\end{array}$ & $\begin{array}{r}30 \\
2 \\
150 \\
N \\
N \\
1 \\
N \\
N \\
100 \\
N \\
20 \\
N \\
30 \\
N \\
N \\
N \\
.13\end{array}$ & $\begin{array}{c}15 \\
N \\
70 \\
N \\
N \\
N \\
N \\
N \\
N \\
N \\
70 \\
N \\
150 \\
1.5 \\
N \\
N \\
.05\end{array}$ & $\begin{array}{r}30 \\
N \\
20 \\
N \\
N \\
L \\
N \\
N \\
150 \\
N \\
20 \\
N \\
70 \\
1 \\
N \\
N \\
.02\end{array}$ & $\begin{array}{r}20 \\
200 \\
70 \\
\mathrm{~N} \\
\mathrm{~L} \\
100 \\
\mathrm{~L} \\
\mathbf{N} \\
\mathrm{G} \\
\mathbf{1 , 5 0 0} \\
\mathbf{1 0} \\
\mathbf{N} \\
\mathrm{N} \\
\mathrm{N} \\
300 \\
\mathrm{~N} \\
\mathbf{3 . 0}\end{array}$ & $\begin{array}{c}200 \\
1.5 \\
7 \\
\text { N } \\
7 \\
10 \\
\mathrm{~L} \\
5 \\
1,000 \\
150 \\
50 \\
\mathrm{~N} \\
\mathrm{~N} \\
\mathrm{~N} \\
2,000 \\
\mathrm{~N} \\
.19\end{array}$ & $\begin{array}{r}70 \\
N \\
70 \\
N \\
7 \\
30 \\
\mathrm{~L} \\
\mathbf{3 0} \\
\mathbf{7 0 0} \\
\mathbf{1 5 0} \\
\mathbf{3 0} \\
\mathrm{N} \\
\mathrm{N} \\
\mathrm{N} \\
\mathbf{2 , 0 0 0} \\
\mathrm{N} \\
.84\end{array}$ & $\begin{array}{c}30 \\
\mathrm{~N} \\
30 \\
\mathrm{~N} \\
\mathrm{~L} \\
1.5 \\
\mathrm{~N} \\
\mathrm{~L} \\
15 \\
\mathrm{~N} \\
2,000 \\
\mathrm{~N} \\
\mathrm{~N} \\
\mathrm{~N} \\
\mathrm{~N} \\
\mathrm{~N} \\
.06\end{array}$ & $\begin{array}{r}200 \\
30 \\
100 \\
\mathbf{N} \\
3 \\
150 \\
\mathbf{L} \\
7 \\
\mathbf{G} \\
50,000 \\
100 \\
10 \\
\mathbf{L} \\
\mathbf{N} \\
\mathbf{3 , 0 0 0} \\
\mathbf{N} \\
\mathbf{3 . 3 0}\end{array}$ & $\begin{array}{c}2,000 \\
N \\
70 \\
3 \\
1.5 \\
500 \\
\mathrm{~L} \\
15 \\
5,000 \\
\mathrm{~N} \\
150 \\
30 \\
100 \\
\mathrm{~N} \\
5,000 \\
\mathrm{~N} \\
.63\end{array}$ & $\begin{array}{r}7 \\
500 \\
2,000 \\
\text { N } \\
5 \\
700 \\
\text { L } \\
\text { L } \\
\text { G } \\
\text { G } \\
100 \\
\text { L } \\
15 \\
\text { N } \\
3,000 \\
\text { N } \\
.58\end{array}$ \\
\hline
\end{tabular}

Sample description and locality

7. Calcite marble, upper bench.

18. Calcite marble, west side of lower bench.

20. Quartz-sericite schist, west side of middle bench

.

3. White barite, bulldozer cut north west of main cut.

25. White barite, north end of upper bench.

8. White barite, folded into marble, upper bench.

13. White colloform calcite, east-trending vein, south end of upper bench

24. Pale-y ellowish-green aragonite, east-trending vein, upper bench

4. Purple fluorite, lower bench.

5. Purple fluorite, lower bench.

6. White fluorite, upper bench.

9. White fluorite, east side of upper bench.
10. White fluorite, collected about 6 feet north of sample 9 .

11. Clear fluorite, upper bench.

19. Deep-purple fluorite clots in iron-stained schist near west side of north end of upper bench.

15. Quartz-sulfide mass, east side of middle bench

17. Dolomite with sulfide veinlets, east side of middle bench.

23. Gossan (goethite-calcite rock), upper bench.

1. White calcite, vein on lower bench.

14. Composite of sheared fluorite rock and unsheared vein, east side of middle bench.

14A. Sheared rock with fluorite, calcite, quartz, and goethite at edge of vein; locality

14B. Sulfide minerals and quartz from center of vein; locality same as for 14 . 
Table 2.-Fire assay values of selected samples from the Sinuk River barite deposit, Seward Peninsula, Alaska

[Gold determined by fire assay plus atomic absorption method by W. D. Goss, A. W. Haubert, and J. A. Thomas. Silver determined by fire-assay difference method by L. B. Riley]

\begin{tabular}{|c|c|c|c|c|c|}
\hline \multirow{2}{*}{$\begin{array}{l}\text { Sample } \\
\text { No. }\end{array}$} & \multirow{2}{*}{ Material } & \multicolumn{2}{|r|}{ Gold } & \multicolumn{2}{|r|}{ Silver } \\
\hline & & (ppm) & (oz per ton) & $(\mathrm{ppm})$ & (oz per ton) \\
\hline 8. & White barite ....... & $<0.05$ & $\cdots$ & $\cdots$ & $\cdots$ \\
\hline 10. & Fluorite $\ldots \ldots \ldots$ & $<.05$ & $\cdots$ & $\cdots$ & $\ldots$ \\
\hline & $\begin{array}{l}\text { Composite of } \\
\text { sheared rock } \\
\text { and unsheared }\end{array}$ & & & & \\
\hline 15. & vein $\ldots \ldots \ldots$ & .2 & $<0.1$ & 260 & 7.65 \\
\hline 15. & $\begin{array}{l}\text { Quartz-sulfide } \\
\text { mass } \ldots \ldots \ldots \ldots\end{array}$ & 3.6 & .1 & 155 & 4.55. \\
\hline $\begin{array}{l}17 . \\
22 .\end{array}$ & Dolomite .... & $<.05$ & $\ldots$ & asonen & , n....... \\
\hline & $\begin{array}{c}\text { Dolomite } \\
\text { breccia }\end{array}$ & $<.05$ & & $\cdots$ & \\
\hline 23. & Gossan $\ldots \ldots \ldots \ldots$ & $<.05$ & & $\ldots$ & $\ldots \ldots$ \\
\hline 25. & White barite ...... & .8 & $<.1$ & ... & ............ \\
\hline
\end{tabular}

\section{GOSSAN}

A small gossan is exposed on the upper bench. The material looks dense, but it contains a few percent, by volume, of tiny cavities which are lined with calcite. Thin-section and X-ray studies show that the material is chiefly goethite, which is both very fine grained and well crystallized. A sample of this material contains 2,000 ppm zinc and a little lead and copper (table 1, sample 23). The lead and zinc content in the gossan material is roughly comparable to that in the analysis of the sulfide materials shown in table 1 .

Pyrite $\left(\mathrm{FeS}_{2}\right)$ is a common accessory mineral disseminated through many rocks at the deposit, and some also is associated with galena. There is no evidence, however, to suggest either that large amounts of pyrite were introduced to the area or that the goethite-rich gossan was derived from pyrite.

\section{FLUID INCLUSIONS}

Fluid inclusions are abundant in all the fluorite that was studied. Slices of fluorite about $2 \mathrm{~mm}$ thick were cut and polished on both sides. These slices were examined under a microscope equipped with a heating stage and a device to record temperatures.

The inclusions are of two kinds, those along healed fracture planes and those along the grain boundaries of recrystallized fluorite. The inclusions along the healed fracture planes are mostly equidimensional and have negative crystal faces, as though they may be primary inclusions; that is, fluid trapped along crystal faces while the fluorite was being deposited. The planes defined by these inclusions, however, seem to be curved and do not meet at right angles. Thus, they are fracture planes in massive fluorite and not crystallographic planes, and these inclusions are of secondary origin.

Fluid inclusions of the second type-those along the grain boundaries of recrystallized fluorite-are extremely thin and irregular in shape. They lie along curved planes of ellipsoidal shape, between which are zones of clear fluorite that contains no fluid inclusions. The three-dimensional aspect of the ellipsoid is clearly seen by raising or lowering the focal plane of the microscope through the polished plate. These fluid inclusions are along grain surfaces of the granulated and recrystallized (healed) fluorite described above, and the fluids probably were trapped during recrystallization of the fluorite.

The fluids in both types of inclusions consist of three phases-liquid water, liquid carbon dioxide, and gas. The carbon dioxide was identified by warming and cooling the inclusion to temperatures above and below the critical temperature $\left(31.1^{\circ} \mathrm{C}\right)$ of carbon dioxide and observing the disappearance and reappearance of the carbon dioxide phase.

The filling temperatures of eight inclusions were determined by heating each sample until the gas bubble disappeared in a homogenized liquid phase and then cooling the sample until the bubble reappeared. The measurements obtained are shown in figure 2. Three of the inclusions studied were among those that surround clear granules of fluorite, and the other five were among those along the healed fracture planes. Seven of the inclusions filled at $243^{\circ} \pm 6^{\circ} \mathrm{C}$, and the other inclusion filled between $255^{\circ}$ and $256^{\circ} \mathrm{C}$. The uncertainty in the filling temperature is the result of poor optical properties of the inclusions rather than erratic behavior during the heating experiments. The temperatures given are a reasonable approximation of the temperature that prevailed when the deposits were recrystallized and later fractured. A more accurate estimate of the temperature would have to take into account corrections for the salinity of the fluid and the pressure that prevailed when the fluids were trapped. The data for such corrections are not available, but the corrections, if applied, probably would not significantly affect the conclusions.

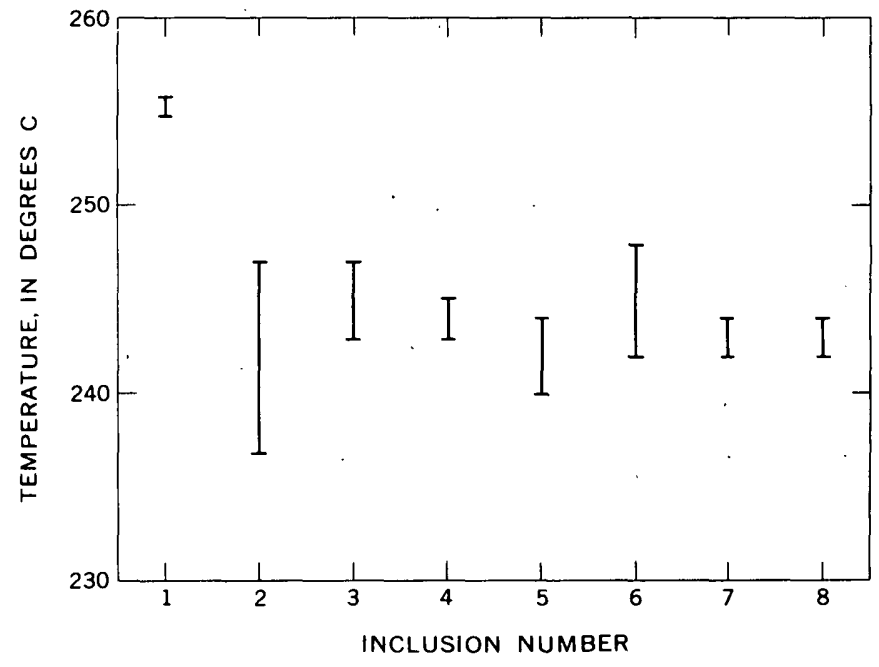

Figure 2.-Filling temperatures of fluid inclusions in fluorite. The fluid inclusions, upon heating, converted to a single phase (liquid) at the temperature shown by the vertical bars. Inclusions $1-3$ are along grain boundaries of recrystallized fluorite; inclusions 4-8 are along fracture planes in fluorite. 
The composition of the fluid inclusions was determined in order to estimate the pressure that prevailed and, therefore, the minimum depth of cover in the area when the inclusions were trapped. The carbon dioxide and water were extracted from the fluid inclusions in a sample of fluorite. The fluorite was cut into thin slabs, polished on both sides, and examined microscopically for fluid inclusions showing three phases. The slabs were soaked in hydrochloric acid to remove any traces of calcite from the small veinlets mentioned above. The slabs were then placed in an evacuated chamber in a furnace and heated to $425^{\circ} \mathrm{C}$ to rupture the inclusions and release the water and carbon dioxide. Experiments showed that calcite, if present, would not release carbon dioxide at this temperature. The released gases were passed into a vacuum line, which is designed specifically to separate carbon dioxide and water, and the amounts of carbon dioxide and water were measured. The fluid recovered consists of 3.2 mole percent carbon dioxide. According to the data of Takenouchi and Kennedy (1964), a mixture of this composition exerts a pressure of 233 bars at $250^{\circ} \mathrm{C}$. This pressure is equivalent to that exerted by a column of water about 7,900 feet in height or by a column of rock (density 2.6) about 3,000 feet in height. From these data, the depth of the deposit at the time of recrystallization of the fluorite is estimated to have been at least a few thousand feet.

\section{INTERPRETATIONS}

The significance of the observations at the Sinuk River barite deposit may be evaluated by synthesizing the events in the geologic history in the area and relating them to the events in the geologic history of the Seward Peninsula.

At the barite deposit, originally layered rocks were metamorphosed (recrystallized and foliated) into a sequence of marble and micaceous schist. These rocks were then deformed, the compositional layers and the micaceous minerals within them were folded and partly fractured, and southerly trending linear structures were developed. Solutions entered the country rocks pervasively and deposited fluorite, barite, sulfide minerals, and some precious metals along the foliation planes and contacts between schist and marble. Some of the introduced material was partly sheared and recrystallized under a pressure equivalent to a cover of a few thousand feet of rock and at a temperature of about $250^{\circ} \mathrm{C}$, as indicated by the fluid inclusions in the fluorite. Later, some thin, steeply dipping veins were filled with carbonate and some metal sulfides. These late veins trend west, across the preexisting structures of the metamorphic rocks.

A considerable amount of information on the rocks, geologic structure, and history of the Seward Peninsula has been outlined by Sainsbury, Coleman, and Kachadoorian (1970), and is summarized below. Among the younger, but not the youngest, rocks of Precambrian age is a sequence of marble and schist called the Nome Group, which is exposed in thrust sheets that occupy more than 10,000 square miles of the peninsula. The rocks of the Nome Group have been through two cycles of thrusting, the earlier characterized by intense folding and eastward transport, and the later characterized by imbricate thrusting, without folding, and northward transport. The thrusting was completed before middle Cretaceous time; the thrust sheets have been intruded by granites of middle Cretaceous age (100 m.y. years ago). Associated with these granites is a regional thermal metamorphism that generated the retrograde metamorphic effects in the blueschist facies so common in the rocks of the Nome Group. In latest Cretaceous, or earliest Tertiary time, about $74 \mathrm{~m}$.y. ago, more bodies of granite intruded the Seward Peninsula. These intrusive rocks have associated ore deposits containing tin, lead, zinc, and fluorite that were introduced into the country rocks in a largely pervasive manner, rather than as vein fillings. Later in Tertiary time, another group of igneous rocks was emplaced. Ores associated with these rocks are fissure-filling deposits containing gold, silver, and antimony. These deposits, notably lacking in fluorite, are the source of some of the gold mined from the famous placer deposits of the Nome district.

The rocks at the barite deposit are mineralogically similar to other rocks of the Nome Group on the Seward Peninsula, and they display other characteristics of folding, metamorphism, shear, and even a southward-plunging lineation attributable to northward transport. Because of these similarities, we assign the rocks to the Nome Group.

Continued study of the Seward Peninsula shows that the structure of the Nome region is even more complex than formerly realized. Preliminary geologic maps of the Nome C-1 and Nome D-1 quadrangles (Hummel, 1962a, b), which lie about 10 miles east of the barite deposit (fig. 1), show many faulted areas consisting of markedly different metamorphosed rocks, all designated as Paleozoic in age. In the Nome D-1 quadrangle, the difference between the rocks north and south of the Stewart River suggests that each area could be interpreted as a different thrust sheet whose boundary fault may lie in the valley of the Stewart River. The blue-gray marble and micaceous schists south of the Stewart River have the same characteristics as those rocks at the barite deposit. Thrust sheets involving rocks of the Nome Group probably do extend into the Nome region of the Seward Peninsula.

If the assumption is correctly made that the metamorphic rocks exposed at the barite deposit are part of the Nome Group, then these rocks have been involved in the two cycles of thrusting and the mid-Cretaceous thermal metamorphism. Thus, the folding in the country rocks at the barite deposit probably resulted from the movements in the first cycle of thrusting; and the south-plunging lineations probably resulted from movements in the second cycle. The retrograde metamorphic effects, including the development of some of the sericite and chlorite, resulted from the thermal metamorphism during the emplacement of bodies of mid-Cretaceous granite, some of which pierced the core of the Kigluaik Mountains about 20 miles north of the barite deposit.

The suite of minerals, including fluorite, barite, and metal sulfides, was introduced to the host rocks by a process of 
impregnation that seems best correlated with the pervasive mineralization characteristic of that associated with the emplacement of tin-bearing granites, about 74 m.y. ago.

After the introduction of these minerals, they were recrystallized in the presence of carbon dioxide-rich solutions at moderately high temperature (about $250^{\circ} \mathrm{C}$ ). The recrystallization may have occurred late in the original cycle of mineralization or in a later cycle of hydrothermal activity, such as that which produced the later Tertiary fissure veins containing the gold, silver, and antimony in the rocks of other nearby thrust sheets.

The steeply dipping, west-trending fissure veins of calcite and aragonite, with accessory amounts of base and precious metals, were emplaced later than the impregnating fluorite, barite, and sulfide minerals. These vein fillings are not sheared, but the colloform structures are broken and healed, suggesting that the area of emplacement was then under tension and not compression as it probably was during the time of major fluorite-barite mineralization. These veins are perhaps related to later Tertiary fissure-filling deposits.

The precious metals and antimony are characteristic of the suite of minerals associated with the later Tertiary vein fillings, but not necessarily exclusively so. Gold and silver are detected in areas mineralized by the impregnations associated with the 74-m.y.-old bodies of granite. The presence, however, of seemingly unsheared galena and boulangerite with associated silver and gold, along with fluorite recrystallized at about $250^{\circ} \mathrm{C}$ at the barite deposit, allows for the possibility that the rocks of the Nome Group in this thrust sheet were mineralized more than once.

\section{CONCLUSIONS}

In conclusion, we are suggesting that the area is an attractive target for further exploration for mineral deposits of commercial value.

The complex folding and faulting of several ages in a large area suggests that channels for entry and dispersion of ore-depositing solutions through sheets of foliated rocks probably have been opened during several intervals since Precambrian time.

The occurrence of pervasively disseminated fluorite, barite; and sulfides of lead, zinc, and antimony with associated silver and gold, and anomalous amounts of mercury at the barite deposit suggests that the major mineralization belongs to that associated with the emplacement of the bodies of tin-bearing granite in the Seward Peninsula, about 74 m.y. ago.

The temperature of homogenization of the fluid included in the fluorite $\left(243^{\circ} \pm 6^{\circ} \mathrm{C}\right)$ suggests that sources of hot solutions were nearby, at least once, and that hydrothermal ore deposits displaying the classic features of mineral zonation may occur in the area. The fluorite is partly sheared and recrystallized, events which might have occurred late in the cycle of original deposition or even later. The fluorite certainly was not completely sheared and recrystallized after the entrapment of the fluids. Mineralization might have occurred in more than one cycle of activity.

The vertical and lateral extent of the mineralized rock exposed at the barite deposit is unknown. The structural and lithologic controls of the mineralizing solutions clearly involve the marble exposed in the area. Other marble, which could also be mineralized, may be inferred at depth. Mineralization might have taken place only in the shear zones between the thrust sheets or might have penetrated favorable host rocks in both the overriding and underlying sheets.

Further exploration in this area seems warranted.

\section{REFERENCES}

Eakin, H. M., 1915, Iron-ore deposits near Nome: U.S. Geol. Survey Bull. 622-I, p. 361-365.

Herreid, Gordon, 1966, Preliminary geology and geochemistry of the Sinuk River area, Seward Peninsula, Alaska: Alaska Div. Mines and Minerals Geol. Rept. 24, 19 p.

Hummel, C. $H_{\text {., }}$ 1962a, Preliminary geologic map of the Nome C-1 quadrangle, Seward Peninsula, Alaska: U.S. Geol. Survey Mineral Inv. Field Studies Map MF-247.

1962b, Preliminary geologic map of the Nome D-1 quadrangle, Seward Peninsula, Alaska: U.S. Geol. Survey Mineral Inv. Field Studies Map MF-248.

Moffit, F. H., 1913, Geology of the Nome and Grand Central quadrangles, Alaska: U.S. Geol. Survey Bull. 533, 140 p.

Mulligan, J. J., 1965, Examination of the Sinuk iron deposits, Seward Peninsula, Alaska, with a section by H. D. Hess: U.S. Bur. Mines open-file report, $34 \mathrm{p}$.

Sainsbury, C. L., Coleman, R. G., and Kachadoorian, Reuben, 1970, Blueschist and related greenschist facies rocks of the Seward Peninsula, Alaska, in Geological Survey Research 1970: U.S. Geol. Survey Prof. Paper 700-B, p. B33-B42.

Smith, P. S., 1910, Geology and mineral resources of the Solomon and Casadapaga quadrangles, Seward Peninsula, Alaska: U.S. Geol. Survey Bull. 433, 234 p.

Takenouchi, Sukune, and Kennedy, G. C., 1964, The binary system $\mathrm{H}_{2} \mathrm{O}-\mathrm{CO}_{2}$ at high temperatures and pressures: Am. Jour. Sci, v. 262 , no. 9, p. 1055-1074. 


\title{
OIL-SHALE BEDS IN THE GREEN RIVER AND WASATCH FORMATIONS IN THE LITTLE SNAKE RIVER AREA OF NORTHWESTERN COLORADO
}

\author{
By EDWARD J. McKAY, Denver, Colo.
}

\begin{abstract}
Oil shale occurs in four mapped rock units of Eocene age in the southeastern part of the Sand Wash basin. The rock units in ascending order are (1) the Tipton Tongue of the Green River Formation, (2) an unnamed gray zone in the Wasatch Formation above the Cathedral Bluffs Tongue of the Wasatch and below the Laney Shale Member of the Green River, (3) the Laney Shale Member, and (4) an unnamed oil-shale tongue of the Laney Shale Member, both in the upper part of the Green River.
\end{abstract}

The Little Snake River area consists of about 200 square miles at the south edge of the Sand Wash basin, about 15 miles northwest of the small settlement of Maybell, Colo. (fig. 1).

Intertonguing of the lacustrine Green River Formation and fluviatile Wasatch Formation in the Little Snake River area, and the presence of oil shale in several zones, were reported by Sears (1.924) and by Sears and Bradley (1924). In the present work I attempt to designate stratigraphic zones of possible economic interest on the basis of oil-shale thickness and grade.

Oil-shale samples taken for assay during the work were weathered grab samples from 10 stratigraphic sections measured in the area (fig. 2 and table 1 ). Weathered samples generally have about half the assay value of unoxidized samples. The samples are assumed to be representative of the grade of shale present in the area. Fischer assays were made by the U.S. Bureau of Mines, Laramie, Wyo.

\section{OIL-SHALE BEDS}

\section{Tipton Tongue of the Green River Formation}

The Tipton Tongue is a drab-gray claystone and siltstone, brown oil shale, and light-gray lenticular sandstone sequence, underlain by variegated mudstone and sandstone of the main body of the Wasatch Formation and overlain by variegated mudstone and sandstone of the Cathedral Bluffs Tongue of the Wasatch Formation (figs. 1 and 2). The Tipton increases in thickness from 140 to 500 feet from Lower Sand Creek (8, fig. 2) northeastward to Upper Sand Creek (9). The amount of oil shale increases in the same direction. Total thickness of oil shale on Upper Sand Creek is about 15 feet, most of which is in one bed 10 feet thick. Shale-oil yield for the oxidized rock ranges from a trace to 19.1 gallons per ton.

\section{Unnamed gray zone of Wasatch Formation below Laney Shale Member of the Green River Formation}

The unnamed gray zone consists mostly of gray siltstone, grayish-brown claystone, gray clayey mudstone, and grayishwhite sheet sandstone between overlying grayish-brown siltstone and claystone of the Laney and underlying chocolate-red mudstones of the Cathedral Bluffs Tongue of the Wasatch Formation (fig. 1). The zone has no oil shale in the Bend (3, fig. 2) and Godiva (6) sections, but it contains some oil shale in the Bald Mountain (7) and Deep Canyon (5) sections and 21 feet of oil shale, in beds $1-5$ feet thick, in the Sevenmile section (2). Assays of oil shale in the short Deep Canyon section and in the Sevenmile section range from 0.4 to 11 gallons per ton (fig. 2), and suggest higher grade and thicker beds of oil shale west of Deep Canyon.

\section{Laney Shale Member of the Green River Formation}

The Laney Shale Member is a sequence of alternating gray claystone, brown fissile oil shale, and pale-yellow to grayishwhite fine-grained sandstone. It is 4,40 feet thick at the Sevenmile section (2, fig. 2), 460 feet thick at the Bend section (3), and 520 feet thick at the Sellers Hole section (4). The oil shale is probably thicker and richer west of a line between the Sevenmile, Sellers Hole, and Bend sections, and thinner and lower grade toward the Godiva (6) and Bald Mountain (7) sections.

Oil shale composes much of the Laney Shale Member in the Sellers Hole, Bend, and Sevenmile sections, and it assays from 0.3 to 16.6 gallons of shale oil per ton in the Bend and Sevenmile sections.

\section{Unnamed oil-shale tongue of Laney Shale Member of the Green River Formation}

The Bridger Formation consists of grayish-green, white, and olive-brown tuffaceous claystone and siltstone, lavender dense 

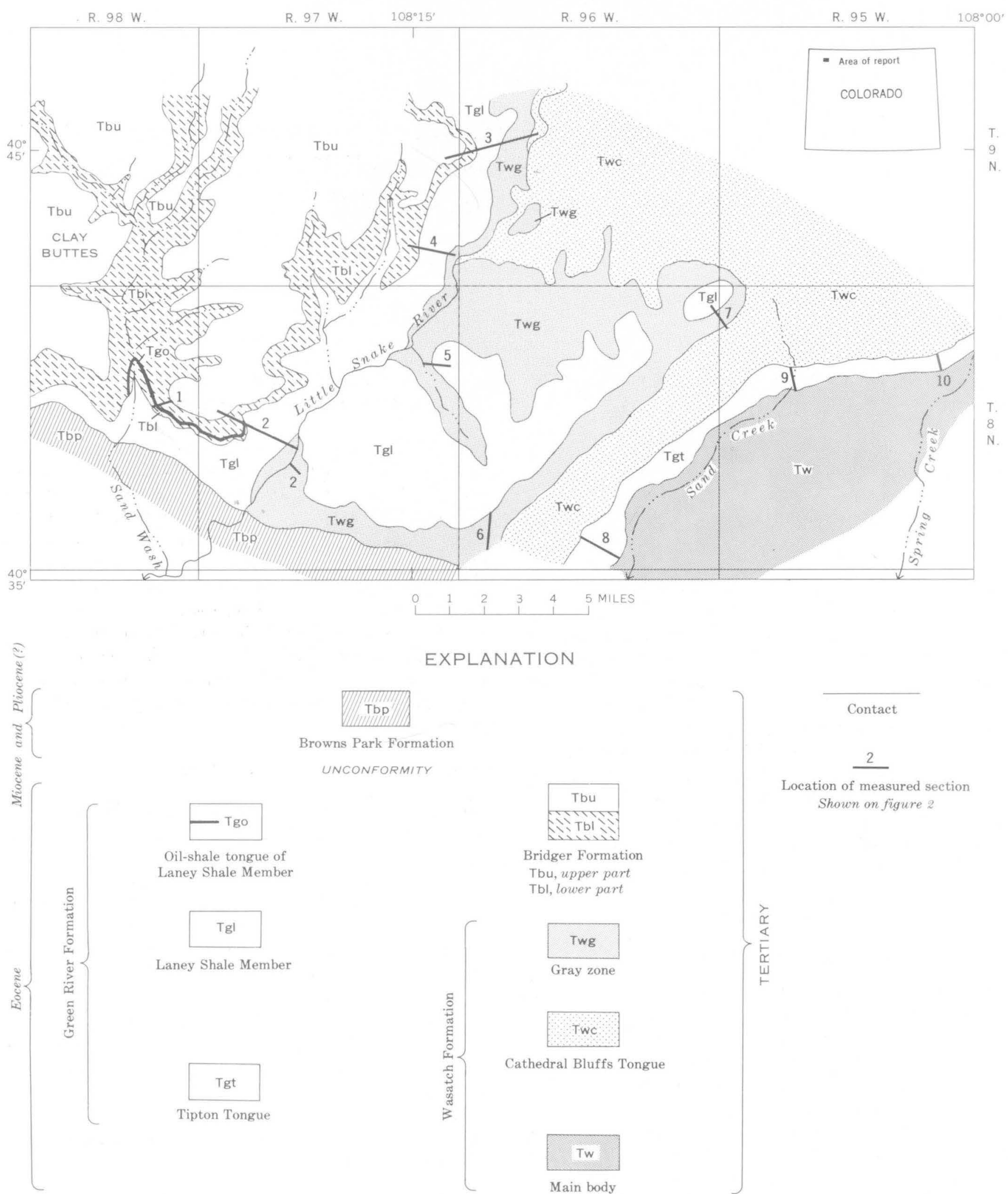

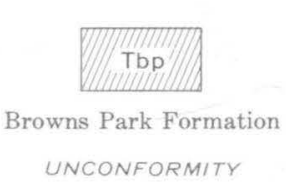

UNCONFORMITY

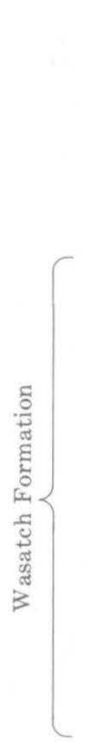

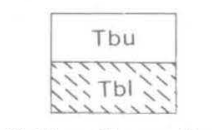

Bridger Formation

Tbu, upper part

Tbl, lower part

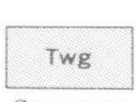

Gray zone

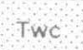

Cathedral Bluffs Tongue

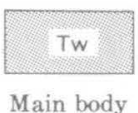

Contact

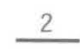

Location of measured section Shown on figure 2

Figure 1.-Generalized geologic map of Little Snake River area, Sand Wash basin, Colorado, showing locations of stratigraphic sections illustrated on figure 2 . 


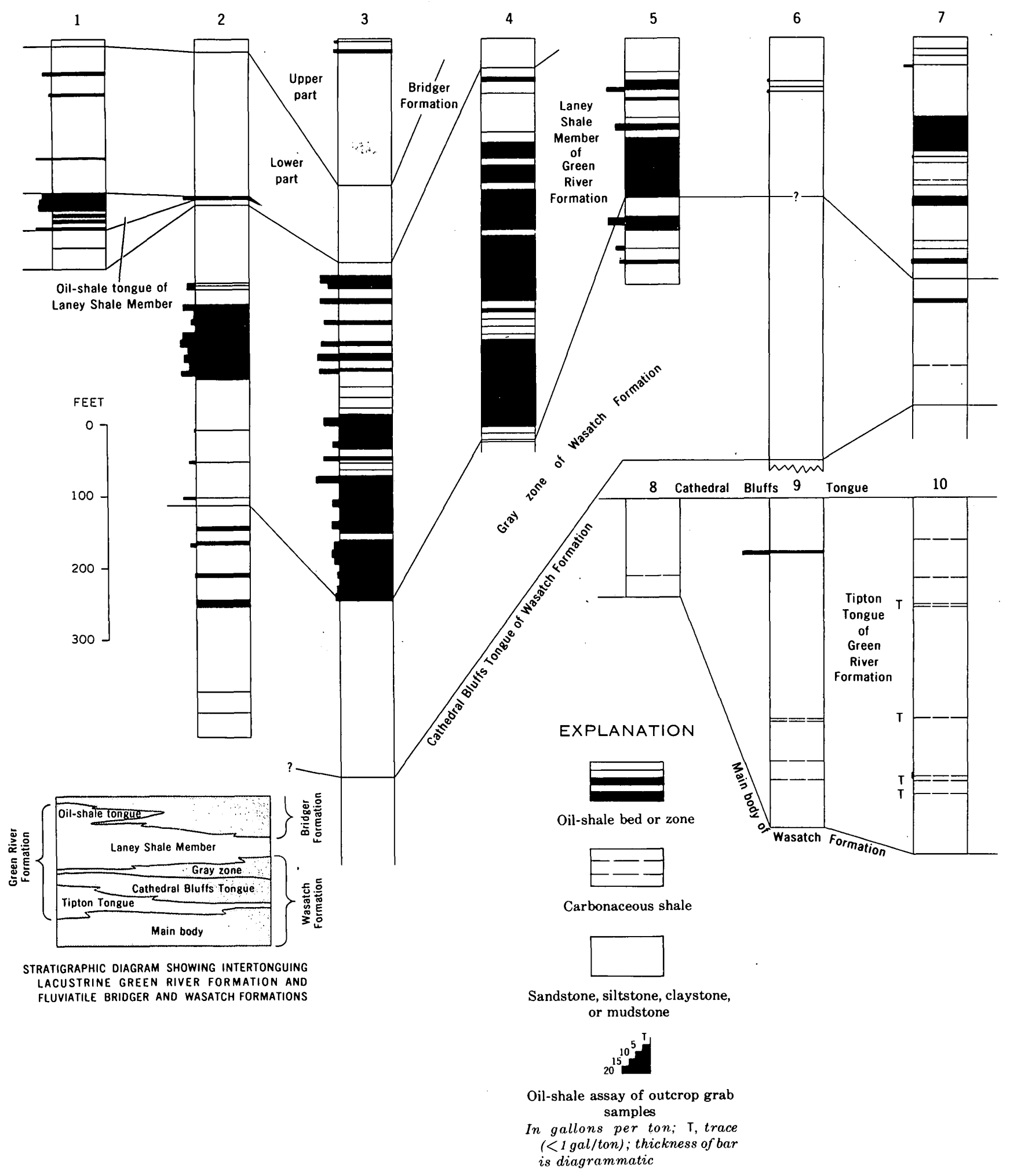

Figure 2.-Stratigraphic sections showing zones of oil shale and shale-oil assays of grab samples in Little Snake River area at the locations numbered on figure 1 and described in table 1. 
Table 1.-Location of measured stratigraphic sections

\begin{tabular}{|c|c|c|c|c|}
\hline \multirow{2}{*}{$\begin{array}{l}\text { Stratigraphic } \\
\text { section No. } \\
\text { (figs. } 1 \text { and } 2 \text { ) }\end{array}$} & \multirow[b]{2}{*}{ Name } & \multicolumn{3}{|c|}{ Location } \\
\hline & & Section & $\begin{array}{l}\text { Townsĥip } \\
\text { (N.) }\end{array}$ & $\begin{array}{l}\text { Range } \\
\text { (W.) }\end{array}$ \\
\hline$\ldots \ldots$ & Sand Wash & 23 & 8 & 98 \\
\hline $2 \ldots \ldots$ & Sevenmile & $.17,21$ & 8 & 97 \\
\hline$\ldots \ldots$ & Bend & 17,18 & 9 & 96 \\
\hline$\ldots \ldots$ & Sellers Hole & 36 & 9 & 97 \\
\hline $5 \ldots \ldots$ & Deep Canyon & 12 & 8 & 97 \\
\hline $6 \ldots \ldots$ & Godiva & 30 & 8 & 96 \\
\hline $7 \ldots \ldots$ & Bald Mountain & 1 & 8 & 96 \\
\hline $8 \ldots \ldots$ & Lower Sand Creek & 34 & 8 & 96 \\
\hline $9 \ldots \ldots$ & Upper Sand Creek & 8 & 8 & 95 \\
\hline $10 \ldots \ldots$ & Hardgrove Rim & 12 & 8 & 95 \\
\hline
\end{tabular}

clayey limestone, black and white chert, and rusty-brown lenticular crossbedded medium- to coarse-grained, gritty, tuffaceous biotite sandstone. The top of a rusty-brown sandstone zone 10-50 feet thick at the top of the main body of the Laney Shale Member of the Green River is the base of the Bridger. A sandstone zone, 5-25 feet thick, about 100-300 feet above the base of the Bridger can be mapped separately, and on figures 1 and 2 the top of the zone has been used to subdivide the Bridger into an upper and a lower part. The lower part of the Bridger is thin and barren of oil shale in the Bend section (3, fig. 2). A 2-foot-thick oil shale in an unnamed tongue of the Laney in the Sevenmile section (2) and 53 feet of oil shale in beds 5-15 feet thick in the same unnamed tongue of the Laney in the Sand Wash section (1) 2 miles to the northwest (figs. 1 and 2) intertongue with the lower part of the Bridger. The shale-oil yield of the unnamed tongue of the Laney in the Sand Wash section is 0.2-11.2 gallons per ton.

\section{TRENDS IN THICKNESS AND GRADE OF OIL SHALE IN SOUTHEASTERN SAND WASH BASIN}

Lateral changes in lithology and thickness shown in measured sections seem to support the concept of a shifting northeast-trending early Eocene shoreline in the southern part of the Sand Wash basin. Trends toward thicker and perhaps higner grade oil shale are indicated to the northwest in the unnamed oil-shale tongue in the lower part of the Bridger, in the Laney, and in the unnamed gray zone of the Wasatch Formation. Proof of these trends, however, awaits detailed stratigraphic study and mapping of these rocks on the northwest side of the Sand Wash basin and probably exploratory drilling in the vicinity of Clay Buttes (fig. 1).

\section{REFERENCES}

Sears, J. D., 1924, Geology and oil and gas prospects of part of Moffat County, Colorado, and southern Sweetwater County, Wyoming: U.S. Geol. Survey Bull. 751-G, p. 269-319.

Sears, J. D., and Bradley, W. H., 1924, Relations of the Wasatch and Green River formations in northwestern Colorado and southern Wyoming, with notes on oil shale in the Green River Formation: U.S. Geol. Survey Prof. Paper 132-F, p. 93-107. 


\title{
DISSEMINATED SULFIDE DEPOSITS IN THE EASTERN ELK MOUNTAINS, COLORADO
}

\author{
By BRUCE BRYANT, Denver, Colo.
}

\begin{abstract}
Disseminated sulfide deposits occur in areas as much as 2 miles long in granodiorite and associated hornfels in the Maroon Bells Snowmass Wilderness in the eastern Elk Mountains southwest of Aspen, Colo. Sulfide minerals, generally pyrite but locally chalcopyrite and molybdenite, fill fractures and are disseminated in both granodiorite and hornfels. Molybdenite is most abundant in locally numerous quartz veins in the granodiorite. Most of the granodiorite is fresh, but locally it is highly albitized or sericitized. Semiquantitative spectrographic analyses show that $\mathrm{Mg}, \mathrm{Ca}, \mathrm{Sr}, \mathrm{Ba}$, and some $\mathrm{Fe}$ were lost during alteration; $\mathrm{Na}$ increased and $\mathrm{K}$ decreased in albitized rocks, and $\mathrm{Na}$ decreased in silicified and sericitized rocks. The occurrence of as much as 2,000 ppm Mo and 5,000 ppm $\mathrm{Cu}$ in selected samples and local intense quartz-sericite alteration are favorable indications for ore. The spotty occurrence of molybdenite and chalcopyrite in altered rock, lack of large areas of pervasive alteration, and lack of any volume of highly differentiated rock visible in surface exposures are unfavorable indications.
\end{abstract}

Disseminated sulfide deposits were noted in the eastern Elk Mountains during a general geologic study of the Aspen, Colo., area and were described briefly elsewhere (Bryant, 1969a). Here I discuss them somewhat more fully and present some analytical data from them. More thorough investigations have been undertaken by industry, but the results are unavailable to the general public. As the deposits are located in and adjacent to the Maroon Bells Snowmass Wilderness, it is hoped that the information herein will aid in the future mineral survey of the wilderness.

Disseminated sulfide deposits associated with Tertiary igneous rocks are numerous in Colorado. The best known deposits contain molybdenum ores and are now being mined at Urad in the Front Range and at Climax in the Tenmile Range (fig. 1). Disseminated sulfide deposits containing molybdenite are also known in the Sawatch Range south of Independence Pass (Horton, 1916; Howell, 1919; Worcester, 1919; King, 1.964) and in the Elk Mountains at Paradise Pass (Worcester, 1919; King, 1964; F. E. Mutschler, written commun., 1968) northwest of Crested Butte (fig. 2). The White Rock pluton is between Independence Pass in the Sawatch Range and Paradise Pass in the Elk Mountains.

The eastern Elk Mountains is a high, rugged area with a relief of 3,000-4,000 feet in distances of 1-2 miles. Except for the lower part of the valleys, the country is above timberline, and

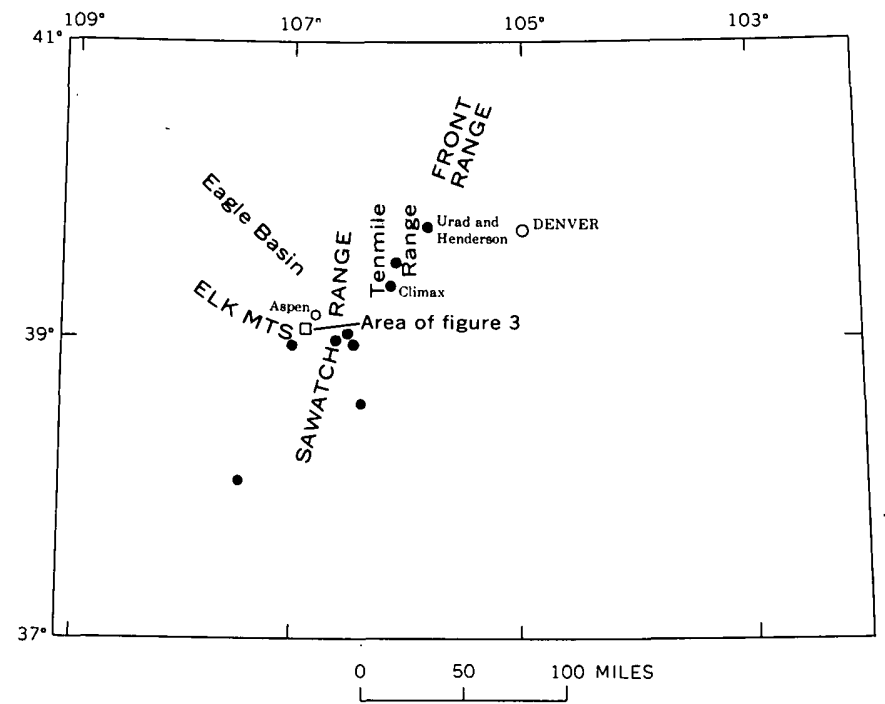

Figure 1.-Index map of Colorado, showing location of disseminated sulfide deposits (solid dots) that contain more than 100,000 pounds of molybdenum. (From King, 1964.)

large areas of rusty-weathered rock mark the disseminated sulfide deposits and make them obvious both from the air and on the ground.

The disseminated sulfide deposits are in the eastern part of the Maroon Bells Snowmass Wilderness in the Hayden Peak and Maroon Bells 71/2-minute quadrangles (Bryant, 1969b, 1970). One deposit extends from an altitude of 9,900 feet along East Maroon Creek, eastward upslope for about 6,000 feet to an altitude of 12,200 feet. It has a maximum width of about 3,000 feet (figs. 3, 4). The best exposures are in a postglacial gorge 50-100 feet deep along a tributary to East Maroon Creek that heads in a cirque between Hunter and Keefe Peaks. A second area of disseminated sulfides extends from west of Conundrum Creek across the Cataract Creek valley into the head of the southwest fork of Sandy Creek, a tributary of Castle Creek. The area is about 8,000 feet wide along the Cataract Creek and 7,000 feet wide along Conundrum Creek. Good exposures occur in a postglacial gorge of Cataract Creek between altitudes of 11,200 and 12,000 feet (fig. 4). 


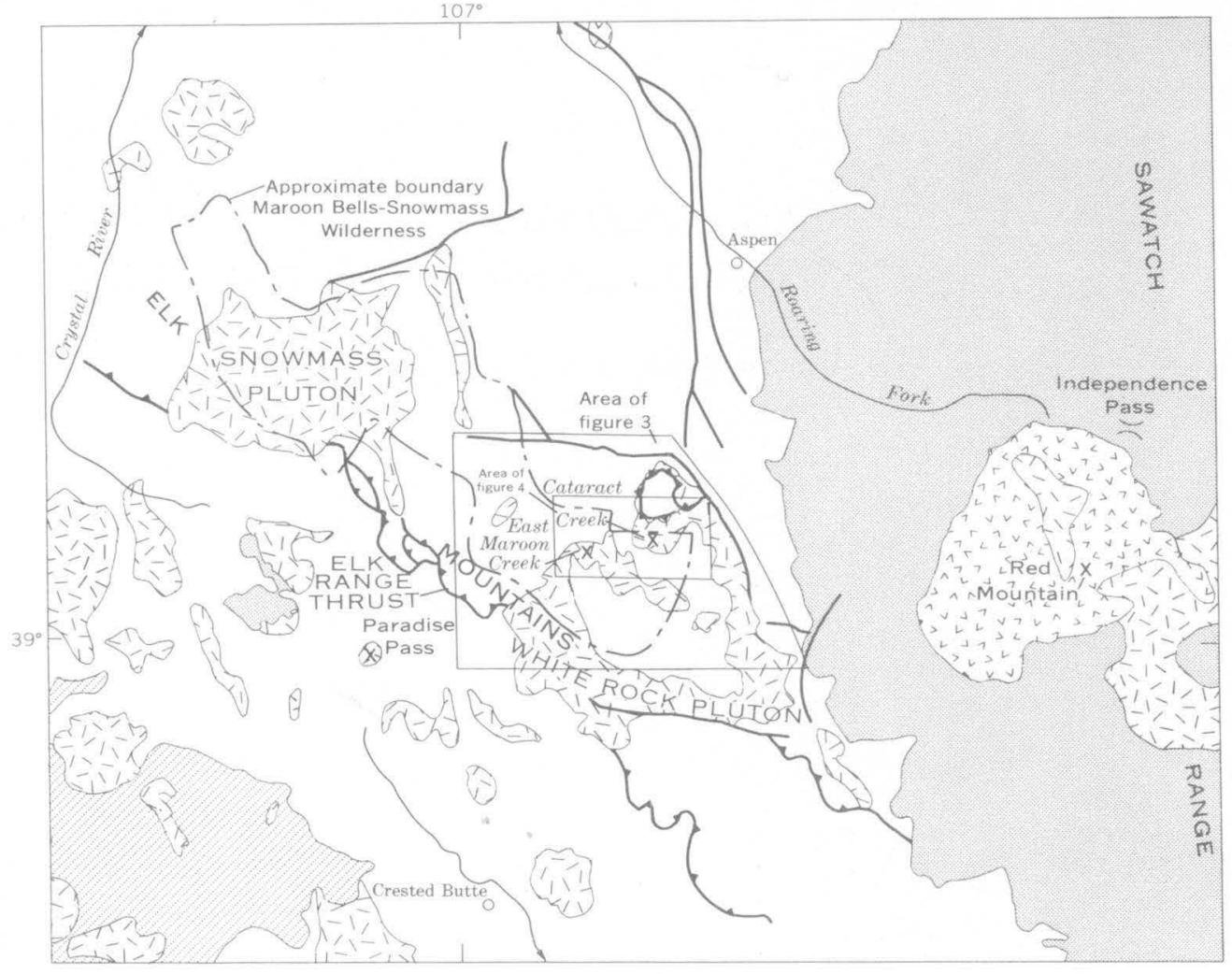

10 MILES
EXPLANATION

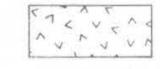

Extrusive rocks

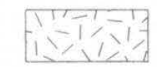

Intrusive rocks

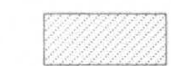

Sedimentary rocks
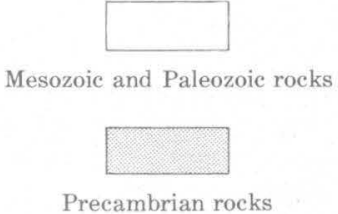

Contact

Fault

Thrust fault

$x$

Disseminated sulfide deposit

Figure 2.-Generalized geologic map of the Sawatch Range and the Elk Mountains, showing Tertiary igneous rock. (From Obradovich and others, 1969 , pl. 1.)

Other smaller areas that contain disseminated sulfides are north and south of Crater Lake on West Maroon Creek and in the upper part of the Castle Creek drainage (fig. 3). These minor areas are not discussed further here.

\section{GEOLOGY}

The Elk Mountains are composed chiefly of a sequence of sandstone, siltstone, and conglomerate more than 2 miles thick. This sequence was deposited on the southwest side of the Eagle basin during late Paleozoic time. Most of the sedimentary rocks are red beds of the Maroon Formation of Pennsylvanian and Permian age. Small areas of older Pennsylvanian rocks are exposed locally, such as north of the disseminated sulfide deposit on Conundrum Creek (fig. 4), where sandstone and siltstone of the Gothic Formation of Langenheim (1952) and shale and limestone of the Belden Formation crop out. Younger nonmarine and marine sedimentary rocks of Mesozoic age crop out locally in the eastern Elk Mountains and are widespread in the southwestern Elk Mountains.

The Sawatch Range to the east was uplifted in Late Cretaceous time, and most of the upper Paleozoic rocks and several thousand feet of Mesozoic rocks may have slid southwestward along the Elk Range thrust at their base. The rocks of the Gothic Formation and Belden Formation on Conundrum Creek occur in a structurally complex area, which has been interpreted as a window through that glide sheet (Bryant, 1966).

In Oligocene time, about $35 \mathrm{~m} . \mathrm{y}$. (million years) ago, granodiorite magma invaded the rocks of the glide sheet; in part the magma was injected along bedding planes or along faults at the base of the glide sheet and in part it was intruded discordantly. In consequence, two somewhat contrasting plutons were formed: (1) the generally concordant Snowmass pluton which has only a narrow halo of contact metamorphism and which lacks disseminated sulfide deposits, and (2) the irregularly shaped partly discordant White Rock pluton, which has a wide halo of contact metamorphism and which locally contains abundant disseminated sulfide deposits (figs. $2,3)$. Numerous dikes and sills are associated with the White Rock pluton. Some high-angle faulting accompanied emplacement of both plutons. Adjacent to the White Rock pluton, red beds of the Maroon Formation were widely changed to gray and greenish-gray calc-silicate hornfels of the hornblende hornfels facies; the metamorphic halo ranges in thickness from a few hundred feet to at least several thousand feet, and in places it extends laterally as much as 2 miles from the intrusive 


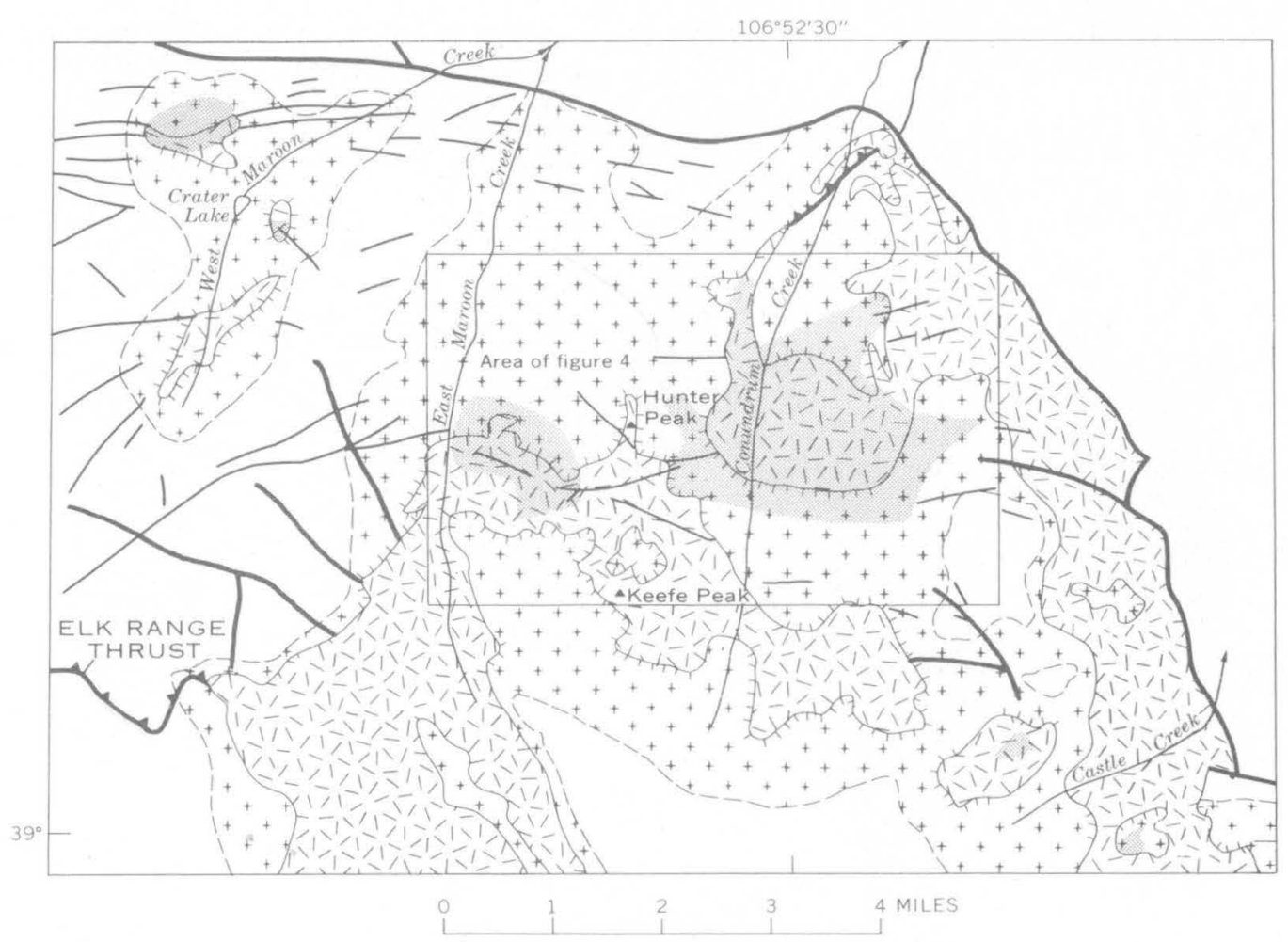

EXPLANATION

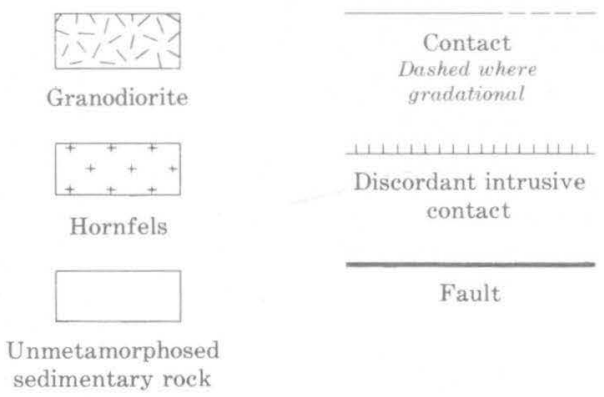

Figure 3.-Map of the eastern Elk Mountains, showing location of disseminated sulfide deposits in relation to Tertiary intrusives and areas of contact metamorphism.

contact (fig. 3). The distribution of hornfels suggests that the numerous irregular intrusives may be connected at depth and could be cupolas of a batholith or laccolith underlying as much as 80 square miles.

After the granodiorite of the White Rock pluton cooled to a temperature low enough to allow fractures to form, dikes and small irregular bodies of porphyritic granodiorite were intruded. Biotite from one sample of this rock type became a closed system 32 m.y. ago (Obradovich and others, 1969).

\section{ALTERATION AND SULFIDE MINERALIZATION}

Hydrothermal activity followed emplacement of the porphyritic granodiorite, and the hornfels, granodiorite, and porphyritic granodiorite were all pyritized in one place or another.
Most of the pyritized rock is not altered, and in the granodiorite, in particular, the biotite and plagioclase remained fresh. Locally, however, the granodioritic rocks have been highly fractured and altered. The pyrite forms coatings along fractures and to a lesser extent is disseminated in the rock. Locally small amounts of chalcopyrite or molybdenite occur with the pyrite. Sulfur must have been introduced; iron could have been derived from magnetite, although some magnetite remains in the rock.

Pyrite is the principal sulfide. Chalcopyrite and molybdenite can rarely be identified megascopically except in areas of highly altered rock, where they are irregularly distributed. Molybdenite is most conspicuous in molybdenite-pyrite-quartz veins and veinlets.

Along Cataract Creek, alteration was concentrated along 


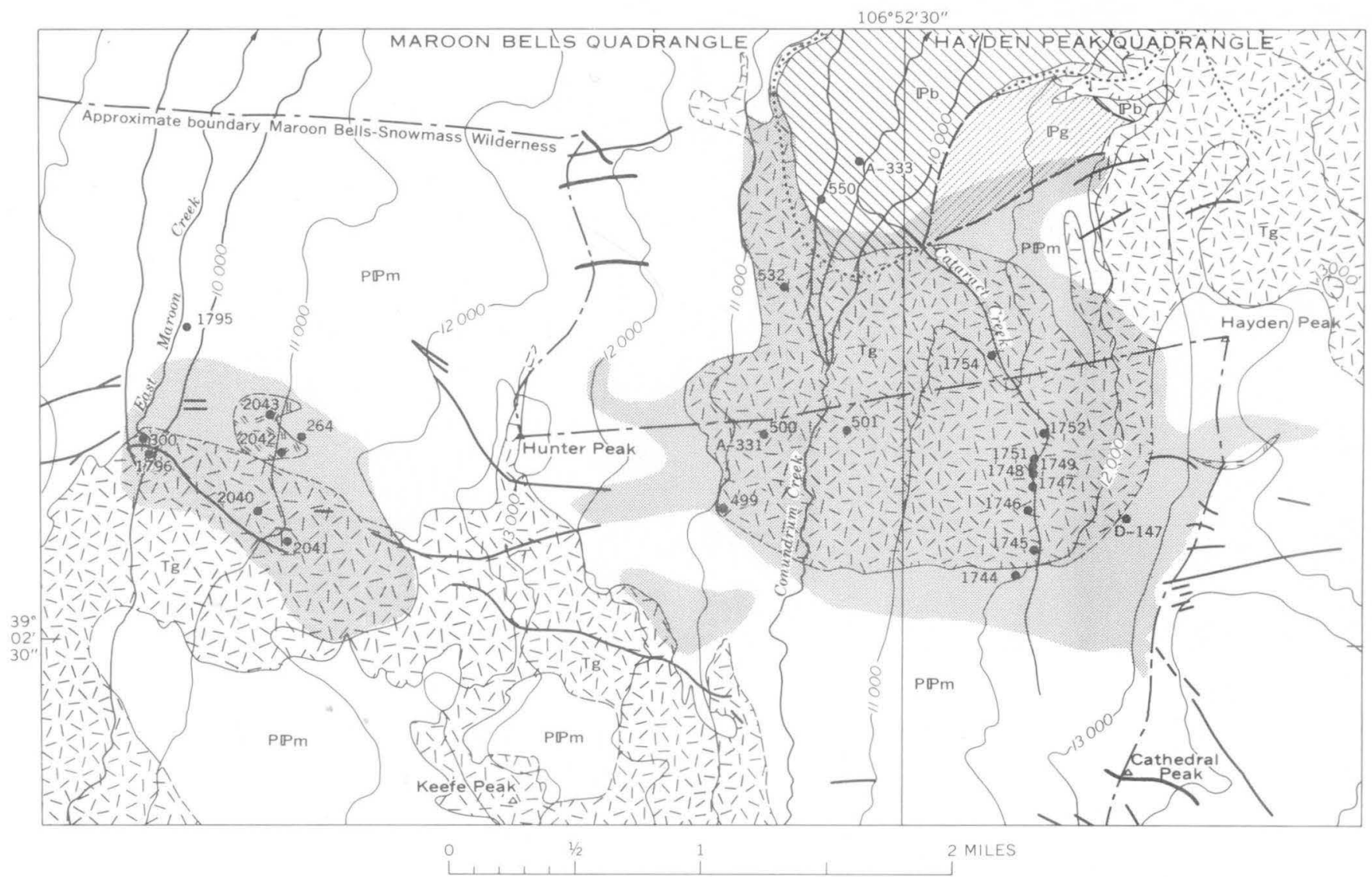

EXPLANATION
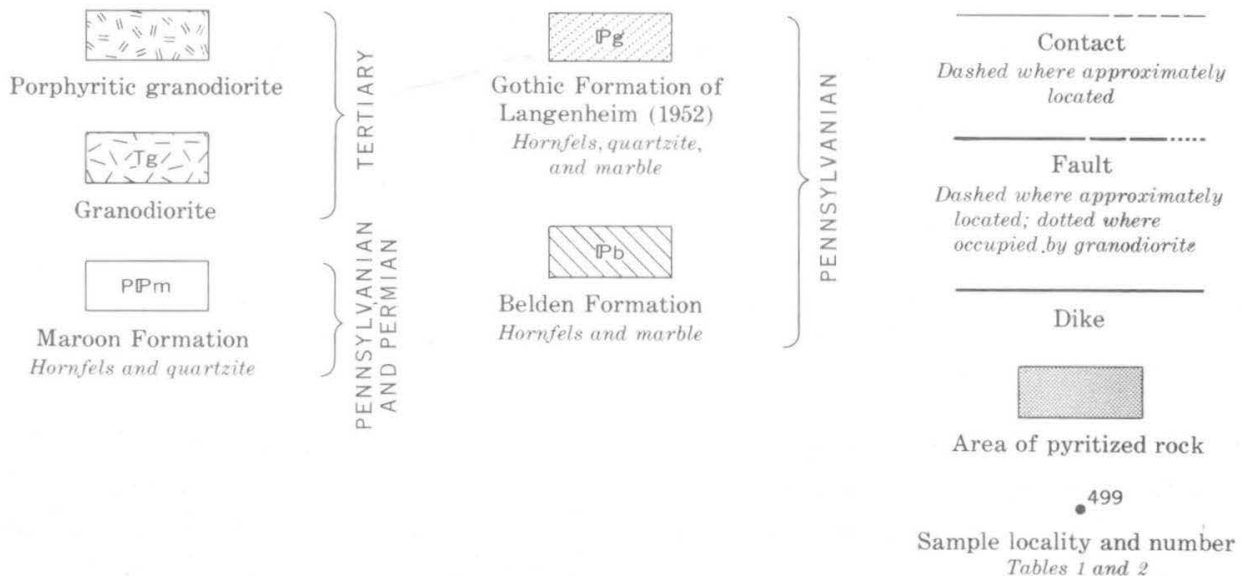

Figure 4.-Map of disseminated sulfide deposits in eastern Elk Mountains, showing location of analyzed samples. Contour interval 1,000 feet. Base from U.S. Geol. Survey Maroon Bells and Hayden Peak quadrangles, 1960, 1:24,000.

east-west-trending fracture zones, and it formed zones of altered rock a few feet to a few tens of feet thick. These fractures apparently controlled the alteration, and they are nearly parallel with the trends of the dikes of porphyritic granodiorite which cut granodiorite and hornfels in the area.

Small veins in and adjacent to the pyritized area contain abundant pyrite and lesser chalcopyrite. Many thin shear zones were intensely altered and pyritized and some of these were prospected in the past. At least one thin vein on the west side of the Conundrum Creek valley carries high silver values. Although considerable developmental work was done on that vein between 1880 and 1910, I have found no record of production.

The crosscuting irregularities of the White Rock pluton allowed a wider distribution of high temperatures to produce contact metamorphic rocks than did the generally concordant 
roof of the Snowmass pluton. These same irregularities may have been a factor in a more intense later fracturing of granodiorite and hornfels and attendant circulation of hydrothermal solutions in and adjacent to the White Rock pluton compared with the Snowmass pluton.

\section{PETROGRAPHIC AND ANALYTIC DATA}

Suites of representative samples were collected from the most altered and pyritized rocks in the eastern Elk Mountains, where well exposed in postglacial gorges of Cataract Creek and a tributary of East Maroon Creek, and from float of the porphyritic granodiorite body near East Maroon Creek. The samples were studied in thin and polished section and analyzed spectrographically (tables 1 and 2). In addition, J. H. McCarthy, Jr., of the U.S. Geological Survey, and I, in connection with heavy-metals investigations, collected several samples from the dumps of some workings on a silver-bearing vein west of Conundrum Creek. No petrographic information is available for those samples other than hand-specimen description, but they are included because of their interest. These samples all have field numbers with an " $A$ " prefix. I thank Mr. McCarthy for permission to use these analyses.

The parts of some samples analyzed spectrographically when compared with polished surface from another part of the same sample show discrepancies in molybdenum content. (For examples see samples 27 and 43, tables 1 and 2.) These discrepancies probably indicate the irregular distribution of molybdenite in the samples.

Spectrographic analyses of 54 samples of rock containing disseminated sulfides or from veins from 25 localities are given in table 1. Petrographic data from 26 of the samples, all of them granodiorite or porphyritic granodiorite, are given in table 2. For comparison, spectrographic analyses of nine samples of ordinary granodiorite (samples 1-9) are given in table 1, and petrographic data for six of them (samples 1, 2, 5, $6,7,8$ ) are given in table 2 . At some sample localities the rock was altered to different degrees over short distances (for example, samples $1.9,31 ; 20,32 ; 28,29,30,42)$. Obviously sample coverage is of a reconnaissance nature with emphasis on areas of well-exposed, unweathered rock.

\section{INTRUSIVE ROCKS}

Most of the rock in the White Rock pluton has an hypidiomorphic granular to microporphyritic texture. Large porphyritic potassic feldspar phenocrysts are locally abundant, and in these places the rock resembles the porphyritic granodiorite described in the following paragraph. Plagioclase (40-60 percent) forms subhedral phenocrysts as much as $2-3$ millimeters long with normal and oscillatory zoning. Compositions range from andesine $\left(A_{n_{5}}\right)$ in the core to calcic oligoclase $\left(A n_{25}\right)$ in the rim. Quartz (15-30 percent) ranges from small grains in the groundmass, interstitial to plagioclase in part, to anhedral phenocrysts as much as $3 \mathrm{~mm}$ across.
Potassic feldspar (10-20 percent) generally occurs as groundmass and interstitial grains. Locally it forms porphyroblasts that replace quartz and plagioclase. Brown biotite (5 percent) forms anhedral to euhedral phenocrysts $0.5-2 \mathrm{~mm}$ in diameter. Hornblende is only a minor constituent in most of the granodiorite near the pyritized areas, but locally it forms as much as 5 percent of the rock as subhedral to euhedral phenocrysts. Augite is an even less common mafic mineral. Accessory minerals are apatite, sphene, zircon, and magnetite. Secondary chlorite and epidote occur locally.

The porphyritic granodiorite is similar to the granodiorite except that the porphyritic granodiorite contains phenocrysts of potassic feldspar as much as 7 centimeters long and a finer grained groundmass. It contains quartz, plagioclase, hornblende, and biotite phenocrysts of a size similar to those in the equigranular granodiorite.

\section{ALTERED ROCKS}

Two types of altered rocks were seen in the area studied: (1) rock formed by albitization was the dominant type in the Cataract Creek area, and (2) rock formed by silicification and sericitization was dominant in the East Maroon Creek area.

In partly altered granodiorite the original textures are preserved, but the feldspar is partly to completely sericitized or albitized. Biotite is altered to chlorite in sericitized areas and is absent in albitized areas.

In more completely albitized rock the albite replacing the phenocrysts recrystallized into somewhat smaller grains. The most completely albitized rocks are composed of albite and quartz and a minor amount of sericite. Quartz was introduced in the silicified and sericitized rocks, and it forms veins, locally with sericite and sulfides. The highest degree of alteration of this type results in a rock consisting largely of quartz and sericite.

In the altered rocks magnetite is partly to completely altered to maghemite and hematite.

The distribution of alteration and mineralization apparently was partly controlled by fractures and shear zones. On Cataract Creek some of the strongly albitized rock shows evidence of cataclasis in thin section, probably indicating that fracturing continued during or after alteration. Numerous tiny molybdenum-bearing quartz veins are fracture controlled. Outside the areas of altered rock the granodiorite is very fractured, and pyrite is concentrated along the fractures.

\section{GEOCHEMISTRY}

Pyritization of granodiorite and hornfels was accompanied by some local enrichment in copper and molybdenum (fig. 5, table 1). These elements are most abundant in significantly altered rocks, but even in the most highly altered rocks concentrations of present economic grade are very sparse. Molybdenum is more abundant in highly altered rocks, whereas copper is more abundant in partly altered rocks. 
[Explanation of symbols: $N$, element looked for but not found; leaders (...), element not determined; $L$, element is present in undetermined amount below sensitivity limit; $M$, element present in amount $>10$ percent. Sensitivity of analy tical method not shown because analyses were done at several different time

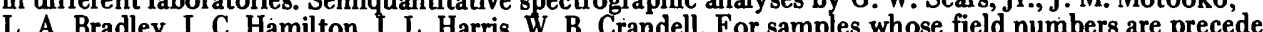

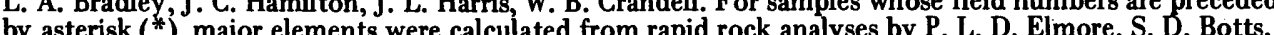
$G$. W . semiquantitative spectrographic analyses). Gold analyses by J. A. Thomas, G. D. Shipley, E. Martinez,

R. L. Miller, J. G. Frisken, and J. B. McHugh]

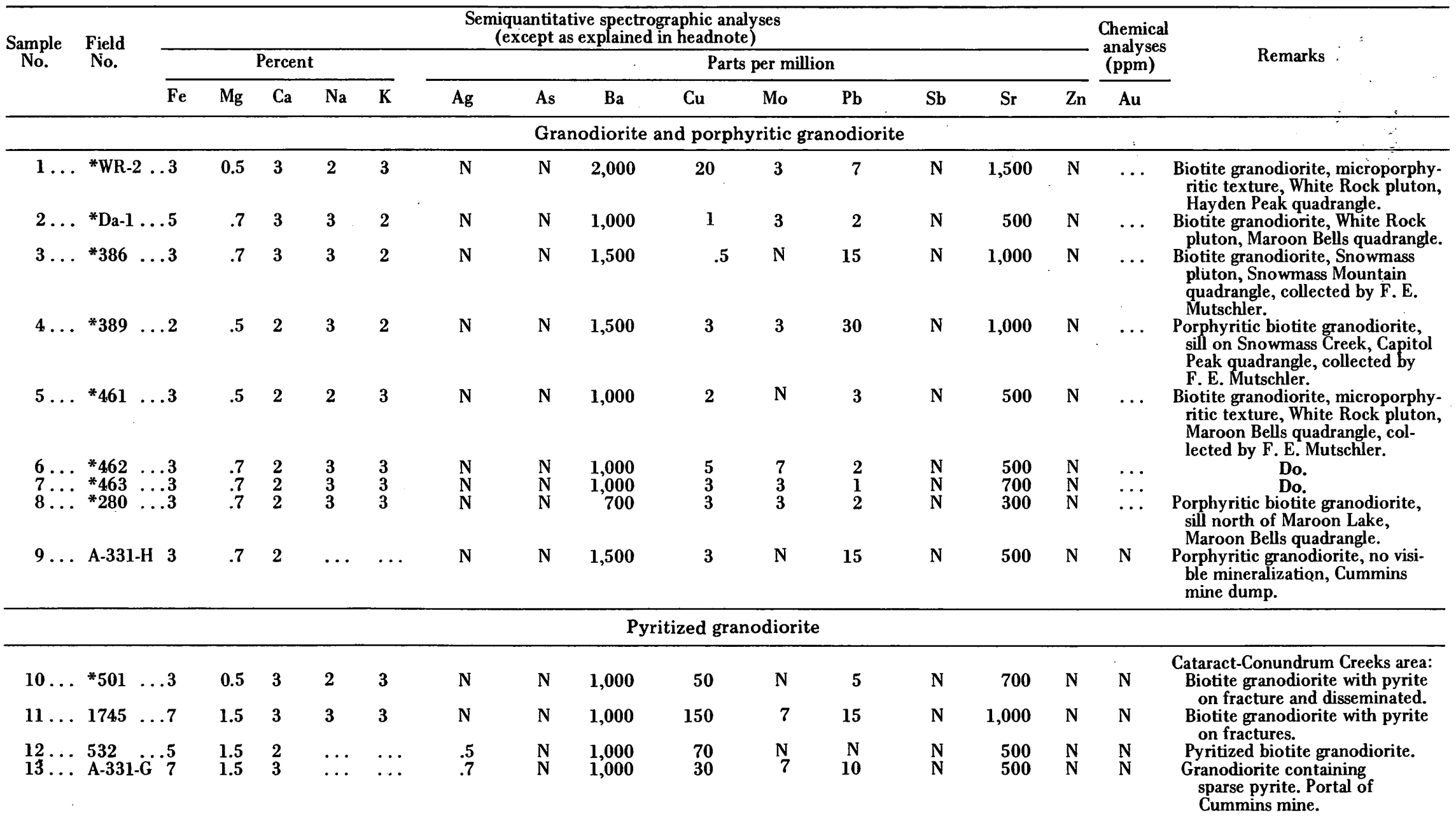




\begin{tabular}{|c|c|c|c|c|c|c|c|c|c|c|c|c|c|c|c|c|c|}
\hline \multirow{3}{*}{$\begin{array}{l}\text { Sample } \\
\text { No. }\end{array}$} & \multirow{3}{*}{$\begin{array}{l}\text { Field } \\
\text { No. }\end{array}$} & \multicolumn{14}{|c|}{$\begin{array}{l}\text { Semiquantitative spectrographic analyses } \\
\text { (except as explained in headnote) }\end{array}$} & \multirow{3}{*}{$\begin{array}{l}\begin{array}{l}\text { Chemical } \\
\text { analyses } \\
\text { (ppm) }\end{array} \\
\mathrm{Au}\end{array}$} & \multirow{3}{*}{ Remarks } \\
\hline & & \multicolumn{5}{|c|}{ Percent } & \multicolumn{9}{|c|}{ Parts per million } & & \\
\hline & & $\mathrm{Fe}$ & $\mathbf{M g}$ & $\mathrm{Ca}$ & $\mathrm{Na}$ & $\mathbf{K}$ & $\mathbf{A g}$ & As & $\mathbf{B a}$ & $\mathbf{C u}$ & Mo & $\mathbf{P b}$ & $\mathbf{S b}$ & $\mathrm{Sr}$ & $\mathrm{Zn}$ & & \\
\hline \multicolumn{18}{|c|}{ Pyritized granodiorite- Continued } \\
\hline $14 \ldots$ & A-331-I & $\mathbf{3}$ & 0.7 & 2 & ... & $\cdots$ & 0.7 & $\mathrm{~N}$ & 2,000 & 100 & $\mathbf{N}$ & 50 & $\mathbf{N}$ & 700 & $\mathbf{N}$ & $\mathbf{N}$ & $\begin{array}{l}\text { Granodiorite with disseminated } \\
\text { pyrite. Portal of Cummins } \\
\text { mine. }\end{array}$ \\
\hline $15 \ldots$ & A-331-N & 3 & .7 & 1.5 & $\cdots$ & $\cdots$ & 1.5 & $\mathbf{N}$ & 1,500 & 15 & 50 & 20 & $\mathbf{N}$ & 300 & $\mathbf{N}$ & $\mathbf{N}$ & $\begin{array}{l}\text { Pyritized granodiorite with silver } \\
\text { gray mineral on fracture. Dump } \\
\text { of Cummins mine. }\end{array}$ \\
\hline $\begin{array}{l}16 \ldots \\
17 \ldots\end{array}$ & $\begin{array}{l}1796 \mathrm{a} \ldots \\
2042 \mathrm{a} .\end{array}$ & & $\begin{array}{r}0.7 \\
.5\end{array}$ & $\begin{array}{l}3.7 \\
.7\end{array}$ & $\begin{array}{l}3 \\
\mathbf{3}\end{array}$ & $\begin{array}{l}3 \\
5\end{array}$ & $\underset{\mathbf{N}}{\mathbf{N}}$ & $\stackrel{N}{N}$ & $\begin{array}{l}1,500 \\
1,000\end{array}$ & $\begin{array}{r}150 \\
20\end{array}$ & $\begin{array}{r}15 \\
150\end{array}$ & $\begin{array}{l}15 \\
20\end{array}$ & $\stackrel{N}{N}$ & $\begin{array}{l}500 \\
700\end{array}$ & $\begin{array}{l}\mathbf{N} \\
\mathbf{N}\end{array}$ & $\begin{array}{l}\mathbf{N} \\
\mathbf{N}\end{array}$ & $\begin{array}{l}\text { East Maroon Creek: } \\
\text { Pyritized biotite granodiorite. } \\
\text { Pyritized porphyritic granodio- } \\
\text { rite containing quartz veinlet } \\
\text { and molvbdenite }\end{array}$ \\
\hline $18 \ldots$ & $300 \ldots$ & & 1 & 1 & ... & $\ldots$ & $\mathbf{N}$ & $\mathbf{N}$ & 1,500 & 50 & 5 & 10 & $\mathbf{N}$ & 500 & $\mathbf{N}$ & 0.3 & $\begin{array}{l}\text { Pyritized porphyritic granodio- } \\
\text { rite dike cutting granodiorite. }\end{array}$ \\
\hline \multicolumn{18}{|c|}{ Pyritized, partly altered granodiorite } \\
\hline $19 \ldots$ & $1746 \mathrm{a} \ldots$ & & 0.07 & 0.3 & 5 & 0.7 & $\mathbf{N}$ & $\mathbf{N}$ & 300 & 30 & 200 & $\mathbf{N}$ & $\mathbf{N}$ & 150 & $\mathbf{N}$ & $\mathbf{N}$ & $\begin{array}{l}\text { Cataract-Conundrum Creeks area: } \\
\text { Altered granodiorite with dissem- } \\
\text { inated pyrite and molybdenite. }\end{array}$ \\
\hline $20 \ldots$ & $1747 a \ldots$ & .1 .5 & .7 & .7 & 5 & 1.5 & $\mathbf{N}$. & $\mathbf{N}$ & 300 & 70 & 30 & $\mathbf{N}$ & $\mathbf{N}$ & 200 & $\mathbf{N}$ & $\mathbf{N}$ & $\begin{array}{l}\text { Altered granodiorite with relict } \\
\text { texture; pyrite on fractures. }\end{array}$ \\
\hline $21 \ldots$ & $1748 \mathrm{a} \ldots$ & & 1 & 1.5 & 7 & .7 & $\mathrm{~N}$ & $\mathrm{~N}$ & 150 & 700 & 150 & $\mathrm{~N}$ & $\mathrm{~N}$ & 200 & $\mathrm{~N}$ & $\mathbf{N}$ & $\begin{array}{l}\text { Altered granodiorite with pyrite, } \\
\text { chalcopyrite, and molybdenite. }\end{array}$ \\
\hline $\begin{array}{l}22 \ldots \\
23 \ldots\end{array}$ & $\underset{A-331-B}{1752 a}$ & .3 & $.1^{.7}$ & $\begin{array}{l}1.5 \\
1.5\end{array}$ & $\begin{array}{l}5 \\
\cdots\end{array}$ & $\begin{array}{l}3 \\
\cdots\end{array}$ & $\stackrel{N}{N}$ & $\stackrel{N}{N}$ & $\begin{array}{r}200 \\
1,500\end{array}$ & $\begin{array}{r}150 \\
10\end{array}$ & $\begin{array}{r}70 \\
5\end{array}$ & $\begin{array}{l}30 \\
15\end{array}$ & $\begin{array}{l}\mathbf{N} \\
\mathbf{N}\end{array}$ & $\begin{array}{l}300 \\
300\end{array}$ & $\stackrel{\mathbf{N}}{\mathbf{N}}$ & $\stackrel{N}{N}$ & $\begin{array}{l}\text { Partly altered granodiorite. } \\
\text { Incipiently al tered granodiorite } \\
\text { with disseminated pyrite. }\end{array}$ \\
\hline $24 \ldots$ & A-331-J & 2 & .7 & 1.5 & $\ldots$ & $\ldots$ & $\mathrm{N}$ & $\mathbf{N}$ & 1,500 & 15 & 5 & 15 & $\mathrm{~N}$ & 15 & $\mathbf{N}$ & $\mathrm{N}$ & $\begin{array}{l}\text { Partly altered granodiorite } \\
\text { with disseminated pyrite. }\end{array}$ \\
\hline $25 \ldots$ & A-331 $\ldots$ & .3 & 1 & 2 & $\ldots$ & $\ldots$ & $\mathbf{N}$ & $N$ & 700 & 3 & $\mathbf{N}$ & 10 & $\mathrm{~N}$ & 300 & $\mathbf{N}$ & $\mathrm{N}$ & $\begin{array}{l}\text { Partly altered granodiorite with } \\
\text { pyrite on fractures and } \\
\text { disseminated. }\end{array}$ \\
\hline $26 \ldots$ & $2040 \mathrm{a} \ldots$ & & 1 & 3 & 3 & 3 & $\mathbf{N}$ & $\mathbf{N}$ & 1,500 & 500 & 20 & 20 & $\mathrm{~N}$ & 1,000 & $\mathbf{N}$ & $\mathrm{N}$ & $\begin{array}{l}\text { East Maroon Creek: } \\
\text { Slightly altered and pyritized } \\
\text { granodiorite. }\end{array}$ \\
\hline $27 \ldots$ & 2040 b. . & & 1 & .7 & 3 & 3 & $\mathbf{N}$ & $\mathbf{N}$ & 1,000 & 100 & 50 & 10 & $\mathrm{~N}$ & 500 & $\mathbf{N}$ & $\mathbf{N}$ & $\begin{array}{l}\text { Altered granodiorite containing } \\
\text { quartz veins. }\end{array}$ \\
\hline $28 \ldots$ & 2041a ... & & .7 & 2 & 2 & 3 & $\mathbf{N}$ & $\mathrm{N}$ & 1,500 & 300 & 5 & 15 & $\mathbf{N}$ & 500 & $\mathbf{N}$ & $\mathbf{N}$ & $\begin{array}{l}\text { Somewhat altered pyritized } \\
\text { granodiorite. }\end{array}$ \\
\hline $29 \ldots$ & 2041b.... & & .5 & .5 & 2 & 5 & $\mathbf{N}$ & $\mathbf{N}$ & 1,000 & 200 & 100 & $\mathbf{N}$ & $\mathrm{N}$ & 200 & $\mathbf{N}$ & $\mathbf{N}$ & $\begin{array}{l}\text { Partly altered and pyritized } \\
\text { granodiorite containing pyrite, } \\
\text { quartz sericite veinlet. }\end{array}$ \\
\hline $30 \ldots$ & 2041c ... & & .5 & .7 & 2 & 5 & $\mathrm{~N}$ & $\mathbf{N}$ & 1,000 & 200 & 20 & $\mathbf{N}$ & $\mathbf{N}$ & 300 & $\mathbf{N}$ & $\mathbf{N}$ & $\begin{array}{l}\text { Partly altered and pyritized } \\
\text { granodiorite. }\end{array}$ \\
\hline
\end{tabular}


Table 1.-Analyses of granodiorite, pyritized granodiorite and hornfels, altered granodiorite, and associated veins

[Explanation of symbols: $N$, element looked for but not found; leaders (...), element not determined; $L$, element is present in undetermined amount below sensitivity limit; $M$, element present in amount $>10$ percent. Sensitivity of analytical method not shown because analyses were done at several different times

in different laboratories. Semiquantitative spectrographic analyses by G. W. Sears, J ., J. M. Motooko,

Ly A. Brask (*) major elements were calculated from rapid rock analyses by P. L. D. Elmore, S. D. Botts,

G. W. Chloe, H. Smith, James Kelsey, Lowell Artis, and J. L. Glenn (figures rounded off to nearest step of

semiquantative spectro

R. L. Miller, J. G. Frisken, and J. B. McHugh]

\begin{tabular}{|c|c|c|c|c|c|c|c|c|c|c|c|c|c|c|c|c|c|}
\hline \multirow{3}{*}{$\begin{array}{l}\text { Sample } \\
\text { No. }\end{array}$} & \multirow{3}{*}{$\begin{array}{l}\text { Field } \\
\text { No. }\end{array}$} & \multicolumn{14}{|c|}{$\begin{array}{c}\text { Semiquantitative spectrographic analyses } \\
\text { (except as explained in headnote) }\end{array}$} & \multirow{3}{*}{$\begin{array}{c}\begin{array}{c}\text { Chemical } \\
\text { analyses } \\
(\mathrm{ppm})\end{array} \\
\mathrm{Au}\end{array}$} & \multirow{3}{*}{ Remarks } \\
\hline & & \multicolumn{5}{|c|}{ Percent } & \multicolumn{9}{|c|}{ Parts per million } & & \\
\hline & & $\mathbf{F e}$ & $\mathbf{M g}$ & $\mathrm{Ca}$ & $\mathrm{Na}$ & $\mathrm{K}$ & Ag & As & $\mathbf{B a}$ & $\mathrm{Cu}$ & Mo & $\mathrm{Pb}$ & $\mathbf{S b}$ & $\mathrm{Sr}$ & Zn & & \\
\hline \multicolumn{18}{|c|}{ Pyritized altered granodiorite } \\
\hline $31 \ldots$ & $1746 \mathrm{~b}$ & & 0.15 & 0.3 & 5 & 1.5 & $\mathbf{N}$ & $\mathbf{N}$ & 300 & 15 & $\mathbf{3 0}$ & $\mathbf{N}$ & $\mathbf{N}$ & 150 & $\mathbf{N}$ & $\mathbf{N}$ & $\begin{array}{l}\text { Cataract-Conundrum Creeks area: } \\
\text { Altered granodiorite with dissem- } \\
\text { inated pyrite. }\end{array}$ \\
\hline $32 \ldots$ & $1747 \mathrm{~b} \ldots$ & & .5 & .7 & 5 & 1.5 & $\mathbf{N}$ & $\mathbf{N}$ & 300 & 15 & 2,000 & $\mathbf{N}$ & $\mathbf{N}$ & 200 & $\mathbf{N}$ & $\mathbf{N}$ & $\begin{array}{l}\text { Altered granodiorite with dissem- } \\
\text { inated molybdenite. }\end{array}$ \\
\hline $\begin{array}{l}33 \ldots \\
\mathbf{3 4} \ldots\end{array}$ & $\begin{array}{l}1749 a \\
1751 \ldots\end{array}$ &. .5 & $\begin{array}{l}.07 \\
.3\end{array}$ & $\begin{array}{l}.5 \\
.7\end{array}$ & 7 & $\mathrm{~N}_{.7}$ & $\begin{array}{l}\mathbf{N} \\
\mathbf{N}\end{array}$ & $\stackrel{\mathbf{N}}{\mathbf{N}}$ & $\begin{array}{r}100 \\
70\end{array}$ & $\begin{array}{r}3 \\
5,000\end{array}$ & $\stackrel{\mathbf{N}}{\mathbf{N}}$ & $\stackrel{N}{N}$ & $\stackrel{\mathbf{N}}{\mathbf{N}}$ & $\begin{array}{l}150 \\
150\end{array}$ & $\stackrel{\mathbf{N}}{\mathbf{N}}$ & $\stackrel{\mathbf{N}}{\mathbf{N}}$ & $\begin{array}{l}\text { Very altered granodiorite. } \\
\text { Altered granodiorite with chal- } \\
\text { copyrite and pyrite on } \\
\text { fractures and disseminated. }\end{array}$ \\
\hline $\begin{array}{l}35 \ldots \\
36 \ldots\end{array}$ & $\begin{array}{l}1752 b \ldots \\
1754 \ldots\end{array}$ & $\begin{array}{l}.3 \\
.1 .5\end{array}$ & .15 & .15 & $\begin{array}{l}5 \\
7\end{array}$ & $\stackrel{\mathbf{N}}{\mathbf{N}}$ & $\stackrel{N}{N}$ & $\stackrel{\mathbf{N}}{\mathbf{N}}$ & $\begin{array}{l}30 \\
15\end{array}$ & $\begin{array}{l}\mathbf{3} \\
\mathbf{5}\end{array}$ & $\begin{array}{l}70 \\
10\end{array}$ & $\stackrel{\mathbf{N}}{\mathbf{N}}$ & $\underset{\mathbf{N}}{\mathbf{N}}$ & $\begin{array}{l}70 \\
70\end{array}$ & $\begin{array}{l}\mathbf{N} \\
\mathbf{N}\end{array}$ & $\stackrel{\mathbf{N}}{\mathbf{N}}$ & $\begin{array}{l}\text { Vuggy altered granodiorite. } \\
\text { Altered granodionite with pyrite } \\
\text { on fractures. }\end{array}$ \\
\hline $37 \ldots$ & A-331-A & 1.5 & .15 & .1 & $\cdots$ & ... & 7 & $\mathbf{N}$ & 3,000 & 15 & 7 & 50 & $\mathbf{N}$ & 70 & $\mathbf{N}$ & $\mathbf{N}$ & $\begin{array}{l}\text { Highly altered and silicified gran- } \\
\text { odionite with disseminated }\end{array}$ \\
\hline $38 \ldots$ & A-331-C & .7 & .07 & .02 & $\ldots$ & $\ldots$ & 500 & $\mathbf{N}$ & 30 & 1,500 & 100 & 3,000 & 1,000 & 5 & 7,000 & $\mathbf{N}$ & $\begin{array}{l}\text { Silicified granodiorite, quartz- } \\
\text { filled vugs, disseminated pyrite, } \\
\text { and other minerals. }\end{array}$ \\
\hline $\begin{array}{l}39 \ldots \\
40 \ldots\end{array}$ & $\begin{array}{l}\text { A-331-K } \\
\text { A-331-M }\end{array}$ & $\begin{array}{l}7 \\
\mathbf{3}\end{array}$ & $\begin{array}{l}.07 \\
.7\end{array}$ & $2^{.1}$ & $\cdots$ & $\cdots$ & ${ }^{\mathrm{N}} .5$ & $\underset{\mathbf{N}}{\mathbf{N}}$ & $\begin{array}{r}1,500 \\
500\end{array}$ & $\begin{array}{r}\mathbf{3} \\
\mathbf{3 0}\end{array}$ & $\mathbf{L}$ & $\begin{array}{l}15 \\
20\end{array}$ & $\underset{\mathbf{N}}{\mathbf{N}}$ & $\begin{array}{l}10 \\
70\end{array}$ & $\underset{\mathbf{N}}{\mathbf{N}}$ & $\stackrel{\mathbf{N}}{\mathbf{N}}$ & $\begin{array}{l}\text { Altered porphyritic granodiorite. } \\
\text { Altered pyritized granodiorite. }\end{array}$ \\
\hline $41 \ldots$ & $2040 \mathrm{c} \ldots$ & & .2 & .05 & 3 & 2 & $\mathbf{N}$ & $\mathbf{N}$ & 500 & 10 & 200 & $\mathbf{N}$ & $\mathbf{N}$ & 100 & $\mathbf{N}$ & $\mathbf{N}$ & $\begin{array}{l}\text { East Maroon Creek area: } \\
\text { Altered granodiorite with vuggy }\end{array}$ \\
\hline $42 \ldots$ & $\begin{array}{l}2041 d \ldots \\
2042 b \ldots\end{array}$ & & .3 & $\begin{array}{l}.02 \\
.05\end{array}$ & $3^{.5}$ & $\begin{array}{l}\mathbf{5} \\
\mathbf{2}\end{array}$ & $\stackrel{\mathbf{N}}{\mathbf{N}}$ & $\stackrel{\mathbf{N}}{\mathbf{N}}$ & $\begin{array}{l}\mathbf{7 0 0} \\
\mathbf{1 5 0}\end{array}$ & $\begin{array}{l}20 \\
10\end{array}$ & $\begin{array}{r}500 \\
1,000\end{array}$ & $\stackrel{\mathbf{N}}{\mathbf{N}}$ & $\stackrel{\mathbf{N}}{\mathbf{N}}$ & $\begin{array}{l}\mathbf{5 0} \\
\mathbf{5 0}\end{array}$ & $\underset{N}{N}$ & $\stackrel{\mathbf{N}}{\mathbf{N}}$ & $\begin{array}{l}\text { Silicified pyritized granodiorite. } \\
\text { Altered pyritized granodiorite } \\
\text { cut by quartz veins. }\end{array}$ \\
\hline $44 \ldots$ & $2042 c \ldots$ & & .1 & .05 & .7 & 2 & $\mathrm{~N}$ & $\mathrm{~N}$ & 100 & 10 & 1,500 & $\mathbf{N}$ & $\mathbf{N}$ & 10 & $\mathbf{N}$ & $\mathbf{N}$ & $\begin{array}{l}\text { Altered porphyritic granodiorite } \\
\text { with molybdenite quartz veins. }\end{array}$ \\
\hline $45 \ldots$ & 2042d... & . . .5 & .1 & .02 & .2 & 3 & $\mathbf{N}$ & $\mathbf{N}$ & 100 & 10 & 100 & $\mathbf{N}$ & $\mathrm{N}$ & 10 & $\mathbf{N}$ & $\mathbf{N}$ & $\begin{array}{l}\text { Altered and silicified porphyritic } \\
\text { granodiorite. }\end{array}$ \\
\hline
\end{tabular}


Table 1.-Analyses of granodiorite, pyritized granodiorite and hornfels, altered granodiorite, and associated veins in disseminated sulfide deposits of the eastern Elk Mountains, Colo. - Continued

\begin{tabular}{|c|c|c|c|c|c|c|c|c|c|c|c|c|c|c|c|c|c|}
\hline \multirow{3}{*}{$\begin{array}{l}\text { Sample } \\
\text { No. }\end{array}$} & \multirow{3}{*}{$\begin{array}{l}\text { Field } \\
\text { No. }\end{array}$} & \multicolumn{13}{|c|}{$\begin{array}{l}\text { Semiquantitative spectrographic analyses } \\
\text { (except as explained in headnote) }\end{array}$} & \multirow{2}{*}{\multicolumn{2}{|c|}{$\begin{array}{l}\text { Chemical } \\
\text { analyses } \\
\text { (ppm) }\end{array}$}} & \multirow{3}{*}{ Remarks } \\
\hline & & \multicolumn{5}{|c|}{ Percent } & \multicolumn{8}{|c|}{ Parts per million } & & & \\
\hline & & $\mathbf{F e}$ & $\mathrm{Mg}$ & $\mathrm{Ca}$ & $\mathrm{Na}$ & $\mathbf{K}$ & $\mathrm{Ag}$ & As & $\mathbf{B a}$ & $\mathbf{C u}$ & Mo & $\mathbf{P b}$ & $\mathrm{Sb}$ & Sr & $\mathrm{Zn}$ & $\mathrm{Au}$ & \\
\hline \multicolumn{18}{|c|}{ Veins and pyritized hornfels } \\
\hline $46 \ldots$ & $2042 \mathrm{e} \ldots 1$ & & .2 & .05 & 3 & 2 & $\mathrm{~N}$ & $\mathrm{~N}$ & 200 & 20 & 500 & $\mathbf{N}$ & $\mathbf{N}$ & 70 & $\mathbf{N}$ & $\mathbf{N}$ & $\begin{array}{l}\text { Altered porphyritic granodiorite } \\
\text { cut by quartz veinlets. }\end{array}$ \\
\hline $47 \ldots$ & $1796 \mathrm{~b} . . .1$ & & .5 & .03 & .3 & 3 & $\mathbf{N}$ & $\mathrm{N}$ & 1,000 & 10 & 15 & $\mathbf{N}$ & $\mathbf{N}$ & $\mathbf{5 0}$ & $\mathrm{N}$ & $\mathbf{N}$ & $\begin{array}{l}\text { Silicified, altered pyritized } \\
\text { granodiorite. }\end{array}$ \\
\hline $48 \ldots$ & D-147 $\ldots$ & & 5 & 1 & 3 & 7 & $\mathbf{N}$ & $\mathbf{N}$ & 700 & 30 & 200 & $\mathbf{N}$ & $\mathbf{N}$ & $\mathbf{3 0 0}$ & $\mathbf{N}$ & $\mathbf{N}$ & $\begin{array}{l}\text { Cataract-Conundrum Creeks area: } \\
\text { Pyritized hornfels, Maroon } \\
\text { Formation. }\end{array}$ \\
\hline $49 \ldots$ & $1744 \ldots$ & & 7 & $\mathbf{M}$ & 2 & $\mathbf{N}$ & $\mathrm{N}$ & $\mathrm{N}$ & 150 & 1,500 & 15 & $\mathbf{N}$ & $\mathbf{N}$ & 500 & $\mathrm{~N}$ & $\mathbf{N}$ & $\begin{array}{l}\text { Brecciated pyritized pyroxene } \\
\text { hornfels from prospect, Maroon } \\
\text { Formation. }\end{array}$ \\
\hline $50 \ldots$ & $499 \ldots$ & & 5 & 10 & $\ldots$ & $\cdots$ & 10 & $\mathbf{N}$ & 1,000 & 70 & 5 & 15 & $\mathbf{N}$ & 100 & $\mathbf{N}$ & $\mathbf{N}$ & $\begin{array}{l}\text { Pyritized hornfels, Maroon } \\
\text { Formation. }\end{array}$ \\
\hline $51 \ldots$ & $550 \ldots$. & & 10 & $\mathbf{M}$ & $\ldots$ & $\therefore$ & 1 & $\mathbf{N}$ & 20 & 300 & $\mathbf{N}$ & $\mathbf{N}$ & $\mathbf{N}$ & $\mathbf{N}$ & $\mathbf{N}$ & $\mathbf{N}$ & $\begin{array}{l}\text { Pyritized pyroxene hornfels from } \\
\text { Belden Formation. }\end{array}$ \\
\hline $52 .$. & A-333 $\ldots$ & & $\mathbf{M}$ & 7 & $\cdots$ & $\cdots$ & 15 & $\mathbf{N}$ & 300 & 50 & 20 & 15 & $\mathrm{~N}$ & 300 & $\mathrm{~N}$ & $\mathbf{N}$ & $\begin{array}{l}\text { Pyritized hornfels from prospect, } \\
\text { Belden Formation. }\end{array}$ \\
\hline $53 \ldots$ & A-331-E & 1 & .1 & .1 & $\ldots$ & $\cdots$ & 3,000 & 1,000 & 1,500 & 5,000 & 70 & 1,000 & 7,000 & 30 & 5,000 & 01.1 & $\begin{array}{l}\text { Silicified, vuggy granodiorite } \\
\text { with disseminated pyrite } \\
\text { and a veinlet of gray mineral. }\end{array}$ \\
\hline $54 \ldots$ & A-331-Q & .7 & .07 & .1 & $\cdots$ & $\cdots$ & 2,000 & 1,500 & 100 & 7,000 & 50 & 2,000 & 7,000 & 150 & 7,000 & $\begin{array}{ll}0 & .3\end{array}$ & $\begin{array}{l}\text { Altered granodiorite with quartz- } \\
\text { lined vugs and black mineral. }\end{array}$ \\
\hline $55 \ldots$ & A-331-R & .7 & .1 & .1 & $\cdots$ & $\cdots$ & 2,000 & 1,500 & 150 & 7,000 & 20 & 2,000 & 7,000 & 150 & 7,000 & $\begin{array}{ll}0 & .3\end{array}$ & $\begin{array}{l}\text { Altered pyritized granodiorite } \\
\text { with quartz vein containing } \\
\text { gray mineral and vugs. }\end{array}$ \\
\hline $56 \ldots$ & $500-B \ldots$ & 1.5 & .1 & .5 & $\cdots$ & $\cdots$ & 1,500 & 700 & 1,000 & 5,000 & 300 & 1,000 & 5,000 & 300 & 5,000 & 0 & $\begin{array}{l}\text { Quartz vein with disseminated } \\
\text { ore minerals. }\end{array}$ \\
\hline $\begin{array}{l}\mathbf{5 7} \ldots \\
\mathbf{5 8} \ldots \\
\mathbf{5 9} \ldots\end{array}$ & $\begin{array}{l}\text { A-331-L } \\
\text { A-331-D } \\
\text { A-331-F }\end{array}$ & $\begin{array}{l}.07 \\
.07 \\
.7\end{array}$ & $\begin{array}{l}.03 \\
.02 \\
.15\end{array}$ & $\begin{array}{l}.05 \\
.15 \\
.15\end{array}$ & $\begin{array}{l}\cdots \\
\cdots\end{array}$ & $\begin{array}{l}\cdots \\
\cdots\end{array}$ & $\stackrel{20}{2} .5$ & $\begin{array}{l}\mathbf{N} \\
\mathbf{N} \\
\mathbf{N}\end{array}$ & $\begin{array}{r}\mathbf{5 0} \\
\mathbf{3 0} \\
\mathbf{3 0 0}\end{array}$ & $\begin{array}{r}70 \\
7 \\
2\end{array}$ & $\begin{array}{r}\mathbf{5} \\
\mathbf{3} \\
\mathbf{N}\end{array}$ & $\begin{array}{l}50 \\
50\end{array}$ & $\begin{array}{l}\mathbf{N} \\
\mathbf{N} \\
\mathbf{N}\end{array}$ & $\begin{array}{r}\mathbf{7} \\
\mathbf{5} \\
\mathbf{3 0}\end{array}$ & $\begin{array}{l}\mathbf{5 0 0} \\
\mathbf{N} \\
\mathbf{N}\end{array}$ & $\begin{array}{l}\mathbf{N} \\
\mathbf{N}\end{array}$ & $\begin{array}{c}\text { Vuggy quartz vein with pyrite. } \\
\text { Barren quartz vein. } \\
\text { Do. }\end{array}$ \\
\hline $60 \ldots$ & $1795 a \ldots$ & & 7 & $\mathbf{M}$ & .3 & $\mathbf{N}$ & 2 & $\mathbf{N}$ & 5 & 3,000 & 20 & $\mathbf{N}$ & $\mathbf{N}$ & 20 & $\mathrm{~N}$ & $\mathbf{N}$ & $\begin{array}{l}\text { East Maroon Creek: } \\
\text { Magnetite-pyrite veins in horn- } \\
\text { fels, Maroon Formation, } \\
\text { from prospect. }\end{array}$ \\
\hline $61 \ldots$ & $\begin{array}{l}1795 b \ldots 1 \\
264 b \ldots\end{array}$ & $\begin{array}{l}\mathbf{M} \\
\mathbf{M}\end{array}$ & $\begin{array}{l}\mathrm{M} \\
\mathbf{3}\end{array}$ & $\begin{array}{l}\mathrm{M} \\
7\end{array}$ & 2 & $\begin{array}{l}\mathbf{N} \\
\cdots\end{array}$ & ${ }^{\mathrm{N}} .5$ & $\stackrel{\mathbf{N}}{\mathbf{N}}$ & $\begin{array}{r}30 \\
1,000\end{array}$ & $\begin{array}{r}1,000 \\
200\end{array}$ & $\begin{array}{r}N \\
1,000\end{array}$ & $\mathrm{~N}_{10}$ & $\begin{array}{l}\mathbf{N} \\
\mathbf{N}\end{array}$ & $\begin{array}{l}300 \\
200\end{array}$ & $\begin{array}{l}\mathbf{N} \\
\mathbf{N}\end{array}$ & $\mathrm{N}_{.3}$ & $\begin{array}{l}\text { Do. } \\
\text { Pyritized hornfels, Maroon } \\
\text { Formation. }\end{array}$ \\
\hline $63 \ldots$ & $1796 c \ldots$ & & .5 & .05 & .3 & 3 & $\mathbf{N}$ & $\mathbf{N}$ & 2,000 & 30 & 5 & $\mathbf{N}$ & $\mathbf{N}$ & 70 & $\mathbf{N}$ & $\mathbf{N}$ & $\begin{array}{l}\text { Quartz vein in altered, pyritized } \\
\text { granodiorite. }\end{array}$ \\
\hline
\end{tabular}


Table 2.-Estimated modes, in volume percent, of granodiorite, pyritized granodiorite, and altered granodiorite of table 1, for which data are available

[Leaders $(. .$.$) mean mineral is absent; P$ means mineral is present but in quantities $<1$

percent. Accessory minerals: a, apatite; $z$, zircon; s, sphene; al, allanite; $r$, rutile]

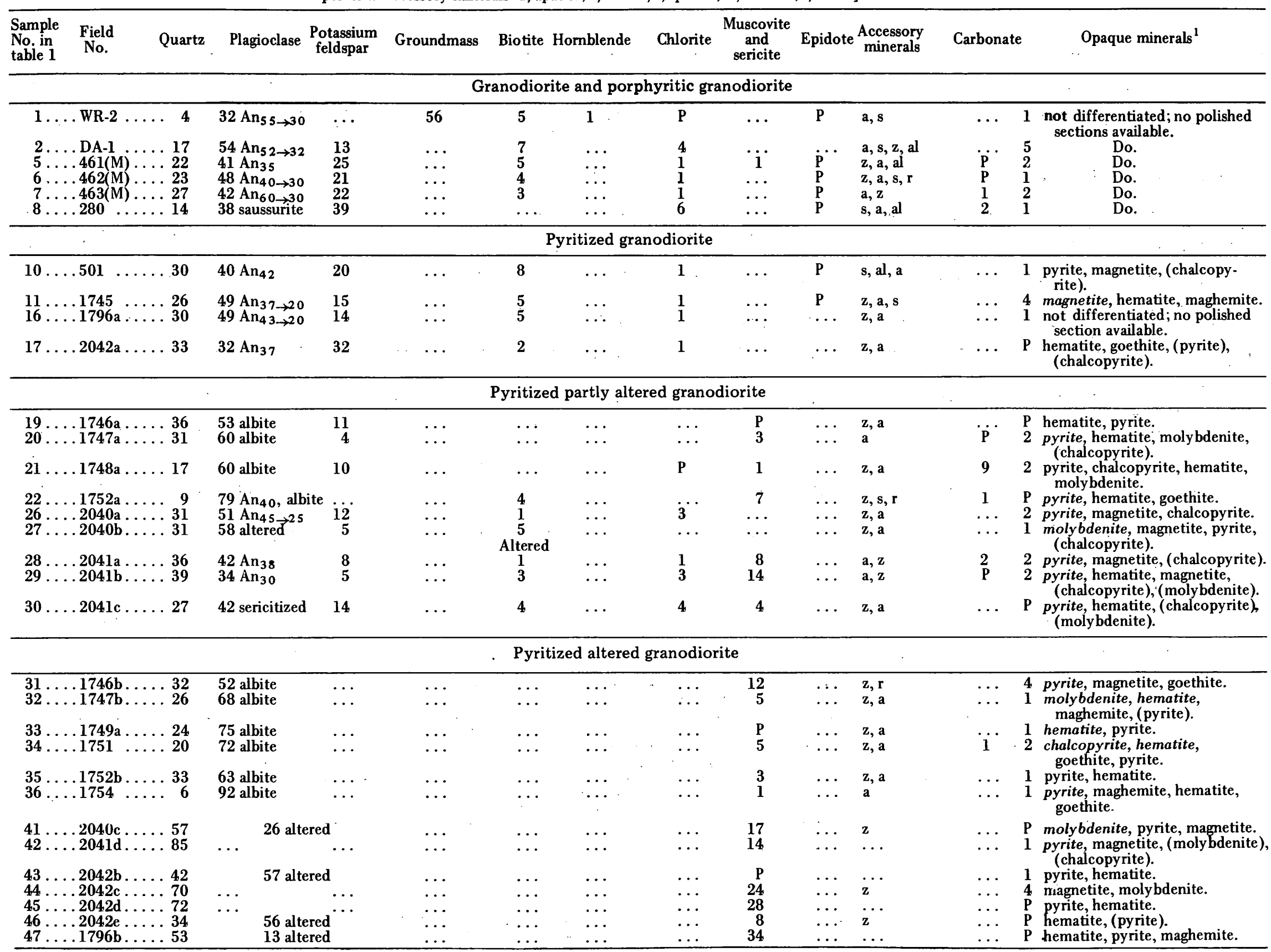

${ }^{1}$ Parentheses indicate mineral that is present only in trace amounts in polished section; italic indicates mineral that is present in greatest quantity. 

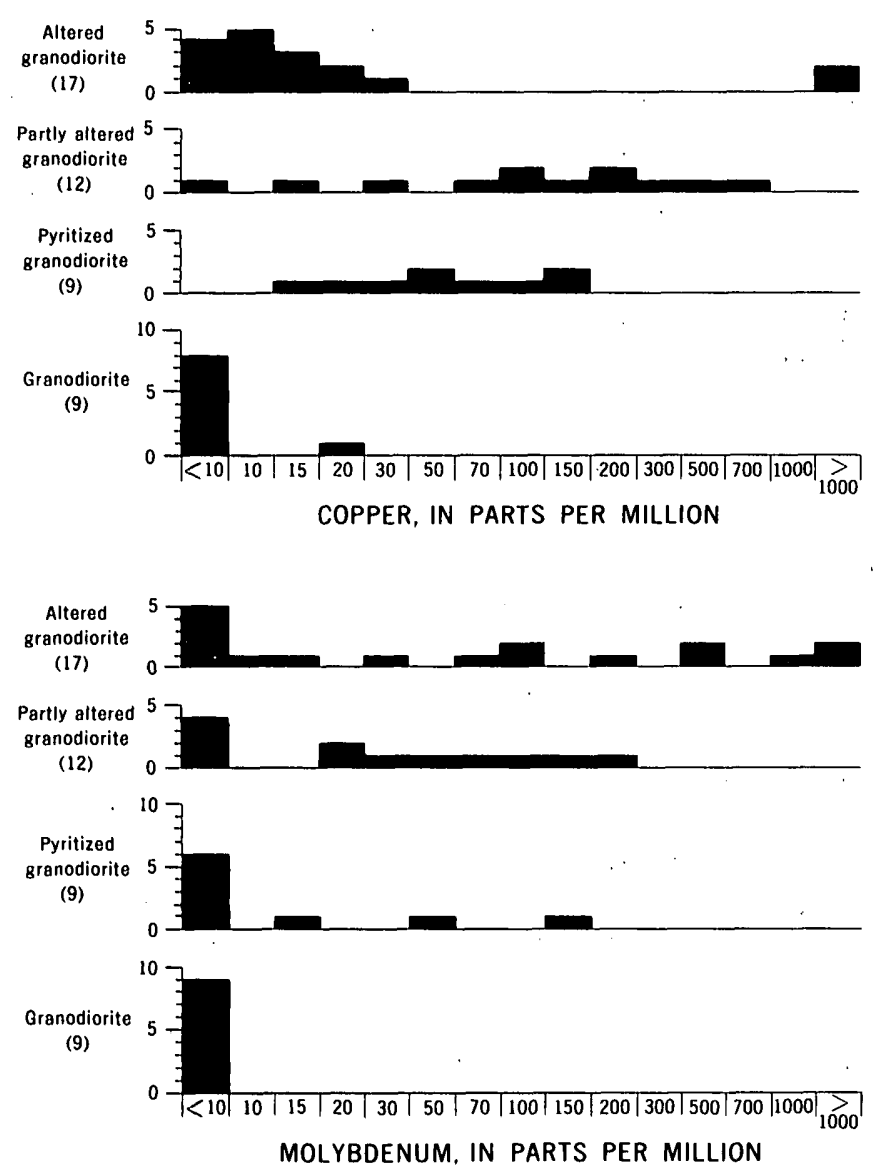

Figure 5.-Histogram of copper and molybdenum contents of granodiorite, pyritized granodiorite, partly altered pyritized granodiorite, and altered granodiorite as determined by semiquantitative spectrographic analysis. Number of analyses in parentheses.

Content of other metals was only slightly increased in either highly altered or partly altered rocks except near the silverbearing vein west of Conundrum Creek.

During alteration the granodiorite lost much magnesium, calcium, strontium, and barium, and some iron (fig. 6, table 1.). Mineralogically this is shown by the absence of biotite and chlorite and by the albitization, sericitization, or silicification of plagioclase without any concomitant increase in calcite or epidote. The loss of strontium was probably closely related to loss of calcium as both probably were closely associated in the original plagioclase. Where albitization occurred, sodium increased and potassium decreased, but where silicification and sericitization occurred, sodium decreased (fig. 7, table 1). Where silicification was extreme, potassium diminished.

Samples of the silver-bearing vein west of Conundrum Creek contain substantial amounts of copper, lead, zinc, antimony, and arsenic (table 1), which suggests that one or more sulfosalts may be present. Small amounts of gold were detected in the samples. Some granodiorite wallrock samples contain anomalous amounts of silver, and in sample 38, from outside a well-defined vein, gold, copper, lead, and zinc were
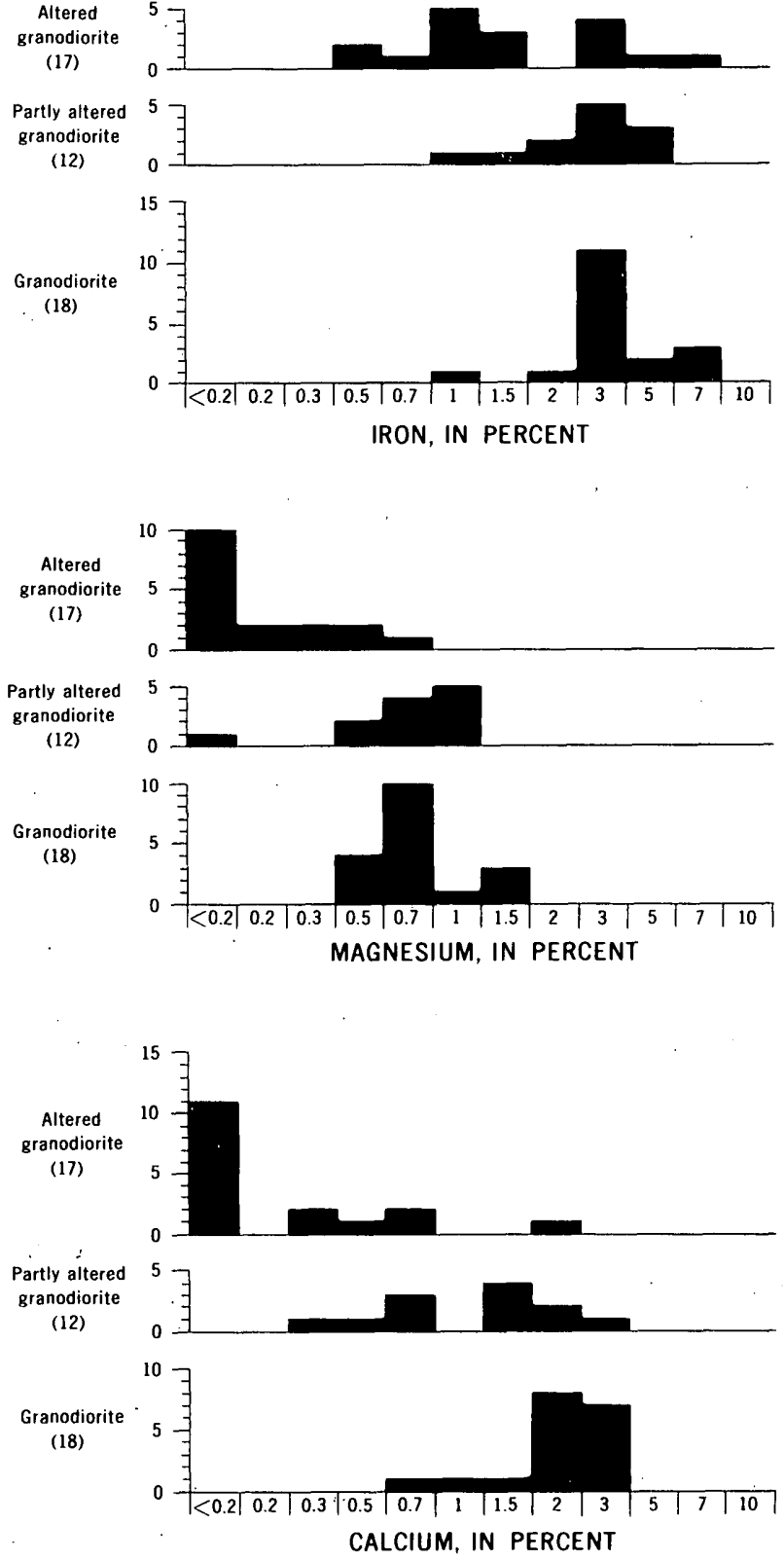

Figure 6.-Histogram of iron, magnesium, and calcium contents of granodiorite, partly altered granodiorite, and altered granodiorite as determined by semiquantitative spectrographic analysis. Number of analyses in parentheses.

detected. These analyses clearly indicate that ore-grade material is present along the vein; the limited data at hand, however, do not permit speculations on the width of the vein or tonnage of the ore present.

Pyritized hornfels and associated vein material locally contain anomalously high concentrations of copper and molybdenum and a few low concentrations of silver. None of the selected samples from veins other than the silver-bearing vein west of Conundrum Creek contain sufficient metal to be of economic interest at this time. 

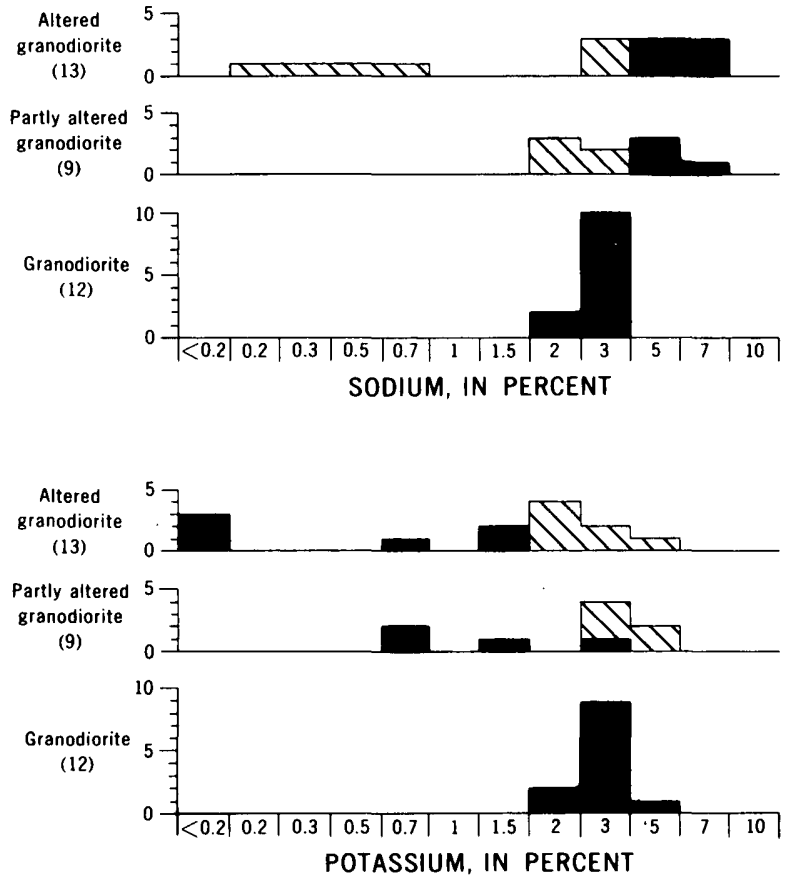

Figure 7.-Histogram of sodium and potassium contents of granodiorite, partly altered granodiorite, and altered granodiorite as determined by semiquantitative spectrographic analysis. Lined histograms represent analyses of samples from East Maroon Creek; solid, from the CataractConundrum Creeks area. Number of analyses in parentheses.

\section{DISCUSSION}

The outcropping disseminated sulfide deposits of the eastern Elk Mountains seem to be uneconomic at the present time, as judged on the basis of available data. On the surface only a small proportion of the granodiorite is intensely altered, and even in the intensely altered zones high metal values for molybdenum or copper ( $1,000 \mathrm{ppm}$ or more) were found in less than half the samples. This statistic is distinctly discouraging inasmuch as most samples were selected for their "high grade" aspect.

Producing molybdenum deposits in the region, such as Urad and Henderson in the Front Range, Climax in the Tenmile Range, and Questa in the Sangre de Cristo Range in New Mexico, occur in or near the margins of more silicic and potassic rocks that appear to be more differentiated than those found in the eastern Elk Mountains (Clark, 1968; Wallace, Mackenzie, and Blair, 1968; Wallace, Muncaster, and others, 1968). A few small dikes of aplitic alaskite occur in the granodiorite in the White Rock pluton, but they are so small and discontinuous that they seem better interpreted as the products of crystallization of small amounts of residual fluid from the exposed granodiorite rather than as indications of a larger, more differentiated mass at depth.

In the Paradise stock southwest of the eastern Elk Mountains, intensive quartz-sericite alteration and molybdenum mineralization are much more pervasive (F. E. Mutschler, written commun., 1968) than in the occurrences here discussed. Mappable dikes of aplitic alaskite are large and numerous (Gaskill and others, 1967), and suggest that the rocks here are more differentiated and that larger masses of more silicic and potassic material might be found at depth. Mutschler stated that in the altered rocks of the Paradise stock, hydrothermal alteration caused a loss of calcium, sodium, magnesium, and aluminum and a gain in silicon, potassium, sulfur, copper, lead, zinc, molybdenum, tungsten, and $\mathrm{CO}_{2}$. Although to date no mine has been developed at the Paradise deposit, these features suggest that it has more economic potential than do deposits of the eastern Elk Mountains.

Although the disseminated sulfide deposits are exposed over a vertical range of 3,000 feet, no systematic variations in altered rocks or distribution of metal with altitude were detected.

The boundaries of the sulfide-bearing rock are not everywhere sharp, but the map patterns of the pyritized areas in relation to the rugged topography suggest that they have steeply dipping contacts and thus may extend to some depth. Whether more differentiated rocks and possibly more intensely altered rocks and greater concentrations of metal occur at depth is very uncertain.

The shape of the White Rock pluton at depth is another factor to consider. Detailed mapping in the Maroon Bells and Hayden Peak quadrangles suggests that the pluton has a structurally lower contact that is approximately concordant, except where modified by faulting, with the Elk Range thrust zone (Bryant, 1969b, 1970). That contact contrasts with the partly concordant but also partly highly discordant structurally upper contact. If this interpretation is correct, the pluton cannot extend many thousands of feet below the valley bottoms. Such a configuration of the pluton would diminish chances for more differentiation, alteration, and metallization at depth.

\section{REFERENCES}

Bryant, Bruce, 1966, Possible window in the Elk Range thrust sheet near Aspen, Colorado, in Geological Survey Research 1966: U.S. Geol. Survey Prof. Paper 550-D, p. D1-D8.

- 1969a, Disseminated sulfide deposits in the eastern Elk Mountains, Colorado, in Abstracts for 1968: Geol. Soc. America Spec. Paper 121, p. 590.

- 1969b, Geologic map of the Maroon Bells quadrangle, Pitkin and Gunnison Counties, Colorado: U.S. Geol. Survey Geol. Quad. Map GQ-788.

1970, Geologic map of the Hayden Peak quadrangle, Pitkin and Gunnison Counties, Colorado: U.S. Geol. Survey Geol. Quad. Map GQ-863.

Clark, K. F., 1968, Structural controls in the Red River district, New Mexico: Econ. Geology, v. 63, no. 5, p. 553-566.

Gaskill, D. L., Godwin, L. H., and Mutschler, F. E., 1967, Geologic map of the Oh-be-joyful quadrangle, Gunnison County, Colorado: U.S. Geol. Survey Geol. Quad. Map GQ-578.

Horton, F. W., 1916, Molybdenum; its ores and their concentration, 
with a discussion of markets, prices, and uses: U.S. Bur. Mines Bull. $111,132 \mathrm{p}$.

Howell, J. V., 1919, Twin Lakes district of Colorado: Colorado Geol. Survey Bull. 17, 108 p.

King, R. U., 1964, Ferrous metals-Molybdenum in Mineral and water resources of Colorado: U.S. 88th Cong., 2d sess., Comm. Print, p. $102-108$.

Langenheim, R. L., Jr., 1952, Pennsylvanian and Permian stratigraphy in Crested Butte quadrangle, Gunnison County, Colorado: Am. Assoc. Petroleum Geologists Bull., v. 36, no. 4, p. 543-574.

Obradovich, J. D., Mutschler, F. E., and Bryant, Bruce, 1969, Potassium-argon ages bearing on the igneous and tectonic history of the Elk Mountains and vicinity, Colorado-A preliminary report:
Geol. Soc. America Bull., v. 80, no. 9, p. 1749-1756.

Wallace, S. R., MacKenzie, W. B., and Blair, R. G., 1968, Preliminary report on the geology of the molybdenite deposits at Red Mountain, Daly mining district, Colorado [abs.]: Econ. Geology, v. 63, no. 1, p. 87-88.

Wallace, S. R., Muncaster, N. K., Jonson, D. C., MacKenzie, W. B., Bookstrom, A. A., and Surface, V. E., 1968, Multiple intrusion and mineralization at Climax, Colorado, in Ore deposits of the United States, 1933-1967 (Graton-Sales volume), v. 1: New York, Am. Inst. Mining, Metall., and Petroleum Engineers, p. 605-640.

Worcester, P. G., 1919, Molybdenum deposits of Colorado, with general notes on the molybdenum industry: Colorado Geol. Survey Bull. 14, $131 \mathrm{p}$. 


\title{
PLATINIFEROUS CHROMITITE IN THE TOCANTINS COMPLEX, NIQUELÂNDIA, GOIÁS, BRAZIL
}

\author{
By RICHARD W. WHITE; JORGE MOTTA, and VANDERLEI A. de ARAÚJO, \\ Denver, Colo.; Goiânia, Brazil
}

Prepared in cooperation with the Companhia de Pesquisas de Recursos Minerais, under the auspices of the Government of Brazil and the Agency for International Development, U.S. Department of State

\begin{abstract}
Four channel samples of podiform-type chromitite from a discontinuous tabular deposit in the ultramafic zone of the Tocantins complex contain 0.16-3.42 ppm platinum metals. Platinum constitutes 61-84 percent of the total, the remainder consisting of equal parts of palladium and rhodium. The inferred reserves of chromitite include several $(5-10$ ?) thousand metric tons of hard fragments concentrated in the lateritic soil overlying the sampled deposit, plus a few (5?) thousand tons per meter of depth, in situ, over a strike length of 1,900 $m$. The discontinuous character of the deposit, the small reserves, and the low content of platinum metals indicate that the economic potential of the chromitite as a load platinum deposit is small. However, a large volume of gravel derived from the ultramafic zone has been deposited in a canga-covered alluvial plain to the east of the complex, and should be explored for possible placer deposits of platinum metals.
\end{abstract}

The Tocantins complex is one of three similar gabbroperiodotite complexes that form a 300-km-long north-trending alinement within the Precambrian serpentinite belt of central Goiás (Almeida, 1967; Godoy, 1968). A geologic investigation of the complex was undertaken cooperatively by the Departamento Nacional da Produção Mineral (DNPM), the Companhia de Pesquisas de Recursos Minerais (CPRM), and the U.S. Geological Survey (USGS), under the sponsorship of the Government of Brazil and the Agency for International Development (AID), U.S. Department of State, during the month of April 1970.

Acknowledgements. - The writers have benefited from discussion of various aspects of the Tocantins complex with $\mathrm{C}$. $\mathrm{O}$. Berbert and Iran Machado of the Companhia de Pesquisas de Recursos Minerais (CPRM), J. L. G. Costa of the Companhia Niquel Tocantins (CNT), D. H. Lindenmayer (DNPM), R. N. Spencer of the U.S. Bureau of Mines (USBM) and T.P. Thayer (USGS). We thank Mr. Lindenmayer and Mr. Machado for permission to use their unpublished chemical analyses. Labor for opening pits and trenches was supplied by CNT.

\section{GEOLOGY}

The Tocantins complex is about $40 \mathrm{~km}$ long and $20 \mathrm{~km}$ wide, and consists of gabbroic rocks and lesser amounts of ultramafic rocks, anorthosite, amphibolite, and large inclusions of high-grade metasedimentary rocks. Most of the layering and foliation in these rocks dips steeply toward the west. Ultramafic rocks are confined to a west-dipping zone $2-4 \mathrm{~km}$ wide that underlies the Serra da Mantiqueira near the east side of the complex. This zone is bounded throughout the length of the complex by two-pyroxene gabbros which have gneissic structures (Pecora, 1944). The general aspect of the Tocantins complex is that of a pseudostratiform assemblage like the Camaguey complex, Cuba (Flint and others, 1948), or the Bay of Islands complex, Newfoundland (Smith, 1958).

The eastern (lower) part of the ultramafic zone is made up predominantly of lenses and layers of partly to completely serpentinized, foliated harzburgite and dunite, and lesser pyroxenite, whereas the western part contains more abundant lenses of websterite and bronzitite in addition to partly serpentinized peridotites and dunites (Lindenmayer, oral commun., 1970; Costa, 1970). No sharp contact exists between the eastern and western parts of the zone; rather the transition is marked by a gradational change in the proportion and size of pyroxenite and dunite lenses. The different rocks, however, form discrete layers and lenses that generally have sharp contacts. Small lenses of gneissic norite are found throughout the ultramafic zone.

Our studies of several specimens by oil immersion and X-ray diffraction have shown that the ultramafic rocks consist of forsteritic olivine, bronzite $\left(\operatorname{En}_{76-92}\right)$, diopside or augite, and disseminated chromite, as well as lizardite, lesser chrysotile, magnetite, talc, and brucite (in dunites only) produced during serpentinization. Norites within the ultramafic zone contain bytownite $\left(\mathrm{An}_{74-92}\right)$, bronzite $\left(\mathrm{En}_{68-81}\right)$, augite, and sporadic traces of sulfide minerals, chiefly pyrrhotite. The primary 
minerals differ in composition from place to place within the ultramafic zone, but these variations apparently are not systematic.

The summit of the Serra da Mantiqueira is characterized by low ridges and relatively broad valleys parallel to the strike, the ridges being capped by chalcedony that has resulted from weathering of dunite and peridotite. Unweathered outcrops of dunite and peridotite generally are found only in areas of high relief, whereas outcrops of pyroxenite are more common. Lateritic nickel deposits in the ultramafic zone (Pecora, 1944) are being explored by CNT (Costa, 1970) and by Emprêsa de Desenvolvimento de Recursos Minerais, Ltd.

\section{DISTRIBUTION AND CHARACTER OF CHROMITITE}

The initial discovery of chromitite in the complex was made by geologists of CNT in the area of the Fazenda group of nickel silicate deposits at the bead of Córrego da Fazenda. This chromite-bearing zone, which proved to be the largest in the area, was traced out by geologists of DNPM during reconnaissance mapping of the complex (Motta and others, 1969). More detailed examination of the area, reported by Motta and others (1970) and in this paper, has disclosed other smaller chromite-bearing zones within the ultramafic zone.

The area within which these scattered chromite-bearing zones have been found is about $500 \mathrm{~m}$ wide and $8,500 \mathrm{~m}$ long, and trends parallel to the foliation of the ultramafic rocks (fig. 1). It lies along the summit of the Serra da Mantiqueira in the southern half of the complex, west of (above) the transition zone where the ultramafic zone grades from more abundant peridotite at the east to more abundant pyroxenite at the west. Chromitite is generally lacking in the westernmost part of the ultramafic zone, and reconnaissance traverses have disclosed only scattered transported fragments of chromitite in the eastern part of the zone. Much of the northern half of the ultramafic zone has been examined only by reconnaissance, but no chromitite is known there. Furthermore, the ultramafic horizons within which the chromitite is found probably pinch out within $5 \mathrm{~km}$ north of the northernmost known chromitite (see fig. 1), and do not continue to the north end of the complex. Small amounts of disseminated chromite or chromium-rich spinel are found in most peridotites and dunites and in some pyroxenites throughout the ultramafic zone.

The main chromite-bearing zone at the head of Córrego da Fazenda (fig. 1) can be traced in float for $1,900 \mathrm{~m}$; its trend is parallel to the layering and foliation of the enclosing ultramafic rocks. The chromite is concentrated in lenses, discontinuous layers, and pods of massive chromitite of irregular size (fig. 2) in a discontinuous tabular zone $2-5 \mathrm{~m}$ thick. The small masses of chromitite within this zone are enclosed in a gangue consisting of deeply weathered serpentinized dunite or olivine-rich peridotite, which makes up 50-90 percent of the zone. Disseminated chromite and silicate-bearing chromitite laminae are common within and adjacent to the same zone over a thickness of as much as $10 \mathrm{~m}$. Thin feldspathic layers and lenses are widespread within the serpentinized dunite or peridotite of the chromite-bearing zone, but pyroxenite has not been found within this zone even though it is common both above and below the zone.

Some individual chromitite lenses are more than $1 \mathrm{~m}$ thick. More commonly, however, the thickness is $2-30 \mathrm{~cm}$, and the lenses pinch out abruptly along the strike as well as down the dip, or grade laterally into disseminated chromite (fig. 2). The few well-exposed pods of chromitite that were observed define a subhorizontal lineation conformable with the boundaries of the chromite-bearing zone. No single layer could be traced for more than $4 \mathrm{~m}$, although better exposures might reveal more continuous layers.

The residual soil is enriched in chromite over the chromitebearing zone and in a band 5-30 m wide on the downslope side of the zone. Commonly the uppermost half meter of soil contains 50 percent or more of hard chromitite fragments as much as $15 \mathrm{~cm}$ in diameter; the matrix is a dark red-brown soil consisting of clay, abundant magnetic grains, lateritic ironstone pellets, and fine-grained chromite.

The chromite in the massive chromitites forms interlocking anhedral grains as much as $\mathbf{1} \mathbf{~ c m}$ long. Many specimens exhibit a conspicuous rock cleavage that cuts across the grain boundaries and gives the impression that the grain size is much coarser than it actually is. A distinct linear elongation of the chromite grains may be recognized in some fragments, but it has not been possible to establish the orientation of this structure. Most of the disseminated chromite forms anhedral grains without crystal faces, but a small number of octahedra are found in alluvial samples from streams draining the ultramafic zone.

The mineralogy of the chromite-bearing zone is not well known because no unweathered specimens of chromitite or of gangue material are available. Polished sections of the chromitites show that the chromite, despite an inherent resistance to weathering, is pitted and fractured, especially near grain boundaries, and that it contains films of goethite along most fractures. Some of the pits and fractures are partly filled with kaolinite; in one area the chromitite also contains concentrations of supergene manganese oxide. Grains of chromite that have goethite coatings or staining are decidedly magnetic, but clear translucent fragments are not attracted by a hand magnet. This distinction is readily made by passing a pencil magnet near a powder mounted in an immersion liquid, while observing the powder through a microscope.

Sparse tiny rounded grains of ilmenite are visible in most polished specimens of the chromitite. Some of these grains contain exsolution lamellae of hematite; one specimen also contains sparse rounded grains of hematite with exsolution lamellae of ilmenite.

The other scattered lenses of chromitite noted above are found within a larger area adjacent and parallel to the main chromite-bearing zone. Most are structurally below (to the east of) the main zone; the most extensive of them, in the Angiquinho area, can be traced for about $500 \mathrm{~m}$ in a 


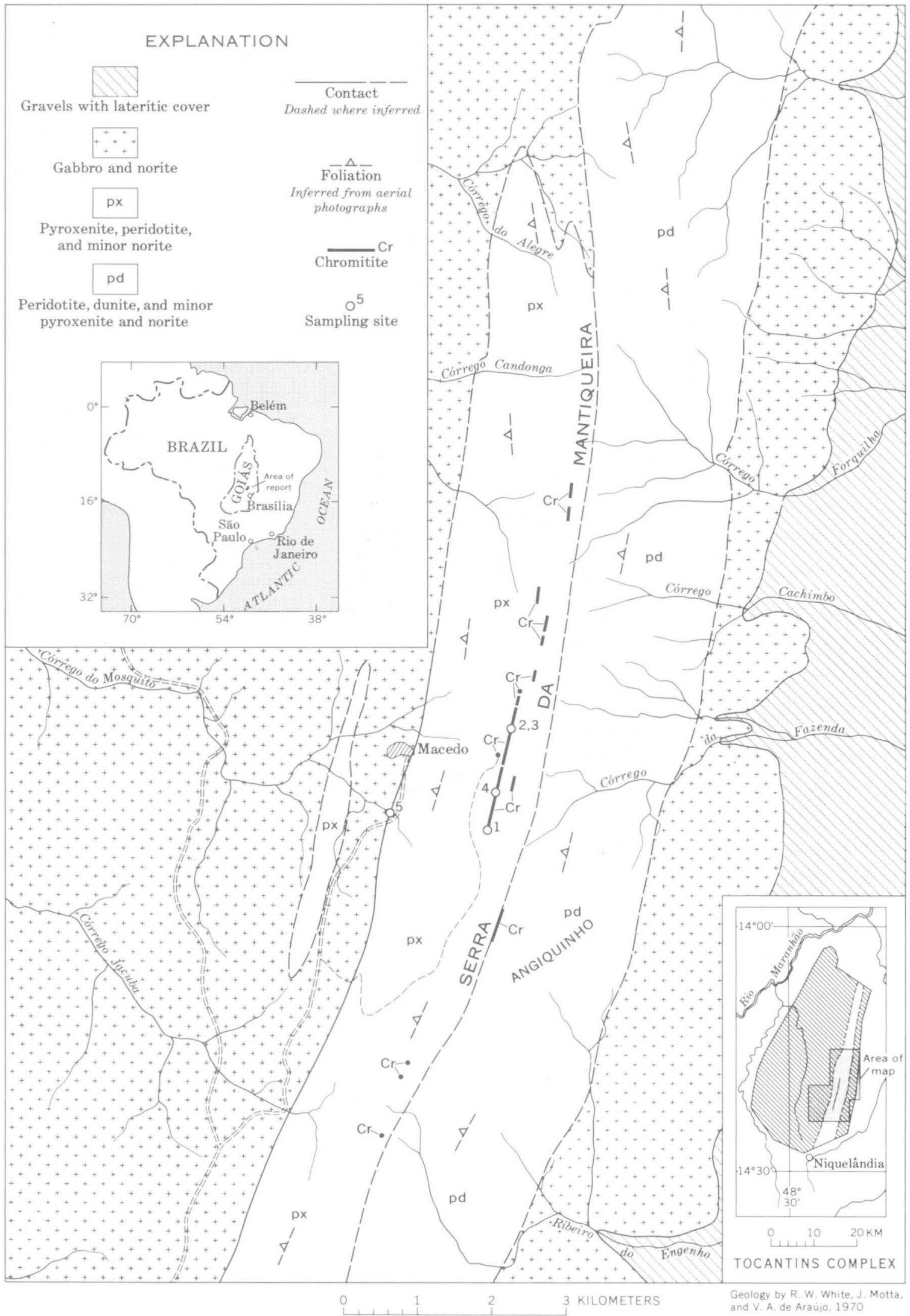

Figure 1.-Distribution of chromitite in the Tocantins complex, Brazil. 


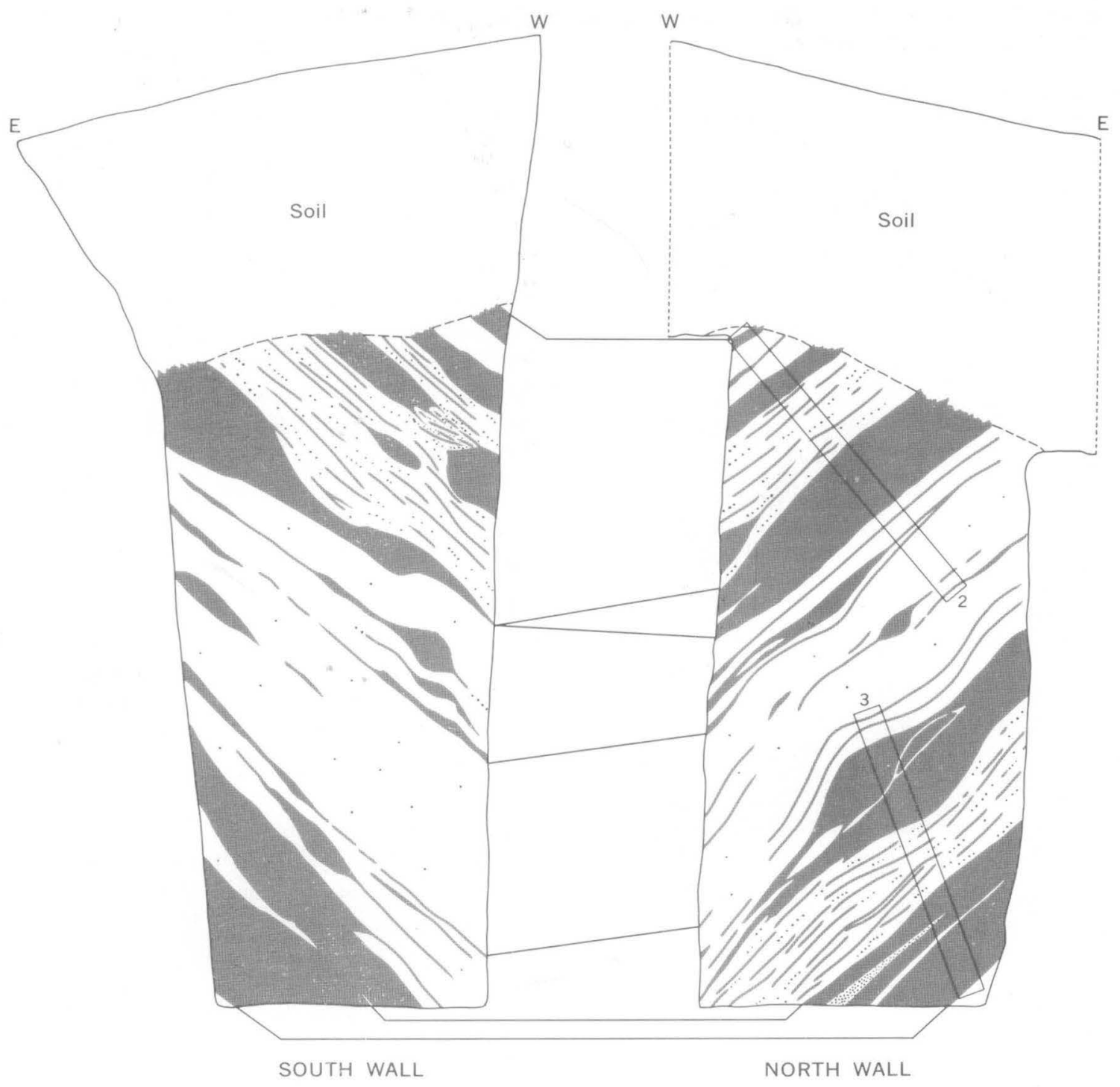

1 METER

Figure 2.-Sketch of the opposite walls of a pit in a relatively rich part of the main chromite-bearing zone at the head of Córrego da Fazenda, showing discontinuous character of the chromitite lenses and pods (dark) in serpentinized dunite or peridotite gangue (white), and locations of channel samples 2 and 3.

discontinuous tabular zone that is parallel to the foliation of the enclosing rocks. Texture, structure, and form of these chromitites are generally similar to those of the main zone, but the size of the chromitite bodies and the thickness of the chromite-bearing zones are less.

Several artificial exposures across the main chromite-bearing zone, as well as the few natural exposures, reveal no consistent stratigraphy such as might be expected in stratiform-type chromitite. The observed textures, structures, and forms of the chromitite reflect an intense deformation of it and the surrounding rocks, such as is characteristic of podiform-type chromite deposits. Relict cumulus texture (uniform subhedral grains as large as $1 \mathrm{~mm}$ in a silicate matrix) is observed in some specimens of chromitite from the northernmost known lenses; such relict textures are also recognized in podiform-type chromite deposits elsewhere (Thayer, 1969). No good examples of cumulus textures have yet been found in silicate rocks anywhere in the complex.

\section{COMPOSITION OF CHROMITE}

The composition of the chromite was determined by analysis of purified concentrates obtained from the less weathered fractions of three channel samples. Two analyses of grab samples of raw chromitite are also available (table 1). 
Table 1.-Analyses of chromite samples from the Tocantins complex, Niquelândia, Goiás, Brazil

[Abbreviations: A, absent; Tr., trace; N, not detected]

\begin{tabular}{|c|c|c|c|c|c|}
\hline Sample . & $\mathbf{1}$ & 2 & 3 & 6 & 7 \\
\hline \multicolumn{6}{|c|}{ Chemical analysis (weight percent) } \\
\hline $\mathrm{Cr}_{2} \mathrm{O}_{3} \ldots \ldots \ldots$ & 43.43 & 48.46 & 47.23 & 42.0 & 39.0 \\
\hline $\mathrm{Al}_{2} \mathrm{O}_{3} \ldots \ldots \ldots$ & 23.65 & 19.68 & 20.24 & 22.6 & 26.9 \\
\hline $\mathrm{Fe}_{2} \mathrm{O}_{3} \ldots \ldots \ldots$ & 20.47 & 21.35 & 21.41 & 22.0 & 18.6 \\
\hline $\mathrm{FeO} \ldots \ldots \ldots \ldots$ & 1.05 & .38 & .48 & $\ldots$ & 1.7 \\
\hline MgO . . . . . & 10.6 & 9.8 & 9.8 & 7.8 & 8.8 \\
\hline MnO......... & .17 & .16 & .16 & & \\
\hline $\mathrm{CaO} \ldots \ldots$ & $\ldots$ & $\ldots$ & $\ldots$ & A & \\
\hline $\mathrm{TiO}_{2} \ldots$ & .38 & .22 & .30 & Tr. & \\
\hline $\mathrm{SiO}_{2} \ldots \ldots$ & $<.1$ & $<.1$ & $<.1$ & .5 & \\
\hline $\mathrm{Na}_{2} \mathrm{O} \ldots \ldots \ldots$ & .26 & .16 & .09 & & \\
\hline $\mathrm{H}_{2} \mathrm{O} \ldots \ldots \ldots$ & .15 & .12 & .11 & & \\
\hline Sum $\ldots \ldots \ldots$ & 100.2 & 100.4 & 99.8 & 94.9 & 95.0 \\
\hline Total $\mathrm{Fe}$ as $\mathrm{FeO}$ & 19.50 & 19.61 & 19.77 & & \\
\hline $\mathrm{Cr} / \mathrm{Fe} \ldots \ldots \ldots$ & 1.96 & 2.18 & 2.10 & 1.86 & 1.87 \\
\hline
\end{tabular}

Inferred molecular composition ${ }^{1}$

\begin{tabular}{|c|c|c|c|}
\hline$(\mathrm{Mg}, \mathrm{Fe}) \mathrm{Cr}_{2} \mathrm{O}_{4}$. & 55 & 62 & 60 \\
\hline$(\mathrm{Mg}, \mathrm{Fe}) \mathrm{Al}_{2} \mathrm{O}_{4}$ & 44 & 38 & 39 \\
\hline$(\mathrm{Mg}, \mathrm{Fe}) \mathrm{Fe}_{2} \mathrm{O}_{4}$ & 1 & $\mathbf{0}$ & 1 \\
\hline $\mathrm{MgO} / \mathrm{RO} \ldots \ldots$ & 50 & 47 & 47 \\
\hline
\end{tabular}

Semiquantitative six-step spectrographic analysis $(\mathrm{ppm})^{2}$

\begin{tabular}{|c|c|c|c|}
\hline $\mathrm{Ca}$ & $\ldots \ldots \ldots \ldots \ldots$ & 100 & 100 \\
\hline $\mathbf{B a}$ & $\ldots \ldots \ldots \ldots$ & 15 & 15 \\
\hline Co & $\ldots \ldots \ldots \ldots 200$ & 200 & 200 \\
\hline $\mathrm{Cu}$ & $\ldots \ldots \ldots \ldots$ & 70 & 200 \\
\hline Mo & $\ldots \ldots \ldots \ldots$ & 7 & 7 \\
\hline $\mathrm{Ni}$ & $\ldots \ldots \ldots \ldots \ldots 500$ & 500 & 500 \\
\hline Sc & …..... 7 & 7 & 7 \\
\hline Sn & $\ldots \ldots \ldots \ldots, \quad \mathrm{N}$ & $\mathbf{N}$ & 15 \\
\hline V & $\ldots \ldots \ldots \ldots 2,000$ & 1,500 & 1,500 \\
\hline Ga & $\ldots \ldots \ldots \ldots \ldots \quad 10$ & 10 & $\mathbf{N}$ \\
\hline
\end{tabular}

1. W44D, clean chromite concentrate from less weathered fraction of same channel sample on which platinum-metal analyses were run. See analysis 1, table 2. J. I. Dinnin and J. J. Warr, Jr., U.S. Geol. Survey, analysts.

2. W47, clean chromite concentrate from less weathered fraction of channel sample. See analysis 2, table 2. J. I. Dinnin and J. J. Warr, Jr., U.S. Geol. Survey, analysts.

3. $\mathbf{W} 48$, clean chromite concentrate from less weathered fraction of channel sample. See analysis 3 , table 2 . Samples 2 and 3 represent the upper and lower lenses, respectively, exposed in the north wall of the same pit. See figure 2. J. I. Dinnin and J. J. Warr, Jr., U.S Geol. Survey, analysts.

6. NTQ-1, grab sample of chromitite fragments from dump at pit where channel samples 2 and 3 were cut. Collected by D. H. Lindenmayer (DNPM). Carmen Lucia Roquette Pinto (DNPM), analyst.

7. 359-70, grab sample of chromitite fragments from dump at pit where channel samples 2 and 3 were cut. Collected by Iran Machado (DNPM). Cecile Stark Mayer (DNPM), analyst.

${ }^{1}$ Molecular composition calculated after recalculating $\mathrm{FeO}$ and $\mathrm{Fe}_{2} \mathrm{O}_{3}$ so that $\mathrm{RO}=\mathrm{R}_{2} \mathrm{O}_{3}$, ignoring minor elements.

2 Also looked for but not detected: Ag, As, Au, B, Be, Bi, Cd, K, La, $\mathrm{Nb}, \mathrm{P}, \mathrm{Pb}, \mathrm{Pd}, \mathrm{Pt}, \mathrm{Sb}, \mathrm{Sr}, \mathrm{Te}, \mathrm{U}, \mathrm{W}, \mathrm{Y}, \mathrm{Zn}, \mathrm{Zr}, \mathrm{Ce}, \mathrm{Ge}, \mathrm{Hf}, \mathrm{In}, \mathrm{Li}, \mathrm{Re}, \mathrm{Ta}$, Th, Ti, Yb, and Eu. Semiquantitative results are identified by geometric brackets whose boundaries are $1.2,0.83,0.56,0.38,0.26,0.18,0.12$
The analyzed samples are all characterized by an exceptionally high proportion of ferric iron. Most of the iron in these chromites would have to be in the ferrous state if the mineral were to be a stoichiometrically balanced spinel with $\mathrm{RO}=\mathrm{R}_{2} \mathrm{O}_{3}$. Small amounts of hematite as well as remnants of supergene goethite are responsible for some of the excess of ferric iron in the purified samples, but the bulk of the iron must be bound in the chromite. The imbalance probably is not primary, but is due to intense lateritic weathering of the chromite, during which most of the iron was oxidized so that it now forms a maghemite component which has a deficiency of divalent cations. The low silica content of the raw samples $(6$, table 1$)$ reflects prior removal of silicate minerals by weathering; this probably is characteristic of most of the eluvial chromite deposit.

The total iron content of the chromite is relatively constant at about 15 percent (as $\mathrm{Fe}$ ) despite variation in the chromium content, whereas the aluminum and chromium contents vary reciprocally. This behavior is a recognized characteristic of podiform-type chromite (Thayer, 1970, fig. 2). The uniformity of samples of purified chromite ( 2 and 3 , table 1 ) from adjacent strata (see fig. 2) also is typical of podiform chromites, whereas stratiform chromites may differ in composition within short distances across the strata (Jackson and others, 1960). The $\mathrm{MgO}$ content is rather low for podiform chromite, however.

Comparison of the composition of clean chromite concentrates ( 2 and 3 , table 1$)$ with that of chromitite fragments ( 6 and 7 , table 1) from the same excavation possibly shows the effect of the cleaning process. This included scrubbing and washing to remove goethite and clay slimes, and magnetic separation to remove the most altered chromite grains as well as secondary magnetite from the serpentinized dunite gangue. It is not known whether the chromium content and the chromium-to-iron ratio could be increased economically by cleaning.

The composition of the chromite is such that it is not uniquely of metallurgical, chemical, or refractory type, although it approaches all of these, especially the latter two. Specifications for each of these types are based more on available supply than on industry requirements; hence the chromite from the Tocantins complex might be usable for any of these purposes, depending upon needs in Brazil.

\section{PLATINUM METALS IN CHROMITITES}

Channel samples of chromitites, of 4-6 kg, were crushed to pass a $1.5-\mathrm{mm}$ screen and then separated at 80 mesh. The coarser, less weathered fraction (approximately 80 percent of each sample) was processed to yield a chromite concentrate,

and so forth, but are reported arbitrarily as midpoints of the brackets as $1.0,0.7,0.5,0.3,0.2,0.15,0.1$, and so forth. The precision of a reported value is approximately plus or minus one bracket at 68-percent, or two brackets at 95-percent confidence. J. L. Harris, U.S. Geol. Survey, analyst. 
whereas the finer fraction was partly deslimed by washing and gentle decanting so as to discard only the lightest slime fraction, and then split to yield samples for analysis of platinum metals. The analyzed fine fraction consisted mostly of weathered chromite as well as goethite and other finegrained minerals resulting from complete weathering of serpentinized peridotite.

Fractions of $15 \mathrm{~g}$ were analyzed for platinum metals by the method of Haffty and Riley (1968), and are reported in table 2 . The two richest samples were analyzed in duplicate $(2 a, 2 b$, $4 a$, and $4 b$, table 2) using fractions of only $3 \mathrm{~g}$, and gave consistent results, indicating that the samples are "quite homogeneous" (L. B. Riley, written commun., 1970). This homogeneity suggests that the platinum metals are very finely dispersed and that they may be bound in solid solution in the chromite lattice rather than concentrated in separate platinum-rich minerals or alloys. For example, studies by Grimaldi and Schnepfe (1969) of a platiniferous sample from the Stillwater "A" chromitite, Montana, U.S.A., have shown that most of the rhodium and some of the platinum in that sample probably are bound in solid solution in the chromite, whereas the rest of the platinum and all the palladium are found outside of the chromite.

To gain an impression of the significance of these data, the range of total platinum metals reported in table 2 may be compared with the average tenors of lode ores presently being

Table 2.-Analyses of platinum-bearing chromitite samples from the Tocantins complex, Niquelândia, Goiás, Brazil

[Analysts: Pt metals, L. B. Riley, W. D. Goss, and Joseph Haffty; Au, W. D. Goss and J. A. Thomas; Ni, Claude Huffman, Jr., and J. A. Thomas; and semiquantitative spectrographic data, B. W. Lanthorn, U.S. Geol. Survey. Äbbreviations: G, > 10 percent; $L$, detected; $N$, not detected ]

\begin{tabular}{|c|c|c|c|c|c|c|c|c|c|}
\hline Sample......... & 1 & 2 & $2 a$ & $2 \mathbf{b}$ & 3 & 4 & $4 \mathbf{a}$ & $4 b$ & 5 \\
\hline \multicolumn{10}{|c|}{ Quantitative Analysis (parts per million) } \\
\hline $\begin{array}{l}\mathrm{Pd} \ldots \ldots \ldots \ldots \ldots \ldots \\
\mathrm{Pt} \ldots \ldots \ldots \ldots \ldots \\
\mathrm{Rh} \ldots \ldots \ldots\end{array}$ & $\begin{array}{c}0.14 \\
.35 \\
.057\end{array}$ & $\begin{array}{r}0.30 \\
2.86 \\
.26\end{array}$ & $\begin{array}{r}0.29 \\
2.58 \\
.36\end{array}$ & $\begin{array}{r}0.31 \\
2.43 \\
.32\end{array}$ & $\begin{array}{r}0.037 \\
.098 \\
.025\end{array}$ & $\begin{array}{r}0.29 \\
1.49 \\
.23\end{array}$ & $\begin{array}{r}0.32 \\
1.44 \\
.25\end{array}$ & $\begin{array}{r}0.31 \\
1.40 \\
.22\end{array}$ & $\begin{array}{r}0.078 \\
<.047 \\
<.005\end{array}$ \\
\hline $\begin{array}{r}\text { Total } \ldots \ldots \ldots \ldots \ldots \\
\mathrm{Au} \ldots \ldots \ldots \ldots \ldots \ldots \\
\mathrm{Ni} \ldots \ldots \ldots \ldots\end{array}$ & $2,400 . .55$ & $2,000^{3.42}$ & $\begin{array}{l}3.23 \\
\cdots \cdots \\
\cdots\end{array}$ & $\begin{array}{l}3.06 \\
\cdots \cdots \\
\cdots\end{array}$ & 1,700 & $\stackrel{2.01}{<.1}$ & $\begin{array}{l}2.01 \\
\cdots \cdots \\
\cdots\end{array}$ & $\begin{array}{l}1.93 \\
\cdots \cdots \\
\cdots\end{array}$ & $3,300^{.05}$ \\
\hline \multicolumn{10}{|c|}{$\begin{array}{c}\text { Semiquantitative Six-Step Spectrographic Analysis }{ }^{1} \\
\text { In percent }\end{array}$} \\
\hline 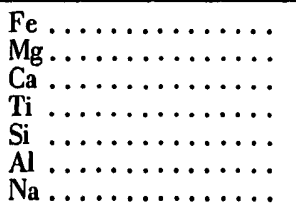 & $\begin{array}{l}G \\
5 . \\
.15 \\
.3 \\
.7 \\
G \\
N\end{array}$ & $\begin{array}{l}\mathrm{G} \\
5 . \\
.15 \\
.2 \\
.2 \\
\mathrm{G} \\
\mathrm{N}\end{array}$ & $\begin{array}{l}\cdots \cdots \\
\cdots \cdots \\
\cdots \cdots \\
\cdots \cdots \\
\cdots \cdots\end{array}$ & $\begin{array}{l}\cdots \cdots \\
\cdots \cdots \\
\cdots \cdots \\
\cdots \cdots \\
\cdots \cdots\end{array}$ & $\begin{array}{l}\mathrm{G} \\
7 . \\
.15 \\
.2 \\
.07 \\
\mathrm{G}\end{array}$ & $\begin{array}{l}\mathrm{G} \\
5 . \\
.15 \\
.2 \\
.5 \\
\mathrm{G} \\
\mathrm{N}\end{array}$ & $\begin{array}{l}\ldots \cdots \\
\cdots \cdots \\
\cdots \\
\cdots \\
\cdots \cdots\end{array}$ & $\begin{array}{l}\cdots \cdots \\
\cdots \cdots \\
\cdots \cdots \\
\cdots \cdots \\
\cdots \cdots\end{array}$ & $\begin{array}{l}\mathrm{G} \\
\mathrm{G} \\
\mathrm{N} \\
10 . \\
103 \\
.05\end{array}$ \\
\hline \multicolumn{10}{|c|}{ In parts per million } \\
\hline 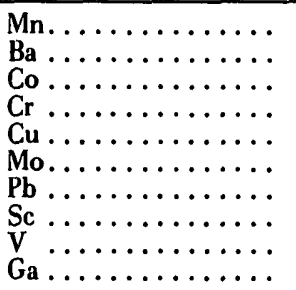 & $\begin{array}{r}700 \\
7 \\
300 \\
\mathrm{G} \\
150 \\
\mathrm{~N} \\
\mathrm{~N} \\
20 \\
1,500 \\
20\end{array}$ & $\begin{array}{r}1,000 \\
30 \\
300 \\
G \\
150 \\
N \\
15 \\
20 \\
1,500 \\
30\end{array}$ & $\begin{array}{l}\ldots \cdots \\
\ldots \cdots \\
\ldots \cdots \\
\ldots \cdots \\
\cdots \\
\cdots \cdots \\
\cdots \cdots\end{array}$ & $\begin{array}{l}\ldots \cdots \\
\cdots \cdots \\
\cdots \cdots \\
\cdots \cdots \\
\cdots \cdots \\
\cdots \cdots \\
\cdots \cdots\end{array}$ & $\begin{array}{r}700 \\
7 \\
300 \\
G \\
\mathbf{G} \\
3 \\
\mathbf{3} \\
\mathbf{2 0} \\
1,500 \\
30\end{array}$ & $\begin{array}{r}3,000 \\
150 \\
1,500 \\
G \\
300 \\
3 \\
\text { L } \\
50 \\
1,500 \\
30\end{array}$ & $\begin{array}{l}\ldots \cdots \\
\cdots \cdots \\
\cdots \cdots \\
\cdots \cdots \\
\cdots \cdots \\
\cdots \cdots \\
\cdots \cdots\end{array}$ & $\begin{array}{l}\ldots \\
\cdots \cdots \\
\cdots \cdots \\
\cdots \cdots \\
\cdots \cdots \\
\cdots \cdots \\
\cdots \cdots\end{array}$ & $\begin{array}{r}1,000 \\
2 \\
150 \\
5,000 \\
1,000 \\
N \\
N \\
15 \\
100 \\
N\end{array}$ \\
\hline
\end{tabular}

1. W44D-2, more weathered fraction of channel sample across chromitite lenses and pods in outcrop on slope; length of channel $0.6 \mathrm{~m}$, excluding intervening gangue; partly deslimed. See figure 1 for location, table 1 for analysis of chromite.

2. W47-2, more weathered fraction of channel sample of chromitite and gangue in wall of pit; length $1.2 \mathrm{~m}$; partly deslimed. See figures 1,2 ; analysis 2 , table 1.

2a, 2b. Duplicate analysis of W47-2, run with 3 -g fractions.

3. W48-2, more weathered fraction of channel sample of chromitite and gangue; length $1.1 \mathrm{~m}$; completely deslimed by repeated washing and decanting. See also analysis 3 , table 1 .

4. W58-2, more weathered fraction of sample across two chromitite lenses in floor of trench; length $0.2 \mathrm{~m}$ excluding intervening gangue; partly deslimed.

4a, 4b. Duplicate analysis of W58-2, run with 3-g fractions.

5. W34E, selected specimen of pyrrhotite-bearing harzburgite, from excavation for hydroelectric generator $0.8 \mathrm{~km}$ south of Macedo.

${ }^{1}$ Also looked for but not detected: $\mathrm{Ag}, \mathrm{As}$, B, Be, Bi, Cd, K, La, Nb, P, Sb, Sn, Sr, Te (sample 5 only), U, W, Y, Zn, Zr, Ce, Ge, Hf, In, Li, Re, Ta, $\mathrm{Th}, \mathrm{Tl}, \mathrm{Yb}, \mathrm{Eu}, \mathrm{Ir}, \mathrm{Os}$, and Ru. Semiquantitative results are identified by geometric brackets whose boundaries are 1.2, 0.83, 0.56, 0.38, 0.26, 0.18, 0.12 , and so forth, but are reported arbitrarily as midpoints of the brackets as $1.0,0.7,0.5,0.3,0.2,0.15,0.1$, and so forth. The precision of a reported value is approximately plus or minus one bracket at 68-percent, or two brackets at 95-percent confidence. 
mined in the Bushveld Complex, South Africa: Merensky reef, 8 to $12 \mathrm{ppm}$; dunite pipes, 4.5 to $31 \mathrm{ppm}$. Average tenors of other lode deposits that are not currently being worked include the Bushveld chromitites, 2 to $200 \mathrm{ppm}$; Great Dyke chromitites, Rhodesia, 5 to $7 \mathrm{ppm}$; and the Stillwater " $\mathrm{A}$ " chromitite, $3.5 \mathrm{ppm}$. Platinum metals present in low tenor are recovered as byproducts of copper-nickel-sulfide ores in Canada (Sudbury, 0.6 ppm) and U.S.S.R. (Noril'sk, $2 \mathrm{ppm}$ ), and placers with much lower tenors are worked in Colombia, U.S.S.R., and Alaska (Data are converted from Mertie, 1969; Page and others, 1969).

A fifth sample was selected from one of the richest sulfide-bearing rocks known in the complex, a harzburgite carrying 1 to 2 percent of pyrrhotite, lesser chalcopyrite, and traces of pentlandite $(5$, table 2$)$. The analysis shows more palladium than platinum, which is typical of some sulfide deposits of platinum metals. However, the palladium and nickel contents of this harzburgite are within the range of "average" ultramafic rocks compiled by Goles (1967), although the gold and copper contents may be higher than average. The locality appears to lack economic significance because of the restricted distribution of the sulfides and the low tenor of platinum metals, nickel, and copper.

\section{ECONOMIC CONSIDERATIONS}

The reserves of platiniferous chromitite in the Tocantins complex are inferred to total several (5 to 10?) thousand metric tons in the residual soil over the main chromite-bearing zone, and a few (5?) thousand tons per meter of depth in situ. The subhorizontal orientation of the chromitite pods suggests that continuity of the chromite-bearing zone down the dip may be even less than that along the strike; thus, prediction of total reserves in situ is uncertain. The low grade and small reserves indicate that the economic potential of the chromitebearing zone as a lode platinum deposit is small or negligible. Furthermore, if any part of the platinum metals is bound in solid solution in the chromite, the recoverable tenor will be correspondingly reduced, or complete dissolution of the chromite will be necessary prior to recovery of the platinum metals from the residue.

The relatively small tonnage of chromite and the long distance to a market $(1,300 \mathrm{~km}$ to São Paulo) may make the deposit unfavorable for utilization of the chromite as chrome ore under present market conditions. However, should the chromite be utilized for the manufacture of sodium bichromate, it may be possible to recover the platinum metals as byproducts of the chemical process.

Alluvial concentrations of platinum metals may exist in the gravels of the canga-capped alluvial plain east of the Tocantins complex. The existence of such deposits is dependent upon the state of combination of the platinum metals in the source area, as only the native metals are known to yield workable placers. Nevertheless, testing of the gravels is definitely justified and desirable on the basis of existing information. Near the western edge of the alluvial plain the gravels have been derived predominantly from the ultramafic and gabbroic rocks of the complex. Those gravels containing a large proportion of cobbles of chalcedony and ultramafic rocks have been derived in large part from the weathered dunite and peridotite in the Serra da Mantiqueira, and would seem to have the best potential for placer deposits of platinum metals.

\section{RECOMMENDATIONS}

The occurrence of platinum metals in chromitite in the Tocantins complex is of a type which, to our knowledge, has not heretofore been recognized in Brazil. Production of platinum metals from deposits of this type historically has been considerably less than that from copper-nickel-sulfide deposits and placers; however, some small deposits of this type have been of phenomenally high grade, for example in the Nishniy-Tagil dunite, U.S.S.R. (Mertie, 1969, p. 53). We recommend that chromitites throughout Brazil be sampled and analyzed in search for economic deposits of platinum metals, and that alluvial deposits derived from chromite-bearing ultramafic rocks be examined for possible placers.

\section{REF́ERÉNCES}

Almeida, F. F. M. de, 1967, Origem e evolução da platforma Brasileira: Brazil Div. Geol. Mineral. Bol. 241, 36 p.

Costa, J. L. G., 1970, Nickel deposits of the São José do Tocantins massif-notes on economic geology and on exploration by C.N.T. [abs.]: Cong. Brasileiro Geologia, 24th, Brasilia 1970, Resumos Conf. e Comun., p. 142-143.

Flint, D. F., de Albear, J. F., and Guild, P. W., 1948, Geology and chromite deposits of the Camaguey district, Camaguey Province, Cuba: U.S. Geol. Survey Bull. 954-B, p. 39-62.

Godoy, A. C. de, 1968, Mapa das ocorrencias minerais do estado de Goiás, com localizacao dos principais macicos básicos e/ou ultrabásicos: Cong. Brasileiro Geologia, 22d, Belo Horizonte 1968, Anais, p. 223-229.

Goles, G. G., 1967, Trace elements in ultramafic rocks, in Wiley, P. J., ed., Ultramafic and related rocks: New York, John Wiley \& Sons, p. $352-362$.

Grimaldi, F. S., and Schnepfe, M. M., 1969, Mode of occurrence of platinum, palladium, and rhodium in chromitite, in Geological Survey Research 1969: U.S. Geol. Survey Prof. Paper 650-C, p. C149-C151.

Haffty, Joseph, and Riley, L. B., 1968, Determination of palladium, platinum, and rhodium in geologic materials by fire assay and emission spectrography: Talahta, v. 15, no. 1, p. 111-117.

Jackson, E. D., Dinnin, J. I., and Bastron, Harry, 1960, Stratigraphic variation of chromite composition within chromitite zones of the Stillwater complex, Montana [abs.]: Geol. Soc. America Bull., v. 71 , no. 12 , pt. 2 , p. 1896.

Mertie, J. B., Jr., 1969, Economic geology of the platinum metals: U.S. Geol. Survey Prof. Paper 630, 120 p.

Motta, Jorge, Araújo, V. A. de, and White, R. W., 1970, Occurrence of chromite in the São José do Tocantins massif, Niquelândia, Goiás [abs.]: Cong. Brasileiro Geologia, 24th, Brasilia 1970, Resumos Conf. e Comun., p. 111-113. 
Motta, Jorge, Lindenmayer, D. H., and Silveira Filho, N. C. da, 1969, Preliminary note on the geology of the São José do Tocantins massif, Niquelândia, Goiás State [abs.]: Cong. Brasileiro Geologia, 23d, Salvador 1969, Resumos Conf. e Comun., p. 31-32.

Page, N. J., Riley, L. B., and Haffty, Joseph, 1969, Platinum, palladium, and rhodium analyses of ultramafic and mafic rocks from the Stillwater complex, Montana: U.S. Geol. Survey Circ. 624, 12 p.

Pecora, W. T., 1944, Nickel-silicate and associated nickel-cobaltmanganese-oxide deposits near São José do Tocantins, Goiaz, Brazil: U.S. Geol. Survey Bull. 935-E, p. 247-305.
Smith, C. H., 1958, Bay of Islands igneous complex, western Newfoundland: Canada Geol. Survey Mem. 290, 132 p.

Thayer, T. P., 1969, Gravity differentiation and magmatic re-emplacement of podiform chromite deposits, in Wilson, H. D. B., ed., Magmatic ore deposits, a symposium: Econ. Geology Mon. 4, p. 132-146.

- 1970, Chromite segregations as petrogenetic indicators, in Symposium on the Bushveld igneous complex and other layered intrusions: Geol. Soc. South Africa Spec. Pub. 1, p. 380-390. 


\title{
POTASSIUM-ARGON AGES OF PLUTONS IN THE SKYKOMISH- STILLAGUAMISH AREAS, NORTH CASCADES, WASHINGTON
}

\author{
By ROBERT S. YEATS ${ }^{1}$ and JOAN C. ENGELS, \\ Athens, Ohio, Menlo Park, Calif.
}

\begin{abstract}
Several small calc-alkaline plutons north of the Snoqualmie batholith, dated by the potassium-argon method, yield these ages: the Granite Falls stock, 43.3 \pm 2.0 m.y.; Mount Pilchuck stock, 47.6 \pm 1.4 m.y. and $48.0 \pm 1.7$ m.y.; Index batholith, 32.5 m.y.; Grotto batholith, $26.3 \pm 0.8 \mathrm{~m} . \mathrm{y}$. and $25.0 \pm 1.5 \mathrm{~m} . \mathrm{y}$.; and Monte Cristo stock; $24.2 \pm 1.1$ m.y. and $24.1 \pm 1.0 \mathrm{~m}$.y. These plutons are older than the previously dated Snoqualmie and Tatoosh plutons of the central Cascade Range. Their time range is comparable to that previously established by radiometric dating elsewhere in the North Cascades. The view that acidic intrusions added material to the core of the North Cascades throughout a considerable part of Cenozoic time is thus supported.
\end{abstract}

The Cascade Range consists of a north-trending zone of calc-alkaline extrusive and intrusive rocks of Eocene through Quaternary age resting with angular unconformity on a deeply eroded pre-Eocene basement. In Washington, the Cascades are uplifted as a broad, south-plunging arch, and the range can be divided into two geologic subprovinces on the basis of erosion level. The southern and central Cascades are predominantly Tertiary volcanic rocks; the deeply eroded North Cascades are predominantly plutonic rocks of pre-Tertiary and Tertiary age (Misch, 1966). The boundary between these subprovinces is approximately at the latitude of Snoqualmie Pass (fig. 1). South of the pass, plutonic rocks are restricted to a westtrending zone at Mount Rainier, and the stratigraphic record of Cascade volcanism is relatively complete (Waters, 1961; Fiske and others, 1963). Between Snoqualmie Pass and the South Fork of the Stillaguamish River, a group of calc-alkaline stocks and small batholiths is exposed. Except for local remnants, the Tertiary volcanic rocks in this region have been removed by erosion (see fig. 1 and Huntting and others (1961) which contains references to mapping for University of Washington theses). The pre-Tertiary metamorphic basement (Yeats, 1964; Misch, 1966, p. 121) is also widely exposed in this region.

Early field mapping in the Cascade Range (Smith and Calkins, 1906; Smith, 1915) distinguished between the Mesozoic plutonic rocks (Mount Stuart batholith and related stocks) and the middle Cenozoic Snoqualmie batholith.

\footnotetext{
${ }^{1}$ Ohio University.
}

Radiometric study of plutons began with the Snoqualmie batholith, which was dated as 18 million years old by Baadsgaard and others (1961) and 17 m.y. old by Curtis and others (1961). Subsequently, R. E. Folinsbee (in Fiske and others, 1963) determined the age of the Tatoosh pluton near Mount Rainier to be 13-15 m.y. Near the Canadian border, Misch $(1964,1966)$ reported radiometric ages ranging from late Eocene to Miocene for the Chilliwack composite batholith and related stocks. Near Glacier Peak, the Cloudy Pass batholith was dated as 20-22 m.y. old (Tabor and Crowder, 1969; Cater, 1969). Older plutons with ages of 86,57 , and 45 m.y. were identified in that area by radiometric dating (Cater and others, 1967; Tabor and others, 1968; Cater, 1969). The broad age distribution of plutons led Cater and others (1967) to suggest that the intrusive activity in the North Cascades has been going on more or less continuously from at least late Mesozoic time to the present day.

This paper reports radiometric ages for the group of stocks and small batholiths north of the Snoqualmie batholith; the Granite Falls, Mount Pilchuck, Squire Creek, and Monte Cristo stocks, and the Index and Grotto batholiths. Most of the other small plutons in the area can be correlated with one of these bodies. Until the present study was undertaken, it remained uncertain whether these plutons were restricted to the Miocene, as suggested by the Snoqualmie and Tatoosh ages, or whether they, like the surface-accumulated volcanic rocks nearby and the Chilliwack composite batholith and the plutons near Glacier Peak, are of differing ages. We show that they are of differing ages, all older than the reported Snoqualmie ages (table 1).

\section{GRANITE FALLS STOCK}

In the valley of the South Fork of the Stillaguamish River in the western foothills of the Cascades, the Granite Falls mafic granodiorite stock (fig. 1) has intruded pre-Tertiary metasedimentary rocks including fossiliferous Permian limestones (Danner, 1957). Hornblende separated from the Granite Falls stock gives an age of $43.3 \pm 2.0 \mathrm{~m}$.y. In thin section, this rock appears rather altered, and the amphiboles show a complete 


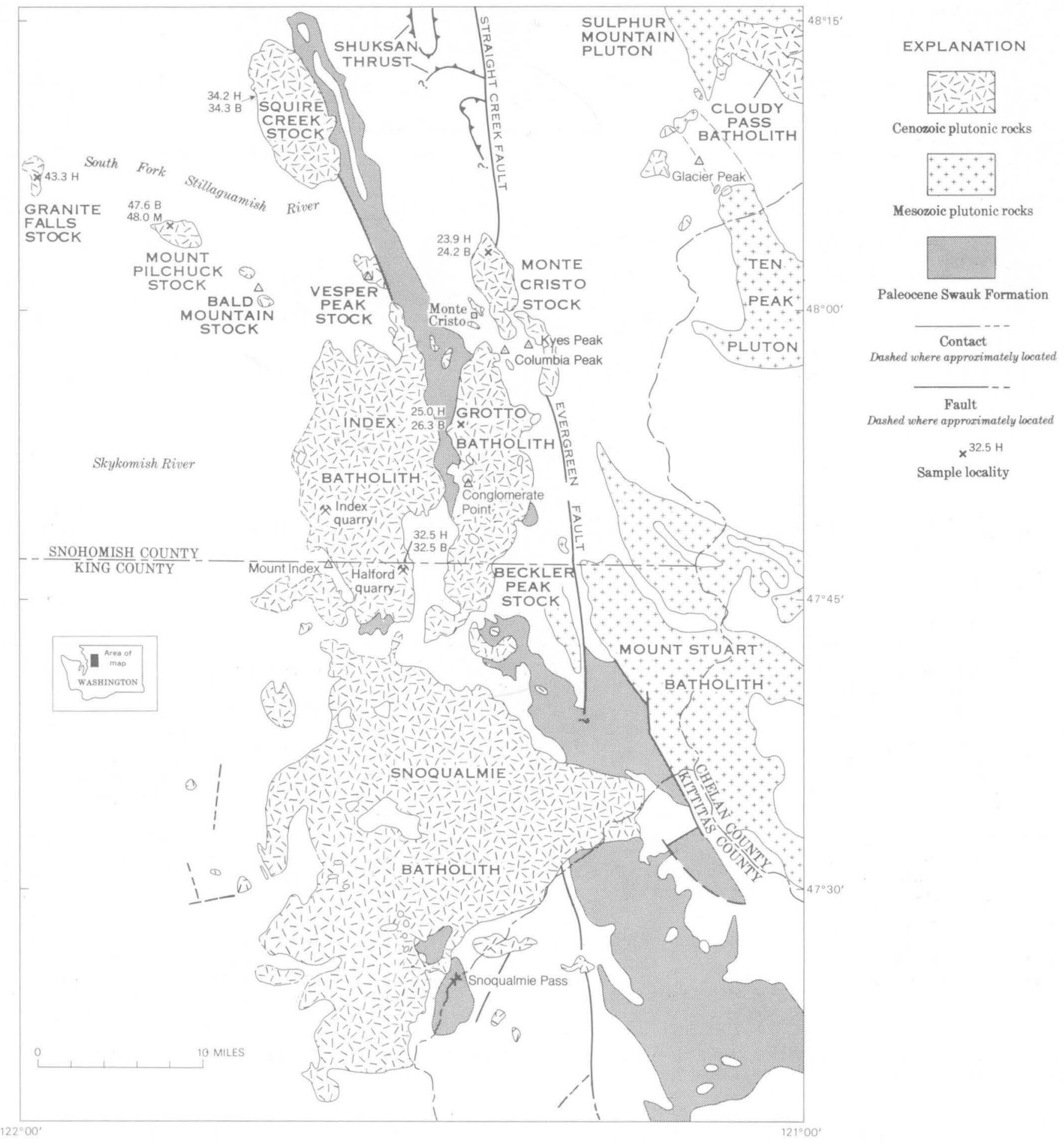

Figure 1.-Map of part of the Cascade Range, Wash. Contacts modified by Plummer (1964) and Yeats (from Huntting and others, 1961). 
Table 1.-Potassium-argon ages of plutons north of the Snoqualmie batholith, North Cascades, Wash.

\begin{tabular}{|c|c|c|c|c|c|c|c|}
\hline \multirow{3}{*}{$\begin{array}{c}\begin{array}{c}\text { Sample locality } \\
\text { and No. }\end{array} \\
\begin{array}{c}\text { Mount Pilchuck stock } \\
\text { RWT } 20-68\end{array}\end{array}$} & \multirow{3}{*}{ Mineral } & \multirow{3}{*}{$\begin{array}{c}\begin{array}{c}\text { Mesh } \\
\text { size }\end{array} \\
60-140\end{array}$} & \multirow{2}{*}{\multicolumn{2}{|c|}{$\begin{array}{c}\mathrm{K}_{2} \mathrm{O} \\
\text { (percent) }\end{array}$}} & \multicolumn{2}{|c|}{ Radiogenic $\mathrm{Ar}^{40}$} & \multirow{3}{*}{$\begin{array}{c}\begin{array}{c}\text { Age } \\
\text { (m.y.) }\end{array} \\
48.0 \pm 1.7\end{array}$} \\
\hline & & & & & \multirow{2}{*}{$\frac{\text { (moles/gram) }}{7.101 \times 10^{-10}}$} & \multirow{2}{*}{$\frac{\text { (percent) }}{56.4}$} & \\
\hline & & & $\left\{\begin{array}{l}9.87 \\
9.92\end{array}\right\}$ & 9.895 & & & \\
\hline & Biotite..$\ldots \ldots \ldots$ & $60-140 \ldots \ldots$ & $\left\{\begin{array}{l}7.93 \\
7.97 \\
7.93 \\
7.97\end{array}\right\}$ & 7.95 & $5.668 \times 10^{-10}$ & 85.3 & $47.6 \pm 1.4$ \\
\hline $\begin{array}{c}\text { Granite Falls stock } \\
\text { RWT 12-68 }\end{array}$ & Hornblende ....... & $140-230 \ldots \ldots$ & $\left\{\begin{array}{l}.659 \\
.649 \\
.659 \\
.653\end{array}\right\}$ & .655 & $4.242 \times 10^{-10}$ & 39.6 & $43.3 \pm 1.4$ \\
\hline \multirow[t]{2}{*}{$\begin{array}{l}\text { Squire Creek stock } \\
\text { PM } 32\end{array}$} & Hornblende ........ & $\ldots \ldots \ldots \ldots$ & $\left\{\begin{array}{l}.908 \\
.915\end{array}\right\}$ & .9115 & $4.648 \times 10^{-11}$ & 68.9 & $34.2 \pm 1.8$ \\
\hline & Biotite..$\ldots \ldots \ldots$ & $40-60 \ldots \ldots$ & 7.79 & & $3.98 \times 10^{-10}$ & $\mathbf{5 9 . 0}$ & $34.3 \pm 1.4$ \\
\hline \multirow[t]{2}{*}{$\begin{array}{l}\text { Index batholith } \\
\text { JE 10.67 }\end{array}$} & Hornblende ....... & $60-140 \ldots \ldots$ & $\left\{\begin{array}{l}.365 \\
.366\end{array}\right\}$ & .3655 & $1.746 \times 10^{-11}$ & 18.6 & $32.5 \pm 2.5$ \\
\hline & Biotite $^{1} \ldots \ldots \ldots$ & $60-140 \ldots \ldots$ & $\left\{\begin{array}{l}8.592 \\
8.62\end{array}\right\}$ & 8.605 & $4.170 \times 10^{-10}$ & 53.3 & $32.5 \pm 1.2$ \\
\hline $\begin{array}{c}\text { Grotto batholith } \\
\text { RWT 16-68 }\end{array}$ & Hornblende . . . . . . & $100-140 \ldots \ldots$ & $\left\{\begin{array}{l}.915 \\
.922 \\
.910 \\
.928\end{array}\right\}$ & .9188 & $3.417 \times 10^{-11}$ & 29.1 & $25.0 \pm 1.5$ \\
\hline . & Biotite.$\ldots \ldots \ldots$ & $100-140 \ldots$. & $\left\{\begin{array}{l}8.61 \\
8.58 \\
8.59 \\
8.64\end{array}\right\}$ & 8.605 & $3.401 \times 10^{-10}$ & 79.8 & $26.3 \pm 0.8$ \\
\hline \multirow[t]{2}{*}{$\begin{array}{c}\text { Monte Cristo stock } \\
\text { RWT 13-68 }\end{array}$} & Hornblende ........ & $60-100 \ldots \ldots$ & $\left\{\begin{array}{l}.565 \\
.567 \\
.563 \\
.567\end{array}\right\}$ & .5655 & $2.007 \times 10^{-11}$ & 45.0 & $23.9 \pm 1.0$ \\
\hline & Biotite .......... & $60-100 \ldots \ldots$ & $\left\{\begin{array}{l}8.54 \\
8.56 \\
8.48 \\
8.55\end{array}\right\}$ & 8.532 & $3.068 \times 10^{-10}$ & 68.1 & $24.2 \pm 1.1$ \\
\hline
\end{tabular}

Constants used in the age calculation: $\lambda_{\epsilon}=0.585 \times 10^{-10} \mathrm{yr}^{-1}, \lambda_{\beta}=4.72 \times 10^{-10} \mathrm{yr}^{-1}, \mathrm{~K}^{40} / \mathrm{K}=1.19 \times 10^{-2}$ atom percent. Errors ( \pm values) represent $2 \sigma$ and are based on uncertainties in the individual runs and experience with replicate analyses.

Potassium analyses by Lois Schlocker, using an Instrumentation Laboratories flame photometer with lithium internal standard.

RWT 20-68 Locality: On Mount Pilchuck trail; sec. 29, T. 30 N., R. 8 E. Fine-grained biotite granodiorite with scattered pink feldspar phenocrysts. Biotite separate: about 4 percent chlorite. Muscovite separate: about 3 percent impurity (chlorite, quartz, biotite, epidote).

RWT 12-68 Locality: Granite Falls fish ladder; center sec. 7, T. 30 N., R. 7 E. Biotite-hornblende quartz diorite; relatively fresh, but with some chlorite and epidote in joints. Amphibole separate: all amphibole, but varying from green to bottle brown and colorless.

PM 32 Locality: Center sec. 13, T. 31 N., R. 9 E. Biotite-hornblende quartz diorite. Hornblende separate: about 8 percent biotite, 2 percent chlorite, epidote. Biotite separate: about 5-10 percent impurity (hornblende, colorless minerals).
JE 10-67 Locality: Halford quarry, just north of town of Baring; sec. 2, T. 26 N., R. 10 E. Biotite-hornblende granodiorite; very fresh, large mafic minerals; fine-grained dark inclusions(?) avoided in sampling. Biotite separate: $>98$ percent pure. Hornblende separate: about 95 percent pure.

RWT 16-68 Locality: North Fork of Skykomish River where road crosses it northeast of Index; $\mathrm{SE}^{1 / 4}$ sec. 20, T. $28 \mathrm{~N}$., R. $11 \mathrm{E}$. Biotite-hornblende quartz diorite. Biotite separate: $>99$ percent pure. Hornblende separáte: $<1$-percent chlorite, colorless amphibole.

RWT 13-68 Locality: Elliot Creek logging road, east of mouth of Pearsall Creek; SW $1 / 4$ sec. 34, T. 30 N., R. 11 E. Biotite-hornblende quartz diorite. Biotite separate: all mica, but about 5 percent of grains have chloritized edges. Hornblende separate: $>99$ percent pure:

\footnotetext{
${ }^{1}$ Work done at Lamont Geological Observatory of Columbia University, reported here with the permission of Peter Misch; potassium determinations by isotope dilution.
}

gradation from light green to light brown, with minor colorless patches. The mineral separate was pure amphibole, but the various types were inseparable; about one-third of the grains were predominantly brown. No petrographic evidence could be found to indicate that age differences exist between the green, brown, and colorless amphiboles. If one or more of these phases are due to later alteration, then the 43-m.y. age would be a minimum.

\section{MOUNT PILCHUCK STOCK}

Southeast of the Granite Falls stock, three small stocks of quartz monzonite and granite occur along the crest of a 
west-northwest-trending ridge south of the South Fork of the Stillaguamish River. These were mapped in part by Carithers and Guard (1945) and Danner (1957), and a detailed study of one of these quartz monzonite plutons, the Mount Pilchuck stock, was made by Wiebe (1963). The plutons are intrusive into metasedimentary rocks of pre-Tertiary age. Biotite from the Mount Pilchuck stock has an age of 47.6 $\pm 1.4 \mathrm{~m} . y$., and muscovite is dated as $48.0 \pm 1.7 \mathrm{~m}$.y.

It is likely that these ages are representative of the age of all four stocks from Granite Falls east-southeast to Bald Mountain, considering their compositional similarity and their alinement. This alinement is parallel to the regional structural grain of the pre-Tertiary metasedimentary terrane into which the stocks were emplaced. Plutons of this age elsewhere in the Cascades include quartz diorite and granodiorite (45 m.y.) of the Duncan Hill pluton and granodiorite and quartz monzonite (43-44 m.y.) of the Railroad Creek pluton of Cater and others (1967) east of Glacier Peak, granite of the Golden Horn pluton of Misch $(1952 ; 1966)$ (48 m.y.) (Naeser and others, 1970; Engels, unpub. data), and granodiorite of the Castle Peak pluton (50 m.y.) and granite of the Monument Peak pluton (48 m.y.) of the northeastern Cascades (Tabor and others, 1968).

\section{INDEX BATHOLITH}

The quartz diorite and granodiorite batholith of the Index mining district was considered Jurassic in age by Weaver (1912), but this was questioned by Carithers and Guard (1945). H. J. Zwart (oral commun., 1955) and Yeats (1958) showed that the Index batholith intruded the Swauk Formation which is considered by J. A. Wolfe (oral commun., 1971) to be Paleocene on the basis of all available paleobotanic evidence. Plummer (1964) presented evidence that the batholith intruded volcanic rocks of possible Eocene age near Mount Index. Throughout most of its outcrop, the Index batholith is thought to be eroded far beneath its original roof, on the basis of its coarse grain size, the absence of roof pendants, and the presence of steeply dipping contacts. At the south end of the outcrop area, however, the contact is gently dipping, and pendants are exposed. A broad screen of altered volcanic rocks separates the Index batholith from the northern end of the Snoqualmie batholith (Plummer, 1964). Grant (1969) speculated that the Index and Snoqualmie were the same body, but the fact that no contact between the two plutons is exposed has made the determination of their relative ages impossible prior to the present geochronologic" studies.

Yeats and McLaughlin (1968) obtained a K-Ar age on biotite of $33 \pm 5 \mathrm{~m} . \dot{y}$. at Index quarry, type locality of the batholith, and $\mathrm{Rb}-\mathrm{Sr}$ biotite ages of $35 \pm 5$ and $40 \pm 2 \mathrm{~m}$.y., respectively, from the Index quarry and the Halford quarry to the southeast. We report here a $\mathrm{K}$-Ar age of $32.5 \mathrm{~m}$.y. from a concordant biotite-hornblende pair from Halford quarry. These results indicate that the Index batholith is not a northern extension of the Snoqualmie. However, the Snoqual- mie is a composite batholith (Erikson, 1969), and older phases of it may be equivalent to the Index batholith or other nearby plutons.

\section{SQUIRE CREEK STOCK}

North-northwest of the Index batholith is the Squire Creek stock of Vance (1957). Concordant ages of 34.2 $11.8 \mathrm{~m} . \mathrm{y}$. and $34.3 \pm 1.4 \mathrm{~m} . \mathrm{y}$. have been determined for hornblende and biotite, respectively. The emplacement of the Index batholith and Squire Creek stock, together with a third body at Vesper Peak, appears to have been controlled by a fault separating a tightly folded syncline of Swauk Formation on the east from pre-Tertiary rocks on the west. Although the Vesper Peak stock was not dated, its field relationships suggest that it was intruded at the same time as the adjacent and petrographically similar Index batholith and Squire Creek stock.

\section{GROTTO BATHOLITH AND MONTE CRISTO STOCK}

In the Monte Cristo mining district, Spurr (1901) mapped parts of the Grotto batholith and Monte Cristo stock as "Tertiary tonalite" on the basis of field relationships. Smith's map (1915) shows the south end of the Grotto batholith as part of the Snoqualmie batholith. Reconnaissance mapping of the plutons was completed by H. J. Zwart (written commun., 1955), Galster (1956), and Yeats (1958). The Monte Cristo stock intrudes gently folded interbedded volcanic and sedimentary rocks which unconformably overlie the Paleocene Swauk Formation (J. A. Vance, oral commun., 1969). The Grotto batholith intrudes gently dipping andesite flows and breccias which unconformably overlie strongly folded Swauk beds (Yeats, 1958). The two plutons are separated by nearly flat-lying breccias on Columbia and Kyes Peaks, shown by earlier mapping to overlie the plutonic rocks nonconformably. However, recent work by Michael Heath (oral commun., 1968) has shown that the plutonic rocks intruded these breccias.

The Monte Cristo stock was intruded along the high-angle Straight Creek fault (Vance, 1957; Misch, 1966) and along the Evergreen fault (Yeats, 1958); these faults displace rocks as young as Swauk. The Grotto batholith, however, may have been emplaced along th.e high-angle root zone of the Shuksan thrust of late Mesozoic age (Misch, 1966), or along a high-angle southward continuation of the Straight Creek fault.

The Monte Cristo stock is dated as $24.2 \pm 1.1$ m.y. (biotite) and $24.1 \pm 1.0 \mathrm{~m} . \mathrm{y}$. (hornblende) and the Grotto batholith as $26.3 \pm 0.8 \mathrm{~m} . \mathrm{y}$. (biotite) and 25.0 $\pm 1.5 \mathrm{~m}$.y. (hornblende). Both plutons apparently were emplaced at about the same time, even though the fault zones controlling them may be of different ages. Lithologic similarity between the two plutons also supports a single age of emplacement (J. A. Vance, oral commun., 1970).

\section{CONCLUSIONS}

The ages reported here, together with previous work, suggest more or less continuous plutonism in this part of the North 
Cascades, beginning about $48 \mathrm{~m} . \mathrm{y}$. ago and extending at least to $14 \mathrm{~m} . \mathrm{y}$. ago. This confirms the conclusions previously expressed by Misch (1966) and Cater and others (1967) on the basis of field and radiometric evidence. However, there is no evidence that this continuous plutonism extended back into the Mesozoic, as suggested by Cater and others (1967) on the basis of their studies near Glacier Peak and in the northeastern Cascades. In the part of the Cascades described herein, there is no evidence that plutonism occurred in the interval between about 48 and $90 \mathrm{~m} . \mathrm{y}$. ago. The next oldest pluton in the area is the Late Cretaceous Beckler Peak stock just east of the Grotto batholith (Yeats and McLaughlin, 1968; Engels and Crowder, 1971, this chapter, p. D39-D43). The Swauk Formation was; deposited during this pluton-free time interval; it is almost unique among western Washington bedded units in being free of intercalated volcanic rocks. It is suggested that the 48-90-m.y. time interval was a cool period in this region during which plutonic trends were reoriented from northnorthwesterly in the Cretaceous (Misch, 1966) to slightly east of north in the Tertiary.

\section{REFERENCES}

Baadsgaard, Halfdan, Folinsbee, R. E., and Lipson, J. I., 1961, Potassium-argon dates of biotites from Cordilleran granites: Geol. Soc. America Bull., v. 72, p. 689-701.

Carithers, Ward, and Guard, A. K., 1945, Geology and ore deposits of the Sultan Basin, Snohomish County, Washington: Washington Div. Mines and Geology Bull., v. 36, 90 p.

Cater, F. W., 1969; The Cloudy Pass epizonal batholith and associated subvolcanic rocks: Geol. Soc. America Spec. Paper 116, 54 p.

Cater, F. W., Crowder, D. F., Engels, J. C., Hopson, C. A., and Tabor, R. W., 1967, Late Cretaceous and Tertiary potassium-argon ages of plutons in part of the North Cascades, Washington [abs.]: Geol. Soc. America, Ann. Mtg., San Francisco, Calif., 1966, Program, p. 37.

Curtis, G. H., Savage, D. E., and Evernden, J. F., 1961, Critical points in the Cenozoic, in Geochronology of rock systems: New York Acad. Sci. Annals, v. 91, art. 2, p. 342-351.

Danner, W. R., 1957, A stratigraphic reconnaissance in the northwestern Cascade Mountains and San Juan Islands of Washington State: Univ. Washington, Seattle, Ph. D. thesis, $562 \mathrm{p}$.

Engels, J. C., and Crowder, D. F., 1971, Late Cretaceous fission-track and potassium-argon ages of the Mount Stuart Granodiorite and Beckler Peak stock, North Cascades, Washington, in Geological Survey Research 1971: U.S. Geol. Survey Prof. Paper 750-D, p. D39-D43.

Erikson, E. H., 1969, Petrology of the composite Snoqualmie batholith, central Cascade Mountains, Washington: Geol. Soc. America Bull., v. 80, p. 2213-2236.

Fiske, R. S., Hopson, C. A., and Waters, A. C., 1963, Geology of Mount Rainier National Park, Washington: U.S. Geol. Survey Prof. Paper 444,93 p.
Galster, R. W., 1956, Geology of the Miller-Foss River area, King County, Washington: Univ. Washington, Seattle, M.S. thesis, 93.p.

Grant, A. R., 1969, Chemical and physical controls for base metal deposition in the Cascade Range of Washington: Washington Div. Mines and Geology Bull., v. 58, 107 p.

Huntting, M. T., Bennett, W. A. G., Livingston, V. E., Jr., and Moen, W. S., compilers, 1961, Geologic map of Washington:- Washington Div. Mines and Geology Geol. Map, scale 1:500,000.

Misch, Peter, 1952, Geology of the Northern Cascades of Washington: Mountaineer, v. 45, p. 4-22.

1964, Age determinations on crystalline rocks of Northern Cascade Mountains, Washington, in Kulp, J. L., senior investigator, and others, Investigations in isotope geochemistry: Palisades, N.Y., Columbia Univ., Lamont Geol. Observatory (U.S. Atomic Energy Comm. NY0-7243), App. D, p. 1-15.

- 1966, Tectonic evelution of the Northern Cascades of Washington State-A west cordilleran case history, in A symposium on tectonic history and mineral deposits of the western cordillera in British Columbia and neighboring parts of the United States: Canadian Inst. Mining and Metallurgy Spec. Volume 8, p. 101-148.

Naeser, C. W., Engels, J. C., and Dodge, F. C. W., 1970, Fission track annealing and age determination of epidote minerals: Jour. Geophys. Research, v. 75, p. 1579-1584.

Plummer, C. C., 1964, The geology of the Mount Index area of Washington State: Univ. Washington, Seattle, M.S.'thesis, 62 p.

Smith, G. O., and Calkins, F. C., 1906, Description of the Snoqualmie quadrangle [Washington]: U.S. Geol. Survey Geol. Atlas, Folio 139, $14 \mathrm{p}$.

Smith, W. S., 1915, Petrology and economic geology of the Skykomish basin, Washington: School Mines Quart." [Columbia Univ., New York ], v. 36, p. 154-185.

Spurr, J. E., 1901, The ore deposits of Monte Cristo, Washington: U.S. Geol. Survey, 22nd Ann. Rept., pt. 2, p. 777-865.

Tabor, R. W., and Crowder, D. F., 1969, On batholiths and volcanoesIntrusion and eruption of late Cenozoic magmas in the Glacier Peak area; North Cascades, Washington: U.S. Geol. Survey Prof. Paper 604, $67 \mathrm{p}$.

Tabor, R. W., Engels, J. C., and Staatz, M. H., 1968, Quartz diorite-quartz monzonite and granite plutons of the Pasayten River area, Washington-Petrology, age, and emplacement, in Geological Survey Research 1968: U.S. Geol. Survey Prof. Paper 600-C, p. C45-C52.

Vance, J. A., 1957, The geology of the Sauk River area in the northern Cascades of Washington: Univ. Washington, Seattle, Ph. D. thesis, $312 \mathrm{p}$.

Waters, A. C., 1961, Keechelus problem, Cascade Mountains, Washington: Northwest Sci., v. 35, p. 39-57.

Weaver, C. E., 1912, Geology and ore deposits of the Index mining district: Washington Geol. Survey Bull., v. 7, 96 p.

Wiebe, R. A., 1963, The geology of Mount Pilchuck: Univ. Washington, Seattle, M.S. thesis, 52 p.

Yeats, R. S., 1958, Geology of the Skykomish area in the Cascade Mountains of Washington: Univ. Washington, Seattle, Ph. D. thesis, $243 \mathrm{p}$.

— 1964, Crystalline klippen in the Index district; Cascade Range, Washington: Geol. Soc. America Bull., v. 75, p. 549-562.

Yeats, R. S., and McLaughlin, W. A., 1968, Radiometric ages of three Cascade plutons, Skykomish area, Washington [abs.]: Geol. Soc. America, Ann. Mtg., Mexico City 1968; Program with abstracts, p. 332. 


\title{
LATE CRETACEOUS FISSION-TRACK AND POTASSIUM-ARGON AGES OF THE MOUNT STUART GRANODIORITE AND BECKLER PEAK STOCK, NORTH CASCADES, WASHINGTON
}

\author{
By JOAN C. ENGELS and DWIGHT F. CROWDER ${ }^{1}$, \\ Menlo Park, Calif.
}

\begin{abstract}
The Mount Stuart Granodiorite, one of the largest tonalite-granodiorite masses of rock in the core of the North Cascades, is an elongate batholith, wide and massive at its southeastern end and narrower, more irregular, and locally gneissic at its northwestern end. The Beckler Peak stock lies just west of the main batholith and has long been considered correlative with it. Potassium-argon ages on six biotite-hornblende pairs and fission-track ages on allanite and epidote from two of these samples indicate that the batholith and the stock crystallized in the Late Cretaceous about 88 m.y. ago. The Swauk Formation (Late Cretaceous and Paleocene), which depositionally overlies the batholith, cannot be older than about 80 m.y. Apatite fission-track dates on the same rocks vary from 71 to 28 m.y., possibly reflecting subsequent heating by the nearby Miocene Grotto pluton and other Tertiary intrusions to the west. Prolonged deep burial of the batholith, especially the northwestern part, which may be the deepest, slowest cooling part, could explain the lower apatite dates as well as the few potassium-argon ages of about $80 \mathrm{~m}$. y.
\end{abstract}

Potassium-argon dates on biotite-hornblende pairs from the Mount Stuart Granodiorite and Beckler Peak stock and fission-track dates on apatite, allanite, and epidote from the same rocks were determined by the authors as part of a regional study of the North Cascades. Earlier work had indicated that pulses of magma have been injected more or less continuously from at least the'latest Cretaceous to the present (Cater and others, 1966; Tabor and others, 1968; and Yeats and Engels, 1971, this chapter, p. D34-D38). The latest Cretaceous intrusions seem to be the most voluminous, and of these, the Mount Stuart batholith is one of the largest masses: Acknowledgments. -We thank Peter Misch, R. W. Tabor, and R.S. Yeats for valuable discussions and aid in sample collection and $\dot{C}$. W. Naeser for his instruction and discussion on fission-track dating.

\section{MOUNT STUART GRANODIORITE}

"The Mount Stuart Granite (fig. 1) was named by Russell (1900), who mapped the southeastern corner. Later workers

\footnotetext{
${ }^{1}$ Deceased April 1970.
}

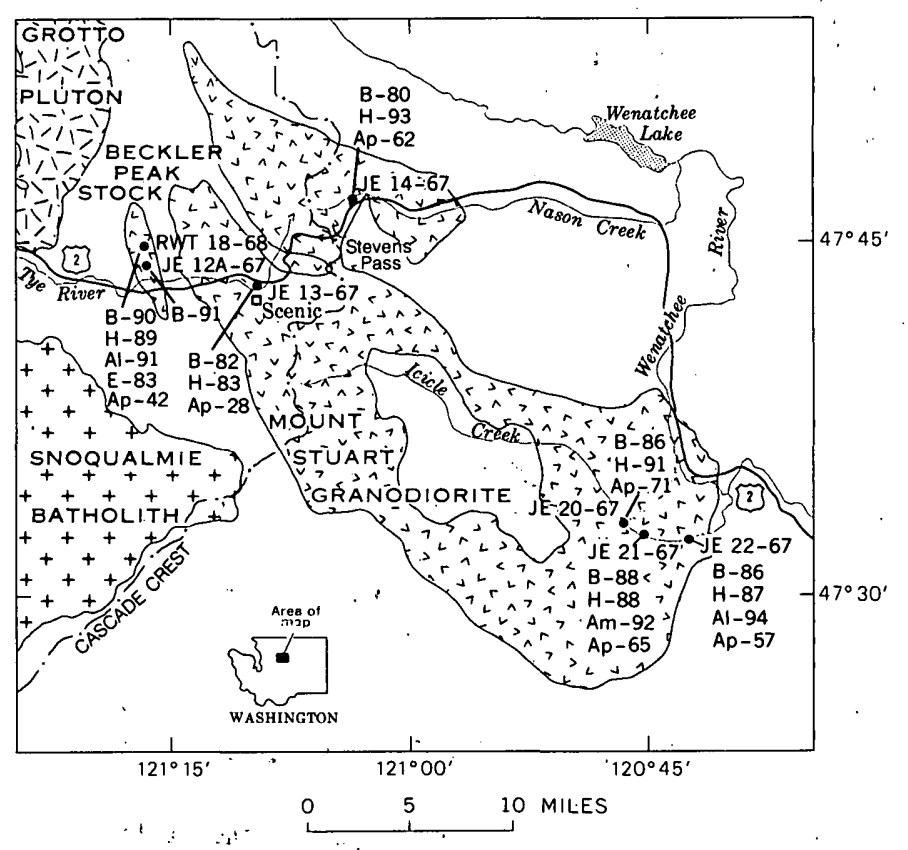

Figure 1.-Potassium-argon and fission-track ages (in million years) of samples from the Mount Stuart Granodiorite and Beckler Peak stock. $\mathrm{B}$, biotite $\mathrm{K}-\mathrm{Ar}$; $\mathrm{H}$, hornblende $\mathrm{K}-\mathrm{Ar}$; Am, colorless amphibole $\mathrm{K}$ - $\mathrm{Ar}$; Al, allanite FT; E, epidote FT; Ap, apatite FT. Map simplified from Huntting and others (1961), "Geologic Map of Washington."

(Oles, 1956; Pratt, 1958; and Smith, 1903, 1904) extended the limits of the batholith northwestward, and it is now known to crop out over an area of some 300 square miles. Most of the body has been described as massive, homogeneous, and magmatic with intrusive contacts. Pioneer workers did not map internal subdivisions but describe numerous varieties (Oles, 1956; Pratt, 1958). Near Stevens Pass, the batholith appears to be partly gneissic, and it becomes narrow and embayed with host rock's. Oles (1956, p. 174-183), and Yeats (1958, p. $37-38)$ suggest a replacement origin for the northeastern part. Further mapping may show that the 
batholith is composite as has been shown for Tertiary batholiths in the Cascades (see Misch, 1966; Erikson, 1969). Although we attempt to explain the age results in terms of one heating episode, it is possible that some of the age differences observed could be explained by separate episodes of intrusion or granitization.

Tonalites and granodiorites are the dominant rocks of the batholith; trondjemites, alaskites, and diorites also occur. (For petrography of samples used in this study, see notes with table 1.)

The batholith intrudes a partial sheath of ultramafic rocks (peridotite of Smith and Calkins, 1906) and a variety of phyllites, greenstones, and schists, the youngest of which is thought to be Permian (Thompson and others, 1950). Arkoses and minor conglomerates and shales of the Swauk Formation overlie the batholith and locally contain cobbles of it (Page, 1939 , p. 47, and Pratt, 1958, p. 48-49). Before Swauk deposition the batholith was not only deroofed but deeply weathered (Pratt, 1958, p. 48-49; Lupher, 1944; Page, 1939, p. 47). The Swauk was deposited in the latest Cretaceous and Paleocene, on the basis of paleobotanic evidence (Foster, 1960, p. 104; Cater, 1969, pl. 1).

\section{BECKLER PEAK STOCK}

One smaller pluton, the Beckler Peak stock (fig. 1), was included in this study because it has long been considered a correlative of the batholith (Oles, 1956, p. 166-171; Yeats, 1958 , p. 81 ). The stock is typically a coarse-grained biotite granodiorite. It intrudes phyllite of poorly known age and is not in contact with the Swauk Formation (Yeats, 1958, p. 75, 81).

\section{LATE CRETACEOUS EVENTS}

The potassium-argon age results (fig. 1 and table 1 ) are compatible with known field relations. Three biotitehornblende pairs from this southeastern part of the batholith indicate a time of crystallization of about 88 million years ago. Two biotites and a hornblende from the Beckler Peak stock give 90-m.y. ages, indicating that the Beckler may well be a satellite of the Mount Stuart Granodiorite. Yeats (1968) reports a $94 \pm 16-m . y . ~ R b-S r$ age for biotite from the Beckler Peak stock.

Argon determinations were made by standard techniques of isotope dilution on a 6 -inch $60^{\circ}$ Nier-type mass spectrometer, potassium determinations were made on Baird and Instrumentation Laboratories flame photometers with lithium internal standards, and fission-track ages were determined using methods and procedures described by Naeser (1967).

One hornblende-biotite pair at 83 and 82 m.y. (this paper) and two biotites at 78 and 80 m.y. (Yeats, 1968, and this paper, respectively) were collected from the northwestern gneissic part of the batholith. The 78 $\pm 5-\mathrm{m}$.y. biotite has a

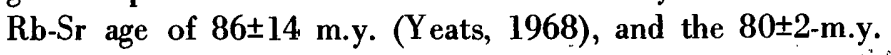

biotite has a coexisting hornblende with a K-Ar age of $93 \pm 3$ m.y. These dates suggest that the original age of these samples is the same as that of the other samples studied and that partial argon loss may have occurred to bring them into the 80-m.y. range. Thin sections of these samples show evidence of mild deformation and alteration such as sutured quartz grains, fractured minerals, and chlorite forming from biotite, but there is no indication of whether these features formed during a late magmatic stage or after it. Possibly argon was lost from rocks in this area because they crystallized in a deeper, locally gneissic part of the batholith that stayed hot longer than the rest. This deeper part has been tilted up to view by greater uplift and erosion along the Cascade crest relative to flank parts farther southeast (fig. 1). (A similar situation is discussed by Hopson and others (1970) for the Duncan Hill pluton to the northeast.) Another possible explanation for the lower age is Tertiary plutonism to the west. But neither of these explanations accounts for the apparent argon retention by the Beckler Peak biotites, which are geographically between an area of low-age samples and one of known Tertiary plutonism and are also in the deep zone supposedly exposed by greater uplift. Unmapped or subsurface Tertiary plutons could also account for these anomalies.

\section{EARLY TERTIARY EVENTS}

The fission-track ages of epidote and allanite from two of the samples (table 1) confirm the Late Cretaceous K-Ar ages and indicate that there has been no profound reheating of the batholith or stock since initial crystallization. If temperatures had exceeded $350^{\circ} \mathrm{C}$, these fission-track ages of epidote-family minerals would have been lower (Naeser and others, 1970). The three concordant biotite-hornblende pairs from separate samples from the southern end of the batholith similarly indicate that the rocks were not intensely reheated-for these samples, to not over about $200^{\circ}-250^{\circ} \mathrm{C}$ (Hart, 1964).

A mild, irregular reheating of the batholith is suggested by the low fission-track ages on apatites from these samples (table 1). Eocene, Oligocene, and Miocene plutons are known to intrude the region along a north-trending belt just west of the batholith (Yeats and Engels, 1971; Baadsgaard and others, 1961). Apatite from the Beckler Peak stock collected about 5 miles east of the 26-m.y.-old Grotto pluton gives a 42-m.y. fission-track date, even though biotites from the stock still record the apparent $90-\mathrm{m} . \mathrm{y}_{\text {. date }}$ of crystallization. A Mount Stuart apatite collected 10 miles from the eastern edge of the Tertiary plutonic belt has a 28-m.y. age. The apatites in the southeastern part of the Mount Stuart Granodiorite are much farther from the Tertiary plutons and show an average age of $63 \mathrm{~m} . \mathrm{y}$. Scattering of apatite ages could also result from irregular reheating by unknown Tertiary plutons' lying within the Mount Stuart batholith or buried close to the surface.

Swauk time (Late Cretaceous and Paleocene) is so poorly defined that we can only speculate on when or how rapidly the 90-m.y.-old batholith was deroofed. The clustering of four 
apatite dates around $30 \mathrm{~m} . \mathrm{y}$. after initial crystallization may represent the stage in the cooling history when fission tracks began to be retained. If the batholith stayed about $6 \mathrm{~km}$ below the surface for $30 \mathrm{~m} . \mathrm{y}$. after crystallization, a temperature of $150^{\circ} \mathrm{C}$ would be maintained (Lachenbruch, 1968, fig. 7 ), and this would be sufficient to prevent preservation of any fission tracks (Naeser and Faul, 1969, fig. 3). Sixty million years ago the apatite tracks may have been retained as the batholith came closer to the surface and cooled below $150^{\circ} \mathrm{C}$. According to this model, removal of $6 \mathrm{~km}$ of roof, deep weathering of the surface, and Swauk deposition would have to be confined to the few(?) million years between mid-Paleocene and the poorly defined date marking the end of Swauk time.

\section{REFERENCES}

Baadsgaard, Halfdan, Folinsbee, R. E., and Lipson, J. I., 1961, Potassium-argon dates of biotites from Cordilleran granites: Geol. Soc. America Bull., v. 72, no. 5, p. 689-702.

Cater, F. W., 1969, The Cloudy Pass epizonal batholith and associated subvolcanic rocks: Geol. Soc. America Spec. Paper 116, 54 p.

Cater, F. W., Crowder, D. F., Engels, J. C., Hopson, C. A., and Tabor, R. W., 1966, Late Cretaceous and Tertiary potassium-argon ages of plutons in part of the North Cascades, Washington [abs.]: Geol. Soc. America Ann. Mtg., San Francisco, Calif., 1966, Program, p. 37.

Erikson, E. H., 1969, Petrology of the composite Snoqualmie batholith, central Cascades Mountains, Woshington: Geol. Soc. America Bull., v. 80, p. 2213-2236.

Fleischer, R. L., and Price, P. B., 1964, Technique for geological dating of minerals by chemical etching of fission fragment tracks: Geochim. et Cosmochim. Acta, v. 28, p. 1705-1714.

Foster, R. J., 1960, Tertiary geology of a portion of the central Cascade Mountains, Washington: Geol. Soc. America Bull., v. 71, p. 99-126.

Hart, S. R., 1964, The petrology and isotopic mineral age relations of a contact zone in the Front Range, Colorado: Jour. Geology, v. 72, p. 493-525.

Hopson, C. A., Cater, F. W., and Crowder, D. F., 1970, Emplacement of plutons, Cascade Mountains, Washington: Geol. Soc. America Abstracts with Programs, v. 2, no. 2, Cordilleran Sec., 66th Ann. Mtg., p. 104.

Huntting, M. T., Bennett, W. A. G., Livingston, V. E., Jr., and Moen, W. S., compilers, 1961, Geologic map of Washington: Washington Div. Mines and Geology geol. map, scale 1:500,000.

Lachenbruch, A. H., 1968, Preliminary geothermal model of the Sierra Nevada: Jour. Geophys. Research, v. 73, p. 6977-6989.

Lupher, R. L., 1944, Stratigraphic aspects of the Blewett-Cle Elum iron ore zone, Chelan and Kittitas Counties, Washington: Washington Div. Mines and Geology Rept. Inv. 11, 63 p.

Misch, Peter, 1966, Tectonic evolution of the northern Cascades of Washington State-A west cordilleran case history, in A symposium on tectonic history and mineral deposits of the western cordillera in British Columbia and neighboring parts of the United States: Canadian Inst. Mining and Metallurgy Spec. Volume 8, p. 101-148.

Naeser, C. W., 1967, The use of apatite and sphene for fission track age determinations: Geol. Soc. America Bull., v. 78, p. 1523-1526.

Naeser, C. W., and Faul, H., 1969, Fission track annealing in apatite and sphene: Jour. Geophys. Research, v. 74, p. 705-710.

Naeser, C. W., Engels, J. C., and Dodge, F. C. W., 1970, Fission track annealing and age determination of epidote minerals: Jour. Geophys. Research, v. 75, p. 1579-1584.

Oles, K. F., 1956, The geology and petrology of the crystalline rocks of the Beckler River-Nason Ridge areas, Washington: Univ. Washington, Seattle, Ph. D. thesis, 192 p.

Page, B. M., 1939, Geology of a part of the Chiwaukum quadrangle, Washington: Stanford Univ., Stanford, Calif., Ph. D. thesis, 203 p.

Pratt, R. M., 1958, The geology of the Mount Stuart area, Washington: Univ. Washington, Seattle, Ph. D. thesis, 229 p.

Russell, I. C., 1900, A preliminary paper on the geology of the Cascade Mountains in northern Washington: U.S. Geol. Survey 20th Ann. Rept., pt. 2, p. 83-210.

Smith, G. 0., 1903, Geology and physiography of central Washington: U.S. Geol. Survey Prof. Paper 19, p. 9-39.

- 1904, Description of the Mount Stuart quadrangle [Washington]: U.S. Geol. Survey Geol. Atlas, Folio 106.

Smith, G. O., and Calkins, F. C., 1906, Description of the Snoqualmie quadrangle [Washington]: U.S. Geol. Survey Geol. Atlas, Folio 139, $14 \mathrm{p}$.

Tabor, R. W., Engels, J. C., and Staatz, M. H., 1968, Quartz diorite-quartz monzonite and granite plutons of the Pasayten River area, Washington-Petrology, age, and emplacement, in Geological Survey Research 1968: U.S. Geol. Survey Prof. Paper 600-C, p. C45-C52.

Thompson, M. L., Wheeler, H. E., and Danner, W. R., 1950, Middle and Upper Permian fusulinids of Washington and British Columbia: Cushman Found. Foram. Research Contr., v. 1, pts. 3 and 4, no. 8, p. 46-63.

Yeats, R. S., 1958, Geology of the Skykomish area in the Cascades Mountains of Washington: Univ. Washington, Seattle, Ph. D. thesis, $243 \mathrm{p}$.

Yeats, R. S., and Engels, J. C., 1971, Potassium-argon ages of plutons in the Skykomish-Stillaguamish areas, North Cascades, Washington, in Geological Survey Research 1971: U.S. Geol. Survey Prof. Paper 750-D, p. D34-D38.

Yeats, R. S., and McLaughlin, W. A., 1968, Radiometric age of three Cascade plutons, Skykomish area, Washington [abs.]: Geol. Soc. America Ann. Mtg., Mexico City 1968, Programs with Abstracts, p. 332. 
Table 1.-Age data for the Mount Stuart Granodiorite and Beckler Peak stock, North Cascades, Wash.

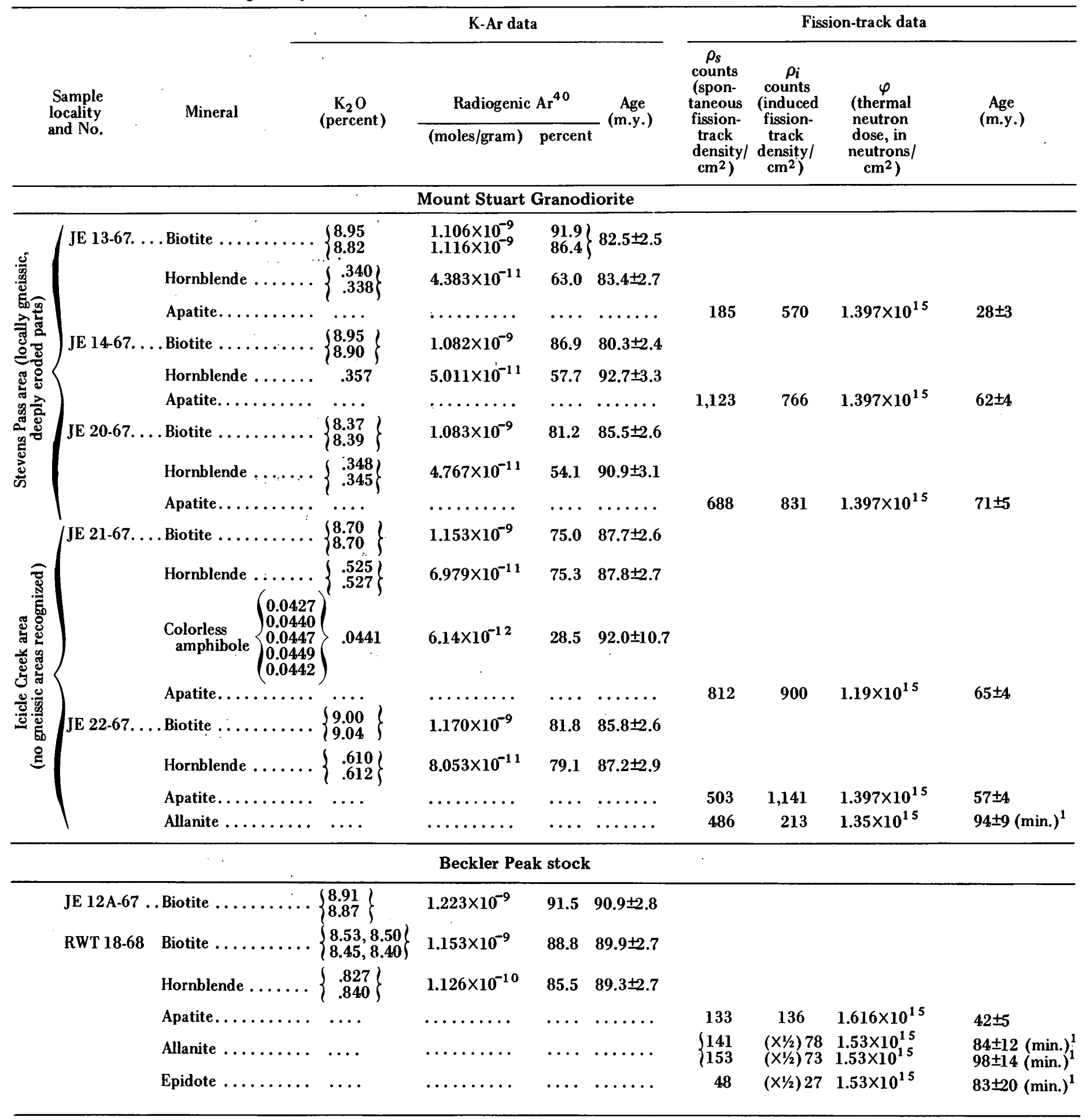

Argon determinations were made by standard techniques of isotope dilution on a 6 -inch $60^{\circ}$ Nier-type mass spectrometer; potassium determinations were made on Baird and Instrumentation Laboratories flame photometers with lithium internal standards. Constants used in the age calculations are: $\lambda_{\epsilon}=0.585 \times 10^{-10} \mathrm{yr}^{-1}, \lambda_{\beta}=4.72 \times 10^{-10} \mathrm{yr}^{-1}$, and $\mathrm{K}^{40} / \mathrm{K}=1.19 \times 10^{-2}$ atom percent.

Fission-track ages were determined using methods and procedures described by Naeser $(1967)$. Constants used in the age calculations are: $\lambda_{a} \lambda_{F}$, total decay constant for uranium, $=1.54 \times 10^{-10} \mathrm{yr}^{-1} ; \lambda_{F}$ fission decay constant for $\mathrm{U}^{238},=6.85 \times 10^{-17} \mathrm{yr}^{-1}$ (Fleischer and Price, 1964); and $I$ isotopic ratio $\mathrm{U}^{235} / \mathrm{U}^{238}=7.26 \times 10^{-3}$. 
JE 13-67 Locality: U.S. Route 2 at intersection with road to Scenic; $\mathrm{SE}^{1 / 4}$ sec. 29 , T. 26 N., R. 13 E. Fine- to medium-grained hornblende-biotite tonalite; hypidiomorphic, with oscillatory zoning of plagioclase; interstitial quartz. Alteration: sericite after plagioclase, chlorite, and prehnite after biotite; patches of biotite in hornblende. Biotite separate: no impurities seen. Hornblende separate: no impurities seen.

JE 14-67 Locality: U.S. Route 2, east of Stevens Pass, just east of junction of Nason and Stevens Creek; NE $1 / 4$ sec. 1, T. 26 N., R. 13 E. Medium-grained hornblende-biotite granodiorite, with interstitial K-feldspar and quartz; oscillatory zoned plagioclase showing sineusis twins; myrmekite at K-feldspar-plagioclase contacts; quartz aggregates; trace of pyroxene. Alteration: plagioclase moderately altered to sericite, hornblende to sphene and biotite, biotite to chlorite; trace of interstitial calcite. Biotite separate: $<0.5$ percent hornblende. Hornblende separate: $<1.0$ percent quartz aggregate.

JE 20-67 Locality: Icicle Creek, just east of Bridge Creek; NE corner sec. 24, T. 24 N., R. 16 E. Medium-grained biotite-hornblende tonalite; hypidiomorphic plagioclase rarely zoned, trace mottled extinction; biotite and hornblende in clots; hornblende has poikilitic cores, brownish rims. Alteration: some biotite altered to chlorite. Biotite separate: $\approx 3$ percent hornblende, 1 percent chlorite. Hornblende separate: $\approx 1$ percent colorless amphibole overgrowths.

JE 21-67 Locality: On Icicle Creek Road; SE1/4 sec. 29, T. 24, N., R. 17 E. Medium-grained biotite-hornblende tonalite with minor pyroxene; hypidiomorphic with interstitial quartz; subparallel; both green

${ }^{1}$ The age of the allanites is a minimum because the neutron dose used to irradiate the samples was not composed entirely of thermal neutrons. Fast neutrons would cause thorium in the allanite to fission, resulting in a $\rho_{\mathrm{i}}$ value that is too high. hornblende and colorless amphibole present (ferro-anthophyllite(?) from X-ray). Alteration: nil. Biotite separate: $<2$ percent hornblende-actinolite. Hornblende separate: $<1$ percent colorless amphibole overgrowth. Colorless amphibole separate: $<0.85$ percent hornblende, $<0.06$ percent biotite.

JE 22-67 Locality: On Icicle Creek Road; center sec. 27, T. 24 N., R. 17 E. Medium-grained hornblende-biotite tonalite; ragged mafic minerals, subhedral plagioclase, interstitial quartz, pockets of chloritized biotite and sericite, sericitized plagioclase. Biotite separate: $\approx 1$ percent impurity (various alteration products). Hornblende separate: no impurities seen.

JE 12A-67 Locality: 1.5 miles east of Foss River on U.S. Route 2; center sec. 28, T. 26 N., R. 12 E. Medium-grained biotite granodiorite; hypidiomorphic, equigranular; quartz sutured, strained. Alteration: plagioclase altered, biotite sericitized, sometimes peripherally; epidote present. Biotite separate: $<0.5$ percent chlorite.

RWT 18-68 Locality: Log road on south side of Beckler Peak. SW $1 / 4$ sec. 21, T. 26 N., R. 12 E. Medium-grained hornblende-biotite tonalite, gneissose with alined biotite; quartz strained, cracked, sutured; biotite hornblende and apatite bent, broken. Alteration: biotite fresh but dotted with magnetite; no chlorite; minor epidote; patches of biotite in hornblende; plagioclase clouded with alteration products except in clear rims. Biotite separate: $<0.5$ percent alteration products. Hornblende separate: $<0.6$ percent alteration products. 


\title{
RADIOMETRIC AGES IN THE SANTANDER MASSIF, EASTERN CORDILLERA, COLOMBIAN ANDES
}

\author{
By RICHARD GOLDSMITH; RICHARD F. MARVIN, and \\ HARALD H. MEHNERT, Washington, D.C.; Denver, Colo.
}

Prepared in cooperation with Instituto Nacional de Investigaciones Geologico-Minero, Republica de Colombia

\begin{abstract}
Fifteen samples of metamorphic and igneous rocks from the Santander massif, Eastern Cordillera (Cordillera Oriental), Colombia, were dated by $\mathrm{K}-\mathrm{Ar}$ or $\mathrm{Rb}-\mathrm{Sr}$ methods as part of geological and mineral resource investigations by the Instituto Nacional de Investigaciones Geologico-Minero of Colombia and by the U.S. Geological Survey. Radiometric ages indicate (1) that Precambrian gneisses are present in the massif, (2) that upper Precambrian or lower Paleozoic sedimentary rocks were intruded and metamorphosed during the Ordovician, and (3) that major batholithic intrusions occurred in Late Triassic-Early Jurassic time, followed by lesser intrusions during the Jurassic and Early Cretaceous.
\end{abstract}

The radiometric ages discussed below were determined during a minerals survey and reconnaissance geologic mapping program in the Santander massif of the Eastern Cordillera (Cordillera Oriental), Colombia (fig. 1). The program was conducted by the Instituto Nacional de Investigaciones Geologico-Minero (formerly the Inventario Minero Nacional) of Colombia in collaboration with the U.S. Geological Survey. Samples were collected and age determinations were made during 1967-1969. Radiometric ages were needed to delineate the main plutonic and metamorphic events in the massif and to help deduce more accurately the geologic history of this part of the Eastern Cordillera in conjunction with evidence from the sedimentary and fossil record.

The radiometric age determinations were done by the U.S. Geological Survey in Denver, Colo. Preliminary mineral separation work on three of the samples was done in the laboratory of the Universidad Industrial de Santander, Bucaramanga, Colombia, by Jaime Galvis V. of the Instituto and Milton Manrique of the Universidad. Gerald T. Cebula supervised the sample preparation work for the U.S. Geological Survey.

Sample localities are shown on figure 2, and analytical data are given in tables 1 and 2 . Three duplicate analyses, not performed by the Geological Survey, are included in table 2. Specific locations referred to in the tables may be found on

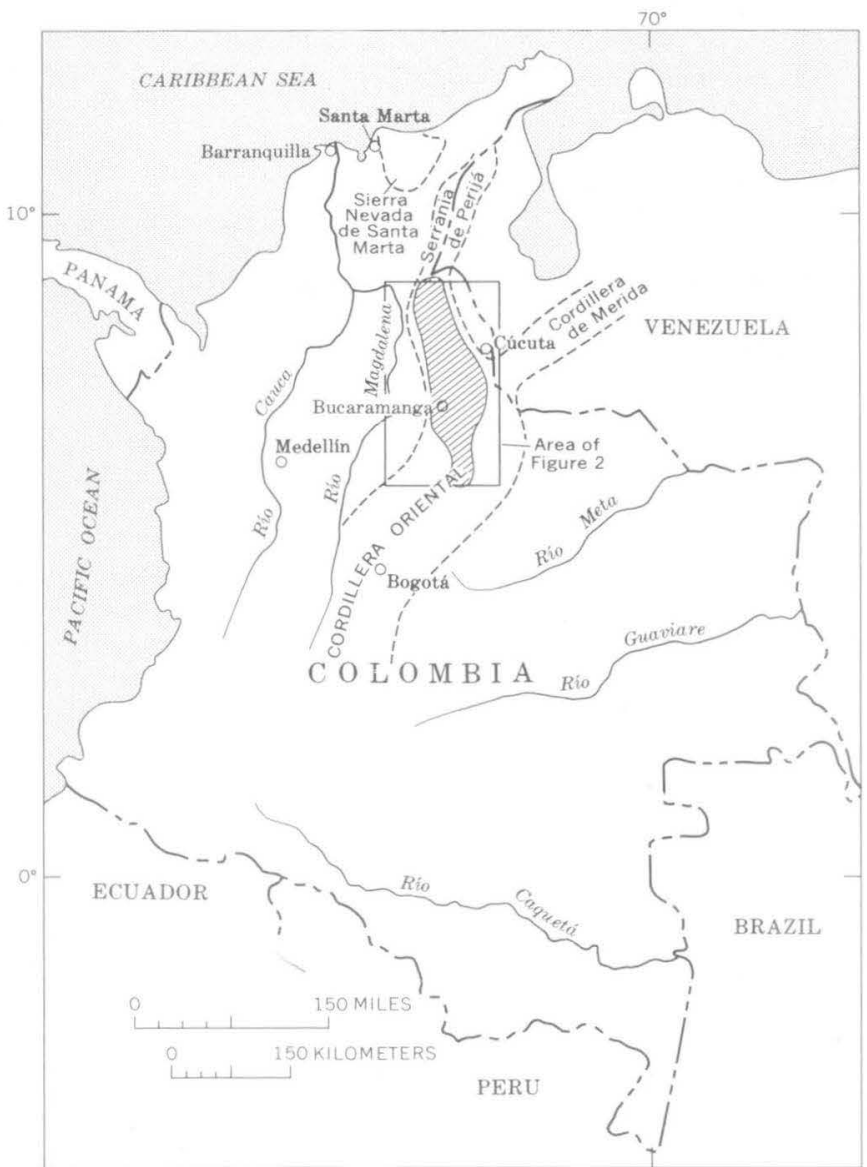

Figure 1.-Index map of Colombia, showing Santander massif (patterned) and area of figure 2.

preliminary topographic maps of Colombia (planchitas) prepared by the Instituto Geográfico Agustin Codazzi, Bogotá, Colombia. The geology shown on figure 2 is adapted from recently published maps of the southern half of the massif 


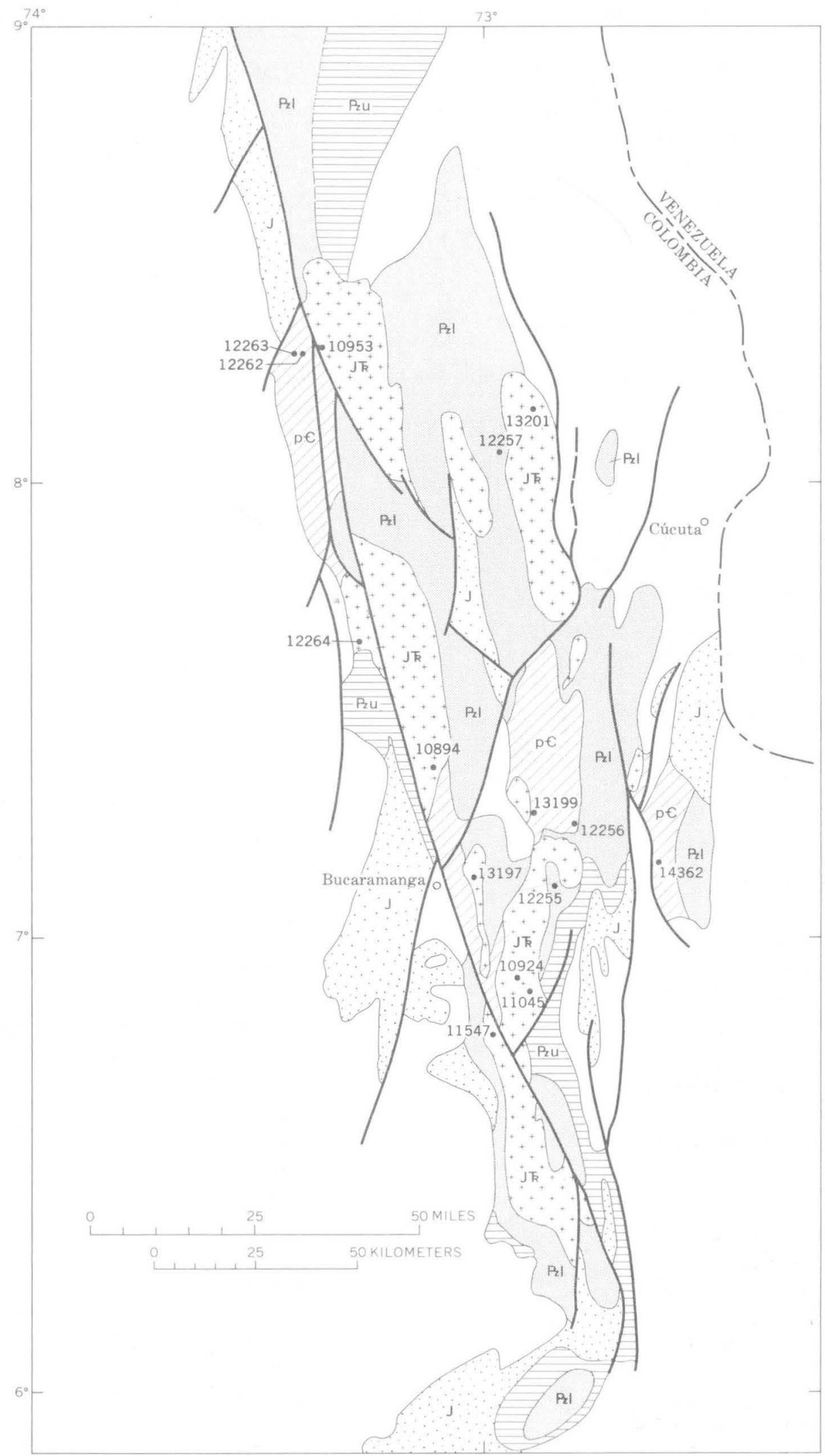

EXPLANATION

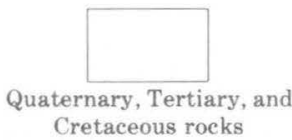
Cretaceous rocks

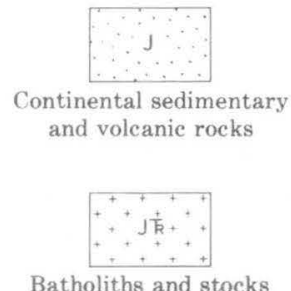

Batholiths and stocks

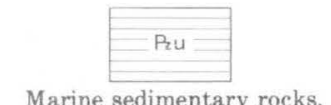
Devonian to Permian in age

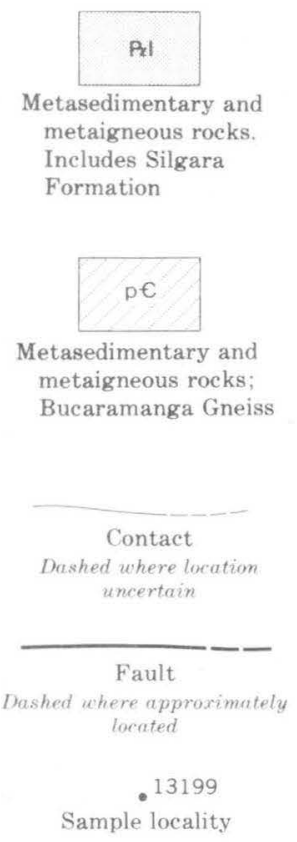

Figure 2.-Generalized geologic map of the Santander massif, showing sample localities. 
Table 1.-Location, analytical data, and calculated whole-rock $\mathrm{Rb}-\mathrm{Sr}$ ages of samples collected in the Santander massif, Santander, and Norte de Santander, Colombia

[Analysts: R. A. Hildreth and W. T. Henderson. Decay constants $\mathrm{Rb}^{87}: \lambda_{\beta}=1.39 \times 10^{-11} / \mathrm{yr}$ ]

\begin{tabular}{|c|c|c|c|c|c|c|c|c|c|}
\hline \multirow{2}{*}{$\begin{array}{l}\text { Sample } \\
\text { No. }\end{array}$} & \multicolumn{2}{|c|}{ Sample location } & \multirow{2}{*}{$\begin{array}{l}\text { Rock type, } \\
\text { formation, or } \\
\text { intrusive body }\end{array}$} & \multirow{2}{*}{$\underset{(\mathrm{ppm})}{\mathrm{Rb}}$} & \multirow{2}{*}{$\underset{(\mathrm{ppm})}{\mathrm{Sr}}$} & \multirow{2}{*}{$\frac{R b^{87}}{S r^{86}}$} & \multirow{2}{*}{$\frac{\mathrm{Sr}^{87}}{\mathrm{Sr}^{86}}$} & \multirow{2}{*}{$\frac{\text { Radiogenic } \mathrm{Sr}^{87}}{{\text { Total } \mathrm{Sr}^{87}}^{87}}$} & \multirow{2}{*}{$\underset{(\mathrm{m} . \mathrm{y} .)}{\mathrm{Rb}-\mathrm{Sr} \mathrm{age}^{1}}$} \\
\hline & Lat (N) & Long (W) & & & & & & & \\
\hline IMN-12264 & . $7^{\circ} 39^{\prime}$ & $73^{\circ} 16^{\prime}$ & Riebeckite granite & 92.6 & 17.0 & 15.78 & 0.7406 & 0.048 & $160 \pm 30$ \\
\hline 12256 & . $7^{\circ} 15^{\prime}$ & $72^{\circ} 48^{\prime}$ & $\begin{array}{l}\text { Granite gneiss } \\
\text { (orthogneiss). }\end{array}$ & 190 & 90.2 & 6.13 & .7433 & .052 & $450 \pm 80$ \\
\hline 13199 & $7^{\circ} 16^{\prime}$ & $72^{\circ} 54^{\prime}$ & $\begin{array}{l}\text { Biotite gneiss, } \\
\text { Bucaramanga Gneiss. }\end{array}$ & 186 & 152 & 3.54 & .7387 & .046 & $680 \pm 140$ \\
\hline
\end{tabular}

${ }^{1}$ Initial $\mathrm{Sr}^{87} / \mathrm{Sr}^{86}$ assumed to be 0.705 .

Table 2.-Location, analytical data, and calculated K-Ar ages of samples collected in the Santander massif, Santander, and Norte de Santander, Colombia

[Analysts: R. F. Marvin, H. H. Mehnert, Violet Merritt, and Roberta Wilkey. Decay constants $\mathrm{K}^{40}: \lambda_{B}=4.72 \times 10^{-10} / \mathrm{yr} . \lambda_{\epsilon}=0.584 \times 10^{-10} / \mathrm{yr}$. Abundance: $\left.\mathrm{K}^{40}=1.22 \times 10^{4} \mathrm{~g} / \mathrm{g} \mathrm{K}\right]$

\begin{tabular}{|c|c|c|c|c|c|c|c|}
\hline \multirow{2}{*}{$\begin{array}{l}\text { Sample } \\
\text { No. }\end{array}$} & Sample location & \multirow{2}{*}{$\begin{array}{l}\text { Rock type, } \\
\text { formation, or } \\
\text { intrusive body }\end{array}$} & \multirow{2}{*}{$\begin{array}{l}\text { Material } \\
\text { analyzed }\end{array}$} & \multirow{2}{*}{$\begin{array}{c}\mathrm{K}_{2} \mathrm{O}^{1} \\
\text { (wt percent) }\end{array}$} & \multirow{2}{*}{$\begin{array}{c}\text { Radiogenic } \\
\operatorname{Ar}^{40} \\
(\operatorname{moles} / g)\end{array}$} & \multirow{2}{*}{$\frac{\text { Radiogenic } \mathrm{Ar}^{40}}{\text { Total } \mathrm{Ar}^{40}}$} & \multirow{2}{*}{$\begin{array}{c}\text { K-Ar age } \\
\text { (m.y.) } \\
\pm 2 \sigma\end{array}$} \\
\hline & Long (W) & & & & & & \\
\hline IMN-10953 $\ldots .8^{\circ} 17^{\prime}$ & $73^{\circ} 23^{\prime}$ & Rhyolite porphyry & Sanidine & 14.76 & $28.71 \times 10^{-10}$ & 0.95 & $127 \pm 3$ \\
\hline $10894 \ldots 7^{\circ} 22^{\prime}$ & $73^{\circ} 06^{\prime}$ & $\begin{array}{l}\text { Porphyritic granodiorite, } \\
\text { Río Negro batholith. }\end{array}$ & $\begin{array}{l}\text { Biotite } \\
\text {... do ... }\end{array}$ & $\begin{array}{l}8.65 \\
8.70\end{array}$ & $\begin{array}{l}23.64 \times 10^{-10} \\
23.07 \times 10^{-10}\end{array}$ & $\begin{array}{l}.95 \\
.95\end{array}$ & $\begin{array}{l}177 \pm 6 \\
172 \pm 6\end{array}$ \\
\hline $11547 \ldots 6^{\circ} 48^{\prime}$ & $72^{\circ} 59^{\prime}$ & $\begin{array}{l}\text { Pescadero Granite, } \\
\text { Mogotes batholith. : }\end{array}$ & Biotite $^{2}$ & 7.02 & $21.04 \times 10^{-10}$ & .95 & $193 \pm 6$ \\
\hline $13201 \ldots 8^{\circ} 09^{\prime}$ & $72^{\circ} 54^{\prime}$ & $\begin{array}{l}\text { Quartz monzonite, } \\
\text { Aguablanca batholith. }\end{array}$ & Biotite & 8.60 & $26.22 \times 10^{-10}$ & .96 & $196 \pm 7$ \\
\hline $10924 \ldots 6^{\circ} 55^{\prime}$ & $72^{\circ} 56^{\prime}$ & $\begin{array}{l}\text { Quartz monzonite, } \\
\text { Santa Barbara batholith. }\end{array}$ & Biotite $^{2}$ & 9.16 & $27.29 \times 10^{-10}$ & .94 & $192 \pm 7$ \\
\hline $11045 \ldots .6^{\circ} 53^{\prime}$ & $72^{\circ} 54^{\prime}$ & $\ldots \ldots \ldots$ do $\ldots \ldots \ldots$ & $\ldots$ do ... & 7.40 & $22.29 \times 10^{-10}$ & .96 & $194 \pm 7$ \\
\hline $13197 \ldots 7^{\circ} 08^{\prime}$ & $73^{\circ} 03^{\prime}$ & $\begin{array}{l}\text { La Corcova } \\
\text { quartz monzonite. }\end{array}$ & $\begin{array}{l}\text { Biotite } \\
\text { Muscovite }\end{array}$ & $\begin{array}{l}7.18 \\
5.58\end{array}$ & $\begin{array}{l}12.06 \times 10^{-10} \\
16.91 \times 10^{-10}\end{array}$ & $\begin{array}{l}.94 \\
.86\end{array}$ & $\begin{array}{l}111 \pm 4 \\
195 \pm 7\end{array}$ \\
\hline $12255 \ldots 7^{\circ} 07^{\prime}$ & $72^{\circ} 52^{\prime}$ & $\begin{array}{l}\text { Phyllite, } \\
\text { Silgara Formation. }\end{array}$ & Whole rock & 4.95 & $15.22 \times 10^{-10}$ & .92 & $198 \pm 8$ \\
\hline $12257 \ldots 8^{\circ} 04^{\prime}$ & $72^{\circ} 57^{\prime}$ & $\ldots \ldots \ldots$ do $\ldots \ldots \ldots$ & Whole rock ${ }^{3}$ & 6.36 & $21.98 \times 10^{-10}$ & .98 & $221 \pm 8$ \\
\hline $13199 \ldots 7^{\circ} 16^{\prime}$ & $72^{\circ} 54^{\prime}$ & $\begin{array}{l}\text { Biotite gneiss, } \\
\text { Bucaramanga Gneiss. }\end{array}$ & $\begin{array}{l}\text { Biotite } \\
\ldots \text { do ... }\end{array}$ & $\begin{array}{l}8.75 \\
9.12_{5}\end{array}$ & $\begin{array}{l}26.96 \times 10^{-10} \\
26.77 \times 10^{-10}\end{array}$ & $\begin{array}{l}.96 \\
.98\end{array}$ & $\begin{array}{r}198 \pm 7 \\
{ }^{4} 189 \pm 4\end{array}$ \\
\hline $12262 \ldots .8^{\circ} 17^{\prime}$ & $73^{\circ} 24^{\prime}$ & $\begin{array}{l}\text { Metadiorite, } \\
\text { Bucaramanga Gneiss(?). }\end{array}$ & Hornblende & .39 & $2.661 \times 10^{-10}$ & .93 & $413 \pm 30$ \\
\hline $14362 \ldots 7^{\circ} 10^{\prime}$ & $72^{\circ} 37^{\prime}$ & $\begin{array}{l}\text { Pegmatite, } \\
\text { Bucaramanga Gneiss. }\end{array}$ & $\begin{array}{l}\text { Muscovite } \\
\ldots \text { do } \ldots \\
\ldots \text { do } \ldots\end{array}$ & $\begin{array}{c}10.12 \\
10.50_{5} \\
9.90_{4}\end{array}$ & $\begin{array}{l}77.32 \times 10^{-10} \\
75.05 \times 10^{-10} \\
72.41 \times 10^{-10}\end{array}$ & $\begin{array}{l}.96 \\
.96 \\
.95\end{array}$ & $\begin{array}{l}457 \pm 13 \\
5432 \pm 8 \\
4439 \pm 12\end{array}$ \\
\hline $12263 \ldots 8^{\circ} 17^{\prime}$ & $73^{\circ} 25^{\prime}$ & $\begin{array}{l}\text { Hornblende gneiss, } \\
\text { Bucaramanga Gneiss(?). }\end{array}$ & Hornblende & 1.11 & $20.08 \times 10^{-10}$ & .99 & $945 \pm 40$ \\
\hline
\end{tabular}

\footnotetext{
${ }^{1}$ Potassium determined with a Perkin-Elmer flame photometer with a lithium internal standard. The potassium value listed is an average of two or more analyses.
}

${ }^{2}$ Biotite separations made by Jaime Galvis V. and Milton Manrique.

\footnotetext{
${ }^{3}$ Magnetic fraction was removed before sample was analyzed.

${ }^{4}$ Analyses by Isotopes, Inc., Westwood, N.J.

${ }^{5}$ Analysis by Geochron Laboratories, Inc., Cambridge, Mass.
} 
(Ward and others, 1969a, 1969b, and 1970) and from reconnaissance and photointerpretation in the northern part of the massif.

\section{GEOLOGIC SETTING}

The Santander massif is in a node of the Eastern Cordillera of the Colombian Andes where the cordillera splits to form the northeast-trending Cordillera de Merida of central Venezuela and the north- to northeast-trending arc of the Serranía de Perija' which separates the Maracaibo basin of Venezuela from the Cesar Valley of Colombia.

The core of the massif consists of metamorphic rocks of pre-Devonian age cut by batholiths and plutons of Mesozoic age. The core rocks are flanked by sedimentary rocks ranging in age from Devonian to Tertiary. Remnants of these sedimentary rocks cap the massif in places and crop out in infaulted wedges.

The metamorphic rocks of the core are divided into two formations. The older, the Bucaramanga Gneiss, is a thick sequence of thick-bedded geosynclinal wackes and shales and probable volcanic rocks metamorphosed to high grade and in part migmatitic. The younger and overlying formation, the Silgara Formation, is a thick series of shallow-water turbidites and cyclic deposits of siltstone, shale, sandstone, and limestone metamorphosed to low and middle grade. The nature of the contact between the older and younger formations is not clear but is possibly an unconformity. Gneissic plutonic rocks intrude the older formation and in places form wide areas of migmatite with it. Gneissic plutonic rocks also intrude the younger formation, generally discordantly. Two ages of gneissic plutonic rocks may be involved, however.

Generally unmetamorphosed fossiliferous Middle and Lower Devonian strata unconformably overlie the pre-Devonian metamorphic rocks on the flanks of the massif but are metamorphosed to low grade where they crop out in the core of the massif. This metamorphism may be related to the batholithic intrusions. However, the rocks are phyllitic argillites and phyllitic slates, for example, rather than hornfels. Unmetamorphosed to very locally lightly metamorphosed marine strata of late Paleozoic age are overlain disconformably and in places with angular unconformity by continental sedimentary and volcaniclastic deposits of Late Triassic and Jurassic age. Felsic and andesitic extrusive and intrusive rocks are locally interlayered with the Triassic and Jurassic red beds. The major batholiths appear to have been emplaced at this time.

The major batholiths of the massif (fig. 2) are nonfoliated, pink to gray quartz monzonite and granodiorite with subordinate granite and tonalite. Gradational textures and color indices between the gray and pink granites suggest that they are approximately of the same age. The youngest rocks observed to be cut by the granites are Devonian, but Permian and Lower Triassic marine strata are recrystallized near one of the batholiths. Conglomerates in red beds beneath the lower- most Cretaceous strata contain pebbles and cobbles of batholithic rocks.

A marine transgression occurred in the Early Cretaceous, and the massif was eventually covered by a thick to thin miogeosynclinal sequence of Cretaceous strata succeeded by a locally thick sequence of continental strata of very latest Cretaceous and Tertiary age.

The present uplift of the massif began in the late Tertiary and continued into Pleistocene time. Uplift of the massif was accompanied by appreciable high- and low-angle faulting. The most conspicuous fault is the northwest-trending linear nearly vertical Bucaramanga fault on the west side of the massif. Major displacement on this fault, however, is probably strike slip, and the fault appears to have had a long history.

\section{AGE DATA}

The isotopic ages of the rocks of the massif have confirmed the Triassic-Jurassic age of the batholiths which has been deduced from geologic evidence, have revealed a metamorphic event in the early Paleozoic, and have shown the presence of Precambrian rocks.

Radiometric ages of the rocks predating batholithic emplacement-Silgara Formation, Bucaramanga Gneiss, and orthogneiss (tables 1 and 2)-are few but are sufficient to indicate general events. Two ages from the Bucaramanga Gneiss indicate a Precambrian age for these rocks. Ages of 1,200 to 1,300 million years for the basement crystalline rocks are reported in the Guaviare region of the western Guyana shield in eastern Colombia (Pinson and others, 1962) and in the Santa Marta massif (C. M. Tschanz and others, unpub. data; MacDonald and Hurley, 1969). The K-Ar hornblende age of $945 \pm 40 \mathrm{~m} . \mathrm{y}$. for a hornblende gneiss (sample 12263) and the $\mathrm{Rb}-\mathrm{Sr}$ whole-rock age of $680 \pm 140 \mathrm{~m} . \mathrm{y}$. for a biotite gneiss (sample 13199) are much younger and therefore may be "hybrid" ages or may indicate discrete metamorphic or thermal events in the Precambrian. Evidence for the latter supposition is a K-Ar hornblende age of $940 \mathrm{~m} . \mathrm{y}$. from the Santa Marta massif: (C. M. Tschanz and others, unpub. data) and K-Ar mica ages of 930 to $960 \mathrm{~m} . \mathrm{y}$. for anorogenic tin-bearing granites in Rondonia, northwestern Brazil (Priem and others, 1966, p. 192). No 680-m.y. age has been recorded from elsewhere in Colombia or Venezuela; however, the uncertainty on this $\mathrm{Rb}-\mathrm{Sr}$ age results largely from the unradiogenic nature of the sample. As the K-Ar age of the biotite (198 m.y.) of sample 13199 indicates that it has been subjected to a Triassic-Jurassic thermal event, the same event may have affected the $\mathrm{Rb}-\mathrm{Sr}$ isotopic system, causing a "hybrid" Rb-Sr age.

The three following ages-K-Ar hornblende age of $413 \pm 30$ m.y. for metadiorite (sample 12262), K-Ar muscovite age of $457 \pm 13 \mathrm{~m} . \mathrm{y}$. from a pegmatite in the Bucaramanga Gneiss (sample 14362), and the Rb-Sr whole-rock age of $450 \pm 80 \mathrm{~m}$.y. for a granite gneiss (sample 12256)-suggest a thermal event in the Late Ordovician or Early Silurian. Field evidence indicates. 
that the granite gneiss and metadiorite were emplaced during the main period of pre-Devonian metamorphism and plutonism. In places, small masses and layers of granite gneiss are sufficiently abundant in the Bucaramanga Gneiss to form migmatite. Insufficient radiometric ages are available to clearly define this thermal event. However, supporting evidence for the validity of a 410- to $450-\mathrm{m}$.y. event in this part of South America comes from ages of 410 to $420 \mathrm{~m}$.y., reported by Bass and Shagam $(1960$, p. 377) from the Meridan Andes in Venezuela, and 450-m.y. ages from igneous rocks in the Guaviare region of eastern Colombia, reported by Pinson and others (1962).

The above three ages could also be described as hybrid ages, representing partial readjustment of the isotopic systems in different Precambrian rocks and minerals to a post-Ordovician event, for instance, a Mesozoic plutonic event. This explanation of the ages is, however, deemed more tenuous than the preceding explanation.

Field evidence indicates that the Silgara Formation is pre-Devonian in age, but whether it is Precambrian or early Paleozoic is not known. Contact relations between the Silgara Formation and the underlying Bucaramanga Gneiss are not clear, and some question exists in places as to where the actual division between the two should be made. The metamorphism of the Silgara Formation could have occurred during the 410-450-m.y. event. If so, the two K-Ar whole rock ages on phyllite of the Silgara Formation (samples 12255 and 12257) do not date the metamorphism but reflect a later thermal event. For sample 12255 this event is clearly the emplacement of the batholiths about $195 \mathrm{~m}$.y. ago. For sample 12257 the age of $221 \pm 8 \mathrm{~m}$.y. could represent incomplete recalibration of a probable 410-450-m.y. age by the 195-m.y. event.

The geologic setting permits another explanation, however. Fossiliferous Devonian strata are not metamorphosed along the flanks of the Santander massif, whereas Devonian strata are metamorphosed at low grade within the massif. Thus, the 221-m.y. age for sample 12257 may indicate a rather localized Permian-Triassic metamorphic event, or the age may have been lowered from that of an unidentified post-Middle Devonian event. Upper Devonian and Lower Pennsylvanian strata are not represented in the stratigraphic column of the massif, but no great angular unconformity is recognized. Middle Pennsylvanian and Upper Permian marine strata are represented, but a disconformity is present between them. Another hiatus in the column, although less well documented by fossils, comes between Late Permian and Late Triassic time, after which continental deposits of Late Triassic and Jurassic age began to accumulate. It is likely that the Devonian and late Paleozoic strata were folded and in part metamorphosed in this interval prior to the emplacement of the Late Triassic-Early Jurassic batholiths.

No radiometric ages in eastern Colombia or adjacent Venezuela support a thermal event during the Late Devonian-Early Pennsylvanian hiatus. Some ages, however, indicate or suggest a thermal event in Late Pennsylvanian and
Permian time. Bass and Shagam (1960) report ages of 285 to 277 m.y. and 230 to 242 m.y. in metamorphic rocks of the Meridan Andes. C. M. Tschanz and others (unpub. data) discussed a published age of 250 m.y. for a metadiorite in the Santa Marta massif. These data suggest a thermal event or events in the late Paleozoic.

The age data from the batholithic rocks are, on the whole, remarkably consistent. Most of the batholithic rocks of the massif were emplaced in Late Triassic or possibly earliest Jurassic time. The K-Ar ages on biotites from the Santa Barbara and Aguablanca batholiths (samples 10924, 11045, 13201), the Pescadero Granite of the Mogotes batholith (sample 11547), and muscovite from the La Corcova quartz monzonite (sample 13197), are remarkably close in age, well within the limit of error of the analyses. The total-rock K-Ar age of $198 \pm 8 \mathrm{~m} . \mathrm{y}$. of phyllite (sample 12255), taken from within $1 \mathrm{~km}$ horizontally of the probably shallowly dipping contact of the Santa Barbara batholith, and the K-Ar age of $198 \pm 7$ m.y. on biotite from Bucaramanga Gneiss, (sample 13199, table 2) near a tonalite pluton, further support this plutonic event.

The K-Ar ages of $172 \pm 6$ m.y. and $177 \pm 6$ m.y., duplicate determinations on biotite from a granodiorite (sample 10894) from the Río Negro batholith, were unexpected in that no field evidence indicated that this batholith was any younger than others. Either the age represents the prevailing Late Triassic age made younger by some later event, or a greater time spread exists in the emplacement of the different batholiths than is indicated by the other age data. Several of the batholiths in the Santa Marta massif are comparable in isotopic age (C. M. Tschanz and others, unpub. data) to the Rio Negro batholith.

The $\mathrm{Rb}$-Sr whole-rock age of $160 \pm 30$ m.y. for riebeckite granite (sample 12264) dates a granite mass separated from the Rio Negro batholith by the Bucaramanga fault. The riebeckite granite is distinct from the rocks in the Rio Negro batholith and appears not to be related to it. Detailed field mapping has not been done in the area of the granite, so that its field relations are not known. At face value, the age indicates that plutonic activity in the massif continued into Middle Jurassic time. Probably the riebeckite granite is a close contemporary of the Rio Negro batholith; however, because of the large analytical uncertainty, the time of emplacement could range from Late Triassic to Early Cretaceous.

Sanidine from rhyolite porphyry in contact with the Ocana batholith gave an unexpectedly young K-Ar age of $127 \pm 3$ m.y. (sample 10953). The medium-grained quartz monozonite in this batholith is similar to that of the Aguablanca batholith and phases of the Mogotes and Santa Barbara batholiths. These last three batholiths are conisidered to be the same age. The rhyolite porphyry is a fairly abundant rock at the north and east flanks of the Ocaña batholith, and it was thought to be either a hypabyssal equivalent or to represent earlier roof rocks of the plutonic phase. Detailed geologic mapping has not. yet been done in this area, and the field relations of the 
porphyry with the quartz monzonite are not known with certainty. It is quite possible that the porphyry, if not the quartz monzonite, is actually of Early Cretaceous age. Dacite porphyry dikes 30 to $40 \mathrm{~km}$ northeast of Bucaramanga cut the Tambor Formation of Early Cretaceous (Valanginian to Hauterivian) age. Early Cretaceous igneous activity resulting in the Golero Rhyolite (129 m.y.) and the Socorro stock (131 m.y.) was reported by C. M. Tschanz and others (unpub. data) to have occurred in the Santa Marta massif.

The K-Ar biotite age of $111 \pm 4$ m.y. (sample 13197) for the La Corcova quartz monzonite is significantly lower than the $195 \pm 7-m . y$. age given by coexisting muscovite and strongly suggests that an unidentified local thermal event has affected the biotite.

This age study has been a reconnaissance of the major igneous and metamorphic rock types in order to place them in the proper time sequence. Use of one or two samples to date large igneous or metamorphic bodies is fraught with the possibility of error in sampling. Our success has been limited; some questions have been answered, but others take their place. The time sequence presented here may be modified by future geochronological work.

\section{REFERENCES}

Bass, Manuel, and Shagam, R., 1960, Edades Rb-Sr de las rocas cristalinas de los Andes Merideños, Venezuela: Venezuela Dirección Geología Bol. Geología, Pub. Esp. 3, v. 1, p. 377-381.

MacDonald, W. D., and Hurley, P. M., 1969, Precambrian gneisses from northern Colombia, South America: Geol. Soc. America Bull., v. 80, no. 9, p. 1867-1871.

Pinson, W. H., Jr., Hurley, P. M., Mencher, Ely, and Fairbairn, H. W., 1962, K-Ar and $\mathrm{Rb}-\mathrm{Sr}$ ages of biotites from Colombia, South America: Geol. Soc. America Bull., v. 73, p. 907-910.

Priem, H. N. A., Boelrijk, N. A. I. M., Hebeda, E. H., Verschure, R. H., and Bon, E. H., 1966, Isotopic age of tin granites in Rondonia, N.W. Brazil: Geol. Mijnbouw, v. 45, p. 191-192.

Ward, D. E., Goldsmith, Richard, Jimeno, V. A., Cruz, B. J., Restrepo, H., and Gomez, R. E., 1969a, Mapa geologico del cuadrangulo H-12, Bucaramanga, Colombia: Bogotá, Colombia, Inst. Nac. Inv. Geologico-Mineras.

Ward, D. E., Goldsmith, Richard, Cruz, B. J., Tellez, I. N., and Jaramillo, C. L., 1969b, Mapa geologico San Gil y Malaga (Parte de los cuadrangulos 1-12 y 1-13), Colombia: Bogotá, Colombia, Inst. Nac. Inv. Geologico-Mineras.

Ward, D. E., Goldsmith, Richard, Cruz, B. J., Jaramillo, C. L., and Vargas, I. R., 1970, Mapa geologico del cuadrangulo H-13, Pamplona, Colombia: Bogotá, Colombia, Inst. Nac. Inv. GeologicoMineras. 


\title{
SODIC HARMOTOME IN LACUSTRINE PLIOCENE TUFFS NEAR WIKIEUP, MOHAVE COUNTY, ARIZONA
}

\author{
By RICHARD A. SHEPPARD and ARTHUR J. GUDE 3d, Denver, Colo.
}

\begin{abstract}
Harmotome of diagenetic origin found near Wikieup in Mohave County, Ariz., is associated with a variety of authigenic zeolites and clay minerals in originally silicic vitric tuffs. The harmotome occurs as prismatic or acicular crystals, 2-30 $\mu \mathrm{m}$ long, and it has a mean index of refraction of 1.506. Monoclinic cell parameters are $a=9.921 \pm 0.004$ $A ; \quad b=14.135 \pm 0.009 \quad A ; \quad c=8.685 \pm 0.006 \quad A ; \quad \beta=124^{\circ} 55^{\prime} \pm 2^{\prime} ; \quad$ and $V=998.59 \pm 0.76 \mathrm{~A}^{3}$. Chemical analysis gave a formula of $\mathrm{Na}_{1.46} \mathrm{~K}_{0.65}$ $\mathrm{Ba}_{0.78} \mathrm{Sr}_{0.01} \mathrm{Ca}_{0.16} \mathrm{Mg}_{0.51} \mathrm{Al}_{4.04} \mathrm{Fe}^{+3}{ }_{0.54} \mathrm{Si}_{11.31} \mathrm{O}_{32} \cdot 11.23 \quad \mathrm{H}_{2} \mathrm{O}$. The Wikieup harmotome is the most alkali-rich and barium-poor harmotome thus far reported and can be derived from ideal harmotome by $\mathrm{Na}_{2}\left(\mathrm{~K}_{2}\right)$ replacement of $\mathrm{Ba}(\mathrm{Sr}, \mathrm{Ca}, \mathrm{Mg})$ and $\mathrm{Na}(\mathrm{K}) \mathrm{Al}\left(\mathrm{Fe}^{+3}\right)$ replacement of Si.
\end{abstract}

Harmotome, probably the most common of the barium-rich zeolites, has been reported from a variety of metamorphic and igneous rocks throughout the world (Deer and others, 1963, p. 399). Harmotome is also commonly associated with metallic ore deposits. Although harmotome has been reported from deep-sea sediments (Arrhenius, 1963, p. 698-701; Morgenstein, 1967), confirming data, particularly chemical, are generally lacking. The harmotome described herein occurs in a lacustrine deposit and has a chemical composition that sets it apart from other analyzed harmotomes.

\section{OCCURRENCE}

Zeolites are particularly abundant in diagenetically altered vitric tuffs of saline lacustrine deposits, especially those in the southwestern United States (Hay, 1966; Sheppard and Gude, 1969). Recent work by the authors on the alteration of tuffs in an unnamed Pliocene lacustrine deposit near Wikieup, Ariz. (fig. 1), has shown that the tuffs consist of a variety of zeolites, clay minerals, potassium feldspar, opal, and quartz. Most of these authigenic minerals are so finely crystalline that positive identification can be made only by X-ray techniques. Routine examination of X-ray powder diffractometer patterns of bulk samples in 1968 showed that one sample (No. W7-44) from locality A (fig. 1) contained a zeolite whose $d$ spacings matched those of harmotome. Subsequent semiquantitative spectrographic analysis for barium and optical determinations confirmed the identification. Harmotome was later identified

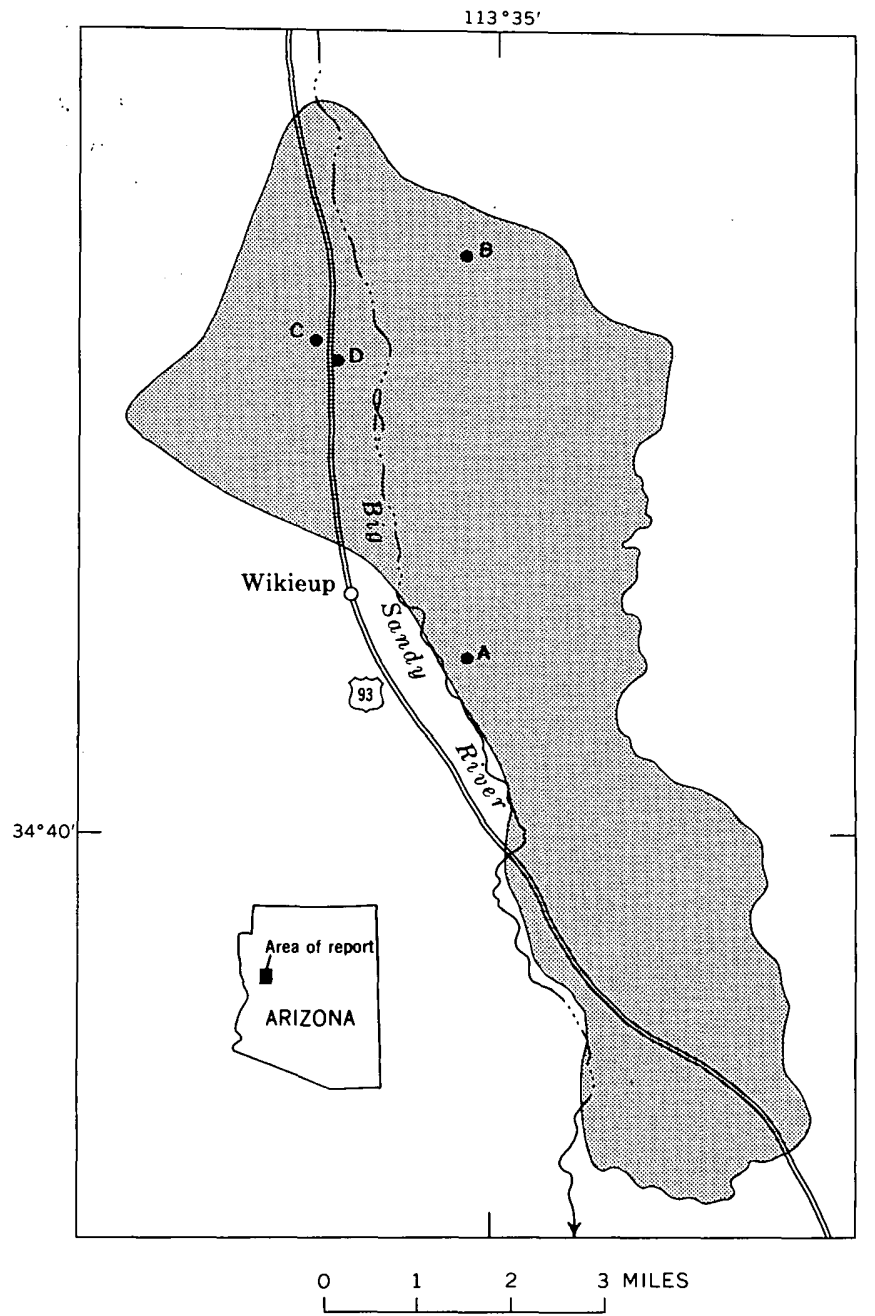

Figure 1.-Index map showing the distribution of unnamed lacustrine rocks of Pliocene age (shaded) near Wikieup, Ariz. A-D, sample localities.

in another tuff from three other localities at the northern part of the lacustrine deposit (fig. 1).

The harmotome-bearing tuffs range in thickness from about 0.5 inch at locality A (fig. 1 ) to about 7 inches at locality B. The 
tuffs are white or pastel shades of yellow and brown, and break with a platy or blocky fracture. Harmotome makes up less than 1 percent to as much as 40 percent of the tuffs and is associated with authigenic clay minerals and one or more of the following zeolites: analcime, chabazite, clinoptilolite, and erionite (table 1 ). The tuffs also contain about $1-5$ percent angular crystal fragments of pyrogenic or detrital origin. These crystal fragments are quartz, sodic plagioclase, biotite, hornblende, and epidote, listed in order of decreasing abundance.

The harmotome occurs as prismatic or acicular crystals that are about $2-30 \mu \mathrm{m}$ long. The crystals are commonly in radial aggregates (fig. 2) or small spherulites that are $20-30 \mu \mathrm{m}$ in

Table 1.-Mineralogic composition of harmotome-bearing tuffs as estimated from X-ray diffractometer patterns of bulk samples

[Leaders (...), looked for but not found; Tr., trace]

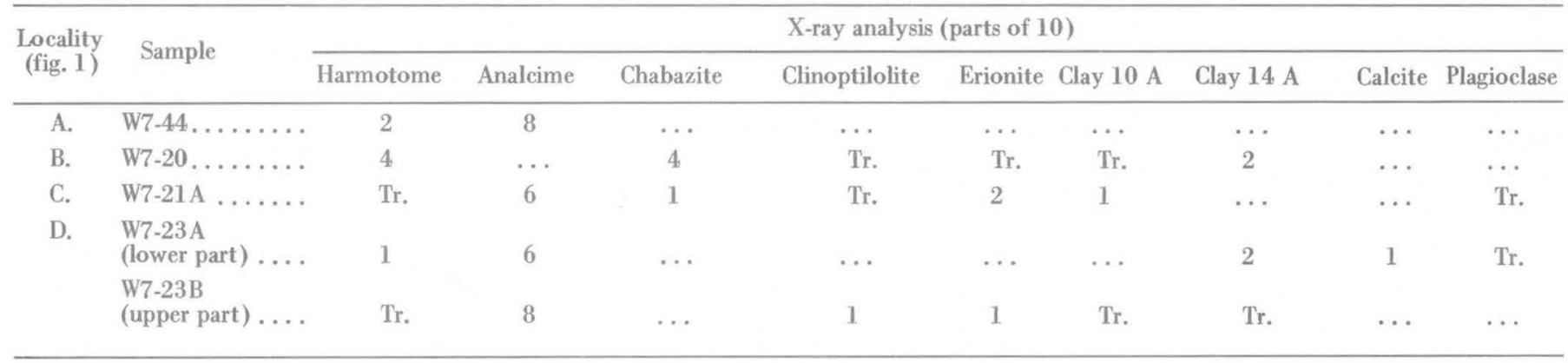

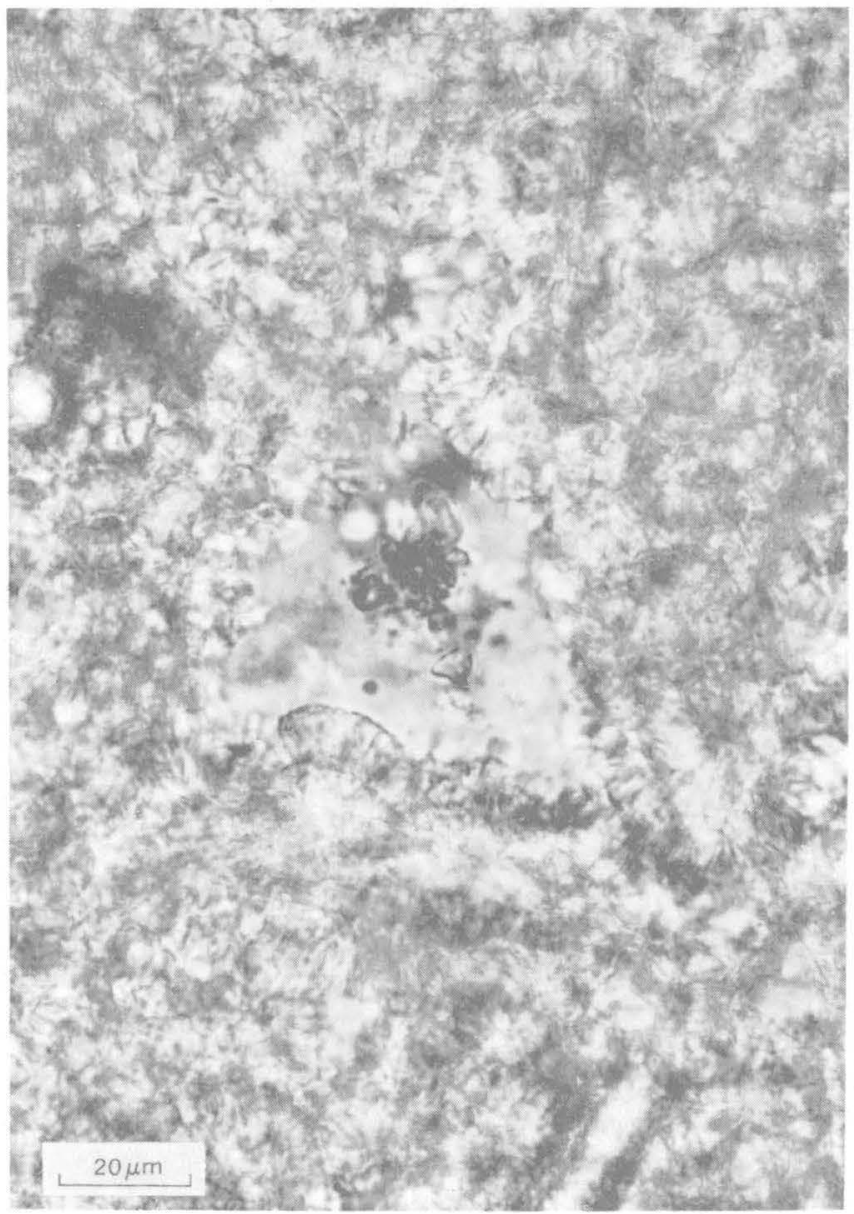

Figure 2.-Photomicrograph of zeolitic tuff, showing radial aggregates of harmotome. Unpolarized light. diameter. Harmotome from the Wikieup area has a mean index of refraction of $1.506 \pm 0.002$ and is length fast. Other optical parameters could not be determined because of the small size of the crystals.

\section{X-RAY DATA}

X-ray powder diffraction data for the harmotome near Wikieup are given in table 2. The $d$ values for this harmotome are compared in table 2 with those for a low-alkali harmotome from Finland (Sahama and Lehtinen, 1967) and for a sodium-exchanged harmotome (Barrer and others, 1959, p. 1527). The $d$ values of the Wikieup harmotome are similar to those of the two other harmotomes.

$\mathrm{X}$-ray powder diffractometer patterns are shown in figure 3 for the Wikieup harmotome and for phillipsites from a lacustrine deposit and a deep-sea deposit. Although the harmotome has many peaks that are coincident with those of the phillipsites, its pattern is sufficiently different to be distinguished. Harmotome characteristically has three relatively strong peaks between about 10.5 and 14.0 degrees $2 \theta$ $(\mathrm{CuK \alpha})$, whereas the phillipsites from sedimentary rocks have only one strong peak in this interval. Harmotome also has a doublet near 28 degrees $2 \theta$, whereas the phillipsites are characterized by a single peak at this position. The phillipsites have a moderately intense peak near 16.5 degrees $2 \theta$, but harmotome has either a weak peak at this position or no peak at all. Mixtures of harmotome and phillipsite, however, probably cannot be recognized in bulk samples by X-ray powder diffraction techniques.

Cell parameters for the Wikieup harmotome were obtained by a least-squares refinement of the X-ray powder diffraction data 
Table 2.-X-ray powder data'for harmotome

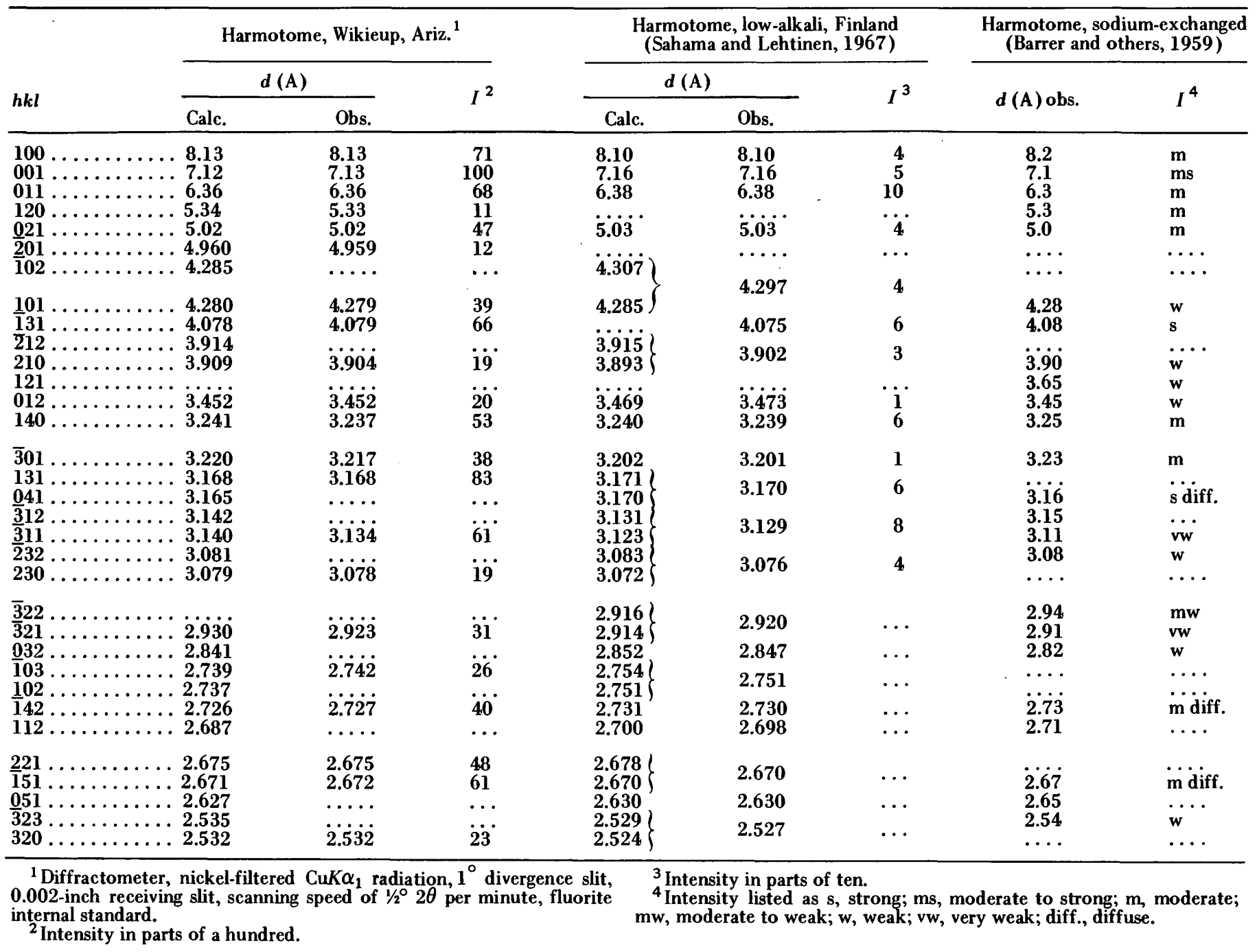

utilizing the U.S. Geological Survey's Fortran IV computer program W9214. The monoclinic cell parameters of Sahama and Lehtinen (1967, p. 448) were used as starting parameters in the computer program. The resulting monoclinic cell dimensions and volume for the Wikieup harmotome are $a=9.921 \pm 0.004 \mathrm{~A}, b=14.135 \pm 0.009 \mathrm{~A}, c=8.685 \pm 0.006 \mathrm{~A}$, $\beta=124^{\circ} 55^{\prime} \pm 2^{\prime}$, and $V=998.59 \pm 0.76 \mathrm{~A}^{3}$. The $b$ dimension is similar to that for the other reported harmotomes; however, the $a$ dimension is larger and the $c$ dimension is smaller than that for the other reported harmotomes. Perhaps the lengthened $a$ and shortened $c$ are caused by the relatively high sodium content of the Wikieup harmotome.

\section{CHEMICAL COMPOSITION}

The Wikieup harmotome was separated for chemical analysis by first crushing the tuff (sample W7-44) and was then disaggregated in an ultrasonic bath. Because the associated analcime was so much larger in size than the harmotome, wet sieving concentrated most of the harmotome in the less-than$37-\mu \mathrm{m}$-size fraction. A further concentration was made by elutriation. The final harmotome concentrate contained about 7 percent analcime impurities, as estimated by X-ray diffraction and optical techniques.

Chemical analyses of the impure harmotome and of a pure analcime separated from a different tuff in the same lacustrine deposit are given in table 3 . The analcime is considered to be representative of that which occurs with the harmotome; therefore, its composition was used to correct the analysis of impure harmotome. The corrected analysis of harmotome was then recalculated to 100 percent and is also given in table 3 .

The calculated formula for the Wikieup harmotome on the basis of 32 oxygen atoms is $\mathrm{Na}_{1.46} \mathrm{~K}_{0.65} \mathrm{Ba}_{0.78} \mathrm{Sr}_{0.01} \mathrm{Ca}_{0.16}$ $\mathrm{Mg}_{0.51} \mathrm{Al}_{4.04} \mathrm{Fe}^{+3}{ }_{0.54} \mathrm{Si}_{11.31} \mathrm{O}_{32} \cdot 11.23 \mathrm{H}_{2} \mathrm{O}$. Monovalent cations are in excess of divalent ones, and the $\mathrm{Si}: \mathrm{Al}+\mathrm{Fe}^{+3}$ ratio is 2.47 .

The ideal formula for harmotome is $\mathrm{Ba}_{2} \mathrm{Al}_{4} \mathrm{Si}_{12} \mathrm{O}_{32}$ $12 \mathrm{H}_{2} \mathrm{O}$, but natural specimens generally contain substantial 


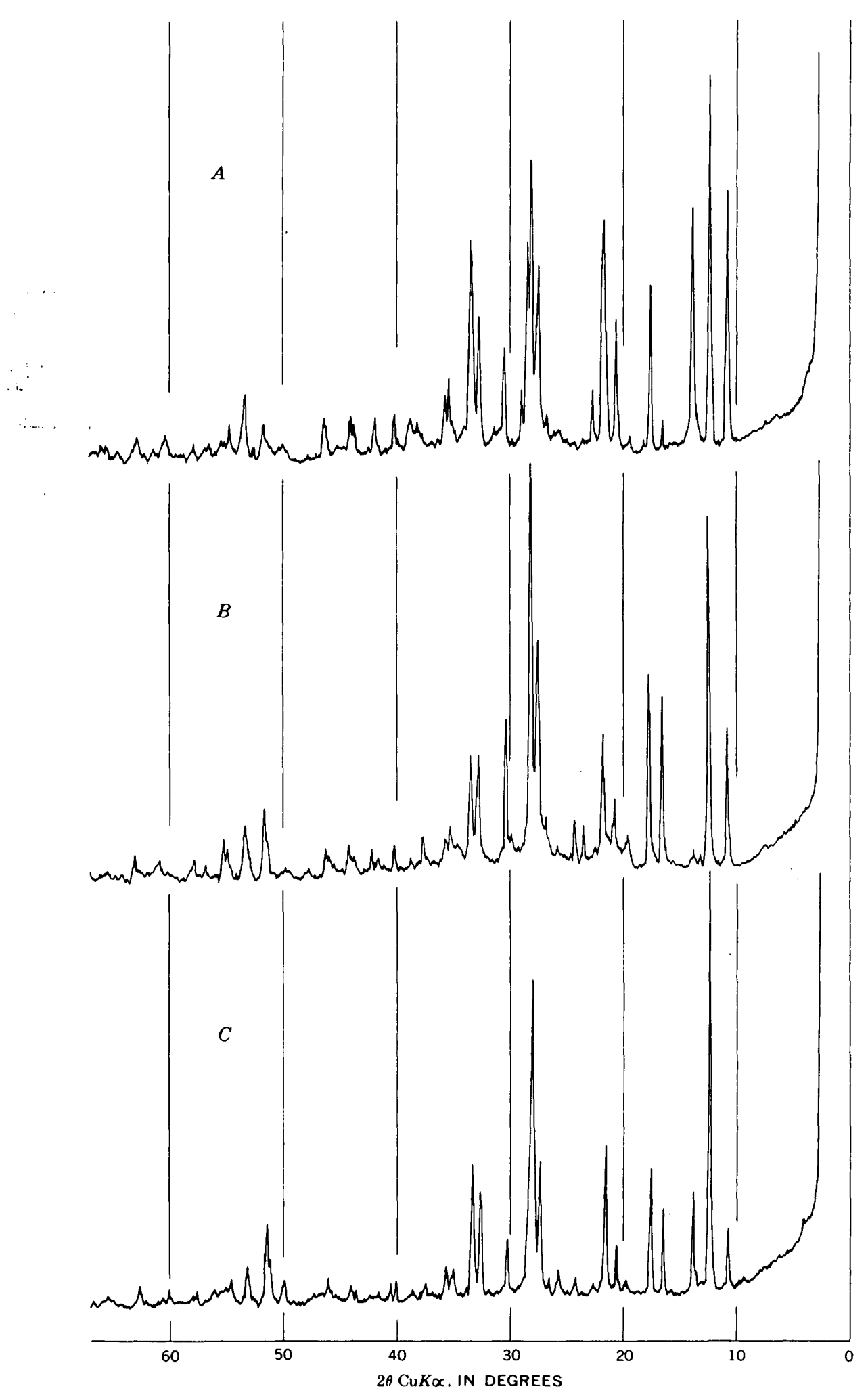

Figure 3.-Comparison of X-ray diffractometer traces of $(A)$ harmotone from Wikieup, Ariz., with $(B)$ phillipsite from a lacustrine tuff near Wikieup, Ariz., and with $(C)$ phillipsite from a deep-sea clay from the Pacific Ocean. 
Table 3.-Chemical analyses of analcime and harmotome

[Analyst: Vertie C. Smith except for $\mathrm{Na}_{2} \mathrm{O}, \mathrm{K}_{2} \mathrm{O}$, and $\mathrm{SrO}$ of analysis 1 and $\mathrm{SrO}$ of analysis 2 which were determined by atomic absorption by Violet Merritt; and $\mathrm{BaO}$ of analysis 1 which was determined gravimetrically by $\mathrm{V}$. E. Shaw. The $\mathrm{Al}_{2} \mathrm{O}_{3}$ content includes $\mathrm{P}_{2} \mathrm{O}_{5}$, and the $\mathrm{Fe}_{2} \mathrm{O}_{3}$ content represents total iron]

\begin{tabular}{|c|c|c|}
\hline 1 & 2 & 3 \\
\hline $\mathrm{SiO}_{2} \ldots \ldots \ldots 58.62$ & 50.29 & 49.97 \\
\hline $\mathrm{Al}_{2} \mathrm{O}_{3} \ldots \ldots \ldots 19.37$ & 15.36 & 15.15 \\
\hline $\mathrm{Fe}_{2} \mathrm{O}_{3} \ldots \ldots \ldots \quad .95$ & 2.98 & 3.15 \\
\hline $\operatorname{MgO} \ldots \ldots \ldots . \quad .23$ & 1.42 & 1.52 \\
\hline $\mathrm{CaO} \ldots \ldots \ldots$ & .60 & .64 \\
\hline $\mathrm{BaO} \ldots \ldots \ldots . \quad .02$ & 8.08 & 8.75 \\
\hline SrO $\ldots \ldots \ldots . .02$ & .09 & .10 \\
\hline $\mathrm{Na}_{2} \mathrm{O} \ldots \ldots \ldots 11.00$ & 3.86 & 3.33 \\
\hline $\mathrm{K}_{2} \mathrm{O} \ldots \ldots \ldots . .38$ & 2.10 & 2.24 \\
\hline $\mathrm{H}_{2} \mathrm{O}+\ldots \ldots 7.91$ & 8.61 & 8.72 \\
\hline $\mathrm{H}_{2} \mathrm{O}-\ldots \ldots \ldots .31$ & 5.71 & 6.16 \\
\hline $\mathrm{TiO}_{2} \ldots \ldots \ldots \ldots$ & .26 & .27 \\
\hline Total . . . . . 99.02 & 99.36 & 100.00 \\
\hline
\end{tabular}

1. Pure analcime, laboratory No. D138981, field No. SW-3-2A. Locality: NE1/4NW1/4 sec. 25, T. 16 N., R. 13 W., Mohave County, Ariz.

2. Impure harmotome, laboratory No. D138983, field No. W7-44. Locality: SW1/4SE $1 / 4$ sec. 26, T. 16 N., R. 13 W., Mohave County, Ariz.

3. Harmotome corrected for 7 percent analcime impurities (analysis 1) and recalculated to 100 percent.

amounts of alkalis, chiefly sodium. Alkalis in harmotome are due to substitutions of the type $\mathrm{Na}_{2}\left(\mathrm{~K}_{2}\right) \rightleftarrows \mathrm{Ba}(\mathrm{Sr}, \mathrm{Ca}, \mathrm{Mg}$ ) or $\mathrm{Na}(\mathrm{K}) \mathrm{Al} \mathrm{Si}$. The latter type of substitution is the more common and accounts for most of the high-alkali harmotomes (Black, 1969). The deviation in composition of the Wikieup harmotome from the ideal formula can be approximated by about $0.54 \mathrm{Na}_{2}\left(\mathrm{~K}_{2}\right)$ replacement of $0.54 \mathrm{Ba}(\mathrm{Sr}, \mathrm{Ca}, \mathrm{Mg})$ and by about $0.69 \mathrm{Na}(\mathrm{K}) \mathrm{Al}\left(\mathrm{Fe}^{+3}\right)$ replacement of $0.69 \mathrm{Si}$. These substitutions, however, still leave an excess of about $0.34 \mathrm{Na}$ atom in the Wikieup harmotome.

The minor-element content of sample No. W7-44 is shown in table 4. Although there are only meager published data on the minor-element content of zeolites from sedimentary environments, this Wikieup harmotome seems particularly rich in Ce, $\mathrm{La}, \mathrm{Li}$, and $\mathrm{Nd}$.

\section{DISCUSSION}

The cation-oxide contents of 24 harmotomes are shown in figure 4. The Wikieup harmotome (T) is set apart from the other analyzed harmotomes by its high content of alkalis. The most alkali-rich, barium-poor harmotome previously reported was a specimen from New Zealand (Black, 1969). With the exception of the Wikieup specimen, all other analyzed harmotomes occur in igneous or metamorphic rocks. The
Table 4.-Semiquantitative spectrographic analysis of harmotome from Wikieup, Ariz.

[Results are reported in parts per million and are to be identified with geometric brackets whose boundaries are $1.2,0.83,0.56$, $0.38,0.26,0.18,0.12$, and so forth, but are reported arbitrarily as midpoints of these brackets, $1.0,0.7,0.5,0.3,0.2,0.15,0.1$, and so forth. The precision of a reported value is approximately plus or minus one bracket at 68-percent and two brackets at 95-percent confidence. The following elements were looked for but not found: $\mathrm{Ag}, \mathrm{As}, \mathrm{Au}, \mathrm{Bi}, \mathrm{Cd}, \mathrm{Eu}, \mathrm{Ge}, \mathrm{Hf}, \mathrm{In}, \mathrm{Mo}, \mathrm{Nb}, \mathrm{Pd}$, Pr, Pt, Re, Sb, Sm, Sn, Ta, Te, Th, Tl, U, W, and Zn. Analyst: L. A. Bradley]

\begin{tabular}{|c|c|}
\hline 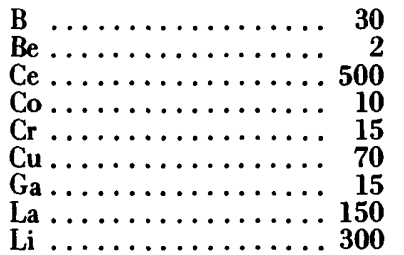 & 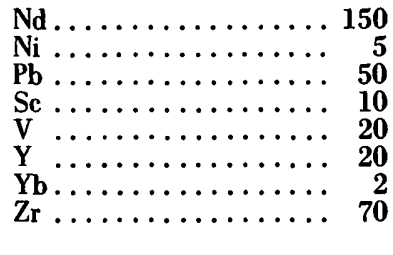 \\
\hline
\end{tabular}

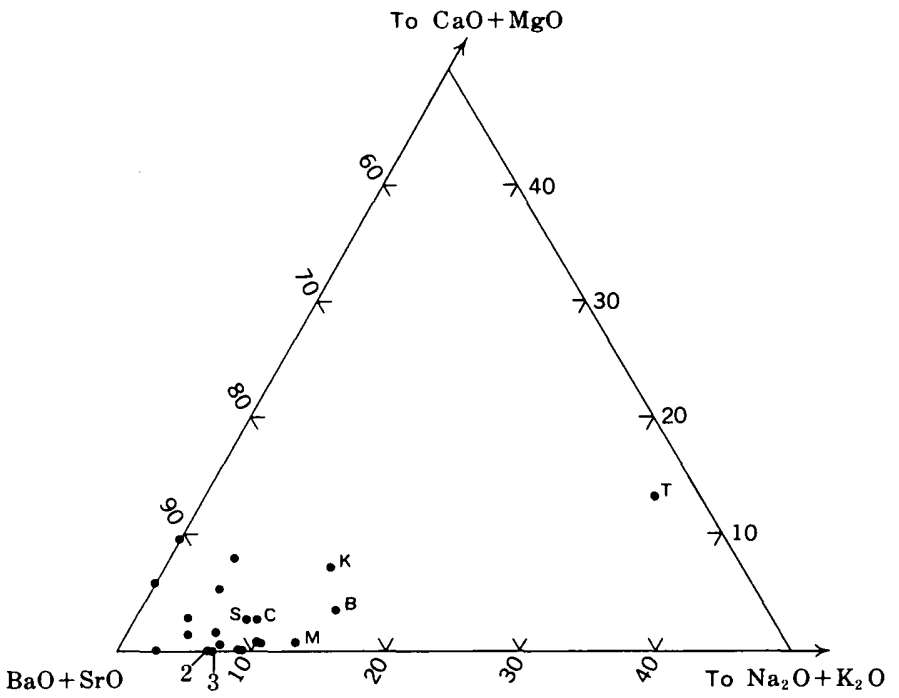

Figure 4.-Compositional variation of harmotome in weight-percent cation oxides. Sources for analyses: unlettered dots, Doelter (1921); B, Black (1969); C, Cèrný and Povondra (1965); K, Kinoshita (1922); M, Meier (1939); S, Sahama and Lehtinen (1967); and T, this report. Numbers at certain dots refer to the number of analyses that have identical cation-oxide ratios.

Wikieup harmotome seems unique in composition; however, future analyses of other harmotomes from sedimentary environments may reveal them to be rich in alkalis. Unfortunately, the only other reported harmotome from a sedimentary rock (Morgenstein, 1967) was not completely analyzed. Maury Morgenstein (written commun., 1970) did, however, state that electron microprobe analyses of the harmotome from the South Pacific showed a "moderately high concentration of sodium."

Charles Milton (written commun., 1969) identified harmotome in the lacustrine Green River Formation, and the finding suggests that this barium-rich zeolite may be relatively common in closed-basin deposits. The Green River harmotome 
occurs with barite in oil shale from drill core in the Piceance basin of Colorado. No chemical analysis was performed on the Green River material, but X-ray and optical parameters match those of the Wikieup harmotome.

\section{REFERENCES}

Arrhenius, Gustaf, 1963, Pelagic sediments, chap. 25 in Hill, M. N., ed., The sea-Ideas and observations on progress in the study of the seas-v. 3, The earth beneath the sea [and] history: New York, Interscience Publishers, p. 655-727.

Barrer, R. M., Bultitude, F. W., and Kerr, I. S., 1959, Some properties of, and a structural scheme for, the harmotome zeolites: London, Chem. Soc. Jour., p. 1521-1528.

Black, P. M., 1969, Harmotome from the Tokatoka district, New Zealand: Mineralog. Mag., v. 37, no. 288, p. 453-458.

Černý, Petr, and Povondra, Pavel, 1965, Harmotome from desilicated pegmatites at Hrubšice, Western Moravia: Carolinae Univ. ActaGeologica, no. 1, p. 31-44.
Deer, W. A., Howie, R. A., and Zussman, J., 1963, Framework silicates, v. 4 of Rock-forming minerals: London, Longmans, Green, and Co. Ltd., $435 \mathrm{p}$.

Doelter, C. A., 1921, Handbuch der Mineralchemie: Dresden, T. Steinkopff, v. 2, pt. 3, 472 p.

Hay, R. L., 1966, Zeolites and zeolitic reactions in sedimentary rocks: Geol. Soc. America Spec. Paper 85, 130 p.

Kinoshita, Kameki, 1922, Harmotome from Udo, Shimane Prefecture: Geol. Soc. Japan Jour., v. 29, p. 83-89.

Meier, A. E., 1939, Association of harmotome and barium feldspar at Glen Riddle, Pennsylvania: Am. Mineralogist, v. 24, no. 9, p. 540-560.

Morgenstein, Maury, 1967, Authigenic cementation of scoriaceous deep-sea sediments west of the Society Ridge, South Pacific: Sedimentology, v. 9, no. 2, p. 105-118.

Sahama, Th. G., and Lehtinen, Martti, 1967, Harmotome from Korsnäs, Finland: Mineralog. Mag., v. 36, no. 279, p. 444-448.

Sheppard, R. A., and Gude, A. J., 3d, 1969, Diagenesis of tuffs in the Barstow Formation, Mud Hills, San Bernardino County, California: U.S. Geol. Survey Prof. Paper 634, 35 p. 


\title{
THE THIEL MOUNTAINS PALLASITE OF ANTARCTICA
}

\author{
By A. B. FORD and R. W. TABOR, Menlo Park, Calif.
}

Work done in cooperation with the National Science Foundation

Abstract.-Two fragments of a pallasite were found on December 7, 1961 , at lat $85^{\circ} 23.9^{\prime} \mathrm{S}$., long $86^{\circ} 35.4^{\prime} \mathrm{W}$., in the eastern part of the Thiel Mountains, one of the southernmost mountain groups in Antaretica. The meteorite fragments lay with morainal debris on ice, apparently carried from nearby Mount Wrather, but the exact site of impact is not known. The meteorite, weighing $28.6 \mathrm{~kg}$, is the largest of four known antarctic meteorite finds and the only one of pallasitic material. Mineral phases are those typical of pallasites, including olivine (55.7 wt percent) and nickle-iron (38.1 wt percent), and minor troilite and schreibersite. The pallasite is classed with Brezina's Krasnojarsk group $(\mathrm{Pk})$ on the basis of rounded form of the olivine in the metal meshwork.

Two fragments of pallasite, a comparatively rare stony-iron meteorite composed of olivine in a meshwork of nickel-iron, were found on December 7, 1961, by geologists of the U.S. Geological Survey during exploration of the Thiel Mountains, Antarctica (fig. 1). The purpose of this report is to record the discovery and occurrence of the meteorite find and to provide a general description of its features. The fragments of the pallasite are now in the meteorite collection of the U.S. National Museum, Washington, D.C.

The meteorite, named Thiel Mountains, is one of only 42 pallasites known (Mason, 1963). Although pallasites are rare compared with other types of meteorites, only two having been seen to fall, they are relatively common as finds because, according to Mason (1963, p. 3),

**** the metal phase renders them quite resistant to weathering and also makes them easily recognizable even to inexperienced finders as meteorites or at least as stones worthy of preservation and record.

Only three other meteorites from Antarctica, all finds, are known. They include (1) a $1.0-\mathrm{kg}$ stony type found on ice near Cape Denison, Adelie Coast, on December 5, 1912 (Bayly and Stillwell, 1923); (2) two fragments, the larger weighing about $7 \mathrm{~kg}$, of an iron meteorite, a coarse octahedrite, found on a nunatak near Lazarev Station on January 21, 1961 (Ravich and Revnov, 1963); and (3) another coarse octahedrite, weighing $1.07 \mathrm{~kg}$, found by a U.S. Geological Survey party on

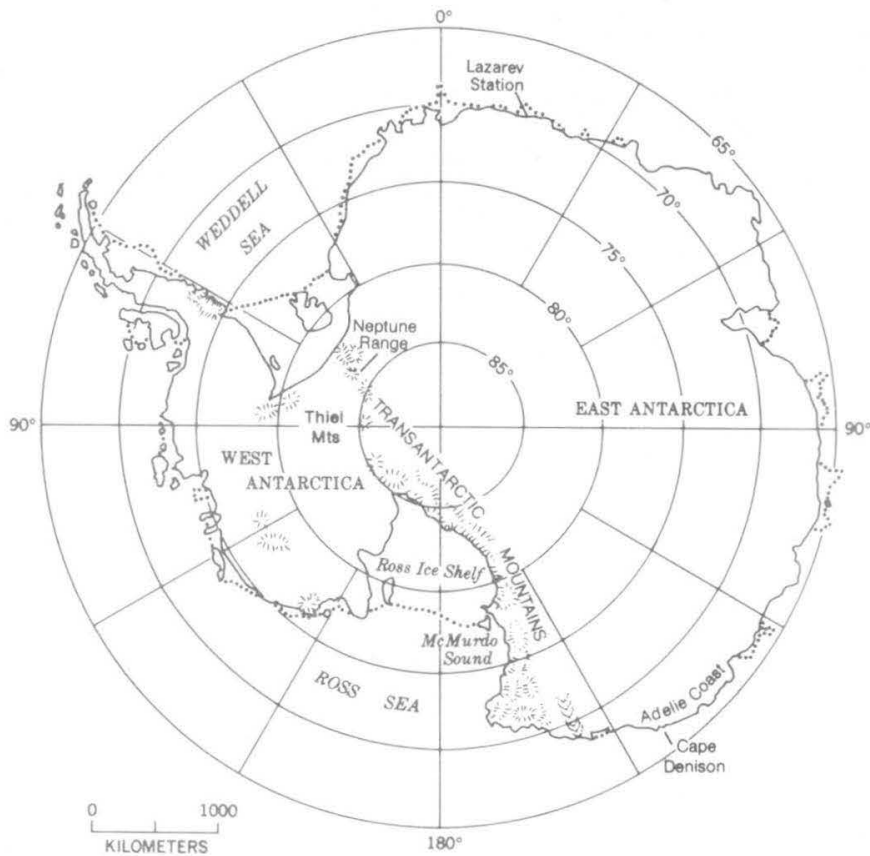

Figure 1.-Index map showing location of Thiel Mountains and other areas (Cape Denison, Lazarev Station, Neptune Range) where meteorites have been found in Antaretica.

a nunatak of the Neptune Range on February 7, 1964 (Schmidt, 1964; Duke, 1965).

Acknowledgments.-E.P. Henderson, of the U.S. National Museum, provided photographs of the specimens and the polished slab on which this preliminary work was based. D. J. Milton aided us greatly by a preliminary study of the mineralogy and identification of the opaque phases. We thank D. J. Milton, D. L. Schmidt, and H. G. Wilshire for helpful reviews of the manuscript, and J. M. Aaron, B. G. Anderson, and R. L. Elliott for help in the fieldwork.

\section{OCCURRENCE}

The two meteorite fragments lay on ice near the northeast base of Mount Wrather (fig. 2), lat $85^{\circ} 23.9^{\prime}$ S., long $86^{\circ} 35.4^{\prime}$ 


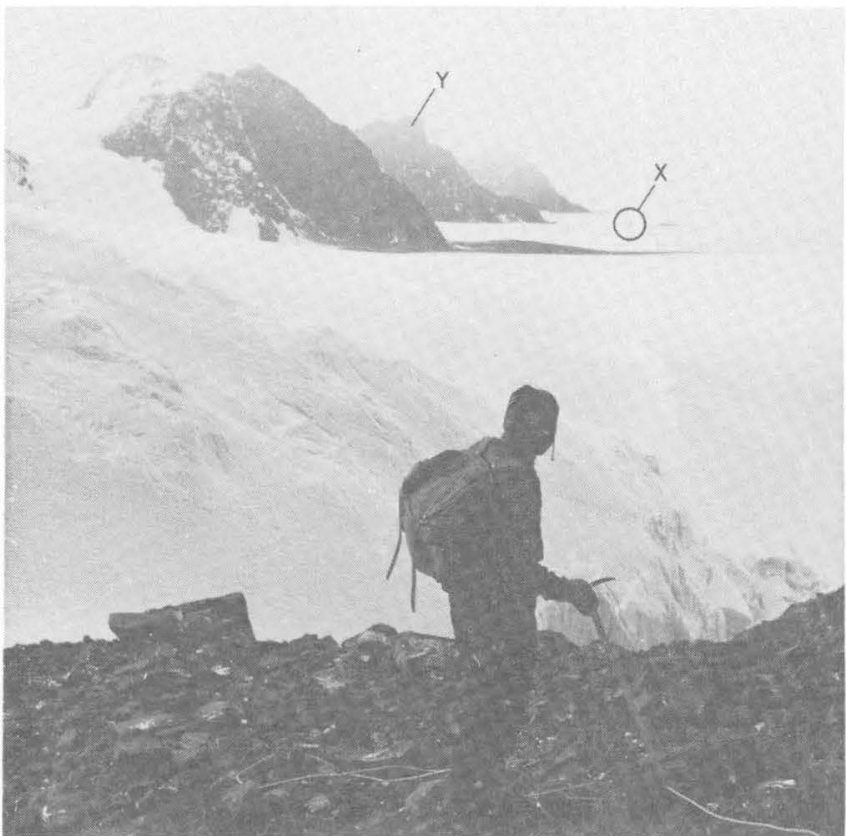

Figure 2,-Meteorite-find locality $(X)$ in moraine at northern foot of Mount Wrather (Y).

W. R. L. Elliott found the larger specimen on hard, irregularly cupped glacier ice about $100 \mathrm{~m}$ northeast of a small end moraine near the foot of the mountain. The smaller fragment, found later, lay in morainal debris about $200 \mathrm{~m}$ southeast of the larger. Although the meteorite was highly distinctive among other rocks of the moraine, mainly a variety of granitic materials (Ford, 1964; Schmidt and Ford, 1969), a search for additional fragments was unsuccessful.

The identical nature of the two fragments (figs. 3 and 4) leaves no doubt that they are of common origin. The specimens each have one or more jagged sides, suggesting that pieces have been torn away. The jagged faces of the two

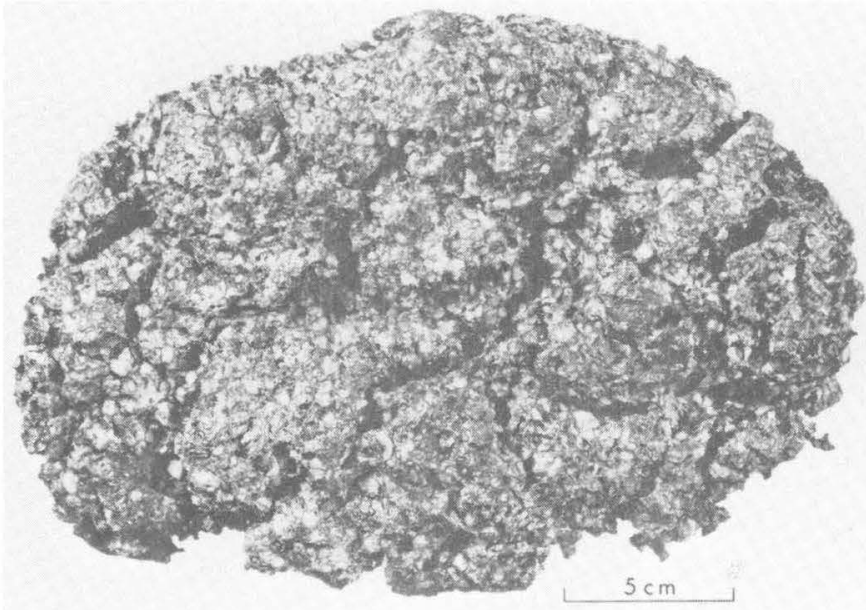

Figure 3.-View of larger meteorite specimen, showing distension cracks. Apparent torn face on bottom. Photograph by U.S. National Museum.

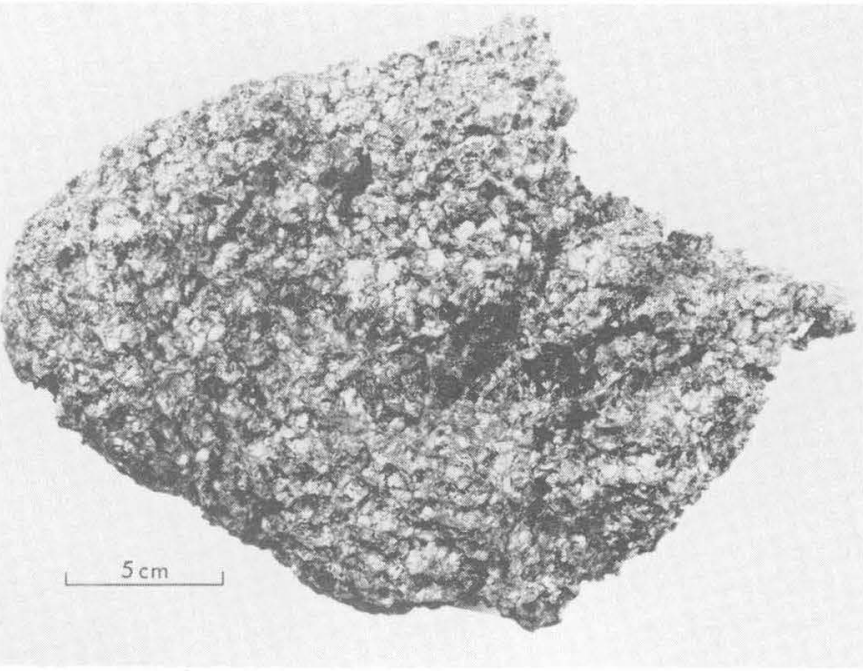

Figure 4.-View of smaller meteorite specimen, showing apparent torn face on right. Photograph by U.S. National Museum.

cannot be refitted, indicating that other pieces might exist. Very likely the two were part of a single body before striking the earth. The point of impact is unknown and might have been either on bedrock or on ice. Their occurrence in moraine suggests at least some transport, probably nearby Mount Wrather. Considerable transport seems unlikely in view of the proximity of the two fragments.

\section{GENERAL DESCRIPTION}

The pallasite, weighing a total of $28.6 \mathrm{~kg}^{1}$, has the appearance of an iron-alloy sponge, with pale-olive-yellow grains of olivine fairly uniformly distributed throughout a continuous network of metal. The general texture resembles that of the pallasite Brenham pictured in Mason (1963, p. 3).

The larger specimen (fig. 3), weighing $18.0 \mathrm{~kg}$, is a crude parallelepiped measuring approximately 19 by 14 by $12 \mathrm{~cm}$. The smaller (fig. 4), weighing $10.6 \mathrm{~kg}$, has the shape of a fragmented ovoid measuring about $18 \mathrm{~cm}$ on long axis by 13 $\mathrm{cm}$ along short axis.

The meteorite surface is generally fresh, the olivine and metal being only locally tarnished by oxide. The freshness does not, however, necessarily indicate recency of fall, as the rate of chemical weathering is extremely slow in the arid, cold continental interior of Antarctica. Mechanical weathering may have been more effective in modifying the surface. Though generally rounded in overall profile, the surface of both specimens is irregular and rough in detail. Numerous small pits (figs. 3 and 4) may be sites of former olivines loosened and released as a consequence of repeated thermal strains and frost action that accompany large-magnitude shifts of temperature on rock surfaces heated by the sun and cooled in shade (Ford and Andersen, 1967).

\footnotetext{
${ }^{1}$ Weight from U.S. National Museum (written commun., 1962). It was reported by Mason (1963, p. 2), however, to be $31.7 \mathrm{~kg}$.
} 
The larger specimen displays irregular to crudely polygonal distension cracks (fig. 3) that are as much as about $0.5 \mathrm{~cm}$ wide, about $1 \mathrm{~cm}$ deep, and generally spaced 3 to $5 \mathrm{~cm}$ apart. Although the geometry of the cracks resembles that of some volcanic breadcrust blocks (Walker, 1969, p. 173), their origin is different, as indicated by lack of evidence of inner vesiculation.

The metal surface of the network and of the thin, bizarrely shaped projections on the apparent torn faces is more or less smoothly rounded and has a semilustrous appearance, as if polished. As the characteristic surface markings formed by fusion of iron during atmospheric transit (Krinov, 1960, p. 265) are not apparent, an original fusion crust, if present, must have been largely removed. The meteorite fragments lay on hard blue ice over which snow, ice crystals, and even sand grains are continually swept by turbulent, high-velocity surface winds. We interpret the smoothness and polished appearance of the metal to be the result of "sandblasting" by windblown particles of rock and ice, the ice having a hardness of about 6 (Blackwelder, 1940) at the extremely low winter temperatures in this area. Corrasion by wind seems to be an effective mechanism of erosion in polar regions elsewhere (Sverdrup, 1938; Teichert, 1939; Wade, 1945) and is doubtless important in the Thiel Mountains.

\section{CLASSIFICATION}

More or less rounded grains of olivine that show little or no fracturing are rather evenly distributed throughout the metal matrix in the polished slab of figure 5 . On the basis of the form of the olivine, the pallasite belongs to the Krasnojarsk group (Pk) of Brezina's classification (Mason, 1962, p. 49). On the basis of the modal content of olivine (table 1), it is a member of the first group, Medvedev, of Chirvinskii's classification (Krinov, 1960, p. 351).

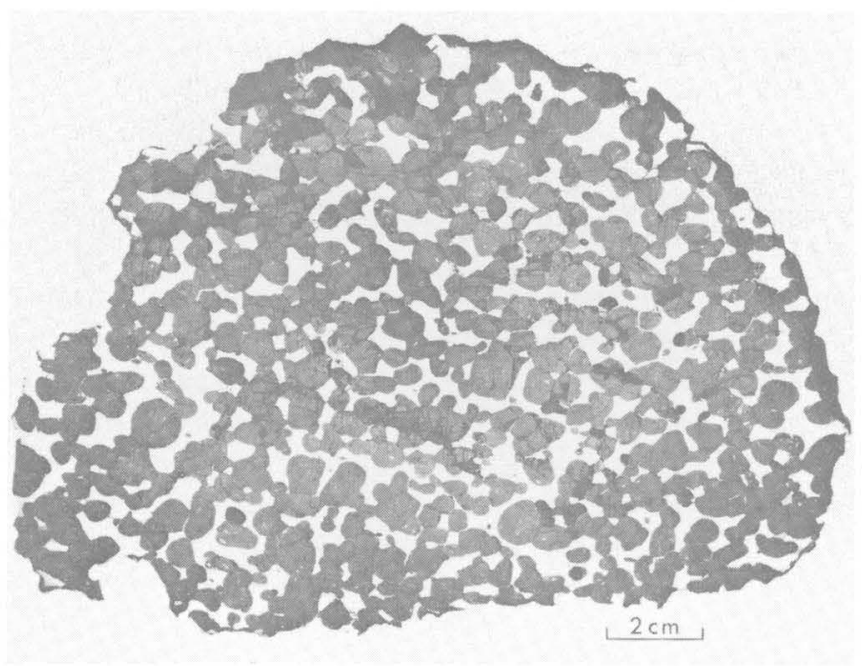

Figure 5.-Polished unetched meteorite slab, showing distribution of rounded olivines (dark gray) in metal reticulum (white).

\section{MINERALOGY}

The mineralogy is relatively simple (table 1) and consists predominantly of the two essential pallasite minerals, olivine and nickel-iron, the latter in its two distinct phases, kamacite and taenite, which are also commonly indistinguishably intergrown as plessite. Also present are accessory troilite and schreibersite. The specific gravity of the Thiel Mountains pallasite, determined by the water-immersion method, is 4.45 , whereas the average for pallasites as a group is 4.74 (Krinov, 1960 , p. 414). The lower-than-average specific gravity reflects higher-than-average olivine content.

Table 1.-Mode of Thiel Mountains pallasite

\begin{tabular}{|c|c|c|}
\hline Constituent & $\begin{array}{l}\text { Volume }{ }^{1} \\
\text { percent }\end{array}$ & $\begin{array}{l}\text { Weight }{ }^{2} \\
\text { percent }\end{array}$ \\
\hline Olivine..$\ldots \ldots \ldots \ldots \ldots$ & 73.4 & 55.7 \\
\hline Nickel-iron (total) . ...... & 21.2 & 38.1 \\
\hline Kamacite (distinct) . . . . . & 14.3 & \\
\hline $\begin{array}{l}\text { Plessite (intergrown } \\
\text { kamacite and taenite) }\end{array}$ & 6.9 & \\
\hline Troilite $\ldots \ldots \ldots \ldots \ldots$ & 4.9 & 5.4 \\
\hline \multirow{2}{*}{ Schreibersite $\ldots \ldots \ldots \ldots$} & .5 & .8 \\
\hline & $\overline{100.0}$ & $\overline{100.0}$ \\
\hline
\end{tabular}

${ }^{1}$ Based on total of 5,000 points, covering entire etched slab of figure 7 ; counted by S. W. Nelson, U.S. Geological Survey.

${ }^{2}$ Recalculated from volume percent using following assumed specific gravities: olivine, 3.3 ; nickel-iron, 7.8 ; troilite, 4.8 ; schreibersite, 7.0 .

\section{Olivine}

The olivine occurs as nearly equant grains, pale tannish yellow, that are generally rounded where against metal but faceted where against other olivine (figs. 5 and 8 ). Individual crystals are fairly uniform in size, between about 0.5 and 1.0 $\mathrm{cm}$ across, but polycrystal groups vary up to several centimeters in long dimension. $2 V_{\mathrm{z}}$ of the olivine, measured conoscopically on the universal stage, is $90^{\circ}$. Unit-cell dimensions, computed from X-ray diffraction peak spacings between $16^{\circ}$ and $65^{\circ} 2 \theta$ and with $\mathrm{CaF}_{2}$ internal standard, are $a=4.765$ $\mathrm{A}, b=10.229 \mathrm{~A}, c=5.994 \mathrm{~A}$, and volume $=292.15 \mathrm{~A}^{3}$.

Table 2 lists Fo determinations that have been made on the olivine. Our analysis by X-ray powder diffraction is based on Jackson's (1960) determinative curve for terrestrial plutonic olivine from the Stillwater Complex. Busek and Goldstein (1969) reported an average composition of $\mathrm{Fe}=9.61$ and $\mathrm{Mg}=28.9$ percent by weight on four grains analyzed by electron microprobe. A plot of the microprobe analysis against Jackson's X-ray parameter shows that the olivine lies very slightly off the terrestrial plutonic curve (fig. 6) but very much closer to it than to the volcanic olivine curve of Murata and others (1965). Variation in X-ray parameter for a given Fo value, a function of unit-cell size, is believed by Murata and others (1965) to be related to the amount of substituent 
Table 2.-Olivine Fo determinations for Thiel Mountains pallasite

\begin{tabular}{|c|c|c|}
\hline Fo value & Method & Source \\
\hline $88 \ldots$ & X-ray diffraction ${ }^{1}$ & Mason $(1963$, p. 10$)$. \\
\hline 88.0 & Electron microprobe & $\begin{array}{c}\text { Busek and Goldstein } \\
(1969, \text { p. 2146). }\end{array}$ \\
\hline 87.2 & .. X-ray diffraction ${ }^{2}$ & This report. \\
\hline
\end{tabular}

${ }^{1}$ Method of Yoder and Sahama (1957).

${ }^{2}$ Method of Jackson (1960).

calcium. The pallasitic olivine (table 3), like the Stillwater plutonic olivine, is far lower in calcium than the Hawaiian volcanic type. Table 3 lists semiquantitative spectrographic data for the pallastic olivine. Busek and Goldstein (1969, p. 2144) found no measurable variation between the four grains analyzed by microprobe, a result supported by our X-ray diffraction scan, which shows only narrow, sharp peaks.

\section{Nickel-iron}

Nickel-iron forms the interconnecting matrix between olivine grains (fig. 5). As is typical of pallasites in general, both iron phases, kamacite and taenite, are present in the Thiel Mountains pallasite. They commonly are indistinguishably intergrown to form plessite. The metal reticulum is as much as about $1 \mathrm{~cm}$ wide in places. When a slab is etched, kamacite can be seen (figs. 7,8 ) to form borders around olivine and also to occur as narrow lamellae, in places showing octahedrite structure within gray fields of plessite. Taenite commonly forms thin, bright rims on kamacite (fig. 8) and, rarely, is intergrown with the kamacite in bands $10 \mu$ to $50 \mu$ wide.

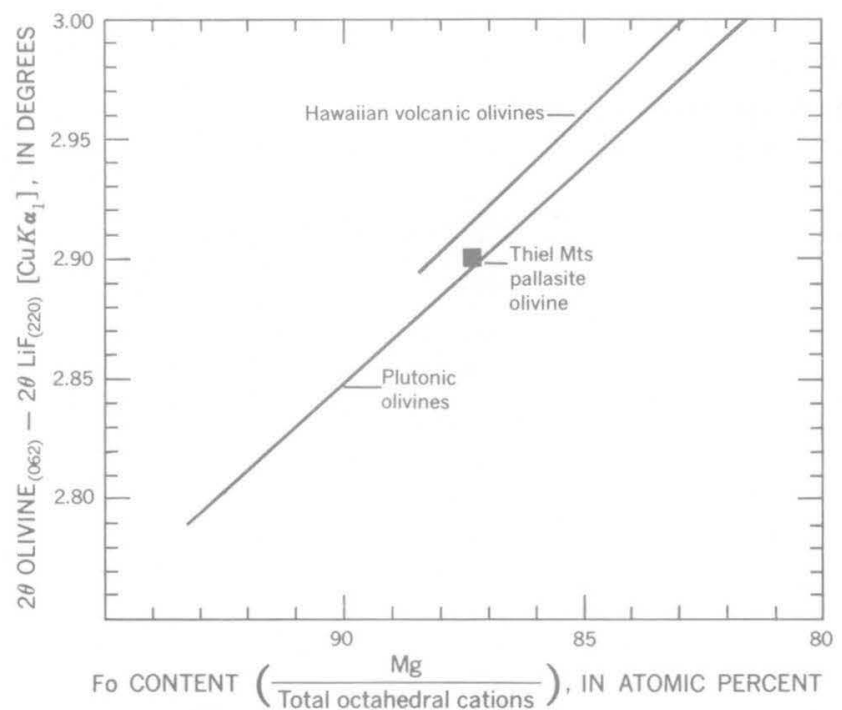

Figure 6.-Thiel Mountains olivine compared with terrestrial olivines. Terrestrial X-ray curves from Murata, Bastron, and Brannock (1965).
Table 3.-Semiquantitative spectrographic analysis of minor elements in Thiel Mountains olivine

\begin{tabular}{|c|c|}
\hline $\mathrm{Al} \ldots \ldots \ldots \ldots 0.015$ & Сo .......... 0.0015 \\
\hline $\mathrm{Ca} \ldots \ldots \ldots \ldots \ldots .007$ & $\mathrm{Cr} \ldots \ldots \ldots \ldots \ldots .02$ \\
\hline $\mathrm{Ti} \ldots \ldots \ldots \ldots<.001$ & $\mathrm{Cu} \ldots \ldots \ldots \ldots \ldots$ \\
\hline Mn........ .1 & $\mathrm{Ni} \ldots \ldots \ldots \ldots \ldots . .005$ \\
\hline Ва........... .0015 & V $\ldots \ldots \ldots \ldots \ldots .001$ \\
\hline
\end{tabular}

Results are reported in percent to the nearest number in the series 1 , $0.7,0.5,0.3,0.2,0.15$, and 0.1 , and so forth, which represent approximate midpoints of interval data on a geometric scale. The assigned interval for semiquantitative results will include the quantitative value about 30 percent of the time. Elements looked for but not detected: $\mathrm{Na}, \mathrm{K}, \mathrm{P}, \mathrm{Ag}, \mathrm{As}, \mathrm{Au}, \mathrm{B}, \mathrm{Be}, \mathrm{Bi}, \mathrm{Cd}, \mathrm{Ce}, \mathrm{Eu}, \mathrm{Ga}, \mathrm{Ge}$, Hf, $\mathrm{Hg}$, In, La, Li, Mo, Nb, Pb, Pd, Pt, Re, Sb, Sc, Sn, Sr, Ta, Te, Th, Tl, U, W, Y, Yb, Zn, Zr. Analyst, Chris Heropoulos.

\section{Troilite}

Brass-yellow troilite forms part of the opaque reticulum. It occurs as small rounded to subangular grains 2 to $3 \mathrm{~mm}$ across and commonly rimmed by kamacite (fig. 8 ), as subangular branching parts of the reticulum as much as 2 or $3 \mathrm{~mm}$ wide by nearly $1 \mathrm{~cm}$ long, and as thin strips less than $1 \mathrm{~mm}$ wide between grains of olivine. Troilite, making up about 5 percent of the mode (table 1), is considerably more abundant than in the average pallasite, in which it is about 1 percent (Mason, 1963, p. 12).

\section{Schreibersite}

Schreibersite commonly lies between nickel-iron and troilite and also occurs in small irregular masses enclosed by nickeliron, concentrated on or near taenite-kamacite boundaries.

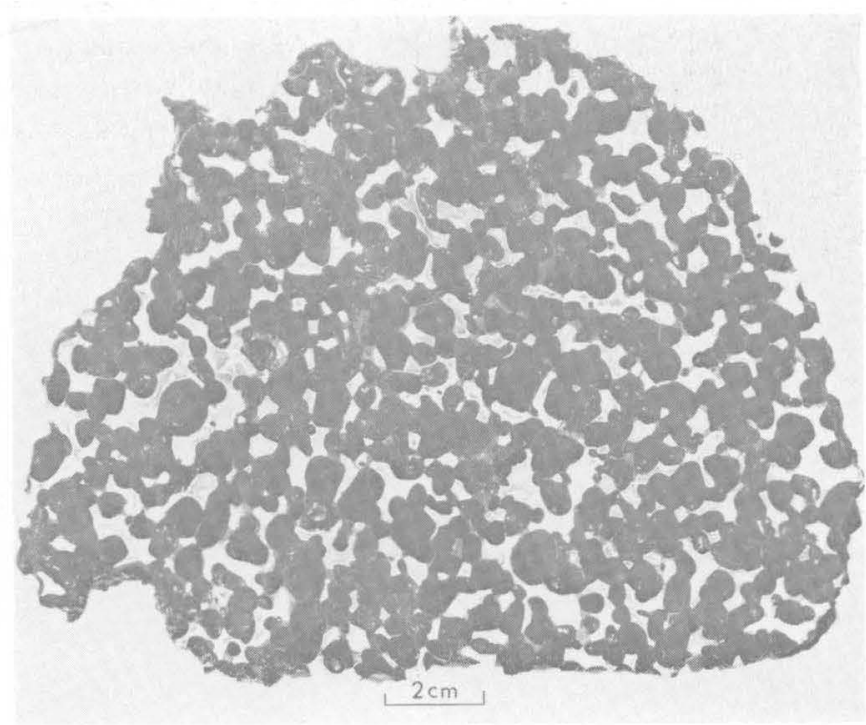

Figure 7.-Meteorite slab (fig. 5) etched to show relations of metal phases. Olivine dark gray to black. Troilite, highly reflective when unetched, here medium to dark gray, making the metal reticulum appear less continuous. Kamacite forms white borders around gray fields of plessite next to olivine. Octahedrite structure visible in some of the larger fields of metal. 


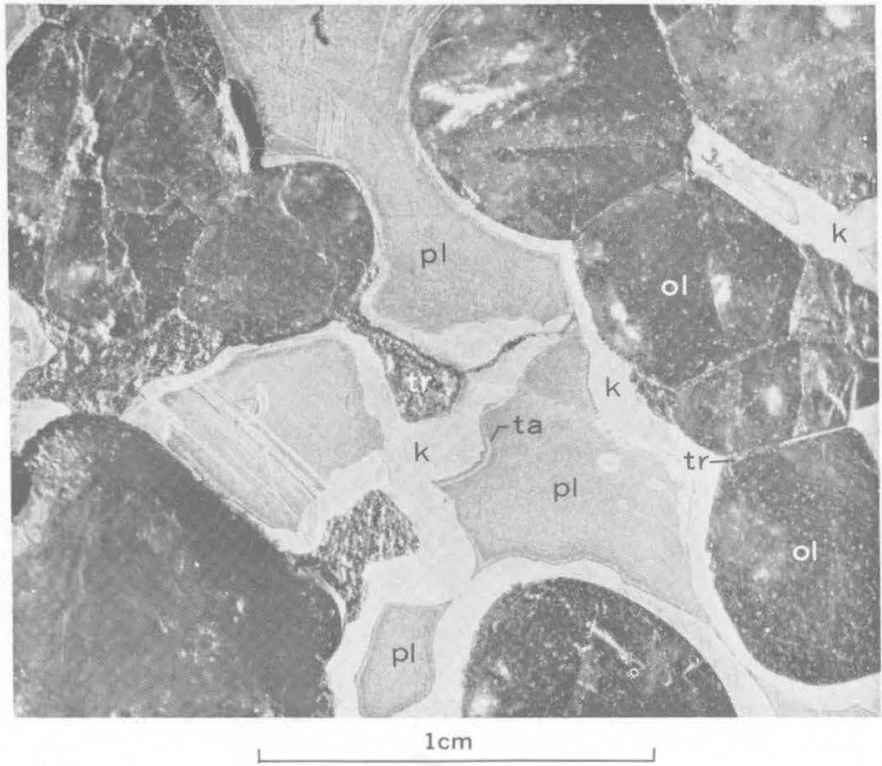

Figure 8.-Photomicrograph of etched meteorite slab (fig. 7) in reflected light, showing textural relations of mineral phases. Kamacite (k) and thin taenite (ta) borders on plessite (pl) of the metal reticulum. Troilite (tr) forms rounded masses in the reticulum (left) and $t$.in septa locally (right) between faceted olivines (ol).

\section{REFERENCES}

Bayly, P. G. W., and Stillwell, F. L., 1923, The Adelie Land meteorite: Australasian Antarctic Expedition, 1911-14, Sci. Repts, Ser. A, v. 4, $11 \mathrm{p}$.

Blackwelder, Eliot, 1940, The hardness of ice: Am. Jour. Sci., v. 238, p. 61-62.

Busek, P. R., and Goldstein, J. I., 1969, Olivine compositions and cooling rates of pallasitic meteorites: Geol. Soc. America Bull., v. 80, p. 2141-2158.
Duke, M. B., 1965, Discovery of Neptune Mountains iron meteorite, Antarctica: Meteorit. Bull., no. 34, p. 2-3.

Ford, A. B., 1964, Cordierite-bearing hypersthene-quartz monzonite porphyry in the Thiel Mountains and its regional importance, in Adie, R. J., ed., Antarctic geology: New York, John Wiley, p. $429-4.41$.

Ford, A. B., and Andersen, B. G., 1967, Sorted talus aprons and the movement of debris in Antaretica by repeated thermal contraction and rupture of underlying ice: Jour, Geology, v. 75, p. 722-732.

Jackson, E. D., 1960, X-ray determinative curve for natural olivine of composition Fo $0_{0-90}$ : Art. 197 in U.S. Geol. Survey Prof. Paper 400-B, p. B432-B434.

Krinov, E. L., 1960, Principles of meteoritics: London, Permagon Press, $535 \mathrm{p}$.

Mason, Brian, 1962, Meteorites: New York, John Wiley, 274 p.

_ 1963, The pallasites: Am. Museum Novitates, no. 2163, p. 1-19.

Murata, K. J., Bastron, Harry, and Brannock, W. W., 1965, X-ray determinative curve for Hawaiian olivines of composition Fo 76 -88, in Geological Survey Research 1965: U.S. Geol. Survey Prof. Paper 525-C, p. C35-C37.

Ravich, M. G., and Revnov, B. I., 1963, Lazarev iron meteorite: Meteoritika, v. 23, p. 30-35 [In Russian]. (Note: English translation in Meteoritica, v. 23, p. 38-43, 1965, New York, Taurus Press.)

Schmidt, D. L., 1964, Geology of the Pensacola Mountains: U.S. Antarctic Projects Officer Bull,, v. 5, p. 98-101.

Schmidt, D. L., and Ford, A. B., 1969, Geology of the Pensacola and Thiel Mountains; sheet 5, Geologic maps of Antarctica: New York, Am. Geog. Soc. (Geologic map folio sheet, 1:1,000,000, with accompanying text.)

Sverdrup, H. U., 1938, Notes on erosion by drifting snow and transport of solid material by sea ice: Am. Jour. Sei., v. 35, p. 370-373.

Teichert, Curt, 1939, Corrasion by wind-blown snow in polar regions: Am. Jour. Sci., v. 237, p. 146-148.

Wade, F. A., 1945, The geology of the Rockefeller Mountains, King Edward VII Land, Antarctica: Am. Philos. Soc. Proc., v. 89, p. $67-77$.

Walker, G. P. L., 1969, The breaking of magma: Geol. Mag., v. 106, p. $166-173$.

Yoder, H. S., Jr., and Sahama, Th. G., 1957, Olivine X-ray determinative curve: Am. Mineralogist, v, 42, p. 475-491. 


\title{
CHEMICAL AND MINERALOGIC DATA ON SOME PLUTONIC ROCKS OF WESTERN NORTH CAROLINA
}

\author{
By ARTHUR E. NELSON, Beltsville, Má.
}

\begin{abstract}
Numerous Paleozoic plutons of quartz monzonite to quartz diorite gneiss in western North Carolina are separated into two distinct groups by the northeast-trending Brevard zone of cataclastic rocks. Northwest of the Brevard zone, the plutonic gneisses, previously described as Whiteside Granite, comprise four rock types: hornblendebiotite gneiss, porphyroblastic microcline gneiss, felsic mica gneiss, and quartz-feldspar gneiss. These rocks are calc-alkalic and are mostly granodiorite in composition. Southeast of the Brevard zone is the Henderson Gneiss which is alkalic-calcic and predominately quartz monzonite in composition. Most Henderson Gneiss contains higher amounts of potassium, titanium, silver, and molybdenum than the plutonic gneisses northwest of the Brevard zone.
\end{abstract}

New mineralogic and chemical data are presented for plutonic gneisses in western North Carolina originally named Whiteside Granite and Henderson Granite by Keith (1905). The data show broad regional differences in the major oxide and minor-element contents of the plutonic gneisses and also indicate that many of the plutons of Keith's Whiteside are mineralogically and chemically dissimilar.

Flat-stage methods were used to determine the anorthite content of the plagioclase, and the Rosiwal method was used to determine the modes.

This report stems from mapping by the U.S. Geological Survey in 1965-68 of the Knoxville 1- by 2-degree quadrangle, North Carolina, Tennessee, and South Carolina (Hadley and Nelson, 1.971).

\section{GENERAL GEOLOGIC SETTING}

The northeast-trending Brevard zone of cataclastic rocks (Keith, 1905; and Reed and Bryant, 1960) separates the report area into two parts (fig. 1). Northwest of the Brevard zone the area is underlain by an undivided Precambrian gneiss-schist complex consisting mostly of layered felsic gneiss, mica gneisses and schists, metasandstone, quartzo-feldspathic gneiss, and migmatite. Keith (1907) called these rocks the Carolina Gneiss. Numerous amphibolite bands intercalated in the Carolina Keith called Roan Gneiss. These names are no longer in use. Hadley and Nelson (1971) divided this complex into unnamed older and younger Precambrian rock units. Units of the Ocoee Series (Hadley and Goldsmith, 1963) are exposed east and northeast of the gneiss-schist complex. Gneissic rocks of Paleozoic age within the gneiss-schist complex and the Ocoee Series range in size from thin discontinuous layers or pods 1 inch thick to sheetlike masses and bodies measured in miles. The larger units, called Whiteside Granite by Keith (1907), have been divided into four lithologically distinct rock types: prophyroblastic microcline gneiss, hornblende-biotite gneiss, felsic mica gneiss, and quartz-feldspar gneiss.

The area southeast of the Brevard zone (fig. 1) is underlain by the Henderson Gneiss which consists of quartz-biotitefeldspar augen gneiss and interlayered paragneisses and an unnamed complex of stratified mica schist and gneiss, quartzite, and amphibolite, intruded by quartz monzonite and migmatite. All these rocks are probably Paleozoic in age (Hadley and Nelson, 1971). Some of the plutonic rocks in this area were called Whiteside Granite by Keith (1905), but, because of lithologic dissimilarities to the type Whiteside, more recent workers (Overstreet and Bell, 1965, p. 64-78) have restricted the term Whiteside Granite to rocks northwest of the Brevard zone.

Within the report area, all rock units are foliated, but the foliation is vague in parts of plutons with few mafic constituents. The foliation in the plutons is parallel to foliation in the enclosing paragneisses and, except along fold hinges, has a regional northeast strike. Fold axes trend northeast.

The plutonic rocks contain inclusions of older rocks in a few places. These range from tiny discontinuous streaks of dark biotite schist greater than $1 / 2$ inch thick to layers of paragneiss several tens of feet thick.

In the report area the stratified rocks are polymetamorphic as also reported by Hadley and Goldsmith (1963, p. B107) for an area to the northwest. Except for retrograded rocks in and adjacent to the Brevard zone, most of the rocks are in the kyanite-muscovite-quartz and sillimanite-almandine subfacies of the almandine amphibolite facies of regional metamorphism (Fyfe and others, 1958, p. 230-231).

After an early period of folding, regional thermal metamorphism, and emplacement of the plutons, the plutonic and 


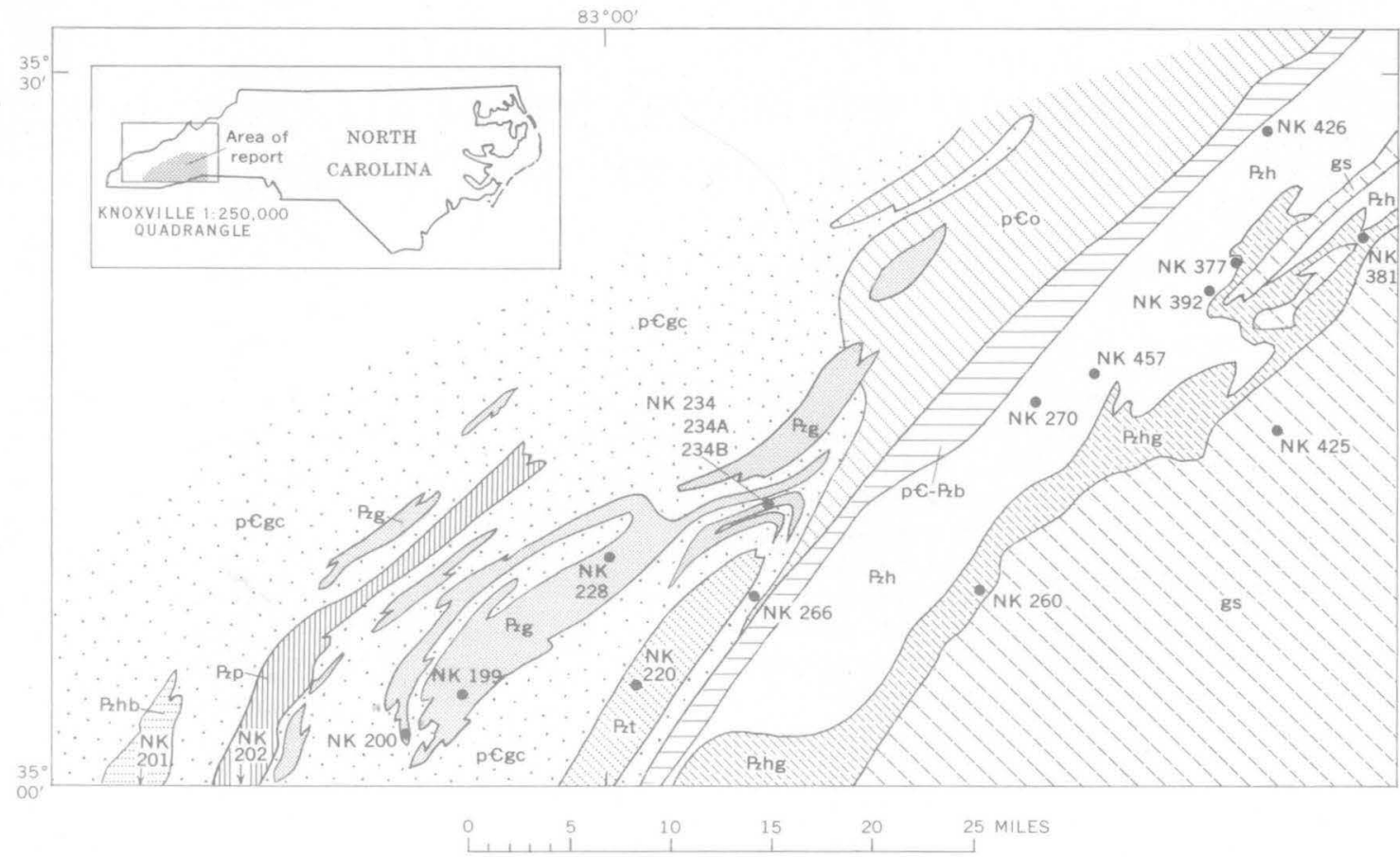

EXPLANATION

NORTHWEST OF BREVARD ZONE

SOUTHEAST OF BREVARD ZONE

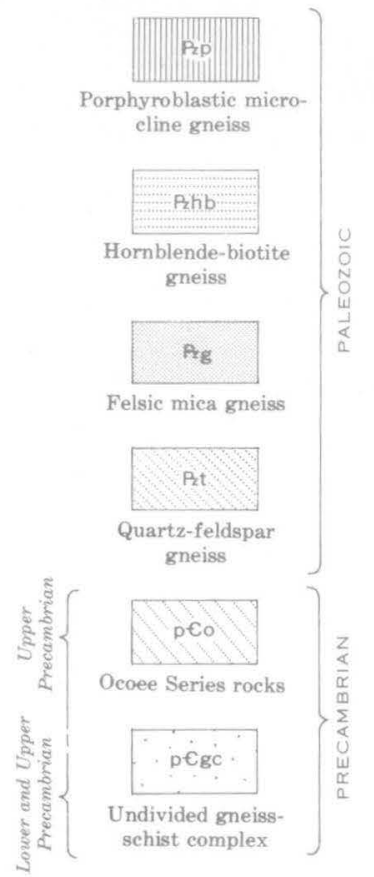

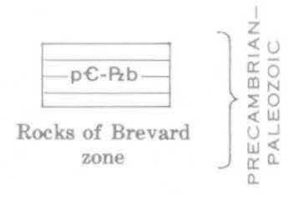

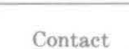

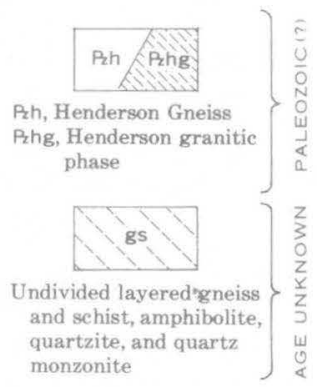

NK 457

Sample locality

Figure 1.-Generalized geologic map of part of western North Carolina (generalized from Hadley and Nelson, 1971). 
stratified rocks underwent a later period of folding which was locally isoclinal. This later episode of folding which has also been reported by Hadley and Goldsmith (1963, p. B107) superposed northeast-trending folds and foliation on the earlier folds, resulting in locally complex fold patterns.

\section{DESCRIPTION OF THE PLUTONIC ROCKS}

\section{Porphyroblastic microcline gneiss}

The porphyroblastic microcline gneiss is light to pinkish gray and characterized by porphyroblasts of microcline in a fine- to medium-grained groundmass. It has a granodiorite composition. Plagioclase, quartz, and biotite are the principal minerals of the groundmass, which has a xenomorphic granular texture. Microcline, both as tiny grains in the groundmass and as porphyroblasts, is light tan to light pink. The porphyroblasts commonly are $3 / 4$ to $1 \frac{1}{2}$ inches long and have ragged edges. Some are poikilitic with tiny inclusions of quartz and plagioclase; Carlsbad twins are common. Most of the porphyroblasts are elongated parallel to the foliation, but some are elongated almost normal to the foliation. Quartz is commonly strained; in places it forms a myrmekitic intergrowth with plagioclase. Other minerals are epidote, apatite, magnetite, and muscovite, which appears younger than biotite. The rock has been cataclastically deformed, and tiny crush zones are present along a small shear zone. A mode of one sample (NK 202) of this gneiss is shown in table 1.

\section{Hornblende-biotite gneiss}

The hornblende-biotite gneiss is a massive dark- to mediumgray, well-foliated equigranular gneiss with the composition of quartz diorite. Plagioclase, quartz, biotite, and hornblende are the principal minerals and together form a crystalloblastic texture. Twin lamellae in many of the plagioclase grains are bent, and the quartz is strained. Other minerals are epidote, apatite, sphene, zircon, and some opaque mineral probably magnetite. A mode of this gneiss (sample NK 201) is given in table 1 .

\section{Felsic mica gneiss}

These rocks are mostly nonlayered two-mica gneisses whose compositions range from granodiorite to quartz diorite. They are generally light gray, moderately foliated, fine to medium grained, and equigranular with crystalloblastic texture. Rocks from the Whiteside Mountain area are the typical Whiteside Granite of Keith (1907). Plagioclase, quartz, microcline, biotite, and muscovite are the chief minerals. In the samples examined the microcline, muscovite, and biotite contents vary widely (table 1, samples NK 199, 200, 228, 234, 234A, and 234B); microcline, which appears to replace plagioclase, ranges from less than 1 to 22 percent. In exposures where biotite- and muscovite-rich zones alternate, a faint color banding is produced. Much less abundant are epidote, chlorite, apatite, sphene, magnetite, and zircon. Small amounts of myrmekite are present. Pegmatites are abundant in these rocks.

\section{Quartz-feldspar gneiss}

The quartz-feldspar gneiss, which ranges from quartz monzonite to granodiorite in composition, is made up of light- to medium-gray, medium- to coarse-grained rocks. They are poorly to well foliated, nonlayered to faintly layered, and equigranular to inequigranular. Most of the rocks are characterized by coarse eyes or knots of quartz and feldspar enclosed by folia of medium-grained biotite. In some places, the gneiss is medium gray, equigranular; and appears massive; elsewhere it is markedly streaked with alternating bands of biotite and flattened segregations of quartz and feldspar. In still other places the quartz-feldspar gneiss has faint bands of differing composition. Coarse blocky porphyroblasts of microcline are abundant in these gneisses. The texture of most specimens is crystalloblastic, but some are lepidoblastic or cataclastic. Quartz, plagioclase, and biotite are the chief minerals; rarer minerals are muscovite, epidote, sphene, magnetite, apatite, and zircon. Knots, pods, and stringers of pegmatite are common.

Modes of two quartz-feldspar gneiss samples (NK 220 and 226) are shown in table 1.

\section{Henderson Gneiss}

Keith $(1905,1907)$ first named this rock unit the Henderson Granite, but later workers have referred to it as the Henderson Gneiss (Reed, 1964). Mostly quartz monzonite in composition, it is generally a fine-grained, medium- to dark-gray, well-foliated quartz-feldspar-biotite gneiss characterized by pink microcline augen that average $3 / 4$ inch in length. Much of the microcline has Carlsbad twinning and is jacketed by a thin zone of plagioclase and quartz. Most exposures of the Henderson appear massive, but in places the gneiss is faintly layered; the Henderson has some intercalations of layered fine-grained biotite gneiss. The principal minerals are quartz, plagioclase, microcline, and biotite; other minerals are muscovite, calcite, sericite, epidote, sphene, hornblende, chlorite, ilmenite, apatite, zircon, and traces of fluorite. Textures range from lepidoblastic to granoblastic to recrystallized cataclastic.

This augen gneiss grades eastward (fig. 1) into a less distinctly foliated light-gray gneiss with few or no augen, but with porphyroblasts of microcline. Except for a higher content of quartz and feldspar and lower content of biotite, the mineral composition is the same as that of the augen gneiss. This is called the granitic phase of the Henderson Gneiss.

Near the Brevard zone the Henderson Gneiss is more intensely crushed and cataclastically deformed.

Modes of some Henderson Gneiss samples are shown in table 1 (NK 260, 270, 377, 381, 392, 425, 426, and 457). 
Table 1.-Chemical and modal analyses of some plutonic rocks from western North Carolina

[Samples analyzed by methods described by Shapiro and Brannock (1962). Analysts: P. L. D. Elmore, S. D. Botts, G. W. Chloe Lowell Artis, H. Smith, and J. L. Glenn. N.d., not determined; Tr. trace]

\begin{tabular}{|c|c|c|c|c|c|c|c|c|c|c|c|c|c|c|c|c|c|c|c|}
\hline Field No. & & $\begin{array}{l}\text { NK } \\
199\end{array}$ & $\begin{array}{l}\text { NK } \\
200\end{array}$ & $\begin{array}{l}\text { NK } \\
201\end{array}$ & $\begin{array}{l}\text { NK } \\
202\end{array}$ & $\begin{array}{l}\text { NK } \\
220\end{array}$ & $\begin{array}{l}\text { NK } \\
228\end{array}$ & $\begin{array}{l}\text { NK } \\
234\end{array}$ & $\begin{array}{r}\text { NK } \\
234 A\end{array}$ & $\begin{array}{r}\text { NK } \\
234 B\end{array}$ & $\begin{array}{c}\text { NK } \\
266\end{array}$ & $\begin{array}{l}\text { NK } \\
260\end{array}$ & $\begin{array}{l}\text { NK } \\
270\end{array}$ & $\begin{array}{l}\text { NK } \\
377\end{array}$ & $\begin{array}{l}\text { NK } \\
381\end{array}$ & $\begin{array}{l}\text { NK } \\
392\end{array}$ & $\begin{array}{l}\text { NK } \\
425\end{array}$ & $\begin{array}{l}\text { NK } \\
426\end{array}$ & $\begin{array}{l}\text { NK } \\
457\end{array}$ \\
\hline Lab. No. & & $\begin{array}{r}\text { W168 } \\
055\end{array}$ & $\begin{array}{r}\text { W168 } \\
060\end{array}$ & $\begin{array}{r}\text { W168 } \\
051\end{array}$ & $\begin{array}{r}\text { W168 } \\
052\end{array}$ & $\begin{array}{r}\text { W } 168 \\
056\end{array}$ & $\begin{array}{r}\text { W168 } \\
057\end{array}$ & $\begin{array}{r}\text { W168 } \\
054\end{array}$ & $\begin{array}{r}\text { W168 } \\
058\end{array}$ & $\begin{array}{r}\text { W168 } \\
059\end{array}$ & $\begin{array}{r}\text { W } 168 \\
050\end{array}$ & $\begin{array}{r}\text { W168 } \\
053\end{array}$ & $\begin{array}{r}\text { W169 } \\
685\end{array}$ & $\begin{array}{r}\text { W169 } \\
686\end{array}$ & $\begin{array}{r}\text { W169 } \\
687\end{array}$ & $\begin{array}{r}\text { W169 } \\
688\end{array}$ & $\begin{array}{r}\text { W169 } \\
689\end{array}$ & $\begin{array}{r}\text { W169 } \\
690\end{array}$ & $\begin{array}{r}\text { W169 } \\
691\end{array}$ \\
\hline \multicolumn{20}{|c|}{ Chemical analyses (weight percent) } \\
\hline $\mathrm{SiO}_{2}$ & & 71.7 & 73.2 & 65.3 & 70.9 & 70.9 & 73.9 & 73.2 & 74.9 & 70.3 & 65.8 & 73.6 & 68.9 & 68.4 & 75.1 & 68.3 & 7.0 .2 & 69.3 & 66.5 \\
\hline $\mathrm{Al}_{2} \mathbf{O}_{3}$ & $\ldots \ldots \ldots \ldots$ & 16.8 & 14.8 & 16.5 & 16.2 & 13.8 & 15.8 & 14.8 & 14.3 & 15.2 & 14.7 & 13.9 & 14.4 & 15.0 & 12.9 & 15.2 & 15.0 & 14.7 & 16.4 \\
\hline $\mathrm{Fe}_{2} \mathrm{O}_{3}$ & $\ldots \ldots \ldots$ & .25 & .43 & .81 & .48 & 1.0 & .15 & .36 & .29 & 1.0 & 1.7 & .83 & 2.1 & 1.0 & .44 & 1.2 & .72 & .90 & 1.4 \\
\hline $\mathrm{FeO}$ & $\ldots \ldots \ldots \ldots$ & .32 & .88 & 2.9 & .56 & 2.0 & .20 & 1.4 & .28 & 2.5 & 3.5 & .88 & 1.2 & 2.4 & .96 & 2.3 & 1.7 & 2.0 & 2.2 \\
\hline Mg0 & $\ldots \ldots \ldots \ldots$ & .18 & .18 & 2.2 & .30 & .47 & .03 & .42 & .05 & .93 & 1.5 & .42 & 1.3 & 1.0 & .50 & 1.0 & .94 & 1.0 & 1.0 \\
\hline $\mathrm{CaO}$ & $\ldots \ldots \ldots \ldots$ & 3.3 & 1.3 & 5.6 & 2.2 & 2.2 & 2.8 & 1.6 & 1.1 & 2.4 & 3.0 & 1.6 & 2.5 & 2.2 & 1.2 & 2.1 & 2.1 & 2.0 & 2.4 \\
\hline $\mathrm{Na}_{2} \mathrm{O}$ & $\ldots \ldots \ldots \ldots$ & 5.5 & 3.8 & 3.7 & 4.4 & 2.4 & 5.0 & 4.2 & 4.3 & 4.3 & 3.2 & 3.5 & 3.3 & 3.6 & 3.3 & 4.0 & 4.0 & 3.6 & 3.7 \\
\hline $\mathrm{K}_{\mathbf{2}} \mathbf{0}$ & $\ldots \ldots \ldots \ldots$ & .60 & 4.1 & 1.2 & 3.9 & 4.8 & 1.6 & 3.1 & 3.6 & 1.7 & 4.0 & 4.0 & 4.8 & 4.9 & 4.8 & 4.2 & 4.0 & 4.8 & 4.7 \\
\hline $\mathrm{H}_{2} \mathrm{O}-$ & $\ldots \ldots \ldots$ & .19 & .04 & .06 & .03 & .04 & .05 & .03 & .02 & .00 & .10 & .05 & .15 & .08 & .11 & .09 & .10 & .06 & .09 \\
\hline $\mathrm{H}_{2} \mathrm{O}+$ & $\ldots \ldots \ldots$ & .29 & .29 & .71 & .28 & .41 & .14 & .33 & .31 & .41 & .81 & .41 & .44 & .44 & .35 & .49 & .59 & .70 & .55 \\
\hline $\mathrm{TiO}_{2}$ & $\ldots \ldots \ldots \ldots$ & .09 & .27 & .48 & .16 & .74 & .06 & .23 & .06 & .83 & .99 & .40 & .65 & .67 & .27 & .65 & .46 & .58 & .65 \\
\hline $\mathrm{P}_{2} \mathrm{O}_{5}$ & $\ldots \ldots \ldots$ & .19 & .14 & .34 & .18 & .42 & .09 & .13 & .10 & .24 & .48 & .17 & .15 & .24 & .09 & .26 & .14 & .20 & .24 \\
\hline $\mathrm{Mn0}$ & $\ldots \ldots \ldots \ldots$ & .00 & .00 & .14 & .00 & .00 & .06 & .12 & .06 & .08 & .02 & .06 & .05 & .03 & .05 & .10 & .10 & .10 & .07 \\
\hline $\mathrm{CO}_{2}$ & $\ldots \ldots \ldots$ & $<.05$ & .05 & $<.05$ & $<.05$ & $<.05$ & $<.05$ & $<.05$ & $<.05$ & $<.05$ & $<.05$ & $<.05$ & $<.05$ & $<.05$ & $<.05$ & $<.05$ & $<.05$ & $<.05$ & $<.05$ \\
\hline Sum & $\cdots$ & 99 & 99 & 100 & 100 & 99 & 100 & 100 & 99 & 100 & 100 & 100 & 100 & 100 & 100 & 100 & 100 & 100 & 100 \\
\hline \multicolumn{20}{|c|}{ Normative minerals (weight percent) } \\
\hline Quartz . & & 30.9 & 32.7 & 23.2 & 25.8 & 34.0 & 33.0 & 32.4 & 34.2 & 31.9 & 23.2 & 34.4 & 24.8 & 22.2 & 34.1 & 22.8 & 25.3 & 23.9 & 20.3 \\
\hline Corundum & & 1.7 & 2.2 & $\ldots$ & 1.3 & 1.8 & 1.1 & 2.1 & 1.7 & 2.6 & .9 & 1.4 & $\ldots$ & .5 & .4 & 1.0 & .7 & .5 & 1.6 \\
\hline Orthoclase & & 3.6 & 24.4 & 7.1 & 23.1 & 28.6 & 9.5 & 18.3 & 21.4 & 10.1 & 23.7 & 23.7 & 28.4 & 29.0 & 28.3 & 24.8 & 23.6 & 28.4 & 27.8 \\
\hline Albite & & 46.9 & 32.2 & 31.3 & 37.4 & 20.5 & 42.4 & 35.6 & 36.6 & 36.4 & 27.1 & 29.7 & 27.9 & 30.5 & 27.9 & 33.9 & 33.8 & 30.5 & 31.3 \\
\hline Anorthite & $\ldots \ldots \ldots$ & 14.9 & 5.3 & 24.9 & 9.5 & 7.9 & 13.0 & 6.8 & 4.5 & 10.0 & 11.5 & 6.5 & 10.3 & 9.0 & 5.0 & 8.4 & 9.2 & 8.3 & 10.0 \\
\hline Wollastonite & te $\ldots \ldots \ldots$ & $\ldots$ & $\ldots$ & .2 & $\ldots$ & $\ldots$ & $\ldots$ & $\ldots$ & . & $\ldots$ & $\ldots$ & $\ldots$ & .3 & & & & & & \\
\hline Enstatite & $\ldots \ldots \ldots$ & .5 & .5 & 5.5 & .8 & 1.2 & .1 & 1.1 & .1 & 2.3 & 3.7 & 1.1 & 3.2 & 2.5 & 1.2 & 2.5 & 2.3 & 2.5 & 2.5 \\
\hline Ferrosilite & $\ldots \ldots \ldots$ & .2 & .8 & 4.1 & .4 & 1.6 & .3 & 2.1 & .3 & 2.5 & 3.4 & .4 & $\ldots$ & 2.5 & 1.1 & 2.3 & 2.0 & 2.2 & 1.9 \\
\hline Hematite & $\ldots \ldots \ldots$ & $\ldots$ & $\ldots$ & $\ldots$ & $\ldots$ & $\ldots$ & $\ldots$ & $\ldots$ & 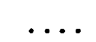 & $\ldots$ & $\ldots$ & $\ldots$ & .6 & & & & & & \\
\hline Magnetite & $\ldots \ldots \ldots \ldots$ & .4 & .6 & 1.2 & .7 & 1.5 & .2 & .5 & .4 & 1.5 & 2.5 & 1.2 & 2.1 & 1.5 & .6 & 1.7 & 1.0 & 1.3 & 2.0 \\
\hline Ilmenite & $\ldots \ldots \ldots \ldots$ & .2 & .5 & .9 & .3 & 1.4 & .1 & .4 & .1 & 1.6 & 1.9 & .8 & 1.2 & 1.3 & .5 & 1.2 & .9 & 1.1 & 1.2 \\
\hline Apatite & $\ldots \ldots \ldots$ & .5 & .3 & .8 & .4 & 1.0 & .2 & .3 & .2 & .6 & 1.1 & .4 & .4 & .6 & .2 & .6 & .3 & .5 & .6 \\
\hline Calcite & $\ldots \ldots \ldots$ & .1 & .1 & .1 & .1 & .1 & .1 & .1 & .1 & .1 & .1 & .1 & .1 & .1 & 1 & .1 & .1 & .1 & .1 \\
\hline
\end{tabular}

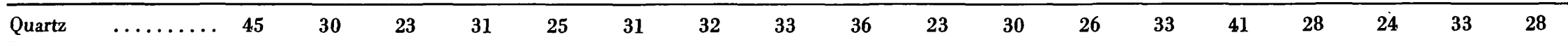

Plagioclase (may include

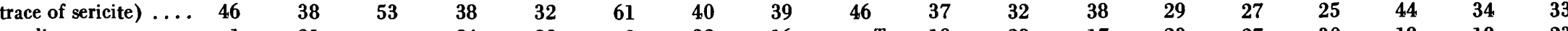

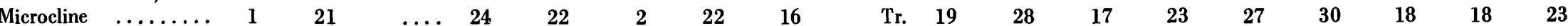

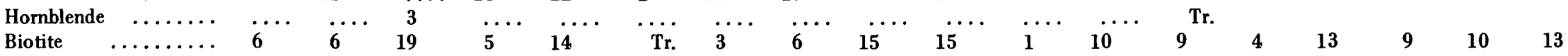

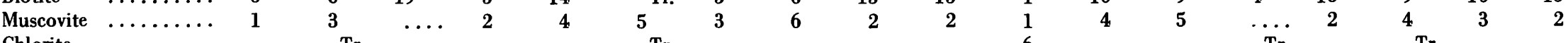

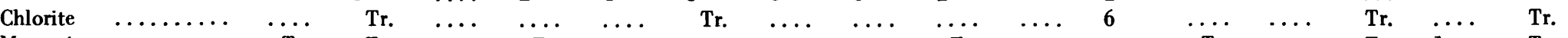

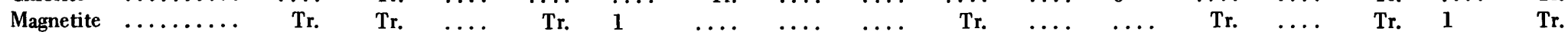


Modal analyses (volume percent) - Continued

\begin{tabular}{|c|c|c|c|c|c|c|c|c|c|c|c|c|c|c|c|c|c|c|}
\hline $\begin{array}{l}\text { Epidote } \ldots \ldots \ldots \ldots \\
\text { Accessory minerals } \\
\text { (include apatite, } \\
\text { sphene, ilmenite, } \\
\text { leucoxene, zircon, } \\
\text { and calcite) ........ }\end{array}$ & Tr. & Tr. & 2 & Tr. & Tr. & Tr. & Tr. & Tr. & Tr. & 3 & Tr. & 4 & $\ldots$ & $\cdots$ & Tr. & $\ldots$ & 1 & Tr. \\
\hline Anorthite content & & & & & & & & & & & & & & & & & & \\
\hline of plagioclase $\ldots \ldots$ & N.d. & N.d. & 30 & 22 & 15 & 22 & 15 & 16 & N.d. & N.d. & 25 & N.d. & 16 & N.d. & 23 & 25 & N.d. & 23 \\
\hline
\end{tabular}

NK 199 Felsic mica gneiss, mostly equigranular fine- to medium-grained, and mediumgray. Principal minerals are quartz, plagioclase, and biotite. Faintly layered or banded, reflecting different concentrations of dark biotite and muscovite. Moderately well foliated. Sample collected on trail 0.6 mile east of Black Rock Mountain in Highlands 7\%2-minute quadrangle, North Carolina.

NK 200 Felsic mica gneiss, equigranular, light-gray, and fine- to medium-grained. Plagioclase, quartz, microcline, and biotite are principal minerals. Foliation accentuated by micaceous minerals where they are abundant. Sample collected along State Route 28, 0.2 mile east of Satulah Falls in Highlands $7 \frac{1}{2} 2$-minute quadrangle, North Carolina.

NK 201 Hornblende-biotite gneiss, dark-gray, fine- to medium-grained, largely equigranular, nonlayered, and moderately foliated to well-foliated. Consists principally of plagioclase, quartz, biotite, hornblende, and locally epidote. Sample collected along a gravel road 0.8 mile northwest of Betty Creek Church in the Dillard 71/2-minute quadrangle, North Carolina-Georgia.

NK 202 Porphyroblastic microcline gneiss, light gray and characterized by conspicuous porphyroblasts of pink microcline set in a fine- to medium-grained groundmass of quartz, feldspar, and biotite. The porphyroblasts range from 1 to 2 inches in length. Foliation moderately developed. Sample collected in the Rabun Bald 71/2-minute quadrangle, North Carolina-Georgia, just south of Knoxville quadrangle, on State Route 106, 1.1 miles from the west edge of Rabun Bald quadrangle.

NK 220 Quartz-feldspar gneiss, equigranular, fine- to medium-grained, and mostly medium-gray. Principal minerals are quartz, plagioclase, microcline, and biotite. Nearby exposures contain scattered microcline porphyroblasts. Outcrops faintly layered and foliated. Sample collected on Bohaynee Road, 0.3 mile south of Union in the Reid 71/2-minute quadrangle, North Carolina.

NK 228 Felsic mica gneiss, light-gray, equigranular, fine- to medium-grained. Principal minerals are quartz, plagioclase, and muscovite. Biotite is much less abundant than in other phases of the felsic mica gneiss. Foliation is indistinct. Sample collected along gravel road in the Big Ridge $7 \frac{1}{2}$-minute quadrangle, 1 mile from the east edge and just north of Big Green Mountain.

NK 234 Felsic mica gneiss, light- to medium-gray. Principal minerals are quartz, plagioclase, microcline, muscovite, and biotite. Foliation well developed. Sample collected in Lamance Creek valley in the Lake Toxaway $7^{1} \frac{1}{2}$-minute quadrangle, North Carolina, 0.2 mile from the east edge of quadrangle.

NK 234A Felsic mica gneiss, medium-gray inequigranular variably textured. Contains quartz, plagioclase, microcline, muscovite, and biotite as the chief minerals. Has a pronounced foliation. Sample collected about 60 feet east of sample NK 234 .

NK 234B Felsic mica gneiss, mostly equigranular, medium-grained, and medium- to dark-gray. Principal minerals are quartz, plagioclase, and biotite. A few discontinuous streaks of biotite give a layered aspect to the outcrop. Sample collected about 30 feet east of NK 234.A.

NK 266 Quartz-feldspar gneiss, medium-gray. Mostly equigranular with a few small

microcline porphyroblasts. Quartz, plagioclase, microcline, and biotite are principal minerals. Biotite is locally concentrated in thin wisplike bands. Sample collected from small unmapped outcrop or body of quartz-feldspar gneiss on U.S. Highway 64 in the Reid 71/2-minute quadrangle, North Carolina, near north edge of quadrangle.

NK 260 Henderson Gneiss granitic phase, inequigranular to porphyroblastic, very light gray, medium to coarse-grained. Contains quartz, feldspar, and biotite. Rock generally massive or faintly foliated; locally foliation is more distinct Locally, pink microcline porphroblast cline porphys exceed 2 inches in length, and in places plagioclase grains are as much as $1 / 2$ inch long. Sample collected along U.S. Highway 276 in the Brevard
$71 / 2$-minute quadrangle, 2.5 miles from the east border.

NK 270 Henderson Gneiss, medium- to dark-gray quartz-biotite-feldspar augen gneiss. Microcline augen are as much as $1 \frac{1}{2}$ inches long and are surrounded by folia of biotite. Rock has a cataclastic texture and matrix is mostly fine-grained quartz, biotite, plagioclase, and epidote. Sample collected in quarry at Penrose in the Pisgah Forest $7 \frac{1}{2}$-minute quadrangle.

NK 377 Henderson Gneiss, medium-gray inequigranular quartz-feldspar-biotite gneiss. Augen are not well developed, but numerous porphyroblasts of microcline are present. Rock is indistinctly foliated. Principal minerals are quartz, plagioclase, muscovite, biotite, and microcline. Sample collected along a gravel road $1 / 2$ mile southeast of vite, biotite, and microcline. Sample collected along a gravel road $1 / 2$ rnile
Rock Mountain in the Fruitland $7 \frac{1}{2}$-minute quadrangle, North Carolina.

NK 381 Henderson Gneiss granitic phase, light-gray; faintly foliated with quartz, feldspar, and biotite as the chief minerals. Rock contains a few feldspar augen and nondeformed microcline porphyroblasts in a fine- to medium-grained matrix. Sample collected in Turnbreeches valley about 1.2 miles north of Mills Gap in the Bat Cave $71 / 2$-minute quadrangle, North Carolina.

NK 392 Henderson Gneiss, medium-gray, well-foliated; inequigranular rock containing microcline augen $1 \frac{1}{2}-2$ inches long set in a fine-grained matrix. Principal minerals are quartz, plagioclase, microcline, and biotite. Sample collected in quarry 0.3 mile southeast of Mount Sinai Church in the Hendersonville 71/2-minute quadrangle, North Carolina.

NK 425 Light-gray inequigranular and moderately foliated quartz-feldspar-biotite gneiss with feldspar porphyroblasts, from small unmapped body lithologically similar to the granitic phase of the Henderson Gneiss. Sample collected within a migmatite zone along Interstate Route 26 in the Hendersonville 7/2-minute quadrangle, North Carolina, 0.5 mile from the east border.

NK 426 Henderson Gneiss, well-foliated, medium- to dark-gray. Characterized by microcline augen set in a fine-grained equigranular quartz-plagioclase-biotite matrix with a cataclastic texture. Sample collected along road to Youngs Gap in the Fruitland 7\%2-minute quadrangle, North Carolina.

NK 457 Henderson Gneiss, well-foliated, dark-gray. Contains numerous microcline augen set in a fine-grained matrix. Chief minerals are quartz, plagioclase, microcline, and biotite. Sample collected from Hebron Road 1.7 miles east of Jones Gap Church in the Horse Shoe 71/2-minute quadrangle, North Carolina. 


\section{GEOLOGIC AGE OF THE PLUTONIC ROCKS}

The ages of the plutonic rocks are not well known owing to the lack of paleontologic evidence and structural control across the Brevard cataclastic zone. Overstreet and Bell (1965, p. 103-105), in summarizing lead-alpha age dating of zircon, suggest that the Henderson Gneiss is no older than Ordovician and no younger than Devonian. On the basis of lead-alpha ages of zircon and monazite, they suggest that the Whiteside Granite of Keith (felsic mica gneiss of this report) is probably Ordovician to Devonian in age. Presumably the other plutons northwest of the Brevard zone are also Ordovician to Devonian in age.

\section{CHEMICAL NATURE OF THE PLUTONIC ROCKS}

Major chemical oxide analyses for the rocks sampled in the report area are presented in table 1. As indicated, these analyses cover a compositional range from quartz diorite to quartz monzonite (fig. 2); they are, in addition, close to the average compositions given by Nockolds (1954) for corresponding rock types. The plutonic rocks northwest of the Brevard zone are calc-alkalic, whereas those southeast of the zone are alkalic-calcic according to their alkali-lime indices.

The rocks in the report area are peraluminous and, except for two samples collected west of the Brevard zone, more than 90 percent salic.

Most of the plutonic rocks west of the Brevard zone range from granodiorite to quartz diorite (fig. 2), although some felsic mica gneiss is granitic in composition (Whiteside Granite of Keith, Livingston, 1966, p. 12). Slight differences in the distribution of the major oxides distinguish the four principal rock types mapped. The porphyroblastic microcline gneiss and the felsic mica gneiss are classed as granodiorite and quartz diorite, but the chemical differences between them are not great. The hornblende-biotite gneiss differs from the other

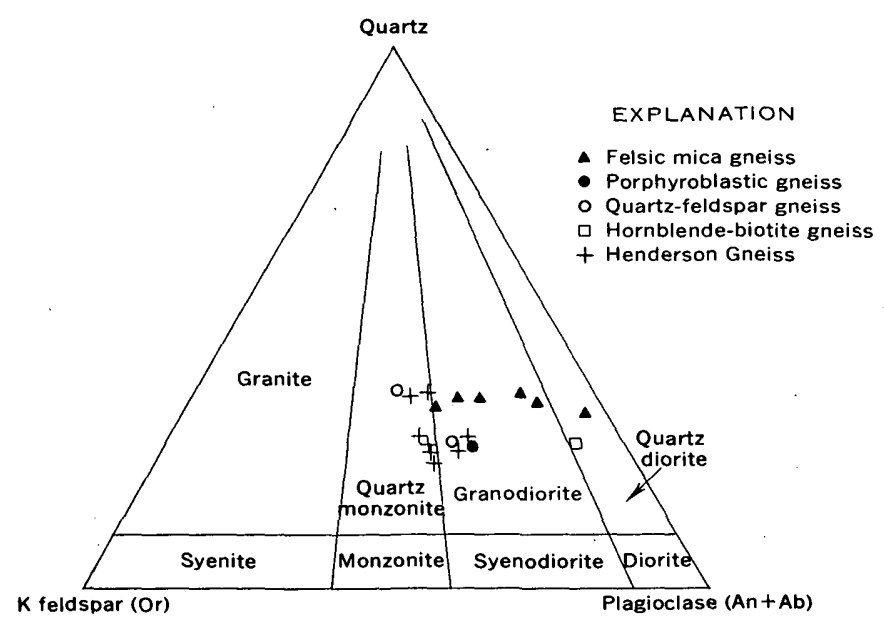

Figure 2.-Diagram of normative minerals from analyzed plutonic gneisses of western North Carolina. plutonic rocks in that it is decidedly more mafic, has less $\mathrm{SiO}_{2}$, and more $\mathrm{MgO}$ and $\mathrm{CaO}$. The quartz-feldspar gneiss is lower in $\mathrm{Na}_{2} \mathrm{O}$ and generally higher in $\mathrm{P}_{2} \mathrm{O}_{5}$ and $\mathrm{TiO}_{2}$ than the other plutonic rocks northwest of the Brevard zone.

The Henderson $\mathrm{Gneiss}$ has on the average less $\mathrm{Ca} 0, \mathrm{Al}_{2} \mathrm{O}_{3}$, $\mathrm{Na}_{2} \mathrm{O}$, and more $\mathrm{K}_{2} \mathrm{O}$ and $\mathrm{TiO}_{2}$ than the plutonic gneisses northwest of the Brevard zone. Figure 2 suggests that the Henderson Gneiss samples are also chemically more uniform than samples collected northwest of the Brevard zone.

The more uniform chemical character of the Henderson Gneiss is also suggested in a plot of the analyses on an AKF diagram (fig. 3). Points representing the rocks northwest of the

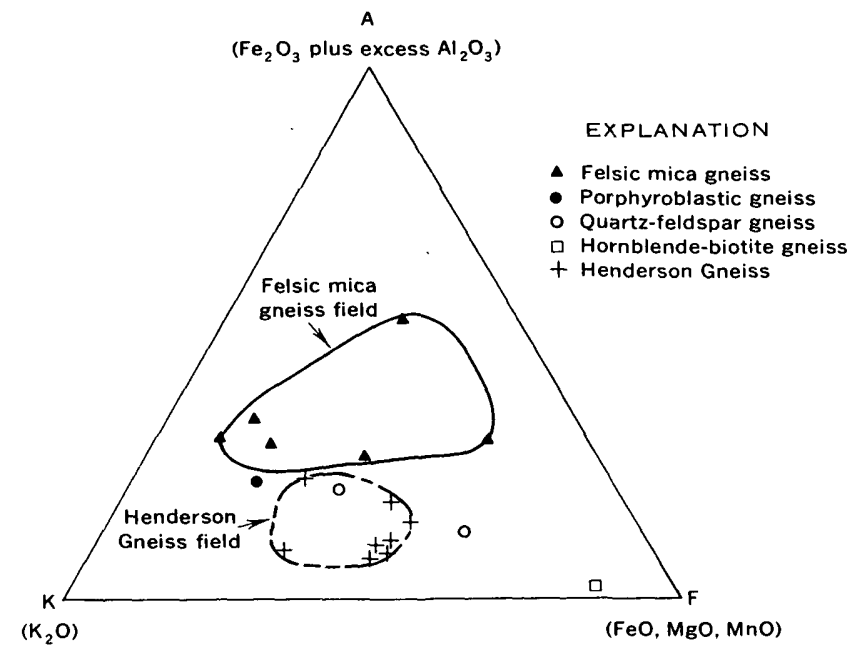

Figure 3.-AKF diagram for the plutonic gneisses analyzed, showing the fields for felsic mica gneiss northwest of the Brevard zone and for the Henderson Gneiss.

Brevard zone are more widely scattered than are the points for the Henderson Gneiss samples, which are confined to a smaller field within the diagram. The quartz-feldspar gneiss is chemically rather similar to the Henderson Gneiss, even though it is northwest of the Brevard zone and in the same tectonic block as the other plutonic gneisses.

Figure 4, a diagram using Niggli $\mathrm{c} / \mathrm{fm}$ values for the samples collected, shows that points for the rocks northwest of the Brevard zone are more widely scattered than points for samples of the Henderson Gneiss. Again a more uniform composition for the Henderson is indicated by the close grouping of its points as compared to the wide scatter for those of the other rocks.

Semiquantitative spectrographic analyses indicate slight differences in minor elements between the rocks southeast and northwest of the Brevard zone (fig. 5). Silver is present only in the Henderson Gneiss and is present in all but one of the Henderson samples analyzed. Molybdenum is also present only in the Henderson although not in all samples. Cobalt and neodymium are sporadically present in only some rocks northwest of the Brevard zone, whereas these elements are 


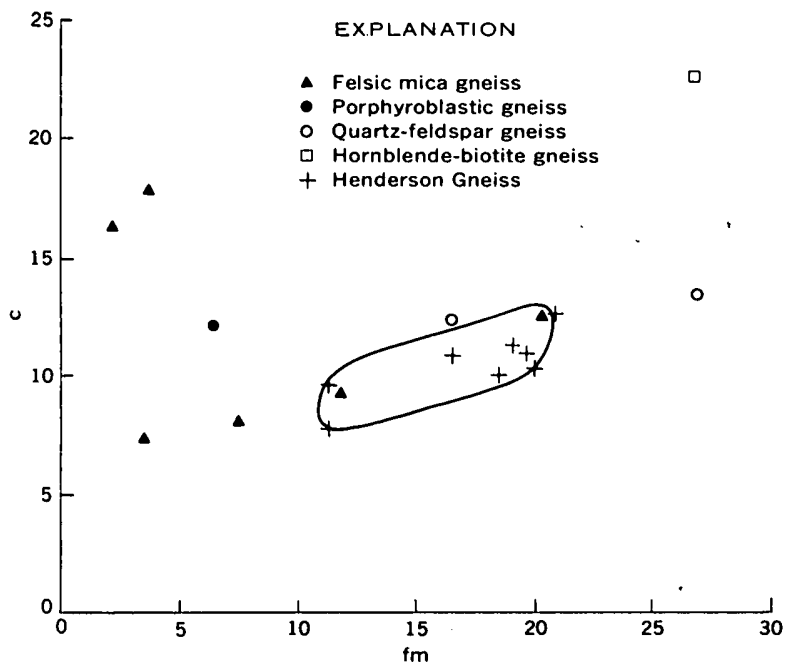

Figure 4.-Diagram, using Niggli $\mathrm{c} / \mathrm{fm}$ values for the analyzed plutonic gneisses of western North Carolina, showing a relatively small field for the Henderson Gneiss samples and the irregular distribution for the samples collected northwest of the Brevard zone.

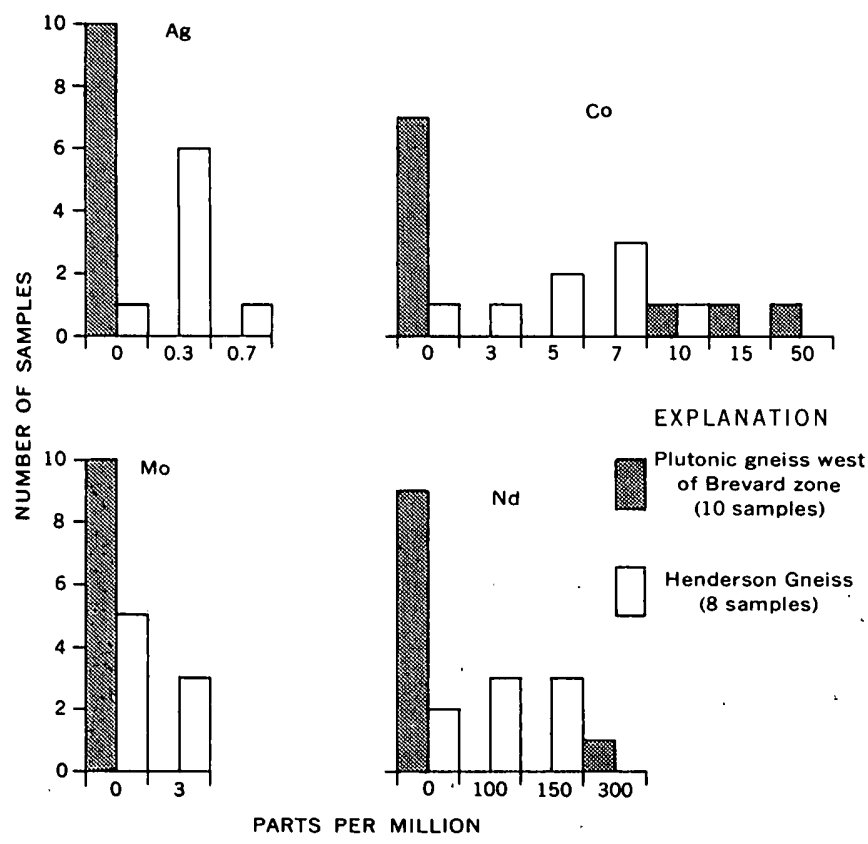

Figure 5.-Histograms showing results of spectrographic analyses for some minor elements in the Henderson and plutonic gneisses:

more evenly distributed in almost all rocks analyzed from the southeast side of the Brevard zone.

\section{CONCLUSIONS}

The plutonic rocks northwest of the Brevard zone, previously called Whiteside Granite, include four distinct lithologic types. Most of the rocks are granodiorite, but they range from quartz monzonite to quartz diorite in composition.
Therefore, it is suggested that the term Whiteside Granite no longer be used in referring to these rocks. The major-oxide contents vary somewhat in the four lithologic types: the hornblende-biotite gneiss is high in $\mathrm{MgO}$ and $\mathrm{CaO}$ and low in $\mathrm{SiO}_{2}$; the quartz-feldspar gneiss is generally high in $\mathrm{P}_{2} \mathrm{O}_{5}$ and $\mathrm{TiO}_{2}$; and there are slight differences between the porphyroblastic microcline gneiss and the felsic mica gneiss.

Although all the rocks sampled in the report area are peraluminous and highly salic, there are distinct chemical differences between most of the plutonic rocks collected from either side of the Brevard zone. The rocks on the southeast side, the Henderson Gneiss, are alkalic-calcic and largely quartz monzonite in composition; on the northwest side the gneisses are calc-alkalic and largely granodiorite in composition. Compared to the rocks on the southeast side of the Brevard zone, the rocks from the northwest side have higher average $\mathrm{Na}_{2} 0$, $\mathrm{CaO}$, and $\mathrm{Al}_{2} \mathrm{O}_{3}$ and lower $\mathrm{K}_{2} \mathrm{O}$ and $\mathrm{TiO}_{2}$. The chemical diagrams suggest chemical uniformity of the Henderson $\mathrm{G}$ neiss and more variety of composition for the plutonic gneisses sampled from the western part of the report area. Spectrographic semiquantitative analyses show that the distribution of some minor elements in the rocks is different on either side of the Brevard zone. Besides containing the only silver and molybdenum found, the Henderson also has more evenly distributed amounts of cobalt and neodymium than the rocks west of the Brevard zone.

\section{REFERENCES}

Fyfe, W. S., Turner, F. J., and Verhoogen, John, 1958, Metamorphic reactions and metamorphic facies: Geol. Soc. America Mem. 73, $259 \mathrm{p}$.

Hadley, J. B., and Goldsmith, Richard, 1963, Geology of the eastern Great Smokey Mountains, North Carolina and Tennessee: U.S. Geol. Survey Prof. Paper 349-B, 118 p.

Hadley, J.B., and Nelson, A.E., 1971, Geology of the Knoxville quadrangle, North Carolina, Tennessee, and South Carolina: U.S. Geol. Survey Misc. Inv. Map I-654. [In press].

Keith, Arthur, 1905, Description of the Mount Mitchell quadrangle, North Carolina-Tennessee: U.S. Geol. Survey Geol. Atlas, Folio 124, $10 \mathrm{p}$.

1907, Description of the Pisgah quadrangle [ North CarolinaSouth Carolina ]: U.S. Geol. Survey Geol. Atlas, Folio 147, 8 p.

Livingston, J.L., 1966, Geology of the Brevard Zone and the Blue Ridge province in southwestern Transylvania County, North Carolina: Houston, Tex., Rice Univ., Ph. D. thesis, 118 p.; abstract, Dissert. Abs., sec. B, v. 27, no. 4, p. 1198B, 1966.

Nockolds, S. R., 1954, Average chemical compositions of some igneous rocks: Geol. Soc. America Bull., v. 65, p. 1007-1032.

Overstreet, W. C., and Bell, Henry, III, 1965, The crystalline rocks of South Carolina: U.S. Geol. Survey Bull. 1183, $126 \mathrm{p}$.

Reed, J. C., Jr., 1964, Geology of the Linville Falls quadrangle, North Carolina: U.S. Geol. Survey Bull. 1161-B, 53 p.

Reed, J. C., Jr., and Bryant, B. H., 1960, A major topographic lineament in western North Carolina and its possible structural significance: Art. 86 in U.S. Geol. Survey Prof. Paper 400-B, p. B195-B197.

Shapiro, Leonard, and Brannock, W. W., 1962, Rapid analysis of silicate, carbonate, and phosphate rocks: U.S. Geol. Survey Bull. 1144-A, 56 p. 


\title{
CRETACEOUS PLUTONIC ROCKS OF ST. LAWRENCE ISLAND, ALASKA-A PRELIMINARY REPORT
}

\author{
BY BÉ LA CSEJTEY, JR., WILLIAM W. PATTON, JR., \\ and THOMAS P. MILLER, Menlo Park, Calif.
}

\begin{abstract}
Reconnaissance mapping on St. Lawrence Island, Alaska, has revealed seven epizonal granitic plutons of middle Cretaceous age with a combined outcrop area of about 350 square miles. The plutonic rocks are dominantly quartz monzonite but include minor amounts of granodiorite, monzonite, syenite, syenodiorite, and alaskite. Plutons on the Chukotsky Peninsula, U.S.S.R., and in western Alaska are similar to these in structure, petrology, and age. The St. Lawrence Island plutons may thus provide evidence of tectonic continuity between Siberia and Alaska since at least Cretaceous time. Several mineralized areas containing molybdenum, copper, lead, and zinc sulfides are associated with the plutonic bodies in the western part of the island.
\end{abstract}

This report is a preliminary description of the petrology, age, and regional relations of seven granitic plutons mapped during reconnaissance geologic investigations on St. Lawrence Island, Alaska.

St. Lawrence Island, roughly 2,000 square miles in area, is in the Bering Sea, 130 miles southwest of the Seward Peninsula and 40 miles southeast of the Chukotsky Peninsula, U.S.S.R. (fig. 1). About two-thirds of the island is a tundra-covered flat

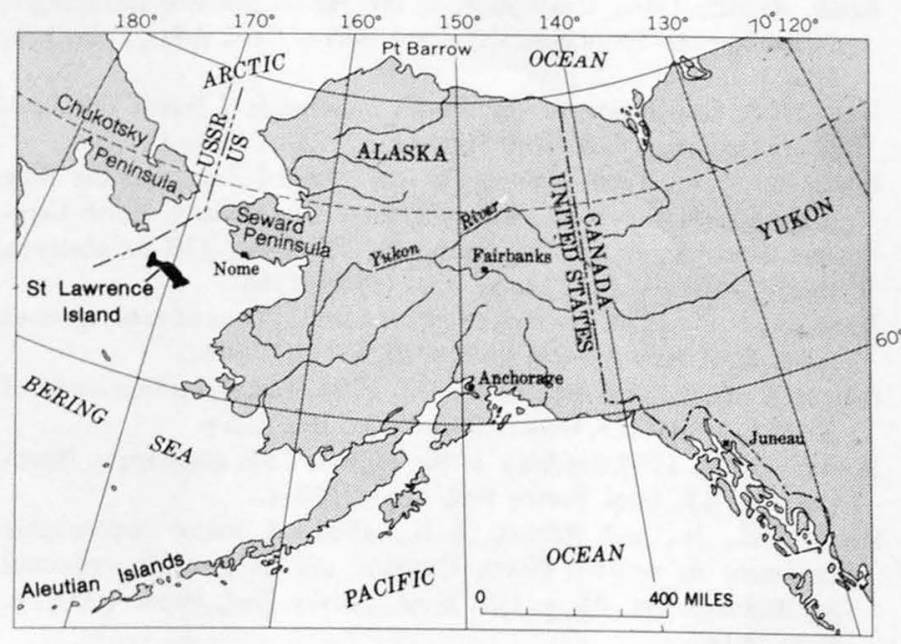

Figure 1.-Index map of Alaska, showing location of St. Lawrence Island. wave-cut platform which has been elevated locally as much as 200 feet above sea level. The remainder consists of isolated groups of barren, talus- and rubble-covered mountains, most of which have cores of granitic rock. Probably former islands, they rise sharply 1,000 to 2,000 feet above the wave-cut platform. Bedrock exposures are scarce and are confined to coastal sea cliffs, scattered cutbanks along streams, and a few erosional knobs in the mountainous areas.

Previous information on the geology of St. Lawrence Island consists of exploratory surveys along the coast (Dawson, 1894; Emerson, 1904, p. 38-42; Collier, 1906), an unpublished reconnaissance map compiled by E. H. Muller (in Dutro and Payne, 1957), two short preliminary papers on the eastern part of the island (Patton and Dutro, 1969; Patton and Csejtey, $1971 \mathrm{~b})$, and two preliminary reports on the western part of the island (Patton and Csejtey, 1970, 1971a).

\section{GEOLOGIC SETTING}

The St. Lawrence plutons range in areal extent from 1 to 100 square miles and have a total outcrop area of about 350 square miles (fig. 2). However, they undoubtedly extend beneath surrounding surficial deposits and the Bering Sea and are probably larger than the above figures indicate.

The contacts between plutons and country rocks are sharp, steep, and apparently discordant wherever observed. The country rocks are dominantly Paleozoic carbonates and andesitic volcanic rocks of Early Cretaceous(?) age; also, there are lesser amounts of mudstone, graywacke, chert, gabbro, and diabase (fig. 2). The andesites are mapped with postplutonic latites and quartz latites of Late Cretaceous and early Tertiary age because both volcanic suites have numerous varieties, are finely crystalline, and are strongly altered. The lithology, age, and correlation of these rocks have been discussed previously by Patton and Dutro (1969), and by Patton and Csejtey (1971a, b).

Postplutonic rocks include poorly consolidated middle Tertiary coal-bearing strata in a few small areas (not shown on fig. 2), Quaternary olivine basalts (mostly in the centrally 


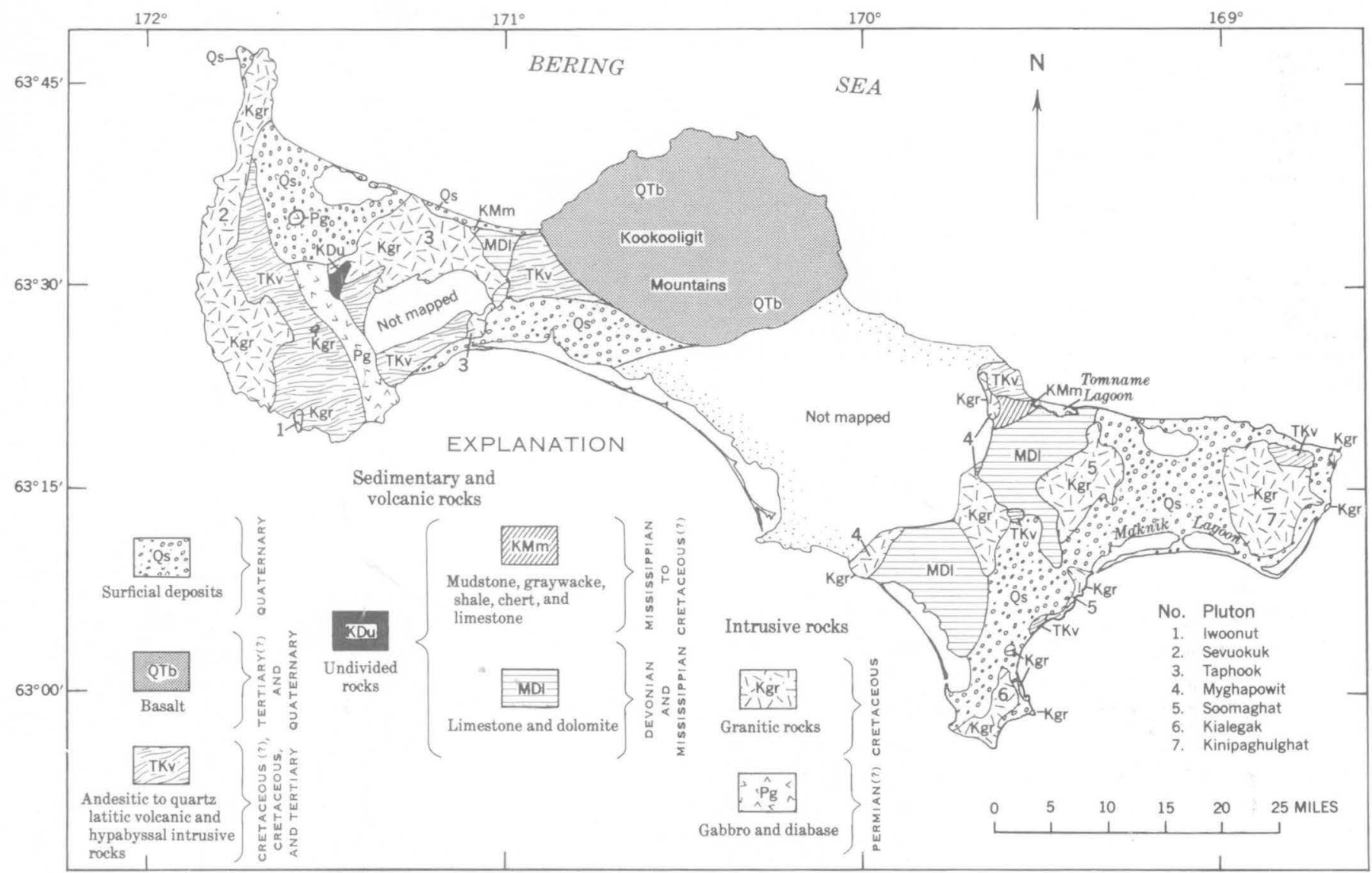

Figure 2.-Generalized geologic map of St. Lawrence Island, Alaska, showing location of plutons.

located Kookooligit Mountains), and extensive unconsolidated surficial deposits.

The plutons appear to truncate steeply dipping beds and several faults in the country rocks and thus may have been emplaced in an already folded and faulted terrane. The postplutonic latites and quartz latites were folded and faulted in Late Cretaceous and Tertiary time.

Thermal metamorphic effects extend as much as a mile into the country rocks. However, the width of the metamorphosed zone in the volcanic rocks is difficult to determine because most of the volcanic rocks have been propylitically altered. Near the intrusive contacts and locally extending out for some tens of feet, the rocks are altered to hornblende hornfels (Fyfe and others, 1958). The carbonate rocks are characterized by a mineral assemblage of garnet-vesuvianite-diopside-quartzcalcite-biotite. The andesitic volcanic rocks are characterized by an assemblage of plagioclase-hornblende-quartz-biotite. Farther away, the volcanic rocks are mostly albite-epidote hornfels; the carbonates are medium-grained marble.

\section{PLUTONIC ROCKS}

\section{Petrography and petrology}

The plutonic rocks of St. Lawrence Island are chiefly quartz monzonite but include granodiorite, monzonite, syenite, alas- kite, and some olivine-bearing syenodiorite. The classification of plutonic rocks used in this report, based on the normalized modes of felsic components, is shown in figure 3. Textural variations range from coarse to fine grained, from granitic to porphyritic and seriate. All the plutonic rocks are massive and nonfoliated. Hybrid rocks rich in mafic minerals and of irregular texture occur in minor amounts near the margins of some plutons.

The modes of 36 plutonic rock specimens from western St. Lawrence Island and of 49 specimens from the eastern part of the island are plotted separately on figure 4 . Both plots show a fair concentration of points in the quartz monzonitegranodiorite fields, and a lesser concentration in the monzonite-syenite fields. The quartz monzonites and granodiorites constitute distinct intrusive masses within the large composite plutons. Boundaries between them appear to be sharp and can be traced over long distances. Several of these intrusive members display a fine- to medium-grained border phase, not only against the volcanic and sedimentary country rocks but against other plutonic rocks as well.

The intrusive relationships between the various intrusive members are not clear everywhere. Where such relationships can be determined, quartz-rich rocks intrude rocks of lesser quartz and higher mafic mineral contents, suggesting a magmatic trend from older quartz-poor rocks to younger, 


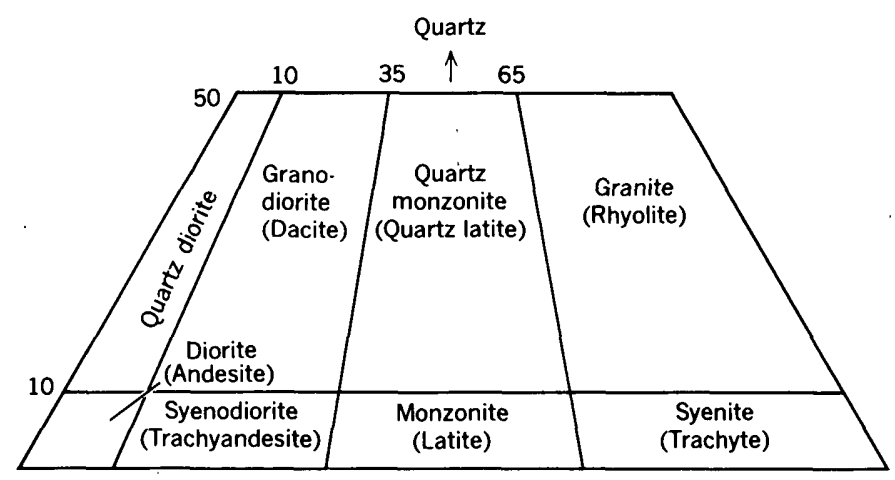

Plagioclase $+$

Alaskite: a granitic rock with a color index of less than 5 , commonly with an irregular texture

Figure 3.-Igneous rock nomenclature used in this report. Aphanitic varieties shown in parentheses.

more felsic rocks.

The petrography of the plutons is summarized in table 1 , and maps of the plutons are shown on figures 5 and 6 . Field mapping of the various intrusive members was based on the characteristic features listed at the bottom of table 1 . Rocks of the Iwoonut; Sevuokuk, and Taphook plutons have been previously described by Patton and Csejtey (1971a). The olivine-bearing monzonite of that report is herein reclassified, on the basis of additional modal data, as an olivine-bearing syenodiorite.

The St. Lawrence plutonic rocks fall more or less into three major categories: (1) monzonites and syenites, including the olivine-bearing syenodiorite, containing abundant mafic minerals but little or no quartz; (2) quartz monzonites, locally grading into monzonites and granodiorites, with an' intermediate amount of quartz and with hornblende as the chief mafic mineral; and (3) quartz monzonites, locally grading into granodiorite and alaskite, which have a high quartz content and lower color index with biotite as the chief mafic mineral. These three groups of rocks are thought to represent the three major magmas, emplaced in a succession, of the middle Cretaceous plutonic episode of St. Lawrence Island.

\section{Dike rocks and xenoliths}

All the plutons contain a large number of dikes and small plugs of a variety of late-stage rocks-namely, aplite and alaskite, lamprophyre, hypabyssal felsic porphyries, and a few thin veins of hydrothermal quartz. The age relationships of these dike rocks are not known, and only the larger bodies have been mapped (figs. 5 and 6 ).

The aplites are fine grained and commonly grade into medium- to coarse-grained irregular-textured alaskite, occasionally with miarolitic cavities. The aplitic rocks rarely grade into coarse-grained pegmatitic nests of K-feldspar, quartz, and muscovite. These rocks occur : in thin dikes and in small intrusive bodies as much as 1 square mile in area. Whereas
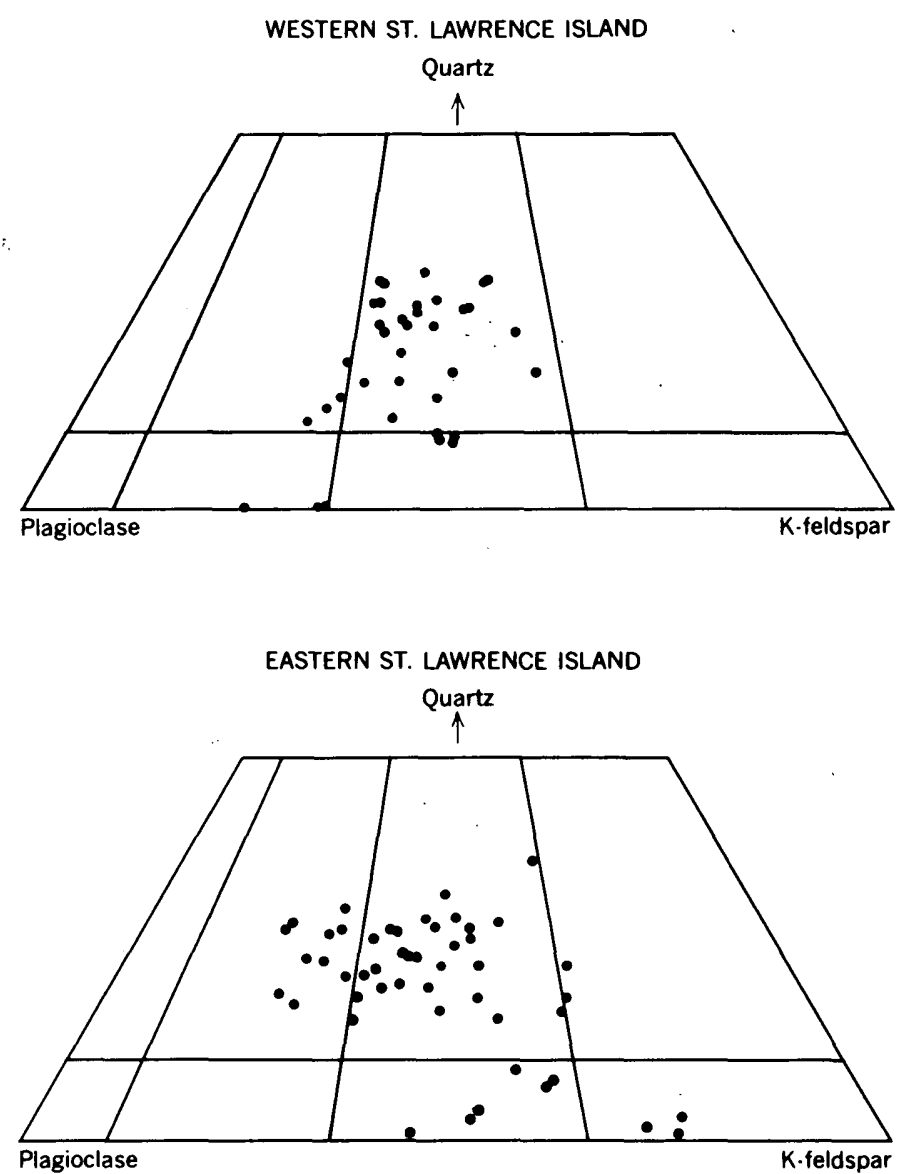

Figure 4.-Summarized plots of plutonic rock modes from western and eastern St. Lawrence Island, Alaska. See table 1 for plots of individual plutons.

aplites are common in all the plutons, they rarely extend into the surrounding country rocks.

Irregular dikes of lamprophyre, a few inches to a few feet in width, are common in the northern half of the Sevuokuk pluton. The lamprophyre is dark gray and porphyritic, with dark hornblende phenocrysts as much as $3 \mathrm{~mm}$ long in a finely crystalline, lamprophyric-textured matrix of brown hornblende, plagioclase, and minor augite.

The felsic porphyries common in every pluton occur as irregular hypabyssal bodies up to 2 square miles in area and intrude both the plutonic and the country rocks. The porphyries range from latite to quartz latite in composition and contain large phenocrysts of corroded quartz and subhedral K-feldspar in a medium- to light-gray aphanitic groundmass. Miarolitic cavities are common. Most of the porphyries are altered to an aggregate of quartz, sericite, kaolin, and pyrite, with minor amounts of chlorite and epidote. These hypabyssal felsic porphyries are probably the source of the latite and quartz latite volcanic rocks of Late Cretaceous and early Tertiary age.

Xenoliths are common in the coarse- and medium-grained rocks. Most xenoliths are rounded and equant, a few inches to 


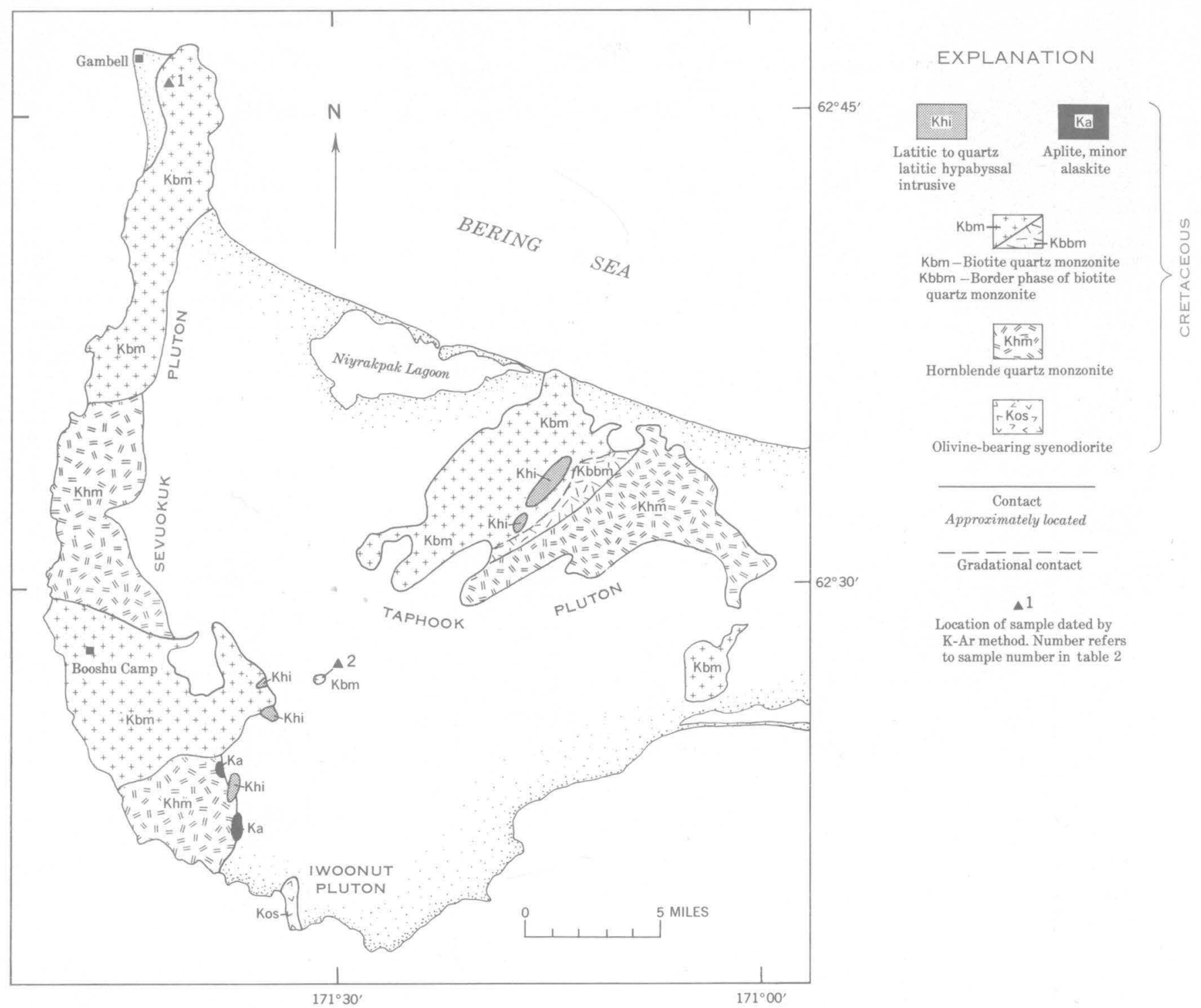

Figure 5.-Generalized geologic map of the Iwoonut, Sevuokuk, and Taphook plutons, western St. Lawrence Island, Alaska.

about 1 foot long, with fairly sharp boundaries; all have been reconstituted to a fine- to medium-grained, hornblende-rich hornfels. Several apparent roof pendants of recrystallized Paleozoic limestone, a few tens of feet in maximum dimension, occur in the Soomaghat and Kinipaghulghat plutons.

\section{Structural features}

All the plutons appear to be jointed, but few joint measurements could be obtained because of scarcity of bedrock exposures. Two sets of vertical joints striking northeast and northwest are conspicuous in every coastline exposure of the Sevuokuk pluton.

One of the major characteristics of the St. Lawrence plutons is the absence of obvious regional foliation and lineation.
Structural features-localized flow alinement of orthoclase phenocrysts-were observed only in the Soomaghat and Sevuokuk plutons. Because most rock specimens were collected as float, no attempt was made to find preferred orientation by petrofabric measurements with thin sections.

\section{Depth and method of pluton emplacement}

The structure and the petrography of the plutons suggest that the plutons were emplaced at relatively shallow depths in the earth's crust. The St. Lawrence plutons are epizonal, according to the usage of Buddington (1959), on the basis of the following features: sharp and discordant contacts with the regionally unmetamorphosed country rocks, presence of chilled border facies, presence of xenoliths and apparent roof 
Table 1.-Petrographic summary of the Cretaceous granitic plutons of St. Lawrence Island, Alaska

[Intrusive members of each pluton are listed in order of decreasing age, known or postulated]

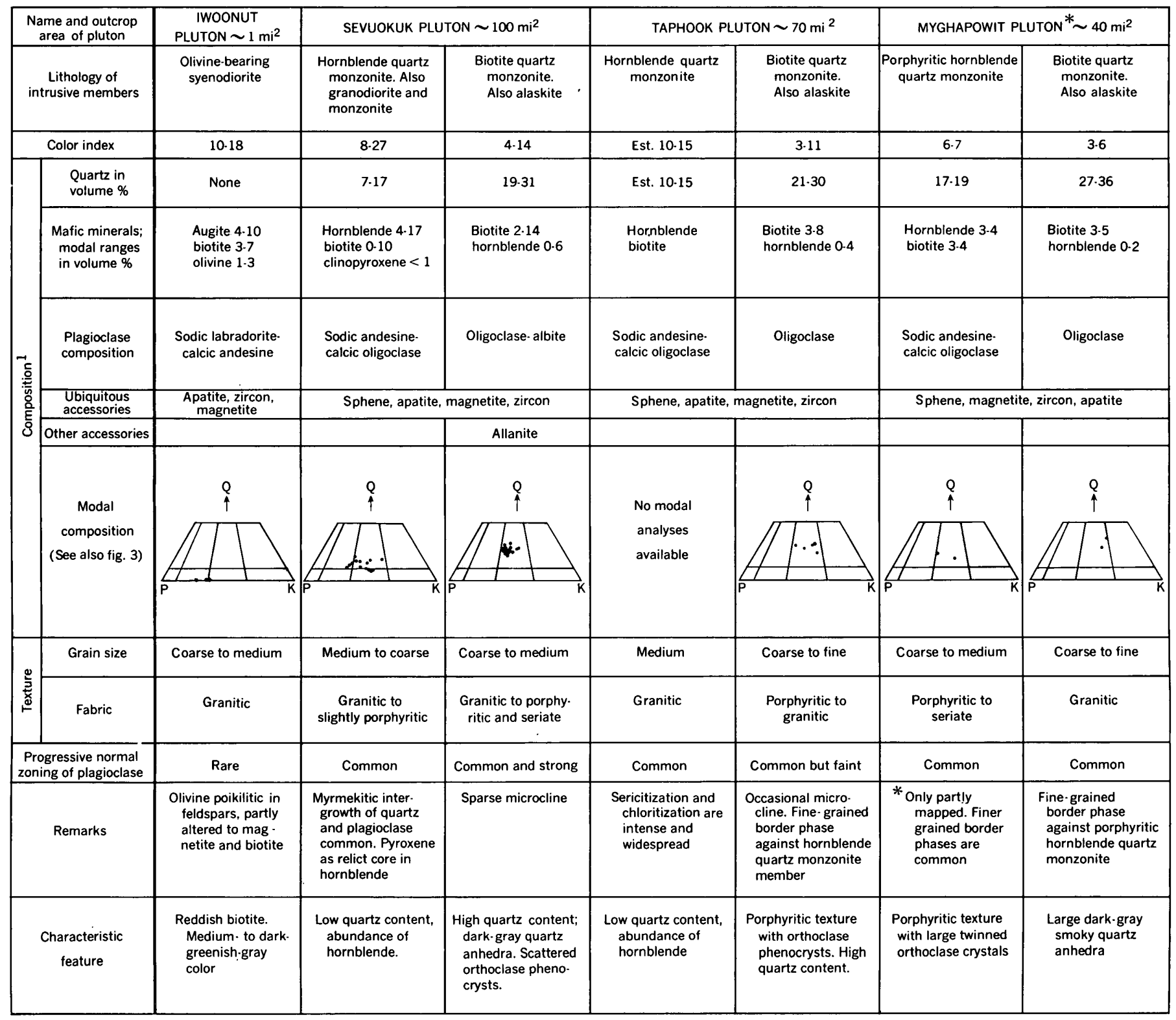

1 During the course of the present study, approximately 300 thin sections were examined. A total of 85 modal analyses was obtained by point counts on sawed slabs stained by sodium cobaltinitrate. Between 600 and 1,000 points were counted on each slab. 
Table 1. - Continued

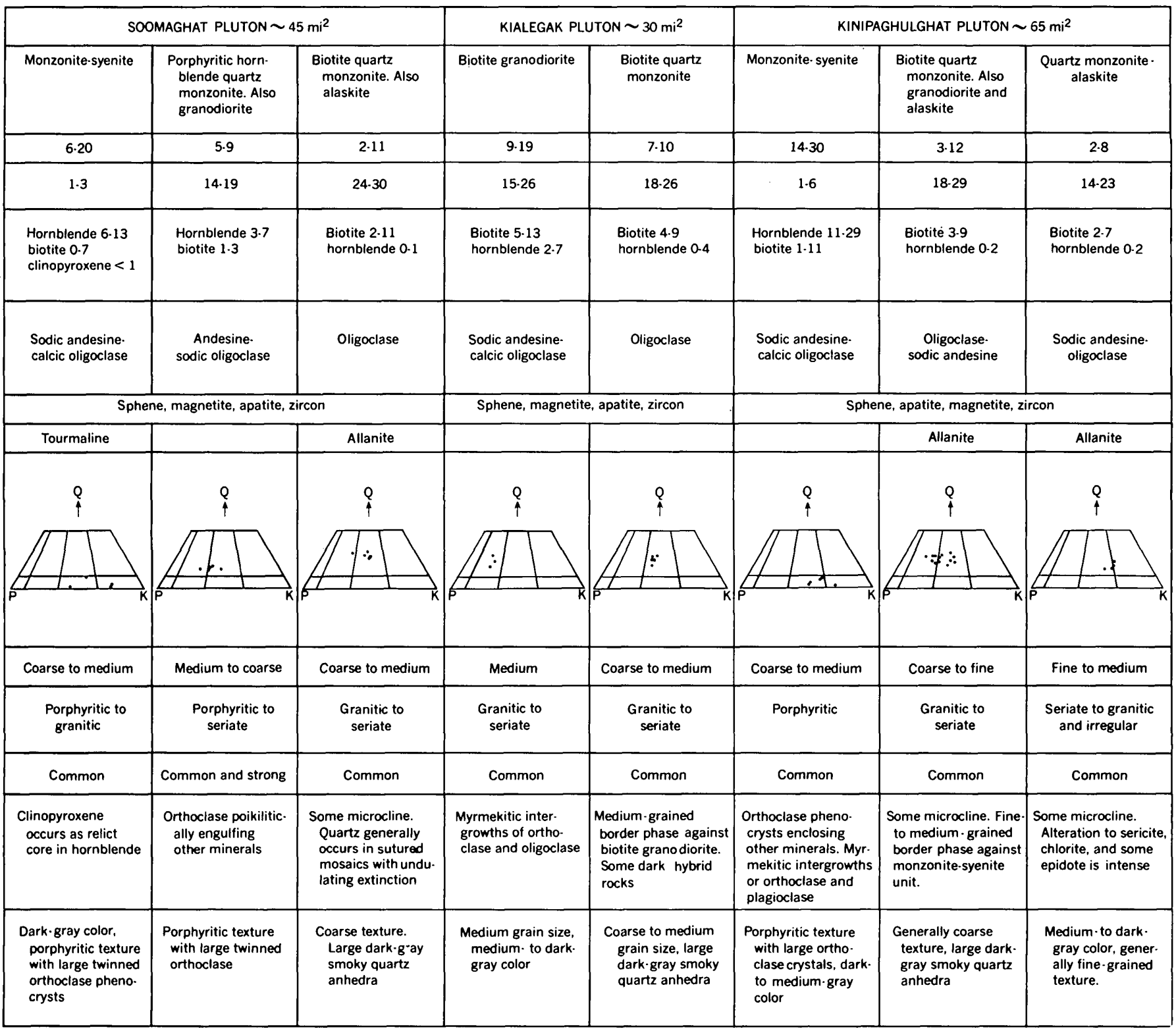



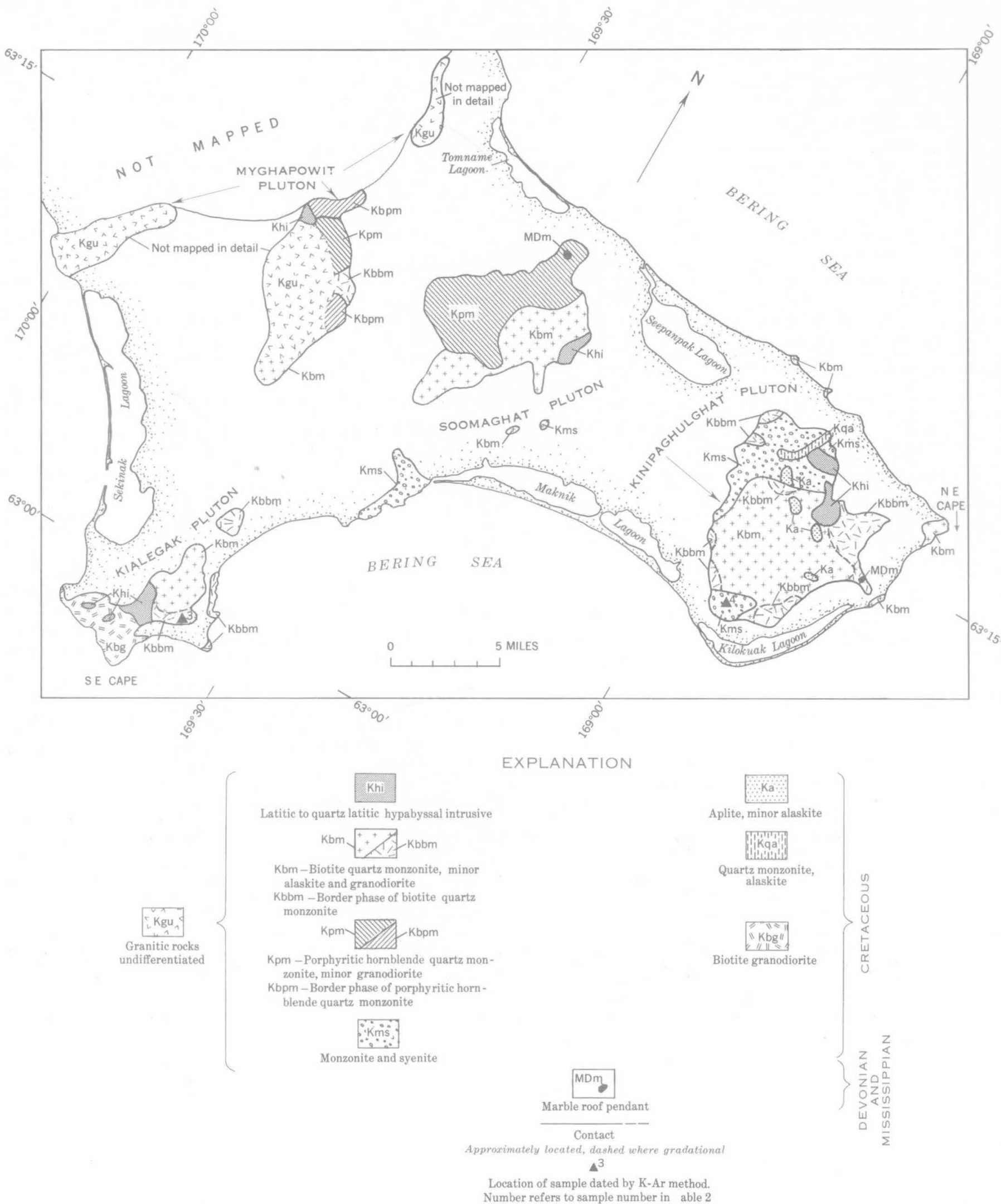

Figure 6.-Generalized geologic map of the Myghapowit, Soomaghat, Kialegak, and Kinipaghulghat plutons, eastern St. Lawrence Island, Alaska. 
pendants, lack of regional foliation and lineation, and association with compositionally similar hypabyssal volcanic intrusives which commonly contain miarolitic cavities.

The plutons were emplaced by successive injections of apparently consanguineous magmas of diverse composition. The method of magma emplacement is not known. There is no evidence that the intrusions deformed the country rocks.

\section{Mineralization}

Several small mineralized areas of molybdenum, copper, lead, and zinc sulfides occur in and around the granitic plutons in the western part of the island. They have been described previously by Patton and Csejtey (1970, 1971a) and are only briefly mentioned here.

Molybdenite is widely disseminated in the Sevuokuk pluton. A small mineralized satellitic stock of biotite quartz monzonite, containing low-grade porphyry copper and minor molybdenite, is located approximately 8 miles east-southeast of Booshu Camp (fig. 5). Five small occurrences of lead-zincsilver sulfides were found along a northeast-trending belt south and east of the Taphook pluton.

Similar mineralized areas have not been found in the eastern part of the island (Patton and Csejtey, 1971b). However, tin was detected in stream-sediment samples from streams draining the Soomaghat and Kinipaghulghat plutons. The source of the tin is unknown, and only 2 of 15 representative rock samples of the two plutons contain detectable amounts of tin.

\section{Age}

Available stratigraphic evidence suggests a probable Cretaceous age for the St. Lawrence plutons. The latest datable country rocks are of Triassic age, according to fossil evidence (Patton and Csejtey, 1971a). The age of the youngest intruded rocks, the andesitic volcanic rocks, is imperfectly known, but similar andesitic volcanic rocks in west-central Alaska have been dated as Early Cretaceous (Patton and Miller, 1966; Patton, 1967). The basal part of the oldest postplutonic rocks, a sequence of latitic and quartz latitic volcanics, yields a Late Cretaceous K-Ar age of $88.7 \pm 3$ m.y. (million years) (Patton and Csejtey, 1971a).

Four K-Ar age determinations were obtained on three of the St. Lawrence plutons (table 2). Two ages were measured on biotite from the biotite quartz monzonite of the Sevuokuk pluton, one on biotite from the finer grained part of the biotite quartz monzonite of the Kialegak pluton, and one on hornblende from the monzonite-syenite member of the Kinipaghulghat pluton.

Three of the four ages are in close agreement, a little over $100 \mathrm{~m} . \mathrm{y}$. each, though they represent different members of the intrusive series. An age of 91 m.y. obtained on a sample from a mineralized satellitic stock of the Sevuokuk pluton (Patton and Csejtey, 1971a) probably reflects the effects of the postplutonic mineralization, or it may represent a younger plutonic episode. In any event, the small range of the measured ages suggests that the composite St. Lawrence plutons were emplaced in a relatively short period of geologic time, around $100 \mathrm{m.y}$. ago.

\section{Regional correlation}

Granitic plutons of similar age, composition, and structure occur in adjacent regions of Siberia and mainland Alaska.

A belt of epizonal granitic plutons has been described from west-central Alaska and from the eastern part of the Seward Peninsula by Miller (1970a). In the Seward Peninsula the plutons consist of quartz monzonite and lesser amounts of syenite and feldspathoidal rocks and have been assigned to a plutonic episode dated at 108-98 m.y. (Miller, 1971). In addition, the plutons in the Seward Peninsula trend approximately north-south and appear to be restricted to the boundary areas between the Precambrian and Paleozoic metamorphic and sedimentary rocks of the Seward Peninsula to the west, and the adjacent Mesozoic volcanogenic province to the east (Miller, 1970).

The country rocks on eastern St. Lawrence Island are dominantly Paleozoic carbonates, whereas those on the western part are chiefly Lower Cretaceous(?) andesitic volcanic rocks (fig. 2). Thus, on the basis of similar age, composition, and geologic setting, the plutons of St. Lawrence Island appear to be a continuation of the 100-m.y.-old plutonic belt of the eastern Seward Peninsula.

A broad belt of granitic plutons extends from the Siberian mainland into the Chukotsky Peninsula, U.S.S.R. (Shilo, 1965). The plutons are epizonal and composite, ranging in composition from quartz monzonite and granite to undersaturated syenite, and most are reportedly 80 to $100 \mathrm{~m}$.y. old. In the southern half of the Chukotsky Peninsula the country rocks are mostly Mesozoic andesitic volcanic rocks, whereas in the northern half they consist mainly of Precambrian to Mesozoic metamorphic and sedimentary rocks (Drabkin, 1970). Thus, the geology and the geographic location of the St. Lawrence plutons strongly suggest a tectonic continuity, at least since the middle of the Cretaceous, across the Bering Sea shelf between the Chukotsky Peninsula and western Alaska.

\section{REFERENCES}

Buddington, A. F., 1959, Granite emplacement with special reference to North America: Geol. Soc. America Bull., v. 70, p. 671-747.

Collier, A.J., 1906, Geology and coal resources of the Cape Lisburne region, Alaska: U.S. Geol. Survey Bull. 278, 54 p.

Dawson, G. M., 1894, Geological notes on some of the coasts and islands of the Bering Sea and vicinity: Geol. Soc. America Bull., v. 5, p. 117-146.

Drabkin I. Ye., ed., 1970, Geologiya SSSR, Tom 30, Severo-Vostok SSSR [Geology of the U.S.S.R., v. 30, northeastern U.S.S.R.]: Moscow, U.S.S.R., Nedra, 1084 p. [In Russian]

Dutro, J. T., Jr., and Payne, T. G., 1957, Geologic map of Alaska: U.S. Geol. Survey, scale 1:2,500,000. 
Table 2.-K-Ar age determinations for granitic rocks of St. Lawrence Island, Alaska

[Argon analyses and age calculations by J. C. Von Essen and J. Engels; potassium analyses by L. B. Schlocker ]

\begin{tabular}{|c|c|c|c|c|c|c|c|c|c|}
\hline \multirow{2}{*}{$\begin{array}{l}\text { Pluton and } \\
\text { rock type }\end{array}$} & \multirow{2}{*}{$\begin{array}{c}\text { Map No. } \\
\text { (figs. } \\
5,6 \text { ) }\end{array}$} & \multicolumn{2}{|c|}{ Location } & \multirow{2}{*}{$\begin{array}{l}\text { Field } \\
\text { No. }\end{array}$} & \multirow{2}{*}{ Mineral } & \multirow{2}{*}{$\begin{array}{c}\mathrm{K}_{2} \mathrm{O} \\
\text { (percent) }\end{array}$} & \multirow{2}{*}{$\begin{array}{c}\mathrm{Ar}^{40} \mathrm{rad} \\
\left(10^{-10} \mathrm{moles} / \mathrm{g}\right)\end{array}$} & \multirow{2}{*}{$\frac{\mathrm{Ar}^{40} \mathrm{rad}}{\mathrm{Ar}^{40} \text { total }}$} & \multirow{2}{*}{$\begin{array}{c}\text { Apparent age } \\
\text { (millions of } \\
\text { years) }\end{array}$} \\
\hline & & Lat (N.) & Long (W.) & & & & & & \\
\hline $\begin{array}{l}\text { Sevuokuk; } \\
\text { biotite quartz } \\
\text { monzonite. }\end{array}$ & 1 & $63^{\circ} 45^{\prime}$ & $171^{\circ} 40^{\prime}$ & $\begin{array}{l}\text { 66 AMm- } \\
211\end{array}$ & Biotite & $\begin{array}{c}4.77,4.72 \\
\text { (avg 4.745) }\end{array}$ & 7.606 & 0.95 & $106 \pm 3$ \\
\hline $\begin{array}{l}\text { Sevuokuk; } \\
\text { biotite quartz } \\
\text { monzonite. }\end{array}$ & 2 & $63^{\circ} 27^{\prime}$ & $171^{\circ} 32^{\prime}$ & $\begin{array}{c}69 \mathrm{APa}- \\
219 \mathrm{e}\end{array}$ & $\ldots$ do $\ldots$ & $\begin{array}{l}7.94,8.01 \\
\text { (avg 7.98) }\end{array}$ & .1102 & .87 & $91.3 \pm 3$ \\
\hline $\begin{array}{l}\text { Kialegak; } \\
\text { biotite quartz } \\
\text { monzonite. }\end{array}$ & 3 & $62^{\circ} 59^{\prime}$ & $169^{\circ} 35^{\prime}$ & $\begin{array}{l}\text { 70ACy- } \\
162\end{array}$ & $\ldots$ do ... & 8.17 & .1257 & .87 & $101 \pm 3$ \\
\hline $\begin{array}{l}\text { Kinipaghulghat; } \\
\text { monzonite- } \\
\text { syenite. }\end{array}$ & 4 & $63^{\circ} 11^{\prime}$ & $168^{\circ} 25^{\prime}$ & $\begin{array}{l}\text { 66AMm- } \\
245\end{array}$ & Hornblende & $\begin{array}{l}1.48,1.47 \\
\text { (avg 1.475) }\end{array}$ & 2.277 & .90 & $101.7 \pm 3.1$ \\
\hline
\end{tabular}

Decay constants for $\mathrm{K}^{40}: \lambda_{\epsilon}=0.585 \times 10^{-10}$ year $^{-1} ; \lambda_{\beta}=4.72 \times 10^{-10}$ year $^{-1}$. Atomic abundance of $\mathrm{K}^{40}=1.19 \times 10^{-4}$.

Emerson, B. K., 1904, General geology; notes on the stratigraphy and igneous rocks [of Alaska], in Harriman Alaska Series, v. 4: Washington, D.C., Smithsonian Institution, p. 11-56.

Fyfe, W. S., Turner, F. J., and Verhoogen, John, 1958, Metamorphic reactions and metamorphic facies: Geol. Soc. America Mem. 73, $259 \mathrm{p}$.

Miller, T. P., 1970, Preliminary correlation of Mesozoic plutonic rocks in the Bering Sea region [abs.]: Am. Assoc. Petroleum Geologists Bull., v. 54, no. 12, p. 2496.

1971, Petrology of the plutonic rocks of west-central Alaska: U.S. Geol. Survey open-file report, $136 \mathrm{p}$.

Patton, W. W., Jr., 1967, Regional geologic map of the Candle quadrangle, Alaska: U.S. Geol. Survey Misc. Geol. Inv. Map I-492, scale $1: 250,000$.

Patton, W. W., Jr., and Csejtey, Béla, Jr., 1970, Analyses of streamsediment samples from western St. Lawrence Island, Alaska: U.S. Geol. Survey open-file report, 50 p. 1971a, Preliminary geologic investigations of western St. Lawrence Island, Alaska: U.S. Geol. Survey Prof. Paper 684-C. [In press]

- 1971b, Preliminary geologic investigations of eastern St. Lawrence Island, Alaska: U.S. Geol. Survey open-file report, 52 p.

Patton, W. W., Jr., and Dutro, J. T., Jr., 1969, Preliminary report on the Paleozoic and Mesozoic sedimentary sequence on St. Lawrence Island, Alaska, in Geological Survey Research 1969: U.S. Geol. Survey Prof. Paper 650-D, p. D138-D143.

Patton, W. W., Jr., and Miller, T. P., 1966, Regional geologic map of the Hughes quadrangle, Alaska: U.S. Geol. Survey Misc. Geol. Inv. Map I-459, scale 1:250,000.

Shilo, N. A., ed., 1965, Pozdnemezozoyskiye granitoidy Chukotki [Late Mesozoic granitic rocks of Chukotka]: Akad. Nauk SSSR Sibirsk. Otdeleniye Severo-Vostoch. Kompleks. Nauchno-Issled. Inst. Trudy, vyp. 12, 243 p. [In Russian] 


\title{
THE NEWPORT FAULT AND ASSOCIATED MYLONITES, NORTHEASTERN WASHINGTON
}

\author{
By FRED K. MILLER, Menlo Park, Calif.
}

\begin{abstract}
The Newport fault is a low-angle, east-dipping fault that juxtaposes a lower plate of plutonic and high-grade metamorphic rocks and an upper plate of little-metamorphosed Precambrian Belt Supergroup and Paleozoic sedimentary rocks. The fault is characterized by a zone of mylonite and cataclastic rock which averages about 700 feet in width. The latest movement along the zone occurred after emplacement of the approximately 50-m.y.-old Silver Point Quartz Monzonite, but before deposition of at least part of the as yet undated Tiger Formation.
\end{abstract}

During the course of mapping the Newport 30-minute quadrangle, a large low-angle fault with a well-developed zone of mylonite and cataclastic rock was discovered. The fault passes along the north edge of the town of Newport, on the Idaho-Washington boundary about 40 miles northeast of Spokane (fig. 1), and has been named the Newport fault. It has not yet been traced beyond the Newport 30-minute quadrangle, but there is little doubt that it extends outside because the width of the fault zone remains undiminished right up to the borders of the quadrangle.

Although other major low-angle faults have been inferred in this region (Clark and Miller, 1968, p. 4), the Newport fault is the first structure of this type to be well documented. Yates (1.964) has mapped several large thrust faults in the Deep Creek area northwest of Newport, but they are related to structures to the north and are unlike the Newport fault.

The purpose of this paper is primarily descriptive. Almost nothing is known about the extent and nature of the fault outside the quadrangle, so no interpretation will be made regarding the actual amount and direction of movement.along the fault. However, because of the contrast in degree of metamorphism and lithologic units across the fault, the amount of movement is considered to be large.

\section{DESCRIPTION OF THE FAULT}

The L-shaped trace of the Newport fault extends about 35 miles through the quadrangle (fig. 1). The fault is well exposed about 2 miles northwest of the town, where it strikes about $\mathrm{N}$. $75^{\circ}-80^{\circ} \mathrm{W}$, and $\operatorname{dips} 45^{\circ}-50^{\circ} \mathrm{N}$. There is little variation from this strike for about 14 miles to the northwest, at which point the fault trace turns rather sharply toward the north. Precise measurements could not be made, but the dip of the fault appears to be more shallow where the strike changes. North of the bend, the fault appears to have a more sinuous trend than along the west-northwest-trending segment. At the north border of the quadrangle, the zone dips $30^{\circ} \mathrm{E}$.

The actual zone of cataclasis is largely hidden by an extensive cover of glacial material. Glaciated outcrops at several places, however, provide excellent exposures. The zone of cataclasis ranges in width from about 400 to 1,000 feet and averages about 700 feet. The eastern and northern margins of the zone appear to be rather sharp; the western and southern margins are gradational from completely crushed rocks to rocks that show no megascopic cataclasis. Almost all the granulated material appears to have been derived from rocks of the western, or lower, plate.

Subdivisions within the zone can be recognized on the basis of the degree of cataclasis. A representative west-to-east section across the fault zone consists of:

1. Plutonic or coarsely crystalline metamorphic rock which contains numerous closely spaced cross-cutting chlorite-filled fractures. Most mafic minerals are altered to chlorite and opaque minerals. Plagioclase composition is similar to that in the unfractured rock, but crystals are broken and twin lamellae are bent. Quartz crystals are broken and strained, and some contain sutured boundaries. This rock grades westward into relatively unfractured plutonic and highly recrystallized metamorphic rock, and eastward into the second subdivision.

2. Intensely shattered rock showing almost no trace of the original texture. No mafic minerals or forms of mafic minerals remain. Many original plagioclase crystals remain, but are broken and rounded. Most are sericitized, and the composition is more sodic than in the unbroken rock. Quartz is highly broken; most is flattened and contains sutured boundaries. The rock contains thin seams and pods of fine-grained quartz and chlorite.

3. Mylonite. Dark-green aphanitic rock with scattered fine-grained, internally broken crystals of calcite and plagioclase. Thin sections show a very fine grained mixture of 


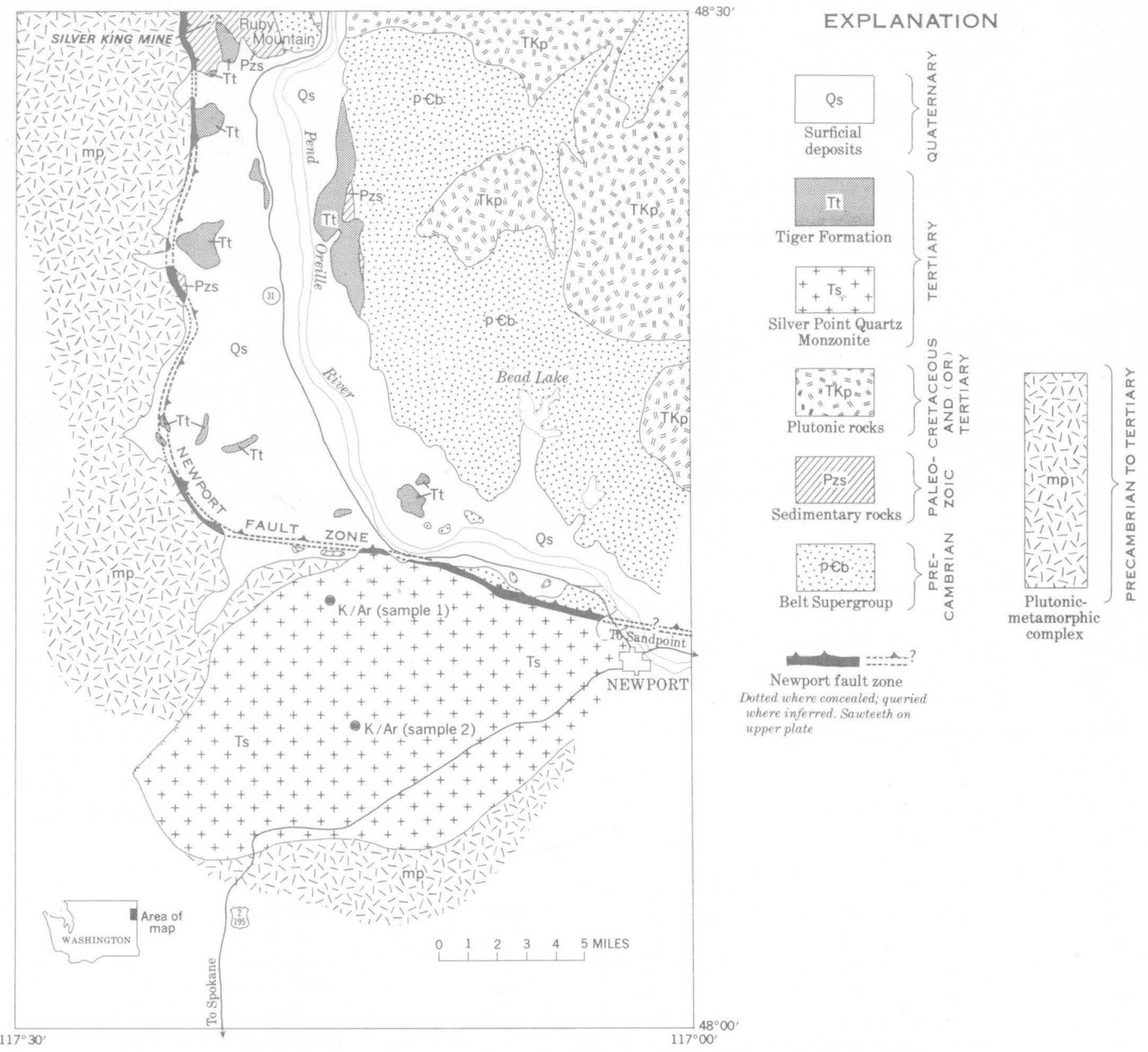

Figure 1.-Generalized geologic map showing the location of the Newport fault zone and the chief lithologic units in the Newport 30-minute quadrangle. Tertiary volcanic rocks found between Bead Lake and the Pend Oreille River are not shown, nor are some Quaternary surficial deposits. Contacts of the Quaternary deposits are highly generalized.

quartz, albite, chlorite, calcite, and iron oxides. This assemblage appears to have formed from rocks which range in composition from muscovite-biotite quartz monzonite to hornblende-biotite granodiorite. The mylonite and the rock of subdivision 2, above, are generally randomly mixed in the central and upper parts of the fault zone, although the mylonitic rock is more abundant in the upper part.

The third subdivision is in sharp contact with intensely brecciated Paleozoic quartzite and carbonate rocks. All contacts between subdivisions within the fault zone are gradational, and the relative proportions of the individual subdivi- sions vary along the strike of the zone. The rock throughout the zone, regardless of its degree of cataclasis, is hard and cohesive. In hand specimen most of the rock within the zone, including the mylonite, has no obvious fabric. Only at a few places in the western part of the zone, and locally within the interior part, does the rock have a slight foliation.

\section{ROCKS SEPARATED BY THE FAULT ZONE}

The Newport fault zone appears to separate two fundamentally different terranes. West of the fault the rocks form a 
complex of plutonic and thoroughly recrystallized metamorphic rocks, whereas east of the fault the rocks are littlemetamorphosed Precambrian Belt Supergroup and Paleozoic quartzite and carbonate. Most of the schist and quartzite which make up the metamorphic portion of the plutonicmetamorphic complex west of the fault appear to have been derived from the Prichard Formation of the Belt Supergroup. The rocks adjacent to the fault trace in the upper plate are metamorphosed only near the north border of the quadrangle, where two plutons, presumably restricted to the upper plate, have formed metamorphic aureoles in the surrounding rock. This situation is in marked contrast with the pervasive metamorphism of the rocks west of the fault. Where extensively exposed in the northeastern part of the Newport quadrangle, the upper plate Belt rocks exhibit the low "background" metamorphism found in the Belt Supergroup east of the Purcell Trench. These upper plate rocks are contact metamorphosed by plutonic rocks near the east border of the quadrangle, but in general they contrast strikingly with the migmatitic terrane west of the Newport fault.

Rocks in the upper plate are extremely brecciated for distances of up to 2 miles from the fault trace, and in places they contain tectonically mixed rock masses of contrasting lithology. The brecciation is much more apparent in the Paleozoic quartzite and carbonate rock than in the more argillitic rocks of the Belt Supergroup.

\section{AGE OF THE NEWPORT FAULT}

The Newport fault cuts the Silver Point Quartz Monzonite north and west of Newport. Joan C. Engels, of the U.S. Geological Survey, obtained the following K/Ar dates on two hornblende and biotite pairs from the pluton:

\begin{tabular}{|c|c|c|}
\hline & Sample 1 & Sample 2 \\
\hline Hornblende & $46.8 \pm 1.7$ m.y. & $51.0 \pm 5$ m.y. \\
\hline Biotite & $46.7 \pm 1.3 \mathrm{~m} . \mathrm{y}$ & $48.1 \pm 1$ m.y. \\
\hline
\end{tabular}

The Silver Point Quartz Monzonite was assigned a Mesozoic age by Miller (1969); however, the dates shown above indicate that the Silver Point is of Tertiary age.

Conglomerate, arkose, and siltstone correlated with the Tiger Formation, of Tertiary age, overlie projections of the fault from beneath surficial material. Nowhere does the formation appear to be cut by the fault or show the effects that proximity to a major fault might produce. Park and
Cannon (1943, p. 23), who first described the formation, considered it Tertiary but did not assign a more specific age.

Although that part of the Tiger Formation which overlies the zone does not appear to be cut by the fault, it is not known if all the Tiger postdates all the movement along the zone. The formation varies greatly in appearance, and may represent deposition during more than one Tertiary epoch. No part of the Tiger shows effects of burial to the depth at which the mylonite probably formed, but local brecciation of the mylonite indicates late movement on the fault at a shallower depth. Therefore, the last activity along the fault may not predate all of the Tiger Formation, but only that part which overlies the zone. The latest movement along the fault would then be younger than 46-51 million years. However, an upper age limit has not yet been established.

\section{MINERALIZATION ASSOCIATED WITH THE FAULT}

Anomalous amounts of sulfide minerals have been found in the upper plate wherever it is exposed near the fault trace. Almost all the sulfides are pyrite or pyrrhotite. The best exposures of the upper plate are on Ruby Mountain at the north edge of the quadrangle. There, much of the rock in the upper plate within 1 mile of the fault trace is classified as undivided breccia by me because the various Paleozoic lithologies appear to have been tectonically mixed. Sulfide minerals are generally sparsely scattered through the breccia but are concentrated in places. Galena, tetrahedrite, pyrite, and sphalerite are found at the Silver King mine about 1 mile east of the fault trace. At several places on the east flank of Ruby Mountain, zones of disseminated sulfides as much as 5 feet thick are composed of up to 10 percent pyrite or pyrrhotite, but sulfides of other metals are rare.

\section{REFERENCES}

Clark, L. D., and Miller, F. K., 1968, Preliminary geologic map of the Chewelah Mountain quadrangle, Stevens County, Washington: Washington Div. Mines and Geology Geol. Map GM-5, scale 1:62,500, separate text.

Miller, F. K., 1969, Preliminary geologic map of the Loon Lake quadrangle, Stevens and Spokane Counties, Washington: Washington Div. Mines and Geology Geol. Map GM-6, scale 1:62,500.

Park, C. F., and Cannon, R. S., Jr., 1943, Geology and ore deposits of the Metaline quadrangle, Washington: U.S. Geol. Survey Prof. Paper $202,81 \mathrm{p}$.

Yates, R. G., 1964, Geologic map and sections of the Deep Creek area, Stevens and Pend Oreille Counties, Washington: U.S. Geol. Survey Misc. Geol. Inv. Map I-412, 1:31,680 [1965]. 


\title{
PERMIAN DEFORMATION IN THE EAGLE BASIN, COLORADO
}

\author{
By VAL L. FREEMAN, Flagstaff, Ariz.
}

\begin{abstract}
The Eagle basin of west-central Colorado formed in Middle Pennsylvanian time concurrent with uplift of the adjacent Front Range and Uncompahgre highlands. The structural pattern formed at this time persisted into the Jurassic Period. During the Permian, two groups of structural features originated: (1) a poorly dated older group in the southern part of the basin, which reflects the continuing structural pattern of relative elevation of the bordering highlands, and (2) a younger group in the northern part of the basin, which was formed by a tectonic event of Leonard age that tilted to the southwest both the northern part of the Front Range highland and the Eagle basin. That event also produced folds in the central part of the basin. The Permian deformation probably caused local flowage of older basin evaporites. Folds of Permian age were the sites of later (Laramide) structural deformation.
\end{abstract}

The Eagle basin is a late Paleozoic tectonic feature in west-central Colorado that is filled with a thick section of dominantly clastic marine and continental sedimentary rocks. It occupies the northern part of the zeugogeosyncline described by Brill (1952). The basin, the Front Range and Uncompahgre highlands, and the Paradox basin (fig. 1) are structural elements that originated in Middle Pennsylvanian time and persisted into the Jurassic Period. This paper describes and discusses structural features developed in the basin during Permian time. The stratigraphic relations of rock units in the northern part of the Eagle basin are shown schematically in figure 2 .

\section{DESCRIPTION OF PERMIAN STRUCTURAL FEATURES}

Permian structural features in the northern part of the Eagle basin are readily deciphered where found beneath an unconformity at the base of the State Bridge Formation. This unconformity was first reported by Murray (1949) in the area near McCoy (fig. 1). Later, Murray (1958) noted that all wells northeast of a line trending northwest from McCoy to Pagoda (fig. 1) penetrated a thin section of Maroon Formation underlying the State Bridge Formation. He stated (1958, p. 56-57) that in the central part of the Eagle basin the State Bridge is conformable on the Weber Sandstone, but that along the northeastern flank of the trough, toward the Front Range highland, it lies with angular unconformity on successively older beds. Murray concluded that after the Weber was deposited, the Front Range highland was elevated slightly and the Weber and upper part of the Maroon were eroded before the State Bridge was deposited.

Additional evidence of growth of the Front Range highland prior to deposition of the State Bridge Formation was shown by Sheridan (1950). He reported that east of McCoy, near Radium, a wedge of coarse conglomerate (informally called the Sheephorn graywacke by Sheridan) is present between the State Bridge and Maroon Formations and that the State Bridge overlaps the conglomerates and rests directly upon Precambrian rocks.

Sharps $(1955,1962)$ recorded the presence of a thin conglomerate at the base of the Park City Formation (equivalent to the lower part of the State Bridge) that he interpreted as marking an unconformity on the Weber Sandstone. This conglomerate extends westward from the vicinity of McCoy to the Wilson Creek oil field (fig. 1). Sharps also delineated more closely the erosional limit of the Weber Sandstone noted by Murray (1958), which is shown on figure 1. Northeast of the erosional limit of the Weber, the State Bridge overlaps older formations and rests on Maroon and Minturn rocks, which fact led Sharps $(1962$, p. 82,198$)$ to conclude that after deposition of the Weber Sandstone, uplift occurred and an unconformity of regional extent was developed.

An apparent pinchout of the Weber Sandstone near Kent Siding, just west to Wolcott, mentioned by Sheridan (1950, p. 127), is neither the erosional edge of the sandstone nor a pinchout. Close examination reveals that the normally gray Weber is abruptly replaced by grayish red but otherwise identical beds and that individual laminae continue through the color change. However, a gray chert bed at the top of the Weber was locally eroded, and debris from it was incorporated in the basal State Bridge. Similar chert pebbles are found in the basal State Bridge about 5 miles southeast of Kent Siding. These occurrences of chert pebbles are considered to be evidence of an unconformity, and they are correlated with the conglomerate noted by Sharps (1955), as shown on figure 1 .

Other Permian structural events within the Eagle basin, but south of known occurrences of the State Bridge Formation, have been reported by Pierce (1969) and DeVoto (1969). Near 


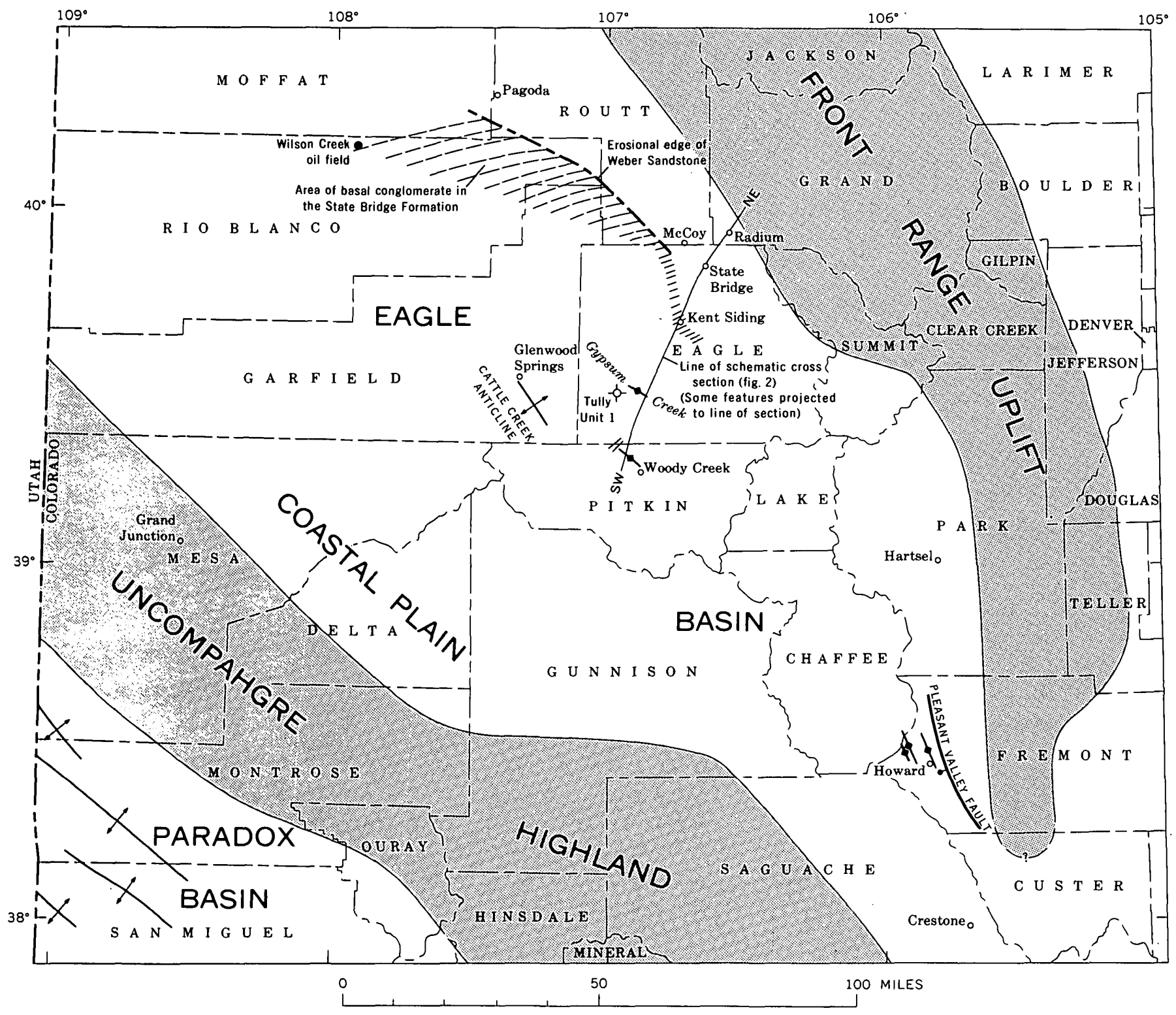

EXPLANATION

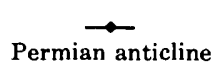

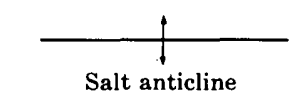

Showing growth by salt flowage during Permian Period

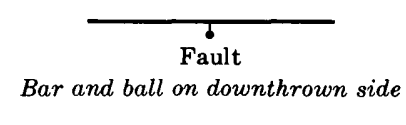

Figure 1.-Permian structural features in west-central Colorado. Location of highlands is their approximate position during Early Permian time.

Hartsel, DeVoto found fault-block positive areas formed during Pennsylvanian time that were overlapped by sediments that he believed were derived from the Uncompahgre highland as it became increasingly active in the Permian Period (DeVoto, 1969). An unconformity within Permian red beds near Howard (fig. 1) was demonstrated by Pierce (1969) as a result of detailed mapping in that area. The structural movement predating the unconformity was mainly an elevation of the Front Range highland northeast of the Pleasant
Valley fault that displaced the basement rocks as much as 10,000 feet. Southwest of the fault the beds were folded, with a northwest trend (fig. 1). Gypsum beds were squeezed into the anticline axes, causing minor diapirism (Pierce, 1969, p. 96). Beds that overlie the unconformity are possibly equivalent to the Crestone Conglomerate Member of the Sangre de Cristo Formation (Bolyard, 1959) to the south, according to Pierce (1969, p. 64), who cited Clement's (1952) statement that the Crestone lies unconformably on Lower Pennsylvanian 


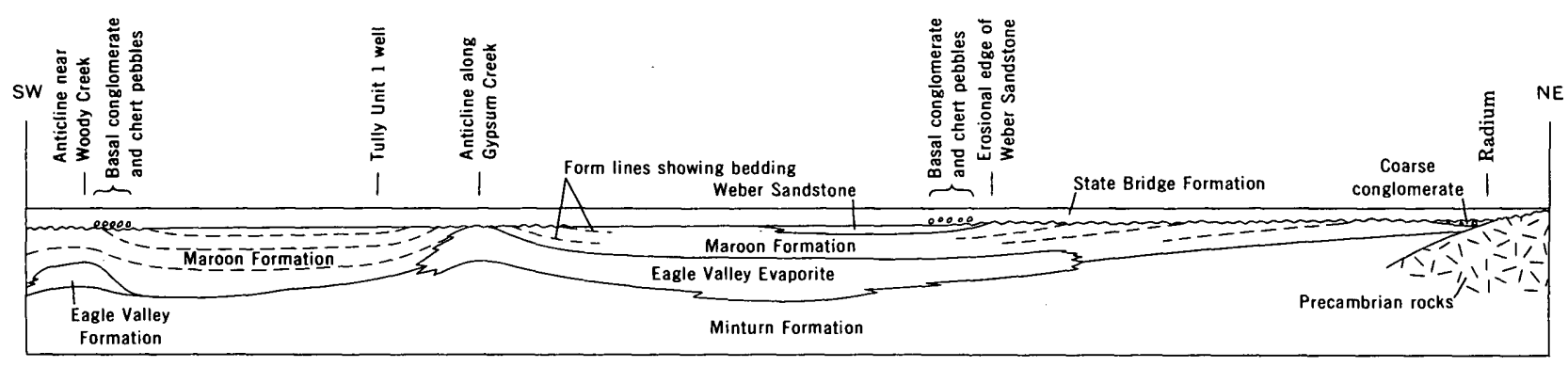

Figure 2.-Schematic cross section showing structural features soon after beginning of deposition of State Bridge Formation.

strata. The very coarse Crestone was derived from the Uncompaghre uplift and must be the result of rapid elevation there (Bolyard, 1959).

Two previously unreported Permian folds are present in the Eagle basin-one near Woody Creek and the other along Gypsum Creek (fig. 1). Unlike the examples of Permian structures in the Eagle basin described earlier, these folds are in the center of the basin and are not obviously related to uplift of the highlands. Although both are only partly exposed, they are definitely elongate anticlinal features, trending N. $50^{\circ}-55^{\circ} \mathrm{W}$., that were beveled prior to deposition of the State Bridge Formation. Both also were the sites of later (Laramide) deformation, and they now contain gypsum layers in their cores. However, no differential movement of the gypsum during the Permian is discernible.

The Permian fold near Woody Creek is deduced from geologic mapping (Freeman, 1972) of the angular unconformity beneath the State Bridge Formation. In this area the State Bridge strikes nearly parallel with, but dips less steeply than, the underlying Maroon Formation above the steep (as much as $60^{\circ}$ ) northeast flank of a pre-State Bridge fold at least 5 miles long. The fold has a poorly exposed broad crest one-half mile to the southwest. Northeast of the steep flank the angular discontinuity beneath the State Bridge decreases, and it becomes undetectable about 2 miles from the crest. Southwest of the crest the exposures are inadequate for determining the presence of a steep flank. The known features of the fold suggest an asymmetrical anticline that may be localized above a basement fault. Laramide structural movements produced the Castle Creek fault zone that, at least locally, follows the Permian fold. In the Woody Creek area the Castle Creek fault zone consists of two parallel-striking faults that bound an uplifted block of gypsum and gypsiferous siltstone assigned to the Eagle Valley Formation.

The Permian fold along Gypsum Creek (fig. 1) has not been mapped in detail. It is imperfectly known, and only the northeast flank is well exposed. Along this flank the State Bridge Formation is unconformable upon the Maroon Formation and, very locally, upon the conformably underlying Eagle Valley Evaporite. The pre-State Bridge fold is at least 4 miles long and its flank dips at least $30^{\circ}$. The crestal area of the old fold is the site of a later (Laramide) faulted anticline with a nearly parallel trend. Rocks exposed in the crestal area are steeply dipping and contorted beds of gypsum that probably moved differentially at the time of the Laramide folding. No intrusive movement of the gypsum during the Permian has been detected.

\section{AGE OF PERMIAN DEFORMATION IN EAGLE BASIN}

The regional uplift and unconformity in the northern part of the Eagle basin (Sharps, 1962) and the elevation of the Front Range northeast of McCoy (Murray, 1958) can be closély dated stratigraphically. In both areas the Weber Sandstone was uplifted and eroded prior to deposition of the State Bridge Formation. To the southwest the formations are conformable, so almost certainly Sharps and Murray describe aspects of a single event which is probably reflected by the wedge of coarse sediments at the base of the State Bridge at Radium reported by Sheridan (1950). The folding near Woody Creek and along Gypsum Creek also occurred prior to deposition of the State Bridge, but, because no Weber is known in these areas, the folding could have started earlier than the uplift to the northeast. However, near Woody Creek the presence of a gray chert conglomerate, similar to that at Kent, in the basal State Bridge suggests a contemporaneous formation of chert and subsequent erosion. Known relations, and the simplest explanation, allow the basin folds to be considered contemporaneous with uplift near McCoy. The conformable contact of the State Bridge upon Weber Sandstone is given by McKee, Oriel, and others (1967, table 1) as late Leonard in age. Structural features beneath the unconformity at the base of the State Bridge in the Eagle basin, therefore, are considered to have formed during a structural episode that occurred in the interval of early to late Leonard time.

Block faulting near Hartsel is considered a Pennsylvanian event, but the area was onlapped by "sediments shed by increasingly active Uncompahgre highland positive block to the west in the Permian" (DeVoto, 1969). No closer dating now exists for uplift of this part of the Uncompahgre. The faulting and folding near Howard occurred between deposition of Pierce's (1969) units V and VI. Unit IV, underlying unit V, correlates with the beds which G. R. Scott (U.S. Geol. Survey, 1967 , p. A82) suggested, on the basis of plant fossils, were 
Permian in age. The upper part of Pierce's unit V has recently been considered by Vaughn (1969), on the basis of vertebrate fossils, as Missouri (Late Pennsylvanian) in age. Pierce tentatively correlated his unit VI with the Crestone Conglomerate Member that is considered Late Pennsylvanian(?) and probably Permian (Wolfcamp) by Bolyard (1959). The age of the structural event near Howard thus remains in doubt, but it is probably Early Permian. If this is the case, Permian structural features in the southern part of the Eagle basin would seem to be related to uplift of parts of both the Front Range and Uncompahgre highlands sometime prior to Leonard uplift and folding in the northern part of the basin.

\section{DISCUSSION AND INTERPRETATION}

In Middle Pennsylvanian time the Eagle basin and the adjacent Uncompahgre and Front Range highlands were formed. The structural pattern of subsidence of the basin coupled with uplift of the highlands continued into the Permian Period. Some of the Permian structures described earlier are clearly a continuing part of this pattern. However, the Leonard structural event in the northern part of the Eagle basin left material evidence of relative uplift of a highland only in the areally small deposit of coarse conglomerate near Radium. Elsewhere the State Bridge clastics deposited after the structural event are in general finer grained than the underlying rocks. The tilting, as indicated by the erosional edge of the Weber Sandstone, had a more westerly trend in its northern part than did the western margin of the Front Range highland. Although the general northwest trend of the folds follows the trend of the basin, it would seem that the tilting and folding in the basin are structures probably independent of the old pattern. During the Laramide orogeny the Permian folds in the Eagle basin were the sites of renewed structural movement.

Within the northern part of the Eagle basin, other structural features perhaps were formed or modified during Permian time, but no direct evidence of Permian movement exists. The features suggest that Permian structural forces strongly influenced the present distribution of evaporites within the basin. One feature, the Cattle Creek anticline (fig. 1), has a thick evaporite section of Pennsylvanian age and is considered by Mallory (1966) as a diapir which, by analogy with the salt anticlines of the Paradox basin (fig. 1), may have grown by salt flowage during the Pennsylvanian and Permian (Cater and Elston, 1963).

An anomaly in the present distribution of the Eagle Valley Evaporite is its absence from the Tully Unit 1 well (Am. Strat. Co., 1961, and fig. 1). The distribution of evaporites in nearby areas suggests that the well is within the basin of evaporite deposition. The well is located on a present-day anticline, and adjacent anticlines do. contain the evaporite section. The Tully well may be located at the site of a Permian syncline from which evaporites were squeezed into adjacent Permian anticlines.

\section{REFERENCES}

American Stratigraphic Company, 1961, Sample log of Pan American No. 1 Unit-Tully, 30-6S-85W, Eagle County, Colorado.

Bolyard, D. W., 1959, Pennsylvanian and Permian stratigraphy in Sangre de Cristo Mountains between La Veta Pass and Westcliffe, Colorado: Am. Assoc. Petroleum Geologists Bull., v. 43, no. 8, p. 1896-1939.

Brill, K. G., Jr., 1952, Stratigraphy in the Permo-Pennsylvanian zeugogeosyncline of Colorado and northern New Mexico: Geol. Soc. America Bull., v. 63, no. 8, p. 809-880.

Cater, F. W., and Elston, D. P., 1963, Structural development of salt anticlines of Colorado and Utah, in Backbone of the AmericasTectonic history from pole to pole; a symposium: Am. Assoc. Petroleum Geologists Mem. 2, p. 152-159.

Clement, J. F., 1952, The geology of the Northeast Baca Grant area, Saguache County, Colorado: Colorado School Mines unpub. M.S. thesis, $129 \mathrm{p}$.

DeVoto, R. H., 1969, Permo-Pennsylvanian block faulting and folding and the sedimentary record, central Colorado, in Abstracts for 1968: Geol. Soc. America Spec. Paper 121, p. 594.

Freeman, V. L., 1972, Geologic map of the Woody Creek quadrangle, Pitkin and Eagle Counties, Colorado: U.S. Geol. Survey Geol. Quad. Map GQ-967. [In press]

Mallory, W. W., 1966, Cattle Creek anticline, a salt diapir near Glenwood Springs, Colorado, in Geological Survey Research 1966: U.S. Geol. Survey Prof. Paper 550-B, p. B12-B15.

McKee, E. D., Oriel, S. S., and others, 1967, Paleotectonic maps of the Permian System: U.S. Geol. Survey Misc. Geol. Inv. Map I-450.

Murray, H. F., 1949, Pennsylvanian stratigraphy of the McCoy area, Colorado [abs.]: Geol. Soc. America Bull,, v. 60, no. 12, pt. 2, p. 1965.

- 1958, Pennsylvanian stratigraphy of the Maroon trough, in Rocky Mtn. Assoc. Geologists, Symposium on Pennsylvanian rocks of Colorado and adjacent areas: p. 47-58.

Pierce, W. H., 1969, Geology and Pennsylvanian-Permian stratigraphy of Howard area, Fremont County, Colorado: Colorado School Mines unpub. M.S. thesis, $129 \mathrm{p}$.

Sharps, S. L., 1955, Correlation of pre-Mancos, post-Weber formations, northwestern Colorado, in Intermountain Assoc. Petroleum Geologists, Guidebook 6th Ann. Field Conf., 1955: p. 16-17.

- 1962, Geology of Pagoda quadrangle, northwestern Colorado: Colorado Univ. Ph. D. thesis, 364 p.; available on microfilm from University Microfilms, Inc., Ann Arbor, Mich.

Sheridan, D. S., 1950, Permian (?), Triassic, and Jurassic stratigraphy of the McCoy area of west central Colorado: Compass, v. 27, no. 3, p. 126-147.

U.S. Geological Survey, 1967, Geological Survey Research 1967, Chapter A: U.S. Geol. Survey Prof. Paper 575-A, 377 p.

Vaughn, P. P., 1969, Upper Pennsylvanian vertebrates from the Sangre de Cristo Formation of central Colorado: Los Angeles County Mus. Contr. Sci. 164, 28 p. 


\title{
SYSTEMATIC PATTERN OF TRIASSIC DIKES IN THE APPALACHIAN REGION-SECOND REPORT
}

\author{
By PHILIP B. KING, Menlo Park, Calif.
}

\begin{abstract}
Mafic dikes of Triassic age in the Appalachian region have a regional systematic pattern; they trend northwest in the southern Appalachians, north in the central Appalachians, and northeast in the northern Appalachians. In the southern Appalachians they are clustered into swarms 60 to 80 miles apart. From Alabama through North Carolina, they terminate northwestward near the Brevard fault zone, although this is an older feature. This termination may be due to differences in deep crustal structure on the two sides of the fault zone.
\end{abstract}

While assembling geologic data for the second Tectonic Map of the United States (Cohee, 1962), the writer recognized a remarkably systematic regional pattern of mafic dikes of Mesozoic age in the Appalachian region; this pattern was reported earlier in the Geological Survey Research series (King, 1961). Briefly stated, the dikes trend consistently northwest in the southern Appalachians, north-northwest to north-northeast in the central Appalachians, and northeast in the northern (or New England) Appalachians.

During the decade since the original observation was made, enough new data have accumulated to warrant a second report. For example, it is now apparent that the same systematic pattern continues into the Canadian Appalachians, where a great dike extends east-northeast across southern Nova Scotia for 80 miles on land and out to sea at both ends (see tectonic maps of Canada and of North America; Stockwell, 1969; King, 1969). Another dike with the same trend extends 30 miles across southern Aroostook County in eastern Maine (Doyle and others, 1967). In the southern Appalachians, much new information on the mafic dikes has appeared on State maps and in quadrangle, county, and other detailed areal reports. The author has recently reviewed these data in connection with a compilation of the geology of the Appalachian region for the forthcoming Geologic Map of the United States.

The remainder of this note will deal with the new data on dikes of the southern Appalachians. As in the previous account, the dikes will be treated mainly in terms of their areal patterns, and only incidental mention will be made of their petrography, history, and ages, fascinating problems in them- selves. In the previous account, speculation was offered as to the possible stress pattern of early Mesozoic time suggested by the dikes (King, 1961, p. B95); this was later discussed at greater length by de Boer (1967, p. 2246-2248) and Rodgers $(1970$, p. 208) and needs no further comment here.

\section{AGE RELATIONS}

The dikes are younger than the pre-Triassic crystalline bedrock of the Piedmont province, whose features they transect indiscriminately, and older than the Cretaceous and Tertiary deposits of the Atlantic Coastal Plain, which overlap them. They have an obscure relation to the sedimentary and igneous rocks of the Upper Triassic Newark Group and the normal faults associated with them; tectonic history during Newark and immediately subsequent Mesozoic time was probably complex, but much of it is poorly documented.

At least some of the dikes seem to be offshoots of the massive diabase stocks and sills embedded in the Newark Group of the central Appalachians (mainly north of the area of fig. 1), some of which have been dated as between 190 and 200 million years old (Erikson and Kulp, 1961); the dikes are therefore commonly ascribed a Late Triassic age. Nevertheless, as they transect both the basins of the Newark Group and the associated faults, they are at least somewhat younger than most of the other Newark events. Paleomagnetic data have been cited that suggest a Jurassic age (de Boer, 1967, p. 2246).

It is true that intrusive bodies in the Valley and Ridge province of central Virginia have been dated as Jurassic (Zartman and others, 1967, p. 861), and that others along the Virginia-West Virginia border a little to the west have been dated as Eocene (Fullagar and Bottino, 1969), but these are minor plugs and dikes of alkalic and mainly felsic composition. Although they seem to lie on the northwestern prolongation of one of the mafic dike swarms mentioned below ( $H$, fig. 1 ), their affinities are as close or closer to intrusives that follow the Rough Creek and Paint Creek-Irvine fault zones ("Thirtyeighth parallel fracture zone') in Kentucky to the west (Zartman and others, 1967, p. 866-867; Dennison and Johnson, 1971, p. 505). 


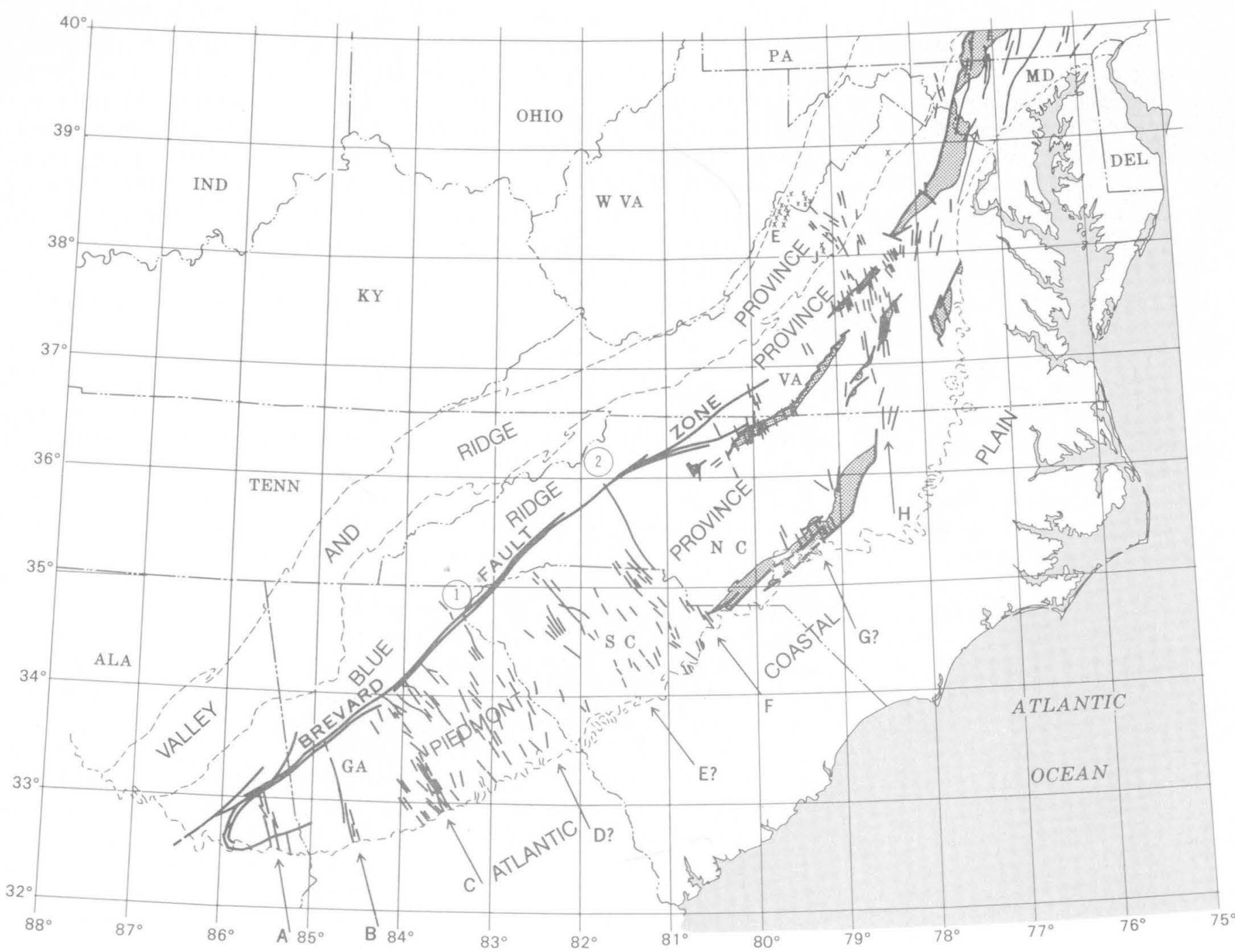

EXPLANATION
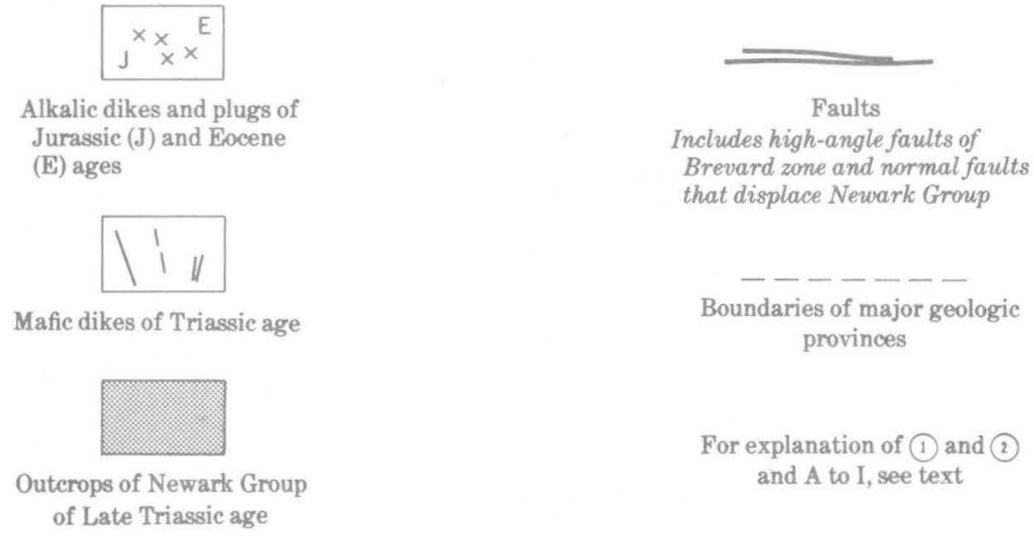

Boundaries of major geologic provinces

For explanation of (1) and (2)

of Late Triassic age
on

and $A$ to $I$, see text

Figure 1.-Geologic sketch map of the southern Appalachian region in the Eastern United States, showing known occurrences of dikes of Triassic age and their relation to other tectonic features. 


\section{DIKE SWARMS}

The new data on the southern Appalachians show the existence of many more dikes than previously known, especially in areas that had been cursorily mapped, so that a clearer notion of this abundance and grouping is becoming apparent. Many of the still "empty" areas on the map will undoubtedly be filled when further mapping is done; yet it now seems that dikes are truly abundant in some areas and are sparse or even absent in others.

In the Piedmont province one can now discern a cluster or swarm of closely spaced, lengthy dikes in eastern Alabama (A, fig. 1), other swarms in western Georgia (B) and in central Georgia (C), more diffuse swarms in eastern Georgia (D?) and central South Carolina (E?), a well-defined swarm in eastern South Carolina and central North Carolina (F), a possible swarm in central North Carolina and western Virginia (G?), and other strong swarms in central Virginia $(\mathrm{H})$ and in Maryland and southern Pennsylvania (I). If this clustering is genuine, successive dike swarms would be spaced rather evenly from 60 to 80 miles apart.

\section{RELATION TO BREVARD ZONE}

The new data reinforce the fact, first noted by Lester and Allen $(1950$, p. 1222), that in the segment south of Virginia virtually all the dikes terminate northwestward at, or a little short of, the Brevard fault zone. The only exceptions I have been able to discover are several short dikes in the Blue Ridge province of northeastern Georgia that extend 15 miles northwest of the Brevard zone, across the Tallulah Falls dome (Hatcher, 1971a, p. 17, pl. 1) (1, fig. 1), and a lengthy dike in western North Carolina that terminates a mile beyond the Brevard zone in the Grandfather Mountain window (Reed, 1964) (2, fig. 1). This relation to the Brevard zone is more than fortuitous, for after the zone disappears near the North Carolina-Virginia border, the dikes continue much farther northwest, into the Blue Ridge province, and even into the Valley and Ridge province of central Virginia (fig. 1) and central Pennsylvania (beyond fig. 1).

The Brevard zone is certainly one of the major features of the southern Appalachians and forms the tectonic (but not the physiographic) boundary between the Blue Ridge and Piedmont provinces. It preserves a remarkably straight northeastward course for 450 miles, from the Coastal Plain overlap in Alabama to the north edge of North Carolina, where it splays out (Butler and Dunn, 1968, p. 23, fig. 8; G.H. Espenshade, written commun., 1970, 1971); although one strand continues a short distance northeastward into Virginia, it is seemingly absent beyond. Throughout its length the fault zone dips steeply and is marked by mylonitization and cataclasis and by absolute differences between the rock formations on either side.

Like many other major tectonic features of orogenic belts, the Brevard zone has been diversely interpreted as to both origin and age-in origin as a simple or complex synclinal downfold (Keith, 1905, 1907; King, 1955, p. 350-351), as a strike-slip fault of large but unknown displacement (Reed and Bryant, 1964), as the root zone of thrust sheets to the northwest (King, 1950, p. 653; Burchfiel and Livingston, 1967), as the front of thrust sheets to the southeast (Jonas, 1932, p. 238-239; Bentley and Neathery, 1970, p. 48-51; Hatcher, 1971b), or some combination of these (Reed and others, 1970); in age from late in the Devonian (Odom and Fullagar, 1970) to early in the Triassic (Reed and Bryant, 1964 , p. 1189). Probably these varied interpretations are not as incompatible as they may seem; very likely contrasting structures formed at different times along the zone, the later being superposed on the earlier.

Be that as it may, why did the Brevard zone inhibit the northwestward prolongation of the mafic dikes? As the dikes are late Triassic or younger and the Brevard structures early Triassic or older, the northwestward termination of the dikes is not merely a truncation by later faulting. It more likely results from contrasts in crustal structures across the Brevard zone. That such contrasts are genuine is suggested by the fact that the great gravity gradient of the Appalachians, in places from +20 milligals on the southeast to -100 milligals or more on the northwest, lies from North Carolina southwestward along the southeastern edge of the Brevard zone (figs. 1, 2) (Woollard and Joesting, 1964). Griscom (1963) interprets the gradient as "a major break in the crust, representing a relative uplift of at least 4 miles on the southeast side." Rodgers $(1970$, p. 208) suggests that the stress system governing the distribution of the dikes was in the upper mantle rather than the crust, and Griscom's surmise implies that the mantle is nearer the present surface southeast of the Brevard zone than northwest of it. Northeast of the end of the Brevard zone, the transition from shallow mantle to deep mantle was evidently more gradual, permitting a more diffuse northwestward termination of the dikes.

Additional note.-After this article went to press, a paper by P. R. May became available which demonstrates that the same systematic pattern of Triassic and Jurassic dikes exists close to the edges of all the continents facing the North Atlantic Ocean and proposes that they are related to the stress field that existed during the time of continental separation (see May, 1971).

\section{REFERENCES}

Bentley, R. D., and Neathery, T. L., 1970, Geology of the Brevard zone and related rocks of the inner Piedmont of Alabama: Alabama Geol. Survey, 8th Ann. Field Trip Guidebook, Dec. 4-5, 1970, 119 p.

de Boer, Jelle, 1967, Paleomagnetic-tectonic study of Mesozoic dike swarms in the Appalachians: Jour. Geophys. Research, v. 72, no. 8, p. 2237-2250.

Burchfiel, B. C., and Livingston, J. L., 1967, Brevard zone compared to Alpine root zones: Am. Jour. Sci., v. 265, no. 4, p. 241-256.

Butler, J.R., and Dunn, D. E., 1968, Geology of the Sauratown Mountains anticlinorium and vicinity, North Carolina: Southeastern Geology, Spec. Pub. 1, p. 19-47. 


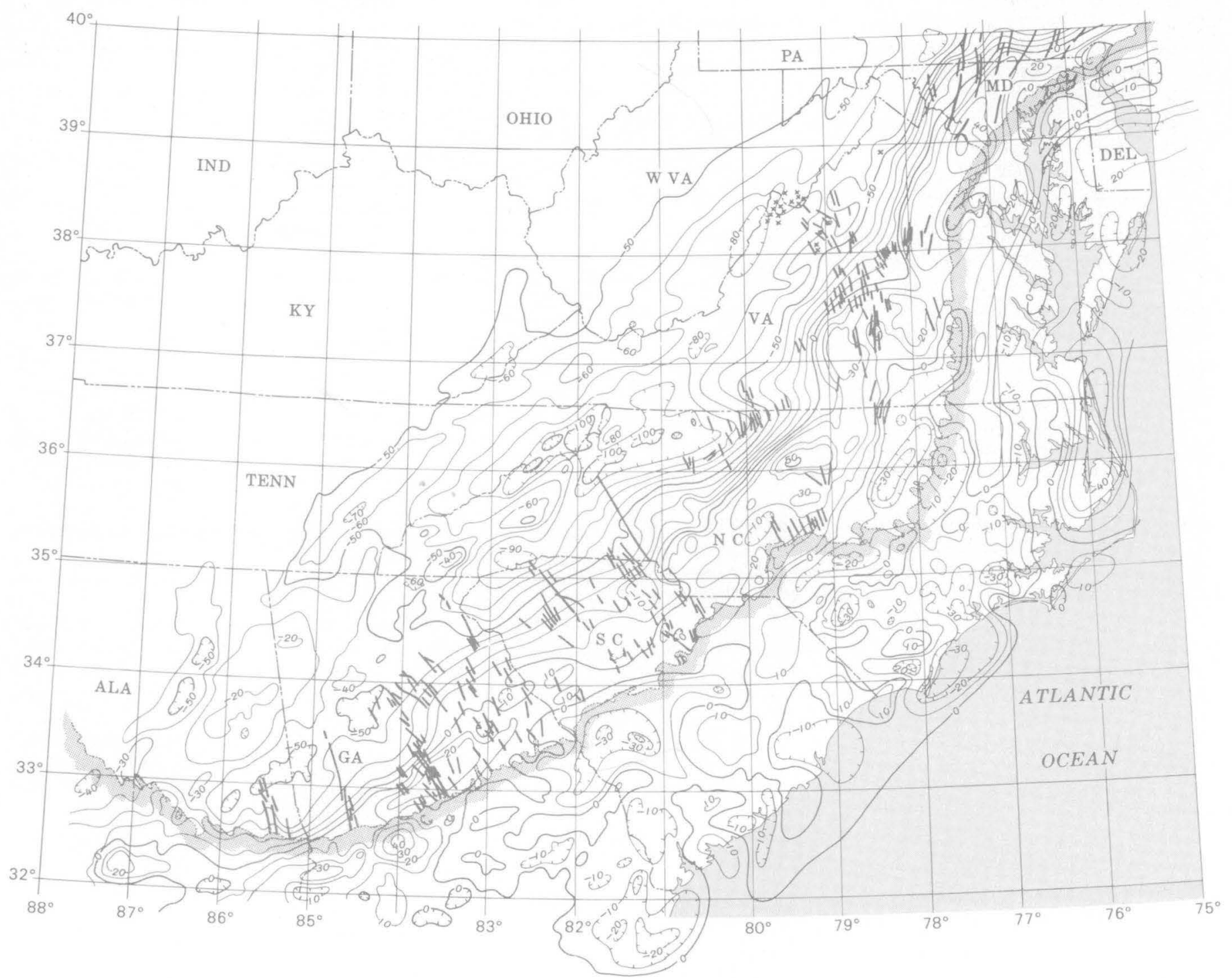

EXPLANATION

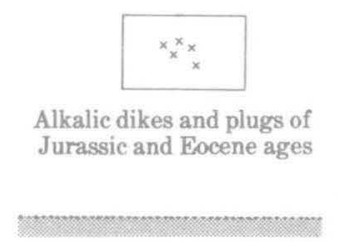

Edge of coastal plain deposits

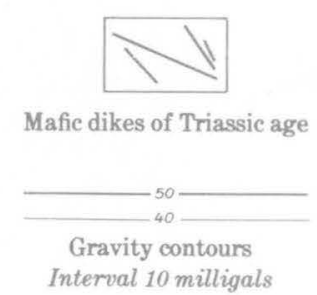


Cohee, G. V., chm., 1962, Tectonic map of the United States, exclusive of Alaska and Hawaii, by the United States Geological Survey and the American Association of Petroleum Geologists: U.S. Geol. Survey, scale $1: 2,500,000$.

Dennison, J. M., and Johnson, R. W., Jr., 1971, Tertiary intrusions and associated phenomena near the Thirty-eighth parallel fracture zone in Virginia and West Virginia: Geol. Soc. America Bull., v. 82, no. 2, p. 501-508.

Doyle, R. G., and others, 1967, Preliminary geologic map of Maine: Maine Geol. Survey, scale 1:500,000.

Erikson, G. P., and Kulp, J. L., 1961, potassium-argon measurements on the Palisades sill, New Jersey: Geol. Soc. America Bull., v. 72, no. 4, p. 649-652.

Fullagar, P. D., and Bottino, M. L., 1969, Tertiary felsite intrusions in the Valley and Ridge province, Virginia: Geol. Soc. America Bull., v. 80, no. 9, p. 1853-1858.

Griscom, Andrew, 1963, Tectonic significance of the Bouguer gravity field of the Appalachian system [abs.]: Geol. Soc. America Spec. Paper 73, p. 163-164.

Hatcher, R. D., Jr., 1971a, The geology of Rabun and Habersham Counties, Georgia: Georgia Geol. Survey, Dept. Mines, Mining and Geology Bull. 33, 48 p.

- $1971 \mathrm{~b}$, Stratigraphic, petrologic, and structural evidence favoring a thrust solution to the Brevard problem: Am. Jour. Sci., v. 270, no. 3, p. 177-202.

Jonas, A. I., 1932, Structure of the metamorphic belt of the southern Appalachians: Am. Jour. Sci., 5th ser., v. 24, p. 228-243.

Keith, Arthur, 1905, Description of the Mount Mitchell quadrangle [ North Carolina-Tennessee]: U.S. Geol. Survey Geol. Atlas, Folio $124,10 \mathrm{p}$.

1907, Description of the Pisgah quadrangle [ North CarolinaSouth Carolina ]: U.S. Geol Survey Geol. Atlas, Folio 147, 8 p.

King, P. B., 1950, Tectonic framework of southeastern United States: Am. Assoc. Petroleum Geologists, v. 34, no. 4, p. 635-671.

- 1955, Geologic section across the Southern Appalachians; an outline of the geology in the segment in Tennessee, North Carolina and South Carolina, in Russell, R. J., ed., Guides to southeastern geology: Geol. Soc. America, Ann. Mtg., New Orleans, 1955, p. 332-373.

1961, Systematic pattern of Triassic dikes in the Appalachian region: Art. 41 in U.S. Geol. Survey Prof. Paper 424-B, p. B93-B95.

King, P. B., compiler, 1969, Tectonic map of North America: U.S. Geol. Survey, scale 1:5,000,000.

Lester, J. G., and Allen, A. T., 1950, Diabase of the Georgia Piedmont: Geol. Soc. America Bull., v. 61, p. 1217-1224.

May, P. R., 1971, Pattern of Triassic-Jurassic diabase dikes around the Northern Atlantic in the context of predrift position of the continents: Geol. Soc. America Bull., v. 82, p. 1285-1292.

Odom, A. L., and Fullagar, P. D., 1970, Isotopic evidence for Late Devonian movement along the Brevard zone [abs.]: Geol. Soc. America Abs. with Programs, v. 2, p. 638-639.

Reed, J. C., Jr., 1964, Geologic map of the Lenoir quadrangle, North Carolina: U.S. Geol. Survey Geol. Quad. Map GQ-242, scale $1: 62,500$.

Reed, J. C., Jr., and Bryant, Bruce, 1964, Evidence for strike-slip faulting along the Brevard zone in North Carolina: Geol. Soc. America Bull., v. 75, no. 12, p. 1177-1196.

Reed, J. C., Jr., Bryant, Bruce, and Myers, W. B., 1970, The Brevard zone; a reinterpretation, in Fisher, G. W., Pettijohn, F. J., Reed, J. C., Jr., and Weaver, K. N., eds., Studies on Appalachian geology; central and southern: New York, Interscience Publishers, p. 261-269.

Rodgers, John, 1970, The tectonics of the Appalachians: New York, John Wiley-Interscience, $271 \mathrm{p}$.

Stockwell, C. H., chm., 1969, Tectonic map of Canada: Canada Geol. Survey Map 1251A, scale 1:5,000,000.

Wollard, G. P., and Joesting, H. R., 1964, Bouguer gravity anomaly map of the United States, by the American Geophysical Union's Special Committee for the Geophysical and Geological Study of the Continents and the U.S. Geological Survey: U.S. Geol. Survey, scale $1: 2,500,000$.

Zartman, R. E., Brock, M. R., Heyl, A. V., and Thomas, H. H., 1967, $\mathrm{K}$-Ar and $\mathrm{Rb}$-Sr ages of some alkalic intrusive rocks from central and eastern United States: Am. Jour. Sci., v. 265, no. 12, p. 848-870. 


\title{
STRATIGRAPHIC DISTRIBUTION OF ECHINODERM PLATES IN THE ANTELOPE VALLEY LIMESTONE OF NEVADA AND CALIFORNIA
}

\author{
By JAMES SPRINKLE, Denver, Colo. ${ }^{1}$
}

\begin{abstract}
Two distinct echinoderm faunas based on silicified plates are present in the Antelope Valley Limestone of Early and Middle Ordovician age in Nevada and eastern California. The lower fauna is confined to the middle and upper parts of the Orthidiella zone, whereas the upper fauna occurs throughout much of the overlying Anomalorthis zone. Only a few elements are common to both faunas, and no localities that have an intermediate or strongly mixed fauna are known. Both Antelope Valley echinoderm faunas suggest an early Middle Ordovician age with Chazy (Marmor) and perhaps Porterfield affinities. These echinoderms show a distribution pattern similar to that of most of the other shelly elements (trilobites, brachiopods, and ostracodes) and support the zonation and correlation framework based on these groups.
\end{abstract}

Echinoderms are common at many localities of the Lower and Middle Ordovician Antelope Valley Limestone in Nevada and eastern California. At most localities, silicified fragmentary plates and columnals are the only remains preserved, but at a single locality in central Nevada complete echinoderm calyces have also been found. The fragmentary nature of the echinoderm material at most localities makes identification especially difficult-sometimes even to the class or order level. However, because the material is silicified, it is easy to recognize and collect in the field and can be recovered in large quantities in the laboratory by acid etching. These features suggest that echinoderm plates can be of use in stratigraphic studies of the Antelope Valley Limestone.

Little previous work has been done on Ordovician echinoderms from the Basin and Range province of the Rocky Mountains, probably because of the lack of complete and well-preserved faunas, the inaccessibility of many of the sections, and the dearth of Paleozoic fossil-echinoderm workers in the Rocky Mountain area. Phleger (1933, p. 3) mentioned the presence of Blastoidocrinus from the Mazourka Formation of eastern California, but he did not describe or figure his specimens. Ross (1951, 1964, 1968, 1970) recorded the presence of echinoderms in faunal lists and measured sections from the Antelope Valley Limestone and Garden City Formation, and he recently figured a plate of Blastoidocrinus

\footnotetext{
${ }^{1}$ Current address: Department of Geological Sciences, University of Texas, Austin, Tex. 78712.
}

from northern Utah (1968, pl. 4, fig. 24). Lane (1970) described a small crinoid fauna on the basis of eight partially complete specimens and two separate plates from the Lower and Middle Ordovician of western Utah. Between 1967 and 1970, I studied the eocrinoids and parablastoids from the Antelope Valley Limestone and Garden City Formation as part of a larger taxonomic study on these groups (Sprinkle, 1972).

The echinoderm material studied here is part of a large collection of paleontological samples and acid residues made by R. J. Ross, Jr., and associates at the U.S. Geological Survey, Denver, Colo. Complete stratigraphic and geographic locations of these USGS collections (hereafter designated by D... CO numbers) have been presented by Ross $(1964,1970,1971)$. I thank Ross and L. A. Wilson, also of the U.S. Geological Survey, Denver, for their assistance during this work. This research was completed during my tenure as a National Research Council-USGS Postdoctoral Research Associate.

\section{MATERIAL AND TECHNIQUES}

More than 1,000 USGS paleontological collections from the Antelope Valley Limestone were examined, and approximately 50 were found to contain appreciable amounts of echinoderm material. The various types of echinoderm plates in these collections were first plotted to determine if any constant associations with host rock were present. Two apparent groupings of plate types were found, one occurring in the lower part of the Antelope Valley and the other in the upper part. Several types of plates dominate each of the echinoderm faunas and occur in most of the studied collections, usually in great abundance. Other types of plates occur only in one or a few collections, either as rare elements or as locally dominant ones. Very few of the echinoderm plate types are common to both faunas; where they are common to both, they are usually abundant in one fauna and rare in the other.

The lower echinoderm fauna is known both from separate plates and from a few complete nonsilicified rhombiferan cystoids and eocrinoids with appendages occurring in and just 
below the famous "sponge beds" described by Bassler (1941, p. 91-92) at Ikes Canyon in the Toquima Range of central Nevada. This single occurrence has greatly facilitated the complete identification of many of the separate plates occurring in this lower fauna at other localities. The upper echinoderm fauna is known only from disarticulated plates; however, a few of the elements have been partially or completely identified by reconstruction work based on nearly 2,000 plates etched from two large blocks of dolomite (40 pounds total) in collection D979 CO from Lucky Strike Canyon, southwestern Nevada. These two echinoderm faunas and their probable ages are discussed in separate sections below.

\section{LOWER FAUNA}

The lower echinoderm fauna in the Antelope Valley Limestone is known to occur in at least 15 localities in southwestern and central Nevada and perhaps in eastern California. This fauna occurs throughout nearly all of the Ranger Mountains Member, the middle member of the Antelope Valley (Byers and others, 1961, p. C106), from within 15 feet of the base (colln. D718 CO) to about 30 feet of the top (colln. D719 CO) (see Ross, 1967, pl. 11); based on extensive sampling at the Nevada Test Site. However, this lower fauna is not known for certain to occur in the underlying Paiute Ridge Member, the basal member of the Antelope Valley Limestone. A few elements belonging to this fauna also occur in the middle part of the Badger Flat Limestone in the Inyo Mountains of eastern California (Ross, 1966 , p. 14), which has been correlated with the lower part of the Antelope Valley Limestone (Ross, 1967, pl. 11).

The stratigraphic, interval occupied by this lower echinoderm fauna seems to be equivalent to the middle and upper parts of the Orthidiella zone (Cooper, 1956, p. 126; Ross, 1970 , p. 45-47). In addition, some members of this fauna are strongly associated with reeflike bioherms or banklike biostromes occurring in this part. of the Antelope Valley Limestone (Ross and Cornwall, 1961; Sprinkle, 1972).

This lower echinoderm fauna is represented by marginal. plates and columnals from one or more rhipidocystid eocrinoid species, deltoid and oral crest plates from two species of the parablastoid Blastoidocrinus, plates and columnals from at least two genera of rhombiferan cystoids, plates from a crinoid resembling Palaeocrinus, small-domed ridged plates belonging to an unknown echinoderm, apparent starfish arm ossicles, and several distinctive types of columnals. Examples of these echinoderms are shown in figure 1, 1-29, and briefly described below.

The rhipidocystid marginal plates and columnals are probably the most common and widespread elements found in the lower fauna. This material consists of elongate, thickened, $U$-shaped marginal plates (fig. 1, 1-5) making up the more massive rim of these elongate flattened eocrinoids, and separate spherical columnals either with one large elliptical facet plus a small round one (proximal columnals) (fig. 1, 6-8,
9) or with two small round facets (distal columnals) (fig. 1 , 10). This fragmentary material may represent a new rhipidocystid genus and species that is based on several complete specimens from Ikes Canyon, central Nevada (Sprinkle, 1972). More than one species (or subspecies), however, may be represented in the rhipidocystid plate material of this report, because both large and small elliptical facets have been observed on proximal columnals from different localities.

Two new species of a parablastoid here assigned to the genus Blastoidocrinus are also present in the lower echinoderm fauna of the Antelope Valley, but at present they are known from only two localities, the large bioherm at Meiklejohn Peak in southwestern Nevada and the sponge beds (a widespread biostrome) at Ikes Canyon. Blastoidocrinus sp. 1 has thick triangular deltoid plates (fig. 1, 13-14) with numerous and relatively long cataspire slits on the aboral margin. Cylindrical or flared oral crest plates (fig. 1, 11-12) have also been recovered from acid residues and are thought to belong to this species. The other new species (Blastoidocrinus(?) sp. 2) is known only from a few unusually shaped deltoids. These are very large and parabolic, with long thickened "limbs" extending down the calyx along the adjacent ambulacra (fig. 1, 15). At least 50 short cataspire slits extend along the entire inside margin of the plate. This latter species may not belong to the genus Blastoidocrinus, but the material available at present does not allow a definite assignment. Parablastoid remains are also known from the Garden City Formation of northern Utah (Ross, 1968, p. H10-H11; Sprinkle, 1972).

Two different types of rhombiferan cystoid plates are represented in this lower fauna. One type is an elongate flattened plate commonly having a single large pectinirhomb with conjunct slits on one suture (fig. $1,17-18$ ). The number of slits (dichopores) in a single pectinirhomb may exceed 120 , an unusually large number. This type of plate belongs to a large, flattened, bottom-living pleurocystitid rhombiferan cystoid represented by numerous complete specimens from the Antelope Valley sponge beds at Ikes Canyon, central Nevada. Other cystoid plates are more equally sided and polygonal and have sets of pectinirhombs with disjunct slits on several sutures (fig. 1,19 ) and in many plates a large radial sinus for an ambulacrum. These plates belong to a cheirocrinid rhombiferan cystoid closely related to Cheirocrinus or Hesperocystis, which is also represented in the fauna at Ikes Canyon by a few complete specimens.

Several other types of plates in the lower echinoderm fauna of the Antelope Valley may belong to crinoids or other echinoderms. Some plates with ridged sutural folds resemble those of the crinoid genus Palaeocrinus (fig. 1, 16). However, these plates are smaller and have fewer folds than typical species of Palaeocrinus. Another widespread type of small plate has radiating domed ridges and open porelike sutural areas (fig. 1, 20-23); these "domed ridged plates" apparently represent calyx plates of some unknown echinoderm. A few small plates probably represent arm ossicles of a starfish 
(asteroid) (fig. 1, 28-29). These locally abundant plates are all identical, having a dumbbell shape with rounded ends and lateral facets. Several distinctive types of columnals are present in this lower fauna. Star-shaped columnals with a round lumen (fig. 1, 26-27) occur at one or two sections; these are probably of crinoid origin and are similar to columnals of the Middle Ordovician crinoid genus Iocrinus figured by Moore and Jeffords (1968, pl. 9, figs. 8-9). Elongate cylindrical columnals with a low central flange (fig. 1, 24-25) apparently come from the distal stem of one of the rhombiferan cystoids in this fauna.

\section{AGE OF THE LOWER FAUNA}

The lower echinoderm fauna of the Antelope Valley has several elements that could be useful for correlation with other Ordovician units and with the standard Ordovician section. The rhipidocystid marginals and columnals, the Blastoidocrinus deltoids, and some of the rhombiferan cystoid plates are distinctive and easily recognized in the field, making them useful for correlating within the formation. Rhipidocystid genera somewhat more advanced than the Antelope Valley form are known from the Chambersburg. Limestone of Porterfield (Black River) age in Maryland, the Benbolt Formation (of Cooper, 1956, p. 45-48) of the same age in southwestern Virginia and northeastern Tennessee, and from the Lower and Middle Ordovician $\left(\mathrm{B}_{\mathrm{II}} \beta-\mathrm{D}_{\mathrm{I}}\right)$ of Russia. The parablastoid Blastoidocrinus has previously been described from the Chazy Group and Aylmer Formation of Chazy (Marmor) age in northeastern New York and southwestern Quebec (Hudson, 1907; Sprinkle, 1972), from the Garden City Formation of northern Utah (Ross, 1951, 1968; Sprinkle, 1972), and has also been listed from the Outram Formation of western Alberta (Aitken and Norford, 1967, p. 203). All these occurrences seem to fall within a narrow stratigraphic interval corresponding to the Chazy (Marmor) Stage (Cooper, 1956, p. 8; Shaw, 1968, p. 21) and the lower part of the Whiterock Stage (Cooper, 1956, p. 7-8). Blastoidocrinus sp. 1 from the Antelope Valley seems to be fairly closely related to $B$. carchariaedens from the Chazy Group, indicating a possible correlation between these two formations. However, Blastoidocrinus appears to be partially facies controlled, because it is found only where reefs or banks were formed under rough water conditions. This casts some doubt on a direct correlation between the Chazy Group and Antelope Valley Limestone by use of this parablastoid, because its occurrence is probably dependent on the presence of a particular facies and not on strictly contemporaneous deposition.

The rhombiferan cystoids have close relatives ranging throughout both the Early and the Middle Ordovician. Direct correlations are difficult because both of the Antelope Valley cystoids represent new taxa, and because other cystoid faunas, including those in the Bromide Formation of Oklahoma and the Benbolt Formation of the southern Appalachians, seem to be slightly younger and to contain somewhat different cystoids. These Antelope Valley rhombiferan cystoids are among the earliest cystoids to appear in the fossil record, only slightly younger than the first cheirocrinids in the Late Tremadocian and Arenigan of England and France. The only other echinoderms that might have some use in correlation are those of unknown origin that are represented by small-domed ridged plates. A few examples of this type of plate have been found in a single USGS collection (D1704 CO) about 100 feet above the base of the Joins Formation in Oklahoma, which has previously been regarded as Chazy or Whiterock in age (Harris, 1957, p. 59-60; Derby, 1969, p. 35).

\section{UPPER FAUNA}

The upper echinoderm fauna in the Antelope Valley Limestone consists of a great many types of plates, but it has a somewhat more restricted distribution than the lower fauna and is known at present from only eight localities. Many of the elements in this fauna are still unidentified because no occurrences of complete specimens have been found. However, a few of the more distinctive crinoids have been reconstructed from abundant silicified plates derived from two large blocks of dolomite from collection D979 CO by acid etching. This upper fauna consists of large pustular plates from a new hybocrinid crinoid, smooth plates from another possible hybocrinid genus, two types of plates resembling those of the crinoid Palaeocrinus(?), several other types of crinoid plates and plates belonging to unknown echinoderms, plates from one type of rhombiferan and one type of diploporan cystoid, rare eocrinoid marginal plates, and a possible blastoid plate. Several distinctive types of columnals and brachial plates are also present, probably belonging to some of the crinoids in this fauna. These elements are illustrated in figure $1,30-86$, and described in more detail below.

The most distinctive element of the upper fauna is probably the large pustular hybocrinid plates. These plates are as much as $25 \mathrm{~mm}$ long and are ornamented on the exterior surface with coarse, regularly spaced pustules (fig. 1, 30-34). Basals, radials, orals, and anal plates have all been identified, and a complete calyx reconstruction has now been made on the basis of nearly 600 complete plates. This crinoid lacks arms and instead has three ambulacra extending down over the calyx from the summit to the stem facet in grooves lying on three of the radial plates (fig. 1,30 ) and between the orals and basals (fig. 1, 32, 34). This material represents a new hybocrinid genus, which is now being studied. Several types of large, smooth plates (fig. 1, 35-37) occurring in the same collections may represent another genus of hybocrinid crinoid.

Several other types of distinctive plates, apparently of crinoid origin, also occur in the upper echinoderm fauna of the Antelope Valley. Two types of plates with ridges and intervening areas with slits (actually weathered, externally projecting folds) are present. One type has high ridges and thin plates (fig. 1, 38-40), whereas the other type has lower ridges, smaller slits, and more massive construction (fig. 1, 41-44). A 


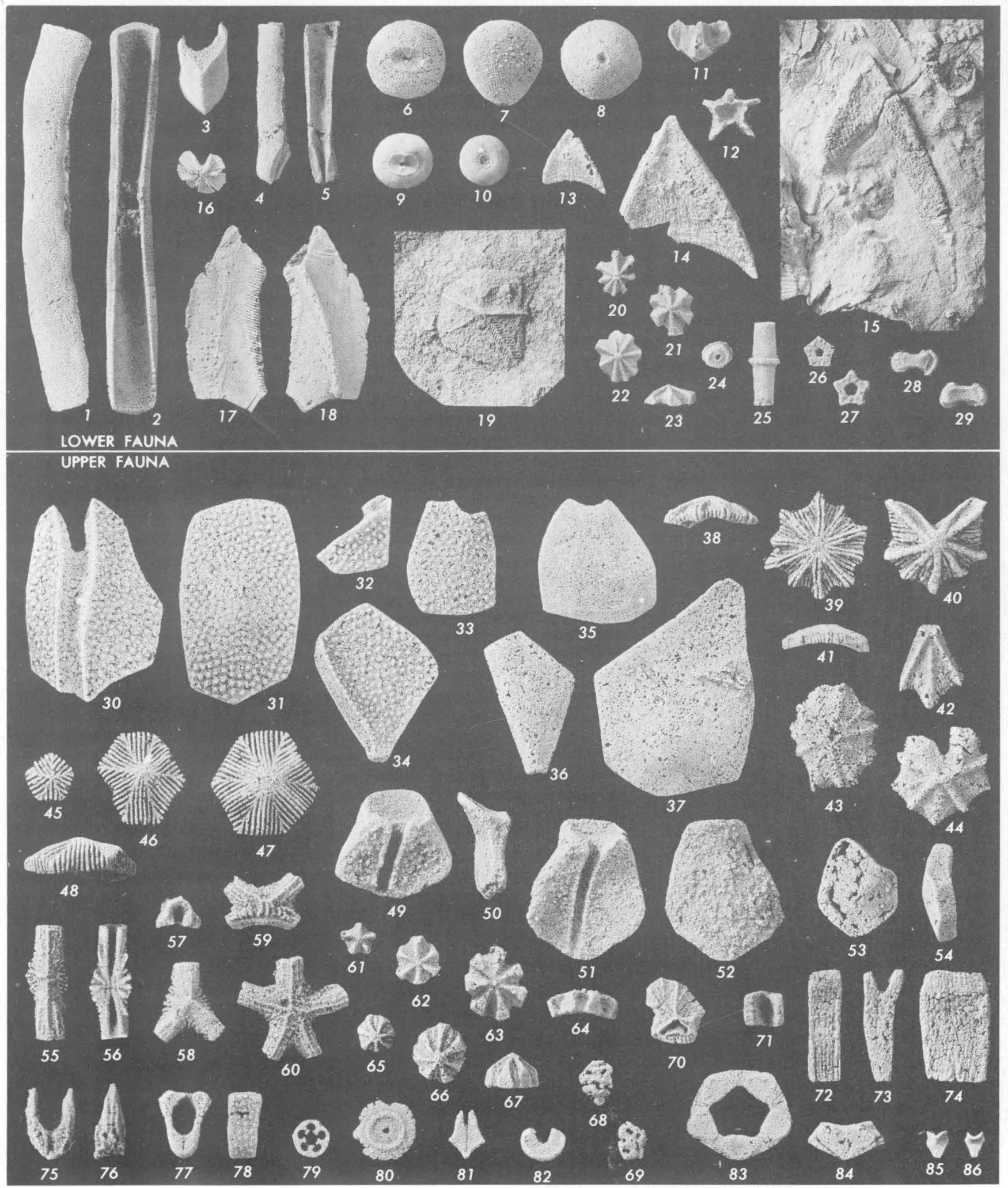

Figure 1. 
Figure 1.-Lower $(1-29)$ and upper $(30-86)$ echinoderm faunas from the Antelope Valley Limestone. (1-29 and 38-86, $\times 2 ; 30-37, \times$ 1.5.)

1-10. Rhipidocystid eocrinoid marginals and columnals. 1-3, side, interior, and end views of a large marginal plate (USNM 165437 from colln. D719l CO). 4 and 5, side and internal views of a basal marginal; note facets at bottom for other marginals and proximal columnal (USNM 165438 from colln. D719i CO). 6-8, top, side, and bottom views of a large elongate proximal columnal (USNM 165439 from colln. D737 CO). 9, top view of another proximal columnal showing elongate facet where three basal marginals are attached (USNM 165440a from colln. D719i CO). 10, top view of a distal rhipidocystid columnal; note small round facet (USNM 165440 b from colln. D719i CO).

11-14. Blastoidocrinus sp. 1, oral crest and deltoids. 11 and 12, side and top views of an oral crest apparently belonging to this species; note lateral facets for wing plates (11) and summit concavity (USNM 165441 from colln. D2052 CO). 13, small deltoid plate showing shape and concave lower margin (USNM 165442 from colln. D2052 CO). 14, large but incomplete deltoid; note trace of cataspire slits at bottom (USNM 165443 from colln. D1993 CO).

15. Blastoidocrinus(?) sp. 2. Large deltoid showing very elongate parabolic limbs with cataspire slits at upper left (USNM 165444 from colln. D2052 CO).

16. Palaeocrinus(?) sp. Small radial plate showing arm facet and few covered folds (USNM 165445 from colln. D719i CO).

17-18. Pleurocystitid rhombiferan cystoid plate (probably L4) showing dorsal and ventral (plus internal) surfaces, broken upper edge, and conjunct pectinirhomb with numerous slits on dorsal surface (USNM 165446 from colln. D719i CO).

19. Cheirocrinid rhombiferan cystoid plate (probably an ILL or LL); note disjunct pectinirhombs and strengthening ridges (USNM 165447 from colln. D1494, CO).

20-23. "Domed ridged plates." Exterior view of three plates and side view showing slightly domed profile; note ridges radiating to plate sides and epispirelike indentations at sutures (USNM 165448a-c from colln. D2052 CO).

24-25. Elongate flanged columnal from the distal stem of one of the rhombiferan cystoids in the lower fauna (USNM 165449 from colln. D719 CO).

26-27. Star-shaped columnals of unknown origin having a round lumen (USNM 165450a-b from colln. D719f CO).

28-29. Probable starfish ossicles. Opposite sides of two specimens showing dumbbell shape and ornamentation (USNM 165451a-b from colln. D2055 CO.).

30-34. Pustular hybocrinid plates. Two radials (30-31), an oral, an anal, and a basal plate belonging to a new hybocrinid crinoid genus; note coarse pustular ornament and ambulacrum extending over surface of radial $(30)$ and along edge of oral (32) and basal (34)(USNM 165452-6 from colln. D979 CO).

35-37. Smooth hybocrinid plates. Anal, basal, and radial from an incompletely known hybocrinid crinoid showing lack of ornament and different shapes when compared to 33,34 , and 31 (USNM 165457a-c from colln. D979 CO).

38-40. Crinoid plates possibly related to Palaeocrinus(?). Calyx plate (side and exterior views) and a radial plate showing larger covered ridges with a central slit $(38-39)$ and shorter slits in between, which may also have been covered externally (USNM $165458 \mathrm{a}-\mathrm{b}$ from colln. D993 CO).

41-44. Crinoid plates possibly related to Palaeocrinus(?). Calyx plate (41, side and 43 , exterior views), an oral or basal plate (42), and a radial plate (44); note thickness of plates and short sutural slits which may have been covered externally (USNM 165459a-c from colln. D979 CO).

45-48. "Ridge and epispire plates." Three calyx plates of an unknown echinoderm possibly related to the rhombiferan cystoid(?) Caryocystites showing strongly developed ridges and slits extending to the sutured sides (48) and perhaps covered externally by a thin calcite sheet (USNM 165460a-c from colln. D979 CO).

49-52. Unusual crinoid radial(?) plates. Two plates showing interior $(49,51)$, side $(50)$, and exterior (52) views; note apparent facet at top and large nerve(?) canal running up interior surface of plate to center of facet (USNM 16546 la-b from colln. D993 CO).

53-54. Thick calyx plate most likely from an unknown inadunate crinoid (USNM 165462 from colln. D979 CO).

55-60. "Multilimb fold plates." Four plates from an unknown echinoderm showing the variety in shape, the major hollow or fold $(56-57)$ under the projecting limbs, the slitlike area on sides of plate or between limbs, and the possible facet for stem in 59 (USNM 165463a-d from colln. D979 CO).

61-64. "Flat-topped ridged plates." Three calyx plates from an unknown echinoderm showing similar ridges and sutural openings to other "ridged plates" but a different lateral profile (64) (USNM 165464a-c from colln. D979 CO).

65-67. "High-domed ridged plates." Two highly domed calyx plates from an unknown echinoderm perhaps related to the plates in 20-23 (USNM 165465a-b from colln. D979 CO).

68-69. Diplopore plates. Two small, thick plates from an unknowr diploporan cystoid bearing randomly oriented paired diplopore: (USNM 165466a-b from colln. D979 CO).

70. Small thombiferan cystoid plate (possibly L4) bearing a single disjunct pectinirhomb surrounded by a prominent rim (USNN. 165467 from colln. D979 CO).

71-74. "High crest plates." Top, side, and edge views of a singli apparent crest plate from an unknown echinoderm and two cres plates sutured together (74) (USNM $165468 \mathrm{a}-\mathrm{b}$ from colln. D979 CO).

75-76. U-shaped crinoid brachial plate showing deep ambulacral groove and ornamented sides (USNM 165469 from colln. D979 $\mathrm{CO})$.

77-78. "Large-canal crinoid brachial plate" showing very large nerve(?) canal running down arm, shallow ambulacral groove, and slight pustular ornament on sides (USNM 1654,70 from colln. D979 CO)

79. Small columnal of unknown origin with complex star-shaped lumen (USNM 165471 from colln. D979 CO).

80. Flanged columnal of unknown origin showing wide irregular flange and small, round lumen (USNM 165472 from colln. D979 $\mathrm{CO}$ ).

81. Small crinoid brachial plate with lateral projections and narrow ambulacral groove (USNM 165473 from colln. D979 CO).

82. Wide U-shaped crinoid brachial plate (USNM 165474 from colln. D979 CO).

83-84. Five-part columnal. Entire columnal from an unknown echinoderm showing segments and large pentagonal lumen plus an individual segment (84) (USNM 165475a-b from colln. D979 $\mathrm{CO})$.

85-86. "Tiny V-shaped plates." Exterior and interior of tiny plates of unknown origin with a concave facet on the summit (USNM $165476 a-b$ from colln. D1634 CO). 
few examples of both types have been found with radial facets for the attachment of arms (fig. 1, 40, 44), implying a crinoid affinity. One or both of these may be related to the Middle Ordovician crinoid genus Palaeocrinus or to some other genus with similar foldlike respiratory structures.

Several types of distinctive plates belong to echinoderms not identified at present. Probably the most widespread and common type of plate in this upper fauna is the polygonal "ridge and epispire plates." These plates are relatively small and thick with closely spaced ridges and grooves extending out from the plate center to the sides (fig. 1, 45-48). These grooves then extend the sutures as epispirelike openings (fig. 1, 48). A few examples show that the exterior of these plates may originally have been covered by a thin sheet of calcite that closed off the grooves externally. If true, these plates would then resemble the numerous calyx plates found in the rhombiferan cystoid(?) Caryocystites from the Lower and Middle Ordovician (Kesling, 1967, p. S229). These plates are very widespread in the upper echinoderm fauna of the Antelope Valley, occurring in nearly all the known collections, often as the dominant plate type.

Another common plate type of unknown origin is the "flat-topped ridged plates" (fig. 1, 61-64). These are similar to the "domed ridged plates" in the lower fauna but have a different profile in edge view (fig. 1, 64). They are small, 5- to 10 -sided plates with porelike openings apparently at the plate corners. A few small and strongly domed ridged plates also occur in the upper fauna (fig. 1, 65-67); these may also be closely related to the "domed ridged plates" in the lower fauna.

Another very distinctive and unusual type of 2- to 5-sided plate consists of large, rounded ridges with intervening concave areas that bear short slits (fig. 1, 55-60). Internally, the large ridges are developed into hollow folds extending toward each suture (fig. 1, 56-57). Most likely these "multilimb fold plates" belong to some unknown crinoid, but I have been unable to find anything similar to them in the described record.

"Tiny V-shaped plates" (1-2 mm) with a possible arm(?) facet are very abundant in a single collection (D1634, CO) near the top of the Antelope $\mathrm{V}$ alley Limestone. Only one type of plate is present (fig. $1,85-86$ ), and it is not known how these plates fit together or whether they were, in fact, calyx plates. A few much larger crinoid radial(?) plates with a similar type of arm(?) facet are also known from this upper fauna (fig. 1, 49-52). However, they are at least ten times larger, have a different shape, and bear a conspicuous groove running up the inside surface of the plate to the facet (fig. 1, 49, 51), perhaps used for a nerve(?) canal. These larger plates are of unknown crinoid origin.

Unusual "high crest plates" are also found in a few collections. They are high, slightly flaring, short, thin plates with a deep $\mathrm{V}$-shaped groove in the top and a shallow groove in the bottom (fig. 1, 71-74). These plates were apparently linked together lengthwise to form an elongate vertical structure (fig. 1, 74), which may have stood vertically on an ambulacrum to protect food-gathering appendages attached alongside. They are somewhat similar to the ambulacral crests found in the Middle Ordovician parablastoid Blastoidocrinus (Sprinkle, 1972) and to the arm crests in the Middle Silurian rhombiferan cystoid Caryocrinites (Sprinkle, 1968). However, as none of the associated plates can be assigned to the same taxon as these crest plates, they are still of unknown origin.

Small polygonal plates with diplopores occur in this upper fauna, apparently representing an unknown diploporan cystoid. Most of these plates have an irregular shape, and the depressions with double pores are scattered around on the exterior surface with little orientation (fig. 1, 68-69). The two pores in each exterior diplopore diverge toward the interior, which usually has an irregular arrangement of single pores. A single rhombiferan cystoid is also sparsely represented in the upper fauna. Unlike the rhombiferans in the lower fauna, this taxon has relatively small plates with only one or two restricted groupings of disjunct pectinirhombs surrounded by a prominent ridge (fig. 1, 70). These features imply a probable echinoencrinitid or callocystid origin (Kesling, 1967, p. S184-S191, S199-S218).

A single possible blastoid plate has also been found in one of the acid-residue collections (D1634 CO) near the top of the Antelope Valley Limestone. This apparent deltoid plate from a fissiculate blastoid has been described in detail elsewhere (Sprinkle, 1972). If the identification is correct, then this new occurrence extends the range of blastoids back from the Middle Silurian to the Middle Ordovician. A few apparent marginal plates from a rhipidocystid eocrinoid also occur in the upper fauna. These are somewhat smaller than, but otherwise similar to, the abundant rhipidocystid marginals occurring in the lower fauna.

Five-piece partially fused columnals (fig. 1, 83-84), flanged thin columnals (fig. 1,80 ), and round columnals with a complex star-shaped lumen (fig. 1, 79) are common in this upper fauna in the Antelope Valley. Some of these are grossly similar to crinoid columnals described by Moore and Jeffords (1968) from the upper Paleozoic, but they probably belong to different genera. Several types of characteristic brachial plates (fig. 1, 75-78, 81-82) belonging to some of the unidentified crinoids are also present. Other types of small calyx plates have also been observed but are not common enough to warrant description here.

\section{AGE OF THE UPPER FAUNA}

The abundance and distinctive nature of many of the plates in the upper echinoderm fauna make them useful as index fossils for identifying and correlating the upper part of the Antelope Valley Limestone from section to section. However, the lack of complete or satisfactorily identified echinoderms limits their usefulness in dating the Antelope Valley or correlating it to other areas. This upper echinoderm fauna is somewhat more advanced than the lower fauna, because it 
contains few of the relict eocrinoids and none of the parablastoids common lower in the section, whereas it does contain somewhat more advanced rhombiferan cystoids, many more of the gradually appearing crinoids, and the only example of a possible blastoid plate known from the Ordovician. Only the hybocrinid crinoid plates are well-enough identified at present to have any value in correlation, and this is minimal. The nearest relative to the new hybocrinid genus is Cornucrinus Regnell (1948) from the late Middle Ordovician and Early Silurian of Sweden; however, this European genus is clearly much more specialized than the Antelope Valley taxon inasmuch as it has reduced plating and modified radials. Other hybocrinid genera range in age from late Early Ordovician to late Middle Ordovician, and the Antelope Valley hybocrinid could fit anywhere in this sequence. Thus, the incompletely known upper echinoderm fauna in the Antelope Valley Limestone at present has little value in correlating outside the Great Basin area.

\section{CONCLUSIONS}

On the basis of the collections presently available, these two echinoderm faunas in the Antelope Valley seem to occupy different parts of the sections and show little intermixing. To test this preliminary observation and to study the possible value of echinoderms as guide fossils in comparison to other invertebrate groups more commonly used (for example, trilobites, graptolites, and brachiopods), I have plotted the occurrence of these echinoderm-bearing USGS collections (fig. $2, B)$ on a combined zonation and range chart based on trilobites, brachiopods, and other fossils from Ross (1970, fig. 2 ) and Ross and Ingham (1970, table 1). The positions of the echinoderm collections in this chart were based on the ranges of other fossils occurring with the echinoderms. Very little stratigraphic information was used in compiling the chart in order to reduce problems caused by facies changes and possible unconformities. However, the use of some stratigraphic information was unavoidable, inasmuch as some of the echinoderm-bearing collections contain few other diagnostic fossils and by themselves could not be plotted on the chart unless information from other nearby collections was used.

Figure 2 shows that these two echinoderm faunas occur in different parts of the Antelope Valley without overlap and with one exception occupy relatively narrow intervals corresponding to the Orthidiella and Anomalorthis brachiopod zones of Cooper (1956, p. 126-127), modified by Ross (1964, p. C74-C79; 1970, p. 45-50). The lower echinoderm fauna is concentrated in the upper part of the Orthidiella zone, with one questionable occurrence (USGS colln. D716 CO; see Ross, 1964, p. C22) lower in this zone. This distribution may be somewhat biased by the occurrence of most of the known Antelope Valley bioherms and biostromes (where echinoderms are especially abundant and varied) in the upper part of the Orthidiella zone. The upper echinoderm fauna appears well above the highest occurrence of the lower fauna, and it is concentrated primarily in the lower and middle portions of the Anomalorthis zone. The single occurrence of echinoderms at the base of the overlying Eofletcheria-Kirkina zone (colln. D1634 CO), which is also within 80 feet of the top of the Antelope Valley stratigraphically, contains several elements ("tiny V-shaped plates," single known blastoid plate) not found in any of the other occurrences of the upper echinoderm fauna. This may indicate that an additional higher fauna may possibly be present at the top of the Antelope Valley. However, this could not be confirmed, because no other echinoderm-bearing collections from this interval were present in the studied material.

The inferred ranges of several of the elements in these two faunas (fig. 2, $C$ ) are similar in length to those of other invertebrates (fig. $2, A$ ) often used as guide fossils for parts of the Antelope Valley (for example, species of Anomalorthis and Palliseria). Thus, several of the more distinctive elements in these echinoderm faunas may have definite use as guide fossils in the Antelope Valley Limestone.

The grouping of these echinoderm faunas on figure 2 also supports the zonation and correlation system proposed by Ross (1970). The fact that the two known echinoderm faunas fall into two discrete and unmixed groups when plotted on a range chart (Ross, 1970, fig. 2) based on brachiopods, trilobites, and other fossils suggests that the overall zonation system and correlations used to make up this chart are probably valid. It also suggests that all of the "shelly fauna" may show the same pattern when plotted on a chart of this type or when correlated from section to section.

The general pattern of these echinoderm faunas and the detailed distribution of some of the separate elements also support some of the specific correlations made by Ross (1970). The occurrence of a large and varied lower echinoderm fauna within and just below the sponge beds at Ikes Canyon strongly supports the assignment of these beds to the upper part of the Orthidiella zone (Ross, 1970, p. 47) and their likely correlation with the large bioherm at Meiklejohn Peak in southwestern Nevada. These two sections share many of the same echinoderms from the lower fauna, including the same two species of the parablastoid Blastoidocrinus. Also, Ross' correlation of collections D1764, CO at Lone Mountain and D1572 CO from the Groom Range (1970, p. 17, 37) based on the occurrence of the distinctive brachiopods Asymphylotoechia nolani and Anomalorthis fascicostellatus is strongly supported by the occurrence of two collections (D1763 CO and D1574, $\mathrm{CO}$; see fig. 2, B) bearing numerous pustular hybocrinid plates ("Cystid: Has coarse pustules"-Ross, 1970, p. 36) as the only echinoderm element, just 8 and 10 feet, respectively, below these other collections.

In conclusion, silicified echinoderm plates from the Antelope Valley Limestone of Nevada and eastern California can be separated into two distinctive faunas that hold the same relative positions across much of the sampled area. Elements in these faunas are distinctive in the field; often very abundant, and well silicified, enabling recovery in large numbers by acid 


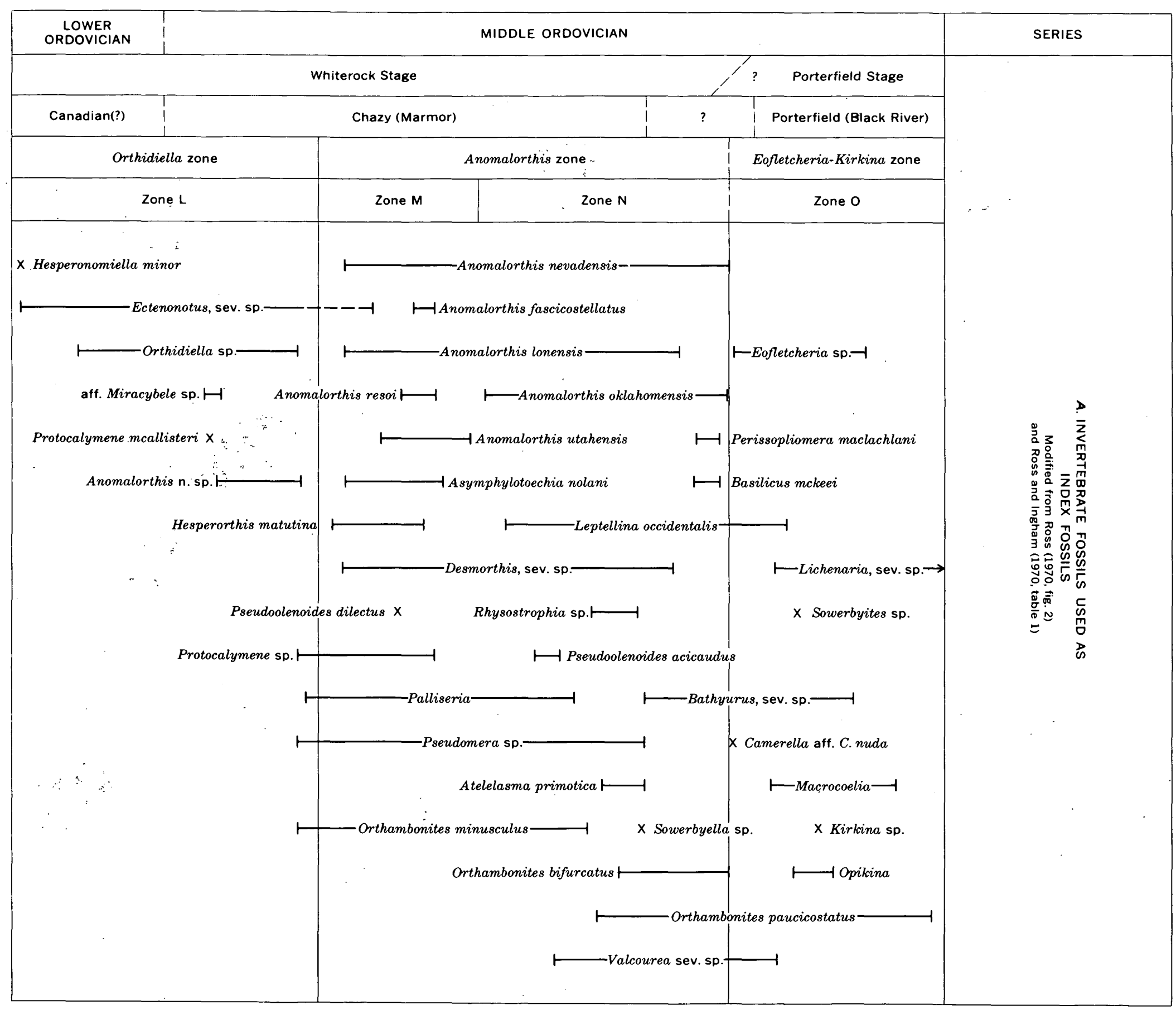




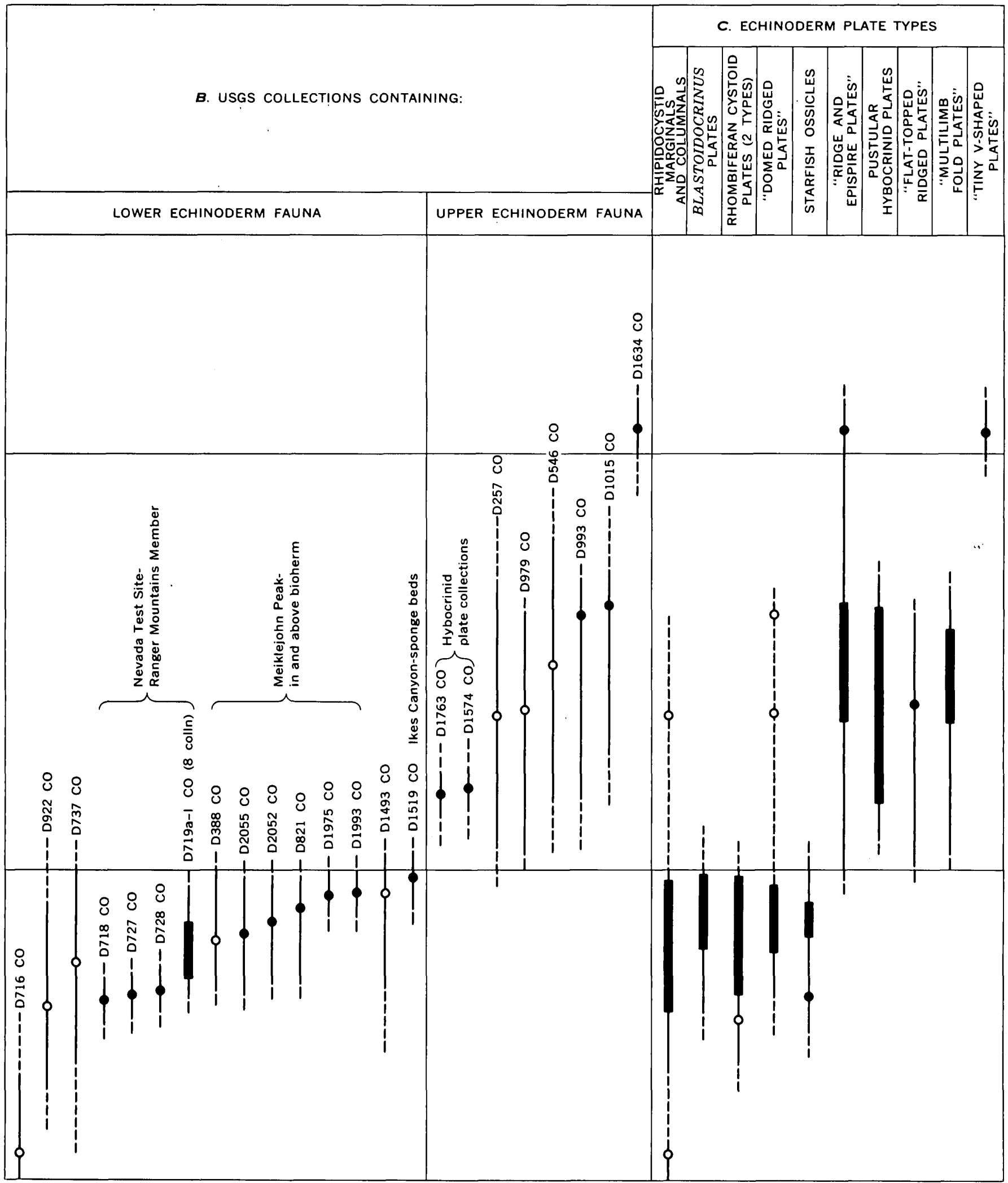

Valley Limestone. Solid circle, position of single occurrence of echinoderm fauna; open circle, questionable position of single occurrence; bar, position of several closely spaced occurrences. Solid line, range of index fossils in collection; dashed line, possible extension of range. 
etching. These features imply that echinoderm plates represent another element of the shelly fauna which can be used to zone the Antelope Valley within the Great Basin and in some cases to correlate the Antelope Valley with the Ordovician of other areas and the standard Ordovician section. A preliminary study of these echinoderm faunas indicates a likely Chazy (Marmor) age for much of the Antelope Valley Limestone and a general agreement with the correlations and zonal framework for the Antelope Valley as proposed by Ross (1970).

\section{REFERENCES}

Aitken, J. D., and Norford, B. S., 1967, Lower Ordovician Survey Peak and Outram Formations, southern Rocky Mountains of Alberta: Bull. Canadian Petroleum Geology, v. 15, no. 2, p. 150-207, 3 pls., 7 figs.

Bassler, R. S., 1941, The Nevada early Ordovician (Pogonip) sponge fauna: U.S. Natl. Mus. Proc., v. 91, no. 3126, p. 91-102, pls. 19-24.

Byers, F. M., Jr., Barnes, Harley, Poole, F. G., and Ross, R. J., Jr., 1961, Revised subdivision of Ordovician system at the Nevada Test Site and vicinity: Art. 189 in U.S. Geol. Survey Prof. Paper 424-C, p C106-C110, 1 fig., 1 table.

Cooper, G. A., 1956, Chazyan and related brachiopods [U.S.-Canada]: Smithsonian Misc. Colln., v. 127, pt. 1, 1024 p., 269 pls.

Derby, J. R., 1969, Revision of Lower Ordovician-Middle Ordovician boundary in western Arbuckle Mountains, Oklahoma: Oklahoma Geol. Survey Guidebook 17, p. 35-37, 1 table.

Harris, R. W., 1957, Ostracoda of the Simpson Group of Oklahoma: Oklahoma Geol. Survey Bull. 75, 333 p., 10 pls., 33 figs.

Hudson, G. H., 1907, On some Pelmatozoa from the Chazy limestone of New York: New York State Mus. Bull. 107, p. 97-131, 10 pls., 8 figs.

Kesling, R. V., 1967, Cystoids, in Moore, R. C., ed., Treatise on invertebrate paleontology, pt. S, Echinodermata 1: New York and Lawrence, Kans., Geol. Soc. America (and Kansas Univ. Press), p. S85-S267, figs. 32-157.

Lane, N. G., 1970, Lower and Middle Ordovician crinoids from west-central Utah: Brigham Young Univ. Geology Studies, v. 17, pt. 1, p. 3-17, 1 pl., 2 figs.

Moore, R. C., and Jeffords, R. M., 1968, Classification and nomencla- ture of fossil crinoids based on studies of dissociated parts of their columnals: Kansas Univ. Paleont. Contr., art. 9, p. 1-86, pls. 1-28, figs. 1-6.

Phleger, F. B., Jr., 1933, Notes on certain Ordovician faunas of the Inyo Mountains, California: Southern California Acad. Sci. Bull., v. 32, pt. 1, p. 1-21, pls. 1-2, 7 figs.

Regnell, Gerhard, 1948, Swedish Hybocrinida (Crinoidea Inadunata Disparata; Ordovician-Lower Silurian): Arkiv Zoologi, v. 40A, no. 9, p. 1-27, 4 pls., 4 figs.

Ross, D. C., 1966, Stratigraphy of some Paleozoic formations in the Independence quadrangle, Inyo County, California: U.S. Geol. Survey Prof. Paper 396, 64 p., 5 pls., 19 figs.

Ross, R. J., Jr., 1951, Stratigraphy of the Garden City formation in northeastern Utah and its trilobite faunas: Peabody Mus. Nat. History Bull. 6, 161 p., 35 pls., 4 figs.

1964, Middle and Lower Ordovician formations in southernmost Nevada and adjacent California: U.S. Geol. Survey Bull. 1180-C, $101 \mathrm{p.}, 1$ pl., 12 figs.

1967, Some Middle Ordovician brachiopods and trilobites from the Basin Ranges, western United States: U.S. Geol. Survey Prof. Paper 523-D, 43 p., 11 pls.

- 1968, Brachiopods from the upper part of the Garden City Formation (Ordovician), north-central Utah: U.S. Geol. Survey Prof. Paper 593-H, 13 p., 4 pls.

- 1970, Ordovician brachiopods, trilobites, and stratigraphy in eastern and central Nevada: U.S. Geol. Survey Prof. Paper 639, 103 p., 22 pls., 2 figs.

1971, Fossils from the Ordovician bioherm at Meiklejohn Peak, Nevada: U.S. Geol. Survey Prof. Paper 685. [In press]

Ross, R. J., Jr., and Cornwall, H. R., 1961, Bioherms in the upper part of the Pogonip in southern Nevada: Art. 97 in U.S. Geol. Survey Prof. Paper 424-B, p. B231-B233, figs. 97.1-2.

Ross, R. J., Jr., and Ingham, J. K., 1970, Distribution of the Toquima-Table Head (Middle Ordovician Whiterock) faunal realm in the Northern Hemisphere: Geol. Soc. America Bull., v. 81, no. 2, p. 393-408, 5 figs., 2 tables.

Shaw, F. C., 1968, Early Middle Ordovician Chazy trilobites of New York: New York State Mus. and Sci. Service Mem. 17, 163 p., 24 pls., 16 figs., 8 tables.

Sprinkle, James, 1968, The "arms" of Caryocrinites, a Silurian rhombiferan cystoid, in Abstracts for 1967: Geol. Soc. America Spec. Paper 115, p. 210.

_ 1972, Morphology and evolution of blastozoan echinoderms: Mus. Comp. Zoology Bull. [In press] 


\title{
GEOLOGY OF THE CARTER CAVES SANDSTONE (MISSISSIPPIAN) IN NORTHEASTERN KENTUCKY
}

\author{
By KENNETH J. ENGLUND and JOHN F. WINDOLPH, Jr., \\ Washington, D.C.
}

Work done in cooperation with the Kentucky Geological Survey

\begin{abstract}
The Carter Caves Sandstone consists of rather pure quartzose and conglomeratic sandstone that appears to have been deposited largely as a marine offshore bar. It is a sandstone that averages about 40 feet in thickness, ranges between 2 and 8 miles in width, and is alined north-northeast to northeast for 30 miles. Previous assignment of this sandstone to the Pennsylvanian System is untenable, as recent studies show an intertonguing relation with shale and limestone of the Newman Limestone (Upper Mississippian). There is similarity of lithology and sequential relation with some beds of the overlying Lee Formation.
\end{abstract}

Mississippian and Pennsylvanian formations exposed in Carter County, Ky., consist of intercalated beds of sandstone, siltstone, shale, coal, clay, and limestone that were deposited in diverse continental and marine environments. Within this sequence occurs a distinct sandstone that is herein named the Carter Caves Sandstone. It is named for the Carter Caves State Park where it is well exposed capping the fringes of box canyons underlain by cavernous limestone.

Previous studies have noted the occurrence of this sandstone and have generally assigned it, unnamed, to the Lee Formation of Pennsylvanian age. Crider (1913) referred to this partly conglomeratic sandstone as the conglomerate of Pennsylvanian age. Subsequently, in eastern Kentucky, the term Lee Formation was applied to basal Pennsylvanian strata consisting largely of conglomeratic sandstone, and in Carter County this formation included, unnamed, the Carter Caves Sandstone (McGrain; 1954, fig. 15; 1956, p. 11; Thomas and others, 1955, p. 17). Also, the sandstone has been included with that of the Lee Formation of Pennsylvanian age on geologic maps of the area.

Contrary to the previous age assignment, Sheppard and Dobrovolny (1963) established a Late Mississippian age for this sandstone on the basis of a marine invertebrate fauna of Late Mississippian age in an overlying shale and limestone sequence. They also noted that the deposition of sandstone that is typical of the Lee Formation began during Late Mississippian time and indicated that the observed relations with laterally equivalent strata may be similar to the intertonguing at the base of the Lee Formation in southeastern Kentucky (Englund and Smith, 1960).

Current investigations consist of geologic mapping and stratigraphic studies which have traced the Carter Caves Sandstone over an area of about 70 square miles, principally in the Ault, Grahn, and Olive Hill quadrangles (fig. 1). Additional data over 30 square miles were obtained from geologic quadrangle maps (Patterson and Hosterman, 1962; Denny, 1964; Sheppard, 1964; Englund and Delaney, 1966). In the Haldeman quadrangle the Carter Caves Sandstone is represented by sandstone beneath the Olive Hill clay of Crider (1913) as shown by Patterson and Hosterman (1962, pl. 4, sec. 15 , and pl. 5 , sec. 4$)$.

\section{STRATIGRAPHY}

The Mississippian and Pennsylvanian rocks exposed in the outcrop area of the Carter Caves Sandstone total about $\mathbf{8 0 0}$ feet in thickness and have been divided into four formationsthe Borden, Newman, Lee, and Breathitt.

The Borden Formation is composed almost entirely of light-greenish-gray evenly bedded slightly calcareous siltstone and minor amounts of greenish-gray and grayish-red shale. Marine fossils of Early Mississippian age are common throughout. The formation underlies the area of study, and as much as 300 feet of beds in the upper part are exposed.

The Newman Limestone consists of a lower limestone unit and an upper shale unit that locally are separated by an unconformity. The lower unit is largely a light-gray to light-olive-gray relatively pure limestone as much as $\mathbf{1 2 0}$ feet thick. Some of its beds contain chert nodules, oolites, or fine to medium grains of quartz sand. Locally, ancient shale-filled sinkholes as much as 50 feet deep are present in the upper part 


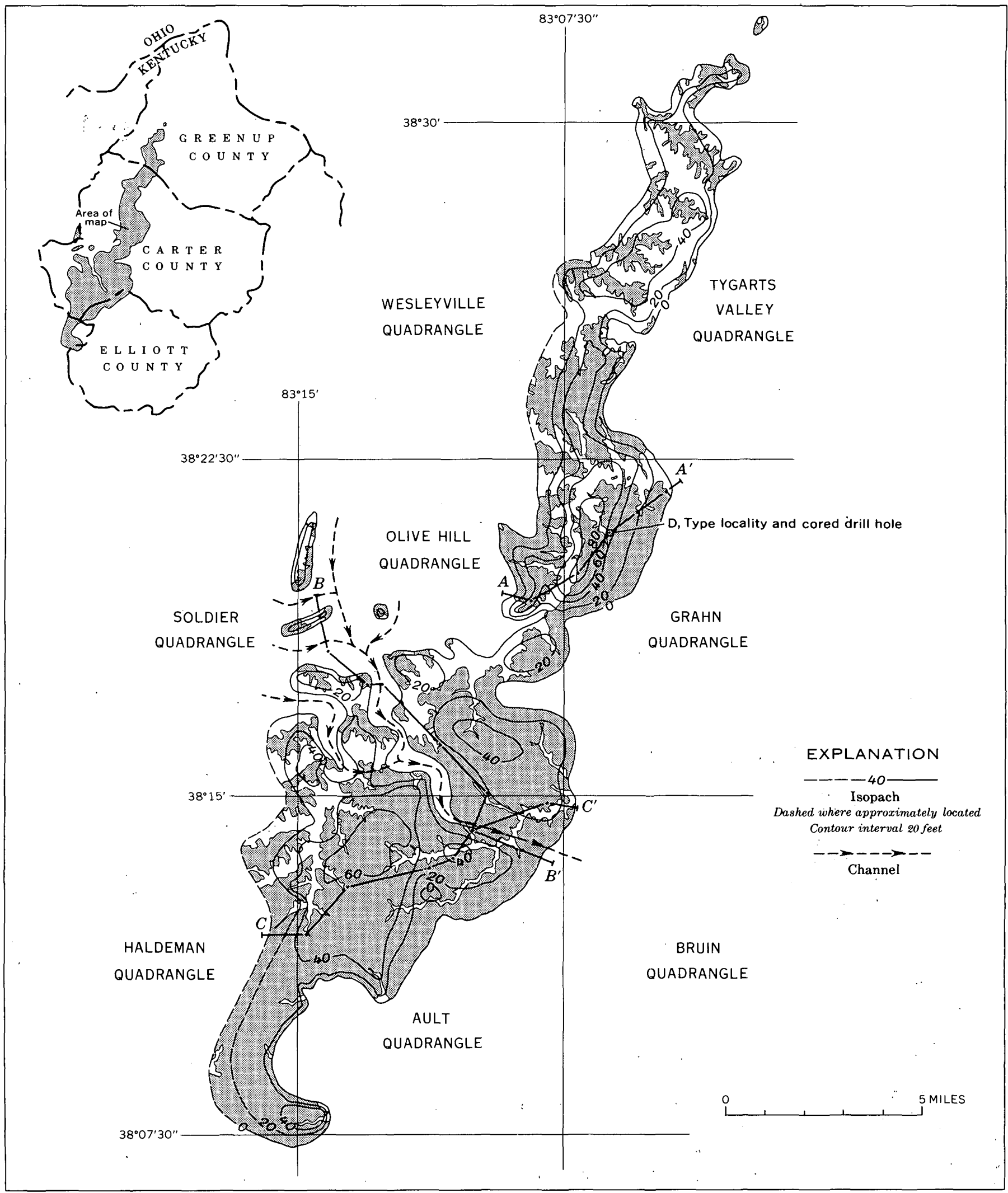

Figure 1.-Map.showing area of outcrop and thickness of the Carter Caves Sandstone (shaded). Cross sections shown in figure 2. 
of the limestone. The upper unit contains 0-100 feet of interbedded slightly calcareous medium-gray, greenish-gray, and grayish-red shale which includes one or two limestone beds as much as 18 inches thick and, locally, a grayish-black chert bed as much as 8 inches thick. In the area of study, the term Newman has been restricted to the lower or predominantly limestone part of the sequence, and the name Pennington(?) has been applied to the overlying interbedded shale and limestone (Sheppard, 1964). However, in the type area of the Pennington Formation, Lee County, Va., approximately the upper half of the Newman Limestone consists of shale and limestone, and the overlying Pennington is largely sandstone and shale, including the widespread Stony Gap Sandstone Member at its base. In consideration of this relation, the shale and limestone in question in the area of study are included in the Newman Limestone in this article. Marine fossils indicate a Late Mississippian age for the formation. The formation is extensive in the area, but it has been completely removed by erosion locally before the deposition of overlying units (fig. 2, sec. $\left.B-B^{\prime}\right)$.

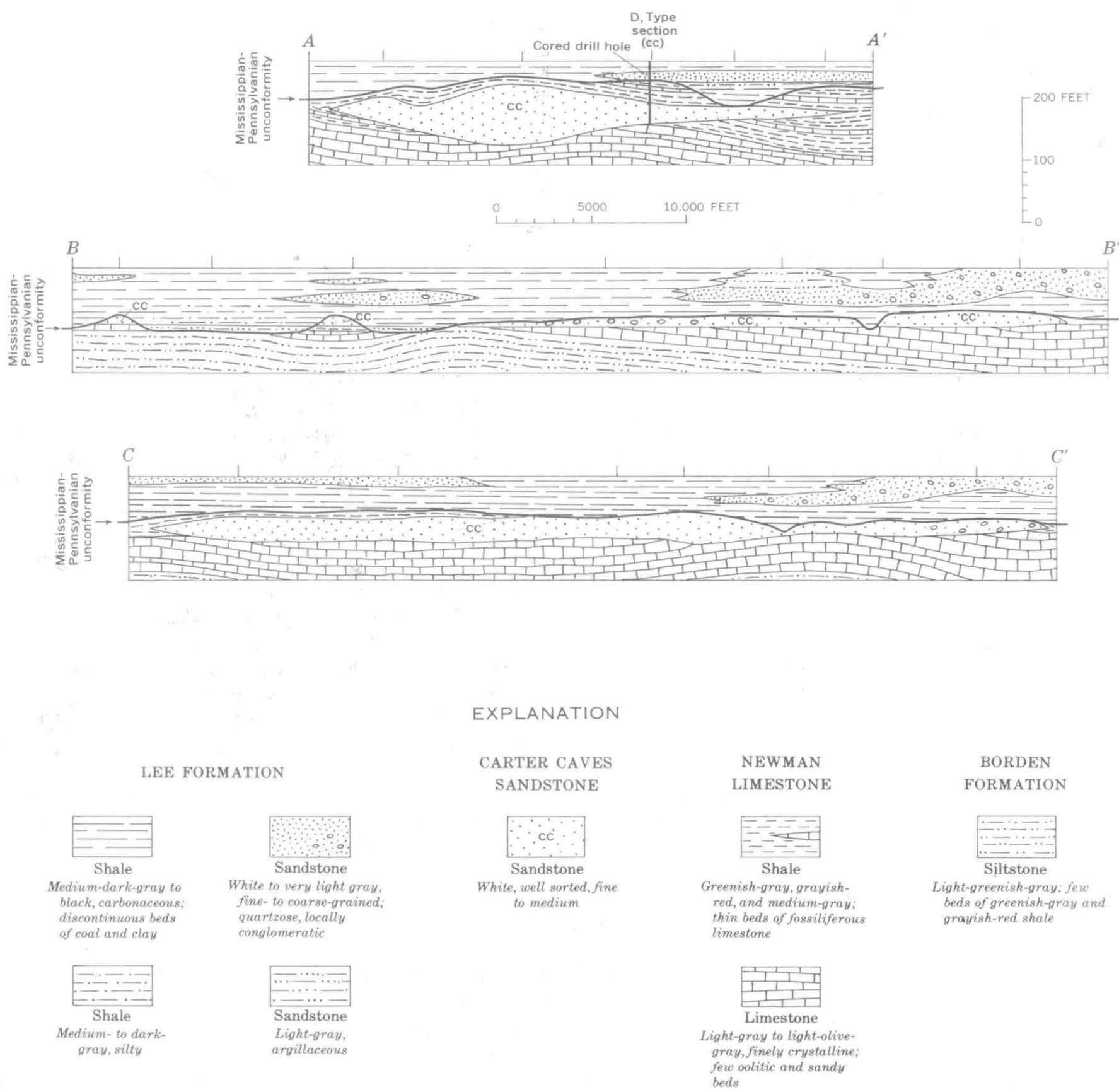

Figure 2.-Cross sections of the Carter Caves Sandstone (cc). Lines of section shown in figure 1. Drill hole projected onto section from a point about 100 feet east. 
Regionally, the Lee Formation is characterized by thick beds of resistant quartzose partly conglomeratic sandstone. In the area of study the formation consists of similar lithology in beds as much as $\mathbf{1 5 0}$ feet thick that in places are separated by medium to dark-gray shale and siltstone and discontinuous beds of coal and clay. Also included in the Lee are a few thin beds of rather impure quartz sandstone. The proportion of sandstone decreases westward across the area. The quartzose sandstone deposits are barlike and trend north-northeast to northeast.

The Breathitt Formation consists of interbedded medium- to dark-gray shale, sandstone, and siltstone and lesser amounts of coal and underclay. In contrast to the sandstone beds in the Lee Formation, those in the Breathitt are thinner, less resistant, and contain about 50-60 percent quartz. The Breathitt occupies hilltop areas where it attains a maximum thickness of about 200 feet.

\section{CARTER CAVES SANDSTONE}

The Carter Caves Sandstone occurs in a 2-8-mile-wide lens that extends north-northeast for about 30 miles from western Elliot County, across Carter County, and into western Greenup County (fig. 1). It is composed almost entirely of white well-sorted fine to medium quartz grains. Analyses of three samples from former mining operations in the bed indicate 95.6-97.9 percent quartz (McGrain, 1956, p. 11, 12, and 20). Other constituents of the sandstone include minor amounts of clay, limonite, and carbonate cement, and occasional heavymineral grains. The sandstone is crossbedded, moderately resistant to erosion, and is usually well exposed in precipitous cliffs. Conglomerate lenses, consisting of well-rounded white quartz pebbles as much as $1 / 2$ inch in diameter, occur in a broad lobe that occupies parts of the Olive Hill and Ault quadrangles.

The type section of the Carter Caves Sandstone is exposed in a cliff just below and west of Statc Highway 182 about $1 / 2$ mile north of the junction with U.S. Route 60 . There, it consists of 45 feet of white to very light gray fine-grained well-sorted quartzose sandstone. It disconformably overlies greenish-gray shale and limestone and is overlain by varicolored shale and two thin limestone beds of the Newman (fig. 2, sec. $A-A^{\prime}$ ). A similar section was penetrated by a cored drill hole about 100 feet east of the highway near the type section (Sheppard and Dobrovolny, 1963). Throughout most of the area of study, the lower boundary is a disconformable contact except at the thin distal edges of the Carter Caves where the sandstone is conformable with the enclosing shale. The disconformity is most evident in the broad lobe in the Olive Hill quadrangle where the Newman Limestone is absent and the Carter Caves is in contact with the Borden Formation. The top contact is conformable with overlying beds of varicolored shale of the Newman, but in most of the area the overlying Newman shale and the upper part of the Carter Caves have been deeply scoured by channels filled with sand or shale of the Lee Formation (fig. 2, sec. $B-B^{\prime}$ ). The Carter Caves attains a maximum thickness of about 100 feet in the western part of the Grahn quadrangle.

Rocks equivalent to the Carter Caves Sandstone were generally considered to be Pennsylvanian in age until Sheppard and Dobrovolny $(1963$, p. E46-E47) reported finding a marine invertebrate fauna of Late Mississippian age, listed below, in the overlying shale and limestone from the cored drill hole near State Highway 182.

\author{
USGS 20207-PC \\ Orthotetes cf. O. kaskaskienses (McChesney) Allorisma sp.; \\ abundant \\ USGS 20209-PC \\ Echinoderm debris, indet.; abundant \\ Fenestrate bryozoans, indet. \\ Ramose bryozoans, undet. \\ Orthotetes cf. O. kaskaskiensis (McChesney) \\ Diaphragmus cf. D. cestriensis (Worthen) \\ Ovatia ovata (Hall) \\ Spirifer cf. S. increbescens Hall \\ Composita subquadrata (Hall) \\ Aviculopecten sp. \\ Bellerophon sp. \\ Stroparollus (Euomphalus) sp. \\ Murchisonia? sp.
}

This assemblage and several others identified by J. T. Dutro, Jr. (Sheppard and Dobrovolny, 1963, p. E46), were assigned a late Chester age. The next younger marine invertebrate fossils, mostly brachiopods, are in a thin bed of argillaceous limestone or calcareous sandstone that is locally within 90 feet of the unconformity and immediately above the upper conglomeratic sandstone, illustrated in sections $B-B^{\prime}$ and $C-C^{\prime}$. A coiled cephalopod, Gastrioceras n. sp. (USGS coll. 22067-PC), from the calcareous bed was identified by MacKenzie Gordon, Jr. (written commun., 1965), who assigned it a Pennsylvanian age.

On the basis of the mapped stratigraphic relations and the paleontological data, the unconformity indicated in figure 2 most likely represents the regionally important MississippianPennsylvanian unconformity. However, this unconformity is obscure in the northwest corner of the Grahn quadrangle and to the north where the Carter Caves Sandstone is in contact with younger lithologically similar sandstone of the Lee Formation that occurs above the unconformity. The sandstones are in contact as a result of nondeposition or erosion of beds along the unconformity.

\section{ORIGIN OF THE CARTER CAVES SANDSTONE}

After the lower or predominantly limestone phase of the Newman was deposited, it was uplifted and locally subjected to subaerial weathering. The effects are most evident in the westernmost part of the area, possibly reflecting the positive character of the Cincinnati arch to the west (fig. 3), and resulted in the development of a karst topography which contains sinkholes as much as $\mathbf{5 0}$ feet deep in the northwest corner of the Bruin quadrangle. 


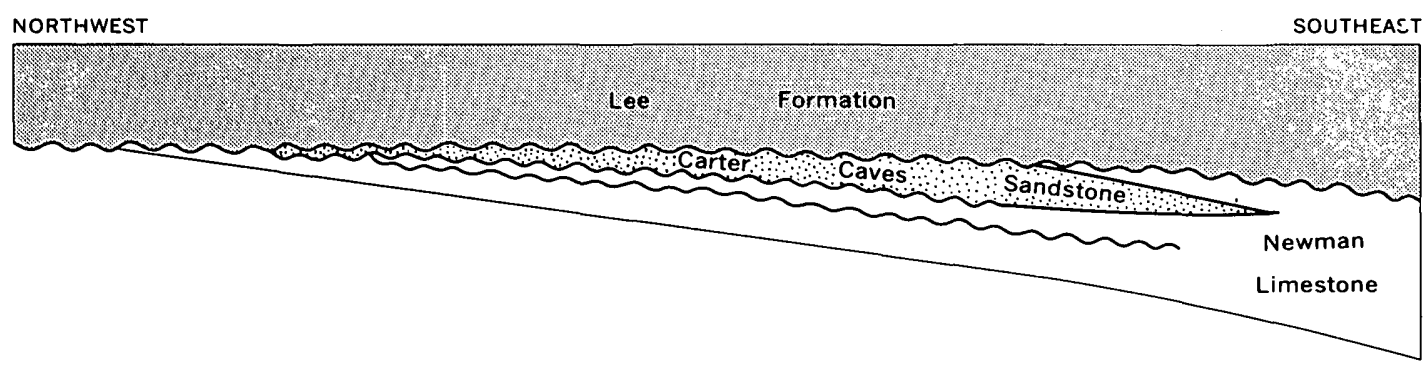

Figure 3.-Diagrammatic section across the area of study, showing the relation of the Lee Formation to the Carter Caves Sandstone and the Newman Limestone. Note the northwestward mergence of three unconformities; the uppermost appears to be the Mississippian-Pennsylvanian systemic boundary.

Subsequent deepening of the sea and inundation of the area permitted the deposition of marine muds that now form the slightly calcareous varicolored shale and thin limestone beds in the upper part of the Newman. Both the sinkholes and the adjacent areas received sediments which thickened to the southeast. Concurrently, drainage from the east flank of the Cincinnati arch also brought coarser sediments into the area, beginning with medium- to coarse-grained pebbly sand which constituted the initial deposits in the deltalike lobe that occupies the southern part of the Olive Hill quadrangle and the northern part of the Ault quadrangle. Sand transported into the lobe was subjected to the winnowing action of waves and shore currents which dispersed incoming fine- to mediumgrained sand north-northeastward to form an elongate bar of clean well-sorted quartz sand.

A source of sand and pebbles was probably from erosion of older Mississippian rocks. Sand is a common constituent in older Mississippian rocks in the area. Quartz pebbles, which make up a very small part of the Carter Caves Sandstone, were observed by Patterson and Hosterman (1962, p. F18) in the Ste. Genevieve Limestone in the Ault quadrangle, and they are common to abundant in some parts of the Cuyahoga and Logan Formations (Mississippian) in Ohio (Hyde, 1953, p. 20-21, 98-120, 188-189). A small spitlike feature formed at the southwest edge of the lobe where the dispersal of sand to the southwest was less effective because of the northeast trend of the shore currents. Preferred progradation to the northnortheast is also indicated by crossbedding in the sand which has a strong easterly to northeasterly trend. Marine transgression accompanied by a gradual decrease in the influx of sand resulted in the mud overlapping the edges of the bar and, in places, extending across the top of the bar. After the deposition of the Carter Caves Sandstone and läterally equivalent shale, the area was uplifted and eroded, particularly near the western edge, where only a few isolated remnants of the sandstone and underlying limestone remain (fig. 2, sec. $\left.B-B^{\prime}\right)$. Other evidence of the erosion after the deposition of the Carter Caves Sandstone includes a conspicuous drainage pattern southeastward across the former deltalike lobe with channels as much as 40 feet deep (fig. 1). Deposition above this unconformity was largely continental and took place in or near broad coastal swamps and lagoons.

In the western part of the area, where Pennsylvanian strata are in contact with the Borden Formation (Mississippian), the basal Pennsylvanian bed contains as much as 3 feet of poorly sorted pebbles and boulders of locally derived material such as chert, sandstone, and limestone. The basal bed is commonly overlain by carbonaceous muds. Within the channels, sedimentation began with the deposition of 0-10 feet of muddy impure quartz sand, overlain by carbonaceous muds containing lenticular beds of clay and peat which also extend beyond the channels. There, the basal beds include the discontinuous but commercially valuable Olive Hill clay bed of Crider (1913) which consists largely of refractory flint clay that appears to have formed by the leaching and alteration of fine sediments under acid conditions in a coastal swamp (Patterson and Hosterman, 1962, p. F80). In places the flint clay is 10-15 feet thick and is oolitic. The swamp sediments, represented by muds, clays, and peat, intertongued near the southeast edge of the study area with sand and pebbly sand of a barrier bar which tongued out to the northwest (fig. 2 , sec. $B-B^{\prime}$, $\left.C-C^{\prime}\right)$.

\section{REFERENCES}

Crider, A. F., 1913, The fireclays and fire clay industries of the Olive Hill and Ashland districts of northeastern Kentucky: Kentucky Geol. Survey, ser. 4, v. 1, pt. 2, p. 589-711.

Denny, C. S., 1964, Geology of the Brushart quadrangle, Kentucky: U.S. Geol. Survey Geol. Quad. Map GQ-324.

Englund, K. J., and DeLaney, A. O., 1966, Geologic map of the Bruin quadrangle, Elliott and Carter Counties, Kentucky: U.S. Geol. Survey Geol. Quad. Map GQ-522.

Englund, K. J., and Smith, H. L, 1960, Intertonguing and lateral gradation between the Pennington and Lee Formations in the Tri-state area of Kentucky, Tennessee, and Virginia [abs.]: Geol. Soc. America Bull., v. 71, no. 12, pt. 2, p. 2015.

Hyde, J. E. (Marple, M. F., ed.), 1953, The Mississippian formations of central and southern Ohio: Ohio Div. Geol. Survey Bull. 51, 355 p.

McGrain, Preston, 1954, Geology of the Carter and Cascade Caves area: Kentucky Geol. Survey, ser. 9, Spec. Pub. 5, 32 p.

- 1956, Recent investigations of silica sands of Kentucky-No. 2: Kentucky Geol. Survey, ser. 9, Rept. Inv. 11, 32 p. 
Patterson, S. H., and Hosterman, J. W., 1962, Geology and refractory clay deposits of the Haldeman and Wrigley quadrangles, Kentucky: U.S. Geol. Survey Bull. 1122-F, 113 p.

Sheppard, R. A., 1964, Geology of the Tygarts Valley quadrangle, Kentucky: U.S. Geol. Survey Geol. Quad. Map GQ.289.

Sheppard, R. A., and Dobrovolny, Ernest, 1963, Mississippian-
Pennsylvanian boundary in northeastern Kentucky: Art. 192 in U.S. Geol. Survey Prof. Paper 450-E, p. E45-E47.

Thomas, R. N., Ferm, J. C., Fisher, F. L., Jr., Huddle, J. W., McGrain, Preston, and Walter, F. H., 1955, Itinerary-Exposures of producing formations of northeastern Kentucky: Geol. Soc. Kentucky Field Trip, April 1955, Guidebook, 32 p. 


\title{
REVISED CORRELATION OF SOME CARBONIFEROUS ROCK UNITS IN THE CAUSEY DAM QUADRANGLE, WEBER COUNTY, UTAH
}

\author{
By THOMAS E. MULLENS, Denver, Colo.
}

\begin{abstract}
Fossils indicate that units formerly considered Pennsylvanian in age and mapped as the lower unit of the Wells Formation and as the Round Valley Limestone in the Causey Dam quadrangle are Late Mississippian in age. These rocks are assigned to the Doughnut Formation in this report on the basis of a reevaluation of their lithology and regional correlation.
\end{abstract}

Some Carboniferous units shown on the geologic map of the Causey Dam 71/2-minute quadrangle, Utah (fig. 1) (Mullens,

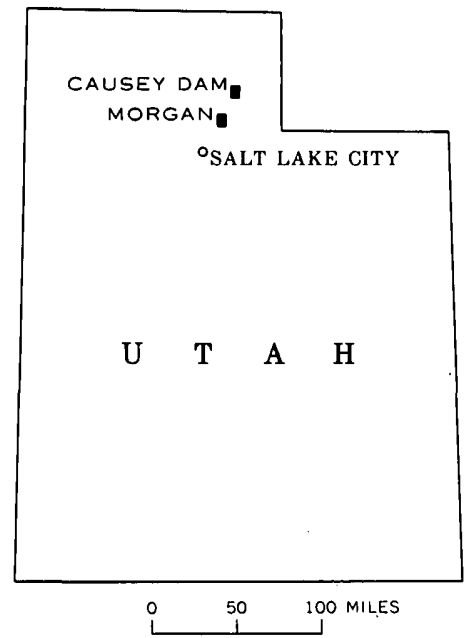

Figure 1.-Index map of Utah, showing location of Causey Dam and Morgan 71/2-minute quadrangles.

1969), are erroneously identified. New faunal information on brachiopods and corals collected during mapping and identified by Mackenzie Gordon, Jr., and W. J. Sando indicates that rocks $I$ assigned to the Round Valley Limestone and the lower unit of the Wells Formation, and to which I assigned a Pennsylvanian age, are of Late Mississippian age. The purposes of this note are to bring attention to the mistake and to suggest new stratigraphic assignments for these rocks. The new stratigraphic assignments are compatible with lithologic and faunal correlations with the Late Mississippian Doughnut Formation exposed about 10 miles southwest of the Causey Dam quadrangle.

The new faunal information is listed below. The stratigraphic positions of the collections are shown in figure 2 , as are the thickness and generalized lithologic characteristics of the rocks involved and the suggested revised correlation.

U.S. Geological Survey locality 23873-PC

SW1/4NE $1 / 4$ sec. 13, T. 7 N., R. 3 E.

(From beds mapped incorrectly as Round Valley Limestone) Horn coral, columellate form

Auloporoid coral

Striatifera n. sp.

Martinia aff. M. lata Girty

Cleiothyridina sp.

U.S. Geological Survey locality 22784-PC

NW1/4NW1/4 sec. 15 , T. 7 N., R. 3 E.

(From beds mapped incorrectly as the lower unit of the Wells Formation)

Trepostomatous bryozoan, ramose form

Fenestella sp.

Antiquatonia sp.

Striatifera n. sp.

Ovatia sp.

Leiorhynchus sp.

Martinia sp.

Cleiothyridina sp.

Composita sp.

Nuculopsis sp.

Of the fossils collected from beds mapped as Round Valley Limestone, Gordon (written commun., 1970) stated:

This collection is Late Mississippian (late Meramec) in age. The Striatifera is a new species that I have in manuscript, typical of the Faberophyllum coral zone. W. J. Sando says the horn coral could be an Ekvasophyllum or young Faberophyllum. Both can occur with this Striatifera. The Martinia is the same species that occurs also with the same Striatifera in USGS colln. 22784-PC, but that collection was recorded as from the "lower unit of the Wells." It is like $M$. lata Girty from the so-called Brazer Dolomite but lacks the sulcus in the brachial valve. Girty (in Mansfield, 1927, USGS Prof. Paper 152, p. 68) mentions a small form of Martinia lata or related species that is locally abundant in the Brazer (so-called) of Idaho. This may be the same species listed above. 


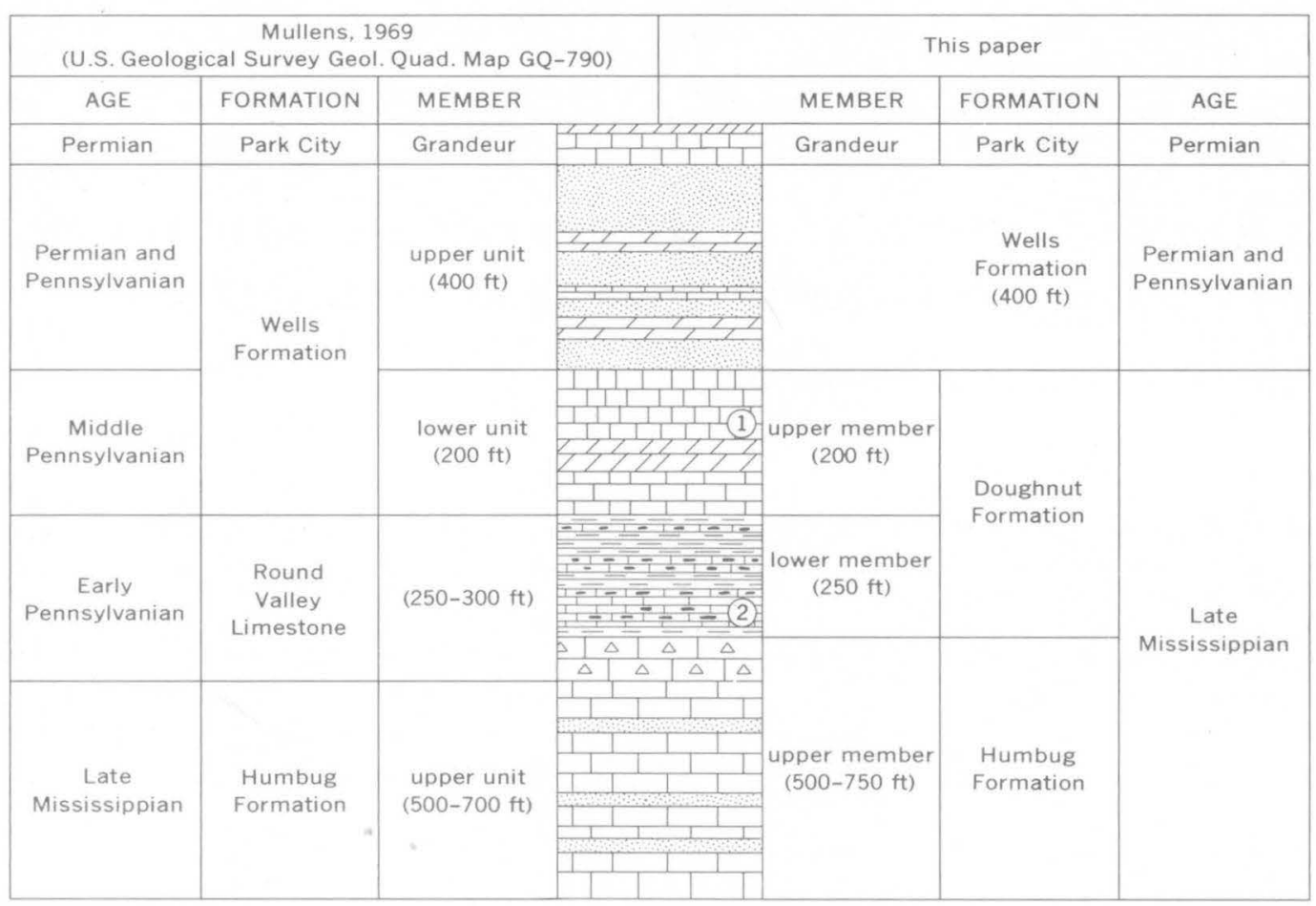

$E X P L A N A T$ I O N

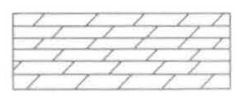

Medium- to thick-bedded dolomite

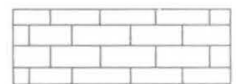

Medium- to thick-bedded limestone

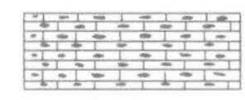

Thin-bedded nodular limestone

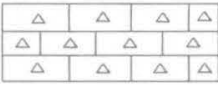

Cherty limestone

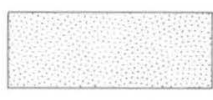

Sandstone

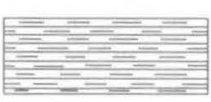

Shale
(1)

Approximate stratigraphic zone of fossil locality $22784-\mathrm{PC}$

Approximate stratigraphic zone of fossil locality $23873-\mathrm{PC}$

Figure 2.-Revised correlation of some Carboniferous map units in the Causey Dam quadrangle, Utah.

Of the fossils collected from beds mapped as lower unit of the Wells Formation, Gordon (written commun., 1969) stated:

This faunule is a rather unusual one, or at least, an assemblage not precisely like those we have previously collected. I have not tried to run down the species as most of them are probably new. It has been my experience that the Striatiferas with deeply impressed dendritic adductor muscle scars within the pedicle valve, such as these, are late Meramec in age, being found commonly in the Faberophyllum coral zone. In the Wasatch Range both Faberophyllum and these Striatiferas occur in the limestone below the shale of the Doughnut Formation. This limestone is placed by some geologists (yourself included, as I recall) in the Doughnut and mapped by others (such as M. D. Crittenden) with the Humbug Formation. These beds with Faberophyllum and Striatifera are equivalent to the Topliff Limestone Member of the Great Blue Limestone in the East Tintic Range, which is the lower limestone member of the Great Blue Formation at its type locality in the Oquirrh Mountains (Silveropolis Ridge, south of Ophir Canyon).
The faunal information and the suggested revisions in nomenclature for rocks in the Causey Dam quadrangle are compatible with lithologic correlations with similar rock units mapped and described in the Morgan 71/2-minute quadrangle (Mullens and Laraway, 1967), about 10 miles southwest. In the Causey Dam quadrangle, with the exception noted below, rocks formerly assigned to the Round Valley Limestone and lower unit of the Wells Formation should be reassigned to the Doughnut Formation. The unit mapped as the "upper unit of the Humbug Formation" does not contain all the upper part of the Humbug Formation. The part omitted was the cherty limestone incorrectly assigned to the basal Round Valley Limestone. Only the upper two-thirds of the rocks mapped as Round Valley Limestone is reassigned to the lower member of the Doughnut Formation. All rocks mapped as lower unit of the Wells Formation are reassigned to the upper member of 
the Doughnut Formation. Rocks mapped as "upper unit of the Wells Formation" now form the entire Wells Formation.

\section{REFERENCES}

Mansfield, G. R., 1927, Geography, geology, and mineral resources of part of southeastern Idaho, with descriptions of Carboniferous and
Triassic fossils, by G. H. Girty: U.S. Geol. Survey Prof. Paper 152, $453 \mathrm{p}$.

Mullens, T. E., 1969, Geologic map of the Causey Dam quadrangle, Weber County, Utah: U.S. Geol. Survey Geol. Quad. Map GQ-790.

Mullens, T. E., and Laraway, W. H., 1967, Preliminary geologic map of the Morgan 71/2-minute quadrangle, Morgan County, Utah: U.S. Geol. Survey open-file report. 


\title{
GROWTH AND MOVEMENT OF DUNES AT WHITE SANDS NATIONAL MONUMENT, NEW MEXICO
}

\author{
By EDWIN D. McKEE and JOHN R. DOUGLASS ${ }^{1}$, \\ Denver, Colo., Yellowstone Park, Wyo.
}

\begin{abstract}
The manner and rate of growth and movement of selected dunes at White Sands National Monument, N. Mex., were investigated. Changes in successive surfaces in dune fronts, determined by introduced magnetite marker beds, 'indicated 'that deposits directly below the dune crest of typical dunes were relatively impermanent because total accumulation was drastically affected by periodic avalanching on slip faces. Very different results were obtained from the lower part of a lee face because of the processes involved. Large accumulations of sand accrued periodically from shearing on slip faces; losses were few. Near the base avalanche sands intertongued with deposits of well-stratified sand carried in by crosswinds. In one dune, these mixed deposits accumulated up to 9.6 inches of sand in 5 days, but the monthly average was much lower because wind strength was negligible on many days. Long term measurements of dunes from fixed markers and from aerial photographs indicated movements that ranged from 38 feet per year in embryonic barchanlike dunes in the westem part of the dune field to no movement in some anchored dunes along the eastern margins. Barchan and transverse dunes in the central area moved 3.5-13 feet per year.
\end{abstract}

Dune growth and movement were measured as part of a long term program of sand-dune investigation at White Sands National Monument, N. Mex. This study was made while the coauthor was stationed at White Sands. The report describes hourly changes in the upper parts of the lee sides and at the bottoms of the slip faces of four dunes at times of major windstorms when depositional activity was intense. Additional long term measurements, repeated over 6-to 12-month periods, were made also at several places in the dune field to determine rates of migration.

Short term measurements of sand deposited on the lee slopes of dunes were made by spreading thin marker layers of pulverized magnetite over the dune surface at 20 - to 30 -minute intervals. These marker layers, when exposed in cross section, showed accretions of sand as well as structures that formed during and immediately following sand deposition. Wind velocity for each time interval was recorded with a hand-held anemometer, and rates of sedimentation were determined for specific strengths of wind.

\footnotetext{
${ }^{1}$ U.S. National Park Service, Yellowstone National Park, Wyo.
}

A stake located upwind from the dune brink (break in slope at top of the slip face) provided a fixed point in measuring. Directly below the brink a rectangular wire-mesh screen was placed on edge in the loose sand, its long dimension parallel to the dip of the lee slope so that the rate of deposition could be observed directly. At the foot of the lee slopes, stakes and rods were used for marking. The equipment is illustrated in figure 1. Because of the strong winds it was necessary to use goggles, dust mask, gloves, and sunburn cream most of the time, and to wear a windbreaker jacket even in hot weather. Most of the short term measurements were made by Douglass.

After individual storms during which short term studies were made, dune surfaces were soaked with water and trenches were dug in various directions but mostly parallel to the dip of the slip face, which is in the direction of the prevailing wind. Latex peels were then obtained from the vertical faces for subsequent analysis and study.

Long term studies of dune movement, discussed briefly in an earlier report (McKee, 1966), have been continued and further results are given here. Some of these studies are based on measurements from fixed stakes (fig. 1A, B), but most consist of comparisons of aerial photographs taken for this project at 6-month intervals by personnel of the Holloman Air Force Base. The dunes are composed of gypsum sand. The form and size of dunes at White Sands and the composition and grain size of the dune sands were described in the earlier report (McKee, 1966).

Acknowledgments.-This project was sponsored by the National Park Service as part of a general program of dune study. The interest and assistance of Superintendents Forrest Benson and Donald A. Dayton of the White Sands National Monument are much appreciated. Early field studies by Ranger W. P. Crawford and help during late stages by Chief Naturalist David Petticord are also gratefully acknowledged. Thanks are extended to David Jones, regional planner for the National Park Service, who initiated the general program. Finally, appreciation is extended the Holloman Air Force Base for making available the air photographs necessary to one phase of this study. 

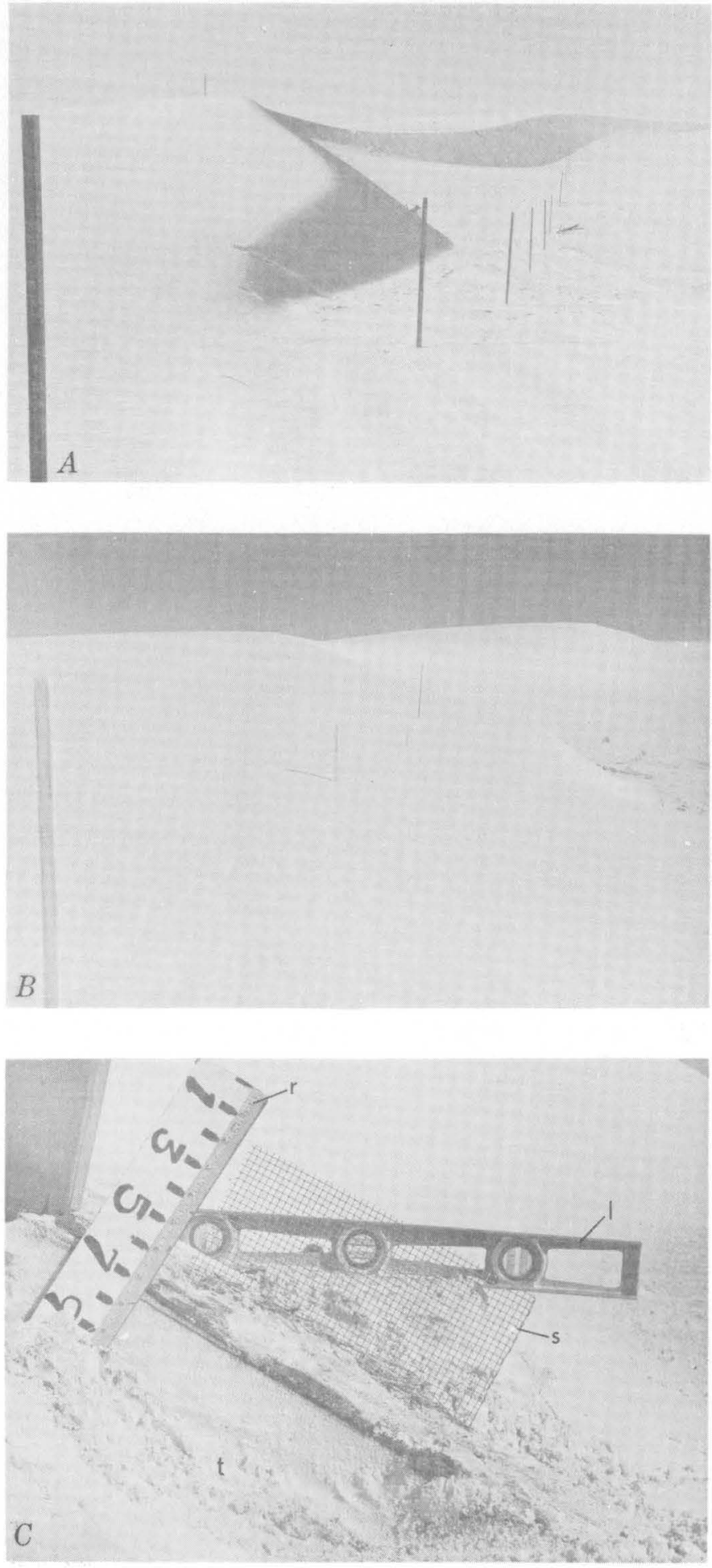

Figure 1.-Methods and equipment employed in dry-sand studies.

A. Stakes along front and on crest of barchan dune, March 25, 1964. Stakes extended 5-6 feet above sand.

B. Same stakes showing dune advance during 1 year, March 24, 1965.

C. Direct readings between magnetite marker beds on side of trench show additions and subtractions to sand deposit. Scale in inches. $\mathrm{s}$, screen; $\mathrm{t}$, trench; $r$, rule; 1 , level.

\section{MANNER OF DUNE GROWTH}

\section{Processes involved}

Windward-side deposits in most dunes are constantly eroded and therefore are ephemeral; lee-side deposits are progressively buried and so most of their lower parts and, under favorable conditions, much of their upper parts have a chance of permanent preservation. Windward-side deposits form largely by the process of saltation or bouncing accompanied by a certain amount of surface creep (Bagnold, 1941, p. 31-34). Upper lee-side deposits form both from sand dropping out of suspension and from the avalanching of oversteepened accumulations at the brink; lower lee-side deposits normally contain much avalanche material from higher parts of the slope, but include less sand from suspension. They may contain considerable amounts of saltated sand accumulated by crosswinds, especially along the dune base.

Deposits on the steeply dipping lee sides of wind-formed dunes normally are composed largely of laminae that stand at angles approaching but somewhat less than the angle of repose. Because these angles are established (Van Burkalow, 1945, p. 693) partly by sand that settles from suspension on the existing lee slope, but mostly by shear planes along which masses of sand have avalanched or slid under the force of gravity, the lee side of the dune has been termed the slip face by Bagnold (1941, p. 189). Observations indicate that avalanche deposits of the slip face, together with a certain amount of sand accumulated by crosswinds through saltation and creep, especially along the base, constitute the dune deposits that are most commonly buried and preserved in the geologic record.

Mass movements or avalanches of sand on the steep lee faces of dunes are of two principal types-sand flow and slump. Sand-flow avalanches are those in which the sand particles move independently of one another and constantly mix. Avalanches of slump type, in contrast, consist of the sliding of thin plates of sand or weakly cohesive masses that move as units. The process is defined (adaption of Sharpe, 1938, p. 65) as the downward slipping of a mass of unconsolidated material, moving as a unit or as several subsidiary units, commonly with rotation on a more or less horizontal axis parallel to the slope from which it descends.

Avalanching sand may start at the dune brink, or, if initially deposited from the suspended load of strong winds, from some distance down the slope. The avalanching mass may travel all or most of the distance to the base of the dune in a single movement or, more commonly, it may descend in a series of movements separated by times of rest.

\section{A typical storm at White Sands}

In order that the reader may better appreciate conditions that prevail during sandstorms, when most dune deposits of 
the type discussed in this paper are accumulated, a description is included which is based on experiences while making field investigations during numerous storms over a period of several years. Because, in general, the stronger the wind, the more striking the record, large storms were preferred for purposes of study. The description follows:

From a position atop a barchan dune in the midst of White Sands National Monument, one may look out on dunes that extend in all directions. Though the breezes may have been drifting in from the east or south, suddenly the observer is aware of a breeze from the southwest that rises and falls in gusts. With each rise there is a rustle as sand grains roll and bounce, urged into motion by the wind. An anemometer shows that the gusts have risen to 10-15 miles per hour.

As the storm moves in, the wind rises to 20-25 miles per hour. Gusts reach 35,40 , or even 55 miles per hour. A weather vane swings wildly back and forth from south to west, steadying occasionally at southwest or west-southwest. In a hand-held Dwyer anemometer, the bounding ball that indicates the wind velocity does not remain steady during even a few seconds of observation. Rivers of sand rise and fall on the windward slope of the dune. At the dune top a distinct brink is formed where sand accumulates near the upper rim of the avalanche face. Toward the horns of the dune the sharpness of the brink is less pronounced and streams of sand flow over the dune toward the interdunal flats and on to the next dune. Dust, driven into suspension, soon obscures the view in all directions. The mountains and other distant landmarks disappear from sight.

As sand accumulates at the brink of the dune, the angle of repose steepens, for the rate of collection of sand is greater at the brink than farther down the slope. Suddenly a mass of sand will "let go" and move down the slope either by sand flow or by slump.

The storm continues for 4-18 hours in the pattern described. Frequently, strong winds come in the afternoon, but die down at night. During the night, winds formed by downslope air drainage from the nearby mountains to the east exert themselves and determine the surface air movement. Two principal downslope winds are recognized-one from the north that affects primarily the western part of the dune field, and one from the east, coming from the Sacramento Mountains, that affects the eastern part. When daylight comes, the storm winds return to the surface.

As the storm moves through the region, the wind usually decreases in force and shifts clockwise to the northwest, north, northeast, and finally to the east, which is typical for storms in the northern hemisphere. Occasionally, periods of strong winds occur during the shifts in direction. Crosswinds that are generated strike greater and greater areas of the lee slope head on and drive sand back from the top of the lee slope to form a counterdune-a small dune on top of a major dune that moves in a different direction.

The higher gusts are extremely important in the formation of the dunes, because the rate of movement of sand varies with the cube of the wind velocity. In 1 minute a wind of 36 miles per hour moves nearly 3.5 times as much sand as a wind of 24 miles per hour. Similarly, in the same period of time, a wind of 54 miles per hour will move 11 times as much sand as a wind of 24 miles per hour.

The wind pattern just described prevails at White Sands National Monument in most storms that occur in fall, winter, and spring, especially in February, March, April, and May. In the summer, the pattern shifts; the major sand-moving winds come from the east and the south. Winds that accompany thunderstorms of the summer seem to have little effect on the overall picture of sand movement, perhaps because of moisture that falls and holds the sand.

\section{DUNE PRESERVATION POSSIBILITIES}

Planar surfaces that bevel crossbedding sets in many dune deposits, both modern and ancient, suggest that parts, perhaps major parts, of the original foresets are missing. However, whether the amount removed represents, for example, 20, 50, or even 80 percent of the original beds cannot be determined for most deposits. Where an abundant supply of sand is available, even strata of the windward sides (topset beds) are occasionally preserved in continuity with steeply dipping foresets (McKee, 1966, figs. 6, 7).

Locally in modern dunes and in certain ancient formations believed to be of eolian origin, such as the Coconino and the Navajo Sandstones of Arizona and Utah, dipping strata 50-100 feet long are preserved. Judged from their size, these strata must be at least major parts of what were originally surface layers of dunes. Thus, all extremes in preservation of dunes probably are possible, though the uppermost parts of dunes obviously are the most vulnerable and commonly are partly or entirely removed before succeeding sets of cross strata bury the remains.

In this investigation, deposits near the brink, as well as those below, were examined and their rates of growth were measured, although the relatively small chance of preserving the upper parts was recognized.

\section{RATES OF DUNE GROWTH AND MOVEMENT}

\section{Short term growth near brink}

Short term accumulations on dune fronts, as discussed in this paper, refer to sand deposits during periods of 15,30 , or 60 minutes, and are measured in terms of fractions of an inch for each period. Deposits that formed during these periods generally contain only one or a few laminae. At the dune brink the deposits form largely from the settling of suspended load, but the total accumulation during any time interval is greatly affected by the intermittent loss of sediment through frequent avalanches. To extrapolate short term measurements for long periods of time, however, may be misleading.

The rates of sand accumulation, exclusive of avalanches, 
Table 1.-Short term record of sand accumulation near dune brink, avalanche occurrences, and local wind velocities

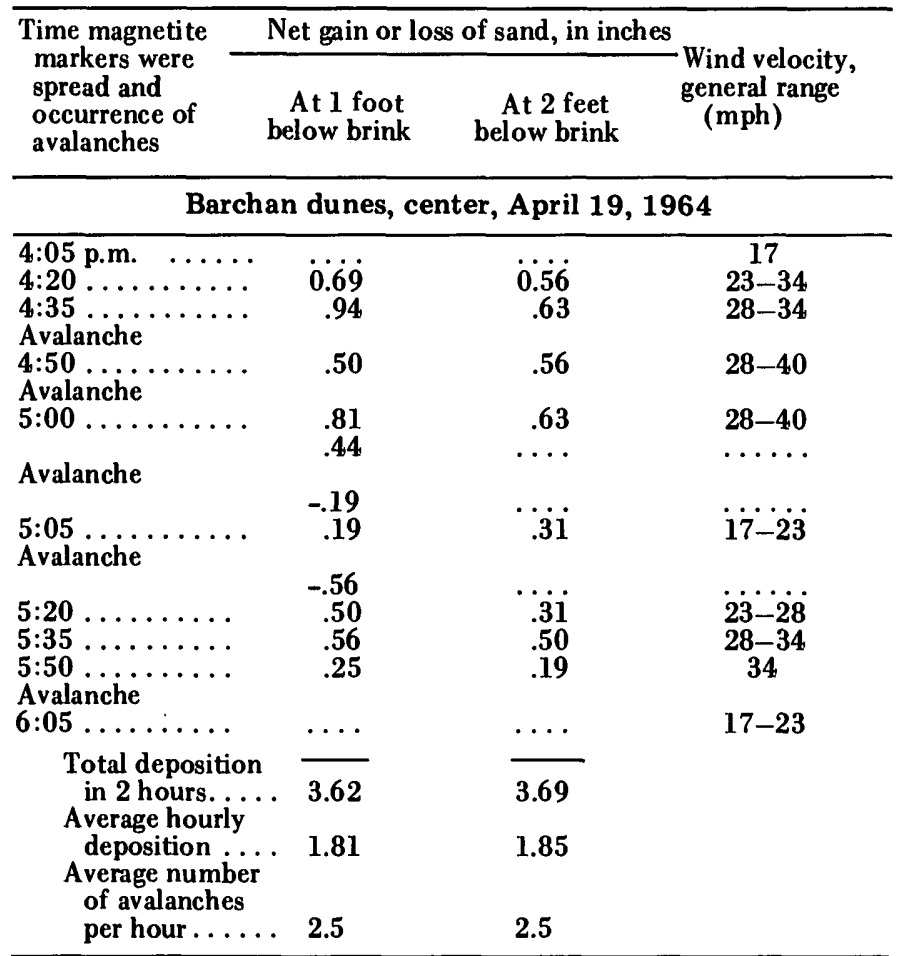

\begin{tabular}{|c|c|c|c|}
\hline \multicolumn{4}{|c|}{ Barchan dunes, center, February 23, 1965} \\
\hline $\begin{array}{l}9: 30 \text { a.m. } \ldots \ldots \\
\text { 10:00 } \ldots \ldots \\
\text { Avalanche }\end{array}$ & 0.38 & -0.13 & $\begin{array}{c}30 \\
20-30\end{array}$ \\
\hline $\begin{array}{l}\text { 10:30 } \ldots \ldots \ldots \\
\text { 11:00 } \ldots \ldots \ldots \\
\text { Avalanche }\end{array}$ & $\begin{array}{r}.25 \\
-2.50\end{array}$ & $\begin{array}{l}.50 \\
.38\end{array}$ & $\begin{array}{l}10-25 \\
10-25\end{array}$ \\
\hline $11: 30 \ldots \ldots \ldots$ & .38 & -3.63 & $10-?$ \\
\hline $\begin{array}{l}\text { Total deposition } \\
\text { in } 2 \text { hours..... }\end{array}$ & -1.49 & -2.88 & \\
\hline $\begin{array}{c}\text { deposition ..... } \\
\text { Average number }\end{array}$ & -.74 & -1.44 & \\
\hline per hour....... & 1.5 & 1.5 & \\
\hline
\end{tabular}

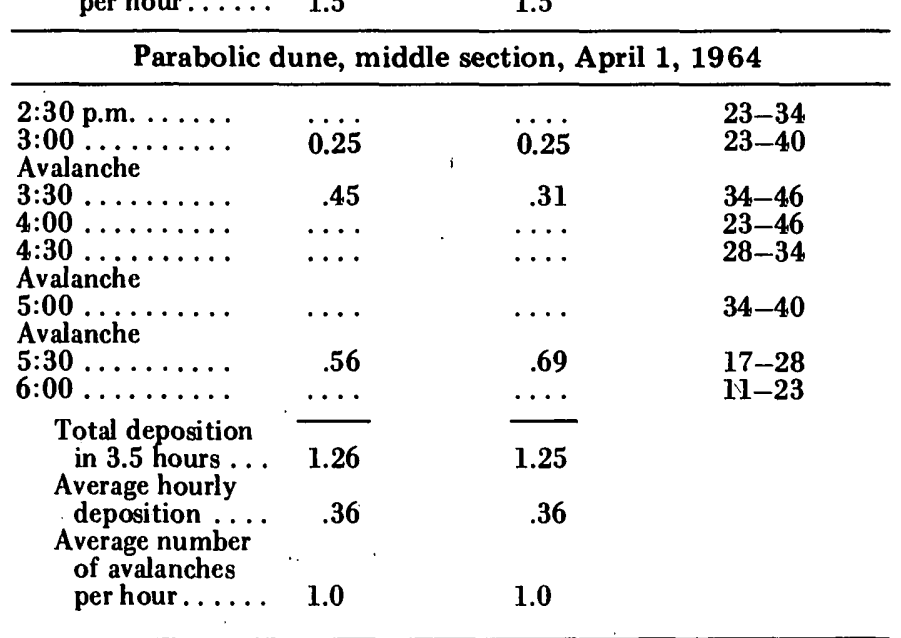

\begin{tabular}{|c|c|c|c|}
\hline \multicolumn{4}{|c|}{ Transverse dune, site 2, June 8, 1964} \\
\hline $\begin{array}{l}\text { 9:00 a.m. } \ldots \ldots \ldots \\
\text { 9:30 } \ldots \ldots \ldots \ldots \ldots \\
9: 45 \ldots \ldots \ldots \ldots\end{array}$ & $\begin{array}{r}\mathbf{0 . 5 0} \\
.38\end{array}$ & $\begin{array}{r}0.38 \\
.13\end{array}$ & $\begin{array}{l}16-20 \\
14-20 \\
14-16\end{array}$ \\
\hline
\end{tabular}

Table 1.-Short term record of sand accumulation near dune brink, avalanche occurrences, and local wind velocities-Continued

\begin{tabular}{cccc}
\hline $\begin{array}{c}\text { Time magnetite } \\
\text { markers were } \\
\text { spread and } \\
\text { occurrence of } \\
\text { avalanches }\end{array}$ & $\begin{array}{c}\text { Net gain or loss of sand, in inches } \\
\text { below brink }\end{array} \quad \begin{array}{c}\text { At } 2 \text { feet } \\
\text { below brink }\end{array}$ & $\begin{array}{c}\text { Wind velocity, } \\
\text { general range } \\
\text { (mph) }\end{array}$ \\
\hline
\end{tabular}

Transverse dune, site 2, June 8, 1964 - Continued

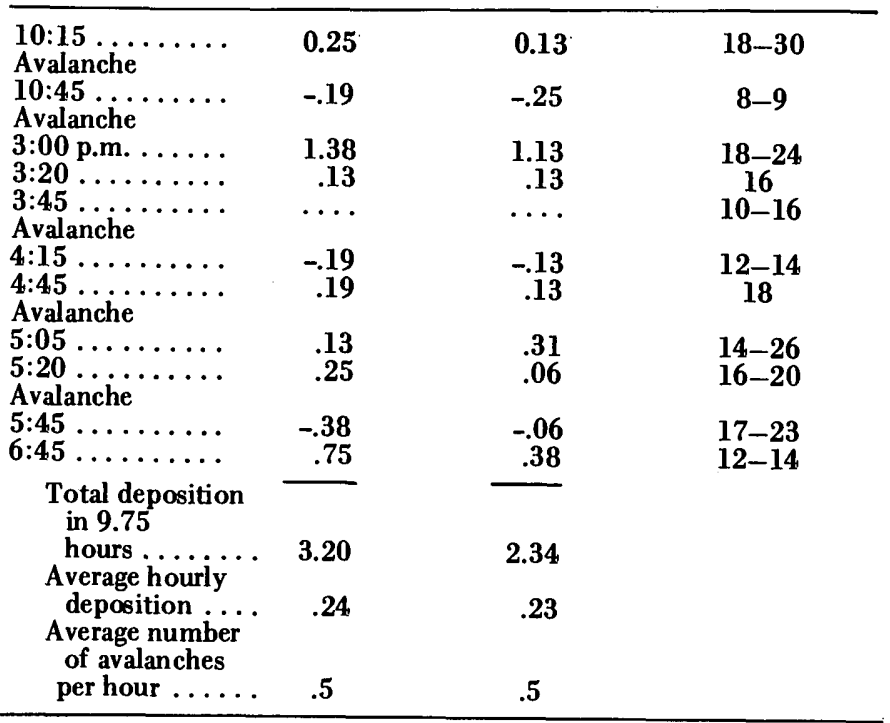

measured near the brinks of four dunes differed considerably, but mostly they ranged from 0.1 to 0.9 inch per hour measured normal to the slope; rarely they were more (tables 1 , 2). These rates were for winds that ranged largely from about 15 to 40 miles per hour. An exceptionally great thickness accumulated on a barchan dune during the windstorm of April 19, 1964; measurements made every 15 minutes over a 2 -hour period showed an average accretion of nearly 2 inches of sand per hour. During this time, winds ranged from 17 to 40 miles per hour (table 1). A very different result was recorded on a barchan on February 23, 1965, in which a series of two large avalanches and one small one, probably triggered by strong crosswinds, caused the loss of about $1.5-3$ inches of sand in 2 hours and resulted in a negative figure for deposits accumulated per hour. Thus, net gains and losses during periods of storm do not necessarily show a close relation to the wind velocities.

As should be expected, the frequency and amount of avalanching on the slip faces of dunes vary considerably from time to time, and from place to place, principally because of difference in strength and direction of wind. Counting the number of naturally triggered avalanches during a sandstorm is difficult, but a general measure is afforded by the nine records given in table 2. These show a range of three avalanches in 10 hours to 12 avalanches in 2 hours. Many were small, involving only a few laminae; others were large, in which layers of sand one to several inches thick moved downhill. 
Table 2.-Summary of short term sand accumulation records for upper slopes of barchan, parabolic, and transverse dunes, showing avalanche occurrences, rate of sand accumulation, and wind velocities at site

\begin{tabular}{|c|c|c|c|c|c|c|}
\hline \multirow{2}{*}{$\begin{array}{c}\text { Dune } \\
\begin{array}{c}\text { Type and part } \\
\text { studied }\end{array}\end{array}$} & \multicolumn{2}{|c|}{ Avalanche occurrence } & \multicolumn{2}{|c|}{$\begin{array}{c}\text { Net gain or loss of sand } \\
\text { (inches) per hour }\end{array}$} & \multicolumn{2}{|c|}{ Wind velocity (mph) } \\
\hline & Number & $\begin{array}{r}\text { Period } \\
\text { (hours) }\end{array}$ & $\begin{array}{c}\text { At } 1 \text { foot } \\
\text { below brink }\end{array}$ & $\begin{array}{l}\text { At } 2 \text { feet } \\
\text { below brink }\end{array}$ & $\begin{array}{l}\text { General } \\
\text { range }\end{array}$ & $\begin{array}{c}\text { Exceptional } \\
\text { velocity }\end{array}$ \\
\hline \multicolumn{7}{|l|}{ Barchan: } \\
\hline Center ${ }^{1}$ & 5 & 2 & 1.81 & 1.85 & $17-40$ & $\ldots$ \\
\hline Horn. & 1 & 2 & .78 & 1.85 & $10-20$ & 34 \\
\hline Center ${ }^{i}$.. & 3 & 2 & -.78 & -1.44 & $10-30$ & 42 \\
\hline Center..$\ldots \ldots \ldots \ldots \ldots \ldots$ & 12 & 3.5 & .08 & & $16-30$ & 54 \\
\hline Horn $\ldots \ldots \ldots \ldots \ldots \ldots \ldots \ldots$ & 3 & 5 & .14 & .11 & $10-20$ & $\ldots$ \\
\hline \multicolumn{7}{|l|}{ Parabolic: } \\
\hline Top upper slope $\ldots \ldots \ldots \ldots$ & 3 & 3 & .13 & .14 & $17-46$ & $\ldots$ \\
\hline Middle upper slope $\ldots \ldots \ldots \ldots$ & 3 & 3 & .36 & .36 & $17-46$ & $\ldots$ \\
\hline \multicolumn{7}{|l|}{ Transverse: } \\
\hline Site $1 \ldots \ldots \ldots \ldots \ldots \ldots$ & 3 & 10 & .29 & .32 & 10-22 & $\ldots$ \\
\hline Site $2^{1}{ }^{1} \ldots \ldots \ldots \ldots \ldots \ldots \ldots \ldots$ & 5 & 10 & .24 & .23 & 8-23 & $\ddot{30}$ \\
\hline
\end{tabular}

${ }^{1}$ Detailed data are shown in table 1.

\section{Short term growth at dune foot}

Rates of growth differ considerably on the lower part of a dune slope from those on the upper part of the slope because of different modes of accumulation. On the upper dune slope, laminae of sand build up when effective winds blow, but the slope loses much of what is deposited by frequent avalanching. In contrast, the basal part of the slope gains sand periodically from avalanching. Weakly laminated or structureless sand that has avalanched down the slope commonly intertongues with well-laminated sand that was moved by saltation in crosswinds and deposited along the dune base.

The conditions accompanying short term growth at the foot of a barchan dune are shown in table 3 and the record of deposits in figure 2 . This dune was approximately 27 feet high and faced northeast. The wind shifted numerous times during

Table 3.-Conditions during short-term sand accumulation, foot of center section of barchan dune, 1965

[Strong wind, $>20 \mathrm{mph}$; weak wind, 10-20 $\mathrm{mph}$; ineffective, $<10 \mathrm{mph}$. *, dominant regional wind direction]

\begin{tabular}{|c|c|c|c|c|}
\hline $\begin{array}{l}\text { Date of wind } \\
\text { measurements }\end{array}$ & $\begin{array}{c}\text { Wind } \\
\text { direction }\end{array}$ & $\begin{array}{l}\text { Wind } \\
\text { strength }\end{array}$ & $\begin{array}{c}\text { Date of } \\
\text { avalanche }\end{array}$ & $\begin{array}{l}\text { Date magnetic } \\
\text { markers spread }\end{array}$ \\
\hline 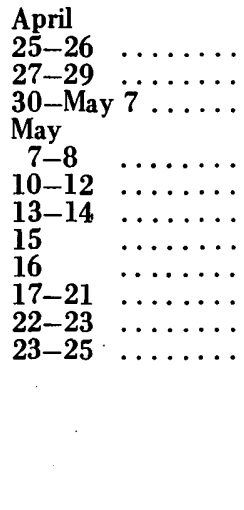 & 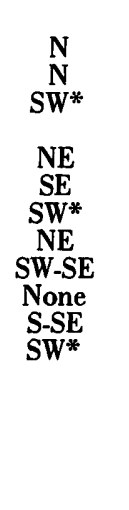 & $\begin{array}{l}\text { Ineffective } \\
\text { Weak } \\
\text {..do....... } \\
\text { Strong } \\
\text { Ineffective } \\
\text { Weak } \\
\text { I.do...... } \\
\text { Ineffective } \\
\text {..do...... } \\
\text { Weak } \\
\text { Weak-strong }\end{array}$ & $\begin{array}{l}\cdots \\
\text { May } 7 \\
\ldots \\
\dddot{\text { May }} 14 \\
\ldots \\
\cdots \\
\cdots \\
\text { g May } 25\end{array}$ & $\begin{array}{c}\text { Apr. 25 } \\
\text { Apr. 27 } \\
\ldots \ldots \\
\text { May } 8 \\
\text { May 14 } \\
\ldots \ldots \cdots \\
\ldots \ldots \cdots \\
\cdots \cdots \\
\text { May } 2 \dot{25} \\
\text { (10:25 } \\
\text { a.m. } \\
\text { and } \\
2: 36 \\
\text { p.m.). }\end{array}$ \\
\hline
\end{tabular}

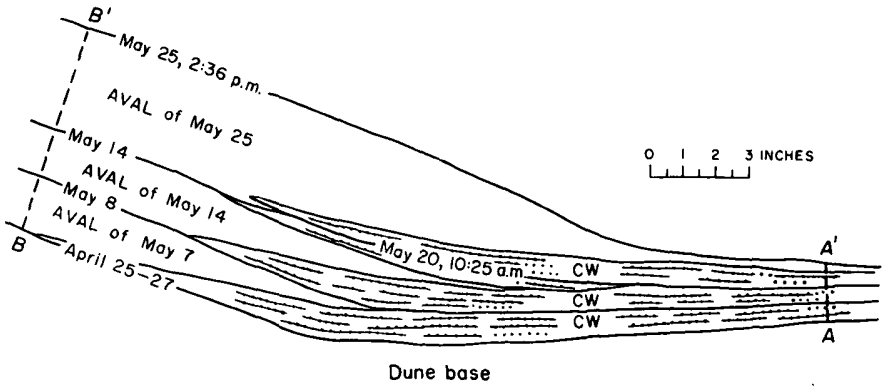

Figure 2.-Intertonguing of avalanche deposits (AVAL) and welllaminated crosswind saltation deposits $(\mathrm{CW})$ at dune base. Tracing from photograph of latex peel, made of vertical section parallel to dip of sand surface, barchan dune, White Sands National Monument, N. Mex. Magnetite layers indicated by dates, which are the dates the layers were spread. $A-A^{\prime}$ and $B-B^{\prime}$, lines along which thickness was measured.

the month that measurements were made, but came from the prevailing direction (southwest) during three separate periods. At each of these times appreciable amounts of sand were moved. Wind velocity was about 20 miles per hour on 2 days, but it was mostly less than 20 miles per hour, and on several days it was too low to be effective.

As shown in figure 2, three large avalanches formed wedges of nonstratified sand that intertongue with the laminated crosswind deposits near the base of the slope. Shortly before the first two avalanches occurred, the wind changed direction, which suggests that crosswinds undermined the lower slope and triggered the avalanches. On May 25, when the largest wedge was formed, the wind remained in the prevailing direction but reached a velocity much stronger than before, which may account for the avalanche of that day. $*$

For the entire month, nearly 2 inches of stratified sand was deposited by crosswinds along line $A-A^{\prime}$ (fig. 2), downslope from the zone of intertonguing. A thickness of 6.5 inches was deposited by avalanches along line $B-B^{\prime}$ (fig. 2), upsilope of: the zone of intertonguing. 
Table 4.-Conditions during short term sand accumulation, foot of center section of barchan dune, 1966

[Strong wind, > $20 \mathrm{mph}$; weak wind, 10-20 mph; ineffective, $<10 \mathrm{mph}$. *, dominant regional wind direction]

\begin{tabular}{|c|c|c|c|}
\hline Date & $\begin{array}{c}\text { Wind } \\
\text { direction }\end{array}$ & $\begin{array}{c}\text { Wind } \\
\text { strength }\end{array}$ & $\begin{array}{l}\text { Description } \\
\text { of avalanche }\end{array}$ \\
\hline $\operatorname{March} 2 \ldots \ldots \ldots$ & $\mathrm{SW}^{*}$ & Weak & $\begin{array}{l}\text { Large (buried } \\
\text { stake) }\end{array}$ \\
\hline & $\mathrm{SW}^{*}$ & .do. .... & $\begin{array}{c}\text { Small }(3 / 4 \text { in. } \\
\text { thick }) .\end{array}$ \\
\hline $\begin{array}{l}4-5 \ldots \ldots \ldots \\
6 \ldots \ldots \ldots \ldots\end{array}$ & $\begin{array}{l}\text { NW } \\
\text { SW* }\end{array}$ & $\begin{array}{l}\text { Ineffective } \\
\ldots \text { do...... }\end{array}$ & $\begin{array}{l}\text { None. } \\
\text { None. }\end{array}$ \\
\hline
\end{tabular}

A second record of conditions accompanying short term growth at the base of a barchan dune (table 4) was made during the 5-day period of March 2-6, 1966. One small and one large avalanche occurred during periods of weak but effective wind movement in the prevailing direction. Probably both avalanches resulted from oversteepening of the lee slope during constant wind conditions, as no evidence of wind change was noted.

During the 5-day period, 9.6 inches of sand accumulated near the dune base in the zone of intertonguing avalanche sand and sand deposited by crosswinds. At 5 feet above the base, where deposits consisted exclusively of avalanche sand, a total thickness of about 7 inches accumulated. Thus, deposits accumulated at an average rate of about 1.4-1.9 inches per day, measured normal to the lee slope.

\section{Long term movement as determined with stakes}

Stakes 84 inches high were placed along the margins of several dunes and were later measured to determine the amount each stake was buried. During the course of a year most stakes were partly buried, but some were reexposed when winds changed from west-southwest to east-southeast, and reburied when wind direction returned to west-southwest. All stakes originally at the foot of slip faces were buried and did not reappear during the period of study.

The rates of movement of five dunes, as determined with stakes, are given on table 5. Movement of the embryonic dune was much greater than that of the others studied. The reasons

Table 5.-Rates of dune movement as determined by measurements from one or more stakes to the foot of the slip face

\begin{tabular}{|c|c|c|c|c|c|c|}
\hline \multirow[b]{2}{*}{ Type of dune } & \multirow{2}{*}{$\begin{array}{l}\text { Dune } \\
\text { No. }{ }^{1}\end{array}$} & \multicolumn{3}{|c|}{ Period covered } & \multirow{2}{*}{$\begin{array}{l}\text { Total } \\
\text { movement } \\
\text { (ft) }\end{array}$} & \multirow{2}{*}{$\begin{array}{l}\text { Average } \\
\text { rate of } \\
\text { movement } \\
\text { per year, } \\
\text { rounded } \\
\text { (ft) }\end{array}$} \\
\hline & & $\begin{array}{l}\text { Total } \\
\text { years }\end{array}$ & $\begin{array}{l}\text { From } \\
\text { (mo/yr) }\end{array}$ & $\frac{\text { To }}{(\mathrm{mo} / \mathrm{yr})}$ & & \\
\hline $\begin{array}{l}\text { Embryonic } \\
\text { (dome- } \\
\text { shaped). }\end{array}$ & 2 & 1 & $6 / 64$ & $6 / 65$ & 29.1 & 29 \\
\hline $\begin{array}{l}\text { Transverse .... } \\
\text { Barchan .... } \\
\text { Parabolic ... } \\
\text { Do ....... }\end{array}$ & $\begin{array}{l}4 \\
5 \\
7 \\
8\end{array}$ & $\begin{array}{l}1 / 2 \\
61 / 4 \\
61 / 2 \\
61 / 2\end{array}$ & $\begin{array}{r}6 / 64 \\
11 / 62 \\
11 / 62 \\
11 / 62\end{array}$ & $\begin{array}{r}12 / 64 \\
2 / 69 \\
5 / 69 \\
5 / 69\end{array}$ & $\begin{array}{c}22.0 \\
29.8 \\
46-52 \\
11-12\end{array}$ & $\begin{array}{r}4 \\
13 \\
8 \\
2\end{array}$ \\
\hline
\end{tabular}

${ }^{1}$ Dune numbers refer to designations used on records at White Sands National Monument. are not definitely known, but probably they include an unobstructed approach for the wind across a flat playa, and the small size of the dune. Because the dune was small, it required relatively little transfer of sand in order to migrate, especially compared to the transfer involved in advances of large transverse dunes. The calculated rate of movement shown in table 5 for the transverse dune is less reliable than those shown for the other dunes because it is based on less than a full year of observation, and rates of movement for various months differ widely. For example, very little dune movement normally occurs in the summer season, and a yearly average based on the summer months would be extremely low.

\section{Long term movement as determined with aerial photographs}

Aerial photographs of selected dune areas were made by the U.S. Air Force, Holloman Air Force Base, N. Mex., at 6-month intervals. Fixed points, established in the interdunal flats around each dune, were marked so that they would be visible in successive photographs. Also, some small bushes were clearly visible in the photographs, and these provided a set of secondary reference points which were utilized in measuring dune movements. Rates of movement obtained from the fixed and secondary points matched well. The results of measurements of the aerial photographs are shown in table 6 , and the results from photographs and from measurements using stakes are summarized as follows:

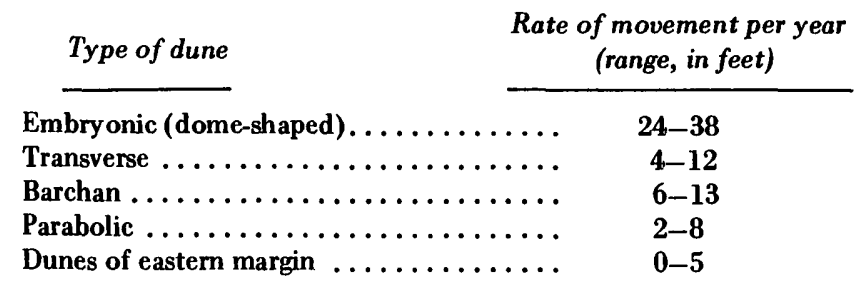

The dunes at White Sands National Monument move most rapidly on the western edge of the dune field (where they originate). They move more and more slowly toward the east. Except locally, no movement is detectable at the eastern margin of the dune field.

As shown by table 6 , the rates of movement for individual dunes of a given type differ considerably. Probably this reflects such variables as: height of the dune; mass of the dune; rate of sand flow, which involves both availability of sand and strength of wind; whether total mass of dune is growing or diminishing; shape of dune; and the amount of vegetation present. Inexactness in locating the foot of dune slip faces may also be a factor.

A comparison of dunes 5 and 6 , table 6 , shows that dune 5 , which was about 21 feet high, moved faster than dune 6 , which was 18.6 feet high. Both were in the same part of the dune field. Other factors being equal, the higher dune should have moved more slowly (Bagnold, 1941, p. 215). Factors that may have caused the reverse relation are not known. 
Table 6.-Rates of dune movement as determined by measurements of distances on aerial photographs

\begin{tabular}{|c|c|c|c|c|c|c|}
\hline \multirow{2}{*}{ Type of dune } & \multirow{2}{*}{$\begin{array}{l}\text { Dune } \\
\text { No. }{ }^{1}\end{array}$} & \multicolumn{3}{|c|}{ Period covered } & \multirow{2}{*}{$\begin{array}{l}\text { Total } \\
\text { movement } \\
(\mathrm{ft})\end{array}$} & \multirow{2}{*}{$\begin{array}{l}\text { Average } \\
\text { rate of } \\
\text { movement } \\
\text { per year, } \\
\text { rounded } \\
\text { (ft) }\end{array}$} \\
\hline & & $\begin{array}{l}\text { Total } \\
\text { years }\end{array}$ & $\begin{array}{l}\text { From } \\
(\mathrm{mo} / \mathrm{yr})\end{array}$ & $\begin{array}{c}\text { To } \\
\text { (mo/yr) }\end{array}$ & & \\
\hline \multirow{2}{*}{$\begin{array}{l}\text { Embryonic ... } \\
\text { (dome- } \\
\text { shaped). }\end{array}$} & 2 & 4 & $12 / 62$ & $12 / 66$ & \multirow{2}{*}{$\begin{array}{c}96^{2} \\
117^{3} \\
33 \\
38 \\
36\end{array}$} & \multirow{2}{*}{$\begin{array}{l}24 \\
29 \\
33 \\
38 \\
36\end{array}$} \\
\hline & $\begin{array}{l}11 \\
11 \mathrm{a} \\
12\end{array}$ & $\begin{array}{l}1 \\
1 \\
1\end{array}$ & $\begin{array}{l}6 / 65 \\
6 / 66 \\
6 / 66\end{array}$ & $\begin{array}{l}6 / 66 \\
6 / 67 \\
6 / 67\end{array}$ & & \\
\hline Transverse ... & $\begin{array}{r}3 \\
4 \\
13 \\
14\end{array}$ & $\begin{array}{l}51 / 2 \\
51 / 2 \\
11 / 2 \\
1\end{array}$ & $\begin{array}{r}12 / 62 \\
12 / 62 \\
6 / 66 \\
12 / 66\end{array}$ & $\begin{array}{l}7 / 68 \\
7 / 68 \\
1 / 68 \\
1 / 68\end{array}$ & $\begin{array}{l}27 \\
19 \\
13 \\
12\end{array}$ & $\begin{array}{r}5 \\
4 \\
9 \\
12\end{array}$ \\
\hline Barchan ..... & $\begin{array}{r}5 \\
6 \\
15\end{array}$ & $\begin{array}{c}51 / 2 \\
51 / 2 \\
2\end{array}$ & $\begin{array}{r}12 / 62 \\
12 / 62 \\
6 / 66\end{array}$ & $\begin{array}{l}7 / 68 \\
7 / 68 \\
7 / 68\end{array}$ & $\begin{array}{c}55 \\
49 \\
14-15\end{array}$ & $\begin{array}{r}10 \\
9 \\
7\end{array}$ \\
\hline Parabolic .... & $\begin{array}{l}7 \\
8\end{array}$ & $\begin{array}{l}51 / 2 \\
51 / 2\end{array}$ & $\begin{array}{l}12 / 62 \\
12 / 62\end{array}$ & $\begin{array}{l}7 / 68 \\
7 / 68\end{array}$ & $\begin{array}{l}37 \\
11.4\end{array}$ & $\begin{array}{l}7 \\
2\end{array}$ \\
\hline $\begin{array}{r}\text { Dunes of } \ldots . \\
\text { eastern }\end{array}$ & 16 & 1 & $6 / 66$ & $6 / 67$ & 0 & 0 \\
\hline margin. & 17 & 2 & $6 / 66$ & $7 / 68$ & $8-10$ & 5 \\
\hline
\end{tabular}

${ }^{1}$ Dune numbers are designations used on records at White Sands National Monument.

${ }^{2}$ Center of dune.

${ }^{3}$ Near end of slip face.

\section{REVERSALS IN WIND DIRECTION}

Reversals in wind direction leave, in some places, easily recognizable reverse-stratified deposits on the tops of normally stratified dunes. An excellent record of such counterdunes was obtained from a barchan dune during the period between February 23 and May 28, 1965, as shown by figure 3 . For most of this period the dominant wind was from the west or southwest, but on 2 days-May 8 and May 28-storms from the north and northeast were responsible for rapid construction of moderate-sized counterdunes. The sequence of wind changes is shown clearly in the sequence of deposits at the top of the dune (fig. 3).

\section{CONCLUSIONS}

1. Short term measurements of dune growth at White Sands National Monument, N. Mex., indicate that sand was deposited near the brinks of various dunes at a rate of about $0.1-0.9$ inch per hour in winds that ranged from about 15 to 40 miles per hour. Penecontemporaneous avalanches periodicallv removed part or all of the deposits, however, so the rates as determined cannot be extrapolated for very long periods of time in determining rates of dune growth.

2. Deposits near the dune base are formed by avalanches that interfinger with crosswind deposits of saltating sand. Rates of deposition are as great as 6.5 inches per month, and, during some storms, more than 2 inches per day.

3. Long term measurements made for four types of dunes show migration of as much as 38 feet per year.

4. The common belief that higher dunes move more slowly than lower dunes of similar type is only generally true. Three types studied-transverse, barchan, and parabolic-provided examples of opposite relations.

5. Winds opposite to the prevailing wind can cause deposits in which dips are opposite to dips of the main slip face. This observation may help in interpreting ancient cross-stratification where dune-top material has been preserved.

\section{REFERENCES}

Bagnold, R. A., 1941, The physics of blown sand and desert dunes: London, Methuen \& Co. Ltd, 265 p.

McKee, E. D., 1966, Structures of dunes at White Sands National Monument, New Mexico (and a comparison with structures of dunes from other selected areas): Sedimentology, v. 7, no. 1, spec. issue, $69 \mathrm{p}$.

Sharpe, C. F. S., 1938, Landslides and related phenomena; a study of mass-movements of soil and rock: New York, Columbia Univ. Press, 136 p.

Van Burkalow, Anastasia, 1945, Angle of repose and angle of sliding friction; an experimental study: Geol. Soc. America Bull., v. 56, no. 6, p. 669-707.

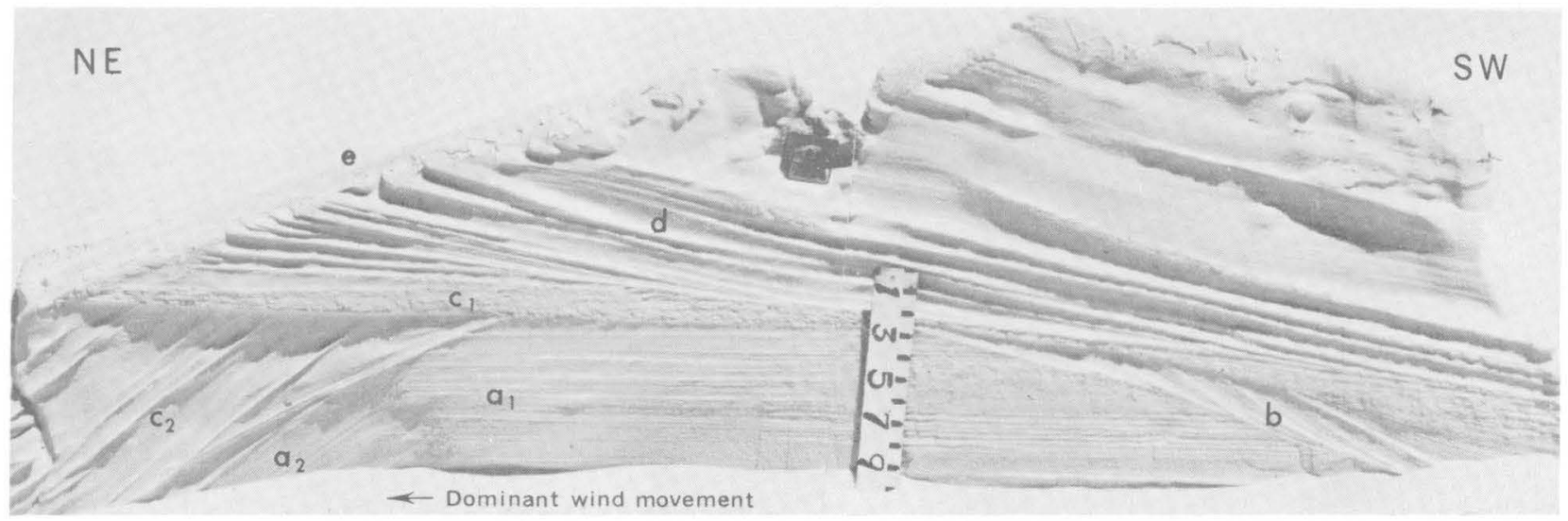

Figure 3.-Cross section taken parallel to dominant wind direction, showing effects of reversal in wind direction on internal structure of barchan. Scale in inches. a, deposit of dominant wind; ( $a_{1}$, topsets; $a_{2}$, foresets); b, deposit of reverse wind (foresets at $34^{\circ}$ ); , second deposit of dominant wind $\left(c_{1}\right.$, topsets at $0^{\circ} ; c_{2}$, foresets at $\left.37^{\circ}-44^{\circ}\right)$; d, second deposit of reverse wind (topsets at $14^{\circ}$ to $15^{\circ}$; foresets removed); e, low-angle, truncating surface formed by return of wind to dominant direction. 


\title{
PALEOCURRENTS IN THE UPPER PART OF THE ALLEGHENY GROUP AND CONEMAUGH FORMATION, BLANDBURG QUADRANGLE, CENTRAL PENNSYLVANIA
}

\author{
By DONALD G. HADLEY, Jiddah, Saudi Arabia
}

\begin{abstract}
Paleocurrent measurements show that fluviatile and deltaic parts of the upper part of the Allegheny Group and Conemaugh Formation of Middle and of Late Pennsylvanian age, respectively, were deposited in the Blandburg quadrangle of central Pennsylvania by currents flowing north and northeast. Of 144 crossbedding measurements, the mean azimuth is $51^{\circ}$. The transport direction is directly opposite that for the Pennsylvanian rocks of Pottsville age, the Sharon Formation in Pennsylvania, and Olean Conglomerate Member in New York, and differs from Allegheny paleocurrents reported previously elsewhere in the Appalachian region by as much as $90^{\circ}$. The paleocurrent direction indicates that source rocks for the Allegheny and Conemaugh Formations lay to the southwest. Detritus was produced by erosion probably during a period of epeirogenic rather than orogenic uplift.
\end{abstract}

Paleocurrent studies previously made in the Appalachian region were chiefly in the Valley and Ridge province in rocks of Mississippian age and older (Meckel, 1967a; Pelletier, 1958; Whitaker, 1955; Yeakel, 1962). Very little quantitative information has been published about dispersal patterns and source areas of formations in the Allegheny Plateau in rocks younger than Mississippian. The present study supplies such information for parts of the Pennsylvanian Allegheny Group and Conemaugh Formation for a $7 \frac{1}{2}$-minute quadrangle area in the southeastern part of the Plateau, and presents some tentative conclusions about the paleogeography and paleotectonics of the area.

Acknowledgments. $-\mathrm{I}$ thank personnel of the Pennsylvania Geological Survey for permitting me to use mine maps and drill-hole data from their files. Mr. William E. Edmunds of that organization assisted with several aspects of the study, and his help is gratefully acknowledged. I also thank Mr. Jack Forman of the Gwinn Engineering Co., Altoona, Pa., and Mr. Samuel Cortis of the Pennsylvania Bureau of Bituminous Mine Subsidence, who provided me with additional surface and subsurface mining data.

\section{GEOLOGIC SETTING}

The Blandburg quadrangle is in the rich bituminous coal field of central Pennsylvania. The Allegheny Front cuts across the southeast corner of the quadrangle (fig. 1), and as a result of erosion along it, there is as much as 1,100 feet of relief in the quadrangle.

Pennsylvanian rocks exposed in the quadrangle are the Pottsville Group and the overlying Allegheny Group and Conemaugh Formation (fig. 2). A slight angular unconformity separates the Pennsylvanian from underlying Mississippian rocks. The inclination of strata is westward, and the dip is greatest near the Allegheny Front. Coal-bearing rocks of Pennsylvanian age, which underlie roughly 75 percent of the area, generally dip about $5^{\circ}$ NW. Several broad anticlines and synclines trend northeastward across the quadrangle.

High-angle wrench faults of small displacement occur in the Blandburg quadrangle; these faults are similar to those in the adjoining Houtzdale quadrangle to the north as reported by Edmunds (1968, p. 77-81). Coal beds and other strata are offset as much as 25 feet by these faults.

Strip mines are extensive in the area, and exposure is excellent in them; many areas are not stripped, however, and natural exposures are uncommon.

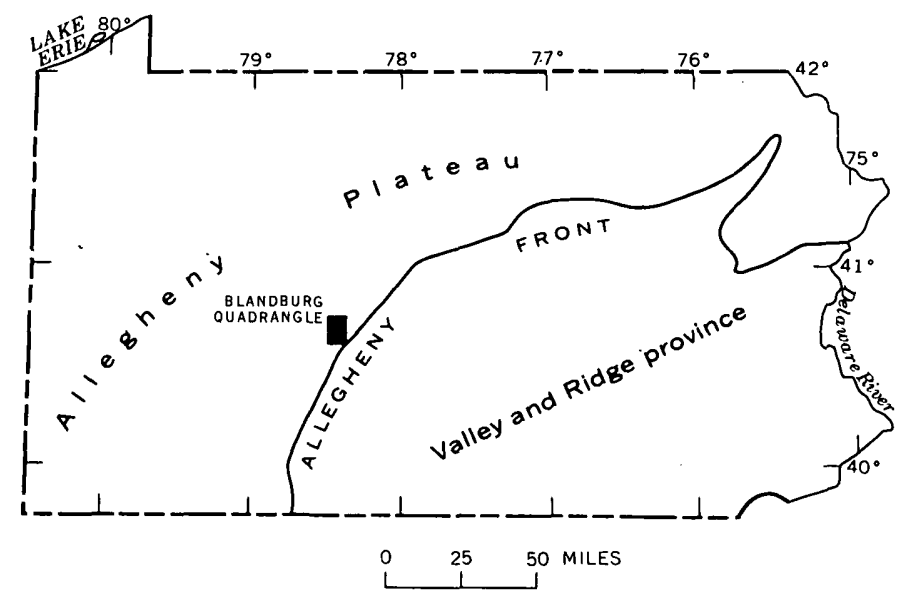

Figure 1.-Location of the Blandburg quadrangle, Pennsylvania. 


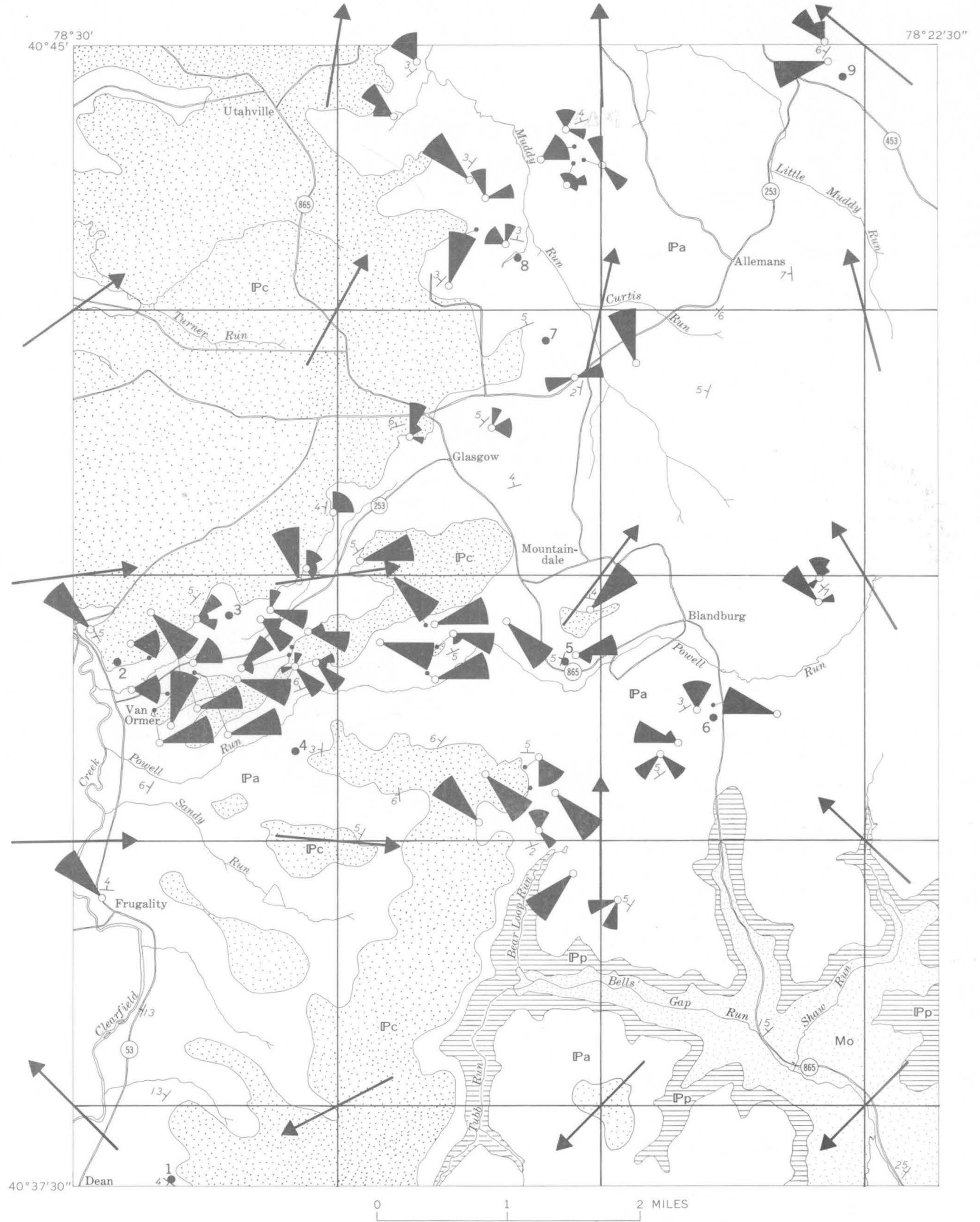

Figure 2. 
EXPLANATION
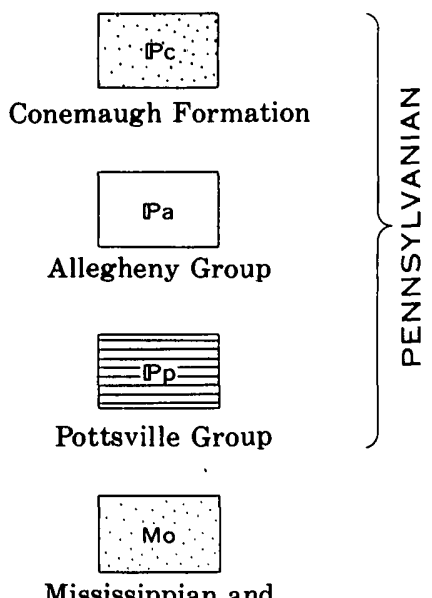

Mississippian and older rocks

Contact

$$
\stackrel{5}{1}
$$

Strike and dip of beds

$$
8
$$

Approximate location of section Shown in figure $s$

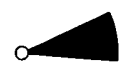

Paleocurrent measurement Total measurements equal 100 percent

Average paleocurrent direction

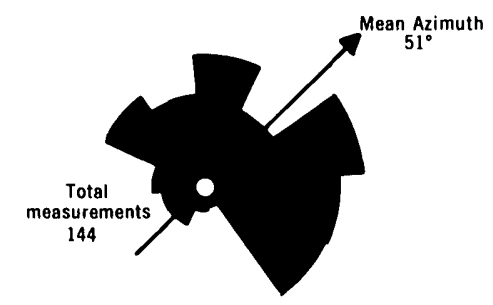

Summary paleocurrent rose diagram

Figure 2.-Geologic map showing paleocurrent directions for the upper part of the Allegheny Group and Conemaugh Formation in the Blandburg quadrangle.

\section{ALLEGHENY GROUP AND CONEMAUGH FORMATION}

About 200 short stratigraphic sections were measured in the Blandburg quadrangle, most of which were in the upper part of the Allegheny Group. Eight of these, shown on figure 3, demonstrate details of the lithology of the Allegheny in the quadrangle.
The Allegheny Group is as much as 190 feet thick in the partial sections shown in figure 3 and consists of conglomeratic, mostly protoquartzite, sandstone; very fine grained to medium-grained protoquartzite to orthoquartzite sandstone; siltstone that is commonly slaty; poorly fissile to massive mudstone; fissile and slaty shale; flint claystone; friable claystone without rootlets; bone coal; coal; and fresh-water limestone. The rocks are invariably shades of gray, ranging from very light gray to grayish black. The sandstone is highly lenticular and commonly varies greatly in thickness within short distances.

Disconformities are common, and coal beds are locally removed by erosion. In a few places sedimentary rocks that fill channels give the appearance of a local angular unconformity with underlying rock. Slump structures are fairly common along channel margins (Williams and others, 1964).

Shale, nodular shale, slaty shale, siltstone, and mudstone generally overlie the coal beds (fig. 3). Rarely, sandstone directly overlies coal. Shale and mudstone units that overlie the coal beds generally contain abundant, well-preserved plant fossils; in some of the beds fossil leaves are as much as $\mathbf{1 0}$ inches long. This abundance of well-preserved plant fossils suggests that when accumulation of peat ceased and siltation began, probably coincident with a rise in water level within the coal-forming swamp, plants continued to grow in or near stagnant water and many accumulated virtually in place. Any appreciable transport would have damaged or destroyed the delicate parts. Generally sandstone abruptly overlies the plant-bearing beds. Most of the sandstone beds are fluviatile and show features that suggest deposition in distributary channels. They are lenticular bedded to wedge bedded and abundantly crossbedded, and they have a preferential transport direction. They contain fossil plant casts, fragments of coal, and cut-and-fill structures, and they lack extreme compositional maturity. The beds have gradational contacts with overlying shale and mudstone, and they have sharp basal contacts.

The Allegheny Group of the Blandburg area, as discussed here, contains five coal beds (fig. 3 ) which, in ascending order, are the Lower Kittanning, Middle Kittanning, Upper Kittanning, Lower Freeport, and Upper Freeport. The coal is chiefly medium-volatile bituminous, and the beds range in thickness from 1 inch to as much as 154 inches for the Middle Kittanning coal bed, which is the thickest (fig. 3, section 9). Substantial changes in thickness occur locally within very short distances, undoubtedly reflecting peat accumulation on very irregular surfaces.

Some of the coal beds-for example, the Lower Kittanning (fig. 3, section 5)-are split into as many as four seams. In the north half of the adjoining Houtzdale quadrangle each of the Allegheny coals occurs as two or more beds (Edmunds, 1968, p. 3).

The most conspicuous marker horizon in the Blandburg quadrangle is a limestone bed near the top of the Allegheny 


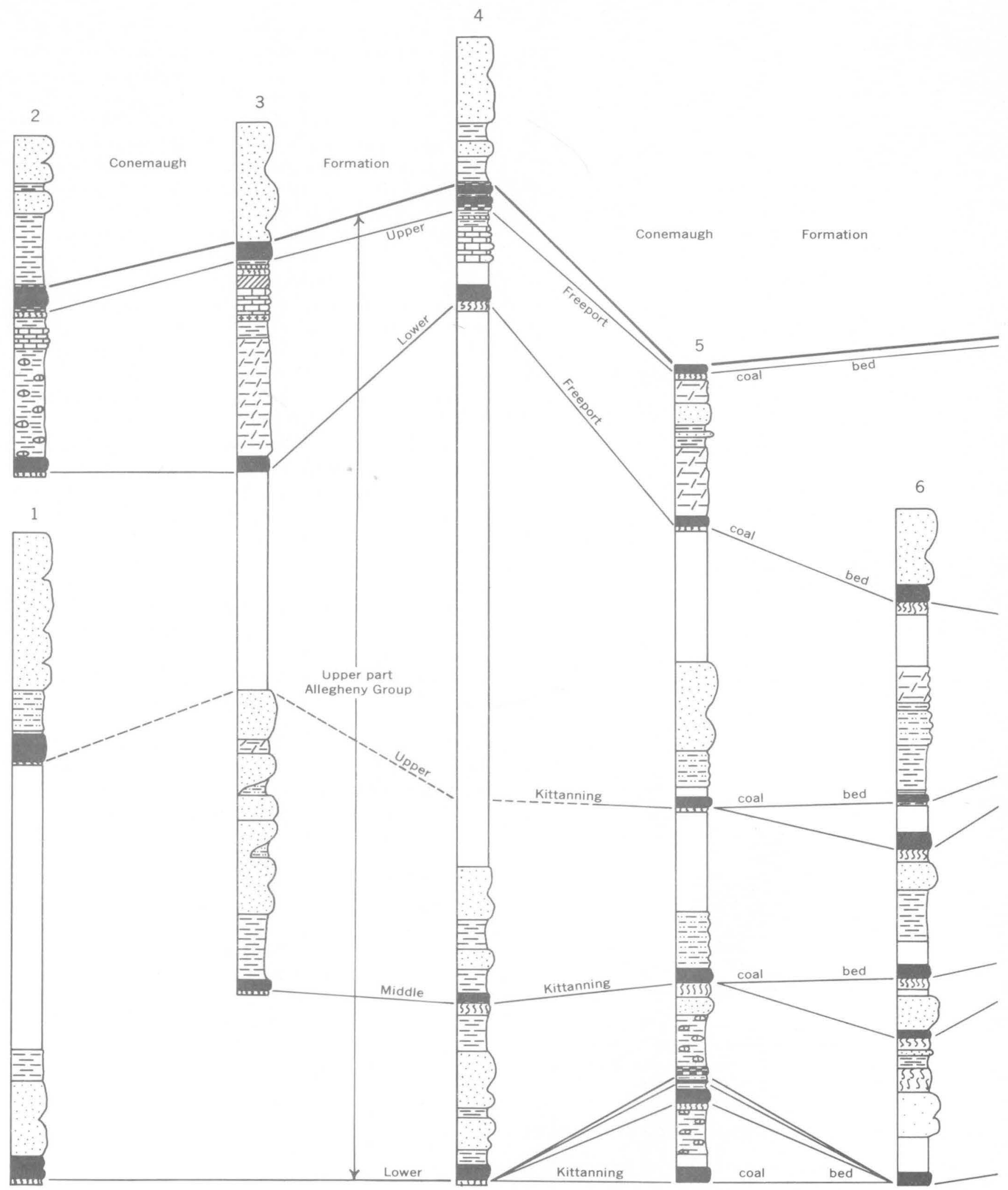

Figure 3.-Stratigraphic relationships of the upper part of the Allegheny Group in the Blandburg quadrangle. 


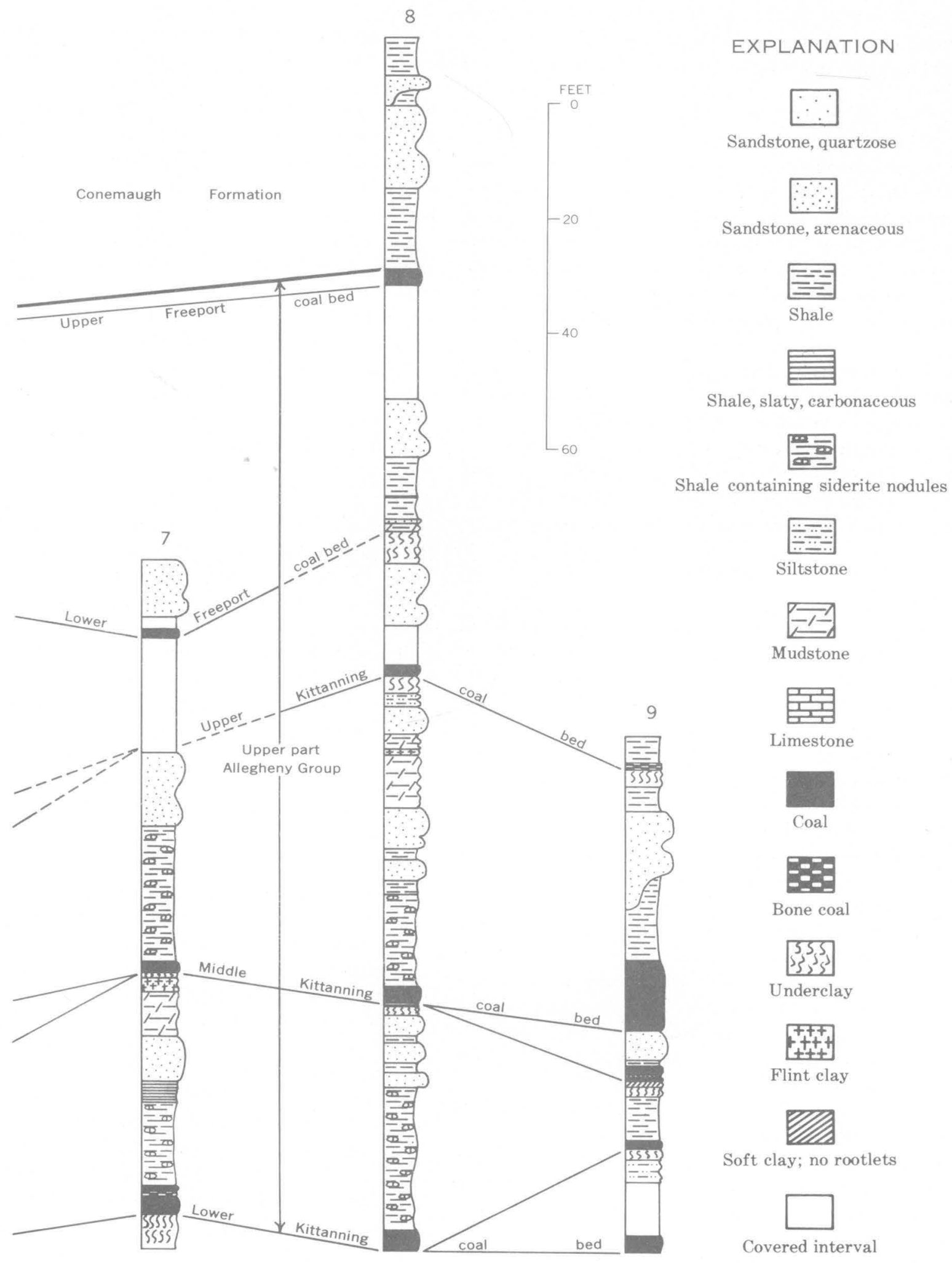

Figure 3. 
Formation beneath the Upper Freeport coal bed (fig. 3, sections 2-4). A similar but much less persistent limestone bed (not shown on fig. 3) also crops out below the Upper Kittanning coal bed. The limestone beneath the Upper Freeport coal bed ranges in thickness from 2 to 11 feet, and it is made up of irregular, wavy beds 8-18 inches thick and very nodular beds less than 8 inches thick. The irregular limestone beds are separated by light- to medium-light-gray, poorly fissile, calcareous shale. On fresh surfaces the limestone is pale yellowish brown to light brownish gray, is extremely compact, and has no visible internal structure. Fossils were not observed in the limestone at any locality. The limestone beds are everywhere overlain by underclay that contains abundant rootlet impressions, which shows that the limestones were probably deposited in fresh water (Edmunds, 1968, p. 56, 58, 61).

The coal beds and their associated underclays formed marginal to or within a deltaic environment as indicated by their alternation with deltaic and fluviatile sediments.

The Conemaugh Formation consists of less than 50 feet of sandstone and shale overlying the Upper Freeport coal bed. Generally overlying the Upper Freeport coal bed is a mediumgrained, wedge- and lenticular-bedded quartzose sandstone.

\section{PALEOCURRENTS}

Dip directions of crossbeds were measured in sandstone of both the Allegheny Group and Conemaugh Formation to determine the paleocurrent direction (fig. 2). No significant difference in paleocurrent direction was found between the two stratigraphic units. No attempt was made to limit the number of measurements at any one outcrop because of the scarcity of crossbeds that could be measured. Despite the scarcity, however, the data are considered dependable because, as shown by Potter and Olsen (1954) in their study of fluvial Pennsylvanian sandstones, two crossbedding measurements per outcrop are statistically sufficient to determine the local transport direction.

Crossbedding, the only type of current indicator found in the quadrangle, is of the trough and tabular types, and the thickness of individual sets ranges from 1 inch to as much as 12 feet. In cross section the individual tabular crossbedded units are generally of uniform thickness. Foreset beds are uniformly planar, parallel, and constant in thickness from top to bottom, and generally average $1 / 2-1$ inch in thickness. With increasing thickness of the crossbedded unit, the foresets increase in thickness correspondingly. The thickest units, for example, have foresets as much as $\mathbf{8}$ inches thick. Most foresets are graded and have an average dip of about $20^{\circ}$. Parting along the foreset planes is common, and it facilitates measurement of the dip azimuths.

The trough-type crossbedded units are typically wedge bedded and lenticular bedded (Meckel, 1967b, fig. 3). The foreset beds are commonly tangential and concave upward at the base. No overall dimensions can be given for the trough-type units inasmuch as three-dimensional exposures were rarely observed, but their average thickness is less than 12 inches.

The dip directions of 90 sets of crossbeds for the Allegheny Group and of 54 for the Conemaugh Formation were measured at a total of 59 stations. The crossbeds were measured according to standard methods described by Potter and Pettijohn (1963, p. 75-80). Planar or tabular crossbeds and trough crossbeds were generally measured by determining the attitude of the foreset planes directly. The dip azimuths were then computed from these data.

Dip azimuths of trough crossbeds were determined by measuring the bisectrix of the trough crossbedded unit in the concave, down-current direction as seen on a bedding plane surface (Potter and Pettijohn, 1963, p. 76-77).

Crossbedding measurements are plotted as circular or rose histograms in which each class is arbitrarily grouped into an interval of $30^{\circ}$. All measurements for each current rose equal 100 percent; thus, for a rose diagram containing only one measurement, 100 percent falls in one $30^{\circ}$ class.

In order to give a broader picture of the paleocurrent pattern in the quadrangle and also to smooth out minor irregularities, the data are also plotted as a moving average (fig. 2). This was done by dividing the quadrangle into squares, each with an area of 4 square miles. Paleocurrent arrows are plotted at the corners of the squares, and each arrow represents the mean azimuth of all crossbeds for squares common to that point. Vector means were calculated by the methods of Curray (1956) and Pincus (1956).

The paleocurrent measurements show that sediment was transported generally from southwest to northeast (fig. 2). The mean current azimuth is $51^{\circ}$. Some variability in the current direction is evident in the southeast-central part of the quadrangle, which may reflect local meanders in the fluviatiledistributary channel system.

Meckel (1967a, p. 242-248) found that crossbedding in the Olean Conglomerate and the Lower Connoquenessing Sandstone, the two lowermost formations of his Pottsville Group in the Plateau area, showed a transport direction from northeast to southwest. These two formations were derived from a cratonic source to the north and northeast. However, during deposition of the Upper Connoquenessing and the Homewood Sandstones in the upper part of his Pottsville Group, the currents flowed from the south and southeast (tectonic source of Meckel). Edmunds (1968, p. 19) qualitatively described the transport direction in the Connoquenessing Formation of the Houtzdale quadrangle as being generally northward. His data agree with Meckel's (1967a) for the Upper Connoquenessing, but disagree with his for the Lower Connoquenessing.

On the basis of thickness measurements and areal distribution patterns of sandstone and shale units in the Allegheny Group in West Virginia, Ferm and Cavaroc (1968, p. 18) suggested that the Allegheny source area was to the southeast. Their data would, therefore, indicate a northwesterly transport 
direction. However, they did not measure any crossbeds for the determination of paleocurrent direction.

The Allegheny and Conemaugh paleocurrent directions, as determined on the basis of crossbedding in the Blandburg quadrangle, differ from those of the Olean Conglomerate of Meckel (1967a) by about $180^{\circ}$, and from the Allegheny data of Ferm and Cavaroc (1968) by about $90^{\circ}$. The difference between Ferm and Cavaroc's data and the data presented here may not be significant because their deltaic model (1968, fig. 10) could accommodate a northeasterly transport direction in Pennsylvania with allowances made for meanders.

Meckel (1967a, p. 254) suggested that the dip of the Pottsville paleoslope was low. The Allegheny and Conemaugh paleoslope probably was low also, inasmuch as the coalforming environment required poorly drained swampy ground. A scarcity of coarse-grained or conglomeratic sediment also would imply a moderate to low gradient for deposition.

The paleocurrents of Paleozoic rocks in the Valley and Ridge province of the Appalachians generally show a dispersal system normal to the trend of the Appalachian folds, including the arcuate fold belt of Pennsylvania: Pottsville Formation of the anthracite area (Meckel, 1967a), Tuscarora (Yeakel, 1962), and Pocono (Pelletier, 1958). In contrast, paleocurrents for the Allegheny and Conemaugh of the Blandburg quadrangle and for the Lower Connoquenessing Sandstone and Olean Conglomerate of the Plateau area show transport of sediment roughly parallel to the Appalachian fold axes (Meckel, 1967a; Edmunds, 1968; this report).

The depositional strike during early Pottsville time and during Allegheny and Conemaugh times was northwest. The paleocurrent data suggest, however, that between Pottsville time and Allegheny time the regional dip of the paleoslope reversed itself from southwest to northeast. The Pennsylvanian depositional basin in which the Pottsville was deposited was probably uplifted and became a positive area. It was from this sedimentary terrane that the Allegheny sedimentary material was derived, possibly in part from reworking of the Pottsville. To determine what part of the Pottsville basin was uplifted and to what extent it was eroded would require additional studies, an important aspect of which would be to determine the distance of the source area from sites of deposition.

The submature composition of the detritus and the general scarcity of coarse-grained and angular material provide evidence that the source area rose slowly and that erosion was not especially vigorous. Therefore, uplift in the source area was probably epeirogenic rather than orogenic.

\section{REFERENCES}

Curray, J. R., 1956, The analysis of two-dimensional orientation data: Jour. Geology, v. 64, no. 2, p. 117-131.

Edmunds, W. E., 1968, Geology and mineral resources of the northern half of the Houtzdale 15-minute quadrangle, Pennsylvania: Pennsylvania Geol. Survey Atlas A85, a and b, 150 p.

Ferm, J. C., and Cavaroc, V. V., Jr., 1968, A nonmarine sedimentary model for the Allegheny rocks of West Virginia: Geol. Soc. America Spec. Paper 106, p. 1-19.

Meckel, L. D., 1967a, Origin of Pottsville conglomerates (Pennsylvanian) in the central Appalachians: Geol. Soc. America Bull., v. 78, no. 2, p. 223-258.

1967b, Tabular and trough crossbedding-Comparison of dip azimuth variability: Jour. Sed. Petrology, v. 37, no. 1, p. 87-95.

Pelletier, B. R., 1958, Pocono paleocurrents in Pennsylvania and Maryland: Geol. Soc. America Bull., v. 69, no. 8, p. 1033-1064.

Pincus, H. J., 1956, Some vector and arithmetic operations on two-dimensional orientation variates, with applications to geological data: Jour. Geology, v. 64, no. 6, p. 533-557.

Potter, P. E., and Olson, J. S., 1954, Geological applications, [Pt. 2] of Variance components of crossbedding direction in some basal Pennsylvanian sandstones of the Eastern Interior Basin: Jour. Geology, v. 62, no. 1, p. 50-73.

Potter, P. E., and Pettijohn, F. J., 1963, Paleocurrents and basin analysis: New York, Academic Press, Inc., 296 p.

Whitaker, J. C., 1955, Direction of current flow in some Lower Cambrian clastics in Maryland: Geol. Soc. America Bull., v. 66, no. 6, p. 763-766.

Williams, E. G., Ferm, J. C., Guber, A. L., and Bergenback, R. E., 1964, Cyclic sedimentation in the Carboniferous of western Pennsylvania: State College, Pa., Pennsylvania Geologists 29th Ann. Field Conf., 1964, Guidebook, 35 p.

Yeakel, L. S., Jr., 1962, Tuscarora, Juniata, and Bald Eagle paleocurrents and paleography in the central Appalachians: Geol. Soc. America Bull., v. 73, no. 12, p. 1515-1540. 


\title{
GLACIATION OF THE RAY MOUNTAINS, CENTRAL ALASKA
}

\author{
By WARREN YEEND, Menlo Park, Calif.
}

\begin{abstract}
The remote Ray Mountains in central Alaska show evidence of two late Pleistocene glaciations. Glaciers as much as 12 miles long occupied the valleys, draining the high, eastern part of the mountains. Remnants of lateral moraines indicate at least three stillstands of the ice during an early Wisconsin(?) glaciation. Hummocky moraines on the high mountain cirque floors were deposited by local cirque glaciers during the late Wisconsin. Evidence of preWisconsin glaciation and Neoglaciation in the Ray Mountains was not found. Glaciers originating in the Ray Mountains in Wisconsin time stopped 28 miles short of the Yukon River and therefore could not have dammed the major drainage. Ice more or less equally distributed around the high parts of the mountains was most likely nourished by precipitation originating in the North Pacific Ocean and (or) Bering Sea.
\end{abstract}

The Ray Mountains in central Alaska, approximately 150 miles by air northwest of Fairbanks and 50 miles south of the Arctic Circle, remain one of the most inaccessible and least known regions of the continental United States. Except for the Alaskan hunter, an occasional prospector, or the U.S. Government topographer, probably only few people have reached the mountains. There are no roads or trails leading into the mountains, and consequently they are readily accessible only by light plane or helicopter.

The range is roughly 75 miles long and 20 miles wide and trends northwest by west. Although few peaks rise above 5,000 feet altitude, Mount Tozi, the highest point, reaches an altitude of 5,519 feet. The Yukon River forms the major drainage boundary southeast of the mountains, the Koyukuk River the drainage boundary northwest of the mountains (fig. 1).

Granitic intrusive rocks make up the bulk of the mountains; the surrounding metamorphic complex is dominated by gneissic hornfels, schists, quartzites, and greenstones.

In the summer of 1913, Henry M. Eakin (1916) led a U.S. Geological Survey field party of four by pack train on a geologic reconnaissance along the northern flank of the Ray Mountains. His report is the only early published account dealing with the geology of the region. Eakin recognized evidence of glaciation in the Ray Mountains and described moraines more than $\mathbf{2 0}$ miles down the valley from the main divides. He felt that ice may have extended "down the valleys considerably beyond the present outermost exposed moraines ***."

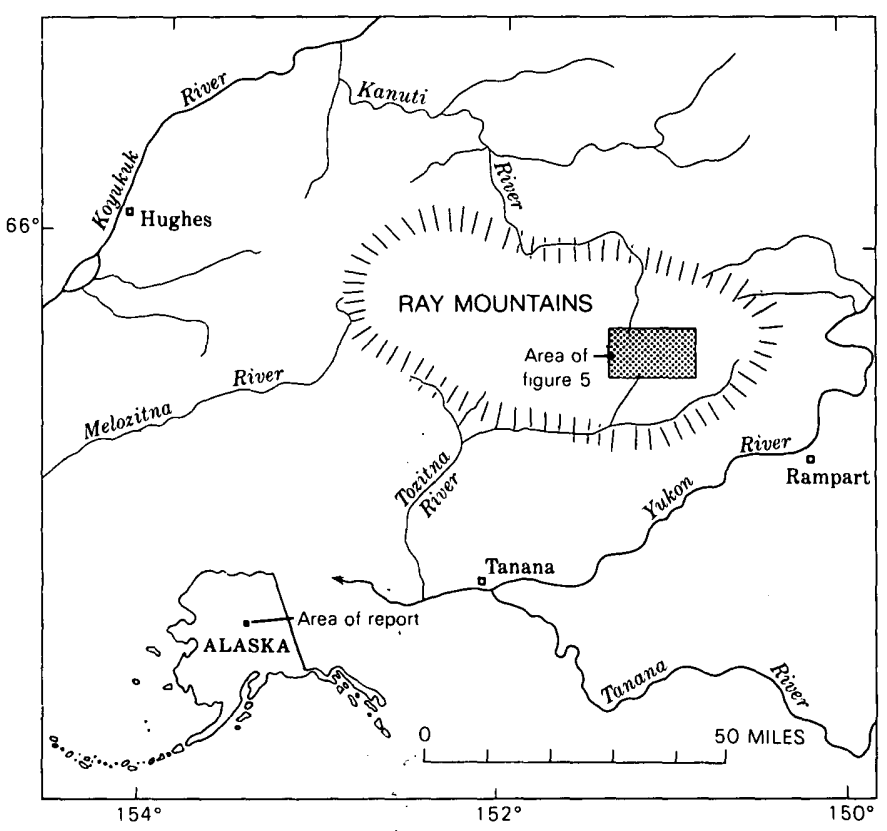

Figure 1.-Index map showing location of Ray Mountains, central Alaska.

Compilations of work in Alaska published in the 1960's and small-scale maps showing extent of glaciation and surficial deposits (Coulter and others, 1965; Karlstrom and others, 1964) show isolated-valley glacial deposits in the Ray Mountains.

Williams (1962, p. $323-324)$ suggested that glaciers originating in the Ray Mountains could have extended to the Yukon River and blocked its path, resulting in the impounding of water and the development of a large lake in the Yukon Flats, a large topographic depression through which the Yukon River flows east of, and upstream from, the Ray Mountains. A closer look at the extent of glaciation in the Ray Mountains seemed warranted. Part of the Ray Mountains were mapped with helicopter support in August and September 1970 as part of a project to map the Tanana 1:250,000 quadrangle, as well as to learn more about the regional geology in the vicinity of the proposed trans-Alaska pipeline. 


\section{EVIDENCE OF GLACIATION}

Erosive glacial features are common in the high parts of the Ray Mountains, providing the observer with the most conclusive evidence for the recognition of glaciation in the mountains. Depositional features such as moraines and outwash deposits are few, of small volume, and generally modified by postglacial solifluction processes. There are at present no active glaciers in the Ray Mountains.

Cirques, arêtes, and horns give the high parts of the mountains the classic rugged character typical of many glaciated mountain ranges. Of the approximately 25 welldeveloped cirques, almost all occur at altitudes of 3,500 and 3,700 feet, a few at 3,000 feet.

The broad, parabolic shape of the valley bottoms is the distinguishing feature of valleys that have been glaciated. The valley of Twilight Creek on the south side of the mountains and that of Halu Creek on the northeast side most markedly exhibit this characteristic profile. In the downstream parts of many of the glaciated valleys where terminal and lateral moraines are lacking, the change in valley profile from parabolic to more $V$-shaped is useful evidence of the maximum extent of ice in the valley.

Moraines are plentiful on the cirque floors, but small cirque lakes are rare. The moraines have no classic ice-bounding forms, but rather are irregular, low hummocky piles of unsorted till occupying the central part of the cirques (fig. 2). This till may represent the final ablation products of the ice subsequent to its withdrawal into the cirques. Ground moraine certainly present on the valley floors downvalley from the cirques has been modified and covered by subsequent active solifluction mantle. Only in several isolated localities is this ground moraine believed to exist unmodified. Two such areas are near the headwaters of the Kanuti Kilolitna and Big Salt Rivers.

Moraine forms marking the boundaries of ice tongues were identified in five separate valleys. Remnants of lateral mor-

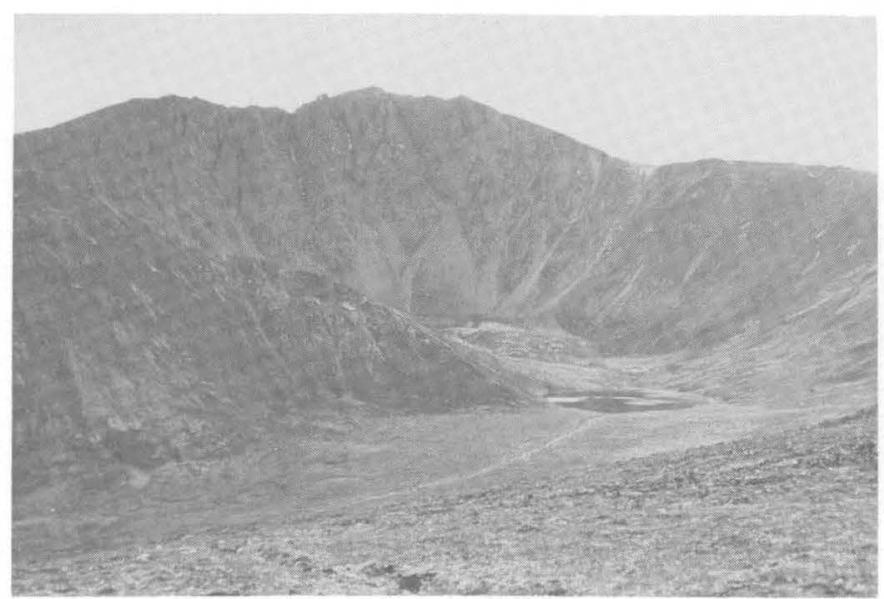

Figure 2.-Cirque at head of Kanuti Kilolitna River. Small lake is just downvalley from a late Wisconsin cirque moraine. aines are preserved on the south side of the Halu Creek valley just upstream from the junction with the Big Salt River. Three separate low, smooth ridges of till less than 50 feet high extend transversely down the valley side to creek level and would seem to mark the termini of the ice tongue at closely spaced time intervals. The farthest downvalley moraine of the three is no more than 1 mile from the farthest upvalley moraine. A few granite and schist boulders as much as 6 feet in diameter are scattered on the moraine surface. The till, examined only in the upper 1 foot because of the ubiquitous permafrost, is composed largely of coarse sand and granules of granitic rocks with a clay matrix. As with most of the moraines observed, solifluction has disturbed the moraine surface producing streamlined slopes. The moraines are very smooth, lacking any hummocky forms.

A single lateral moraine is present on the east side of the Twilight Creek valley, beginning about 3 miles upstream from the junction with the Tozitna River (fig. 3 ). The surface of the moraine is 500-600 feet above the valley floor and would

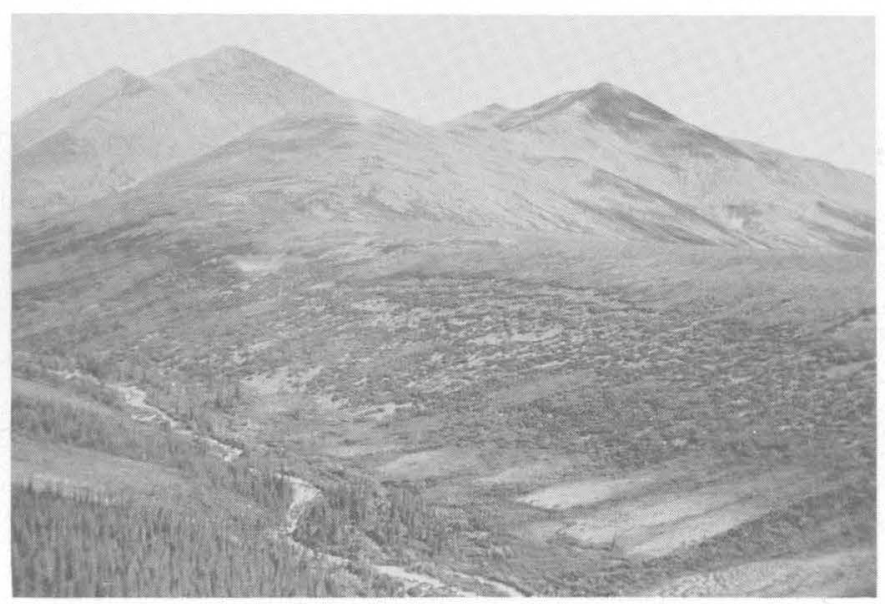

Figure 3,-Valley of Twilight Creek, showing lateral moraine (even, gentle slope in right foreground) left by glaciers of early Wisconsin(?) age. Mount Tozi, highest peak in the Ray Mountains, is the high peak on left. View northeast.

seem to indicate ice of at least that thickness in the valley during glaciation of the mountains. At least three levels of glacial drift seem to be represented beneath the active solifluction mantle on the west side of the Twilight Creek valley. Whether these are kame terraces or moraines is difficult to determine because of the cover.

Unsorted till $150-200$ feet thick is present on the divide between Crash Creek and the Big Salt River. Extending north from this locality into the drainage of the Big Salt River is a low ridge that separates two headwater tributaries of the Big Salt. This feature could be interpreted as a medial moraine.

Remnants of a terminal and a recessional moraine are present in a northwestward-flowing unnamed tributary of the Kanuti Kilolitna River. A small lake is held in by the low 
terminal moraine. These moraines are less than 30 feet high and have bouldery surfaces.

By far the best developed moraine complex is a recessional moraine near the head of the Kanuti Kilolitna River (fig. 4) that curves across the valley, indicating quite vividly the

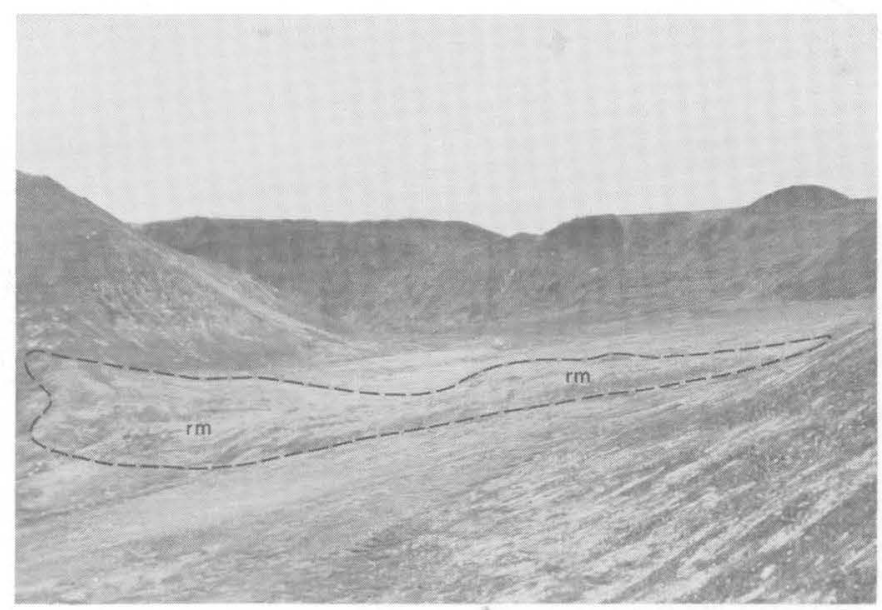

Figure 4.-Early Wisconsin(?) recessional moraine $(\mathrm{rm})$ near the headwaters of the Kanuti Kilolitna River. Moraine has been breached by the river in left foreground. View southwest.

position of the ice front. The moraine is hummocky, having relief of about 40 feet, and has been breached by the Kanuti Kilolitna River near its center.

\section{ICE EXTENT}

The maximum extent of glaciers that occupied the Ray Mountains, interpreted on the basis of erosive and depositional features, is shown in figure 5. Ice accumulated in the eastern, highest part of the mountains to a sufficient thickness to flow down the major drainages, and, in some places, overwhelm low divides between drainages. Much of the mountain range shows no effects of glaciation. A local isolated ice buildup occurred at the headwaters of the Kanuti Kilolitna River on the north-facing slopes of the mountains. It appears that much of the Ray Mountains was below the critical altitude necessary for large ice accumulation, and therefore only those highlands with substantial accumulation area above 3,500 feet were glaciated.

Two major ice tongues occupied the Halu and Twilight Creek valleys. Ice in the Halu Creek valley, on the northeast side of the mountains, reached a length of 12 miles, the longest ice tongue in the mountains. This glacier may have been as much as 800 feet thick. The ice tongue in the Twilight Creek valley, on the south side of the mountains, was 8 miles long and may have averaged 500-600 feet in thickness. Ice was able to flow farther down these drainages than others because the accumulation areas feeding ice into these drainages were extensive. Ice did not extend an appreciable distance down either the Big Salt River or Crash Creek because the snow-accumulating zone on the northeast side of Mount Tozi was small. A similar situation existed at the headwaters of the Kanuti Kilolitna River, where the snow-accumulating area above 3,500 feet is relatively small. Ice flowed less than 2 miles down this drainage.

It seems clear that glaciers from the Ray Mountains did not approach the vicinity of the Yukon River and, therefore, could not have been instrumental in damming this major drainage. The long glacier that flowed down Halu Creek stopped 28 miles short of the Yukon River. If ice from the Ray Mountains did at one time extend to the vicinity of the Yukon River, all evidence of it has vanished.

The location of source areas for the precipitation that resulted in the glaciation of the Ray Mountains is speculative. The logical source areas would have been either the Aretic Ocean to the north, assuming that the Arctic Ocean was ice free (Ewing and Donn, 1963), or the northern Pacific Ocean and Bering Sea to the south and southwest. Had glaciers been nourished by air masses from the north, it is unlikely, considering the greater insolation on the south-facing slopes and the precipitation "shadow" effect, that there would have been much ice buildup on these slopes. And, as figure 5 shows, there was not. Except for the local ice mass that existed near the head of the Kanuti Kilolitna River, glaciers were distributed fairly evenly around the high parts of the Ray Mountains. It seems clear that only with a supply of moisture from the south and (or) southwest could ice have built up on the south-facing slopes. Evidently the heavy snowfall on the south slopes more than offset the effect of insolation. In those areas where the accumulation zone was lower and of smaller area, such as at the headwaters of the Kanuti Kilolitna River, only on the protected north slopes was ice able to build up sufficiently to initiate glaciation, and the effects of insolation on the south-facing slopes overcame those contributing to greater accumulation. A similar North Pacific source area for late Quaternary glaciation in Alaska has been suggested by Péwé and others (1965).

\section{MULTIPLE GLACIATION}

Two major periods of glaciation seem evident within the Ray Mountains. The first, more widespread phase is characterized by the broad $U$-shaped valleys that contained glaciers 12 miles long. The second phase, which may in fact represent nothing more than the withdrawal of ice from the earlier phase, was marked by the presence of cirque glaciers only. This glacial event, restricted to the cirques, would seem to be the youngest, primarily on the basis of the fresh unmodified form of the moraines and complete lack of soil development. The more extensive older glaciation was characterized by at least three minor stillstands of the ice as shown by the three nested moraines in Halu Creek and the three drift levels along the south side of Twilight Creek. The moraines in Halu Creek have only a hint of soil development-a faint colored B horizon, 0.3 


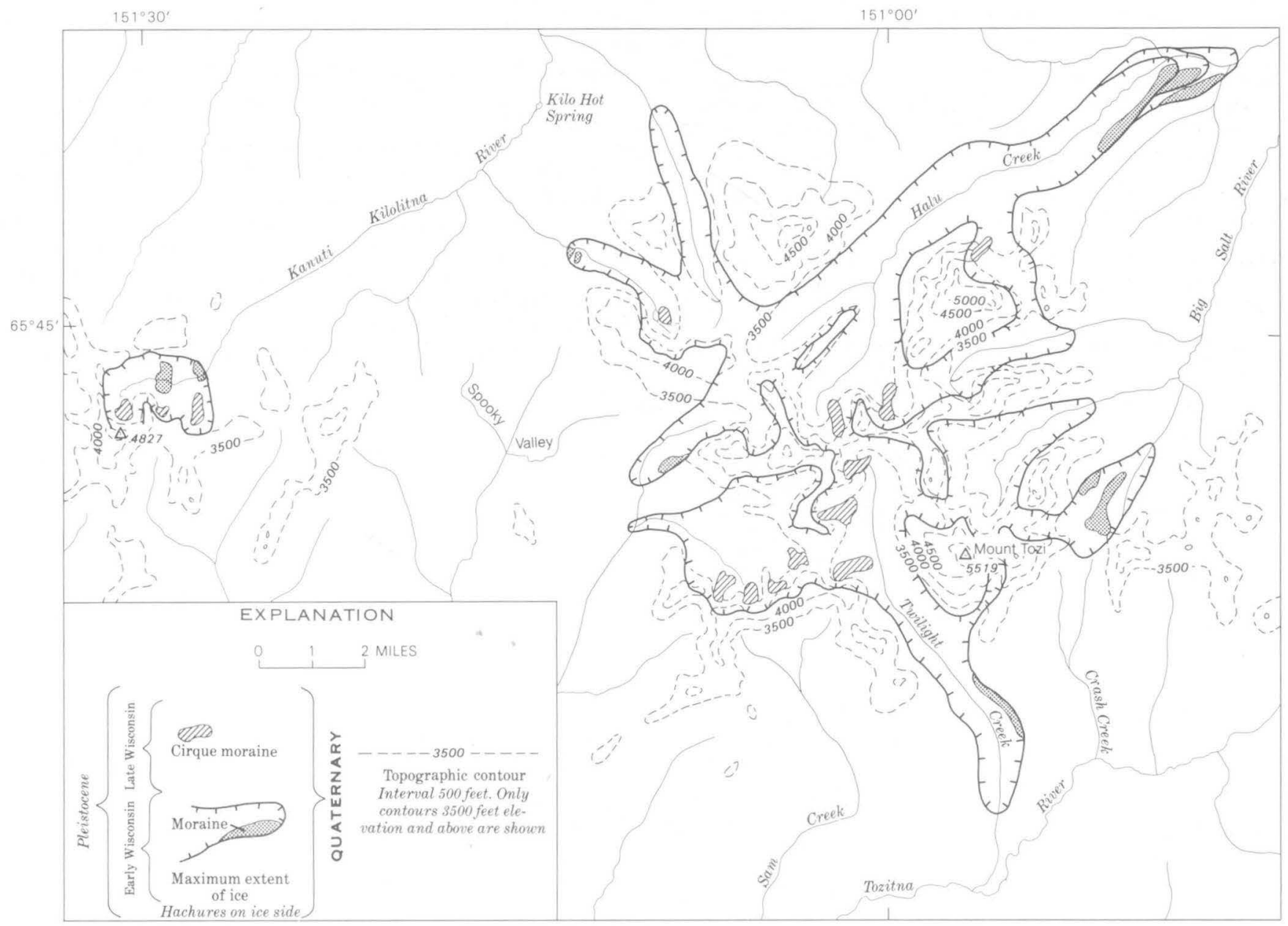

Base from U S Geological Survey

1250.000. Tanana. 1956

Figure 5.-Map of the eastern, highest part of the Ray Mountains, showing maximum extent of glaciation. See figure 1 for location of map area.

feet thick. The B horizon is dark grayish brown, $2.5 Y 4 / 2$, as determined from the Munsell soil-color charts. The underlying clayey till is olive gray, $5 Y 4 / 2$. A textural change is not apparent. Soils on the few glacial deposits of this older phase, determined to be unaffected by postglacial solifluction, are developed very poorly or not at all. On the basis of the morphology of deposits, weak soil development, and extent of ice, the older glaciation in the Ray Mountains is questionably correlated with the Kobuk Glaciation of possible early Wisconsin age, identified in the Alatna Valley of the Brooks Range (Hamilton, 1969).

The younger glacial event is correlated with the late Wisconsin Itkillik Glaciation of the Alatna Valley (Hamilton, 1969). This tenuous correlation is based on the fresh, hummocky moraines lacking soil development. It is thought that the Ray Mountains escaped the effects of Neoglaciation because of their low altitude and small areal extent. An alternative hypothesis is that the cirque glaciation is, in fact, a neoglacial event and the more extensive glaciation of both early and late Wisconsin age.
At least two alpine glaciations are identified in the YukonTanana upland 100-200 miles southeast of the Ray Mountains (Péwé and others, 1967). They have been considered Wisconsin and pre-Wisconsin in age.

\section{CONCLUSIONS}

The Ray Mountains were occupied by glaciers during Wisconsin time. Ice tongues as much as 12 miles long were present in the mountain valleys during early Wisconsin time but had withdrawn to the cirques by late Wisconsin time. Glaciers originating in the Ray Mountains in Wisconsin time did not extend to the Yukon River and therefore could not have dammed the major drainage. The North Pacific Ocean and (or) the Bering Sea most likely provided the precipitation resulting in the Wisconsin glaciations of the Ray Mountains.

Evidence for pre-Wisconsin glaciation in the Ray Mountains was not found. 


\section{REFERENCES}

Coulter, N. W., and others, compilers, 1965, Map showing extent of glaciations in Alaska, prepared by the U.S. Geological Survey, Alaska Glacial Map Comm.: U.S. Geol. Survey Misc. Geol. Inv. Map I-415, scale 1:2,500,000.

Eakin, H. M., 1916, The Yukon-Koyukuk region, Alaska: U.S. Geol. Survey Bull. 631, $88 \mathrm{p}$.

Ewing, M. E., and Donn, W. L., 1963, Polar wandering and climate: Soc. Econ. Paleontologists and Mineralogists Spec. Pub. 10, p. 94-99.

Hamilton, T. D., 1969, Glacial geology of the lower Alatna Valley,
Brooks Range, Alaska: Geol. Soc. America Spec. Paper 123, p. $181-223$.

Karlstrom, T. N. V., and others, compilers, 1964, Surficial geology of Alaska: U.S. Geol. Survey Misc. Geol. Inv. Map I-357, scale $1: 1,584,000$.

Péwé, T. L., Burbank, Lawrence, and Mayo, L. R., 1967, Multiple glaciation of the Yukon-Tanana Upland, Alaska: U.S. Geol. Survey Misc. Geol. Inv. Map I-507, scale 1:500,000.

Péwé, T. L., Hopkins, D. M., and Giddings, J. L., Jr., 1965, The Quaternary geology and archaeology of Alaska, in Wright, H. E., Jr., and Frey, D. G., eds., The Quaternary of the United States: Princeton, N.J., Princeton Univ. Press, p. 355-374.

Williams, J. R., 1962, Geologic reconnaissance of the Yukon Flats district, Alaska: U.S. Geol. Survey Bull. 1111-H, p. 289-331. 


\title{
THE PREGLACIAL KENTUCKY RIVER OF NORTHERN KENTUCKY
}

\author{
By W C SWADLEY, Erlanger, Ky.
}

Work done in cooperation with the Kentucky Geological Survey

\begin{abstract}
An abandoned high-level river valley extends from the Kentucky River near Carrollton, Ky., northeast to the mouth of the Great Miami River at Lawrenceburg, Ind, a distance of about 40 miles. The geographic location, gradient, and fluvial-sediment content of this valley identify it as the preglacial course of the Kentucky River. It follows closely the Ohio River valley but only locally coincides with it. Glaciation reversed the flow of this part of the ancestral Kentucky River and established the course of the Ohio River downstream from Lawrenceburg. Glacial deposits filling the preglacial valley probably prevented the newly formed Ohio River from occupying most of the old valley.
\end{abstract}

The preglacial course of the Kentucky River and its role in the development of the modern drainage system of the Kentucky-Ohio-Indiana areas has long been a problem. The earliest workers in the area concluded that the preglacial Kentucky joined the ancestral Ohio River near the present confluence. Other workers have described the Kentucky as part of a northward-flowing drainage system that predated the development of the Ohio. Recent mapping along the Kentucky side of the Ohio valley between Cincinnati, Ohio, and Carrollton, Ky., has delineated an abandoned high-level river valley that $I$ believe to be the preglacial course of the Kentucky. This report describes this preglacial valley and the glacial deposits in it and relates the valley and deposits to the subsequent development of the major drainage system of the region.

Leverett (1902) and Fenneman (1916) believed that downstream from the mouth of the Great Miami River the preglacial course of the Ohio and Kentucky Rivers was virtually the same as today. Malott (1922) and.Fowke (1933) described the preglacial Kentucky as flowing northeastward from the area of Carrollton along what are now the Ohio and Great Miami valleys. Jillson (1946) described an abandoned river valley 6 miles east of Carrollton and concluded that it was the preglacial course of the southwest-flowing Ohio. Wayne (1952), in describing the evolution of the Ohio and Wabash valleys, summarized much of the previous work in the region and gave further evidence supporting a northeast-flowing
Kentucky River. Durrell (1961) discussed a preglacial northflowing river system in the area southwest of Cincinnati but considered it to be the Eagle River.

\section{REGIONAL SETTING}

The preglacial drainage of the region has been called the Teays River system (fig. 1). The Teays flowed northwestward across West Virginia and Ohio, then generally west across Indiana and Illinois to join the Mississippi. The preglacial Kentucky River flowed northwest virtually along its present course to the area of Carrollton. From here it flowed northeast, was joined by the Licking River north of Cincinnati, and then continued northward to become part of the Teays River in central Ohio. The ancestral Ohio (fig. 1) headed on a divide near Madison, Ind., and flowed southwest. An advance of glacial ice southward into Ohio, Indiana, and Pennsylvania ponded the north-flowing streams and caused them to spill westward over several major north-south divides, initiating a new southwest-flowing drainage system, the Ohio River. The Allegheny and Monongahela Rivers were diverted southwest Anto a tributary of the Teays system. The ponded Teays spilled over a divide into the Kentucky drainage and flowed northwest along a tributary of the Kentucky to the area north of Cincinnati, where the new river turned southwest, reversing the direction of flow in a segment of the preglacial Kentucky River valley. With the breaching of a major divide at Madison, the drainage reversal was completed, and the modern Ohio River was established in this area.

\section{VALLEY DESCRIPTION}

The - abandoned river valley departs from the modern Kentucky River valley about 4 miles upstream from Carrollton (fig. 2). The river flowed northeast through a series of large meanders that, with only one exception, were in or south of the present Ohio valley. East of Warsaw, Ky., the river was joined by the preglacial Eagle Creek and flowed northward along a widely meandering course that was largely east of the Ohio 


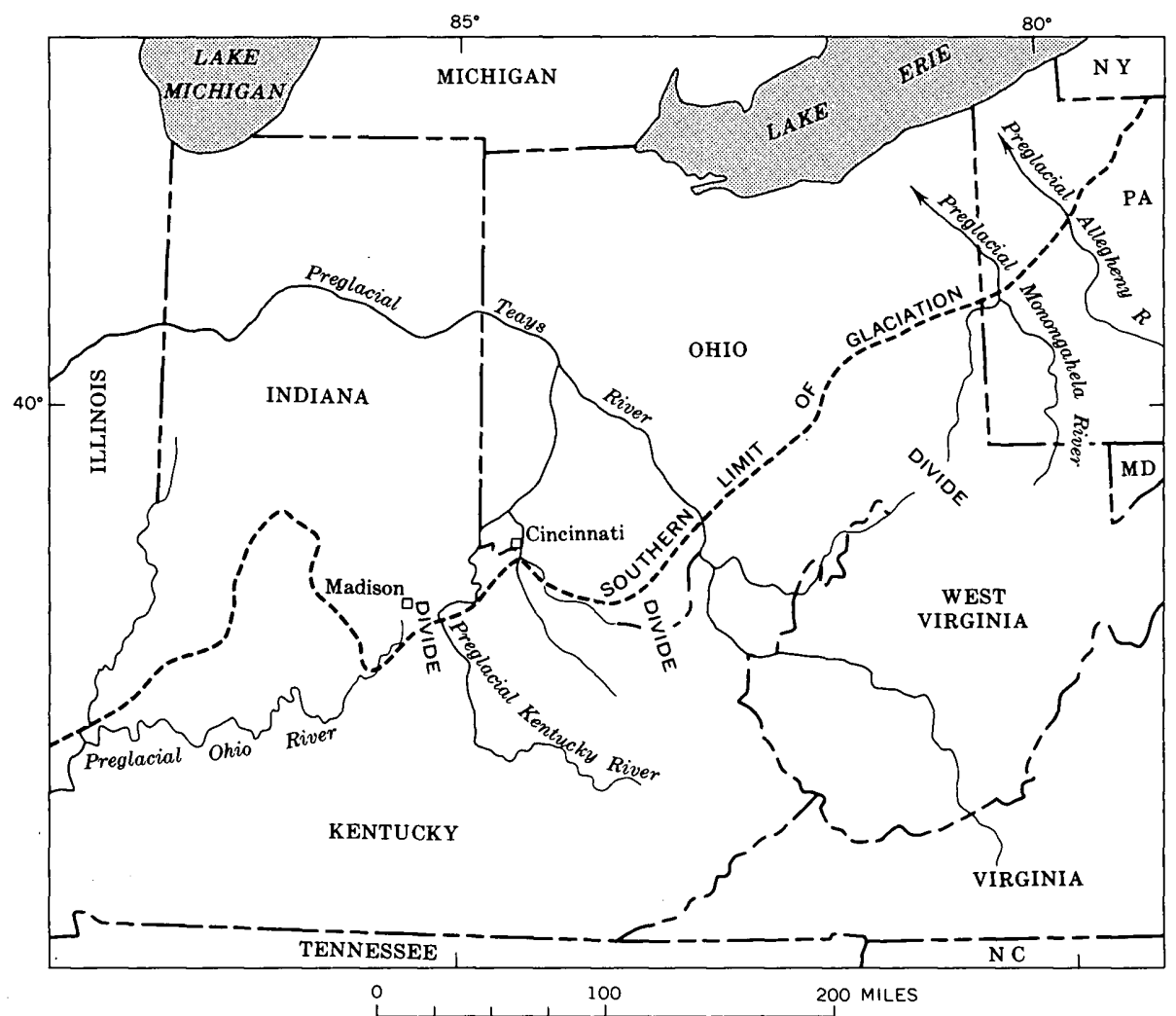

Figure 1.-Preglacial drainage of the Ohio valley region (modified from Thornbury, 1969, p. 389).

valley. The northernmost point of the abandoned valley in Kentucky is on the Ohio bluffs directly opposite the mouth of the Great Miami valley. The path followed by the preglacial Kentucky River was quite sinuous, extending a distance of approximately 95 river miles to cover an air-line distance of less than $\mathbf{5 0}$ miles. The width of the meander belt ranged from 4 to 5 miles. Although the overall trend of the abandoned valley agrees fairly well. with that of the Ohio, the Ohio actually lies along the northern and western edge of the old meander belt, and only locally do the two valleys coincide.

The old valley is incised to a maximum depth of about 200 feet in virtually flat-lying interbedded limestone and shale of Late Ordovician age. Its floor is 200 to 250 feet above the modern Ohio River. At the southwest end, the bedrock floor of the valley is at an altitude of approximately 670 feet. At the northernmost point of good elevation control (fig. 2) the floor is at 630 feet. This is a drop of 40 feet in a distance of about 85 river miles, or a gradient of approximately 6 inches per mile. The modern Ohio has a gradient of 4 inches per mile in this area.

Throughout most of its length, the abandoned valley has been occupied and deepened by modern streams that range in size from the Ohio River to small intermittent creeks. The preservation of the valley and the accuracy with which it can be traced depend largely on the size of these streams. The abandoned valley is well preserved in the southern part of the area between the valleys of the Ohio River and Eagle Creek. Here it is marked by fluvial deposits that form well-developed terrace remnants 40 to 80 feet above the present creeks. These remnants cap flat-topped bedrock spurs that extend out from the sides of the present valley and slope gently toward the creeks. The best preserved terrace remnants are in the large meander 12 miles east of Carrollton. These terrace remnants are as much as 1,500 feet wide, and some deposits continue up the old valley wall to heights of nearly 100 feet above the channel floor.

Where the Ohio River occupies segments of the old valley, the original valley profile and all fluvial deposits have been removed by erosion, and the position of the abandoned channel within the 2-mile-wide Ohio valley can only be inferred. The longest such "missing" segment is near Rising Sun, Ind, and is 7 miles long.

Intermediate between these two extremes of preservation are segments of the abandoned valley now occupied by steep and deeply entrenched creeks that empty directly into the Ohio. These creeks have deepened the valley as much as $\mathbf{2 0 0}$ feet and have extensively modified its shape. Evidence for the old valley is largely limited to small patches of fluvial deposits well up on the old valley walls.

Along meander loops where the preglacial valley was strongly asymmetrical, streams have commonly formed at the foot of the steep outside bank of the old valley meander, at 


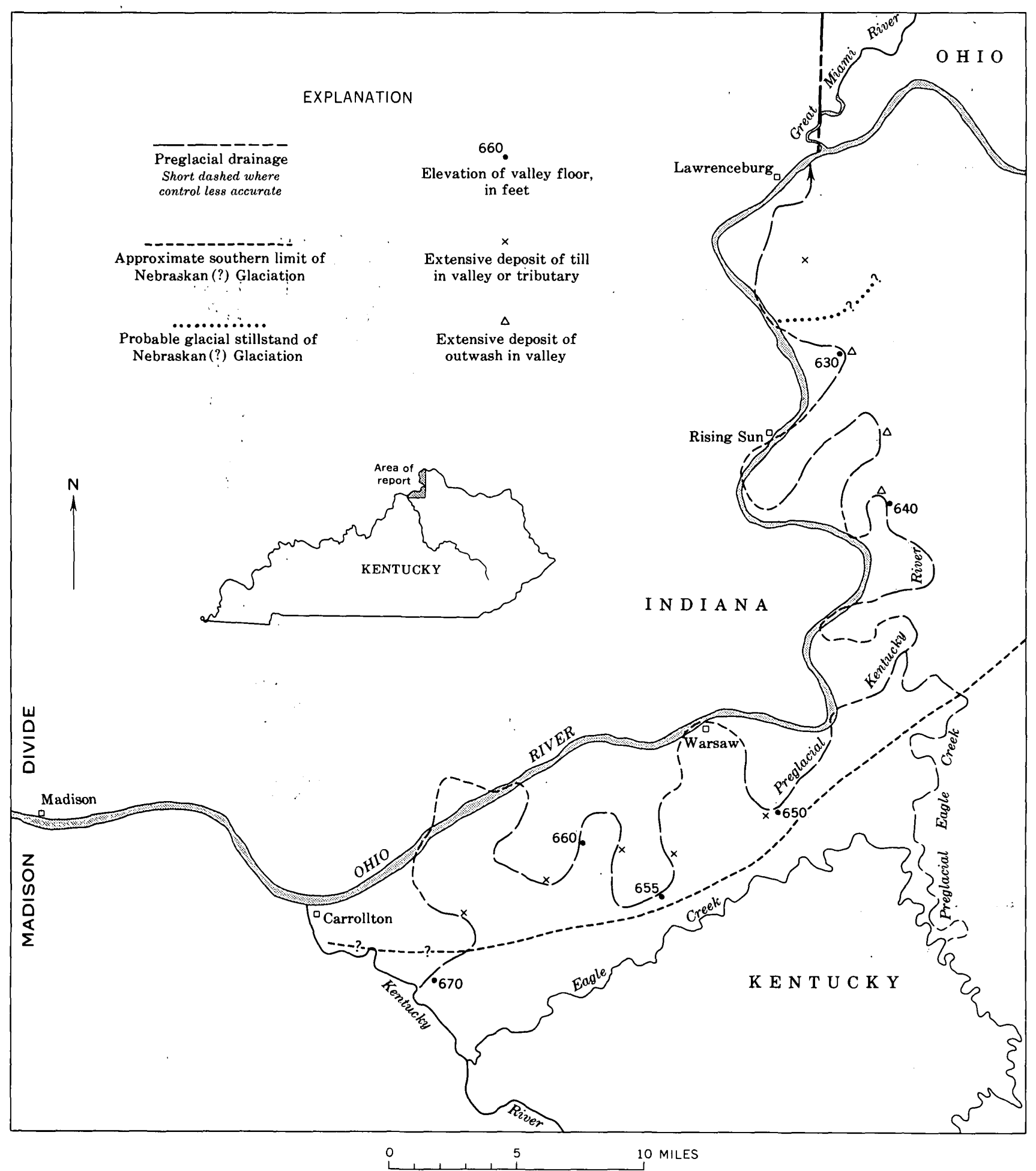

Figure 2.-Map showing the course of the preglacial Kentucky River and principal glacial features along the Ohio River between Carrollton, Ky., and Lawrenceburg, Ind. 
the contact of the bedrock with the fluvial deposits of the valley floor. The deposits of the channel and those mantling the slip-off slope of the meander are still intact except where dissected by the headward erosion of lateral tributaries. In straight reaches of the river the modern streams tend to be incised in the center of the old valley; they have removed much of the channel deposits and have left small terrace remnants along each side of the valley. Seven miles eastnortheast of Warsaw, Ky., streams along both sides of the preglacial valley have left the valley-floor deposits capping a ridgetop and have produced a topographic reversal.

\section{FLUVIAL DEPOSITS}

The fluvial deposits in the preglacial valley consist of clayey silt, sand, and gravel. The material is commonly a reddishbrown clayey silt containing common to scattered pebbles and cobbles and resting on a few inches to a few feet of gravel in a muddy to sandy matrix. The deposits are deeply weathered and completely leached of all limestone gravel. Small limonitic nodules are common in the silt, and the basal gravel is locally cemented with limonitic material. The silt commonly shows no bedding. Sand is locally abundant but overall makes up only a small part of the deposits, most of it occurring in what are probably point-bar deposits. It is fine to coarse, most grains being in the medium range, moderately well sorted, and commonly limonite stained. The sand consists largely of subangular to angular quartz; there are few heavy minerals, but mica is common. Thin beds of limonite-cemented sand occur locally in the silt.

The gravel consists of four types of material: quartz and chert pebbles, fragments of chert and silicified limestone, quartz geodes, and blocks of sandstone. The quartz and chert pebbles are white, yellow, or brown, well rounded, and generally less than 2 inches in diameter, resembling those in the Pennsylvanian-age conglomerate of southeastern Kentucky. Chert and silicified limestone occur as subangular to subrounded pebbles, cobbles, and blocks as much as 12 inches across. Most are some shade of brown, but others are gray and white; some include silicified corals and crinoids of probable Mississippian age. Geodes containing yellow or brown quartz are present throughout the deposits. They range from 1 to 18 inches in diameter and were probably derived from Mississippian-age limestone of south-central Kentucky. The least abundant component of the gravel, blocks of light-brown, medium- to coarse-grained micaceous sandstone as much as 2 feet across, occur locally. All the clasts in the gravel seem to have a southern origin and are similar to those in the alluvial deposits bordering the present Kentucky River.

\section{GLACIAL DEPOSITS}

Outwash sand and gravel as much as $\mathbf{1 5 0}$ feet thick occur in the abandoned valley of the Kentucky River in the northern part of the area (fig. 2), where the glacial deposits are readily distinguishable from the older fluvial deposits. The glacial gravel is composed of mostly subangular to subrounded limestone fragments as much as a foot across with smaller amounts of well-rounded pebbles and cobbles of igneous and metamorphic rocks. It is crossbedded, poorly sorted, and well cemented, standing in cliffs as much as $\mathbf{8 0}$ feet high. To the south, particle sizes in the outwash decrease sharply. The southernmost deposit of outwash (fig. 2) consists of fine to coarse, moderately well sorted sand with only minor lenses of gravel and pebbly sand. The sand is more evenly bedded than the gravel, stained by limonite, and largely uncemented.

Thick deposits of till occur in several segments of the abandoned valley in the southern part of the area and at one locality in the northern part along a small unmapped tributary about 3 miles southeast of Lawrenceburg, Ind. (fig. 2). The till is a medium-gray calcareous silty clay containing scattered sand grains, fragments of limestone from local sources, and wellrounded pebbles, cobbles, and boulders of igneous and metamorphic rocks. In most natural exposures the till is deeply weathered and leached of calcareous material. It consists of reddish-brown clayey silt containing clasts of siliceous composition and of the more resistant igneous and metamorphic rocks. The maximum exposed thickness of till is about 80 feet.

\section{GLACIAL HISTORY}

The southward advance of glacial ice into central Ohio blocked the preglacial Teays River and its tributary, the Kentucky, forming a proglacial lake that overflowed to the southwest across the Madison divide and initiated the development of the modern Ohio River. The glacial deposits along the abandoned Kentucky River valley suggest how this stream diversion may have occurred.

Approximately 5 miles south of Lawrenceburg are indications of a temporary glacial stillstand (see fig. 2). North of this line, the preglacial valleys contain deposits of till but very little outwash. South of this line, the old valley and several tributary valleys are largely filled with outwash that may have been as much as 200 feet thick. Immediately south of the probable ice-front position, the outwash is largely coarse gravel that is strongly crossbedded, the beds dipping generally south. Nearby, a small valley that joined the Kentucky from the southeast was filled with sand and gravel deposits that lap onto the valley sides to a height of about 830 feet. To the south in the main valley, the outwash is almost entirely sand.

The deposits south of the probable stillstand position suggest that the divide near Madison was still largely intact when the ice advanced to the line south of Lawrenceburg. Melt water from the glacial front pouring into the lake built an outwash delta of coarse gravel, the finer sand being carried by currents flowing south toward the Madison spillway. The onlap of outwash up to $\mathbf{8 3 0}$ feet would indicate a lake level in excess of that elevation. The topography of the Madison area (Madison East quadrangle, Kentucky-Indiana) indicates that 
the low point in the Madison divide, excluding the present Ohio gorge, was about 850 feet.

After this pause the ice advanced farther south into the lake, overriding the outwash delta. The ice moved across almost all of the preglacial valley and terminated a very short distance beyond (fig. 2). Till was laid down over the area, the thickest deposits being preserved in north-south segments of the valley. Throughout most of the valley the till rests on fluvial sediments; however, locally, the sediments and some of the underlying bedrock have been removed, probably by glacial scour, and here the till rests on bedrock. Because the glacier was advancing into the proglacial lake, there was little erosion of sediments by melt water in advance of the ice. Only minor amounts of outwash gravel were observed underlying till, suggesting that no proglacial valley train was deposited. It was while the ice stood at or near the southern limit that the first significant downcutting occurred at the Madison divide. As the divide was lowered and the lake began to drain, melt water and probably much of the drainage from the area to the northeast cut a new ice-front channel that is now occupied by the southwest segment of Eagle Creek. The extent of the downcutting by melt water in this valley compared with postglacial erosion by Eagle Creek is not known. However, the lack of any significant valley paralleling the glacial front east of the big bend of Eagle Creek indicates that such ice-marginal melt-water channels were rather limited.

As the glacial front retreated from its southern limit, the newly cut Eagle valley was abandoned as a melt-water channel. It was at this time that the Ohio River of this area probably came into existence. The preglacial Kentucky River valley was effectively blocked by outwash and till at several points and perhaps for the entire length between Carrollton and Lawrenceburg. The Teays drainage system to the east and northeast was still ponded. These lakes drained southwestward along the glacial front and, augmented perhaps by melt water, cut a new and straighter valley. The new Ohio River formed, possibly as an ice-margin stream, along the western and northern edge of the Kentucky meander belt and only locally occupied segments of the preglacial valley. During a subsequent glaciation (Durrell, 1961) the Ohio River upstream from Lawrenceburg was diverted from the north to the south side of Cincinnati, and the Great Miami River was formed.

This study has revealed no conclusive evidence concerning the age of the glaciation that diverted the Kentucky River in this area. The presence of Illinoian Till in the modern Ohio valley near Warsaw requires a pre-Illinoian age for the diversion and for the formation of the Ohio. Wayne (1952) attributed the diversion to Nebraskan Glaciation. Durrell (1961) suggested a Nebraskan age for the formation of the Teays River system and a Kansan-age diversion of the Teays to form the Ohio River. Ray (1966), in a discussion of the glacial deposits of northern Kentucky, described both Nebraskan and Kansan Till in the map area and assigned a Nebraskan age to the formation of the Ohio.

\section{CONCLUSIONS}

Field evidence indicates that the preglacial Kentucky River flowed northeastward from the area of Carrollton to the mouth of the Great Miami River along a course that generally follows but only locally coincides with the Ohio River valley. Ponding by pre-Illinoian glaciation, probably the Nebraskan, produced a proglacial lake in the ancestral Kentucky River valley that spilled over the Madison divide, reversing the preglacial direction of flow. The divide was breached when the glacier stood at or near the southern limit of advance, but the course of the Ohio River across this area became established after the ice had retreated from its southern limit. Extensive glacial deposits in the preglacial Kentucky River valley prevented the Ohio from occupying most of this old valley.

\section{REFERENCES}

Durrell, R. H., 1961, The Pleistocene geology of the Cincinnati area, in Geol. Soc. America, Guidebook for field trips, Cincinnati meeting, 1961: New York, Geol. Soc. America, p. 47-57.

Fenneman, N. M., 1916, Geology of Cincinnati and vicinity: Ohio Geol. Survey, 4th ser., Bull. 19, 207 p.

Fowke, Gerard, 1933, The evolution of the Ohio River: Indianapolis, Ind., Hollenbeck Press, 273 p.

Jillson, W. R., 1946, The Easterday abandoned channel of the Ohio River, a study in Pliocene drainage, physiography, and geology: Frankfort, Ky., Roberts Printing Co., 43 p.

Leverett, Frank, 1902, Glacial formations and drainage features of the Erie and Ohio basins: U.S. Geol. Survey Mon. 41, 802 p.

Malott, C. A., 1922, The physiography of Indiana, in Handbook of Indiana geology: Indiana Dept. Conserv., Div. Geology Pub. 21, p. 59-256.

Ray, L. L., 1966, Pre-Wisconsin glacial deposits in northern Kentucky, in Geological Survey Research 1966: U.S. Geol. Survey Prof. Paper 550-B, p. B91-B94.

Thornbury, W. D., 1969, Principles of geomorphology (2d ed.): New York, John Wiley \& Sons, 594 p.

Wayne, W. J., 1952, Pleistocene evolution of the Ohio and Wabash valleys: Jour. Geology, v. 60, no. 6, p. 575-585. 


\title{
PRE-WISCONSIN GLACIAL DIVERSION OF THE HOUSATONIC RIVER IN NORTHWESTERN CONNECTICUT
}

\author{
By CHARLES R. WARREN, Washington, D.C.
}

Work done in cooperation with the State of Connecticut Geological and Natural History Survey

\begin{abstract}
The Housatonic River was diverted from its preglacial valley at least once, and probably twice, in the part of its course 0.2-0.6 mile below West Cornwall, Conn. One of the diversions, and probably both, occurred longer ago than the Wisconsin Glaciation. Thus, the tills that caused these diversions probably date from two separate pre-Wisconsin glaciations. This evidence supports the inference that the lower till, widespread in the area, dates from pre-Wisconsin time. If it does, much of the topography of western Connecticut reflects pre-Wisconsin glacial events.
\end{abstract}

Although complex multiple glaciation of the Midwest has long been established, evidence of pre-Wisconsin glaciation in New England is scanty (Schafer and Hartshorn, 1965). New evidence showing that glacial deposits diverted the Housatonic River in northwestern Connecticut in pre-Wisconsin time is possibly the first clear proof of multiple glaciation in this area. The evidence probably dates a recognized widespread till as older than the Wisconsin Glaciation; if the correlation is correct, many topographic features that have been assumed by some to reflect Wisconsin glacial events are in part older. The chronology thus indicated not only fits better with that inferred in other parts of the world, but also explains better the evidence already known in New England.

\section{DIVERSION OF THE HOUSATONIC}

In northwestern Connecticut, about 0.2 mile south of the covered bridge at West Cornwall (figs. 1 and 2), the Housatonic River makes an abrupt westward turn of more than $90^{\circ}$. The turn is clearly abnormal, being much sharper than a normal curve of a river as large as the Housatonic.

Immediately downstream from the turn, the river plunges into a gorge with a narrow floor and steep cliffed walls (at B, fig. 1). The floor of the gorge is scarcely wider than the stream itself. This is a sharp contrast with the situation north of the turn and south of the area shown in figures 1 and 2, where the floor of the Housatonic valley is relatively open and

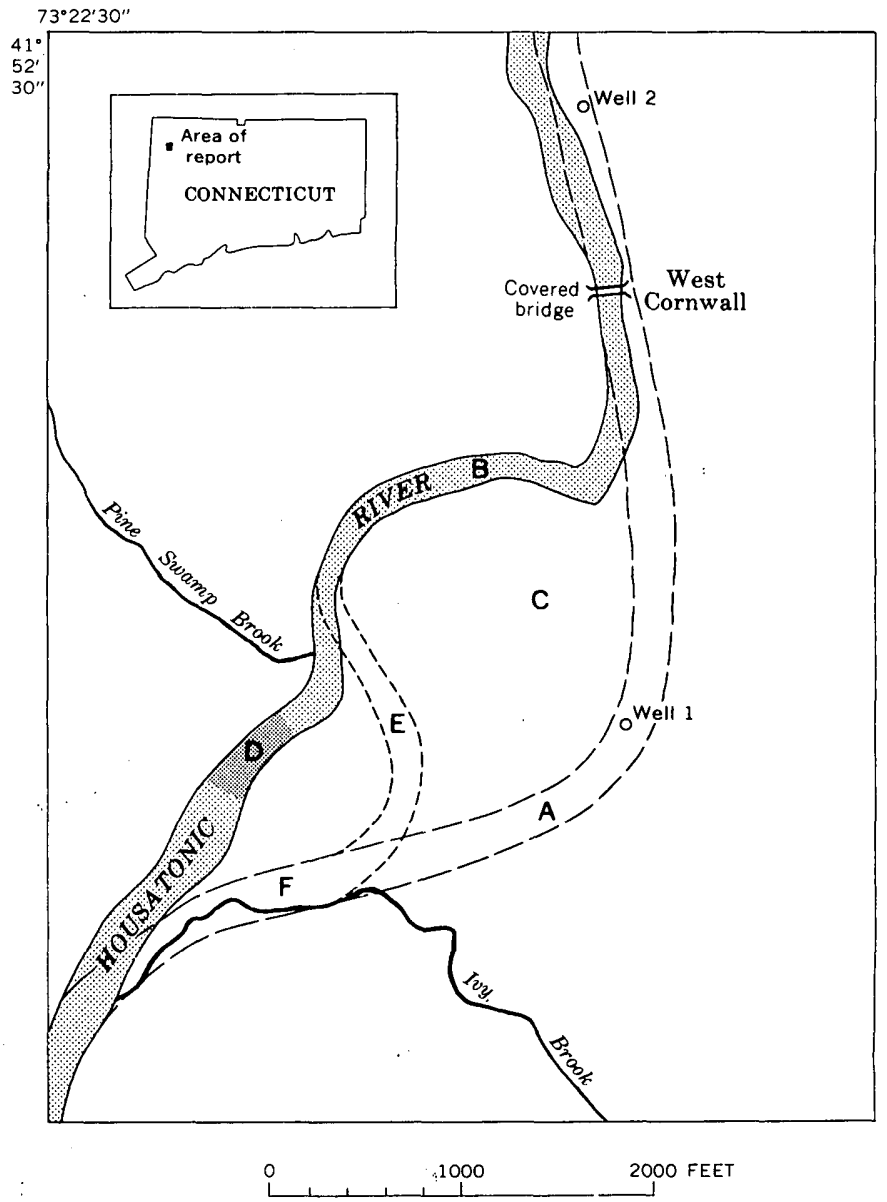

Figure 1.-West Cornwall area, northwest Connecticut, showing present (solid) and inferred former (dashed) routes of the Housatonic River. River is flowing on bedrock (shaded) at $D$. See text for explanation of other lettered localities.

much wider than the river. Moreover, the walls of the gorge are abnormally steep. In Connecticut, as throughout New England, most valleys have been opened out by weathering and 


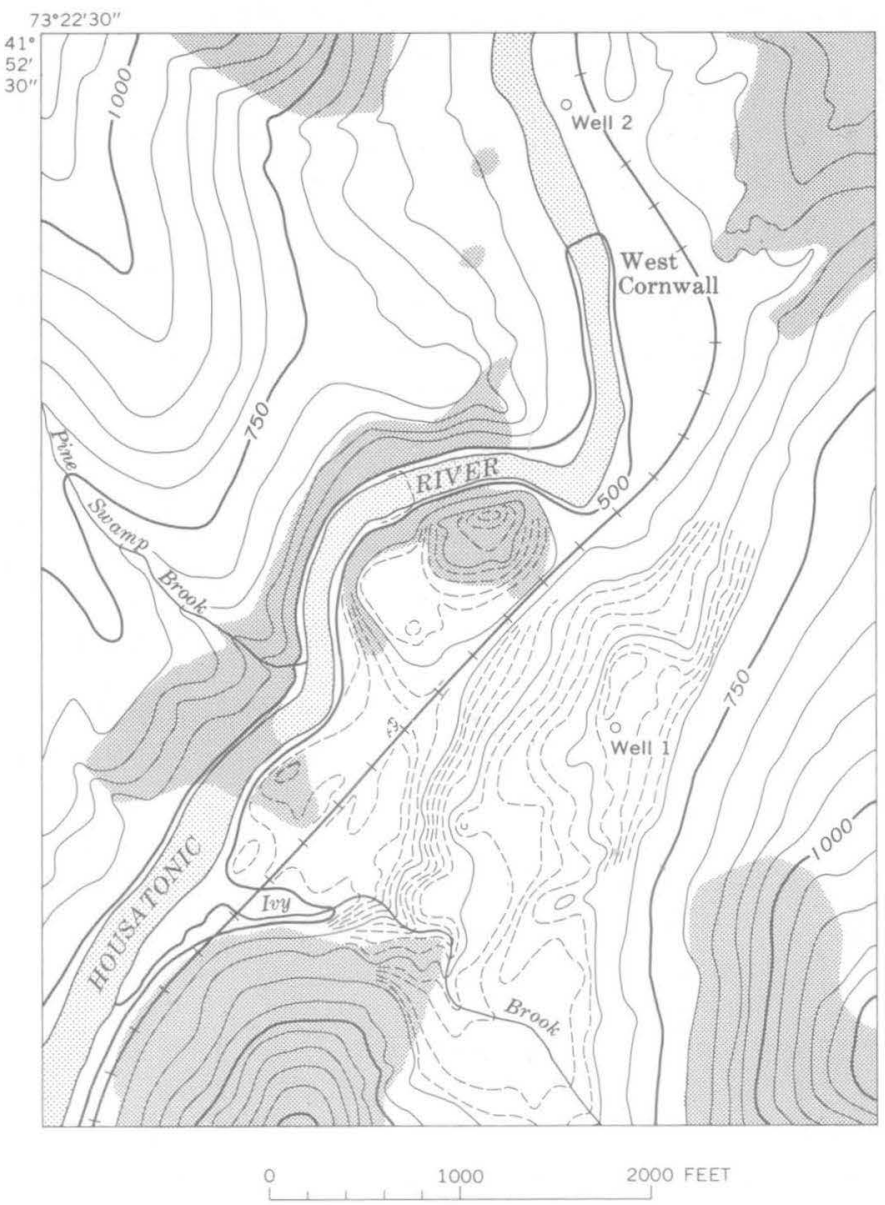

Figure 2,-Topographic map of West Cornwall area, showing nearsurface bedrock and outcrops (shaded); same area as figure 1. Base after northwest corner of U.S. Geological Survey Cornwall, Conn., $7^{1 / 2} 2$-minute quadrangle. Contour interval 50 feet, with supplementary contours (dashed) at 10 feet.

mass wasting, so that steep slopes are generally confined to areas where lithologic contrasts are extreme, as along the border between a gneiss upland and a marble lowland. No such lithologic contrast is present here (Gates, 1961), and no structural controls such as a fault or brecciated zone are known that could account for the steepness of the gorge walls at locality B.

The contrast between the youthful form of the gorge and the more mature landforms elsewhere can best be explained as reflecting a difference in age. The river has not had time to open out the floor of the gorge, and the slopes have not had time to waste back, as other slopes have done. Most slopes in Connecticut are basically inherited from the preglacial (that is, Tertiary) topography. The relative youth of the gorge indicates that it is of Pleistocene origin.

From the south lip of the gorge the rock surface slopes southeast to a trough now followed by the railroad (at C, fig. 1). Although this southeast slope is moderately steep, it is much gentler than the walls of the gorge and is comparable to the slopes of many preglacial valleys in the western upland of Connecticut.

The abnormally sharp turn of the river, the abnormal youthful gorge below the turn, and the southeast slope away from the lip of the gorge, taken together, can best be explained by the inference that the Housatonic River was diverted in Pleistocene time from a preglacial course that continued south from the present abrupt turn. (This inference was suggested to me by Mr. G. C. Kelley.)

\section{PREGLACIAL VALLEY}

Study of the topographic map (fig. 2) suggests that the trough at locality $\mathrm{C}$, now followed by the railroad, may mark the preglacial valley from which the Housatonic River was diverted into the gorge. However, the actual axis of the preglacial valley is farther southeast. The rock surface into which the railroad grade has been blasted stands well above the river level, and the southeastward slope of the rock surface continues farther to the southeast, buried under an increasing thickness of till.

The position of the buried valley is at least approximately indicated by a well that was brought to my attention by $\mathrm{Mr}$. Clifford Ten Broeck, Superintendent of Trinity Parish Boys Camp which owns the land near the railroad cut (the driller, Mr. Earle Thompson, now of Bethlehem, Conn., did not report the drilling results to the State Water Commission because he found no water). The well location is identified as well 1 on figures 1 and 2 .

This well is so unusual, in at least two ways, that it is possibly unique. First, it is in very thick till; it penetrates 225 feet of "hardpan" (glacial till) without reaching bedrock. Only a few of the wells in Connecticut are drilled through as much as 100 feet of till, but here, even after setting 195 feet of casing, the driller had difficulty in keeping the hole open for his cable-tool equipment and finally had to abandon the hole. Second, most wells that encounter thick till in the State are in drumlins or drumlinlike streamline hills, but this well is down on a valley slope.

The bedrock surface at the well site is more than about 50 feet below the present profile of the Housatonic at this latitude. The ground surface at the well site is about 5 feet below the 670-foot contour on the map, so that if the contours are correct, the elevation of the bottom of the well is near 440 feet; the bedrock is an unknown distance below this. The 490-foot contour crosses the Housatonic River in the rock gorge northwest of the well site.

Thus, the well must be in a buried valley. The only available stream that can have carved this valley is the Housatonic. The conclusion that the long profile of the Housatonic was lower in preglacial time than it is today is supported by three additional facts: (a) A well in West Cornwall (well 2 on figs. 1 and 2) penetrated 97 feet of coarse gravel, reaching bedrock at about 445 feet. (b) No rock is known to be exposed in the bed of the Housatonic River either upstream or downstream from 
the area here described, throughout the length of the Housatonic Highlands section of the river. (c) In spite of the steep side slopes, commonly more than $30^{\circ}$, the valley is not $\mathrm{V}$ shaped. Instead, it has a more or less open flat floor underlain by glacial deposits and alluvium.

The depth to rock in the former valley of the Housatonic at the sites of the two wells is not the result of karstic solution of carbonate bedrock. This area is in the Housatonic Highlands, where the bedrock consists of Precambrian gneisses that are stratigraphically well below the marbles of the area, which are of early Paleozoic age (Rodgers and others, 1959).

The great depth to bedrock at the thick-till well is also unlikely to be the result of overdeepening by glacial scour. Scour usually occurs in soft or weathered rocks, especially where ice moves parallel to a straight valley. Here the rock is hard gneiss (Gates, 1961), and so far as is known, the ice flowed transversely across the valley. Glacial grooves and striae, the shapes of streamline till hills, and the distribution of erratics of identifiable provenance all indicate that the ice in western Connecticut moved generally south-southeast, and such ice would not scour effectively here; the unusual thickness of till found by the well indicates that the ice at this site did not scour, but rather deposited its load of sediment.

Even if unknown earlier ice came there from some other direction-any other direction-it would be unlikely to scour effectively. The well data and the distribution of bedrock outcrops (fig. 2) show that the buried valley of the Housatonic River, from which it was diverted to the present course through the gorge, took approximately the course shown at $\mathrm{A}$ in figure 1. Thus the buried valley is strongly curved at the well site, and the site is surrounded by areas where bedrock is at higher elevations.

The thick till at the well site presumably caused the diversion of the Housatonic by blocking the inferred preglacial route via $A$. The reason that the ice deposited till thick enough to cause a diversion here but apparently nowhere else between Great Falls and Cornwall Bridge is probably the fact that the curve at $A$ was the only segment of the preglacial valley where ice moving south-southeast would be forced to converge because it was crowded in from both the north and the west. The curve formed a pocket, with closure in relation to ice moving in this direction, and the ice in it would therefore be relatively stagnant; such ice would tend to be overloaded and to deposit its sediment.

\section{PRE-WISCONSIN DATE OF THE DIVERSION}

Three lines of evidence indicate that the diversion occurred longer ago than the Wisconsin Glaciation; that is, that the glacier ice that deposited the thick till and forced the diversion was of pre-Wisconsin age. These lines of evidence are at least partly independent.

First, the rock gorge at B (fig. 1) is more than 140 feet deep, for the 490 -foot contour crosses the river there, whereas the hill to the south rises above the 630 -foot contour. This cutting was apparently accomplished in solid rock; there is no evidence of faulting or other fracturing that would facilitate the cutting. Post-Wisconsin (Holocene) time, less than 15,000 years, would surely be insufficient to accomplish the cutting of such a deep valley in hard rock.

Corroboration of this conclusion is available. About 8 miles upstream from West Cornwall, at Falls Village, the Housatonic has been diverted across a bedrock ridge to form Great Falls. The diversion occurred at least as long ago as the Wisconsin Glaciation, and the river poured across Great Falls at least from the beginning of Holocene time until it was diverted through the penstocks of the powerplant. At Great Falls the Housatonic has cut down only about 10 or 15 feet, and the falls have retreated less than $\mathbf{2 0}$ feet. If Holocene time has not been long enough for the Housatonic to cut more than this amount at Great Falls, it can scarcely have been long enough for the river to have cut a 140-foot gorge 8 miles downstream.

The second line of evidence showing the pre-Wisconsin date of the diversion of the Housatonic is given by Pine Swamp Brook, a small tributary of the Housatonic that flows generally southeast (fig. 1). Near the mouth of this brook, a narrow glen, with waterfalls, is incised as much as 30 feet into bedrock. At the head of the falls is a distinct knickpoint, upstream from which the brook is not comparably incised. Because the knickpoint is not recognizably related to any lithologic change, it appears to show that the cutting of the glen reflects a relatively recent change in the stream regimen. This change was apparently the diversion of the Housatonic. The preglacial brook was presumably graded to a junction with the inferred preglacial valley at a point between $A$ and $F$ (fig. 1). After the diversion suddenly befooted Pine Swamp Brook (that is, cut off its downstream part), the Housatonic cut down faster than the brook could, leaving the brook hanging and forming a knickpoint. The present glen was then cut by falls retreat.

On this interpretation, cutting of the glen of Pine Swamp Brook did not begin until the Housatonic had cut down significantly in the new course, many millennia after it had been diverted. Moreover, the carving of the glen itself took a long time. It cannot have been accomplished rapidly, by debris-loaded glacial melt water, as is inferred for some other rock gorges in Connecticut, for the glen is narrow, just the width of the present brook; a notch cut by a stream swollen by melt water would be wider. On any reasonable estimate, the time required to cut the glen was longer than Holocene time.

The rejuvenation of Pine Swamp Brook gives independent confirmation that the gorge of the Housatonic at locality $B$ is not a preglacial valley exhumed (reexcavated and freshened) by the glacial diversion. If the trench had existed in preglacial times, the preglacial brook would have been graded to it, and no rejuvenation would have occurred.

Third, the present topography of the thick till that blocks the preglacial valley does not account for the route of the diverted Housatonic. If the gorge did not exist, the Housatonic 
would spill through the trough at $\mathrm{C}$ (fig. 1). It is unreasonable to suppose that a block of ice closed this trough for the many millennia the river needed to cut the gorge at $B$; no ice could last that long. Thus, if the till surface at the time gorge cutting began resembled the present one, the gorge would have been cut at $C$ rather than at $B$. It seems, then, that the thick till must at first have filled the trough at $C$, so that its upper surface sloped northwest to the site of $\mathrm{B}$. Presumably the river started cutting its gorge along the crease or trough between the northwest slope of the till and the southeast slope of the rock. Not until after the gorge was deeply incised, below the Holocene level of the trough at $\mathrm{C}$, did that trough come into existence.

The till that initially blocked the trough at $C$ was not removed by gullying; the trough is not a product of stream erosion. Rather, its topography is glacial. The ice of one or more later glaciations must have reexcavated part of the original thick-till deposit, shaping the trough at $\mathrm{C}$ to the prerailroad surface. This ice cannot have been younger than Wisconsin. Thus, the initiation of cutting at B must antedate the Wisconsin Glaciation by the time it took to cut the gorge down to a level below the trough at $\mathrm{C}$. This erosion required tens and probably hundreds of millennia.

\section{PROBABLE SECOND DIVERSION}

The southwest end of the hill that forms the south wall of the gorge is in part a steep bedrock scarp, which resembles the walls of the gorge to the northeast except that the river does not flow at its base. The origin of this scarp is not evident unless the river formerly did flow at its base. The shape of a curving scarp to the south (fig. 2) suggests that this may in fact have happened: that after the first diversion, the Housatonic may have taken a course approximately as indicated at $E$ and F on figure 1. If so, a second diversion must have occurred to shift the river to the course it now follows, via $D$.

Four lines of evidence support the inference that the river formerly took an S-shaped course via B, E, and F. First, there is a persistent deep in the river, locally known as the Dempsey Hole, at the point, above the bedrock exposures at $D$, where the present course diverges from the inferred former S-shaped course. At most places the Housatonic is less than hip deep, but at the Dempsey Hole the river is well over 10 feet deep (C. Ten Broeck, oral commun., 1969); in local legend it is "bottomless." If the Housatonic had been shifted to its present course at the time of the first diversion, there is no obvious reason, either in known bedrock structures or in predicted erosive forces, why the Dempsey Hole should have formed. In relation to the inferred S-shaped course, however, it is on a curve where overdeepening might be expected.

Second, the glen that constitutes the downstream part of Pine Swamp Brook is barbed to the present southwest course of the Housatonic, but it would have a normal junction with the inferred S-shaped course. This suggests that cutting of the glen was initiated while the brook was tributary to the
S-shaped course. The eastward course of the glen is roughly parallel with the local strike of the foliation in the gneiss, but it is probably not due solely to structural control.

Third, the glen shows that the Housatonic has cut down significantly below the surface on which Pine Swamp Brook flowed in preglacial time. Thus, a rock cliff should have developed not only at $\mathrm{B}$ and $\mathrm{D}$, but continuously between these points. Instead, there is a distinct break in the cliff line southeast of the Dempsey Hole, where drift slopes down to the water.

Fourth, the river bed at $D$ is floored by bedrock for more than 500 feet of its length (fig. 1), but in the deep part of the gorge, at $\mathrm{B}$, no bedrock outcrops are recognizable. Instead, the Housatonic is flowing over bouldery gravel. I had no facilities for probing the actual depth to rock at $B$, but the evidence from the Dempsey Hole suggests that the depth may not be trivial. This evidence suggests that the Housatonic may have cut the S-shaped course down to a profile below the present profile of the river, before it was diverted a second time.

The alternative hypothesis is that the Housatonic was diverted to its present course via $D$ at the time of the first diversion (to B). This would require that at a downstream point the river should have cut down less than 50 feet and been unable to eliminate the bedrock during a time interval long enough to permit it farther upstream to cut down more than 140 feet and to continue to cut down to a profile where the rock is buried except at flood stage (if, indeed, it is reached then). This seems abnormal. Because erosion at every point of a stream is controlled by the local baselevel of the next point downstream, it is usual for a stream to reach grade at downstream points first and for the graded condition to work its way headward. No contrast in lithology (and therefore in erodibility) is evident to account for the greater erosion upstream.

Moreover, the one-diversion hypothesis requires a remarkable coincidence: that the downstream point where the river failed to eliminate the bedrock floor should coincide exactly with the axis of what would have been a rock ridge if a second diversion, suggested by other evidence, occurred.

The S-shaped course, if it is real, seems to consist of three segments: a segment superposed across a preglacial ridge or spur, at $\mathrm{B}$; a segment presumably consequent on the slopes west of this ridge, at $E$; and a reoccupied segment of the preglacial valley, at $F$. The segment at $E$ was presumably consequent on the till surface, which partly reflected the preglacial valley of Pine Swamp Brook.

The inferred second diversion bears the same relation to the topography inferred to have existed at the time (the topography that would be produced by cutting in the S-shaped course) that the first diversion bears to the preglacial topography. If the Housatonic cut down in the S-shaped course to a profile below the present one, ice coming from the northnorthwest would be crowded in from the north and west, converging on the area at $F$ where the blockage that caused the second diversion is inferred to have occurred. 


\section{DATE OF PROBABLE SECOND DIVERSION}

If two diversions of the Housatonic occurred, an initially attractive hypothesis is that the two tills recognized in western Connecticut caused the two diversions. Pessl and Schafer (1968) distinguished a loose unconsolidated upper till, sandy and unoxidized, from a hard compact jointed lower till that contains a higher proportion of fines and is generally stained with oxides, which are commonly deposited along the joints. One might, then, consider the hypothesis that the tills and the diversions serve to date each other. On this hypothesis, the second diversion was caused by the upper till and is therefore of Wisconsin date.

However, the material that caused the second diversion apparently differs from the upper till. Small pits at $\mathrm{F}$ along the inferred S-shaped course of the Housatonic (fig. 1) expose a sandy till with pockets of gravel, which appears to be upper till. This sandy till is reported to be "only about 6 feet deep. Below that you run into clayey hardpan" (C. Ten Broeck, oral commun., 1969). This "clayey hardpan" is not now exposed; it may or may not be lower till. But whatever its identity, the bulk of the material at $F$, which caused the second diversion if two diversions occurred, is apparently something different from the upper till.

The Housatonic River is intrenched approximately 48 feet at D (fig. 1), as measured by hand level from the river to the crest of the rock hill on the southeast. Although this cutting was partly along the strike of the foliation, it was partly at an angle to it. It seems likely to have required a significantly longer time than the slight cutting accomplished in Holocene time at Great Falls, and suggests that the second diversion, like the first, was pre-Wisconsin.

This inference is supported by the rock slope southeast from the southeast rim of the trench at $D$. If the trench at $D$ were not present, the Housatonic would spill south past $E$ and F. Thus the rock slope from the rim of the trench toward the preglacial valley at $F$ must have been buried when cutting began at $D$, or no trench would have been cut at $D$. And as I argued at $\mathrm{C}$ for the first diversion, the burial must have been by drift rather than ice, for ice would not have lasted the many millennia it must have taken to cut the 48-foot trench at D. The trench cutting was presumably initiated along the crease between (a) the northwest slope of the till that ousted the river from the course at $F$ and (b) the southeast slope of the preglacial surface.

The agent that later partly reexcavated the till between $D$ and $F$ is less obvious than that between $B$ and $C$. Here the reexcavation may have been by the Housatonic rather than by ice, for ice can have blocked the trench long enough for the Housatonic to remove part of the till marginal to which the trench was cut. But if the Housatonic took this course, it would not have shifted to the present course at $D$ unless the trench there was already in existence. Whether the reexcavation was by the river or by ice, ice must have been present at the time.
Thus if two diversions occurred, the second diversion, at $F$, antedates the latest glaciation by the length of time needed to cut the trench at $D$ to a profile below the level of the present divide near E. It, too, was probably effected by deposits of a pre-Wisconsin glaciation, though an early Wisconsin date is possible.

Deposits on Martha's Vineyard (Schafer and Hartshorn, 1965, p. 119) have been interpreted as showing that at least two separate pre-Wisconsin glaciations crossed Connecticut. It therefore seems plausible to suppose that the Housatonic was diverted from the route past $A$ to the route past $B, E$, and $F$ by a lower Pleistocene till, possibly equivalent to the Kansan or the Nebraskan of the Midwest, and was then diverted again to the present route past $\mathrm{D}$ by a later but still pre-Wisconsin till, perhaps Illinoian (the applicability of the glacial sequence inferred in the Midwest to the glacial history of New England has not been established; these possible correlations are offered only speculatively). The long Yarmouth Interglaciation (several hundred thousand years), and perhaps the Aftonian as well, would then be available for cutting the S-shaped route (including the 140-foot gorge at B) to a profile below the present profile of the river, and the much shorter Sangamon Interglaciation (perhaps roughly 70,000 years) for cutting the 48-foot rock trough at D. Although the correlations with midwestern glacial events are entirely hypothetical and tenuous, it is perhaps not purely coincidental that the time spans covered appear to be of the correct relative orders of magnitude.

\section{WIDER IMPLICATIONS}

No exposures are available either of the material at $A$ that blocks the preglacial valley, or of that at $F$ that blocks the probable Pleistocene S-shaped course. However, the material in the well near A was reported by the driller as "hardpan," which usually refers to till, and the probable mechanism of diversion suggests that the material in both places is till. Because the upper till must be of Wisconsin age, the pre-Wisconsin till at $\mathrm{A}$ must be lower till, unless it is a material not recognized elsewhere in Connecticut; probably the material at $\mathrm{F}$ is also lower till. The evidence that the lower till was oxidized before it was truncated by the upper-till ice and that oxidized inclusions of lower till are present in unoxidized upper till (Pessl and Schafer, 1968, p. 10-14) also suggests strongly that the lower till is pre-Wisconsin.

If the lower till is of pre-Wisconsin age, much of the topography of Connecticut assumed by some workers to record Wisconsin glacial events is in part inherited from an older glaciation. Lower till forms most and perhaps all drumlins and other streamline till hills in this part of the State (Pessl and Schafer, 1968). Similarly, many gorges cut in bedrock in western Connecticut, as at three places in the Cornwall quadrangle (C. R. Warren, unpub. data) and at five places in the Litchfield quadrangle (Warren, 1970), were very likely cut principally in pre-Wisconsin time. Oilly one of these 
eight gorges had previously been recognized as pre-Wisconsin, but a pre-Wisconsin origin would explain many features that previously seemed anomalous (C. R. Warren, unpub. data).

In summary, evidence presented in this paper demonstrates that thick till blocked the preglacial Housatonic valley at $A$ (fig. 1) and diverted the river, forcing it to cut the gorge at B. The initial diversion was of pre-Wisconsin date. It probably put the Housatonic into an S-shaped course via $\mathrm{E}$ and $\mathrm{F}$; if so, a second diversion shifted it again, to the present course via $D$. The date of the second diversion, if two occurred, might possibly be early Wisconsin, but more likely the diversions occurred in Kansan (or Nebraskan) and Illinoian time. The pre-Wisconsin till or tills that block the prediversion valleys are probably the lower till described by Pessl and Schafer (1968). If all lower till is pre-Wisconsin, much of the glacial topography of Connecticut, sometimes assumed to be Wisconsin, reflects pre-Wisconsin glacial events.

\section{REFERENCES}

Gates, R. W., 1961, The bedrock geology of the Cornwall quadrangle: Connecticut State Geol. and Nat. History Survey Quad. Rept. 11, 35 p.

Pessl, Fred, Jr., and Schafer, J. P., 1968, Two-till problem in Naugatuck-Torrington area, western Connecticut, Trip B-1 in New England Intercollegiate Geol. Conf., 60th Ann. Mtg., Oct. 25-27, 1968, Guidebook for fieldtrips in Connecticut: Connecticut State Geol. and Nat. History Survey Guidebook 2, 25 p. (paged separately).

Rodgers, John, Gates, R. M., and Rosenfeld, J. L., 1959, Explanatory text for preliminary geological map of Connecticut, 1956: Connecticut State Geol. and Nat. History Survey Bull. 84, 64 p.

Schafer, J. P., and Hartshorn, J. H., 1965, The Quaternary of New England, in Wright, H. E., Jr., and Frey, D. G., eds., The Quaternary of the United States: Princeton, N.J., Princeton Univ. Press, p. 113-128.

Warren, C. R., 1970, Surficial geologic map of the Litchfield quadrangle, Litchfield County, Connecticut: U.S. Geol. Survey Geol. Quad. Map GQ-848. 


\title{
GEOLOGIC COMPARISON OF MARE MATERIALS IN THE LUNAR EQUATORIAL BELT, INCLUDING APOLLO 11 AND APOLLO 12 LANDING SITES
}

\author{
By NEWELL J. TRASK, Washington, D.C.
}

Work done in cooperation with the National Aeronautics and Space Administration under NASA contract T-66353G

\begin{abstract}
Mare materials in and around several early Apollo landing sites have been assigned positions in the lunar stratigraphic column on the basis of the oldest craters developed on them. Mare material at the Apollo 11 landing site appears to be older than mare material at the Apollo 12 landing site-in agreement with preliminary radiometric ages determined on returned samples. Mare material at several spots in Oceanus Procellarum appears to be younger than that at the Apollo 12 site.
\end{abstract}

The first two Apollo landings were made at widely separated points on the lunar maria (fig. 1). These regions are distinguished by low albedo relative to the rest of the moon and by nearly level, cratered plains. Mare material covers one-sixth of the surface of the moon and has been the most intensively studied of all lunar geologic units. Two of the three Ranger hard-landing probes and four of five soft-landing Surveyors went to the maria. In addition, Lunar Orbiters I, II, III, and V expended most of their film on mare areas in preparation for the first Apollo landings.

All photographs of mare material have much the same general aspect showing a highly cratered level plain broken in a few places by low ridges, domes, and irregular scarps. Close study of the photographs reveals important differences in detail among mare materials at various points on the moon. These differences are documented in geologic maps of various candidate Apollo landing sites (Trask, 1969) and are summarized here. The differences appear to indicate different times of emplacement of the basaltic mare materials. These observations are consistent with preliminary published reports of differences in the ages of crystallization of materials at the Apollo 11 and 12 landing sites.

\section{CRATERS AND SURFACES}

The craters on the mare surfaces range from sharp to indistinct. The sharpest craters have well-defined rim crests

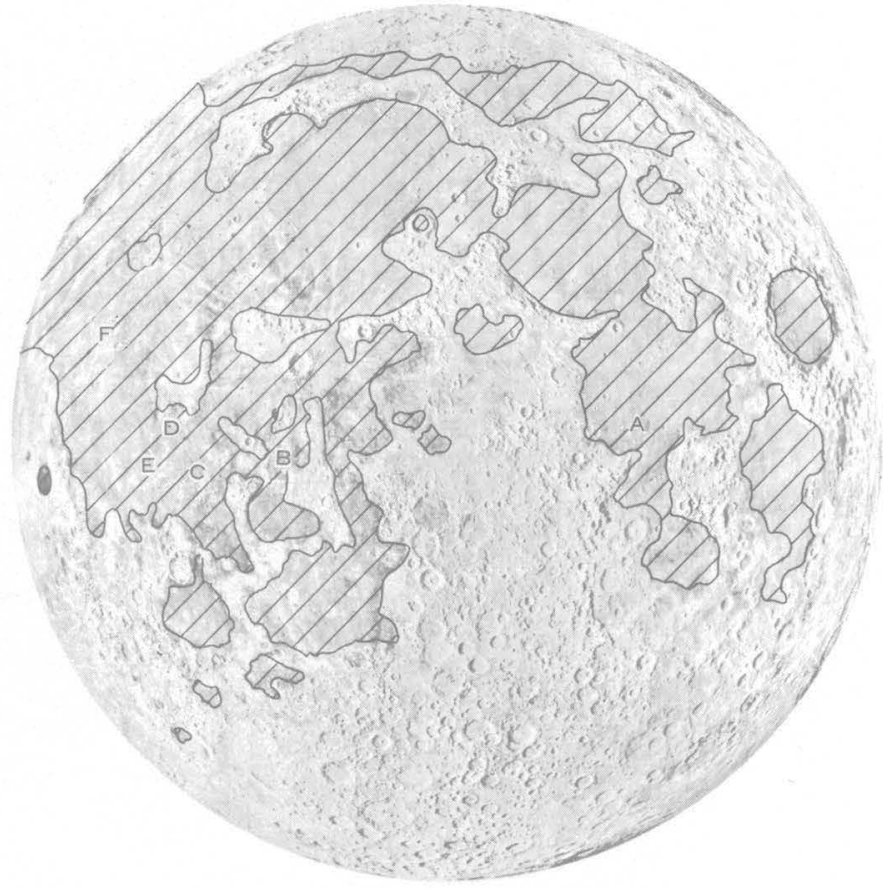

Figure 1.-Index map of the moon, showing the generalized location of mare materials (hatched) and the location of Apollo landing sites referred to in the text: A, Apollo 11 landing site (Tranquillity Base); B, Apollo 12 landing site; C, D, E, three potential early Apollo landing sites in Oceanus Procellarum; F, Marius Hills region.

and bright, blocky ejecta blankets; craters that are less sharp have rounded rim crests, little in the way of an ejecta blanket, and few surrounding blocks; the most indistinct craters are very shallow depressions and lack a well-defined rim crest. Examples of this continuum of crater types for various sizes of craters are shown in figure 2. Wherever superposition relations between craters of the same approximate size are clearly shown on Orbiter photographs, sharper craters are superposed

D138

U.S. GEOL. SURVEY PROF. PAPER 750-D, PAGES D138-D144 


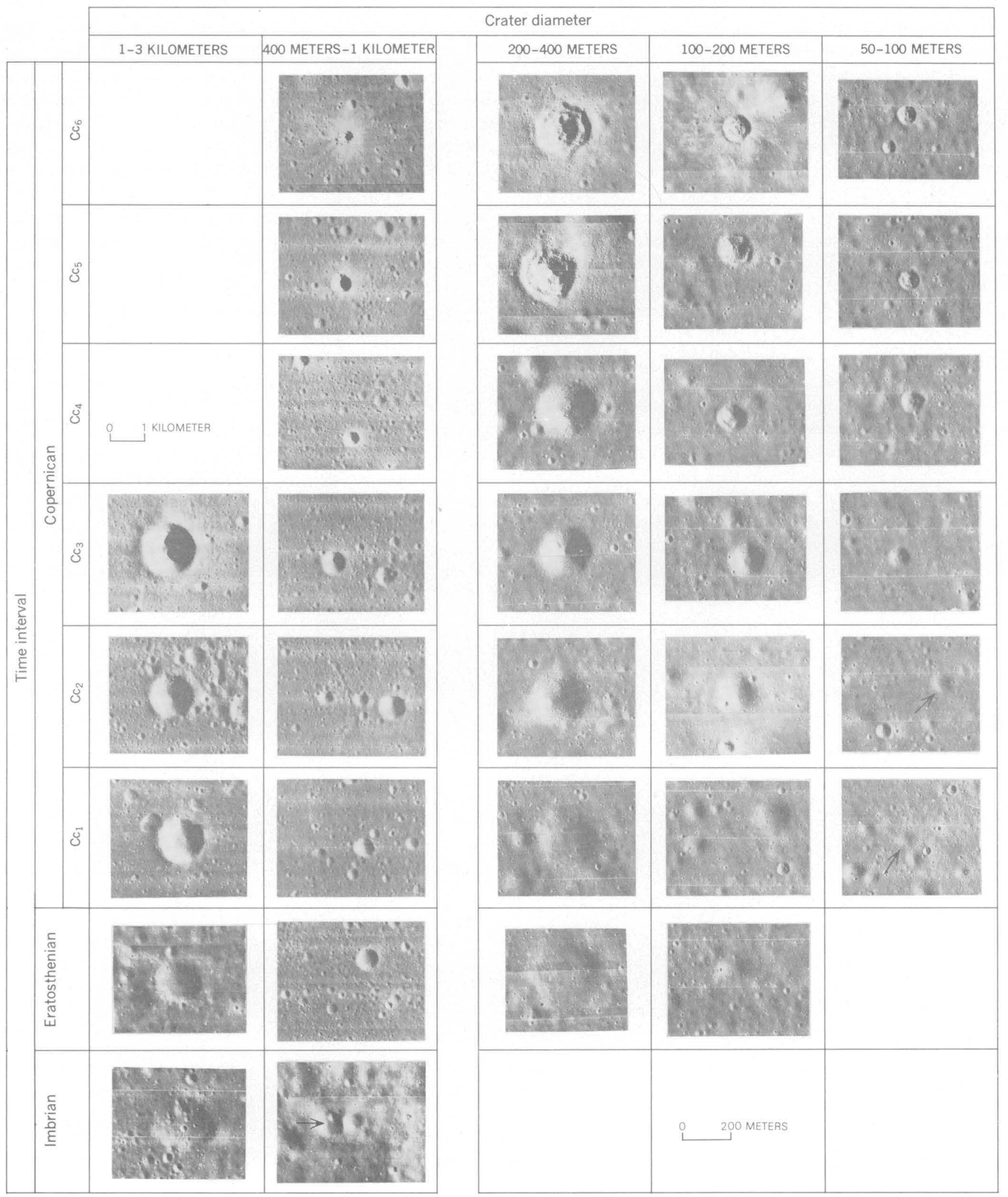

Figure 2.- Illustration of the crater mapping system used in large-seale geologic mapping of Apollo landing sites. Note continuum of crater morphologies from sharp to indistinct. Most examples taken from a single Lunar Orbiter photograph with solar elevation angle of $19.5^{\circ}$. A few examples from photographs taken with solar elevation angles ranging from $18.2^{\circ}$ to $23^{\circ}$. 
on more indistinct craters, indicating that the sharper craters are younger. These observations suggest that most new craters are sharp and distinct and become progressively more subdued and indistinct with time; in other words, craters in the lower frames of figure 2 once looked like those in the upper frames. The sharpest craters shown at the top of figure 2 have all of the characteristics of impact craters, including rays and ray loops. (See Shoemaker, 1962.) It thus seems likely that the great majority of all craters in the $50-\mathrm{m}-3-\mathrm{km}$ size range were formed by impact. If so, older surfaces should have more craters than younger surfaces and should also have more older appearing craters than younger surfaces. Such a relationship between the number of craters on a surface and the number of old-appearing subdued craters is in fact observed.

Examination of craters on the entire suite of Lunar Orbiter photographs therefore leads to the following working hypotheses: (1) When first formed, craters appear sharp and fresh. (2) All craters undergo modification to less sharp and more subdued forms by erosion of the rim crest and infilling of the floors. (3) Smaller craters disappear sooner than larger craters. (4) There exists for any surface a critical crater diameter below which craters display all degrees of aging from fresh craters to shallow, smooth depressions, and above which craters range from fresh to only partly destroyed. This limiting diameter increases with time for a given surface (Morris and Shoemaker,
1968; Ross, 1968; Soderblom, 1970).

These hypotheses form the basis for assigning geologic ages to craters in geologic mapping of potential Apollo landing sites; they also permit an estimate of the geologic ages of various mare surfaces. The system of crater mapping is illustrated in figures 2 and 3. Horizontal lines on both figures represent equal points in time, or isochrons. Thus, according to figures 2 and 3 , a $50-\mathrm{m}$ gentle depression is the same age as a $1-\mathrm{km}$ crater that is only moderately subdued. The amount of crater degradation implied by this assumed equivalence seems reasonable in the light of theoretical studies on the degree and mechanism of crater subdual by the impact of small particles (Ross, 1968; Soderblom, 1970). The number of intervals, spacing, and names of the time intervals on the ordinates of figures 2 and 3 are arbitrary but have been chosen to be consistent with the time scale used in reconnaissance geologic mapping of the moon at scales of 1:5,000,000 (Wilhelms and McCauley, 1971) and 1:1,000,000 (Wilhelms, 1970; and Mutch, 1970). In that mapping, the base of the Imbrian System is defined by the Imbrium basin ejecta blanket, upon which gentle depressions as much as $1 \mathrm{~km}$ across are superposed; therefore, $1-\mathrm{km}$ gentle depressions are placed at the base of the Imbrian System in the scheme for large-scale mapping of craters illustrated in figures 2 and 3. Similarly, the dividing line between the Eratosthenian and Copernican

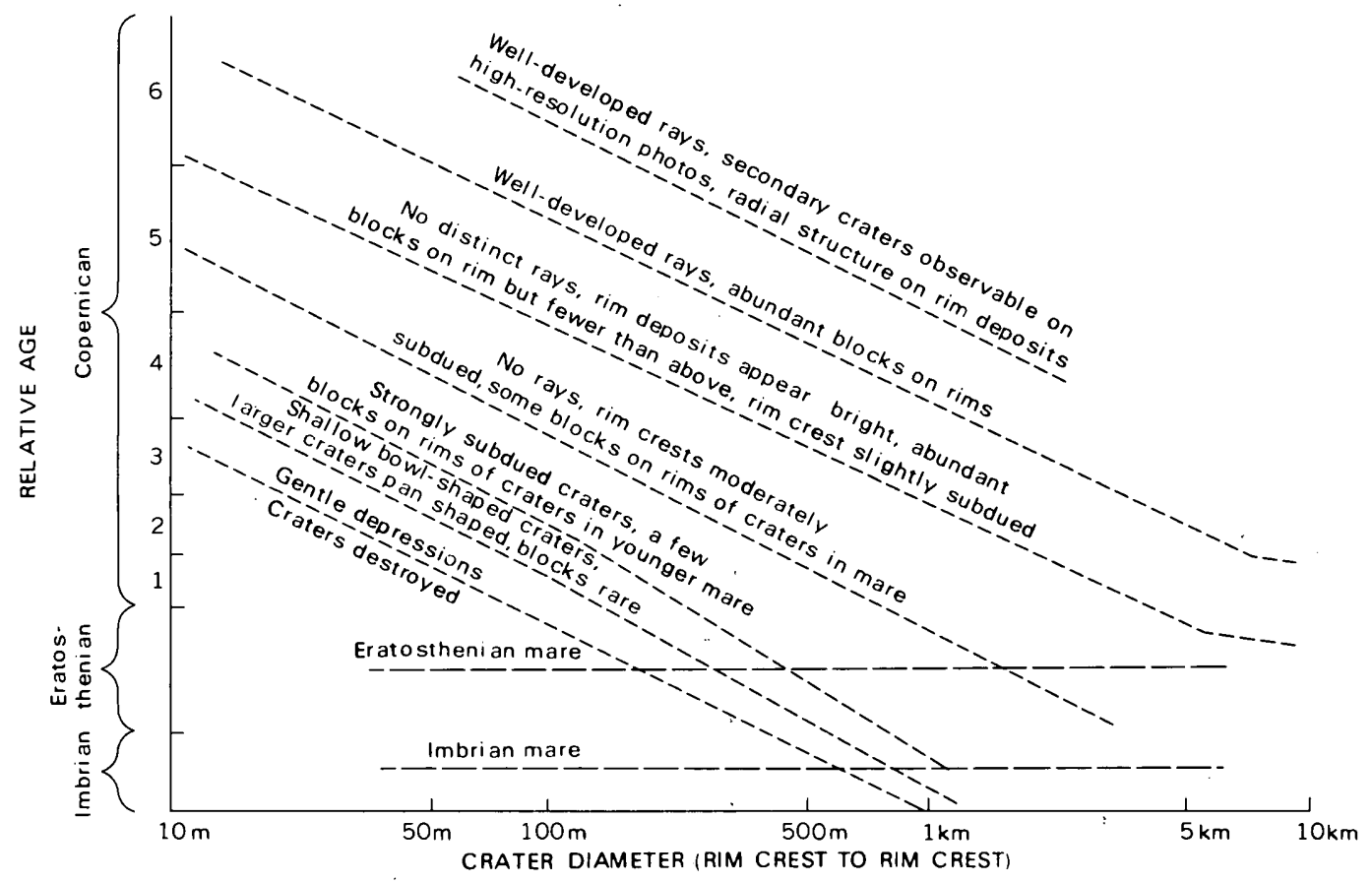

Figure 3.-Assumed relations among sizes, properties, and relative ages of craters from $10 \mathrm{~m}$ to $10 \mathrm{~km}$ in diameter followed in large-scale geologic mapping of Apollo landing sites. Categories are intergradational. Examples are shown in figure 2. Horizontal lines are isochrons indicating crater populations on relatively young and relatively old mare materials. 
Systems occurs between craters with bright halos and craters without bright halos in the size range 5 to $10 \mathrm{~km}$ in both small- and large-scale mapping.

A similar approach for determining the relative ages of craters larger than $8 \mathrm{~km}$ in diameter has been outlined by Pohn and Offield (1970) and Offield and Pohn (1970). The morphologic criteria used for the larger craters are basically the same as those described here and include the sharpness of the rim and the presence or absence of surrounding secondary craters and ejecta blankets. Features such as terraces, radial channels on the walls, and polygonal rims apparently develop in these larger craters at certain points in their evolution and provide additional criteria for estimating relative age.

Having developed a scheme for determining the relative ages of craters, we can examine high-resolution photographs of various parts of the maria to see if there are systematic differences in the relative ages of the oldest craters superposed on them. The isochrons labeled "Eratosthenian mare" and "Imbrian mare" in figure 3 refer to two mare surfaces with different crater populations and different apparent relative age. Craters $700 \mathrm{~m}$ in diameter on the Imbrian mare range in form from fresh to indistinct gentle depressions; craters of the same size on the Eratosthenian mare range from fresh to only partly eroded; the oldest craters on the Imbrian surface are older than the oldest craters on the Eratosthenian surface. The Eratosthenian surface is illustrated in figure $4 A$, a part of Oceanus Procellarum; the Imbrian surface is illustrated in figure $4 C$, a part of Mare Tranquillitatis including the Apollo 11 landing site. The surface shown in figure $4 B$ is intermediate in age between the two; it is a part of Oceanus Procellarum that includes the Apollo 12 landing site. Figure $4 D$ shows a surface in the lunar terra, the Imbrium basin ejecta blanket. This surface is shown for comparison because it has been demonstrated to clearly predate all mare surfaces on the basis of superposition criteria, independent of crater populations (Shoemaker and Hackman, 1962; Baldwin, 1963). The surface shown in figure $4 D$ has older craters than any of the three mare surfaces, an observation consistent with its known relative age.

This method of determining the relative ages of crater populations has been refined by Soderblom and Lebofsky (unpub. data), who measured the ratio of unshadowed to shadowed craters at a series of crater diameters. As can be inferred from figure 3 , this ratio will be zero for craters larger than a particular diameter for a given surface. This critical diameter is larger on older surfaces than on younger surfaces. The diameter of the largest unshadowed crater on a given photograph is also affected by the solar elevation angle of the photograph, and a correction must be made which effectively reduces the observations to a single sun angle. (In using the more subjective criteria of figure 3 , one must also take into account the effect of differences in solar elevation angle on various photographs.) After making the necessary corrections, Soderblom and Lebofsky (unpub. data) determined the relative ages of a large number of mare surfaces. Their relative age estimates for the three mare surfaces shown in figures $4 A$, $B$, and $C$ are in agreement with those proposed here.

Several of the early Apollo landing sites are discussed in more detail below.

\section{APOLLO 11 SITE}

The mare surface at the Apollo 11 landing site in southwest Mare Tranquillitatis (A, fig. 1; fig. $4 C$ ) is one of the oldest studied to date in the equatorial belt; this mare material is assigned to the Imbrian System on the basis of figure 3 (Grolier, 1970). Three main types of rocks were collected from the lunar regolith at the site: (1) Ilmenite-rich basalts make up about half of the large rock fragments and also occur as small fragments in the lunar soil. (2) Plagioclase-rich rocks including some with the composition of anorthosite occur only as small fragments $(1-5 \mathrm{~mm})$ in the soil. (3) Microbreccias containing fragments of both the ilmenite-rich basalts and the plagioclase-rich rocks made up the other half of the large rock fragments and also occur in the soil. Because of their abundance and relatively large size, the basalts and possibly the microbreccias are thought to be representative of uncomminuted bedrock originally present at the landing site. The plagioclase-rich rocks are thought to have been derived from the lunar highlands (Wood and others, 1970). Numerous investigators have extensively described these rocks. ${ }^{1}$

The textures of the ilmenite-rich rocks are nearly identical with those of many terrestrial basalts (James and Jackson, 1970). Additional evidence that the mare material in the vicinity of Tranquillity Base was once molten or partially molten is provided by morphologic features only $5 \mathrm{~km}$ to the southwest of the landing spot. There, low bulbous domes, irregular scarps, and hummocky terrain extend from both sides of a low northwest-trending ridge (fig. $4 C$, arrows), indicating flowage of material either at the surface or in the shallow subsurface. Prior to the return of lunar samples, it had been suggested that such features might be formed by the subsurface movement of ice in a zone of lunar permafrost (Gold, 1968). However, no evidence of water, past or present, was found in any of the returned samples, either rock fragments or fines.

Preliminary ages determined for the ilmenite-rich basaltic rocks are $3.59-3.71 \times 10^{9}$ years by the rubidium-strontium method (Papanastassiou and Wasserburg, 1971), $4.15-4.22 \times 10^{9}$ years by uranium-thorium-lead isotopic systems (Silver, 1970a), and $3.52-3.92 \times 10^{9}$ years by the $\mathrm{Ar}^{40} \cdot \mathrm{Ar}^{39}$ method (Turner, 1970).

\section{APOLLO 12 SITE}

On the mare surface at the Apollo 12 landing site in eastern Oceanus Procellarum (B, fig. 1; fig. $4 B$ ) craters $700 \mathrm{~m}$ across

\footnotetext{
${ }^{1}$ See Science, 1970, v. 167, no. 3918; Geochim. et Cosmochim. Acta, Supp. 1, Proceedings of the Apollo 11 Lunar Science Conference, v. $1-3$.
} 


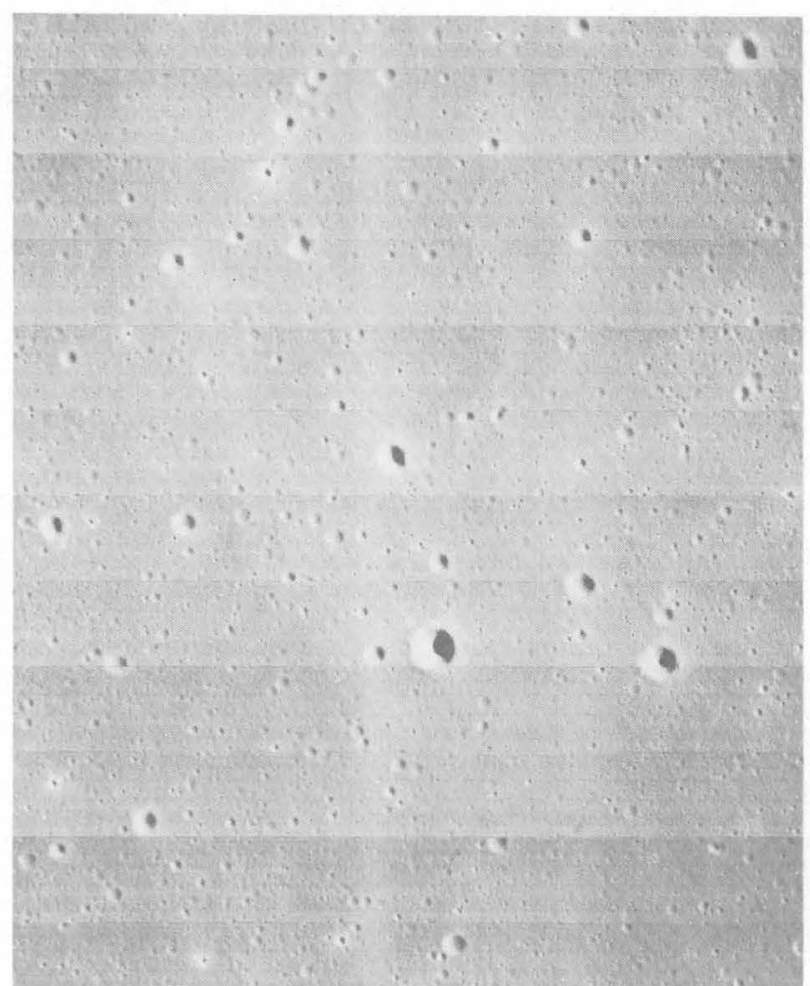

5 KILOMETERS

A

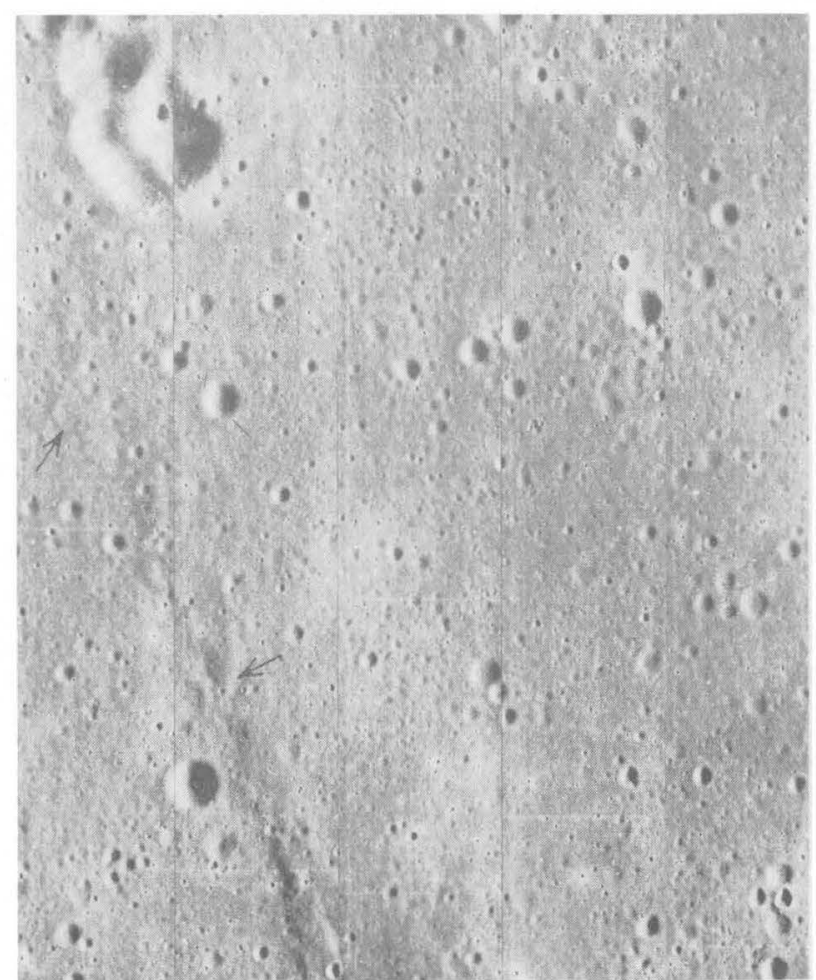

0

C

Figure 4.

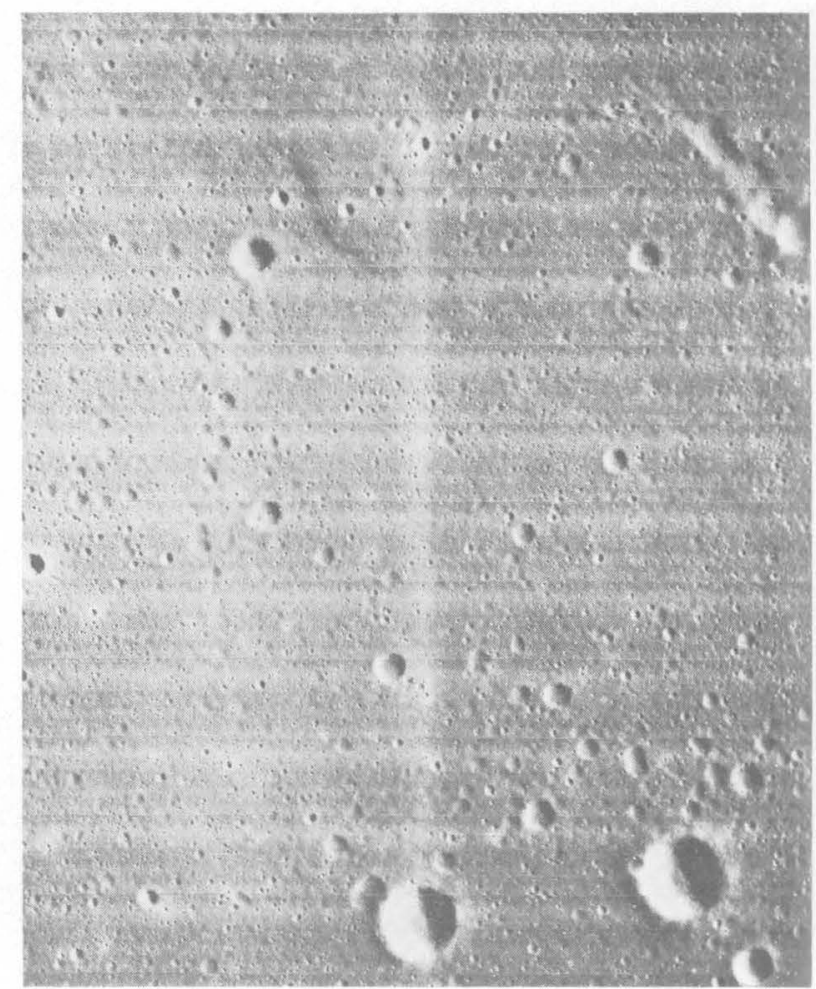

5 KILOMETERS

B

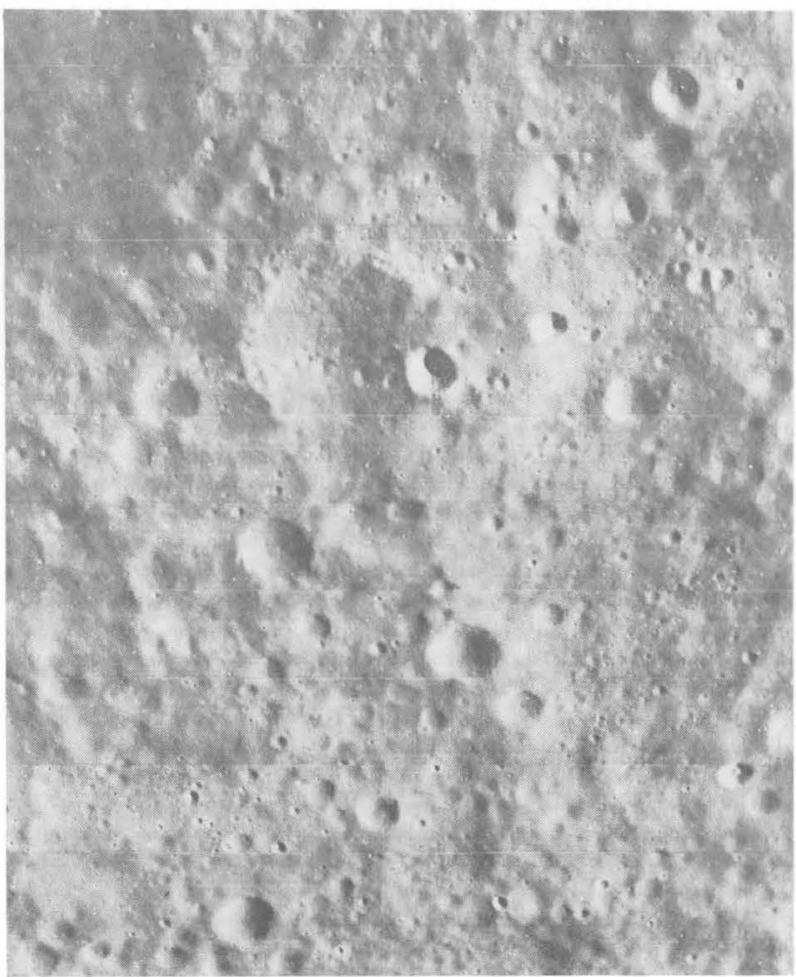

5 KILOMETERS

D 
are both less abundant and less subdued than craters of the same size at the Apollo 11 landing site; this mare material is, therefore, younger than that at the Apollo 11 site and falls close to the Imbrian-Eratosthenian boundary on the basis of the oldest craters developed on it (Pohn, 1971).

Rock fragments were collected both from the lunar regolith in intercrater areas and from discrete blocky ejecta blankets around several young craters. Rock types are generally similar to those at the Apollo 11 site, but there is less ilmenite in the ilmenite-bearing basalts, and microbreccias make up a smaller fraction of the collection. The basalts at the Apollo 12 site have wide variations in modal composition (E. D. Jackson, oral commun., 1970); they may be part of a single differentiated rock suite or may represent several differentiated flows. Like the ilmenite-rich basalts at Tranquillity Base, these rocks have crystallized from a liquid melt and are presumed to be representative of uncomminuted bedrock originally present at the landing site.

Preliminary ages determined for eight of the ilmenite-bearing basalts are $3.16-3.36 \times 10^{9}$ years by the rubidium-strontium method (Papanastassiou and Wasserburg, 1971), significantly younger than the ages of the Apollo 11 rocks. Preliminary ages determined on two Apollo 12 basalts by uranium-thorium-lead isotopic systems are both $3.93 \times 10^{9}$ years, also younger than ages obtained by the same method for Apollo 11 basalts (Silver, 1970b). A third Apollo 12 basalt yielded a $\mathrm{Pb}^{207} / \mathrm{Pb}^{206}$ apparent age of $4.18 \times 10^{9}$ years, indistinguishable from Apollo 11 basalts (Silver, 1970b). These ages are consistent with the interpretation made above that mare materials at the Apollo 12 landing site are generally younger than those at the Apollo 11 landing site.

\section{OTHER LANDING SITES}

Application of the age-dating technique described above indicates that still younger mare materials underlie the surface at three potential landing sites in central Oceanus Procellarum along the equator $(\mathrm{C}, \mathrm{D}, \mathrm{E}$, fig. 1). Gentle, indistinct depressions do not exceed $300 \mathrm{~m}$ in diameter on these surfaces (fig. $4 A$ ), and the materials are therefore assigned to the Eratosthenian System (Carr and Titley, 1969; Cummings, 1971; Offield, 1971). The crater population is indicated by the upper isochron labeled "Eratosthenian mare" in figure 3 . In the Wichmann $\mathrm{CA}$ region ( $\mathrm{C}$, fig. 1 ), high-resolution photographs reveal several poorly defined to well-defined sinuous

Figure 4.-Three surfaces in the maria and one in the terra illustrating differences in crater populations: $A$, relatively young mare material near Flamsteed $\mathrm{P}\left(\mathrm{C}\right.$, fig. 1). Solar elevation angle 21.3 $3^{\circ} \mathrm{B}$, mare of intermediate relative age near the Apollo 12 landing site ( $B$, fig. 1). Solar elevation angle $22.8^{\circ}$. $C$, relatively old mare material near the Apollo 11 landing site (A, fig. 1). Solar elevation angle $22.0^{\circ}$. Arrows indicate low domes and scarps extending from low northwest-trending ridge. $D$, Imbrium basin ejecta blanket near crater Fra Mauro. Solar elevation angle $22.0^{\circ}$. scarps suggestive of flow fronts and a widespread texture of low hummocks and hollows $5-10 \mathrm{~m}$ across suggestive of an original volcanic topography (West and Cannon, 1971). The Flamsteed $K$ region ( $E$, fig. 1 ) has numerous small domes $150-700 \mathrm{~m}$ across and $10-20 \mathrm{~m}$ high scattered over the mare surface (Offield, 1971). These fine-scale features of probable internal origin in the Wichmann $\mathrm{CA}$ and Flamsteed $\mathrm{K}$ regions indicate that relatively small amounts of erosion have occurred in these regions since the emplacement of the mare material, an observation consistent with the relatively young age indicated by the crater populations.

As of this writing, there are no plans for Apollo landings on any of the sites containing Eratosthenian mare material in central Oceanus Procellarum. For a later Apollo mission a potential site which may be close in age to these sites is the Marius Hills area (F, fig. 1) (McCauley, 1968). The morphology of the materials in this site differs from that of typical mare material, and they may, in consequence, have a somewhat different composition.

Rough estimates of the age difference between the Imbrian and Eratosthenian mare materials can be made by extrapolating the results from the Apollo 11 and 12 sites. Soderblom and Lebofsky (unpub. data) have attacked this problem by assuming that crater degradation proceeds largely by the cumulative effect of the impact of particles that are small relative to the crater and that the present degree of degradation of a crater is a measure of the integrated flux of small objects which have struck it. This assumption has a sound theoretical basis (Ross, 1968; Soderblom, 1970). It can also be shown that the diameter of the largest crater that has been brought nearly to destruction on a surface is directly proportional to the integrated flux of small objects on the surface. Craters $700 \mathrm{~m}$ in diameter were nearly destroyed on the Imbrian mare material, 500-m craters were nearly destroyed on the mare material of latest Imbrian or earliest Eratosthenian age, and 300-m craters were nearly destroyed on Eratosthenian mare material. These estimates, of course, must be assigned large statistical errors. It appears, however, that these diameters differ by about 30 percent for the Apollo 11 and 12 sites, while the absolute ages of these surfaces differ by approximately 10 percent. This result suggests a decline in the integrated flux of small objects over the period from the emplacement of the Apollo 11 surface to the present. The data permit a range of estimates of the rate of decline in the flux. Decay rates with half lives ranging from 0.6 to $1.4 \times 10^{9}$ years can be fitted to the data of Soderblom and Lebofsky, implying that the Eratosthenian mare material in the Marius Hills region and elsewhere in Oceanus Procellarum is anywhere from 0.5 to $1.0 \times 10^{9}$ years younger than the Imbrian mare material at the Apollo 11 site. Processes other than small-particle bombardment, such as extensive base surge activity, may have accounted for an especially high rate of crater degradation during early postmare time. 


\section{MARE MATERIAL AND THE EVOLUTION OF THE MOON}

Abundant evidence indicates that the mare materials are considerably younger than the circular basins and other depressions which they fill, although their absolute age is great (Stuart-Alexander and Howard, 1970; Wilhelms and McCauley, 1971). Petrologic evidence and the restriction of the mare material to areas of relatively low elevation further indicate that the mare material formed from magmas generated by melting within the moon-probably at considerable depth (Ringwood, 1970). Eruption of these magmas lasted over a fairly long interval-possibly as much as 1,500 m.y., as suggested above.

The mare material apparently formed long after the accretion of the moon. Melting and volcanism also occurred shortly after the moon formed and resulted in the development of a differentiated lunar crust, allochthonous samples of which apparently have been returned from both the Apollo 11 and 12 sites (Wood and others, 1970). Geochemical considerations require that this early differentiation brought materials with a high concentration of radioactive elements to the surface (Papanastassiou and Wasserburg, 1971), possibly by complete melting and widespread convection in an outer shell of the moon. The later melting which gave rise to the mare materials produced material with a much lower concentration of radioactive elements. Mare volcanism thus differs from the earlier igneous activity both in time and in the degree of melting of primitive lunar material.

\section{REFERENCES}

Baldwin, R. B., 1963, The measure of the Moon: Chicago, Chicago Univ. Press, $488 \mathrm{p}$.

Carr, M. H., and Titley, S. R., 1969, Geologic map of the Maestlin G region of the Moon: U.S. Geol. Survey Misc. Geol. Inv. Map I-622, scale 1:100,000.

Cummings, David, 1971, Geologic map of the Wichmann CA region of the Moon: U.S. Geol. Survey Misc. Geol. Inv. Map I-624, scale $1: 100,000$.

Gold, T., 1968, Surveyor V-Chemical observations: Science, v. 160, no. 3830, p. 904-905.

Grolier, M. J., 1970, Geologic map of the Sabine D region of the Moon [Apollo 11 landing site]: U.S. Geol. Survey Misc. Geol. Inv. Map I-618, scale 1:100,000.

James, O. B., and Jackson, E. D., 1970, Petrology of the Apollo 11 ilmenite basalts: Jour. Geophys. Research, v. 75, no. 29, p. 5793-5822.

McCauley, J. F., 1968, Geologic results from the lunar precursor probes: Jour. Am. Inst. Aeronautics and Astronautics, v. 6, no. 10, p. $1992-1994$.

Morris, E. C., and Shoemaker, E. M., 1968, Television observations from Surveyor, in Surveyor project final report, Pt. II. Science results: California. Inst. Technology Jet Propulsion Lab. Tech. Rept. 32-1265, p. 65-69.

Mutch, T. A., 1970, Geology of the Moon: Princeton, N. J., Princeton Univ. Press, 324 p.

Offield, T. W., 1971, Geologic map of the Flamsteed K region of the Moon: U.S. Geol. Survey Misc. Geol. Inv. Map I-626, scale $1: 100,000$. [In press]

Offield, T. W., and Pohn, H. A., 1970, Lunar crater morphology and relative-age determination of lunar geologic units-pt. 2. Applications, in Geologic Survey Research 1970: U.S. Geol. Survey Prof. Paper 700-C, p. C163-C169.

Papanastassiou, D. A., and Wasserburg, G. J., 1971, Lunar chronology and evolution from Rb-Sr studies of Apollo 11 and 12 samples: Earth and Planetary Sci. Letters, v. 11, p. 37-62.

Pohn, H. A., 1971, Geologic map of the Lansberg P region of the Moon [Apollo 12 landing site]: U.S. Geol. Survey Misc. Geol. Inv. Map I-627, scale 1:100,000. [In press]

Pohn, H. A., and Offield, T. W., 1970, Lunar crater morphology and relative age determination of lunar geologic units-pt. 1. Classification in Geological Survey Research 1970: U.S. Geol. Survey Prof. Paper 700-C, p. C153-C162.

Ringwood, A. E., 1970, Petrogenesis of Apollo 11 basalts and implications for lunar origin: Jour. Geophys. Research, v. 75, no. 32, p. 6453-6459.

Ross, H. P., 1968, A simplified mathematical model for lunar crater erosion: Jour. Geophys. Research, v. 73, no. 4, p. 1343-1354.

Shoemaker, E. M., 1962, Interpretation of lunar craters, in Kopal, Zdeněk, ed., Physics and astronomy of the Moon: New York, Academic Press, p. 283-359.

Shoemaker, E. M., and Hackman, R. J., 1962, Stratigraphic basis for a lunar time scale, in Kopal, Zdeněk, and Mikhailov, Z. K., eds., The Moon-Internat. Astron. Union Symposium 14, Leningrad 1960, Proc.: London, Academic Press, p. 289-300.

Silver, L. A., 1970a, Uranium-thorium-lead isotopes in some Tranquillity Base samples and their implications for lunar history: Geochim. et Cosmochim. Acta, Supp. 1, Apollo 11 Lunar Sci. Conf. Proc., v. 2, p. 1533-1574.

- 1970b, Uranium-thorium-lead isotope relations in lunar materials [abs.]: Geol. Soc. America Abs. with Programs, v. 2, no. 7, p. 684.

Soderblom, L. A., 1970, A model for small impact erosion applied to the lunar surface: Jour. Geophys. Research, v. 75, no. 14, p. 2655-2661.

Stuart-Alexander, D. E., and Howard, K. A., 1970, Lunar maria and circular basins-A review: Icarus, v. 12, no. 3, p. 440-456.

Trask, N. J., 1969, Geologic maps of early Apollo landing sites of set C: U.S. Geol. Survey open-file report.

Turner, G., 1970, Argon $^{40}$-argon $^{39}$ dating of lunar rock samples: Geochim. et Cosmochim. Acta, Supp. 1, Apollo 11 Lunar Sci. Conf. Proc., v: 1, p. 1665-1684.

West, Mareta, and Cannon, P. J., 1971, Geologic map of Apollo landing sites 4 and 4R: U.S. Geol. Survey Misc. Geol. Inv. Map I-625, scale $1: 25,000$.

Wilhelms, D. E., 1970, Summary of lunar stratigraphy-Telescopic observations: U.S. Geol. Survey Prof. Paper 599-F, 47 p.

Wilhelms, D. E., and McCauley, J. F., 1971, Geologic map of the near-side of the Moon: U.S. Geol. Survey Misc. Geol. Inv. Map I-703, scale 1:5,000,000. [In press]

Wood, J. A., Dickey, J. S., Jr., Marvin, U. B., and Powell, B. N., 1970 , Lunar anorthosites and a geophysical model of the Moon: Geochim. et Cosmochim. Acta, Supp. 1, Apollo 11 Lunar Sci. Conf. Proc., v. 1, p. 965-988. 


\title{
SOLAR POSITION DIAGRAMS-SOLAR ALTITUDE, AZIMUTH, AND TIME AT DIFFERENT LATITUDES
}

\author{
By MALCOLM M. CLARK, Menlo Park, Calif.
}

\begin{abstract}
Computer-generated stereographic projections for each $2^{\circ}$ of latitude show azimuth and altitude of the sun simply and quickly for any date and time. These solar position diagrams were designed for users of low-sun-angle aerial photographs, but they will also serve others, such as scientists, agriculturalists, or planners, who must deal with the relationships between solar position, date, time, and latitude.
\end{abstract}

The use of aerial photographs taken with low sun angle will increase as potential users become better acquainted with the ability of such photos to emphasize topography. This advantage of low-angle illumination was strikingly demonstrated by the widely publicized Lunar Orbiter photos of the late 1960's and is also an important part of the success of side-looking radar images (which produce the same effect by different means and appear, for example, in Dellwig and others, 1966; Rydstrom, 1967; Reeves, 1969; Wing and Dellwig, 1970). More recently the use of low-sun-angle aerial photos in terrestrial geologic research has been illustrated by Howard and Mercado (1970) and Clark (1971), although Richter (1958, p. 173) earlier pointed out that fault scarps become very evident from the air under certain conditions of illumination, and Slemmons (1969) has used this technique to map otherwise obscure or undetected fault scarps in several areas.

Both azimuth and altitude of illumination are important to the successful use of low-sun aerial photos. Slemmons (1969) emphasized the importance of solar azimuth for the detection of faults, and MacDonald and others (1969) the importance of radar "look direction" in revealing linear topography such as faults or ridges. Hackman (1.967) pointed out that the best elevation of the sun above the horizon varies with the characteristics of the terrain.

However, after a user has defined the optimum solar altitude and azimuth for an aerial-photo project, no convenient way exists to determine the date and time when the sun is in the desired position. He must either use astronomic tables or use charts and tables that have been prepared for other purposes ${ }^{1}$ or that are not widely available.

Accordingly, the U.S. Geological Survey has generated a series of stereographic projections that show at a glance the date and time of all solar positions that occur at a given latitude. These diagrams are simple and easy to use; furthermore, the stereographic projection is familiar to most geologists. A computer program produces a diagram for each $2^{\circ}$ of latitude from $0^{\circ}$ to $90^{\circ} .2$ Although individual diagrams are not difficult to make by hand using a stereographic net, simple modifications by John Tanida, of the Geological Survey, to an existing program led to the more economical computer plot.

The diagrams are stereographic projections of the hemisphere of sky above any location on the earth's surface at the latitude of the diagram (figs. 1, 2). You see the projection from above the location and its hemisphere of sky (the projection point is on the opposite hemisphere at the nadir of the location). Thus the center of the projection represents the map position of the location. Curves labeled April 11, October 25, and so forth, are the sun's paths through the sky from sunrise to sunset on those dates. Great circles labeled 0600,0800 , and so forth, indicate the time that the sun passes different positions along a daily path. The boundary of the projection is the horizon of the location, and each circle concentric to the horizon represents a constant angular altitude above the horizon. Radial lines from the center of the projection show azimuth or compass direction to points on the horizon and in the sky. (The common intersection of the hour circles is the position in the sky of the extended axis of rotation of the earth.)

As an example, suppose we wish to obtain aerial photos of a region at lat $36^{\circ} \mathrm{N}$. with solar altitude between $20^{\circ}$ and $25^{\circ}$ and azimuth between $110^{\circ}$ and $150^{\circ}$ (shadows cast northwesterly). The $36^{\circ}$-latitude diagram (fig. 1 ) shows the sun to be in the proper position between about 0750 and 0820 on March 11 and October 4, between 0930 and 1000 on December 21, and at intermediate times between October and March. Notice that solar altitudes less than $25^{\circ}$ do not occur

\footnotetext{
${ }^{1}$ For example, the Eastman Kodak Aerial Exposure Computer for aerial films (Rochester, N.Y., 1966), the Libby-Owens-Ford Sun Angle Calculator for architects (Toledo, Ohio, 1951), or the high-sun-angle charts of Fleming (1968)

${ }^{2}$ Clear positive Mylar copies of all the diagrams are sold by the Pacific Region Engineer, U.S. Geological Survey, 345 Middlefield Road, Menlo Park, Calif. 94025.
} 


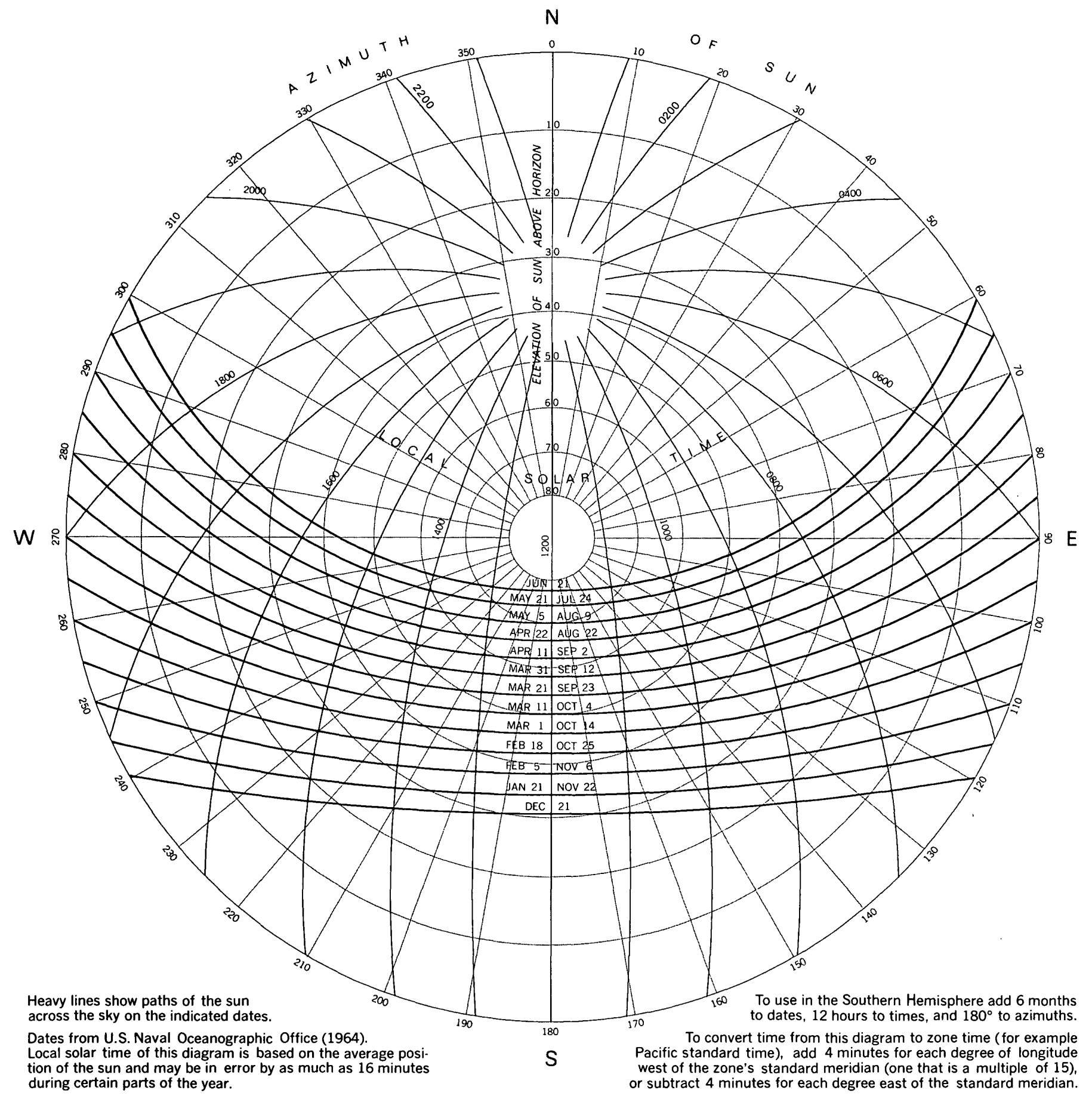

LATITUDE $36^{\circ} \mathrm{N}$

Figure 1.-Solar position diagram for lat $36^{\circ} \mathrm{N}$. 

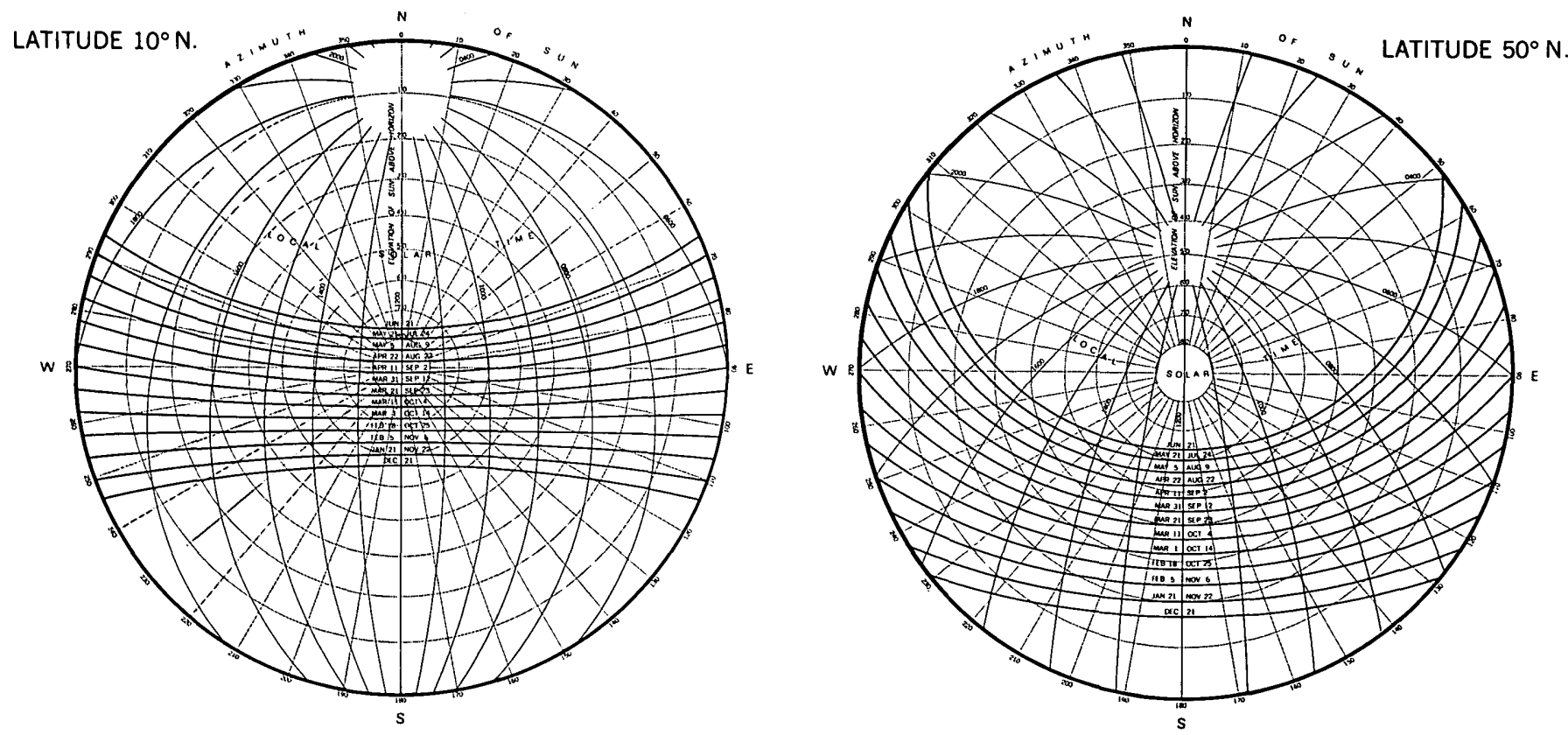

Figure 2.-Solar position diagrams for lat $10^{\circ}$ and $50^{\circ} \mathrm{N}$.

between azimuths of $110^{\circ}$ and $150^{\circ}$ from about March 20 to September 25 at this latitude.

Because the apparent position of the sun in the sky is different from the average position of the sun used for these diagrams, times may be in error by as much as $\mathbf{1 6}$ minutes, depending on the date (Bowditch, 1962, p. 495). This error, however, is insignificant for most practical applications.

The diagrams can be used for many different purposes. Given any three of the following, one can determine the remaining two: latitude, solar altitude, solar azimuth, date (with season ambiguous if not given), and local solar time. Thus the diagrams may be useful to anyone who is concerned with relations between these elements. For example, suppose solar altitude and azimuth can be measured from the shadows cast by objects or terrain of known height in an aerial photo of known date. The diagrams then yield latitude of the scene and local time of the photo. Conversely, if the location, date, and time of an aerial photo are known, the diagrams yield solar altitude and azimuth. Shadows in the photo can then be used to determine north direction and the heights of objects. In addition to photographic applications, the diagrams can be of use to anyone who is concerned with the effects of diurnal and seasonal changes in solar position on natural or manmade environments and processes. For example, the diagrams show the dates during which a slope receives a certain amount of sunlight, or the dates and times during which parks are shaded by adjacent hills or buildings; the diagrams also permit estimates of solar heat loads on surfaces with various orientations. Potential users thus include many in natural and physical sciences, geographers, agriculturalists, and several categories of designers and planners.

\section{REFERENCES}

Bowditch, Nathaniel, 1962, American practical navigator: U.S. Navy Hydrographic Office Pub. 9, 1524 p.

Clark, M. M., 1971, Comparison of SLAR images and small-scale, low-sun aerial photographs: Geol. Soc. America Bull., v. 82, p. 1735-1742.

Dellwig, L. F., Kirk, J. N., and Walters, R. L., 1966, The potential of low resolution radar in regional geologic studies: Jour. Geophys. Research, v. 71, p. 4995-4998.

Fleming, E. A., 1968, Solar altitude monograms, in Smith, J. T., Jr., ed., Manual of color aerial photography: Falls Church, Va., Am. Soc. Photogrammetry, p. 67-75.

Hackman, R. J., 1967, Time, shadows, terrain and photointerpretation, in Geological Survey Research 1967: U.S. Geol. Survey Prof. Paper 575-B, p. B155-B160.

Howard, A. D., and Mercado, Jose, 1970, Low-sun-angle vertical photography versus thermal infrared scanning imagery: Geol. Soc. America Bull., v. 81, p. 521-524.

MacDonald, H. C., Kirk, J. N., Dellwig, L. F., and Lewis, A. J., 1969, The influence of radar look direction on the detection of selected geological features: Internat. symposium on the remote sensing of environment, 6th, Univ. of Michigan, Ann Arbor, 1969, Proc., p. $637-650$. 
Reeves, R. G., 1969, Structural geologic interpretations from radar imagery: Geol. Soc. America Bull., v. 80, p. 2159-2164.

Richter, C. F., 1958, Elementary seismology: San Francisco, W. H. Freeman, $768 \mathrm{p}$.

Rydstrom, H. O., 1967, Interpreting local geology from radar imagery: Geol. Soc. America Bull., v. 78, p. 429-436.

Slemmons, D. B., 1969, New methods of studying seismicity and surface faulting: EOS (Am. Geophys. Union Trans.), v. 50, p. 397-398.

U.S. Naval Oceanographic Office, 1964, Azimuths of the sun and other celestial bodies of declination $0^{\circ}$ to $23^{\circ}:$ H. O. Pub. 260, $226 \mathrm{p}$.

Wing, R. S., and Dellwig, L. F., 1970, Radar expression of Virginia Dale Precambrian ring-dike complex, Wyoming/Colorado: Geol. Soc. America Bull., v. 81, p. 293-298. 


\title{
A SEA TRIAL OF THE LACOSTE-ROMBERG AND BELL AEROSYSTEMS SURFACE SHIP GRAVIMETERS
}

\author{
BY ALAN COOPER and ROLAND VON HUENE, \\ Menlo Park, Calif.
}

\begin{abstract}
LaCoste-Romberg and Bell Aerosystems stable-platform sea gravimeters were operated simultaneously over the San Francisco gravity calibration range. An average value for meter-versus-meter correspondence of $1.4 \pm 1.2 \mathrm{mgal}$ is determined for 28 track lines run in light to heavy seas; comparison of surface-meter and calibration-range values indicates an average difference of $2.0 \mathrm{mgal}$ for both meters. Profiles characterizing the performance of the two meters under all sea conditions are also illustrated.
\end{abstract}

In March 1968 the U.S. Geological Survey and the U.S. Army Topographic Command (formerly Army Map Service) operated LaCoste-Romberg and Bell Aerosystems stableplatform sea gravimeters (fig. 1) simultaneously over the San Francisco gravity calibration range, aboard the 95 -foot vessel RV Polaris. The primary objective of the trial was to observe and compare the performance of the two instruments during normal underway survey operations; a second consideration

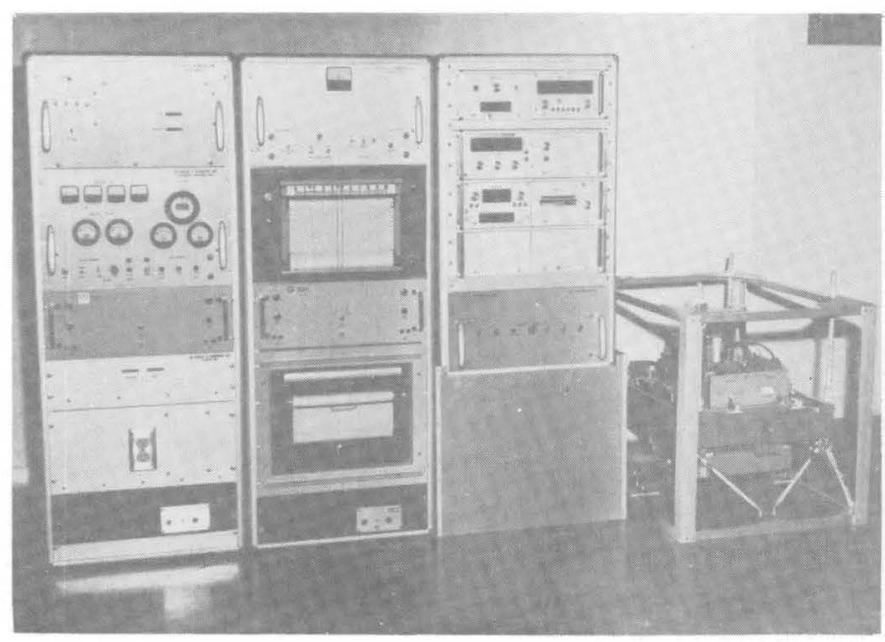

Figure 1.-Equipment for the two sea gravimeter systems discussed in text. Above, LaCoste-Romberg; photograph from LaCoste-Romberg instruction manual. Right, Bell Aerosystems; photograph from Burnfield (1969). was the mobility and ease of operation of the two systems. A total of 490 miles of gravity lines was completed under a variety of sea conditions ranging from calm to extremely rough; on two occasions, violent ship motions due to heavy seas necessitated a temporary postponement of survey operations. The San Francisco gravity calibration range (fig. 2) south of Point Reyes, Calif. was established in 1962 by the U.S. Coast and Geodetic Survey. Gravity gradients over the trial area ranged from 1 to $5 \mathrm{mgal}$ (milligals) per mile. At the average ship speed of 9 knots, the maximum time rate of

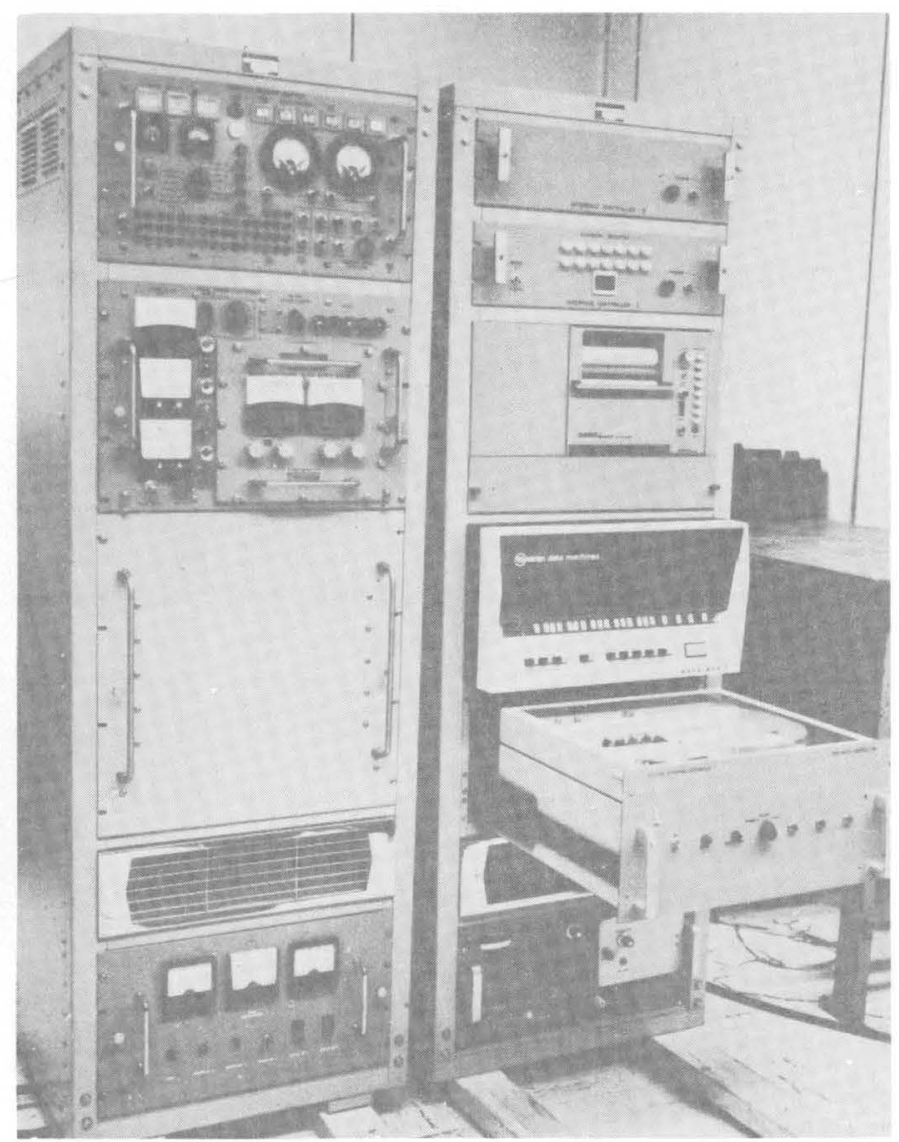




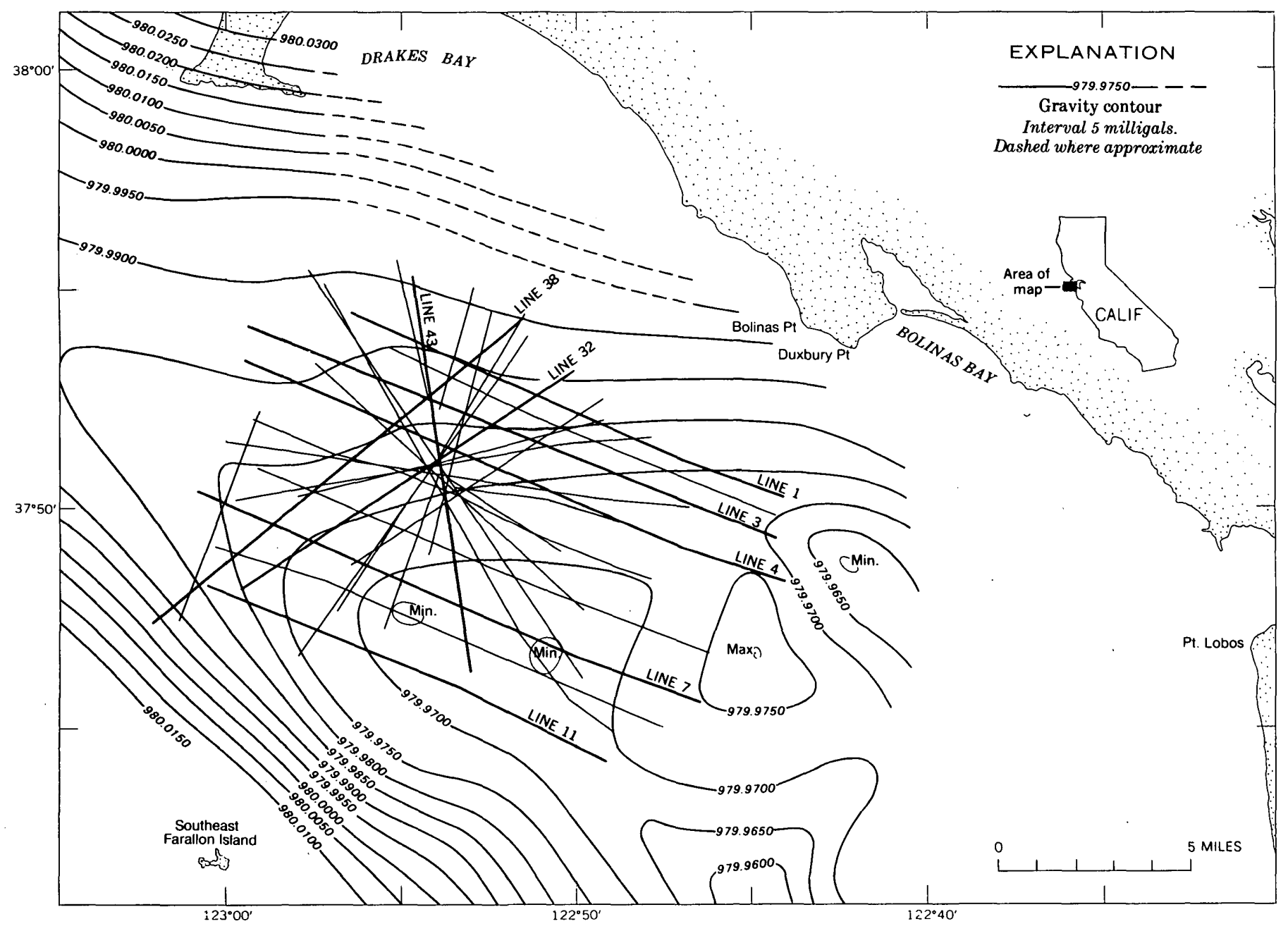

Figure 2.-Location map showing tracklines over the San Francisco gravity calibration range. Profiles for the numbered tracklines are shown in figure 9.

change of gravity was $0.8 \mathrm{mgal} /$ minute, a value within the response range of both meter systems.

Base stations were established with a LaCoste-Romberg land gravimeter at three dockside locations-Port of Redwood City; Pier 42, San Francisco; and Coast Guard dock, Point Reyes. Three independent loops were used to tie the three base stations to the reference mark at USGS Station Menlo A. A maximum reading error of $0.4 \mathrm{mgal}$ was recorded at the Coast Guard dock, Point Reyes. Dockside locations were chosen to be at the approximate position of the sea gravimeters when the ship was tied alongside. During the survey operations, base readings were taken routinely upon arrival at and departure from the dock. An initial base reading was made at the Port of Redwood City after the two gravimeter systems were installed. The cumulative drift of the LaCoste meter over the following 7-day period (fig. 3 ) was $0.6 \mathrm{mgal}$, an average daily drift of 0.1 mgal. Drift of the Bell meter could not be established for the same period because sume of the data were not recoverable from the magnetic tapes; however, over a 5-day period, the drift was $11.7 \mathrm{mgal}$, an average of $2.3 \mathrm{mgal} /$ day.
Acknowledgments. -We wish to thank Glen Cobb, William Gumert, and Robert Ziegler, of the U.S. Army Topographic Command, for their assistance and for giving us the results of their evaluation of the instruments. Thomas Ernst, Norman Burnfield, and Duane Davies, of Bell Aerosystems, and Dr. Lucien LaCoste, Dr. Niel Clarkson, and John England, of LaCoste-Romberg Gravity Meters, have freely helped and advised us in this study. Charles Winegard, Wayne Lowry, and Wyatt Gilbert, of the U.S. Geological Survey, spent many hours in the tedious task of data reduction. Robert Moran, of Moran Instruments, helped operate the MORAN navigation system at sea. We also thank Steve Wolf, Jerry Joslin (Master of the Polaris), and the ship's crew for their many hard hours at sea in unpleasant weather.

\section{PRINCIPLES OF OPERATION}

The LaCoste-Romberg and Bell Aerosystems gravimeters utilize different physical approaches to measure relative changes in gravity. Both meters incorporate heavy damping to 


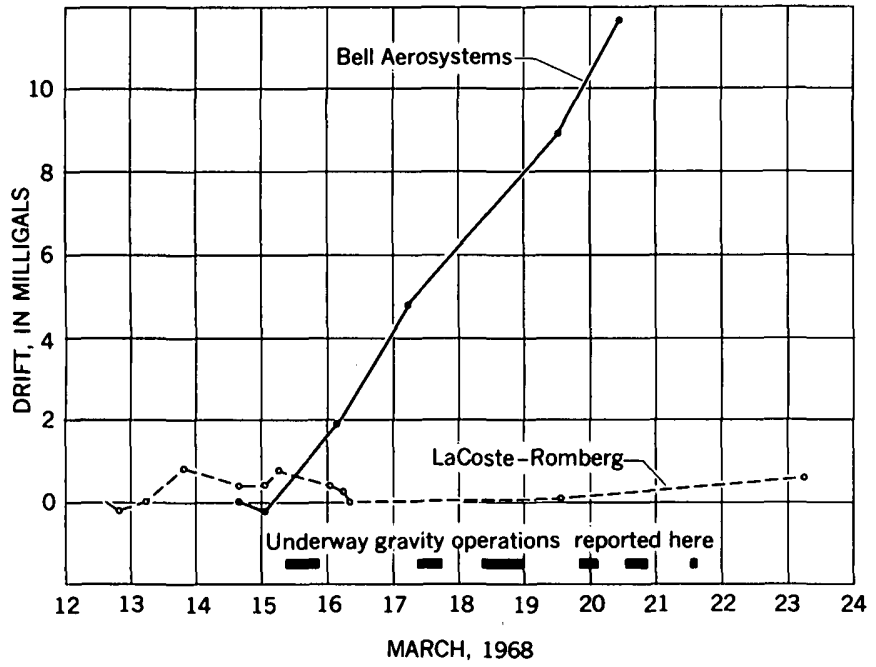

Figure 3.-Drift curves for the two gravimeters during the sea trials.

attenuate the high-frequency accelerations caused by ship motion in order to obtain the gravitational acceleration. Gyroscopically stabilized platforms are integrated into the systems to maintain the sensors in a vertical reference direction. The instruments differ in the design of the sensor system, methods of damping, and techniques for the processing of raw data; however, the final gravity readings should be similar. For a complete description of the gravimeters, the reader is referred to LaCoste (1967) and LaCoste and others (1967) for the LaCoste meter and to Bell Aerosystems ${ }^{1}$ and Burnfield.(1.969) for the Bell meter.

\section{NAVIGATION}

Navigation was controlled by a MORAN radar transponder system. The position determinations were automatically fed to an analog plotter, which maintained a continuous plot of the ship's position; digital position information was manually taken from the instrument at 5-minute intervals. Two calibration lines perpendicular to the shore were run over the width of the survey area with simultaneous theodolite triangulation and MORAN transponder positions. A comparison of visual and MORAN data revealed a systematic error of 2 parts per thousand in the instrument calibration, an error subsequently removed from the field-position determinations.

The corrected position information, accurate to \pm 25 feet, was used as the navigational control for the survey. Errors due to navigation are believed to be within $1 \mathrm{mgal}$ for Eötvös effects and within $0.2 \mathrm{mgal}$ for absolute position in the comparison to the calibration-range values. Three grid patterns were run over the survey area-two cartwheels designed to give headings for each two points of the compass and a northeast-

\footnotetext{
${ }^{1}$ Bell Aerosystems, 1968, Marine gravity measuring system: Unpub. Bell Aerosystems Technical Report D6184-936001, 93 p.
}

southwest and northwest-southeast rectangular grid chosen to equalize the Eötvös effects.

\section{DATA REDUCTION}

Gravity readings picked from the $\mathrm{LaCoste}$ analog records at 30 -second intervals were combined with corrected position information for reduction by an IBM $360 / 65$ computer. The computer Eötvös corrections were then graphically smoothed to correct for any unrecorded course changes and curved courses as determined from the continuous analog navigation plot and the beam trace of the LaCoste analog records. These smoothed Eötvös corrections were reapplied to the LaCoste and Bell data. The initial reduction of the Bell gravity data was done by the Army Map Service. A continuous sample of meter gravity was filtered over a 5-minute period to give a single gravity value for each 5 -minute interval; navigation corrections were later added to the 5-minute readings by the author. To make the gravity readings from the LaCoste meter compatible with the Bell format, the 30 -second LaCoste data were processed through a similar 5-minute filter. Comparison of the two meter systems has been based on the 5-minute values.

The necessary choice for this reduction procedure has introduced into the final gravity values biases that must be taken into consideration when the results are examined. Navigational corrections favor the LaCoste meter owing to the Eötvös smoothing procedure, whereas the 5-minute-filter function acts as a bias toward the Bell meter. For most traverses, data from the LaCoste meter show a greater internal consistency if the 30 -second gravity values are fitted by a least-squares approximation. The method of least squares cannot be applied as effectively to the 5-minute filtered data of the Bell meter owing to a large scatter of the gravity values in the heavier sea conditions. Thus, an evaluation based on crossing points did not appear to be the most useful for the objectives of the survey. Instead, a comparison of the meter and calibration-range gravity is given as a quantitative measure of the internal accuracy for each meter system.

\section{PERFORMANCE OF GRAVIMETERS}

During dockside base-station readings, each meter system showed two types of short-period noise (fig. 4). The records from the LaCoste meter indicate a 3-minute-period noise of 0.5-mgal maximum amplitude for the 1-minute filtered values. Corresponding 1-minute averages were not available for the Bell meter; however, on-board observation of the meter operation indicated an equivalent short-period noise. Fiveminute filtered readings from the LaCoste meter show a 30-minute-period noise of 0.3-mgal maximum amplitude. Similar 5-minute readings from the Bell meter indicate two spikes with amplitudes of 0.5 and $1.0 \mathrm{mgal}$ at periods of 10 and 15 minutes respectively. Six such spikes with maximum amplitudes between 0.5 and $1.2 \mathrm{mgal}$ and periods of 10 to 15 minutes were recorded over a 24 -hour period. The amplitude 

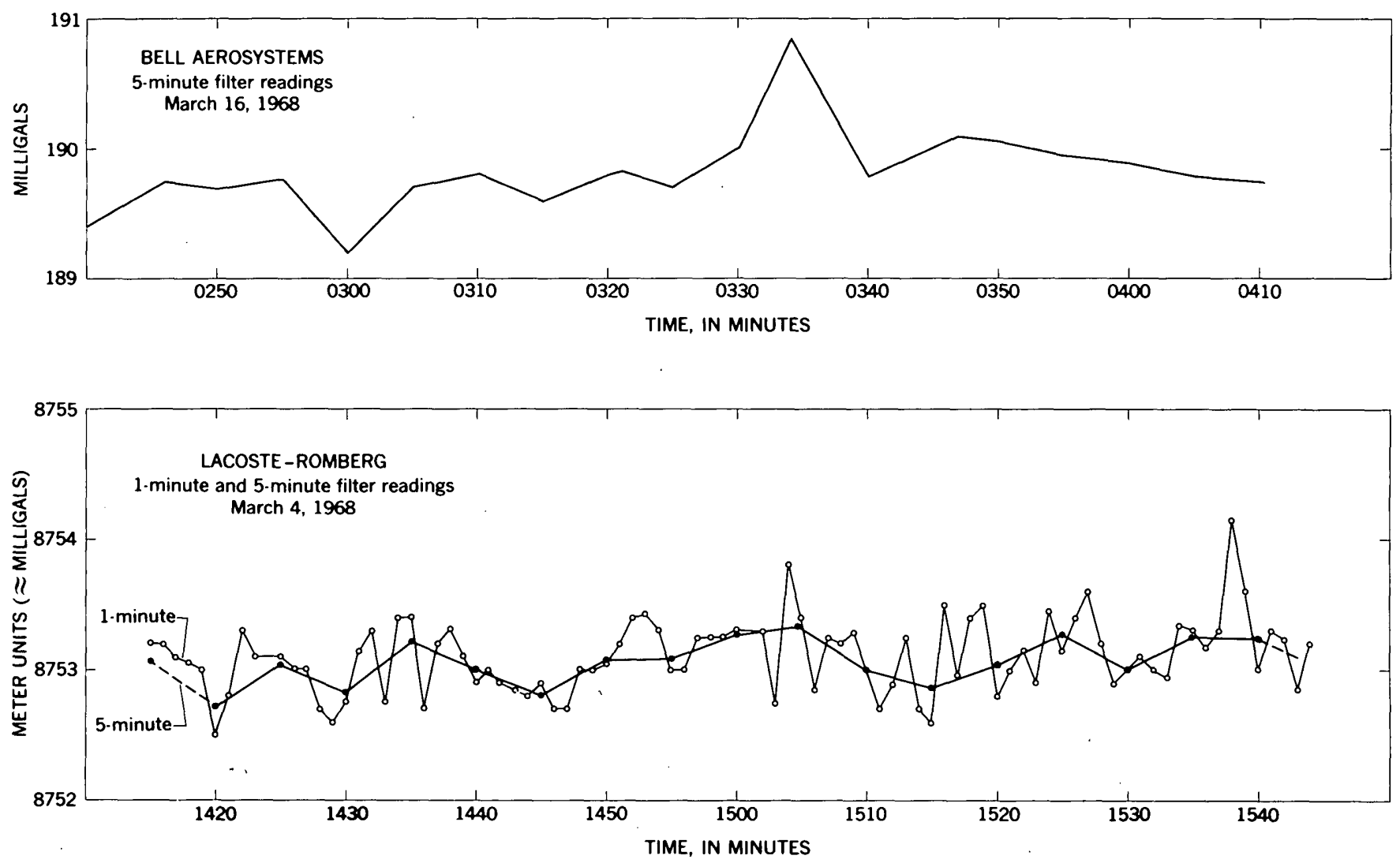

Figure 4.-Samples of short-period noise from the two gravimeters.

of meter noise for periods longer than 10 minutes appears to be slightly larger for the Bell meter. A recent investigation of short-period dockside noise by LaCoste (written commun., 1969) suggests that resonance of water within a harbor may be the source of the noise.

Performance of both instrument systems was similar under all sea conditions. Occasionally, the sea states become severe enough to exceed the operational limits of the two meters. The number of times the Bell meter exceeded its operational limits and required a restart of the system increased in heavier seas. Under similar conditions, the LaCoste-Romberg meter measured cross-coupling corrections greater than its 50 -mgal recording limit. An estimate of the upper limit beyond which usable data cannot be obtained is subjective and presumably depends upon ship size and survey objectives.

The inherent response time of the two meters is on the order of 0.001 second; however, the effective response time has been increased under normal operating conditions by damping and filtering in the meter and data display systems. Both gravimeters offer a selection of damping and filtering to give some choice in the balance between response time and noise. The effective response time of the Bell meter appeared to be somewhat faster than that of the LaCoste meter. The recovery time for the two systems after large course changes was about 3 minutes.
Personnel trained in the operation of each instrument were on board to maintain the equipment. The only malfunction was shorting of a light bulb in an analog recorder of the LaCoste meter system; this interrupted the operation of the stable platform and resulted in a 12-minute loss of data. During the 24, hours following this interruption, data from the LaCoste meter showed large systematic errors that were preferential to ship direction. The meter gradually corrected itself during the 24-hour period and continued to function normally for the remainder of the cruise. A definitive explanation for the systematic errors has not been found. No serious mechanical or electrical problems were observed in the Bell system.

\section{METER CORRESPONDENCE}

Observed gravity values from the two meters are compared at 5-minute reading intervals to obtain the correspondence for each line. The correspondence is defined here as:

$$
\frac{\left|O G_{\cdot B e l l}-O G_{\cdot}{ }_{\text {LaCoste }}\right|}{N},
$$


where O.G. is the observed gravity and $N$ is the number of comparison points. A compilation of the correspondence values for each of the 28 lines used in this study is shown in figure $5 ; 30$ percent of these lines are classified as moderate to very heavy seas. The mean correspondence for all lines is 1.4

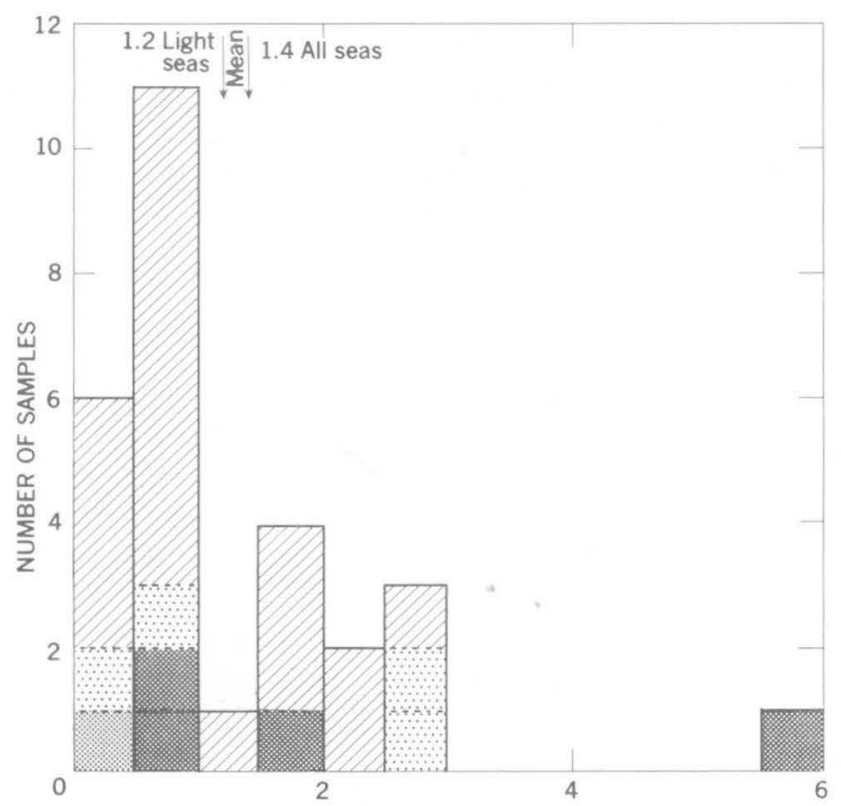

CORRESPONDENCE VALUES (BELL VS. LACOSTE), IN MILLIGALS

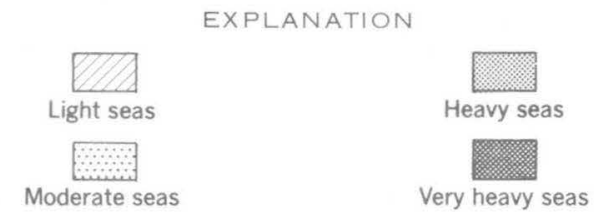

Figure 5.-Histogram of correspondence values (Bell vs. LaCoste gravimeters) for 28 tracklines.

mgal with an rms (root mean square) error of 1.2 mgals; 95 percent of the correspondence values are within $\pm 2.4 \mathrm{mgal}$ of the mean. A 6-mgal correspondence value occurs on a line run under adverse sea conditions in which both meters were operating near their ultimate capabilities. Cross-coupling corrections in excess of $50 \mathrm{mgal}$ were measured by the LaCoste meter; 25 percent of the Bell data was lost because ship accelerations exceeded the setting of the meter-limit switches.

All lines have been categorized, on the basis of the average cross-coupling error for each line, into four sea-state conditions: light, moderate, heavy, and very heavy. The crosscoupling errors are used as an empirical measure of the instantaneous vertical and horizontal movements of the ship, since quantitative sea-state information is not available. There is a substantial scatter of the gravity values (correspondence rms) with increasingly heavy sea conditions, which suggests an exponential correlation (fig. 6). On 19 lines run in light seas,

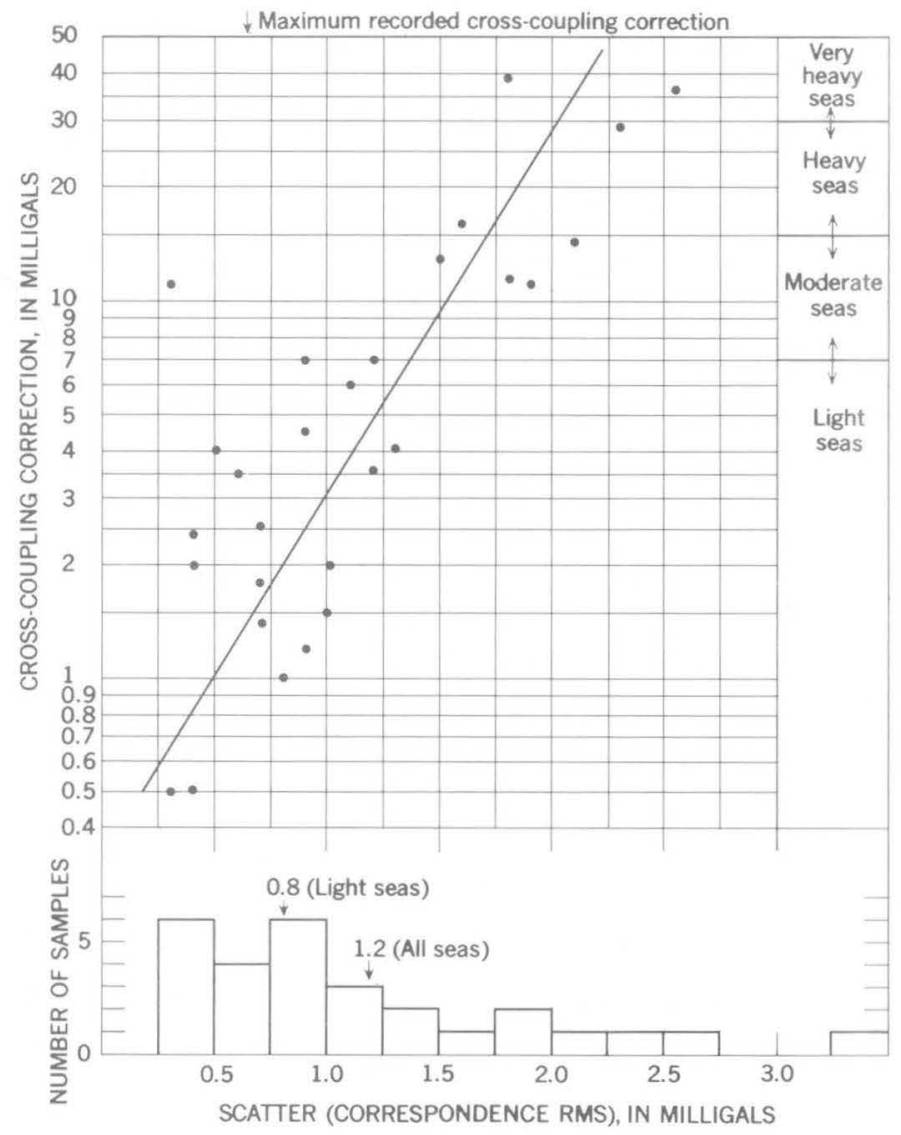

Figure 6.-Graphs showing increases in scatter of correspondence values for four sea-state conditions.

the mean correspondence for 5 -minute filtered gravity readings is $1.2 \mathrm{mgal}$ with an $\mathrm{rms}$ value of $0.8 \mathrm{mgal}$.

\section{ACCURACY}

The accuracy of the two meter systems is evaluated by comparison of meter gravity with calibration-range gravity (sea level) and is given as:

$$
\text { Accuracy }=\frac{0 . G_{\text {meter }}-0 . G_{\text {range }}}{N},
$$

where O.G is the observed gravity and $N$ is the number of comparison points along a line. A single accuracy value is given for each of the 28 lines. Figure 7 is a histogram of the accuracy results from the LaCoste and Bell meters; figure 8 gives the accuracy rms. The results are: (1) Bell Aerosystems, $-2.4 \pm 1.5$ in light seas (19 lines) and $-2.0 \pm 1.5$ in all seas (28 lines); LaCoste-Romberg, $-2.9 \pm 1.2$ in light seas and $-2.0 \pm 1.4$ in all seas.

The accuracy of the two systems is nearly identical if all sea conditions are considered. However, in light seas, the LaCoste meter indicates a more negative average accuracy value. This difference results from a wider distribution of accuracy data 

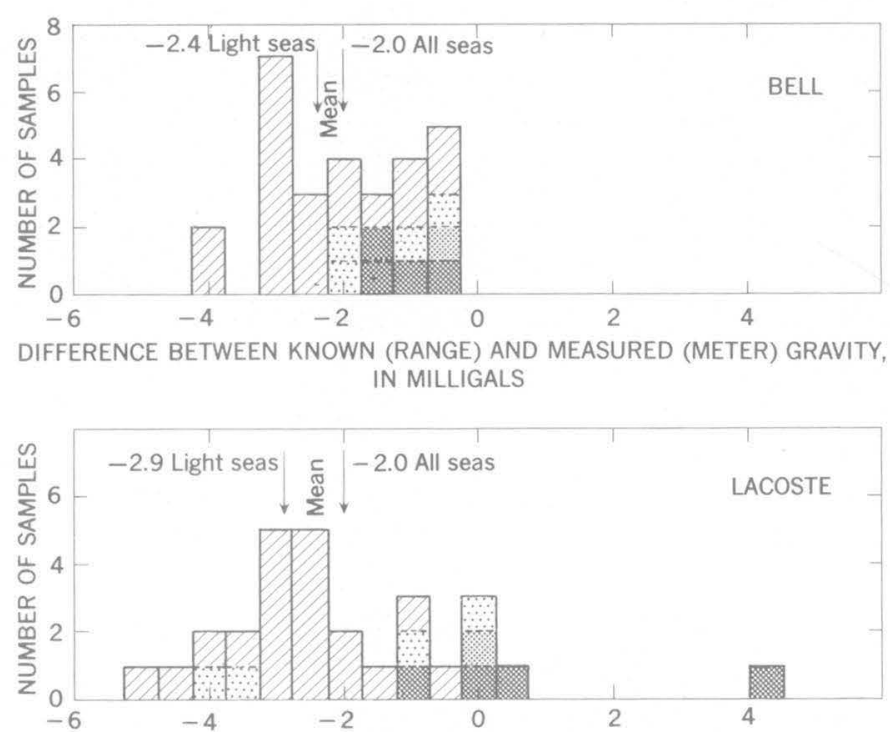

DIFFERENCE BETWEEN KNOWN (RANGE) AND MEASURED (METER) GRAVITY, IN MILLIGALS

EXPLANATION
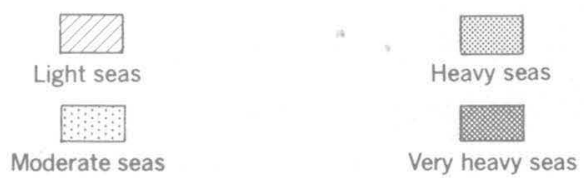

Figure 7.-Histograms of accuracy values for the two gravimeters.

points and a larger concentration of negative LaCoste values. Operation of the meters in heavy seas increases the scatter of the LaCoste readings slightly more than those of the Bell, as indicated by the larger values. The exclusion of Bell data lost when the limit switches were exceeded in heavy seas and the 5 -minute filtering of 30 -second gravity readings from the LaCoste meter may bias the rms values in favor of the Bell meter. In lighter seas, the average rms values favor the LaCoste meter. The accuracy values are generally $2.0 \mathrm{mgal}$ lower than the range gravity for both meters, suggesting an unknown systematic error, possibly in the calibration-range data, dockside base-station ties, or the navigation data.

\section{OVERALL PERFORMANCE}

Profiles representative of the performance of the Bell and LaCoste meter systems under all sea conditions (fig. 9) indicate that the two meters are consistently lower than the calibration range gravity values. The difference reflects the systematic error, which was not uncovered in the data-reduction process. Three trends are common to both meters with the increase in sea state: (1) an increase in the scatter of the 5-minute filtered gravity readings; (2) an increase in the difference between the two meter readings; and (3) an increase in the amount of data lost or adversely affected. The two profiles (lines 1 and 4 ) run in very heavy seas indicate the quality of gravity measurements that might be expected when
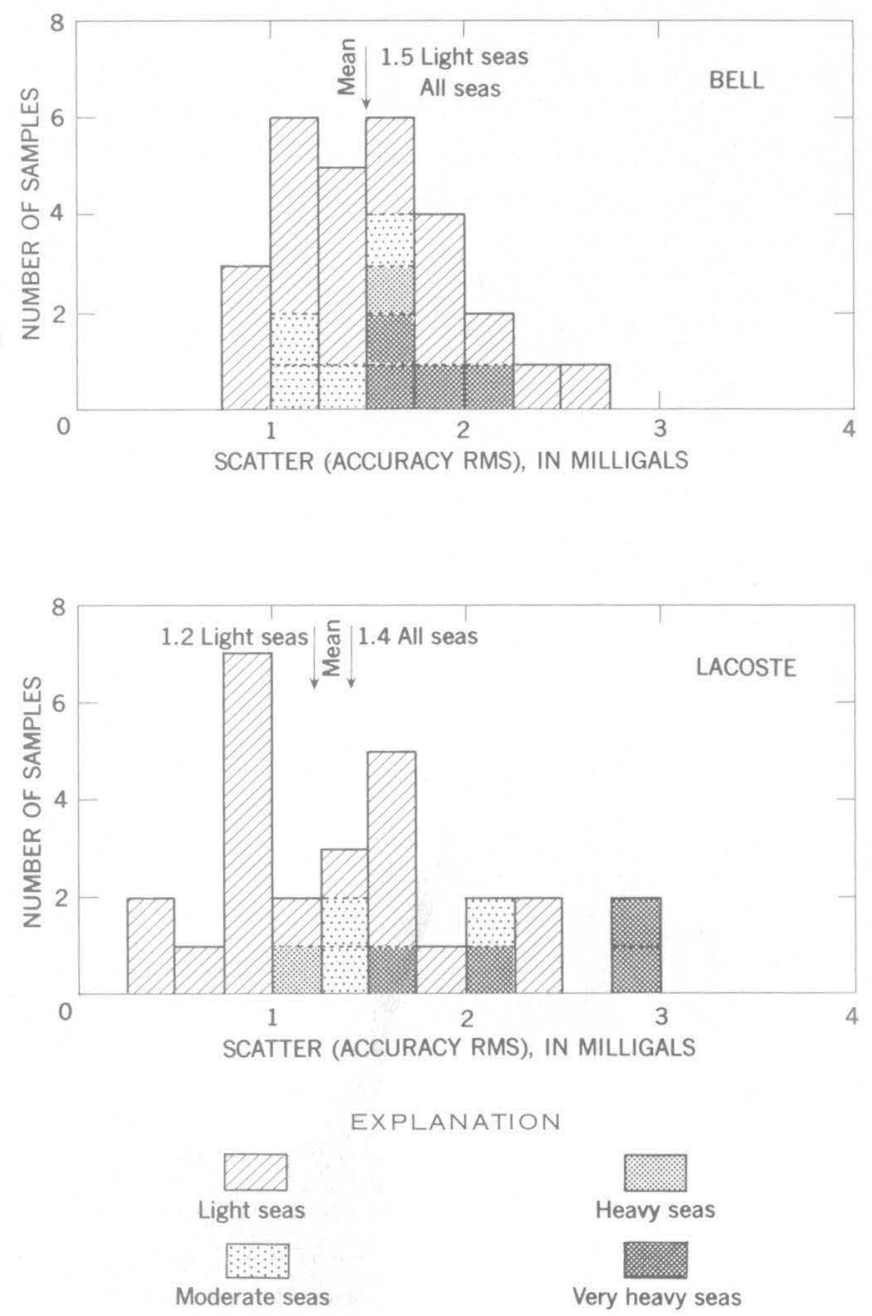

Figure 8.-Histograms of accuracy rms values for the two gravimeters.

the meters are operating at or near their maximum capabilities.

In most gravity evaluation tests, meter performance in light to moderate seas is used. Since our correspondence and accuracy values also incorporate data recorded in heavy sea conditions, they are generally higher than those reported by $\mathrm{LaFehr}$ and Nettleton (1967). LaFehr and Nettleton indicated an average repeatability of $0.7 \mathrm{mgal}$ and an accuracy of 0.5 mgal in an evaluation of a LaCoste stabilized platform meter of the Gulf of Mexico. Gantar and Morelli (1970), in a test of a Bell Aerosystems sea gravimeter in the Gulf of Venice, showed a standard deviation of $0.6 \mathrm{mgal}$ in their measurements over a known gravity range.

Observed gravity values from lines run in light seas (lines 32 , 38 , and 43 ) agree within $1.5 \mathrm{mgal}$, and the meters resolve similar anomalies. A 3.5-mgal spike in the Bell meter profile at 1650 hours on line 32 is due to the partial saturation of the electronics. Such spikes within the gravity troughs are not uncommon; they appear to be the result of an overreaction to the sudden reversal of the gravity gradient. Line 32 gives an 

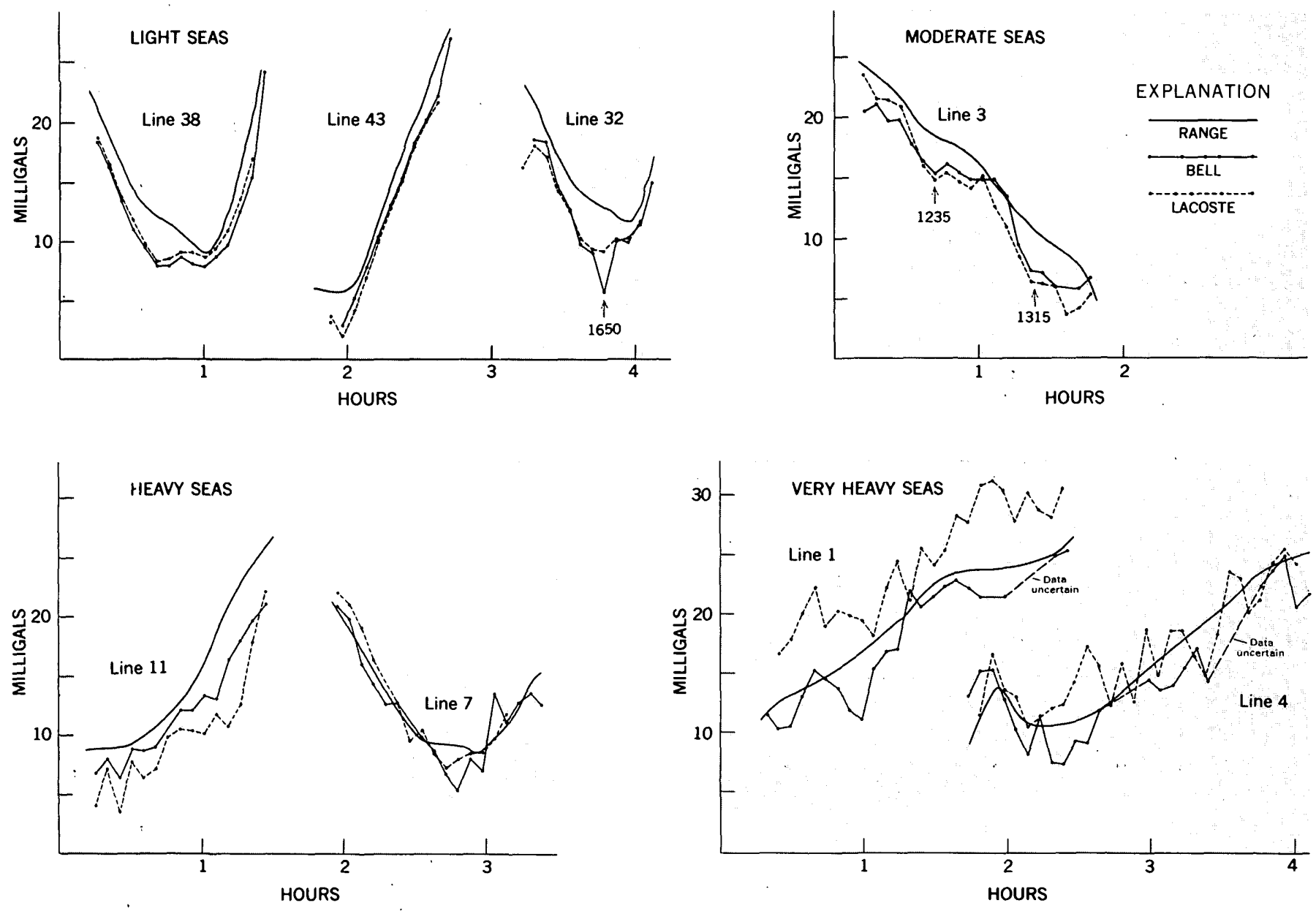

Figure 9.-Representative gravity profiles for the numbered tracklines shown on figure 2.

interesting example in which the meters agree with one another but do not follow the known gravity field. An error in the calibration-range gravity, a navigational error, or meter excursions dependent upon ship motion could explain the differences. Other lines crossing the area from different directions also show discrepancies, suggesting an error in range gravity.

Resolution of small anomalies by both meters decreases steadily in the heavier seas and becomes unreliable beyond an average cross-coupling correction of $15 \mathrm{mgal}$, the arbitrary boundary between moderate and heavy seas. In light seas, the meters resolve an apparent 0.8 -mgal anomaly with a width of 3 miles on line 38 . Two other small anomalies are seen by both meters on line 3 at 1235 and 1315 hours; the average cross-coupling correction on this line is $13 \mathrm{mgal}$. In heavier seas, the small anomalies are hidden in the noise. On lines 1 and 4, which have cross-coupling corrections exceeding 35 mgal, the precision is so poor that little can be said about the performance of the equipment, except that the meters are able to give an approximation of gravity.

\section{MOBILITY AND EASE OF OPERATION}

During transport the Bell system required a continuous power source to maintain a constant temperature within the sensor. The sensor and its battery pack for a 5-hour supply measured 19 by 13 by 21 inches and weighed 106 pounds; this package had to be personally accompanied from the factory.

A convenient feature of both systems was the ease with which the instruments could be handled aboard ship during installation. The size and weight of the instrument boxes was small enough to allow two men to carry the equipment through 24-inch doorways. Power for the equipment was supplied by the ship's generator. The installation and underway operation of the meters was handled by trained personnel.

\section{SUMMARY}

This evaluation of the LaCoste-Romberg and Bell Aerosystems sea gravimeters represents the first reported side-byside trial of the two meter systems in a wide variety of sea 
conditions. Simultaneous operation of both systems aboard a single vessel has eliminated the relative errors in navigation, ship motion, and values of known gravity which usually add uncertainty to comparative evaluations made aboard separate vessels in different areas and under dissimilar sea conditions. Specific objectives of the evaluation included (1) performance during underway operation, and (2) mobility and ease of operation.

\section{Performance during underway operation}

1. The ability of the LaCoste and Bell gravimeters to measure gravity in all sea conditions was similar. Correspondence and accuracy determined in this evaluation were:

\begin{tabular}{|c|c|c|c|c|}
\hline \multicolumn{3}{|c|}{ Correspondence (meter vs, meter) } & \multicolumn{2}{|c|}{ Accuracy (meter vs. range) } \\
\hline & Light seas & All seas & Light seas & All seas \\
\hline Bell & & & $-2.4 \pm 1.5$ & $-2.0 \pm 1.5$ \\
\hline $\mathrm{LaC}$ & $1.2 \pm 0.8$ & $1.4 \pm 1.2$ & $-2.9 \pm 1.2$ & $-2.0 \pm 1.4$ \\
\hline
\end{tabular}

In light seas both meters were able to resolve anomalies of less than $1 \mathrm{mgal}$. As sea states increased, the correspondence decreased exponentially, and there was an increase in the amount of data lost or adversely affected.

2. Meter drift for the trial period was $0.1 \mathrm{mgal} /$ day for the LaCoste and $2.3 \mathrm{mgal} /$ day for the Bell. Other Bell sensors with more time at sea are reported to show significantly less drift (Bell Aerosystems, oral commun.).

3. At dorkside, both meters showed short-period (1-3 minutes) and long-period (15-30 minutes) noise with a maximum amplitude of $1.2 \mathrm{mgal}$. The amplitude of longperiod noise was slightly larger for the Bell meter.

4. The effective response time of the Bell meter appeared to be slightly faster than that of the LaCoste meter. After large course changes, the recovery time for both systems was about 3 minutes.

5. An explanation for the systematic error in the LaCoste data following the failure in the stable platform was not discovered. After the cruise the sensor was completely rebuilt, and a similar problem has not been encountered since.

6. This trial represents the first use of either meter in the field.

\section{Mobility and ease of operation}

1. During transportation from manufacturer to ship, the Bell system required electrical power for its sensor heaters; the LaCoste meter did not.

2. Installation of both gravimeters was accomplished within a few hours with no difficulty.

3. Both the LaCoste and Bell meters required trained personnel for their operation and maintenance.

\section{REFERENCES}

Burnfield, R. N., 1969, A new shipboard gravity meter: Am. Geophys. Union Trans., v. 50, no. 4, p. 205.

Gantar, C., and Morelli, C., 1970, First tests of the new Bell Aerosystems sea gravity meter: Boll. Geofisica Teor. ed Appl., v. 11, nos. 43-44, p. 173-190.

LaCoste, L. J. B., 1967, Measurement of gravity at sea and in the air: Reviews of Geophysics, v. 5, no. 4, p. 477-526.

LaCoste, L. J. B., Clarkson, Neal, and Hamilton, George, 1967, LaCoste and Romberg stabilized platform shipboard gravity meter: Geophysics, v. 32, no. 1, p. 99-109.

LaFehr, T. R., and Nettleton, L. L., 1967, Quantitative evaluation of a stabilized platform shipboard gravity meter: Geophysics, v. 32, no. 1, p. 110-118.

U.S. Coast and Geodetic Survey and U.S. Naval Oceanographic Office, 1962, Sea gravity phase, oceanographic equipment evaluation range: San Francisco, Calif., U.S. Coast and Geod. Survey, 24 p. 


\title{
$\mathrm{Sr}^{87} / \mathrm{Sr}^{86}$ IN MAFIC ROCKS OF THE TROODOS MASSIF, CYPRUS
}

\author{
BY ZELL E. PETERMAN ${ }^{1}$, ROBERT G. COLEMAN ${ }^{2}$, and ROBERT A. HILDRETH ${ }^{1}$, \\ ${ }^{1}$ Denver, Colo., ${ }^{2}$ Menlo Park, Calif.
}

\begin{abstract}
Initial $\mathrm{Sr}^{87} / \mathrm{Sr}^{86}$ values in the range of 0.7038 to 0.7056 for gabbro, basalt, diabase, and trondhjemite of the Troodos massif, Cyprus, are significantly higher than $\mathrm{Sr}^{87} / \mathrm{Sr}^{86}$ values for Holocene ocean ridge tholeiites from the East Pacific and Mid-Atlantic Rises. Compelling geologic evidence indicates that the Troodos massif is a remnant of the Tethyan Mesozoic oceanic plate and possibly a fossil rise, and the isotopic differences suggest that the source mantle that produced the Troodos rocks had a higher $\mathrm{Sr}^{87} / \mathrm{Sr}^{86}$ value than that from which the younger ocean ridge tholeiites are being derived. If both these rocks are derived from mantle that has previously produced basaltic liquid with resultant lowering of $\mathrm{Rb} / \mathrm{Sr}$ values, the mantle underlying the Tethys would have undergone this process much later than the source mantle for the Atlantic and Pacific ocean ridge tholeiites.
\end{abstract}

Ophiolites or associations of ultramafic rocks, mafic volcanic rocks, and marine sediments have received renewed attention in the last few years largely as a result of the concept of sea floor spreading. Many ophiolite suites are currently thought to represent oceanic crust that has escaped the almost inevitable consumption in subduction zones at continental margins and island arcs.

The geology of the Troodos massif is well documented (for example, Wilson, 1959; Bear, 1960; Gass, 1960). Gass (1968) and Moores and Vine $(1969,1971)$ suggested that the massif is a fragment of Tethyan sea floor and possibly a remnant of a Mesozoic rise. These arguments are compelling and, if correct, the Troodos massif provides an opportunity for directly studying the oceanic plate. The U.S. Geological Survey is investigating these rocks in many parts of the world as a part of continuing studies of theories and concepts of plate tectonics.

Acknowledgments. -We thank Marvin Lanphere, U.S. Geological Survey, Menlo Park, Calif., and Eldridge Moores, University of California, Davis, for reviewing the manuscript. We also thank W. T. Henderson and W. P. Doering, U.S. Geological Survey, Denver, Colo., for their technical assistance.

\section{GEOLOGIC SKETCH}

The island of Cyprus lies in the eastern part of the Mediterranean Sea, where it forms part of the Alpine belt that extends from the Alps eastward to the Himalayas, characteristically containing many ophiolite occurrences. The Troodos massif occupies the southern part of Cyprus, where it is surrounded by upper Mesozoic and Tertiary sedimentary rocks. In the following summary of the geologic relations, we have taken liberally from the works of Wilson (1959), Gass and Masson-Smith (1963), Gass $(1967,1968)$, and Moores and Vine (1971).

The massif is divided into three major geologic units, which form a crudely annular pattern in map view (fig. 1). Ultramafic rocks and gabbros of the plutonic complex are surrounded by a unit consisting of generally north-trending diabase dikes called the sheeted intrusive complex. This unit is circumscribed by the pillow lava series, which is divided into an upper and a lower unit on the basis of composition and the amount of intrusive rocks.

The plutonic complex consists of a variety of ultramafic rocks including dunite, periodotite, pyroxenite, and gabbros with silicic differentiates. The gabbroic rocks are more abundant near the margins of the plutonic complex. Silicic differentiates of the gabbros consist of trondhjemites, sodic granophyres, quartz porphyries, and feldspar porphyries.

In the sheeted intrusive complex, near-vertical diabase dikes are locally separated by septa of volcanic rocks that include epidosites and keratophyres. In places the complex consists totally of dikes. Some of the dikes are older than the pillow lava series, whereas others were feeders for these overlying lavas. Alteration in the sheeted intrusive complex has been extensive.

The pillow lava series is dominantly basaltic, although silicic and ultramafic phases are present. In the lower unit, extrusive and intrusive rocks are in about equal proportions; many of the intrusives are feeder dikes for the upper unit. The thinner upper unit contains a considerably smaller fraction of intrusive material.

According to Gass (1967), the Troodos igneous rocks have a markedly tholeiitic character. Although many of the basaltic rocks from Troodos are chemically similar to modern ocean ridge tholeiites, a meaningful comparison is difficult because of pervasive alteration of many of these units (Moores and Vine, 1971). The extremely low potassium content of many of 


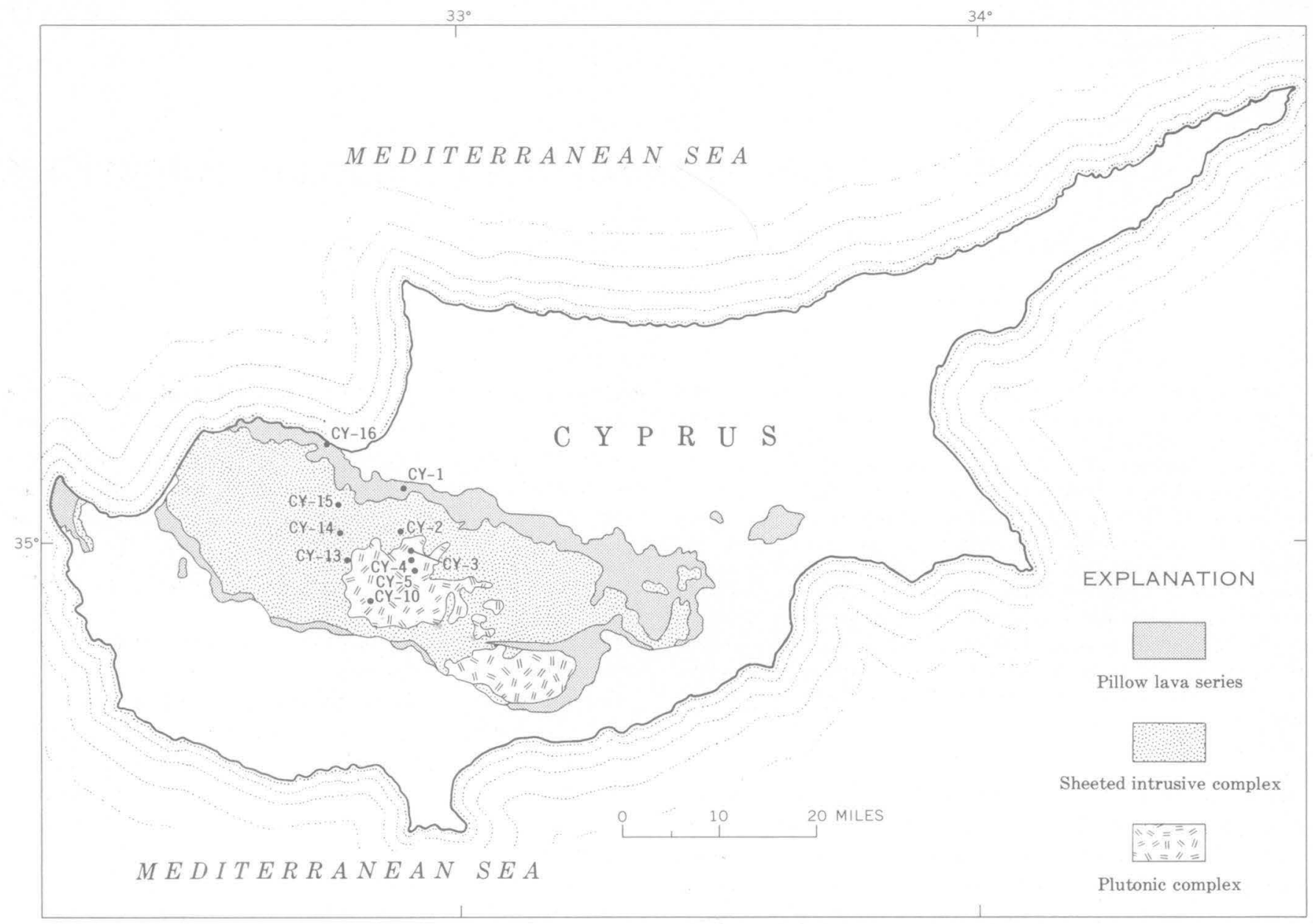

Figure 1.-Generalized geologic map of the Troodos massif, Cyprus (from Gass, 1967), showing sample localities (approximately located).

the gabbroic rocks is also carried through to the very silicic trondhjemites, many of which have less than 0.5 percent $\mathrm{K}_{2} \mathrm{O}$. These low-potassium silicic rocks are similar to those from the Mid-Atlantic Ridge described by Aumento (1969). The possible development of this low-potassium sequence, as discussed by Coleman (1971), may represent initial partial melting of lherzolite at depths of less than $50 \mathrm{~km}$ to produce a subalkaline basaltic liquid. Differentiation of this liquid in the upper levels of the ridge system could produce the plagioclaserich gabbros underlying the sheeted diabase. Depletion of the subalkaline basaltic liquid by precipitating predominantly plagioclase with olivine or pyroxene or both may have produced the small amount of trondhjemite-keratophyre present on Cyprus. Residues developed by partial melting of primitive mantle lherzolites are represented by the harzburgite-dunite masses that form the basement complex upon which the gabbros, diabase, and pillow lavas of Cyprus now rest (Coleman, 1971).

The age of the Troodos massif has been problematical. Wilson (1959) considered the age to be Jurassic or even possibly much older. However, more recent paleontological dating of sediments associated with the upper unit of the pillow lava series suggests a probable age of Cretaceous (Allen, 1967 , p. 8; Pantazis, 1967) as does the paleomagnetic study by Moores and Vine (1971).

The tectonic history of the Troodos massif is complex. Gass and Masson-Smith (1963) have postulated that the emplacement of the massif resulted from thrusting attendant with the closing of the Tethyan Sea. During the Alpine Orogeny, convergence of the African and Eurasian Plates resulted in underthrusting from the south with the oceanic volcanic pile of the Troodos massif being overthrust and uplifted onto the African Plate (Gass and Masson-Smith, 1963, fig. 14, p. 465).

\section{ISOTOPIC RESULTS}

Ten samples of gabbro, diabase, basalt, and trondhjemite were analyzed for strontium isotopic compositions and rubidium, strontium, potassium, and sodium contents (table 1). The isotopic measurements were made on a 6 -inch, $60^{\circ}$ mass spectrometer using a triple-rhenium-filament mode of ionization and a digital output. The measured $\mathrm{Sr}^{87} / \mathrm{Sr}^{86}$ values were normalized by adjusting the $\mathrm{Sr}^{86} / \mathrm{Sr}^{88}$ values to 0.1194 .

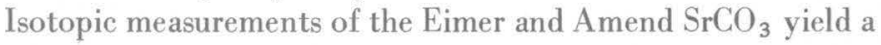


Table 1.-Analytical data for rocks of the Troodos massif, Cyprus

[Analysts: $\mathrm{K}_{2} \mathrm{O}$ and $\mathrm{Na}_{2} \mathrm{O}$ by Violet Merritt; $\mathrm{Rb}$ and $\mathrm{Sr}$ by W. P. Doering; N.D., not detected]

\begin{tabular}{|c|c|c|c|c|c|c|c|c|}
\hline \multirow{2}{*}{$\begin{array}{l}\text { Sample No. } \\
\text { (fig. 1) }\end{array}$} & \multirow{2}{*}{ Rock type } & $\mathrm{K}_{2} \mathrm{O}$ & $\mathrm{Na}_{2} \mathrm{O}$ & \multirow{2}{*}{$\begin{array}{c}\text { Rb } \\
\text { (parts pe }\end{array}$} & $\mathrm{Sr}$ & $\mathrm{Rb} / \mathrm{Sr}$ & $\mathrm{Sr}^{87} / \mathrm{Sr}^{86}$ & \multirow{2}{*}{$\begin{array}{l}\text { Description and locality of samples } \\
\text { (geologic units are from Wilson, 1959) }\end{array}$} \\
\hline & & \multicolumn{2}{|c|}{ (percent) } & & & (weight ratio) & (atom ratio) & \\
\hline \multirow{2}{*}{$\mathrm{CY}-1 \ldots$} & Basalt & 1.12 & 3.99 & 7.7 & 104 & 0.074 & 0.7053 & Basalt flow, 2-3 $\mathrm{ft}$ thick, of the basal group \\
\hline & & 1.13 & 3.99 & & & & & $\begin{array}{l}\text { (BD). Plagioclase and pyroxene with some } \\
\text { chlorite alteration. Collected } 1 / 4 \text { mile south } \\
\text { of milepost } 32 \text { near Evrykhou at roadcut } \\
\text { on east side of Troodos High way. }\end{array}$ \\
\hline \multirow[t]{2}{*}{$2 \ldots$} & .. Diabase ..... & .27 & 3.59 & 2.2 & 98 & .022 & .7056 & Sheeted diabase (D). Plagioclase, amphibole, \\
\hline & & .27 & 3.54 & & & & & $\begin{array}{l}\text { chlorite, and sphene. Collected near mile- } \\
\text { post } 35 \text { at roadcut on east side of Troodos } \\
\text { High way. }\end{array}$ \\
\hline \multirow[t]{2}{*}{3 . } & Gabbro & .26 & 1.57 & 4.3 & 83 & .052 & .7040 & Uralite gabbro $\left(\mathrm{E}^{3}\right)$. Plagioclase, pyroxene, \\
\hline & & .26 & 1.55 & & & & & $\begin{array}{l}\text { and amphibole. From gabbro mass at } \\
\text { Makris Hotel, just above the town of } \\
\text { Galata, near milepost } 37 \text { at roadcut on } \\
\text { east side of Troodos Highway. }\end{array}$ \\
\hline \multirow[t]{2}{*}{4} & $\ldots$ do........ & .08 & .72 & N.d. & 86 & $<.01$ & .7040 & Clinopyroxene gabbro $\left(E^{2}\right)$. Ex tremely \\
\hline & & .09 & .72 & & & & & $\begin{array}{l}\text { fresh with plagioclase, clinopyroxene, } \\
\text { and hypersthene. From banded gabbro } \\
\text { boulder near milepost 39, Troodos High- } \\
\text { way. }\end{array}$ \\
\hline \multirow[t]{2}{*}{$5 \ldots$} & $\ldots$. do....... & .08 & .65 & N.d. & 102 & $<.01$ & .7048 & Olivine gabbro $\left(\mathrm{E}^{2}\right)$. Extremely fresh with \\
\hline & & .07 & .65 & & & & & $\begin{array}{l}\text { plagioclase, clinopyroxene, olivine, and } \\
\text { hypersthene. From unfinished roadcut } \\
\text { just east of milepost } 40 \text {, Troodos High- } \\
\text { way. }\end{array}$ \\
\hline \multirow[t]{2}{*}{10} & . . do ........ & .09 & .28 & 1.3 & 41 & .032 & .7049 & Layered olivine gabbro $\left(\mathrm{E}^{1}\right)$. Plagioclase, \\
\hline & & .09 & .28 & & & & & $\begin{array}{l}\text { olivine, clinopyroxene, and hypersthene; } \\
\text { some alteration. From east side of road- } \\
\text { cut, } 2 \text { miles below Troodos summit on } \\
\text { the road to Pedhoulas. }\end{array}$ \\
\hline \multirow[t]{2}{*}{13.} & Trondhjemite & .34 & 2.70 & 1.9 & 134 & .014 & .7045 & Trondhjemite or quartz diorite $(\mathrm{H})$. Plagio- \\
\hline & & .34 & 2.73 & & & & & $\begin{array}{l}\text { clase, hornblende, quartz, chlorite, and } \\
\text { epidote. From west side of Pedhoulas- } \\
\text { Lefka road at milepost } 49 \text { below Pedhoulas. }\end{array}$ \\
\hline \multirow{2}{*}{\multicolumn{2}{|c|}{$14 \ldots \ldots$ Diabase }} & .57 & 4.11 & 3.1 & 107 & .029 & .7057 & Sheeted diabase (D). Plagioclase, hornblende, \\
\hline & & .57 & 4.12 & & & & & $\begin{array}{l}\text { chlorite, and sphene. From outcrop near } \\
\text { stream at first switchback on the road } \\
\text { from Lefka to Pedhoulas, about } 1 / 2 \text { mile } \\
\text { south of milepost } 43 \text {. }\end{array}$ \\
\hline \multirow{2}{*}{\multicolumn{2}{|c|}{$\ldots$......... }} & .41 & 4.57 & 3.4 & 134 & .025 & .7057 & Sheeted diabase (D). Plagioclase, amphibole, \\
\hline & & .411 & 4.59 & . & & & & $\begin{array}{l}\text { chlorite, quartz, and sphene. From road. } \\
\text { cut on west side of road about } 1 / 4 \text { mile north } \\
\text { of milepost } 42 \text { on Lefka-Pedhoulas road. }\end{array}$ \\
\hline \multirow{2}{*}{\multicolumn{2}{|c|}{$16 \ldots \ldots$ Basalt $\ldots \ldots$}} & .43 & 3.52 & 10.6 & 163 & .065 & .7048 & Vesicular basalt of the upper pillow lava se- \\
\hline & & .44 & 3.51 & & & & & $\begin{array}{l}\text { quence (UPL). Fresh plagioclase with } \\
\text { altered groundmass. From rocky bluff as } \\
\text { a beach cobble at Ayios Nikolaos about } \\
2 \text { miles west of Xeros. }\end{array}$ \\
\hline
\end{tabular}

mean $\mathrm{Sr}^{87} / \mathrm{Sr}^{86}$ value of 0.7080 . Duplicate analyses of similar rocks (Hedge and Peterman, 1970) indicate a standard deviation of \pm 0.0002 for a single $\mathrm{Sr}^{87} / \mathrm{Sr}^{86}$ determination. Rubidium and strontium contents were determined by $X$-ray fluorescence using a direct comparison method with rocks of similar composition and content of these elements (Doering, 1968). Sodium and potassium were determined by conventional flame photometric methods.
The purpose of the isotopic study was to compare the $\mathrm{Sr}^{87} / \mathrm{Sr}^{86}$ values of the Troodos rocks with those of ocean ridge tholeiites that are now being extruded at active rise systems in the Atlantic and Pacific Oceans. The modern ocean ridge tholeiites are characterized by $\mathrm{Sr}^{87} / \mathrm{Sr}^{86}$ values that are dominantly in the range of 0.7020 to 0.7030 , which is significantly lower than ratios observed for most of the island basalts. 
A chemical and isotopic study of the Troodos massif is complicated by the pervasive alteration that has affected many of the units; especially the sheeted intrusive complex. However, it is possible to obtain fresh samples from some of the units; two of the gabbros shown on table 1 (CY-4 and CY-5) are extremely fresh, and the other two (CY-3 and CY-10) show some alteration of the mafic minerals but the plagioclase is fresh. The remaining samples all show some degree of alteration, the diabases being the least fresh.

The strontium isotopic data are illustrated on a conventional isochron diagram (fig. 2) showing two isochrons for reference-the age of the earth and a 100-m.y. (million years)

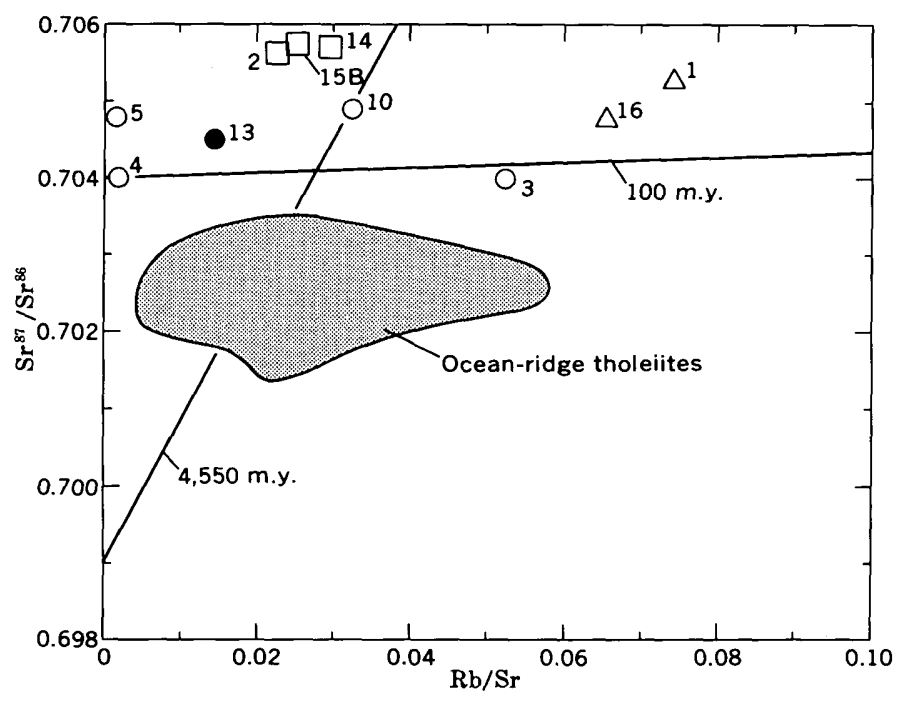

Figure 2.-Isochron plot for rocks of the Troodos massif. Open circle, gabbro; solid circle, trondhjemite; triangle, basalt; square, diabase. Numbers refer to samples listed in table 1.

isochron that may approximate the age of the lithospheric slab of which the Troodos massif is a part. It is obvious, because of the low $\mathrm{Rb} / \mathrm{Sr}$ values, that any age correction in $\mathrm{Sr}^{87} / \mathrm{Sr}^{86}$ is extremely small. The significant feature shown by the isochron plot is that the Troodos rocks have $\mathrm{Sr}^{87} / \mathrm{Sr}^{86}$ values higher than those of ocean ridge tholeiites derived from active rises in the Atlantic and Pacific Oceans. However, the Troodos rocks are isotopically similar to other ophiolites from the Vourinos Complex of Greece (Moores, 1969) that have been analyzed by Montigny, Javoy, and Allegre (1970). Thus, these results suggest that the Mesozoic Tethyan rise, at which these rocks were produced, was tapping a mantle source region with a significantly higher $\mathrm{Sr}^{87} / \mathrm{Sr}^{86}$ value than that of the source regions of the modern Mid-Atlantic and East Pacific Rises.

Although the isotopic differences among the Troodos rocks are well outside the analytical error of individual measurements, many more samples would have to be analyzed to determine if there are any isotopic systematics within the complex or whether alteration in part has caused some of these variations. These differences, however, are no greater than those observed for modern ocean ridge tholeiites from restricted geographic localities (Hedge and Peterman, 1970).

Among modern ocean ridge tholeiites and oceanic island basalts, Peterman and Hedge (1971) have shown a systematic relation between strontium isotopic composition and chemical composition as reflected by the ratio of potassium to total alkalies (fig. 3). This correlation can be explained in terms of an open-system model for the mantle which involves multiple episodes of magma extraction with preservation of the resultant isotopic and chemical heterogeneities. Gast (1968) suggested that the unusual chemical properties of ocean ridge tholeiites are the result of derivation from mantle material that has previously produced basaltic liquid and hence been depleted in many of the large cations. Accepting this hypothesis and geochemical arguments of Hurley $(1968 a, b)$, Peterman and Hedge (1971) suggested that the more potassic basalts with much higher $\mathrm{Sr}^{87} / \mathrm{Sr}^{86}$ values may represent derivatives from more primitive, or less depleted, mantle. This suggestion would place a minimum $\mathrm{Sr}^{87} / \mathrm{Sr}^{86}$ value of 0.7060 on modern undepleted mantle or the total crust-mantle system with an initial $\mathrm{Rb} / \mathrm{Sr}$ value of 0.04 . In this model, the source mantle for modern ocean ridge tholeiites would had to have been depleted in rubidium relative to strontium sometime in the first half of the earth's history.

Several of the Troodos rocks (fig. 3) have ratios of potassium to total alkali in the range of those for modern ocean ridge tholeiites but $\mathrm{Sr}^{87} / \mathrm{Sr}^{86}$ values as high as some of the most potassic basalts. On the basis of the depletion model outlined in the preceding paragraph and a general coherence between potassium to total alkali ratios and $\mathrm{Rb} / \mathrm{Sr}$ values in relatively undifferentiated basalts, it can be shown that the probable field of oceanic basalts would be enclosed within the dashed lines of figure 3. Magma derived from recently depleted mantle, although having the chemical properties of ocean ridge tholeiites, would have $\mathrm{Sr}^{87} / \mathrm{Sr}^{86}$ values much higher than those derived from mantle that was depleted much earlier in time. Such a recent depletion process may be what we are observing in basaltic rocks of the Troodos massif. Why the Mesozoic Tethyan rise tapped a recently depleted mantle $(<1$ b.y. (billion years)), whereas iocks from the Mid-Atlantic and East Pacific Rises seem to be reflecting a mantle depleted much earlier in earth history ( $2-3$ b.y. ago), is a question that remains to be answered. As more isotopic data become available for the active rises and older remnants of oceanic plate, such as the Troodos massif, we may be able to gain a better understanding of the existence of, and processes resulting in, mantle heterogeneities not only in space but also in time.

\section{REFERENCES}

Allen, C. G., 1967, Annual report for 1966: Cyprus Geol. Survey Dept., $42 \mathrm{p}$.

Aumento, F., 1969, Diorites from the Mid-Atlantic Ridge at $45^{\circ} \mathrm{N}$.: Science, v. 165, no. 3898, p. 1112-1113.

Bear, L. M., 1960, The geology and mineral resources of the 


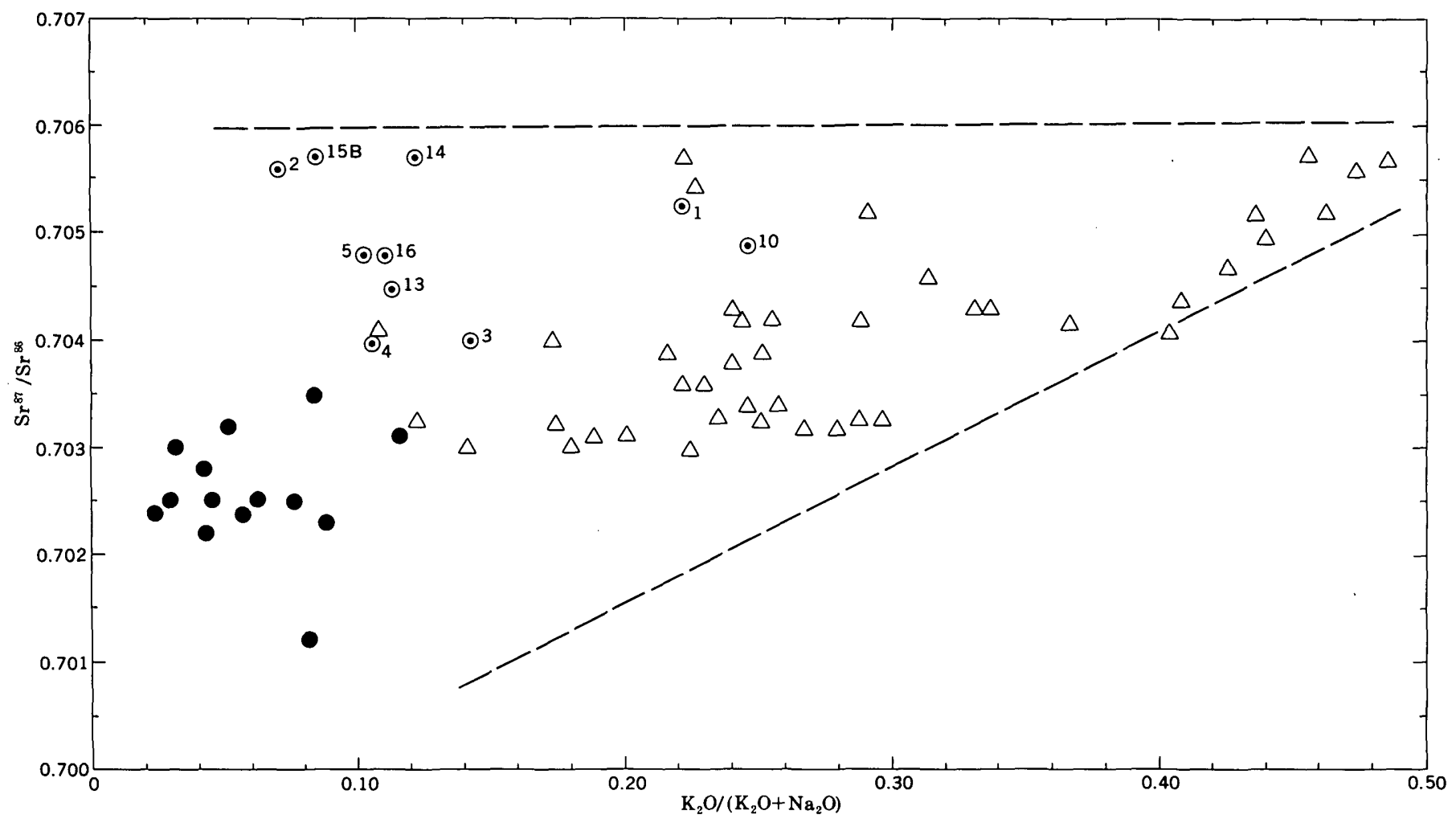

Figure 3. $-\mathrm{Sr}^{87} / \mathrm{Sr}^{86}-\mathrm{K}_{2} \mathrm{O} /\left(\mathrm{K}_{2} \mathrm{O}+\mathrm{Na}_{2} \mathrm{O}\right)$ plot of oceanic basalts (Peterman and Hedge, 1971). Solid circle, ocean ridge tholeiite; triangle, oceanic island basalt; circle and dot, Troodos rock. Dashed lines represent possible field of oceanic basalts as inferred from the data and a depletion model.

Akaki-Lythrodondha area: Cyprus Geol. Survey Dept. Mem. 3, $122 \mathrm{p}$.

Coleman, R. G., 1971, Plate tectonic emplacemert of upper mantle peridotites along continental edges: Jour. Geophys. Research, v. 76, p. 1212-1222.

Doering, W. P., 1968, A rapid method for measuring the $\mathrm{Rb} / \mathrm{Sr}$ ratio in silicate rocks, in Geological Survey Research 1968: U.S. Geol. Survey Prof. Paper 600-C, p. C164-C168.

Gass, I. G., 1960, The geology and mineral resources of the Dhali area: Cyprus Geol. Survey Dept. Mem. 4, 116 p.

- 1967, The ultrabasic volcanic assemblage of the Troodos Massif, Cyprus, in Wyllie, P. J., ed., Ultramafic and related rocks: New York and London, John Wiley and Sons, p. 121-134.

_ 1968, Is the Troodos Massif of Cyprus a fragment of Mesozoic ocean floor?: Nature, v. 220, p. 39-42.

Gass, I. G., and Masson-Smith, D., 1963, The geology and gravity anomalies of the Troodos Massif, Cyprus: Royal Soc. London Philos. Trans., ser. A, v. 255, p. 417-467.

Gast, P. W., 1968, Trace element fractionation and the origin of tholeiitic and alkaline magma types: Geochim. et Cosmochim. Acta, v. 32, p. 1057-1086.

Hedge, C. E., and Peterman, Z. E., 1970, The strontium isotopic composition of basalts from the Gordo and Juan de Fuca Rises, northeastern Pacific Ocean: Contr. Mineralogy and Petrology, v. 27, p. 114-120.
Hurley, P. M., 1968a, Absolute abundance and distribution of $\mathrm{Rb}, \mathrm{K}$ and $\mathrm{Sr}$ in the Earth: Geochim, et Cosmochim. Acta, v. 32, p. 273-283.

- 1968b, Correction to-Absolute abundance and distribution of $\mathrm{Rb}, \mathrm{K}$ and $\mathrm{Sr}$ in the Earth: Geochim. et Cosmochim. Acta, v. 32, p. 1025-1030.

Montigny, Raymond, Javoy, Marc, and Allegre, C. J., $1970, \mathrm{Sr}^{87} / \mathrm{Sr}^{86}$ and $0^{18} \cdot / 0^{16}$ ratios in the Pinde ophiolitic complex, Greece [abs.]: Geol. Soc. America Abs. with Programs, v. 2, no. 7, p. 627-628.

Moores, E. M., 1969, Petrology and structure of the Vourinos ophiolitic complex of Northern Greece: Geol. Soc. America Spec. Paper 118, $74 \mathrm{p}$.

Moores, E. M., and Vine, F. J., 1969, Troodos Massif, Cyprus, as deep ocean floor-preliminary structural and petrologic evidence [abs.]: Am. Geophys. Union Trans., v. 50, p. 333.

1971, The Troodos Massif, Cyprus and other ophiolites as oceanic crust: evaluation and implications: Royal. Soc. London Philos. Trans. A, v. 268, p. 443-466.

Pantazis, Th. M., 1967, The geology and mineral resources of the Pharmakas-Kalavasos area: Cyprus Geol. Survey Dept. Mem. 8, 190 p.

Peterman, Z. E., and Hedge, C. E., 1971, Related strontium isotopic and chemical variations in oceanic basalts: Geol. Soc. America Bull., v. 82, p. 493-500.

Wilson, R. A. M., 1959, The geology of the Xeros-Troodos area: Cyprus Geol. Survey Dept. Mem. 1, 184 p. 


\title{
A SENSITIVE METHOD FOR THE DETERMINATION OF TELLURIUM IN VEGETATION
}

\author{
By A. E. HUBERT, Denver, Colo.
}

\begin{abstract}
A sensitive method which may be useful in geochemical exploration has been developed for the determination of tellurium in vegetation. The sample is digested with sulfuric acid and hydrogen peroxide, hydrochloric acid is added to the cooled solution, and tellurium is measured indirectly by its cataly tic action on the reduction of gold by hypophosphorous acid. The lower limit of sensitivity by this catalytic method is $0.005 \mathrm{ppm}$, using a $5-\mathrm{g}$ vegetation sample. The tellurium content of air-dried limber pine ranged from $0.005 \mathrm{ppm}$ in the trunk wood to $0.05 \mathrm{ppm}$ in the twigs.
\end{abstract}

In a current study of the geochemistry of tellurium in the surface environment, it seemed desirable to determine to what extent tellurium is absorbed by plants and also to determine the variation in tellurium content between species and between plants in different geologic settings. No adequate method for the determination of tellurium in plants is available in the literature; therefore such a method is presented here.

Beath, Eppson, and Gilbert (1935) reported the tellurium content in some types of vegetation, but they did not describe their method of analysis. They (p. 37-38) reported that Atriplex nuttallii (saltbush) and spiny cactus collected on Steele Shale in Natrona County, Wyo., contained 2 and 25 ppm Te, respectively. They also reported that in a greenhouse experiment young wheat plants contained $11 \mathrm{ppm}$ Te when grown in a soil to which $10 \mathrm{ppm}$ Te had been added as tellurium dioxide, but similar plants contained 507 ppm Te when grown in soil to which the same amount of tellurium had been added as the potassium salt.

Abu-Samra and Leddicotte (1969) described a neutron activation method of analysis for tellurium in biological materials in which the iodine-131 daughter of tellurium-131 is isolated and measured. Abu-Samra and Leddicotte's values ranged from $<0.01$ to $0.35 \mathrm{ppm}$ Te in human tissue.

The method presented here is briefly as follows: A 5-g sample of vegetation is completely oxidized with sulfuric acid and hydrogen peroxide (Kodama, 1963, p. 220-24). Tellurium is then estimated by its catalytic enhancement of the reduction of gold by hypophosphorous acid (Lakin and Thompson, 1963).

\section{REAGENTS AND APPARATUS}

Standard tellurium solution, $100 \gamma / \mathrm{ml}$ : Dissolve $0.125 \mathrm{~g}$ of $\mathrm{TeO}_{2}$ in 1 liter of $6 \mathrm{~N} \mathrm{HCl}$.

Dilute tellurium solution, $10 \gamma / \mathrm{ml}$ : Dilute $10 \mathrm{ml}$ of $100 \gamma / \mathrm{ml}$ standard tellurium solution to $100 \mathrm{ml}$ with $6 \mathrm{~N} \mathrm{HCl}$.

Dilute tellurium solution, $1 \gamma / \mathrm{ml}$ : Dilute $10 \mathrm{ml}$ of $10 \gamma / \mathrm{ml}$ tellurium solution to $100 \mathrm{ml}$ with $6 \mathrm{~N} \mathrm{HCl}$.

Dilute tellurium working solution, $0.1 \gamma / \mathrm{ml}$ : Dilute $10 \mathrm{ml}$ of $1 \gamma / \mathrm{ml}$ tellurium solution to $100 \mathrm{ml}$ with $6 \mathrm{~N} \mathrm{HCl}$.

Hydrogen peroxide: 50 percent, reagent grade.

Sulfuric acid: concentrated, reagent grade.

Hydrochloric acid: concentrated, reagent grade.

Hydrochloric acid, 6N: Dilute 1 liter of concentrated hydrochloric acid with 1 liter of water.

Cupric chloride solution, 3 percent: Dissolve $3 \mathrm{~g}$ of cupric chloride $\left(\mathrm{CuCl}_{2} \cdot 2 \mathrm{H}_{2} \mathrm{O}\right)$ in $100 \mathrm{ml} 6 \mathrm{~N} \mathrm{HCl}$.

Stock gold solution, $10 \mathrm{mg} / \mathrm{ml}$ : Dissolve $2.5 \mathrm{~g}$ of $\mathrm{Au}$ in aqua regia. Evaporate to near dryness and dissolve the moist residue in $250 \mathrm{ml}$ of $6 \mathrm{~N} \mathrm{HCl}$.

Dilute gold solution, $2 \mathrm{mg} / \mathrm{ml}$ : Dilute $20 \mathrm{ml}$ of stock gold solution to $100 \mathrm{ml}$ with $6 \mathrm{~N} \mathrm{HCl}$.

Hypophosphorous acid: 50 percent, reagent grade.

Hotplate, oscillating: 12 - by 20 -inch electric hotplate with temperature control from $100^{\circ}$ to $260^{\circ} \mathrm{C}$.

Styrofoam cups, 6 -ounce, insulating.

Filter, Millipore, $0.45 \mu$

Test tubes, screwcap, 25 - by $200-\mathrm{mm}$.

\section{PROCEDURE}

\section{Solution of the vegetation sample}

Add $5 \mathrm{~g}$ of pulverized sample to $20 \mathrm{ml}$ of $\mathrm{H}_{2} \mathrm{SO}_{4}$ in a 250-ml beaker. Heat the beaker and contents on an oscillating hotplate at approximately $150^{\circ} \mathrm{C}$ for 20 minutes. Then add 2 $\mathrm{ml}$ of hydrogen peroxide slowly, drop by drop, to the beaker. It may be necessary to add as much as $30 \mathrm{ml}$ of hydrogen peroxide over a couple of hours' time, allowing the water to boil away between additions until charring ceases and the solution remains clear. Finally, increase the temperature to the boiling point of sulfuric acid and evaporate the solution to approximately $3 \mathrm{ml}$. Cool the solution to room temperature and add $50 \mathrm{ml}$ of $6 \mathrm{~N} \mathrm{HCl}$. Then heat the solution to almost boiling on a hotplate and pour the entire contents of the 
beaker into a 25 - by $200-\mathrm{mm}$ screwcap test tube. Allow the solution to come to room temperature, then cap the tube and place it in a refrigerator to cool to $5^{\circ} \mathrm{C}$.

\section{Estimation of tellurium}

Place $50 \mathrm{ml}$ of $6 \mathrm{~N} \mathrm{HCl}$ at $5^{\circ} \mathrm{C}$ in a Styrofoam cup. Add 0.5 $\mathrm{ml}$ of dilute gold chloride solution, $0.6 \mathrm{ml}$ of cupric chloride solution, and $0.010 \gamma$ of tellurium. Then add $0.3 \mathrm{ml}$ of hypophosphorous acid and allow to stand exactly 5 minutes. At the end of the 5-minute interval, vacuum filter the solution through a $0.45 \mu$ Millipore filter disk. If the gold precipitate is pink the correct amount of hypophosphorous acid has been used; if no colored precipitate appears, add increasing volumes of hypophosphorous acid in successive trials until a suitable pink color is obtained; if the spot is very dark pink or brown add less hypophosphorous acid. Using the appropriate amount of hypophosphorous acid determined above, make a standard series containing $0.005,0.010$, and $0.020 \gamma$ of tellurium. It may be necessary to repeat the series, adjusting the amount of hypophosphorous acid until the filter disks appear in a series from a very slight pink on the blank to deep pink on the highest standard. Once a standard series is obtained, under the same conditions of time, temperature, and amount of hypophosphorous acid, substitute aliquots of the sample solution and proceed as in the preparation of the standard series.

In practice, aliquots of four samples are done at a time, along with a standard as a control. If the control standard color spot differs in any batch of five samples, change the amount of hypophosphorous acid to obtain the same color in the control as in the previously prepared standard series and repeat the four samples. Careful control of the temperature of the reactants is essential. If the temperature of the reactants is above $9^{\circ} \mathrm{C}$ the spots will be brown and unsatisfactory for any standard series. An aliquot of $0.1-10 \mathrm{ml}$ of the sample solution can be taken to make a colored spot that matches a color in the standard series.

With a 5 -g sample diluted to $50 \mathrm{ml}$,

Parts per million tellurium in the sample $=$

$$
\frac{10 \times \text { micrograms found }}{\text { milliliters of aliquot }} \text {. }
$$

\section{DISCUSSION}

Sulfuric acid and hydrogen peroxide (50-percent) digestion decomposes most plant materials quite well. Hydrogen peroxide of 50-percent grade is more effective than the standard laboratory 30-percent grade because the additional water in 30 -percent hydrogen peroxide tends to slow the reaction. The organic materials is first charred by sulfuric acid, then oxidized by hydrogen peroxide. As the water is volatilized more organic material is charred by the sulfuric acid. Repetitive additions of hydrogen peroxide finally oxidize the plant material completely.
Hypophosphorous acid is at best marginal in purity inasmuch as it decomposes with time. Usually the bottle of hypophosphorous acid is opened at least 24 hours before use in the test to obtain consistent results. The rate of reaction will vary with each bottle of acid.

Styrofoam cups are used instead of Pyrex glassware because the glassware is very difficult to clean of precipitated contaminants. The Styrofoam cups also help to maintain a constant temperature.

No interferences in the catalytic test were observed. Lakin and Thompson (1963) reported freedom of interference for many elements at expectable concentrations.

\section{PRECISION AND ACCURACY}

Twigs, bark, and wood from the same limber pine (Pinus flexilus) collected in Cripple Creek, Teller County, Colo., were each analyzed five times for tellurium (table 1). The trunk wood contained the least tellurium, and it was used, in 5-g portions, for repetitive determinations of added tellurium (table 2).

Table 1.-Replicate analysis of tellurium in various parts of a limber pine (Pinus flexilus)

\begin{tabular}{|c|c|c|c|c|c|c|}
\hline Sample & Type & $\begin{array}{l}\text { Low } \\
\text { (ppm) }\end{array}$ & $\begin{array}{l}\text { High } \\
(\mathrm{ppm})\end{array}$ & $\begin{array}{l}\text { Average } \\
\text { (ppm) }\end{array}$ & $\begin{array}{c}\text { Standard } \\
\text { deviation } \\
\text { (ppm) }\end{array}$ & $\begin{array}{c}\text { Relative } \\
\text { standard } \\
\text { deviation } \\
\text { (percent) }\end{array}$ \\
\hline \multirow{2}{*}{$\begin{array}{l}1 \ldots \ldots \\
2 \ldots \ldots \\
3 \ldots\end{array}$} & \multirow{2}{*}{$\begin{array}{l}\text { Twigs } \\
\text { Bark } \\
\text { Trunk } \\
\text { wood }\end{array}$} & $\begin{array}{r}0.05 \\
.01\end{array}$ & $\begin{array}{r}0.05 \\
.02\end{array}$ & $\begin{array}{c}0.05 \\
.012\end{array}$ & ${ }^{0} .004$ & $\begin{array}{l}\mathbf{0} \\
\mathbf{3 3}\end{array}$ \\
\hline & & $<.005$ & .010 & $\leqslant .005$ & $\geqslant .005$ & $\geqslant 100$ \\
\hline
\end{tabular}

Table 2.-Recovery of added tellurium to Pinus flexilus wood samples

\begin{tabular}{lllllllr}
\hline & $\begin{array}{c}\text { Added } \\
\text { tellurium } \\
(\mathrm{ppm})\end{array}$ & $\begin{array}{c}\text { Low } \\
(\mathrm{ppm})\end{array}$ & $\begin{array}{c}\text { High } \\
(\mathrm{ppm})\end{array}$ & $\begin{array}{c}\text { Average } \\
(\mathrm{ppm})\end{array}$ & $\begin{array}{c}\text { Standard } \\
\text { deviation } \\
(\mathrm{ppm})\end{array}$ & $\begin{array}{c}\text { Relative } \\
\text { Percent } \\
\text { recovered }\end{array}$ & $\begin{array}{c}\text { standard } \\
\text { deviation } \\
(\text { percent })\end{array}$ \\
\hline $1 \ldots$ & 0 & $<0.005$ & 0.010 & $\leqslant 0.005$ & $\mathbf{0 . 0 0 5}$ & $\ldots$ & $\geqslant 100$ \\
$2 \ldots$ & .005 & .010 & .010 & .010 & 0 & 100 & 0 \\
$3 \ldots$ & .05 & .025 & .1 & .055 & .027 & 100 & 49 \\
$4 \ldots$ & .1 & .1 & .2 & .14 & .055 & 135 & 39 \\
$5 \ldots$ & .2 & .2 & .2 & .2 & 0 & 97 & 0 \\
$6 \ldots$ & .4 & .4 & .4 & .4 & 0 & 99 & 0 \\
\hline
\end{tabular}

\section{SUMMARY}

The method described in this report is sufficiently precise to be useful in the determination of the tellurium content of vegetation. The Pinus flexilus from the tellurium district of Cripple Creek, Colo., which was used in the present study, contained only $0.005-0.05 \mathrm{ppm} \mathrm{Te}$ in contrast to $25 \mathrm{ppm} \mathrm{Te}$ in spiny cactus and $2 \mathrm{ppm}$ in Atriplex nuttallii reported by Beath, Eppson, and Gilbert (1935). Further work is warranted to determine how abundant tellurium may be in native 
vegetation in telluriferous areas and how significant the tellurium content of plants may be in mineral exploration.

\section{REFERENCES}

Abu-Samra, A., and Leddicotte, G. W., 1969, A useful neutron activation analysis method for the determination of tellurium in human tissues, p. 134-137 in DeVoe, J. R., and LaFleur, P. D., eds., Modern trends in activation analysis: Natl. Bur. Standards
Spec. Púb. 312, v. 1, 691 p.

Beath, O. A., Eppson, H. F., and Gilbert, C. S., 1935, Selenium and other toxic minerals in soils and vegetation: Wyoming Univ. Agr. Expt. Sta. Bull. 206, 56 p.

Kodama, Kazunobu, 1963, Methods of quantitative inorganic analysis-An encyclopedia of gravimetric, titrimetric and colorimetric methods: New York, Interscience Publishers, $507 \mathrm{p}$.

Lakin, H. W., and Thompson, C. E., 1963, Tellurium-A new sensitive test: Science, v. 141, no. 3575, p. 4,2-43. 


\title{
MATHEMATICAL MODEL TO COMPUTE REAERATION COEFFICIENTS FOR THE CONNECTICUT RIVER
}

\author{
By LAWRENCE A. WEISS, Hartford, Conn.
}

\begin{abstract}
Data from a dissolved-oxygen survey on August 27, 1968, at the Connecticut Yankee Atomic Power Co. plant at Haddam Neck, Conn, were used as input to a one-dimensional mathematical model to compute reaeration coefficients for short time intervals in the estuary. The reaeration coefficients ranged from 0.16 to 1.31 per day at $20^{\circ} \mathrm{C}$ and were directly related to stream velocity. Because the fluctuations in depth were small compared to the total depth, they were not evaluated separately. Net oxygen produced from before dawn to after sunset seemed to be affected spatially and temporally by powerplant effluent.
\end{abstract}

In 1968, Northeast Utilities Corp. began operation of the Connecticut Yankee Atomic Power Co. plant on the east bank of the Connecticut River at Haddam Neck, Conn. (see fig. 1).

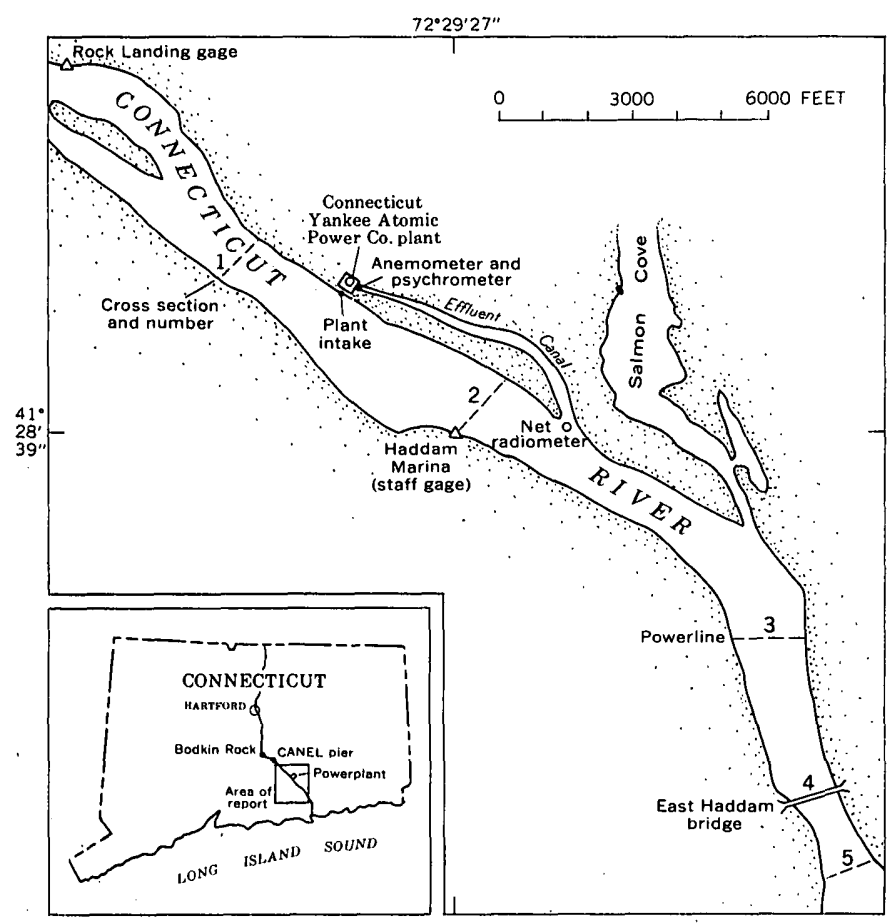

Figure 1.-Map of the Connecticut River near Haddam Neck, Conn, showing locations of cross sections, subreaches, and equipment stations. CANEL, Connecticut Atomic Nuclear Engine Laboratory.
The plant is located within the reach of the Connecticut River that is affected by ocean tides. Public concern over the possible effects of the powerplant operation on the ecology of the river touched off a series of studies, one of which was made by the U.S. Geological Survey on September 9, 1968.

The study of September 1968 was for the purpose of evaluating dispersion coefficients for the Connecticut River and simulating the dispersion of heat in time and space from a point source by use of a mathematical model (Weiss, 1971). The dispersion coefficients developed by Weiss (1971) are used in this study together with dissolved-oxygen balance data collected on August 27, 1968 in order to (1) determine the effects of a thermal effluent and tidal action on $K_{2}$ (reaeration rate coefficient) values, (2) compute $K_{2}$ values for short time intervals in the estuary by use of a one-dimensional mathematical model, and (3) relate $K_{2}$ to other hydraulic parameters.

The University of Connecticut loaned a submarine photometer and some boats to assist in the collection of data.

\section{MATHEMATICAL MODEL}

The one-dimensional equation describing DO (dissolvedoxygen) distribution in time and space in an estuary of homogeneous density (Bella and Dobbins, 1968) is

$$
\frac{\partial(A C)}{\partial t}=-\frac{\partial(Q C)}{\partial x}+\frac{\partial}{\partial x}\left(A E \frac{\partial C}{\partial x}\right)+K_{2} A\left(C_{s}-C\right)
$$

(1)

(2)

(3)

$$
-K_{1} A L-K_{n} A N_{o}+A\left(P-R-D_{b}\right) \text {, }
$$

$$
\text { (5) (6) (7) }
$$

where

$$
\begin{aligned}
A= & \text { area of stream cross section, } \\
C= & \text { dissolved-oxygen concentration at stream cross } \\
& \text { section, } \\
C_{s}= & \text { oxygen saturation in water, } \\
D_{b}= & \text { oxygen consumed by benthic deposits, } \\
E= & \text { longitudinal dispersion coefficient } \\
K_{1}= & \text { carbonaceous decay rate constant, }
\end{aligned}
$$




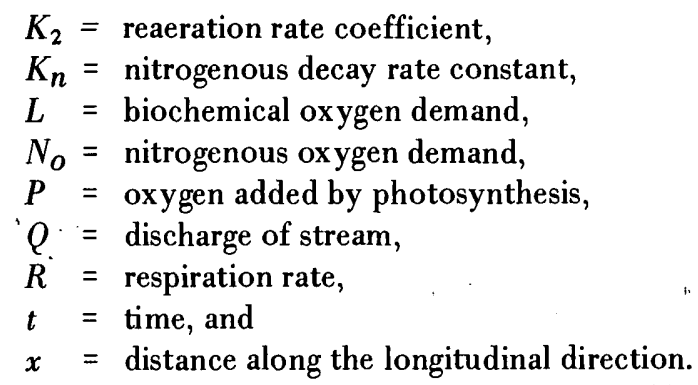

Term 1 is the rate of change of oxygen in storage in a given subreach where oxygen concentration and cross-sectional area vary with time; term 2 is the rate of oxygen advected by tidal interchange; term 3 is the rate of oxygen dispersion due to turbulent dispersion; term 4 is the rate of oxygen addition by surface reaeration; terms 5 and 6 are the rates of oxygen used for carbonaceous and nitrogenous decomposition, respectively; and term 7 is the net rate of oxygen added by photosynthesis or consumed by benthic decay or respiration.

Figure 2 is a time and space scheme of a one-dimensional advection-dispersion mathematical model showing the subreach, cross-section, and time notations. In this scheme, $i$ designates the subreach number, $j$ the cross-section number, and $n$ the time step. This scheme is the basis of the subscript notations used in equation 2.

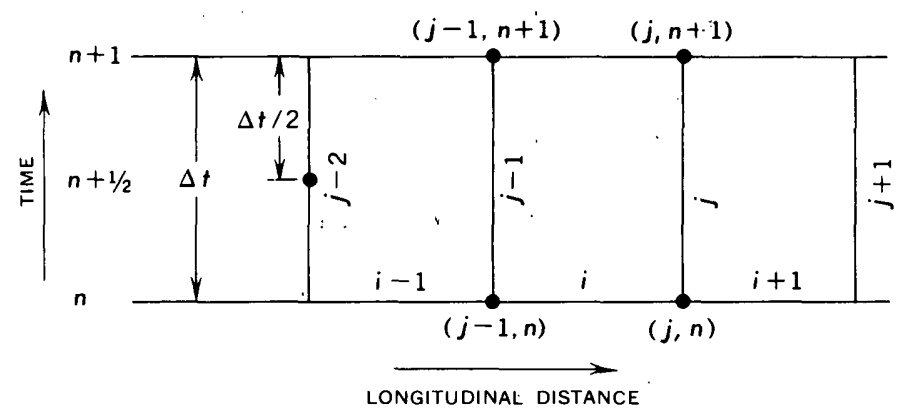

Figure 2.-Time and space scheme of one-dimensional advectiondispersion model.

The partial-differential equation 1 may be expanded to a finite-difference form, as shown in equation 2 . Terms and notations used in equation 2 are as defined previously, but the length of a subreach is expressed by $X$, here. The equation assumes homogeneous density and discharge positive in the downstream direction.

$$
\begin{aligned}
\frac{X_{i}}{4}\left[\left(A_{j-1, n+1}+A_{j, n+1}\right)\left(C_{j-1, n+1}+C_{j, n+1}\right)-\left(A_{j-1, n}+A_{j, n}\right)\right. \\
\left.\left(C_{j-1, n}+C_{j, n}\right)\right]=\frac{\Delta t}{2}\left[Q_{j-1, n+1 / 2}\left(C_{j-1, n}+C_{j-1, n+1}\right)-Q_{j, n+1 / 2}\right. \\
\left.\left(C_{j, n+1}+C_{j, n}\right)\right]+\frac{\Delta t}{2} A_{j, n+1 / 2} E_{j, n+1 / 2}\left[\left(C_{j+1, n+1}+C_{j+1, n}\right)\right.
\end{aligned}
$$

$$
\begin{aligned}
& \left.-\left(C_{j-1, n+1}+C_{j-1, n}\right)\right] /\left(X_{i}+X_{i+1}\right)-\frac{\Delta t}{2} A_{j-1, n+1 / 2} E_{j-1, n+1 / 2} \\
& {\left[\left(C_{j, n+1}+C_{j, n}\right)-\left(C_{j-2, n+1}+C_{j-2, n}\right)\right] /\left(X_{i-1}+X_{i}\right)} \\
& +\frac{\Delta t}{2}\left(K_{2}\right)_{i, n+1 / 2} X_{i}\left(A_{j-1, n+1 / 2}+A_{j, n+1 / 2}\right) \\
& {\left[C_{s-} \frac{1}{2}\left(C_{j-1, n+1 / 2}+C_{j, n+1 / 2}\right)\right]-\frac{\Delta t}{2}\left(K_{1}\right)_{i, n+1 / 2} X_{i}} \\
& \left(A_{j-1, n+1 / 2} L_{j-1, n+1 / 2}+A_{j, n+1 / 2} L_{j, n+1 / 2}\right)-\frac{\Delta t}{2}\left(K_{n}\right)_{i, n+1 / 2} X_{i} \\
& {\left[A_{j-1, n+1 / 2}\left(N_{o}\right)_{j-1, n+1 / 2}+A_{j, n+1 / 2}\left(N_{o}\right)_{j, n+1 / 2}\right]+\frac{\Delta t}{2} X_{i}} \\
& {\left[A_{j-1, n+1 / 2}\left(P-R-D_{b}\right)_{j-1, n+1 / 2}+A_{j, n+1 / 2}\left(P-R-D_{b}\right)_{j, n+1 / 2}\right]}
\end{aligned}
$$

Solving equation 2 for the reaeration coefficient in subreach $i$ at time $(n+1 / 2)$ results in equation 3 .

$\left(K_{2}\right)_{i, n+1 / 2}=\left\{\frac{X_{i}}{4}\left[\left(A_{j-1, n+1}+A_{j, n+1}\right)\left(C_{j-1, n+1}+C_{j, n+1}\right)\right.\right.$
$\left.-\left(A_{j-1, n}+A_{j, n}\right)\left(C_{j-1, n}+C_{j, n}\right)\right]-\frac{\Delta t}{2}\left[Q_{j-1, n+1 / 2}\right.$

$\left.\left(C_{j-1, n}+C_{j-1, n+1}\right)-Q_{j, n+1 / 2}\left(C_{j, n+1}+C_{j, n}\right)\right]$

$-\frac{\Delta t}{2} A_{j, n+1 / 2} E_{j, n+1 / 2}\left[\left(C_{j+1, n+1}+C_{j+1, n}\right)-\left(C_{j-1, n+1}+C_{j-1, n}\right)\right] /$

$\left(X_{i}+X_{i+1}\right)+\frac{\Delta t}{2} A_{j-1, n+1 / 2} E_{j-1, n+1 / 2}\left[\left(C_{j, n+1}+C_{j, n}\right)\right.$

$\left.-\left(C_{j-2, n+1}+C_{j-2, n}\right)\right] /\left(X_{i-1}+X_{i}\right)+\frac{\Delta t}{2}\left(K_{1}\right)_{i, n+1 / 2} X_{i}$

$\left(A_{j-1, n+1 / 2} L_{j-1, n+1 / 2}+A_{j, n+1 / 2} L_{j, n+1 / 2}\right)+\frac{\Delta t}{2}\left(K_{n}\right)_{i, n+1 / 2} X_{i}$

$\left[A_{j-1, n+1 / 2}\left(N_{o}\right)_{j-1, n+1 / 2}+A_{j, n+1 / 2}\left(N_{o}\right)_{j, n+1 / 2}\right]-\frac{\Delta t}{2} X_{i}$

$\left.\left[A_{j-1, n+1 / 2}\left(P-R-D_{b}\right)_{j-1, n+1 / 2}+A_{j, n+1 / 2}\left(P-R-D_{b}\right)_{j, n+1 / 2}\right]\right\}$

$\int\left\{X_{i}\left(A_{j-1, n+1 / 2}+A_{j, n+1 / 2}\right)\left[C_{s}-\frac{1}{2}\left(C_{j-1, n+1 / 2}+C_{j, n+1 / 2}\right)\right]\right\}$

Although information was available for 15-minute intervals at five cross sections and $K_{2}$ could be computed for 15-minute intervals at subreaches $2-3$ and $3-4$, only eight values were computed over the 10-hour period for subreach $2-3$ to demonstrate the fluctuation in $K_{2}$ at various times under variable conditions of flow.

\section{DISCHARGE COMPUTATION}

River stages recorded at Bodkin Rock, CANEL (Connecticut Atomic Nuclear Engine Laboratory), and Haddam Marina 
(locations shown in figure 1) were used to compute discharge at Bodkin Rock and Haddam Marina (table 1). Discharges were extrapolated downstream to cross section 3 (fig. 1) from those computed for Bodkin Rock and Haddam Marina. The resulting error is believed to be small because the distance from Bodkin Rock to the marina is 53,000 feet, whereas the distance from the marina to cross section 3 is only 9,500 feet. The effluent canal contributed $850 \mathrm{cfs}$ (cubic feet per second). The discharges were computed for 15-minute intervals by use of unsteady, nonuniform flow equations by the method of characteristics. The method, computer program, and past results for the Connecticut River were discussed by Lai (1967). At each site the area varied with river stage and was computed by Lai's (1967) method.

\section{DETERMINATION OF BIOLOGICAL AND HYDRODYNAMIC PARAMETERS}

The $K_{1}$ was determined by incubating, at $20^{\circ} \mathrm{C}$, three samples from each site of collection and determining their 1-, 2-, and 3-day BOD (biochemical oxygen demand). The, method of Symons and others (1967) was used to separate oxygen demand by plankton respiration.

Because the nitrate and nitrite concentrations in subreach 2-3 were constant, the equations for computing the $N_{o}$ (nitrogenous oxygen demand) and $K_{n}$ (nitrogenous decay rate constant) were:

$$
\begin{aligned}
N_{o(t)} & =3.22 \frac{Y_{t} \times 10\left(\alpha_{1} t-a_{1}\right)}{1+10\left(\alpha_{1} t-a_{1}\right)}, \text { where } \alpha_{1}\left[\log \left(\frac{Y_{t}}{Y_{i}-Y_{t}}\right) c\right. \\
& \left.-\log \left(\frac{Y_{t}}{Y_{i}-Y_{t}}\right) b\right] \div t_{(b-c)}, a_{1}=\alpha_{1} t-\log \left(\frac{Y_{t}}{Y_{i}-Y_{t}}\right) \\
& \text { and } K_{n}=2.31\left(\log N_{o(c)}-\log N_{o(b)}\right) \div t_{(b-c)}
\end{aligned}
$$

where

$$
\begin{aligned}
& a_{1}=\text { ammonia-nitrogen oxidation constant determined } \\
& \text { at intercept when } t=0 \text {, } \\
& t=\text { time increment, } \\
& Y_{t}=\text { ammonia-nitrogen oxidized to nitrate-nitrogen in } \\
& \text { time }(t) \text {, in milligrams per liter, } \\
& Y_{i}=\text { upper limit of ammonia-nitrogen, in milligrams per } \\
& \text { liter, and } \\
& \alpha=\text { ammonia-nitrogen oxidation rate constant per }
\end{aligned}
$$

The $K_{1}$ and $K_{n}$ values were computed for selected points in time and space and plotted against discharge; the resulting graph allowed selection of $K_{1}$ and $K_{n}$ values for any value of discharge.

Oxygen production as determined from a light- and darkbottle field survey after the method of Gaarder and Gran (1927) was integrated with depth and width at cross sections
2,3 , and 4. Oxygen production by photosynthesis duriing the day varied with solar radiation; production peaked at 1200 e.s.t. at each cross section, as shown in table 1 . Consumption of oxygen by respiration was considered to be constant for the day and was computed from the dark-bottle samples collected at cross sections 2, 3, and 4. Dispersion constants were chosen on the basis of the instantaneous discharge as determined by Weiss (1971). Discharges were plotted versus the computed dispersion constants in order to select the dispersion constant for any flow in time.

\section{FIELD STUDY}

To insure optimum test results, certain conditions of river and powerplant operation were necessary. The following standards were adopted for selecting the study day:

1. Minimum fresh-water inflow to estuary.

2. High ambient river temperature.

3. Powerplant operation reasonably uniform and uninterrupted for at least 7 days before the study.

4. Clear weather and little or no wind.

All these conditions were met on Auguist 27, 1968, when the inflow was approximately $3,000 \mathrm{cfs}$ as compared with the mean annual flow of 16,000 cfs. The Connecticut Yankee Atomic Power Co. plant at Haddam Neck, Conn., operated at a power level of 400 megawatts throughout the observation period: During this time, air temperature ranged from $25.6^{\circ} \mathrm{C}$ to $26.7^{\circ} \mathrm{C}$, while the effluent canal temperature ranged from $33.6^{\circ} \mathrm{C}$ to $34.7^{\circ} \mathrm{C}$. Wind velocity at the powerplant remained below 10 miles per hour.

Net solar radiation measured 4 feet above the water surface at the outlet of the canal (fig. 1) ranged from 0 at 0700 e.s.t. to. $1.55 \mathrm{cal} / \mathrm{cm}^{2} \mathrm{~min}^{-1}$ (calories per square centimeter per minute) at 1215 e.s.t. Net radiation values are listed in table 1 . Psychrometer data collected at the powerplant are on file at the U.S. Geological Survey in Hartford, Conn. River temperatures and dissolved-oxygen concentrations were measured from three 14-foot outboard powerboats. Dissolved-oxygen (DO) concentrations were measured at half-hour intervals with a Yellow Springs Instrument Co. meter and membrane probe at three sites each on cross sections 2, 3 and 4; and at each site at depths of 1, 3, and 6 feet; at depths greater than 6 feet, DO was measured at 3 -foot intervals to the river bottom. Continuous readings of $\mathrm{DO}$ concentration were obtained at Rock Landing and cross section 4. Some values are interpolated; those at cross section 1 . (table 1) were interpolated between measurements at Rock Landing and cross section 2. Samples to determine $\mathrm{BOD}$, ammonia, and nitrate were collected at 1-hour intervals at cross sections 2,3 , and 4 , and were kept in coolers to inhibit decomposition. Elapsed time from collection to initiation of analyses was 1 hour. The interpolated values of initial stream BOD and ammonia are listed in table 1 . The nitrate concentration of each cross section during the day was $2.3 \mathrm{mg} / \mathrm{l}$. 
Table 1.-Data collected on Connecticut River on August 27, 1968, for construction of mathematical model

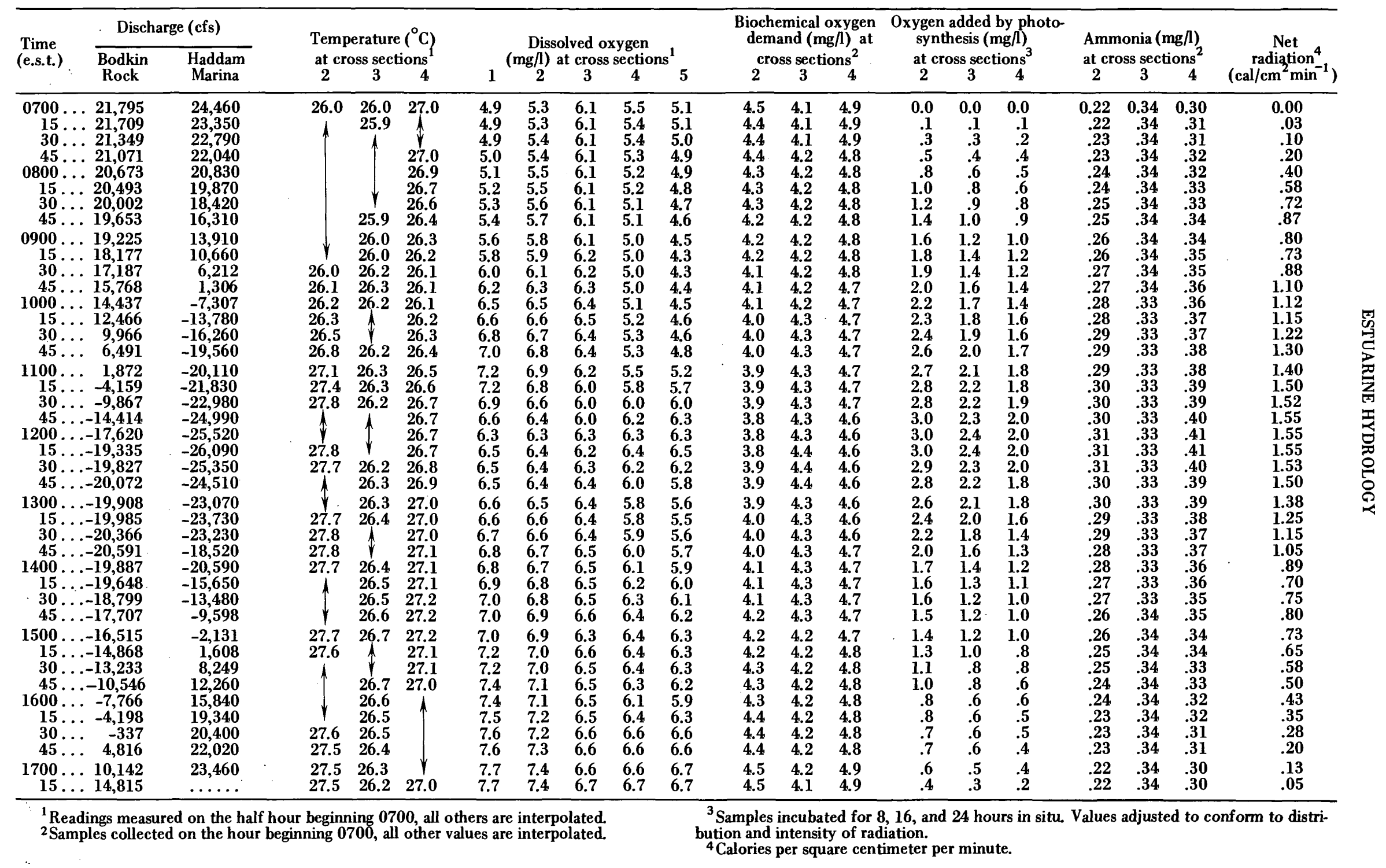


River samples for determining net oxygen added or lost as a result of photosynthesis and respiration were collected twice with a Foerst depth sampler at high and low tide at depths of $1,3,6$, and 9 feet. The samples were suspended in the river in paired BOD bottles-light bottles to permit photosynthesis and dark bottles to prevent it-for periods of 8,16 , and 24 hours. Samples were suspended by immovable floats and were subsequently tested for final DO concentration with an oxygen meter and a DO probe. Oxygen production extended to a depth of 6 feet, the depth of maximum light penetration as indicated by measurements made at cross section 2 . Light penetration was not affected by water turbidity which ranged from $20 \mathrm{mg} / \mathrm{l}$ at low tide to $25 \mathrm{mg} / \mathrm{l}$ at high tide.

\section{DISCUSSION OF RESULTS}

The distribution of oxygen in an estuary with low BOD and $N_{o}$, such as that of the lower Connecticut River, is chiefly controlled by tidal interchange and photosynthesis. Tidal interchange produces larger reaeration coefficients than those prevailing under uniform flow conditions. At cross section 2 (fig. $3 C$ ) the oxygen concentration increased rapidly from 0700 to 1100 e.s.t. owing to photosynthetic oxygen production. Photosynthetic oxygen continued to increase from 1100 to 1200 e.s.t., but the overall oxygen concentration in the river declined; it bottomed at 1200 e.s.t., the time of maximum upstream flow (fig. $3 A$ ). Throughout the period of upstream flow at cross section 2 , the oxygen concentration declined. This was partly due to the thermal effluent transported upstream, as shown in figure $3 B$, and to decreased oxygen transported upstream from below the plant.

Oxygen added by photosynthesis at cross section 2 , determined by the light- and dark-bottle technique (fig. $3 C$, bottom curve) was greatest at 1200 e.s.t. and decreased between cross sections 2 and 4 . (See table 1.) The actual oxygen concentrations in the river at cross section 2 increased in the afternoon (1300-1700 e.s.t.) after photosynthetic oxygen production had subsided (fig. $3 C$, top curve). This indicates that not only photosynthesis but also turbulent mixing and increased reaeration owing to tidal interchange controlled the distribution of oxygen here.

Figure 4 shows the total DO concentrations due to photosynthesis between 0700 and 1715 e.s.t. at different cross sections upstream and downstream from the point of thermal effluent disposal. The cross sections downstream from the point of discharge of heated effluent had the smallest DO concentrations.

Figure 5 illustrates the relation between the discharge and $K_{2}$ during a tidal cycle. The $K_{2}$ ranged from 1.31 per day at a downstream discharge of 24,000 cfs to 0.16 per day at a downstream discharge of 1,000 cfs. Figure 6 shows how $K_{2}$ varies with stream velocity. The coefficients in figure 6 are applicable only to subreach 2-3 and are mass-transfer coefficients rather than reaeration coefficients. However, they are treated as reaeration coefficients here and are applied to
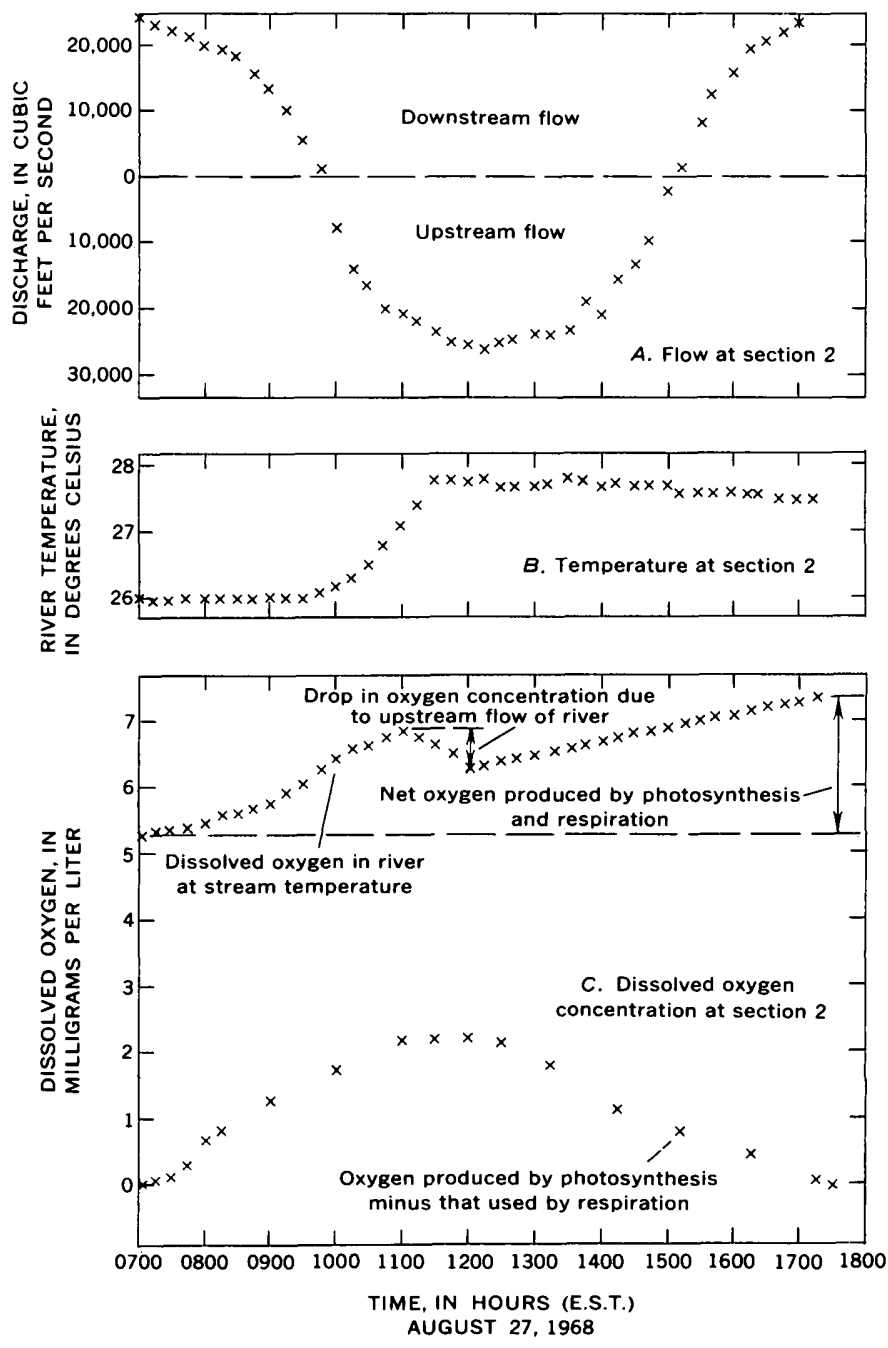

Figure 3.-Effects of tidal flow, temperature, and photosynthesis on dissolved oxygen.

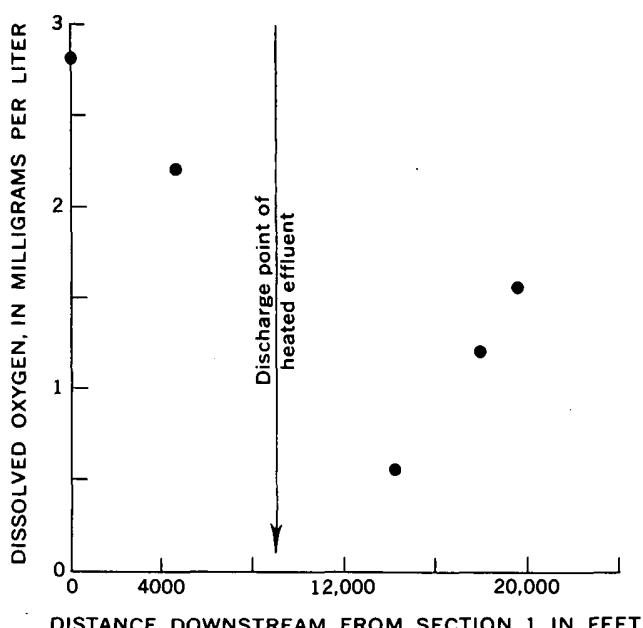

Figure 4.-Effect of heated effluent on photosynthetic oxygen concentration. 


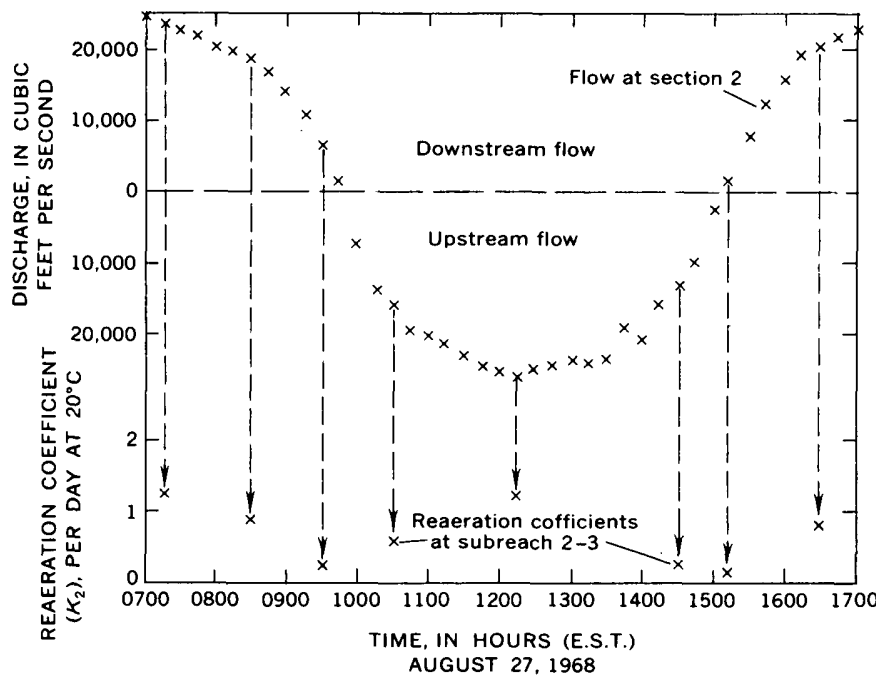

Figure 5.-Range in reaeration coefficient during a tidal cycle.

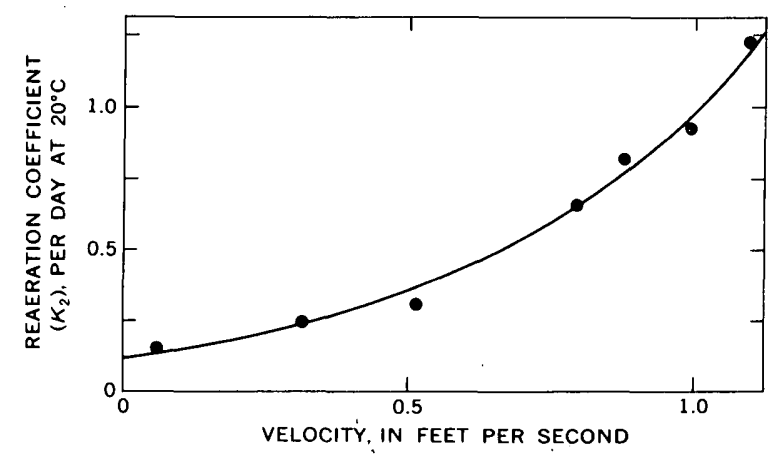

Figure 6.-Relation between reaeration coefficient and stream velocity in subreach 2-3 on August 27, 1968.

subreach 2-3. Velocity fluctuated more than 1,000 percent, whereas the depth of flow fluctuated 20 percent from 10.5 to 13 feet within the subreach. The change in depth was small in comparison to the great change in velocity; therefore, the effect of changes in depth on reaeration coefficients could not be determined separately.

The results of this study corroborate those of Juliano (1969) who found that $K_{2}$ values calculated from empirical equations from the literature, relating reaeration coefficients to velocity and depth, were in good agreement with coefficients measured in shallow estuaries but were much smaller than coefficients measured in deep estuaries.

\section{CONCLUSIONS}

1. Reaeration coefficients for a subreach of the Connecticut River influenced by thermal effluent and tide, varied with instantaneous stream velocity.

2. Tidal advection and photosynthesis were the most important controls of the distribution of dissolved oxygen under the conditions prevailing during this field study.

3. Net oxygen produced in the Connecticut River during daylight decreased from $2.8 \mathrm{mg} / \mathrm{l}$ at cross section 1 to 0.55 $\mathrm{mg} / \mathrm{l}$ at cross section 3 owing to discharge of thermal effluent upstream at cross section 2 .

4. Mathematical models may be used to determine the variability of reaeration coefficients in time and space under conditions of unsteady, nonuniform flow.

More extensive numerical experiments are planned in the future.

\section{REFERENCES}

Bella, D. A., and Dobbins, W. E., 1968, Difference modeling of stream pollution: Am. Soc. Civil Engineers Proc., Jour. Sanitary Eng. Div., v. 94, no. SA5, p. 995-1016.

Gaarder, Torbj申rn, and Gran, H. H., 1927, Investigations of the production of plankton in the Oslo Fjord: Conseil Permanent Internat. Explor. Mer, Rap. et Procès-Verbaux Réunions, v. 42, p. $1-48$.

Juliano, D. W., 1969, Reaeration measurements in an estuary: Am. Soc: Civil Engineers Proc., Jour. Sanitary Eng. Div., v. 95, no. SA6, p. $1165-1178$.

Lai, Chintu, 1967, Computation of transient flows in rivers and estuaries by the multiple-reach method of characteristics, in Geological Survey Research 1967: U.S. Geol. Survey Prof. Paper 575-D, p. D273-D280.

Symons, J. M., Irwin; W. H., Clark, R. M., and Robeck, G. G., 1967, Management and measurement of "DO" in impoundments: Am. Soc. Civil Engineers Proc., Jour. Sanitary Eng. Div., v. 93, no. SA6, p. 181-209.

Weiss, L. A., 1971, Dispersion computation and temperature simulation for the Connecticut River estuary by mathematical model, in Geological Survey Research 1971: U.S. Geol. Survey Prof. Paper 750-B, p. B211-B217. 


\title{
PRELIMINARY FINDINGS ON THE DETERGENT AND PHOSPHATE CONTENTS OF WATER OF SOUTHERN NASSAU COUNTY, NEW YORK
}

\author{
By N. M. PERLMUTTER and ELLIS KOCH, Mineola, N.Y.
}

Work done in cooperation with the Nassau County Department of Public Works

\begin{abstract}
The distribution of MBAS (methylene blue active substance) and phosphate in the water of Nassau County, Long Island, N.Y. were studied from 1966 to 1970 . The MBAS, a detergent constituent, has entered the water in the sewage effluent from several hundred thousand cesspools and septic tanks. The phosphate has a mixed origin. Although some samples of shallow ground water had MBAS contents of as much as $2 \mathrm{mg} / \mathrm{l}$ (milligrams per liter), this constituent is not a significant problem in the Magothy aquifer, the major source of public water supply. MBAS content of streams in some areas averaged as much as $0.48 \mathrm{mg} / \mathrm{l}$. A slight downward trend in MBAS content since 1966 may be due to natural dilution after a regional drought and introduction of a more biodegradable detergent in 1966. The phosphate content of shallow ground water averaged $0.07 \mathrm{mg} / \mathrm{lin}$ some areas and of streams averaged $0.09 \mathrm{mg} / \mathrm{l}$. The low concentrations of MBAS and phosphate in most of the water are not known to be toxic.
\end{abstract}

This report describes part of a 5-year (1966-70) quality of water study in adjoining sewered and unsewered areas in the southern two-thirds of Nassau County (fig. 1). The study area consists of about 180 square miles. The purpose of the overall study was to determine comparative distribution and trends in concentration of the principal chemical constituents in the water. A summary of the findings of water-borne detergent and phosphate contents are given in this report.

For many decades the chemical quality of natural ground water and ground-water fed streams in the study area has been modified by seepage of effluent from several hundred thousand cesspools and septic tanks, leaching of fertilizers applied to former agricultural areas and lawns, and other miscellaneous sources of chemical constituents. Maintenance of a supply of water of good chemical quality is a major concern because all water for about $1 \frac{1}{2}$ million residents and for several thousand industrial plants and commercial buildings in the county is obtained from local ground-water sources. However, because of the deteriorated chemical quality of the water, several public-supply wells screened in a major water-bearing unit, the upper glacial aquifer, have been abandoned and others are pumped only intermittently. The chemical quality of the water in an underlying second major water-bearing unit, the Magothy aquifer, has also deteriorated in places, owing to downward leakage of chemically deteriorated water from the upper glacial aquifer.

A long-range sewer-construction program developed by the Nassau County Department of Public Works is now (1971) in progress. It will eliminate cesspools, septic tanks, and similar systems that discharge untreated or partly treated wastes into the ground water. The sewered area in southwestern Nassau County includes County Sewer District 2 and a small system operated by the village of Freeport. Construction of Sewer District 2 was completed in about 1964. Sewage effluent from Sewer District 2 is discharged into a nearby bay after secondary treatment at Bay Park (fig. 1). Treated effluent from the village of Freeport, which has maintained its own sewer system since about 1925, is discharged into a nearby stream. County Sewer District 3, under construction in southeastern Nassau County (fig. 1), is scheduled for completion in about 1983. The treatment plant for this district, at Wantagh (fig. 1), is nearly completed.

Several hundred selected water-level observation wells, public, industrial, and commercial water-supply wells, and a few wells especially drilled for this study were sampled one or more times from 1966 to 1970 . Early records of analyses of water from public water-supply wells, obtained from the Nassau County Department of Health, also provided background data on long-term trends in concentration of chemical constituents in the water.

Previous investigations of detergents in Long Island water include areal sampling of water from domestic wells in small areas by Health Department personnel in Nassau and Suffolk Counties, a detailed study of the chemical profile of ground water beneath a residential area and of the water from nearby Massapequa Creek (fig. 3) at South Farmingdale in southeastern Nassau County (Perlmutter and Lieber, 1970), and of sewage effluent and nearby ground water at several cesspool and septic tank-tile field sites in Nassau and Suffolk Counties 


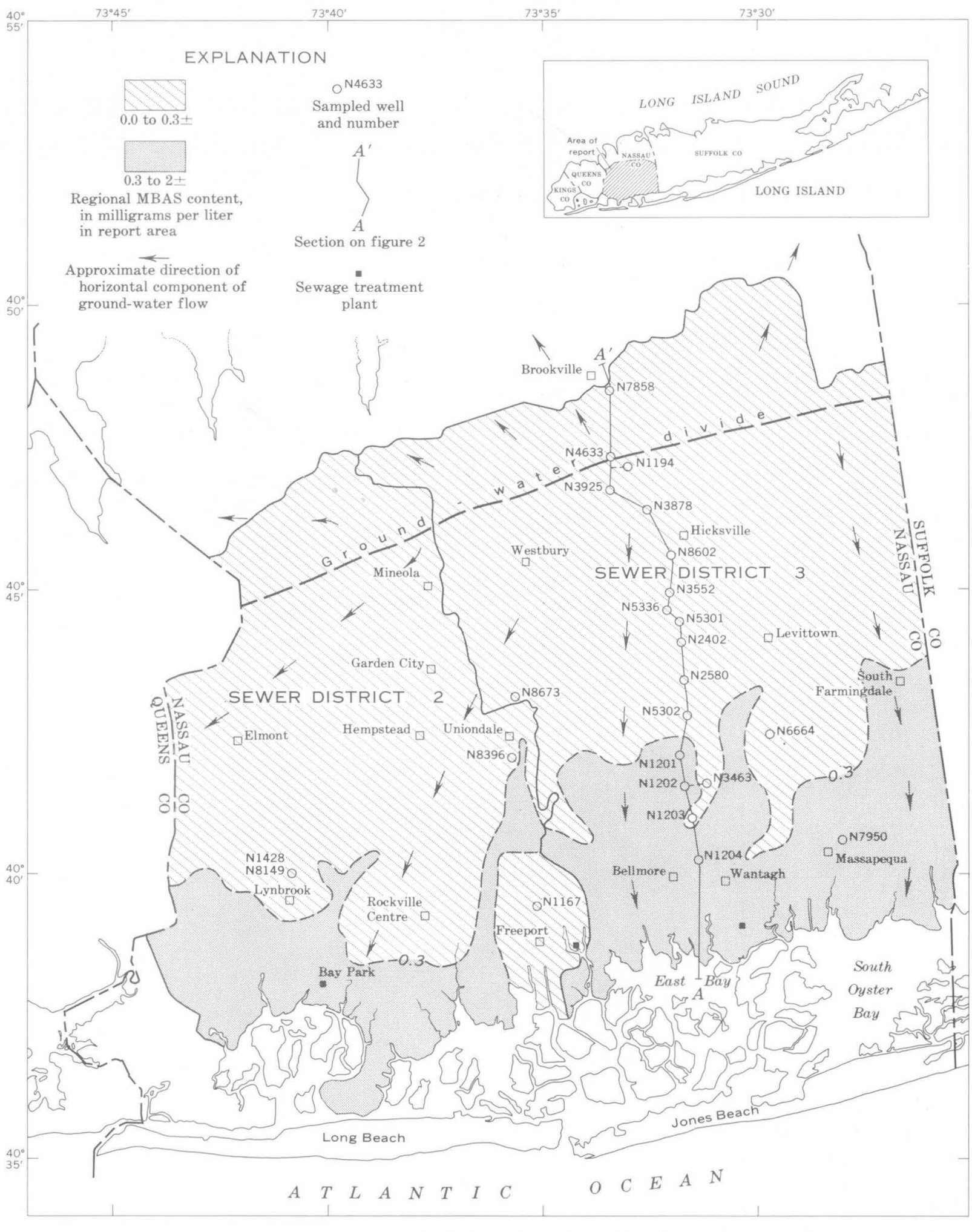

Figure 1.-Regional distribution and concentration of MBAS (methylene blue active substance) in water in the upper glacial aquifer, Sewer Districts 2 and 3 (patterned), Long Island, N.Y., 1966-70. 
(Nassau-Suffolk Research Task Group, 1969). Koch (1970) compared the chemical quality of water from several streams in undeveloped parts of Suffolk County with water from streams in the study area, and Cohen, Vaupel, and McClymonds (1971) investigated the detergent content of streams in Suffolk County. Perlmutter and Guerrera (1970) determined the extent of detergent contamination in shallow ground water and the potential for downward movement of the contaminants at three public-supply well fields in southwestern Suffolk County, N.Y.

This study was made in cooperation with the Nassau County Department of Public Works and with the support and encouragement of Commissioner John H. Peters. Chemical analyses of the water were made by the Nassau County Department of Health under the supervision of Maxim Lieber, and by the U.S. Geological Survey.

\section{DESCRIPTION OF THE HYDROGEOLOGIC SYSTEM}

A generalized section through the ground-water reservoir in the study area and the vertical distribution of MBAS in two aquifers are shown in figure 2. Aquifers in descending order are (1) upper glacial, comprised chiefly of sand and gravel; (2) Magothy, comprised of sand, silt, clay, and some gravel; and (3) Lloyd, comprised of sand, gravel, and clay. Jameco Gravel, a minor water-bearing unit beneath Gardiners Clay in the southwestern part of the study area, is not shown on the section. Gardiners Clay, which occurs mainly near the south shore, and the more extensive Raritan clay (fig. 2) are the chief confining beds. Impermeable crystalline bedrock forms the bottom of the ground-water reservoir. Upper glacial and Magothy aquifers are the principal sources of water in the study area. Water in the Lloyd aquifer is not known to be contaminated by MBAS and is not discussed further in this report.

Under natural conditions, all ground water in Nassau County was initially derived from precipitation. About half of the average precipitation of 45 inches per year enters the ground-water reservoir. Most of the remainder is lost by evapotranspiration, although about 10 percent runs off to streams that discharge into tidewater.

The generalized pattern of ground-water flow in the study area is shown by arrows in figures 1 and 2 . Most of the flow is toward the south shore of Nassau County and toward Queens County to the west; and some water moves toward the north shore. The combined average discharge from 15 small gaining streams (fig. 3) in the study area was about 40 cfs (cubic feet per second) during the 1966-70 water years, and consisted mostly of natural outflow from the upper glacial ayuifer.

The Magothy aquifer supplied about 97 percent of the approximately $140 \mathrm{mgd}$ (million gallons per day) pumped for public supply in the study area in 1969; about 3 percent was pumped from the upper glacial and Lloyd aquifers. Except for about $60 \mathrm{mgd}$ of waste water discharged from the sewered area to the sea after treatment, most of the remainder of the water

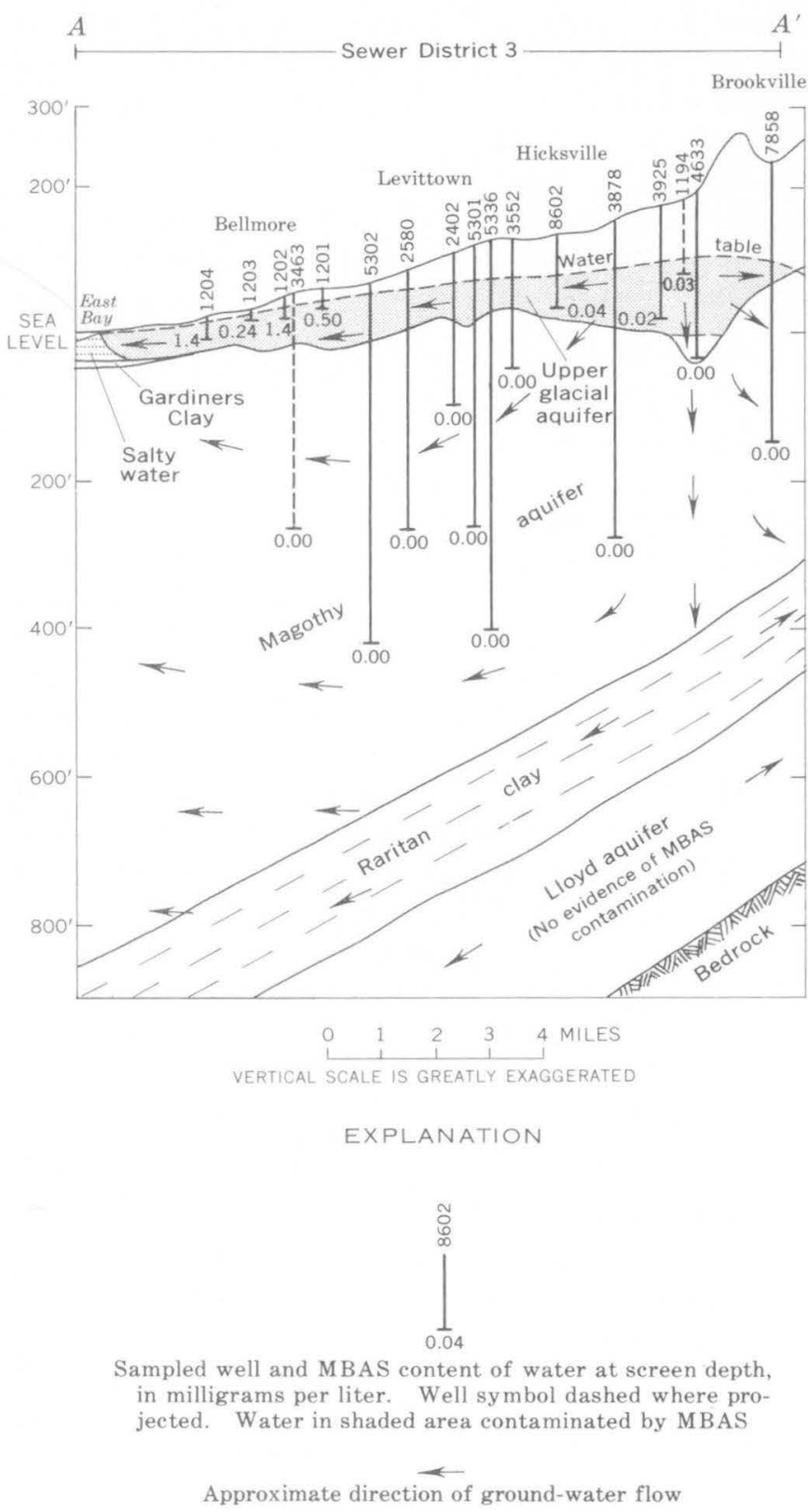

Figure 2.-Vertical distribution of MBAS in water in the upper glacial and Magothy aquifers, 1966-70.

pumped for public supply returns from several hundred thousand cesspools and septic tanks (chiefly in the unsewered area) to the upper glacial aquifer.

\section{DETERGENT CONTENT}

Synthetic detergents have been used as the chief washing compound for laundry, dishwashing, and other cleaning processes in Nassau County since about 1946. Two of the principal ingredients in detergents that affect water quality are (1) the surfactants ABS (alkylbenzenesulfonate), used before 1965, and LAS (linear alkylsulfonate), both of which in 
concentrations as low as 1-2 mg/l (milligrams per liter) may cause foaming of water, and (2) phosphate, which acts as a nutrient for organisms in water in streams and bays. Both surfactants are referred to collectively by the term "MBAS" (methylene blue active substances), after a reagent used in chemical tests for surfactants. The generally low concentrations of MBAS and phosphate in the water of Nassau County are not known to be toxic.

\section{MBAS in Ground Water}

\section{Upper glacial aquifer}

The upper glacial aquifer is readily penetrated by seepage of detergent-bearing sewage effluent from cesspools and septic tanks because of the high permeability of the aquifer and of the material in the overlying unsaturated zone. The effluent moves down to the water table through an unsaturated zone that ranges in thickness from a few feet near the south shore to about 250 feet in the northern part of the study area. Coalescence of numerous individual plumes of waste water as the water moves slowly downgradient mainly along natural flow paths (figs. 1 and 2) has resulted in widespread distribution of MBAS in the upper glacial aquifer.

Locally, in and near cesspools, the MBAS content of the water may be as much as $40 \mathrm{mg} / \mathrm{l}$ (Nassau-Suffolk Research Task Group, 1969, p. 6-9). Regionally, the MBAS content of about 560 samples of ground water in the upper glacial aquifer averaged about 0.16 and $0.36 \mathrm{mg} / \mathrm{l}$, respectively, in the sewered and unsewered areas. The regional distribution of MBAS in ground water in the upper glacial aquifer is shown on figure 1. In the shaded area to the south the MBAS content is generally greater than $0.30 \mathrm{mg} / \mathrm{l}$ and, in places, exceeds the recommended limit of $0.5 \mathrm{mg} / \mathrm{l}$ in drinking water (U.S. Public Health Service, 1962, p. 7).

In the larger area (diagonal lines) to the north, the MBAS content of the water is generally much less than $0.30 \mathrm{mg} / \mathrm{l}$. The low MBAS content is largely accounted for by the small population density and by the greater depth to the water table in the northern part of the study area. Conditions in the thick highly oxygenated unsaturated zone apparently provide a better opportunity for reduction of the MBAS content by biochemical degradation of the MBAS, by sorption on mineral grains, and by other unknown geochemical processes. In contrast, sewage effluent from cesspools and septic tanks in the more densely populated southern part of the study area moves down almost directly through a thin unsaturated zone into the ground water. Under these conditions, reduction of the MBAS content is less effective than in the area to the north.

The smaller areal extent of the ground water containing the higher concentrations of detergent in the southern part of the sewered area compared to that in the unsewered area (fig. 1) may be due partly to the beneficial influence of local sewer systems formerly operated by the villages of Mineola, Garden
City, Hempstead, Rockville Centre, and Freeport, and partly to the beneficial influence of the present county sewer system. However, the presence of residual MBAS in ground water beneath the southern part of the sewered area, even after 10 to 20 years of public sewer operation, suggests continued infiltration of effluent from residual active or abandoned cesspools, some infiltration of effluent from leaky sewers, the slow rate of recovery in the quality of chemically deteriorated ground water after sewering, or a combination of these factors.

\section{Magothy aquifer}

Except for water from, a few scattered industrial and public-supply wells that tap the upper part of the Magothy aquifer a short distance below contaminated water-bearing zones in the overlying upper glacial aquifer, available data indicate that the distribution and the content of MBAS in water in the Magothy aquifer is insignificant (fig. 2). In contrast, contents of nitrate, chloride, and dissolved solids in water in the Magothy aquifer underlying the northern and central parts of the study area exceed the contents of the same constituents in natural ground water on Long Island.

Furthermore, large-scale downward movement of MBAS into the middle and the lower water-bearing zones of the Magothy aquifer, zones tapped by most public-supply wells, seems unlikely. First, the MBAS content of water in the upper glacial aquifer in central Nassau County generally is less than $0.10 \mathrm{mg} / \mathrm{l}$ (figs. 1 and 2), and downward leakage of this water is the principal source of recharge for the Magothy aquifer. Second, part of the recharge area of the Magothy aquifer is already sewered (Sewer District 2) and the remainder will be sewered within about 15 years (Sewer District 3). Thus, the MBAS content of ground water in the recharge area of the Magothy aquifer probably will decrease even more in the future. Finally, natural dilution of the MBAS by uncontaminated water and possible adsorption of the residual low concentrations on silt, clay, and lignite, which are common in the aquifer, may also help prevent a significant buildup in the MBAS content of water in the Magothy aquifer.

Because the materials in the Magothy aquifer and in the Gardiners Clay have low vertical permeabilities and because of the predominantly upward components of flow in the deep water-bearing zones, no significant downward movement of MBAS has been detected to date in the Magothy aquifer in southern Nassau County or in a similar hydrogeologic environment in southwestern Suffolk County (Perlmutter and Guerrera, 1970, p. 9-12 and 20-21). The main danger of a significant increase in the MBAS content of the water in the Magothy aquifer in the southern part of the study area is from pumping deep wells in that area. Slow downward leakage of MBAS-enriched water from the upper glacial aquifer (fig. 1) might occur in the future if increased net withdrawals caused a reversal of the present natural upward hydraulic gradient in the Magothy aquifer. 


\section{MBAS in Streams}

The MBAS content of about 130 samples of water from 15 streams in southern Nassau County ranged from 0.00 to 0.90 $\mathrm{mg} / \mathrm{l}$ and averaged 0.20 in the sewered area and $0.48 \mathrm{mg} / \mathrm{l}$ in the unsewered area. Figure 3 shows the average MBAS content of water in streams at selected gaging stations. The higher MBAS content of the water from streams in the unsewered area reflects the slightly higher average MBAS content of the ground water in that area. Average MBAS contents of water from two streams, Newbridge Creek and Massapequa Creek, exceeded the recommended limit in drinking water (U.S. Public Health Service, 1962, p. 7). The estimated combined load of MBAS discharged by streams into the southshore bays averaged about 75 pounds per day from 1966 to 1970 .

\section{Trends in MBAS Content}

Significant trends in the MBAS content of water from the upper glacial aquifer and from streams were generally difficult to detect from available data because of the short record and the low concentrations of MBAS in "many ground-water samples. The graphs in figures 4 and 5 show the fluctuations in MBAS content of water from selected wells and streams from 1966 to 1970 . Several graphs show slight net downward trends during the past 3-5 years (for example, wells N8149, N8396, N7950, and Massapequa Creek). Although these downward trends may have been partly due to the beneficial influence of sewering on the quality of water in the western part of the area, they probably are related partly to increased dilution of the ground water by recharge from precipitation after the end of the regional drought from about 1962 to 1966 (Cohen and others, 1969). Similar trends were noted in ground water in adjacent Suffolk County by Perlmutter and Guerrera (1970) and in nearly all the streamflow in Suffolk County (Cohen and others, 1971).

Some of the decline in MBAS concentrations, especially in streamflow, also may have been caused by the substitution of the surfactant LAS for ABS in 1965. "Soft" surfactants, of the LAS type, reportedly degrade much more rapidly and more nearly completely than ABS under aerobic conditions where free oxygen is present, for example, in aerated river water and in aerated sewage effluent (Wayman and others, 1965, p. 59-61). Bacterial concentration and suitable temperature also

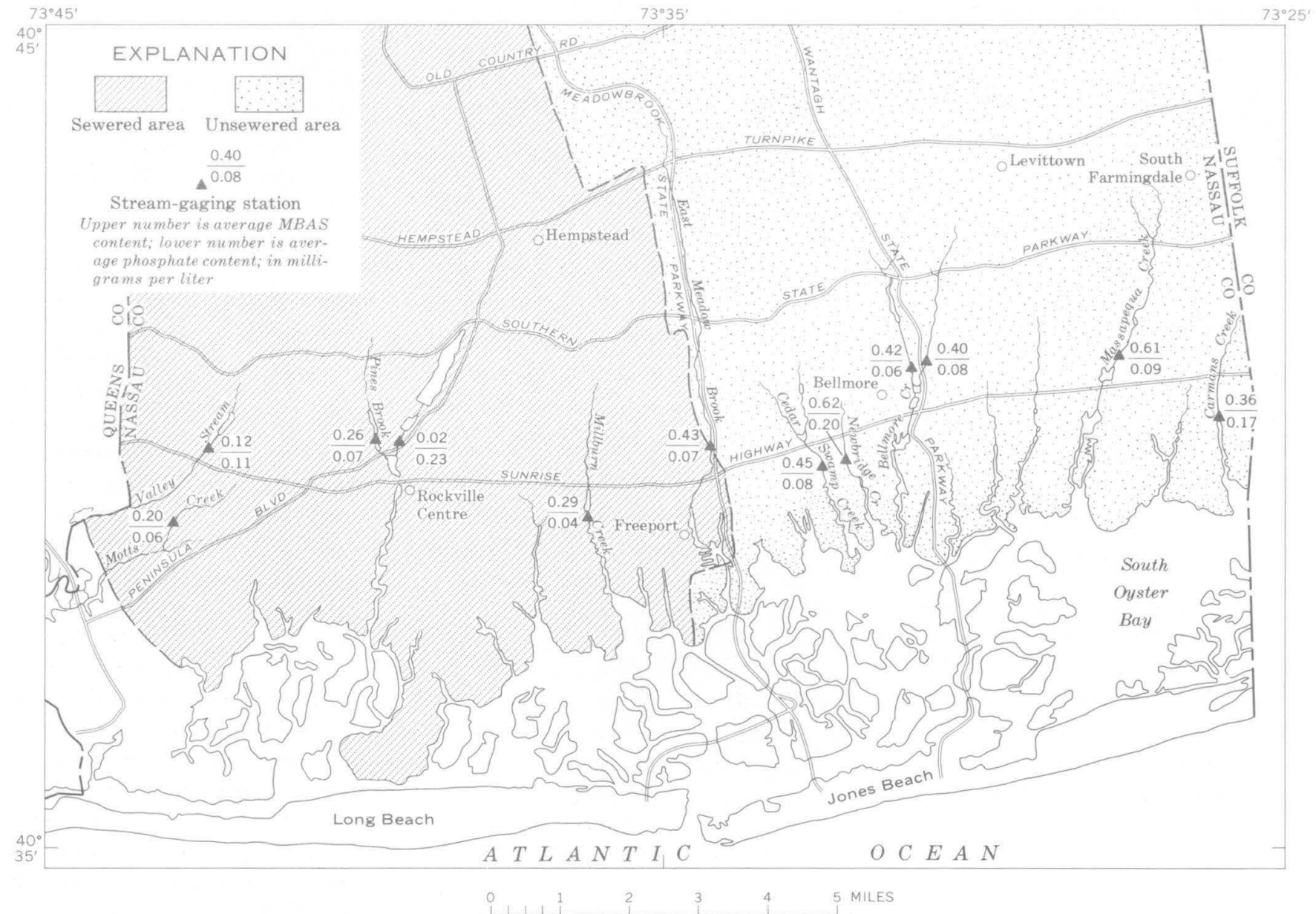

Figure 3.-Average MBAS and phosphate contents of water at gaging stations on selected streams in southern Nassau County, $1966-70$. 
SEWERED AREA

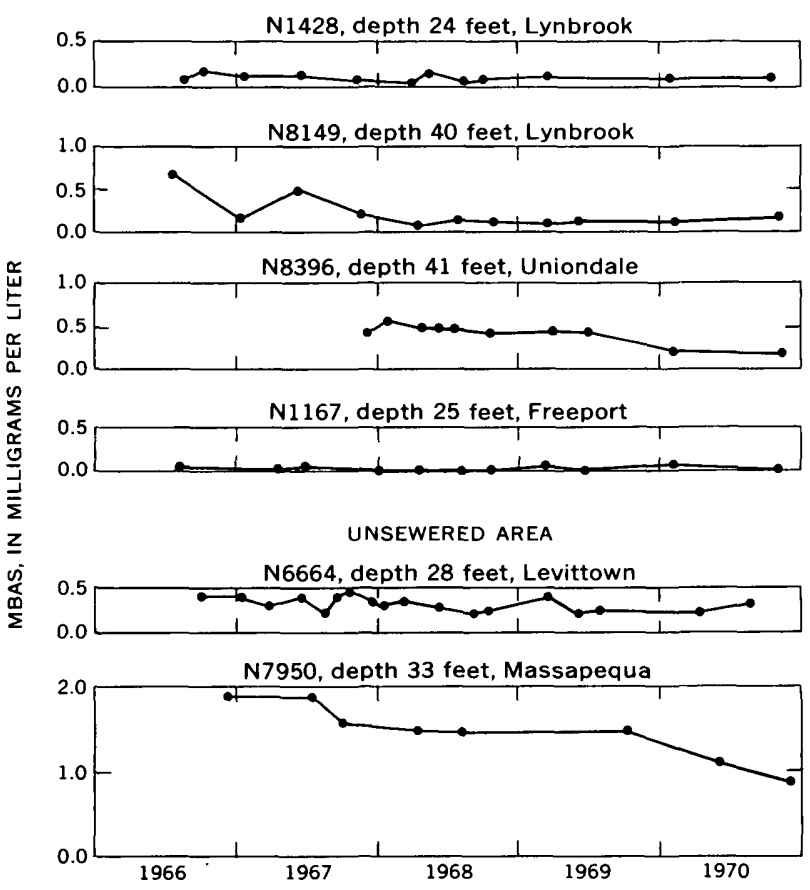

Figure 4.-Trends in MBAS content of water from selected wells screened in the upper glacial aquifer. See figure 1 for locations.
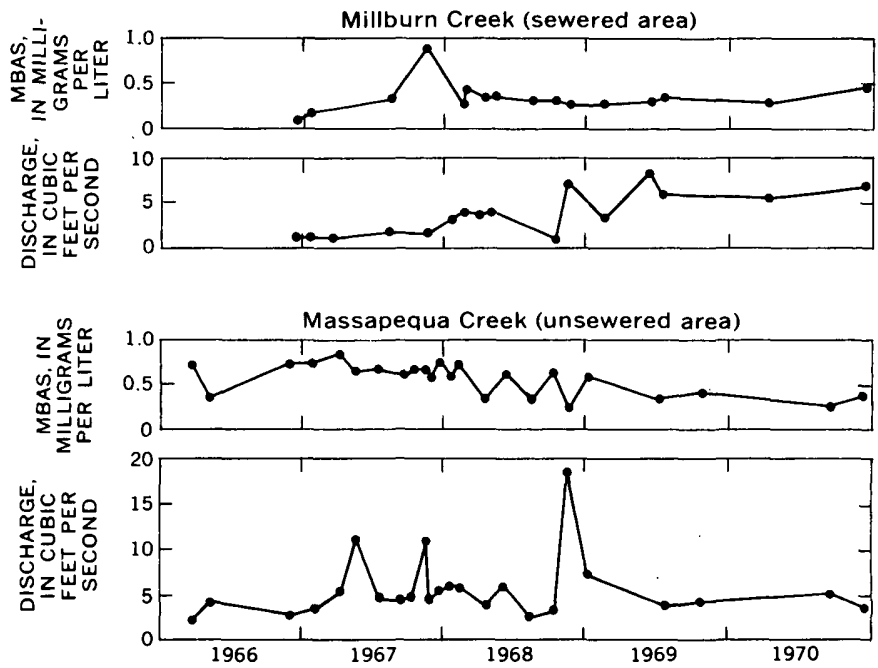

Figure 5.-Trends in MBAS content of water from selected streams. See figures 3 for locations.

influence the rate of biodegradation of surfactants. Sufficient data were not available, however, to fully evaluate the significance of the hypothesis outlined above and its application to conditions in the study area.

\section{PHOSPHATE CONTENT}

The natural phosphate content of ground water in Long Island is generally less than a few hundredths of a milligram per liter. Phosphate in the waters sampled during this investigation occurs mainly as the orthophosphate, and is of mixed origin. The major sources of water-borne phosphate are: (1) Detergent products in sewage effluent, (2) biochemical degradation of organic matter in soils and sewage, (3) chemical fertilizers, and (4) urban runoff.

Although the phosphate content of sewage effluent from several cesspools and septic tanks in Suffolk County ranged from about 50 to $100 \mathrm{mg} / \mathrm{l}$ (Nassau-Suffolk Research Task Group, 1969, p. 4-3), the regional phosphate content of 270 samples of water from the upper glacial aquifer in the study areas ranged from 0.0 to $1.6 \mathrm{mg} / \mathrm{l}$ and averaged 0.04 and 0.07 $\mathrm{mg} / \mathrm{l}$ in the sewered and unsewered areas, respectively. The low regional phosphate content of water in the upper glacial aquifer is attributed mainly to chemical precipitation, biodegradation, sorption on soil particles, and dilution by recharge from precipitation. Large reductions in the phosphate content of sewage-contaminated ground water immediately downgradient from several cesspool and septic-tank systems were noted also by the Nassau-Suffolk Research Task Group (1969, p. 4-33).

The natural phosphate content of water in the Magothy aquifer generally ranges from about 0.0 to $0.05 \mathrm{mg} / \mathrm{l}$. Such low concentrations do not impair the use of the water for public supply or other significant uses.

The average phosphate content of water from selected streams in southern Nassau County is shown in figure 3. The average phosphate content of about 100 stream samples was $0.09 \mathrm{mg} / \mathrm{l}$, slightly higher than the average phosphate content of the shallow ground water. The combined average phosphate load discharged into southshore bays by streams from 1966 to 1970 was about 17 pounds per day.

\section{CONCLUSIONS}

Although MBAS was widely distributed in water in the upper glacial aquifer, concentrations greater than the recommended limit of $0.5 \mathrm{mg} / \mathrm{l}$ were generally restricted to water in the southern part of two adjoining sewered and unsewered areas. Presumably, the relatively high MBAS content of ground water in both areas will decrease substantially in future years as a result of the beneficial effects of present and proposed sewer construction and of dilution by natural recharge from precipitation.

MBAS generally was not detected in water in the Magothy aquifer, the principal source of water for public supply, except in a few places where pumping wells were screened a short distance below MBAS-rich water in the overlying upper glacial aquifer. Low concentrations (generally less than $0.10 \mathrm{mg} / \mathrm{l}$ ) of MBAS in water in the upper glacial aquifer in the recharge area of the Magothy aquifer and the present (1970) natural upward hydraulic gradient in the southern part of the study area suggest that most of the water in the Magothy aquifer will not be significantly enriched by MBAS for many decades. If increased net withdrawals from the Magothy aquifer cause a 
permanent reversal of the natural upward hydraulic gradient near the south shore, some shallow ground water in the southern part of the area that contains MBAS and other contaminants might move downward in future years.

The average MBAS content of water in the streams reflects the average MBAS content of the ground water. Slight downward trends in the MBAS content of ground water and of streamflow both in the sewered and unsewered areas, since 1966, may have been largely due to dilution from increased recharge associated with the end of a long-term drought. Some of the decline may also have been due to the substitution of a more biodegradable surfactant, LAS, for the formerly widely used surfactant, ABS, beginning about 1965.

In spite of the potential availability of large amounts of phosphate from a variety of sources, including detergents, decay of organic wastes in sewage, and chemical fertilizers, the average phosphate content of the ground and of the streamflow was very low, generally less than $0.01 \mathrm{mg} / \mathrm{l}$. The low concentrations of MBAS and the phosphate observed in most of the water in the study area are not known to be toxic.

\section{REFERENCES}

Cohen, Philip, Franke, O. L., and McClymonds, N. E., 1969, Hydro- logic effects of the 1962-66 drought on Long Island, New York: U.S. Geol. Survey Water-Supply Paper 1879-F, 18 p.

Cohen, Philip, Vaupel, D. E., and McClymonds, N. E., 1971, Detergents in the streamflow of Suffolk County, Long Island, New York, in Geological Survey Research 1971: U.S. Geol. Survey Prof. Paper 750-C, p. C210-C214.

Koch, Ellis, 1970, Effects of urbanization on the quality of selected streams in southern Nassau County, Long Island, New York, in Geological Survey Research 1970: U.S. Geol. Survey Prof. Paper 700-C, p. C189-C192.

Nassau-Suffolk Research Task Group, 1969, Final report of the Long Island water pollution study: New York State Department of Health, $395 \mathrm{p}$.

Perlmutter, N. M., and Guerrera, A. A., 1970, Detergents and associated contaminants in ground water at three public-supply well fields in southwestern Suffolk County, Long Island, New York: U.S. Geol. Survey Water-Supply Paper 2001-B, 22p.

Perlmutter, N. M., and Lieber, Maxim, 1970, Dispersal of plating wastes and sewage contaminants in ground water and surface water, South Farmingdale-Massapequa area, Nassau County, New York: U.S. Geol. Survey Water-Supply Paper 1879-G, 67 p.

U.S. Public Health Service, 1962, Drinking water standards: Public Health Service Pub. 956, 61 p.

Wayman, Cooper, Page, H. L., and Robertson, J. B., 1965, Behavior of surfactants and other detergent components in water and soil-water environments: Federal Housing Adm. Tech. Studies Pub. 532,136 p. 


\title{
RELATIONSHIP BETWEEN GROUND-WATER LEVELS AND QUALITY IN SHALLOW OBSERVATION WELLS, MUDDY CREEK BASIN, SOUTHEASTERN YORK COUNTY, PENNSYLVANIA
}

\author{
BY DOUGLAS J. GROWITZ and ORVILLE B. LLOYD, JR., \\ Harrisburg, Pa.
}

Work done in cooperation with the Pennsylvania Topographic and Geologic Survey

\begin{abstract}
Data collected from 13 shallow observation wells indicate a direct relationship between the trends of ground-water levels and the specific conductance of shallow ground water in the Muddy Creek basin, York County, Pa. Specific conductance generally increases when ground-water levels rise and, conversely, decreases when ground-water levels fall. The chemical constituents dissolved in the ground water from these wells come from natural chemical weathering of the regolith and the solution of fertilizers during periods of ground-water recharge.
\end{abstract}

Data on ground-water levels and specific conductance of water obtained from $13 \mathrm{dug}$ and shallow-drilled observation wells, from March 1969 to December 1970, are the basis of this report. The data are part of those collected during a hydrologic-budget investigation in the 133-square-mile Muddy Creek basin. Most of the Muddy Creek basin is in southeastern York County, Pa. (fig. 1). A small part of the basin is in northern Harford County, Md.

\section{METHODS OF INVESTIGATION}

Ground-water-level and specific-conductance measurements were made at approximately monthly intervals in 13 observation wells. General well characteristics and the ranges in specific-conductance data collected from the wells are shown in table 1 .

Solu bridges manufactured by Industrial Instruments, Inc., were used to measure specific conductance in the field. These instruments were checked periodically with a standard laboratory meter and generally read within 5 percent of the laboratory meter.

Observation well Yo-596 was studied in greater detail, over a longer period of time, than the other wells. Data for well Yo-596 consist of continuous water levels, specificconductance measurements made over short time intervals, continuous specific-conductance measurements for part of the

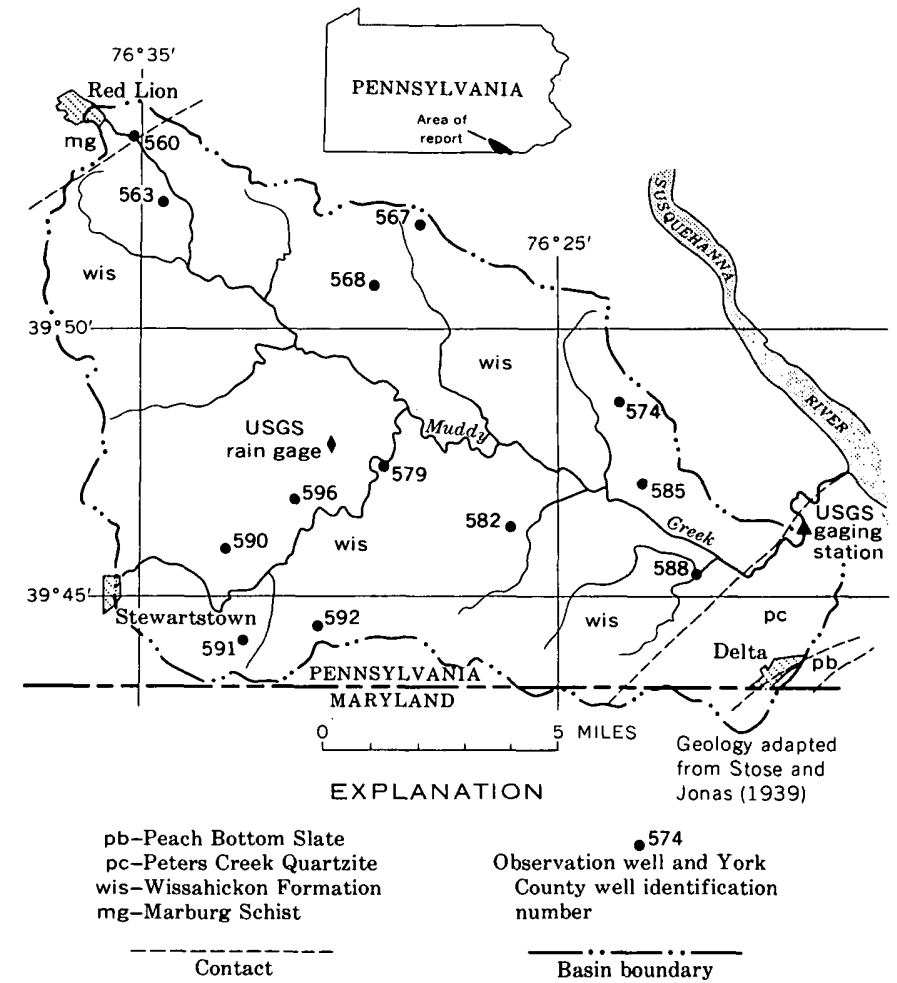

Figure 1.-Map of the Muddy Creek basin, York County, Pa., showing geology and location of observation wells and U.S. Geological Survey gages.

period of record, and five chemical analyses of ground water collected at various times. The chemical analyses were made by the U.S. Geological Survey.

Daily precipitation data were obtained from a recording precipitation gage established by the U.S. Geological Survey in the drainage basin (fig. 1). 
Table 1.-General well characteristics and range in specific conductance of water from observation wells in the Muddy Creek basin, York County, Pa.

\begin{tabular}{|c|c|c|c|c|c|}
\hline \multirow[t]{2}{*}{$\begin{array}{c}\text { Well } \\
\text { number }\end{array}$} & \multirow[t]{2}{*}{$\begin{array}{c}\text { Well } \\
\text { depth } \\
\text { (feet) }\end{array}$} & \multirow[t]{2}{*}{$\begin{array}{l}\text { Type of } \\
\text { well con- } \\
\text { struction }\end{array}$} & \multirow[t]{2}{*}{$\begin{array}{c}\text { Type of } \\
\text { water-level } \\
\text { measurement }\end{array}$} & \multicolumn{2}{|c|}{$\begin{array}{l}\text { Range in field } \\
\text { conductance } \\
\text { values } \\
\text { (micromhos } \\
\text { at } 25^{\circ} \mathrm{C} \text { ) }\end{array}$} \\
\hline & & & & Low & High \\
\hline $\begin{array}{r}\text { Yo-560 } \\
\mathbf{5 6 3} \\
\mathbf{5 6 7} \\
\mathbf{5 6 8} \\
\mathbf{5 7 4} \\
\mathbf{5 7 9} \\
\mathbf{5 8 2} \\
\mathbf{5 8 5} \\
\mathbf{5 8 8} \\
\mathbf{5 9 0} \\
\mathbf{5 9 1} \\
\mathbf{5 9 2} \\
\mathbf{5 9 6}\end{array}$ & $\begin{array}{r}13 \\
. \quad 43 \\
. \quad 29 \\
. \quad 58 \\
.47 \\
. \quad 32 \\
. \quad 28 \\
. \quad 62 \\
. \quad 15 \\
. \quad 39 \\
. \quad 39 \\
. \quad 18\end{array}$ & $\begin{array}{c}\text { Dug } \\
\ldots \text { do.. } \\
\ldots \text { do.. } \\
\ldots \text { do.. } \\
\text {. do... } \\
\text { Drilled } \\
\text { Dug } \\
\text { Drilled } \\
\ldots \text { do.. } \\
\text { Dug } \\
\ldots \text { do.. } \\
\ldots \text { do.. } \\
\ldots \text { do.. }\end{array}$ & $\begin{array}{c}\text { Monthly } \\
\text { Continuous } \\
\text { Monthly } \\
\ldots \text { do } \ldots \\
\text { Continuous } \\
\ldots \text { do } \\
\text { Monthly } \\
\ldots \text { do } \ldots \\
\ldots \text { do... } \\
\ldots \text { do } \ldots \\
\ldots \text { do } \ldots \\
\ldots \text { do... } \\
\text { Continuous }\end{array}$ & $\begin{array}{r}170 \\
200 \\
100 \\
130 \\
65 \\
<50 \\
110 \\
<50 \\
50 \\
60 \\
60 \\
75 \\
80\end{array}$ & $\begin{array}{r}235 \\
305 \\
240 \\
220 \\
80 \\
70 \\
175 \\
100 \\
60 \\
130 \\
220 \\
95 \\
260\end{array}$ \\
\hline
\end{tabular}

\section{BASIN CHARACTERISTICS}

The Muddy Creek basin is a farming area in the dissected Piedmont Upland section of the Piedmont province of Pennsylvania. Maximum relief in the basin is 830 feet, and local relief is about 175 feet. Most of the area is underlain by the Wissahickon Formation of Precambrian to Early Ordovician age (fig. 1). In this area the Wissahickon is a coarse- to medium-grained, sparkling, grayish-blue or green schist composed predominately of albite, chlorite, muscovite, and quartz (Stose and Jonas, 1939, p. 87).

A regolith zone consisting of the soil profile and a mantle of unconsolidated to semiconsolidated, weathered and broken rock material overlies the bedrock. The water table fluctuates mostly within the regolith, and ground water in this zone occurs under unconfined conditions. Thus, precipitation that has reached the water table has infiltrated the soil and at least some part of the remaining regolith.

\section{DISCUSSION OF RESULTS}

Trends of water level and specific conductance and probable causes

Plots of the mean monthly ground-water levels and the mean monthly specific conductance of water from the 13 observation wells are shown in figure 2 . The dominant relationship between the two plots is that the specific-conductance trend follows the ground-water-level trend, with few exceptions. Specific conductance generally increases when ground-water levels rise and decreases when ground-water levels fall. An analogous relationship appears to exist between base-flow discharge and specific conductance of Muddy Creek measured at the U.S. Geological Survey Castle Fin gage (fig. 1). The specific conductance of Muddy Creek was generally high at

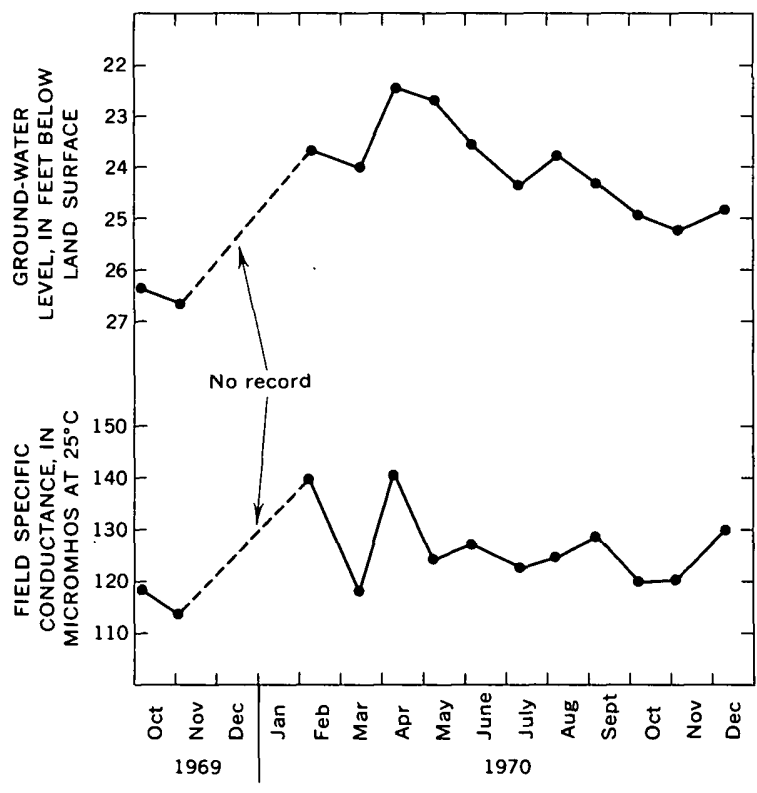

Figure 2.-Mean monthly specific conductance and mean monthly ground-water level for 13 observation wells in the Muddy Creek basin, Pa., for the period October 1969 to December 1970 .

times of high base flow, when high ground-water levels prevailed in the basin, and low during times of low base flow, when low ground-water levels prevailed.

Data from well Yo-596 are used to illustrate specific examples of the observed relationships between ground-water levels and specific conductance of the ground water (fig. 3). This well is located in a farmyard; heavily fertilized fields and wooded land are located successively upslope from the well. The ranges in water level and specific conductance of water from this well are larger than the ranges in water level and specific conductance of water from all 13 wells (fig. 2). However, the trends are generally the same, and because most of the wells are in similar settings the probable causes for the trends are believed to be the same.

The increases in specific conductance coincident with rising water levels observed in well Yo-596 result from a dissolving and flushing of soluble minerals from the unsaturated part of the regolith by infiltrating recharge water. In the farmyard and the fertilized fields immediately upgradient from the well, larger amounts of soluble minerals are available to be dissolved and flushed into the ground-water body than are available in the unfertilized and wooded area farther upslope. Consequently, the specific conductance of the shallow ground water after any given recharge event generally decreases upgradient from the well. Thus, the decreases in specific conductance associated with declining water levels in well Yo-596 most likely result from the lateral downgradient movement of less concentrated ground water to the well.

The two plots in figure 3 diverge significantly between April 3 and April 22, 1970. The decrease in specific conductance 


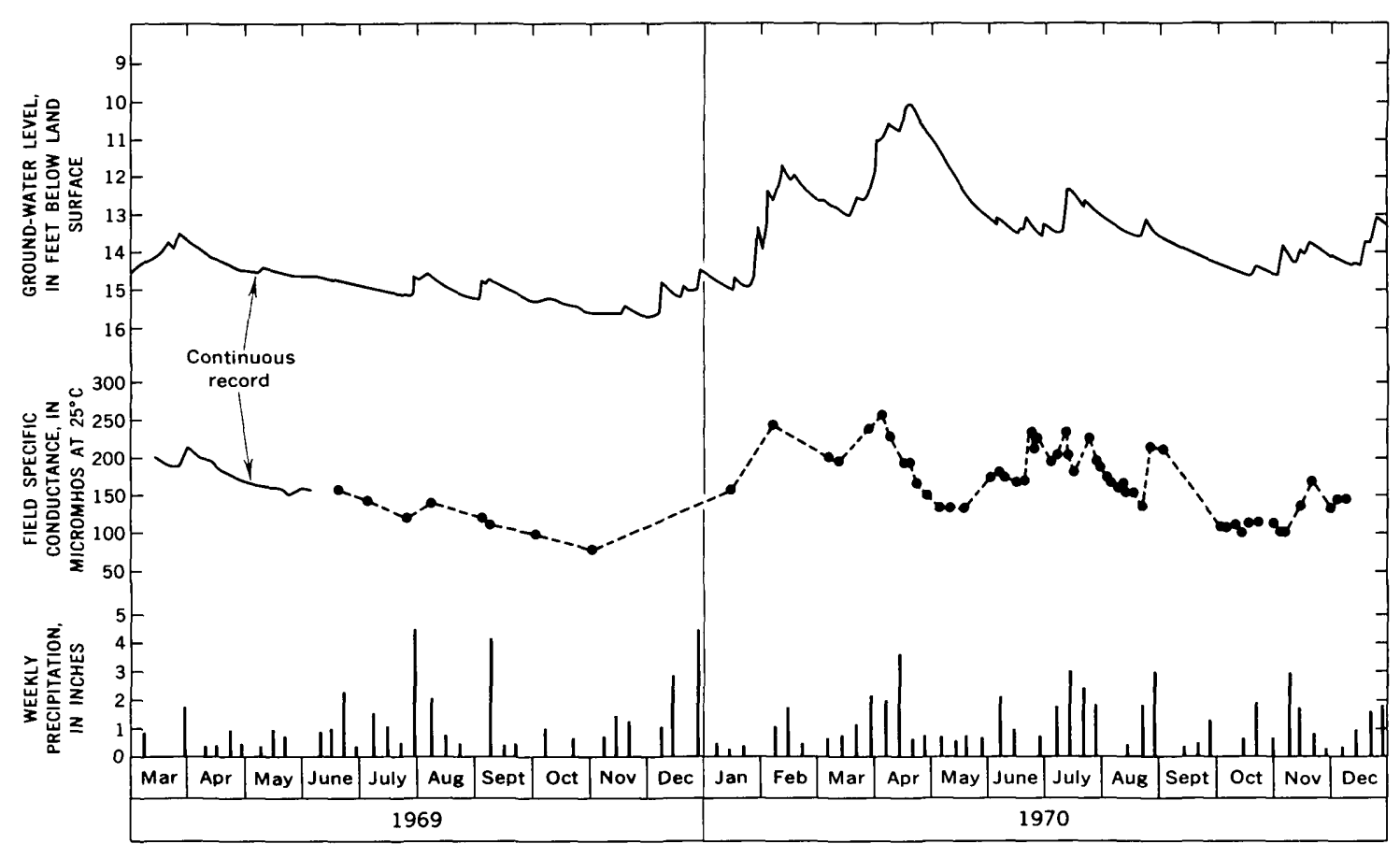

Figure 3.-Ground-water level and specific conductance of ground water from observation well Yo-596 and precipitation in the Muddy Creek basin for the period March 1969 to December 1970.

during this general rise of ground-water level is thought to be a result of the successive recharge events that occurred during this period (fig. 3). Most of the easily soluble minerals available at this time were dissolved by the early recharging waters, leaving fewer minerals available for solution during later recharge events. This process resulted in successively more dilute water reaching the water table and a decrease in the specific conductance of the ground water. This phenomenon is also evident during early March 1969.

Between May 15 and June 4, 1970, the specific conductance increased during a general decline in ground-water level. It is possible that such a divergent trend may be the result of lowering of the hydraulic gradient, thus slowing natural movement and increasing the residence time of ground water in the regolith; this could result in the successive solution of more and more mineral matter from the regolith and an increase in the specific conductance of the ground water. Such a trend may also have been caused by a dissolving and flushing of considerable amounts of soluble minerals by small amounts of recharge (evident on monthly charts from which the water-level information in figure 3 was compiled).

\section{Chemical constituents and probable sources}

Soluble minerals in the regolith control the kinds and proportions of ions found in the ground water in the regolith. The major sources of the soluble minerals in the regolith are believed to be products of natural weathering, fertilizers, and, to a lesser extent, domestic and barnyard wastes. To determine the relative effect of these different sources on ground-water quality, samples were collected for laboratory analysis from well Yo-596 at various times.

The chemical analyses of ground water collected from well Yo-596 are shown in order of decreasing specific conductance in table 2. The concentrations of all cations and anions generally decrease with decreasing specific conductance. $\mathrm{Ni}$ trate, which is generally indicative of some form of pollution, ranges in concentration from 25 to $44 \mathrm{mg} / \mathrm{l}$ (milligrams per liter).

Most of the chemical constituents present in the analyses in table 2 can be attributed, in part, to man's activity in the area. As a result of the application of nitrogen, phosphorus, and potassium fertilizers in the vicinity of well $\mathrm{Y}_{0}-596$, nitrate, phosphate, and potassium are added to the upper part of the regolith. In addition, calcium, chloride, and sulfate can also be introduced through fertilizers. Although fertilizer application generally takes place at specific times, the nutrients may be slowly leached over a period of time (A. N. Ott, oral commun. 1971) and could be available for solution by recharge water throughout the year.

\section{SUMMARY AND CONCLUSIONS}

In general, a direct relationship exists between ground-water levels and specific conductance of ground water from 13 observation wells in the Muddy Creek basin. The increases in specific conductance associated with rising water levels result from the dissolving and flushing of soluble minerals from the 
Table 2.-Chemical analyses of ground water from observation well Yo-596

\begin{tabular}{|c|c|c|c|c|c|c|c|c|c|c|c|}
\hline \multirow{2}{*}{$\begin{array}{c}\text { Date } \\
\text { of } \\
\text { collection }\end{array}$} & \multirow{2}{*}{$\begin{array}{l}\text { Field specific } \\
\text { conductance } \\
\text { (micromhos } \\
\text { at } 25^{\circ} \mathrm{C} \text { ) }\end{array}$} & \multicolumn{10}{|c|}{ Dissolved constituents (milligrams per liter) } \\
\hline & & $\mathrm{SiO}_{2}$ & Ca & $\mathrm{Mg}$ & $\mathrm{Na}$ & K & $\mathrm{HCO}_{3}$ & $\mathrm{SO}_{4}$ & $\mathrm{Cl}$ & $\mathrm{NO}_{3}$ & $\mathrm{PO}_{4}$ \\
\hline $\begin{array}{r}3-11-69 \\
7-15-70 \\
7.24-69 \\
11-4-70 \\
10-30-69\end{array}$ & $\begin{array}{r}205 \\
185 \\
120 \\
108 \\
80\end{array}$ & $\begin{array}{l}6.2 \\
6.5 \\
4.9 \\
5.3 \\
5.8\end{array}$ & $\begin{array}{c}14 \\
13 \\
6.2 \\
4.8 \\
3.8\end{array}$ & $\begin{array}{l}6.0 \\
6.0 \\
3.5 \\
3.8 \\
2.9\end{array}$ & $\begin{array}{l}5.2 \\
4.5 \\
3.2 \\
3.3 \\
2.6\end{array}$ & $\begin{aligned} 16 \\
7.8 \\
7.2 \\
6.4 \\
6.4\end{aligned}$ & $\begin{array}{r}24 \\
18 \\
11 \\
9 \\
10\end{array}$ & $\begin{array}{c}14 \\
7.1 \\
4.4 \\
1.8 \\
2.2\end{array}$ & $\begin{array}{l}16 \\
17 \\
10 \\
9.8 \\
6.7\end{array}$ & $\begin{array}{l}44 \\
43 \\
28 \\
25 \\
26\end{array}$ & $\begin{array}{l}1.0 \\
.00 \\
.00 \\
.00\end{array}$ \\
\hline
\end{tabular}

regolith by recharge. The decreases in specific conductance associated with declining water levels probably result from the lateral movement of dilute ground water toward the observation wells. High specific conductance of stream water at high stream discharges and low specific conductance at low stream discharges have been observed in the basin during base-flow conditions. These data suggest that the trends of ground-water level and specific conductance in the 13 observation wells represent the trend throughout the basin.

Virtually all the chemical constituents found in the groundwater samples can come from natural weathering of the regolith or from the application of fertilizer. However, the presence of high nitrate concentrations in all the samples suggests that man's use of the land has a significant effect on the ground-water quality in well Yo-596 and probably on the ground-water quality throughout the basin.

\section{REFERENCE}

Stose, G. W., and Jonas, A. I., 1939, Geology and mineral resources of York County, Pennsylvania: Pennsylvania Geol. Survey, 4th ser., Bull. C-67, 199 p. 


\title{
RELATION BETWEEN OXIDATION POTENTIAL AND THE OCCURRENCE OF IRON IN GROUND WATER FROM THE CHICOT AQUIFER, LAFAYETTE, LOUISIANA
}

\author{
By LARRY D. FAYARD, Baton Rouge, La.
}

Work done in cooperation with the Louisiana Department of Public Works

\begin{abstract}
A study of the relation of Eh (oxidation potential), $\mathrm{pH}$, and iron concentration of water in the Chicot aquifer underlying Lafayette, La., demonstrates that chemical data obtained using good sampling and analytical testing procedures yield reliable results of conditions in a ground-water environment. The aquifer consists of two sands of Pleistocene age and contains a calcium magnesium bicarbonate water. Iron concentrations range from 0.71 to $7.0 \mathrm{mg} / \mathrm{l}$. Water in the lower of the two sands has higher alkalinity and hardness and lower sulfate content than has water in the upper sand. The iron in solution is in equilibrium with ferric hydroxide and not with hematite or magnetite. The measured oxidation potentials range from +50 to +110 millivolts and agree with the values predicted for equilibrium with ferric hydroxide on the basis of determined iron concentrations.
\end{abstract}

Iron in a water supply is an economic and hydrologic problem in many areas. Recent studies (Back and Barnes, 1965; Langmuir, 1969; Barnes and Clarke, 1969), in which the concept of oxidation potential has been applied to groundwater systems, have greatly aided the understanding of chemical processes that control the iron content of ground water. Other references of interest on the subject of iron in water are those by Barnes and Back (1964), Doyle (1968), Hem and Cropper (1959), Morris and Stumm (1967), Perry (1950), and Turcan and Fader (1959).

The extensive Chicot aquifer underlies most of southwestern Louisiana and is heavily used as a source of water for agricultural, industrial, and domestic purposes. A major problem associated with the use of water from the Chicot aquifer is the generally high iron concentration, which ranges from a few tenths of a milligram per liter to $10-15 \mathrm{mg} / \mathrm{l}$ (milligrams per liter). The variation and distribution of iron in water in the Chicot aquifer is poorly understood and unpredictable. Therefore, this study was undertaken to utilize the fundamental concepts of electrochemistry to define the relationship of oxidation potential (Eh) and $\mathrm{pH}$ to the occurrence of iron in water in the Chicot aquifer.
The nine wells owned and operated by the city of Lafayette (fig. 1) were tested because they are screened in the Chicot aquifer and were available for testing. These wells fulfilled the

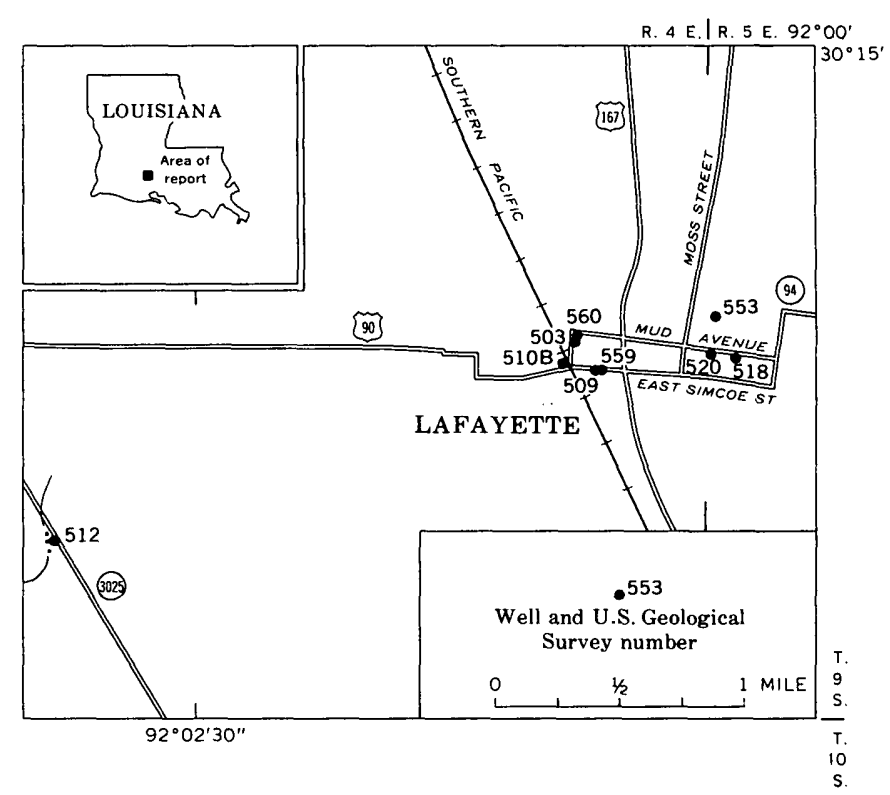

Figure 1.-Map of Lafayette, La., area, showing location of test wells.

requirements for conducting the test, such as completeness of well information, frequent pumping, and suitability for installing testing equipment. Iron bacteria have infected some wells in the study area (Love, 1957), and the effect of these bacteria upon the oxidation potential is considered.

\section{THEORETICAL BACKGROUND}

The significance of the concept of oxidation potential for geochemical studies has been well established (Garrels and 
Christ, 1965; Krauskopf, 1967). Application to ground-water hydrology has been demonstrated by Back and Barnes (1965) and Langmuir (1969). These works and the references contained herein provide the theoretical background, which is only briefly summarized here.

The electrochemical approach permits an evaluation of the relative significance of several possible controls on the distribution of iron in water through application of the Nernst equation. This equation, the fundamental statement for virtually all electrochemistry, is

$$
\mathrm{Eh}=E^{\circ}+\frac{R T}{n F} \ln \frac{A_{\mathrm{ox}}}{A_{\mathrm{red}}},
$$

where $E h$ is the oxidation potential; $E^{\circ}$ is the standard oxidation potential for the desired couple; $R$ is the universal gas constant; $T$ is the temperature in degrees Kelvin; $n$ is the number of electrons involved in the reaction; $F$ is the Faraday constant; and $A_{\mathrm{ox}}$ and $A_{\text {red }}$ are the activity of oxidized and reduced ions, respectively.

For the ferric-ferrous couple,

$$
\mathrm{Fe}^{+2}=\mathrm{Fe}^{+3}+\mathrm{e}^{-}
$$

where $e^{-}$represents an electron. Then equation 1 becomes (at $25^{\circ} \mathrm{C}$, with base 10 logarithm instead of natural logarithm):

$$
\mathrm{Eh}=0.771+0.0592 \log \frac{\left[\mathrm{Fe}_{\mathrm{aq}}^{+3}\right]}{\left[\mathrm{Fe}_{\mathrm{aq}}^{+2}\right]}
$$

where the brackets denote activity or thermodynamic concentrations. The ferric ion activity was calculated from data for $\mathrm{Fe}(\mathrm{OH})_{3 \mathrm{c}}$ to determine the upper limit of solubility, and from data for $\mathrm{Fe}_{2} \mathrm{O}_{3 \mathrm{c}}$ to determine the lower limit of solubility. Calculations were made using the following equations (Back and Barnes, 1965):

$$
\begin{aligned}
& \mathrm{Fe}(\mathrm{OH})_{3 \mathrm{c}}+3 \mathrm{H}^{+}{ }_{\mathrm{aq}}=\mathrm{Fe}_{\mathrm{aq}}^{+3}+3 \mathrm{H}_{2} \mathrm{O}_{1} \\
& K_{4}=\frac{\left[{ }^{a} \mathrm{Fe}^{+3}\right]\left[{ }^{a} \mathrm{H}_{2} \mathrm{O}_{1}\right]^{3}}{\left[{ }^{a} \mathrm{Fe}(\mathrm{OH})_{3 \mathrm{c}}\right]\left[\mathrm{H}^{+}{ }_{\mathrm{aq}}\right]^{3}} \\
& { }^{a} \mathrm{Fe}^{+3} \text { aq }=K_{4}\left(10^{-3} \mathrm{pH}\right), \\
& \mathrm{Fe}_{2} \mathrm{O}_{3 c}+6 \mathrm{H}^{+}{ }_{\mathrm{aq}}=2 \mathrm{Fe}^{+3}{ }_{\mathrm{aq}}+3 \mathrm{H}_{2} \mathrm{O}_{1} \\
& K_{7}=\frac{\left[{ }^{a} \mathrm{Fe}_{\mathrm{aq}}^{+3}\right]^{2}\left[{ }^{a} \mathrm{H}_{2} \mathrm{O}_{1}\right]^{3}}{\left[{ }^{a} \mathrm{Fe}_{2} \mathrm{O}_{3 \mathrm{c}}\right]\left[{ }^{a} \mathrm{H}_{\mathrm{aq}}^{+}\right]^{6}},
\end{aligned}
$$

and

$$
{ }^{a} \mathrm{Fe}_{\text {aq }}^{+3}=K_{7}{ }^{1 / 2}\left(10^{-3} \mathrm{pH}\right)
$$

The equilibrium constants, $K_{7}$ and $K_{4}$, are temperature dependent. This relationship was derived from the van't Hoff equation, using thermodynamic data from several sources and assuming $\Delta C p=0$. The assumption is valid for the temperatures observed. The equilibrium constants are corrected for temperature by the following equations:

$$
\log K_{4}=-9.3523+4.229(10) T^{-1}
$$

and

$$
\log K_{7}=-24.3644+6.8295(10) T^{-1} \text {. }
$$

The ferrous ion activity is the product of the activity coefficient $(\gamma i)$ and the molarity of the ferrous ion as analyzed in the laboratory:

$$
{ }^{a} \mathrm{Fe}_{\text {aq }}^{+2}=\left(\mathrm{Fe}_{\text {aq }}^{+2}\right) \gamma i \mathrm{Fe}^{+2}
$$

where $\gamma i$ is derived from the Debye-Hückel equation. These values for the ferric ion and the ferrous ion were substituted in equation 3 to obtain the respective oxidation potentials.

\section{GEOHYDROLOGIC SETTING}

In order to test the application of these concepts to another geochemical problem, a study area underlain by the Chicot aquifer of Pleistocene age was selected. The Chicot aquifer is about 450 feet thick throughout most of Lafayette Parish. The aquifer is composed of interbedded sand, gravel, and clay of fluviatile and deltaic origin and is overlain by an impermeable clay about 50 feet thick that extends to the land surface. This clay confines the water in the aquifer (artesian conditions). In most of the Lafayette area the aquifer is separated into an upper and a lower unit by a clay approximately 100 feet thick. However, good hydrologic connection exists between the two units of the aquifer, as evidenced by equal water levels of about 40 feet below the land surface.

Drill cuttings from a nearby untested well (Lf-511) contained mostly clear weathered quartz and other siliceous mineral grains as well as some heavy-mineral grains. A few clusters of these grains were found cemented together with secondary deposits of limonite. Some of the particles of limonite-cemented grains contained a magnetite core. The predominant iron minerals were rounded and (or) botryoidal granules of magnetite, which were probably deposited with the sediments.

The uppermost sand has streaks of blue and green clay and carbonaceous material, which denote a reducing environment. Water from the lower sand is higher in hardness and alkalinity and lower in sulfate content than in water from the upper sand 
(table 1). Iron concentrations ranged from 0.71 to $0.83 \mathrm{mg} / \mathrm{l}$ in the lower aquifer, and from 2.1 to $7.0 \mathrm{mg} / \mathrm{l}$ in the upper aquifer.

\section{EQUIPMENT AND TECHNIQUES}

Oxidation potential was measured by withdrawing the water through plastic tubing attached to the pump discharge pipe and allowing it to flow into a field sample jar containing the calomel and thimble-type platinum electrode, as developed by Back and Barnes (1961, 1965). Standard Zobell solution was used to calibrate the electrodes. The tubing and sample jars were flushed until a constant or slowly changing potential was reached (about 3 millivolts per minute); the flow was then stopped and the final potential recorded. Immediately before flow stoppage, a sample for ferrous and ferric iron analysis was collected and stabilized by acidification so that the ferrousferric distribution would be preserved (Rainwater and Thatcher, 1960).

The electrodes for $\mathrm{pH}$ measurement were standardized by use of $\mathrm{pH}$ buffers, which were brought to the temperature of the sample.

\section{DISCUSSION}

Table 2 shows the Eh values measured in the field and those calculated from solubility data for $\mathrm{Fe}(\mathrm{OH})_{3 \mathrm{c}}$ (ferric hydroxide) and $\mathrm{Fe}_{2} \mathrm{O}_{3 \mathrm{c}}$ (hematite). The $\mathrm{Eh}$ from $\mathrm{Fe}(\mathrm{OH})_{3 \mathrm{c}}$ was calculated, using equations 6,12 , and 3 ; and from $\mathrm{Fe}_{2} \mathrm{O}_{3}$, using equation 8 .
Table 2.-Compilation of field data and calculated data from water in the Chicot aquifer underlying Lafayette, La.

\begin{tabular}{|c|c|c|c|c|c|c|}
\hline \multirow{2}{*}{\multicolumn{2}{|c|}{ Well number }} & \multicolumn{3}{|c|}{ Eh (millivolts) } & & \\
\hline & & \multirow[b]{2}{*}{$\begin{array}{l}\text { Meas- } \\
\text { ured }\end{array}$} & \multicolumn{2}{|c|}{ Calculated } & \multicolumn{2}{|c|}{$\log _{10}{ }^{a} \mathrm{Fe}$} \\
\hline City & $\begin{array}{l}\text { U.S. } \\
\text { Geological } \\
\text { Survey }\end{array}$ & & $\begin{array}{c}\text { From } \\
\mathrm{Fe}(\mathrm{OH})_{3 \mathrm{c}}\end{array}$ & $\underset{\mathrm{Fe}_{2} \mathrm{O}_{3 \mathrm{c}}}{\text { From }}$ & $\begin{array}{c}\text { From } \\
\text { laboratory } \\
\text { analysis }\end{array}$ & $\begin{array}{l}\text { From } \\
\text { field } \\
\text { data }\end{array}$ \\
\hline \multicolumn{7}{|c|}{ Upper Chicot } \\
\hline $\begin{array}{l}5 \ldots \\
1 \ldots \\
\text { WD-j } \\
10 \ldots\end{array}$ & $\begin{array}{rr}\text { Lf }-503 \ldots \\
. & 509 \ldots \\
. & 512 \ldots \\
. & 520 \ldots\end{array}$ & $\begin{array}{l}+90 \\
+70 \\
+53 \\
+50\end{array}$ & $\begin{array}{l}+86 \\
+65 \\
+46 \\
+26\end{array}$ & $\begin{array}{l}-245 \\
-267 \\
-285 \\
-305\end{array}$ & $\begin{array}{l}-4.11 \\
-4.03 \\
-4.56 \\
-4.25\end{array}$ & $\begin{array}{l}-4.17 \\
-4.12 \\
-4.67 \\
-4.65\end{array}$ \\
\hline \multicolumn{7}{|c|}{ Lower Chicot } \\
\hline $\begin{array}{l}12 . \\
6 \ldots \\
7 \ldots \\
14 . \\
8 .\end{array}$ & $\begin{array}{rr}. & \text { Lf } \mathbf{5 5 9} \ldots \\
. & 510 \mathrm{~B} \\
. & 518 \ldots \\
. & 560 \ldots \\
. & 553 \ldots\end{array}$ & $\begin{array}{r}+88 \\
+109 \\
+110 \\
+90 \\
+100\end{array}$ & $\begin{array}{l}+72 \\
+77 \\
+77 \\
+53 \\
+83\end{array}$ & $\begin{array}{l}-259 \\
-255 \\
-254 \\
-279 \\
-248\end{array}$ & $\begin{array}{l}-4.97 \\
-5.01 \\
-5.01 \\
-5.03 \\
-5.01\end{array}$ & $\begin{array}{l}-5.23 \\
-5.55 \\
-5.56 \\
-5.66 \\
-5.29\end{array}$ \\
\hline
\end{tabular}

Figure 2 was constructed from solubility data for $\mathrm{Fe}_{2} \mathrm{O}_{3}$. The data points plot in the field of $\mathrm{Fe}_{2} \mathrm{O}_{3} \mathrm{c}$. The iron in solution would be in much smaller concentrations if it were in equilibrium with hematite.

The measured $\mathrm{Eh}$ and $\mathrm{pH}$ values for the samples are plotted in figures 3 and 4 , which were constructed from solubility data for $\mathrm{Fe}(\mathrm{OH})_{3}$. Figure 3 shows the general plotting area for the wells sampled. Figure 4 is an enlargement of the data-point area from figure 3 and shows more clearly the relative positions of the plotted points. Although this figure amplifies the distance of a data point from the concentration lines, it

Table 1.-Chemical analyses of water from wells in the Chicot aquifer, Louisiana

[Analyses by U.S. Geological Survey]

\begin{tabular}{|c|c|c|c|c|c|c|c|c|c|c|c|c|c|c|c|c|c|c|c|}
\hline \multirow{3}{*}{ 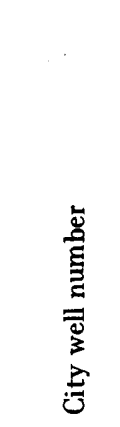 } & \multirow{3}{*}{ 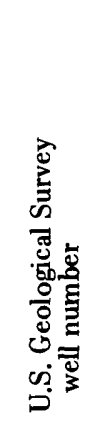 } & \multirow{3}{*}{ 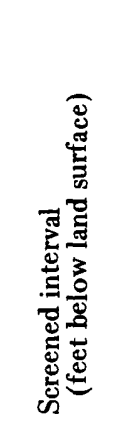 } & \multirow{3}{*}{ 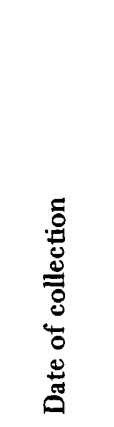 } & \multirow{3}{*}{ 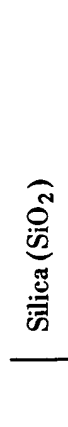 } & \multicolumn{2}{|c|}{$\begin{array}{l} \\
\text { Iron }\end{array}$} & \multirow{3}{*}{ 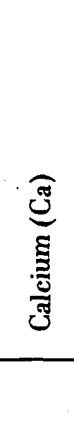 } & \multirow{3}{*}{ 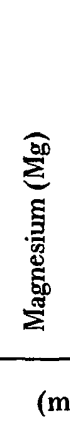 } & \multirow{3}{*}{ 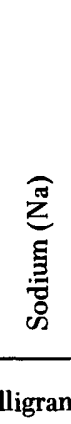 } & \multirow{2}{*}{ 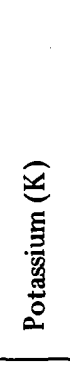 } & \multirow{2}{*}{ 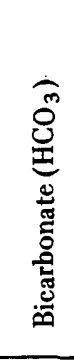 } & \multirow{3}{*}{ 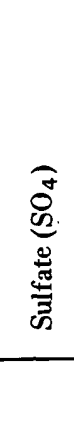 } & \multirow{3}{*}{ 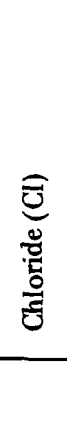 } & \multirow{3}{*}{ 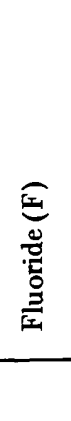 } & \multirow{3}{*}{ 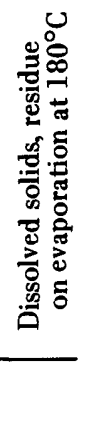 } & \multirow{3}{*}{ 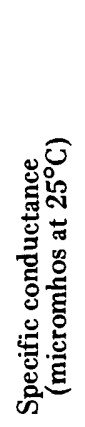 } & \multirow{3}{*}{ 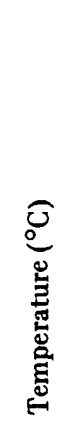 } & \multirow{3}{*}{$\frac{\pi}{2}$} & \multirow[b]{3}{*}{ 量 } \\
\hline & & & & & $\underset{+}{\stackrel{N}{+}}$ & $\stackrel{\widetilde{m}}{\tilde{+}}$ & & & & & & & & & & & & & \\
\hline & & & & & & & & & & per li & er) & & & & & & & & \\
\hline \multicolumn{20}{|c|}{ Upper Chicot } \\
\hline $\begin{array}{l}5 \ldots \ldots \\
1 \ldots \ldots \\
\text { wD.1. } \ldots \\
10 \ldots\end{array}$ & $\begin{array}{r}\text { Lf-503 } \\
\mathbf{5 0 9} \\
\mathbf{5 1 2} \\
\mathbf{5 2 0}\end{array}$ & $\begin{array}{l}125-205 \\
217-257 \\
.247-297 \\
.278-334\end{array}$ & $\begin{array}{l}5-24-67 \\
5-23-67 \\
5-25-67 \\
5-24-67\end{array}$ & $\begin{array}{l}41 \\
43 \\
42 \\
43\end{array}$ & $\begin{array}{l}5.7 \\
7.0 \\
2.1 \\
4.2\end{array}$ & $\begin{array}{r}0.00 \\
.00 \\
.00 \\
.00\end{array}$ & $\begin{array}{l}29 \\
33 \\
40 \\
32\end{array}$ & $\begin{array}{l}15 \\
13 \\
15 \\
17\end{array}$ & $\begin{array}{l}10 \\
13 \\
14 \\
10\end{array}$ & $\begin{array}{l}1.8 \\
2.0 \\
1.7 \\
1.5\end{array}$ & $\begin{array}{l}153 \\
172 \\
221 \\
190\end{array}$ & $\begin{array}{l}12 \\
12 \\
1.8 \\
7.2\end{array}$ & $\begin{array}{l}9.8 \\
8.6 \\
3.4 \\
2.0\end{array}$ & $\begin{array}{r}\mathbf{0 . 3} \\
.3 \\
.3 \\
.3\end{array}$ & $\begin{array}{l}202 \\
214 \\
246 \\
224\end{array}$ & $\begin{array}{l}293 \\
313 \\
352 \\
324\end{array}$ & $\begin{array}{l}20.4 \\
20.6 \\
20.6 \\
20.6\end{array}$ & $\begin{array}{l}6.91 \\
7.00 \\
7.28 \\
7.29\end{array}$ & $\begin{array}{l}+90 \\
+70 \\
+53 \\
+50\end{array}$ \\
\hline
\end{tabular}




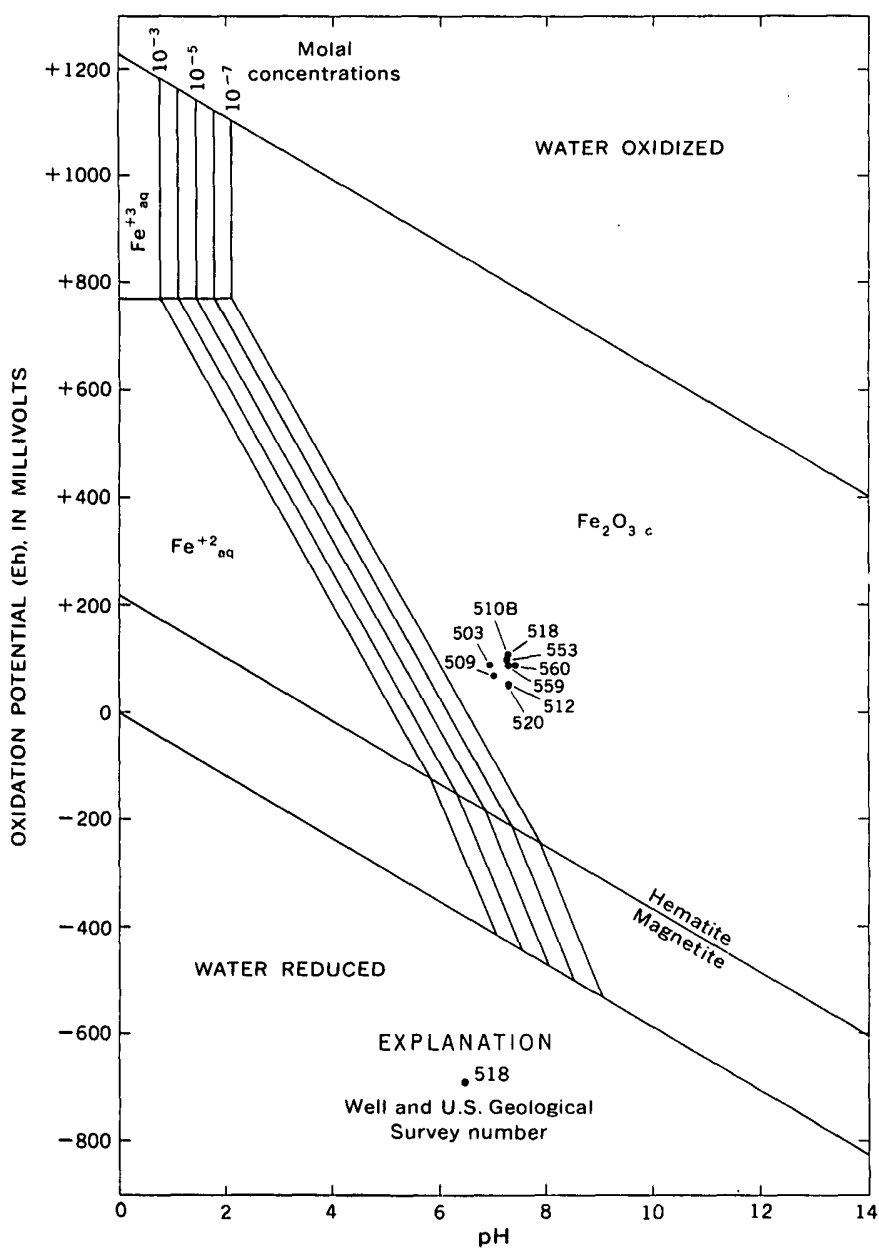

Figure 2.-Eh-pH-iron stability diagram based on $\mathrm{Fe}_{2} \mathrm{O}_{3 \mathrm{c}}$ equilibrium data.

can be seen that this distance is only a few tenths of an order of magnitude.

Using solubility data for $\mathrm{Fe}(\mathrm{OH})_{3 \mathrm{c}}$, field Eh values, and equation 3 , one can calculate the amount of iron that theoretically would be in solution. Equation 12 is used in conjunction with iron concentrations, as analyzed in the laboratory, to calculate the activity of iron in solution. Table 2 shows the iron activities computed from iron concentrations and from measured Eh values. It can be seen that the iron activities computed from the Eh measurements, although lower than those computed from actual iron concentrations, are definitely of the same order of magnitude. This seems to be a good correlation between the field observations and the predicted values.

\section{CONCLUSIONS}

This study provides additional evidence that measurement of oxidation potentials in ground-water systems provides both a more complete description of the geochemical environment

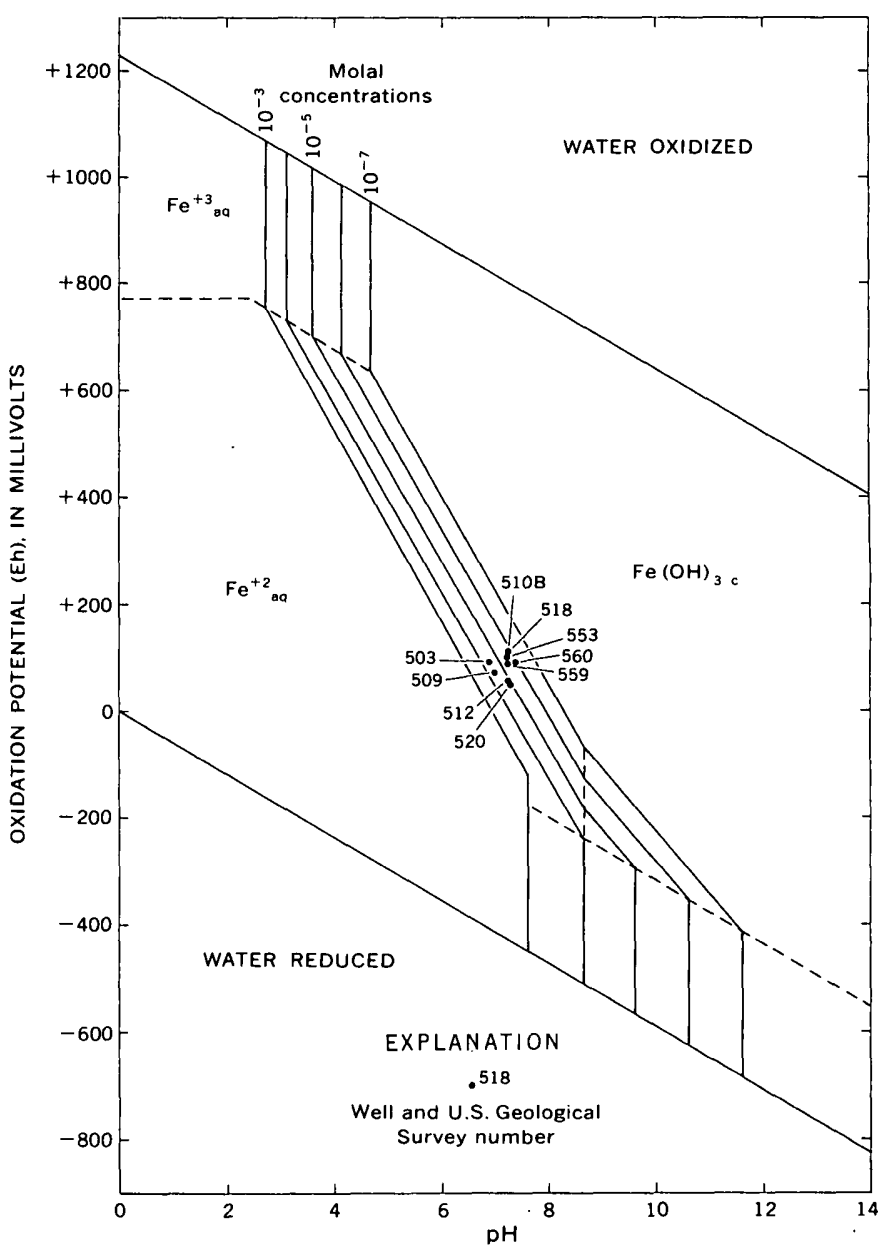

Figure 3.-Eh-ph-iron stability diagram based on $\mathrm{Fe}(\mathrm{OH})_{3}$ c equilibrium data. Figure 4 shows the area of data points in more detail.

and an explanation for the occurrence of multivalent ions in solution.

The oxidation potentials measured in water from wells in the Chicot aquifer underlying Lafayette, La., agree with the values predicted from data for ferric hydroxide. These tests verified a positive difference in the quality of water and the geochemical environment of the two sand units-water from the upper sand had a lower Eh and higher iron concentrations. The iron in solution is in equilibrium with ferric hydroxide and not with hematite or magnetite. This geochemical situation is probably typical of a large part of the Chicot aquifer in southwestern Louisiana; therefore, the agreement between measured and theoretical data could be expected throughout the aquifer.

The samples for chemical analysis were collected after the Eh had stabilized and are believed to be representative of the aquifer environment. The oxidation-potential technique provides a means of validating iron concentrations from the aquifer and detecting spurious values. Therefore, it can be a valuable technique in identifying iron problems. 


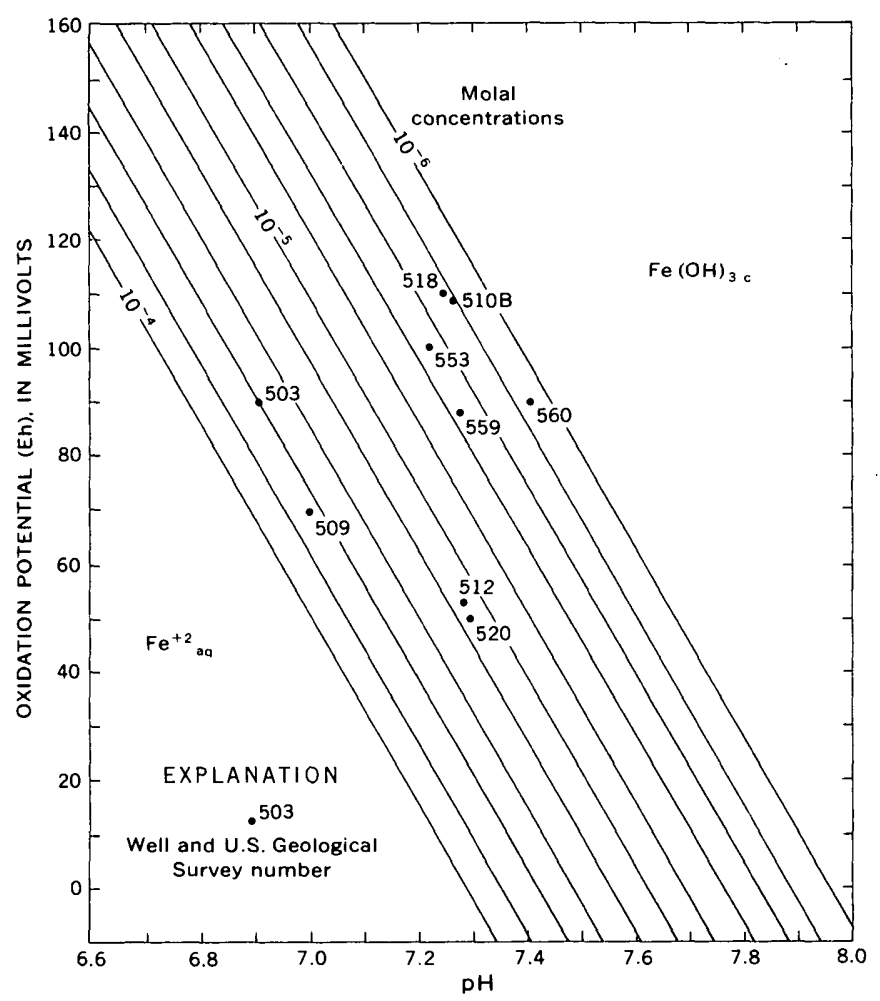

Figure 4.-Expanded part of the Eh-pH-iron stability diagram from figure 3 .

Because the field and the theoretical data are in good agreement, it can be assumed that the iron bacteria in these wells have no detectable effect on the electrochemistry of the environment. The results, being of good quality, demonstrate the reliability of the equipment and techniques used in this study.

\section{REFERENCES}

Back, William, and Barnes, Ivan, 1961, Equipment for field measurement of electrochemical potentials: Article 280 in U.S. Geol. Survey
Prof. Paper 424-C, p. C366-C368.

- 1965, Relation of electrochemical potentials and iron content to ground-water flow patterns: U.S. Geol. Survey Prof. Paper 498-C, p. Cl-C16.

Barnes, Ivan, and Back, William, 1964, Geochemistry of iron-rich ground waters of southern Maryland: Jour. Geology, v. 72, no. 4, p. $435-447$.

Barnes, Ivan, and Clarke, F. E., 1969, Chemical properties of ground water and their corrosion and encrustation effects on wells: U.S. Geol. Survey Prof. Paper 498-D, p. D1-D58.

Doyle, R. W., 1968, The origin of the ferrous ion-ferric oxide Nernst potential in environments containing dissolved ferrous iron: Am. Jour. Sci., v. 266, p. 840-859.

Garrels, R. M., and Christ, C. L., 1965, Solutions, minerals, and equilibria: New York, Harper \& Row, 450 p.

Hem, J. D., and Cropper, W. H., 1959, Survey of ferrous-ferric chemical equilibria and redox potentials: U.S. Geol. Survey Water-Supply Paper 1459-A, p. 1-31.

Krauskopf, K. B., 1967, Introduction to geochemistry: New York, McGraw-Hill, $721 \mathrm{p}$.

Langmuir, Donald, 1969, Geochemistry of iron in a coastal-plain ground water of the Camden, New Jersey, area, in Geological Survey Research 1969: U.S. Geol. Survey Prof. Paper 650-C, p. C224-C235.

Love, J. L., 1957, Study of corrosion and nuisance organisms in the Lafayette water system: Louisiana State Univ. Eng. Expt. Sta. Bull. 61, p. 27-50.

Morris, J. C., and Stumm, Werner, 1967, Redox equilibria and measurements of potentials in the aquatic environment, [Chap.] 13 in Equilibrium concepts in natural water systems-Am. Chem. Soc., 151st Ann. Mtg., Pittsburgh, 1966, Div. Water, Air and Waste Chemistry Symposium: Washington, D.C., Am. Chem. Soc., Adv. Chemistry Ser. 67, p. 270-285.

Perry, J. H., ed., 1950, Chemical engineers' handbook, 3d ed.: New York, McGraw-Hill, 1942 p.

Rainwater, F. .H., and Thatcher, L. L., 1960, Methods for collection and analysis of water' samples: U.S. Geol. Survey Water-Supply Paper 1454, p. 183-187.

Turcan, A. N., Jr., and Fader, S. W., 1959, Summary of ground-water conditions in southwestern Louisiana, 1957 and 1958, with a discussion of iron in water from the Chicot aquifer: Louisiana Dept. Conserv. and Louisiana Dept. Public Works Water Resources Pamph. 6,29 p. 


\title{
CHANGES IN THE ELEVATION OF GREAT SALT LAKE CAUSED BY MAN'S ACTIVITIES IN THE DRAINAGE BASIN
}

\author{
By G. L. WHITAKER, Salt Lake City, Utah
}

Work done in cooperation with the U.S. Department of Justice

\begin{abstract}
The change in the surface elevation of Great Salt Lake caused by man's consumptive use of water in the drainage basin was calculated for each year since 1851, and the calculated changes were accumulated through 1965. The water-surface elevation of the lake in 1965 would have been 5.28 feet higher than the observed elevation had there been no consumptive use of water because of man's activities in the drainage basin.
\end{abstract}

Ownership of the bed of Great Salt Lake, of lands bordering its shoreline, and of lands uncovered by the receding shoreline have been sources of controversy for many years. Resolution of some phases of the controversy may involve knowledge of the surface elevation and corresponding shoreline of the lake on the date that Utah was admitted to statehood, January 4, 1896 , and perhaps at other times. For legal purposes it is also desirable to know what the surface elevation of the lake would have been had there been no consumptive use, because of man's activities, of water that otherwise would have reached the lake. Accordingly, a joint effort was made by the State of Utah, the U.S. Department of Justice ${ }^{1}$, and the U.S. Geological Survey to arrive at a method of adjusting the historic elevations of Great Salt Lake for the effects of man's consumptive use of water.

Great Salt Lake is a closed body of water, and water leaves the lake only by evaporation. The volume of water in the lake at the end of any year is equal to the volume at the beginning of the year plus the total inflow during the year, minus the loss by evaporation from the water surface. Most of the shoreline is on a very gentle slope; therefore, relatively small changes in elevation of the water surface result in relatively large changes in surface area and, hence, large changes in losses through evaporation. Therefore, the changes in evaporation loss must be considered in calculating the change of volume that would result from the decreased inflow caused by man's consumptive use of water in the drainage basin. Accordingly,

\footnotetext{
${ }^{1}$ Represented by E. L. Peck, Research Hydrologist, Environmental Science Services Administration.
}

values representing annual evaporation rate, annual consumptive use of water in the basin by man, a stage-area-volume relation for the lake, and a historic record of observed lake elevations are needed to adjust the lake elevations. Other variables, including the natural consumptive use of water in the drainage basin, are absorbed in the observed annual fluctuations of lake elevation and can be ignored.

An evaluation of consumptive use of water because of man's activities in the Great Salt Lake drainage basin was made in 1969 by the Utah Department of Natural Resources (written commun., 1969), and the results are shown in figure 1 . The computation of consumptive use due to man's activities was based on use of water by crops and evaporation from reservoirs. An appropriate consumptive-use coefficient was applied to the irrigated acreage in the drainage basin, and an evaporation coefficient was applied to the total surface area of all reservoirs in the basin.

The rate of evaporation from the lake surface varies inversely with the concentration of dissolved solids in the water, and the concentration of dissolved solids varies inversely with the volume of water in the lake. In addition, the volume of water evaporated is directly proportional to surface area, which varies directly with lake stage. Estimates of rates of evaporation were taken from a report by Peck (1954) and are shown in figure 2. Although the completion of the Southern Pacific Co. railroad causeway in 1959 changed the evaporation rate-lake elevation relation for the 1959-65 period, the net effect of the change is small.

The historic record of lake elevations was taken from data compiled by the U.S. Geological Survey, and the mean annual elevations of the lake from 1851 to 1969 are shown in figure 3 . Figure 3 also shows the elevation-area-volume relation for the lake that was developed by the U.S. Geological Survey in 1961. All computations in this study were based on mean annual lake elevations.

The computations began with the mean lake elevation for the calendar year 1851, the first year for which records are available, with its corresponding surface area and volume. The 


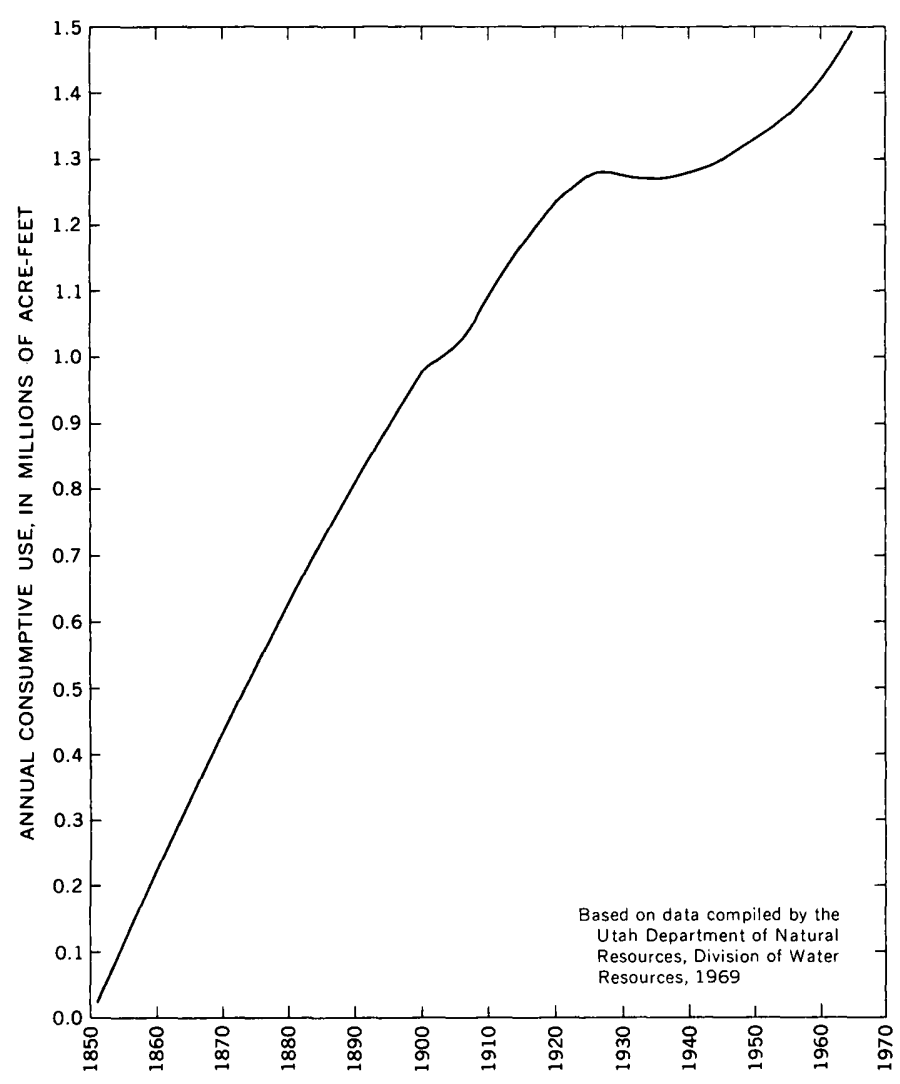

Figure 1.-Consumptive use of water resulting from man's activities in the Great Salt Lake drainage basin, 1850-1970. estimated consumptive use by man for that year was added to the actual volume, giving an adjusted volume and corresponding surface area. The increase in area was multiplied by the estimated rate of evaporation to calculate the increase in evaporation loss. Subtracting this evaporation loss from the first adjusted volume gave a final adjusted volume and a net gain in volume for the year equal to man's consumptive use less the increased evaporation loss. The net gain in volume was then added to the volume corresponding to the observed mean elevation for the next year (1852), and the computations were repeated. The evaporation factor was applied only to the computed increase in area; the actual evaporation loss from the total lake surface did not enter into the computations.

Computations for the entire period of record were run on a digital computer, using a program prepared by E. L. Peck, and another computation was also run for the period of statehood, 1896-1965. The mean annual elevations of Great Salt Lake for the period 1851-1965, adjusted for the computed effects of man's consumptive use, are plotted along with the observed elevations in figure 3 . Results of the computation for 1896-1965 gave the same adjusted elevation for 1965. The computed cumulative reduction in lake elevation caused by consumptive use of water in the drainage basin for the period 1851-1965 was 5.28 feet.

\section{REFERENCE}

Peck, E. L., 1954, Hydrometeorological study of Great Salt Lake, Utah: Utah Eng. Expt. Sta. Bull. 63, p. 7-9.
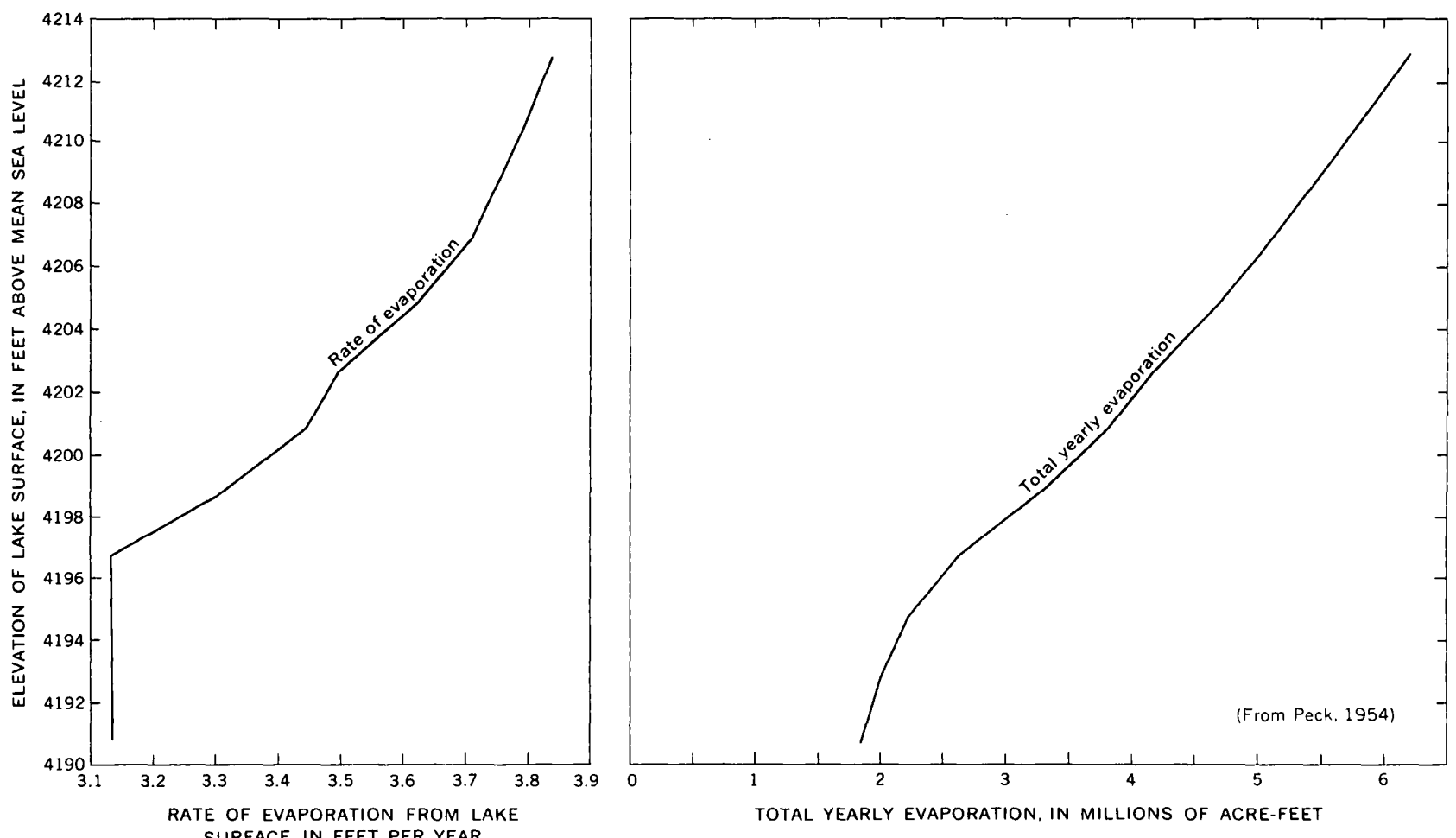

Figure 2.-Evaporation rates from Great Salt Lake. 


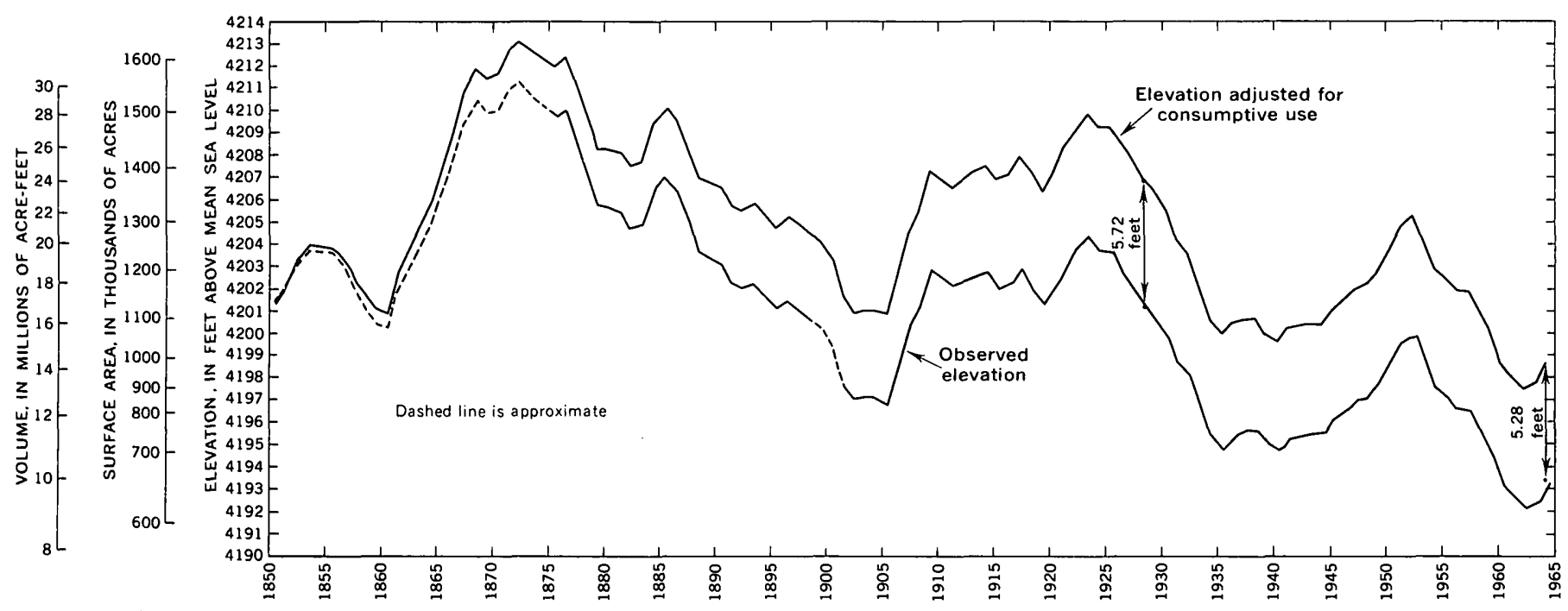

Figure 3.-Effects of consumptive use of water, resulting from man's activities, on historic elevations of Great Salt Lake, 1850-1965. 


\title{
RESISTIVITY AND NEUTRON LOGGING IN SILURIAN DOLOMITE OF NORTHWEST OHIO
}

\author{
By L. M. MacCARY, Denver, Colo.
}

\begin{abstract}
Data from resistivity and neutron logs of the Lockport Dolomite in northwest Ohio may be used in a semiquantitative empirical manner to estimate water quality and formation porosity if sufficient supporting data are available. Zones in the dolomite that appear to function like cemented granular aquifers can be analyzed for water quality and porosity on the basis of log response. The method is empirical, but when applied to carbonate aquifers meeting the specified criteria, meaningful results are obtained. No useful relationships between formation factor and permeability can be established for the Lockport Dolomite owing to the great range in its estimated porosity. Further study is planned on the applicability of these geophysical methods to carbonate rocks in other hydrologic environments.
\end{abstract}

The U.S. Geological Survey and the Division of Water, Ohio Department of Natural Resources, recently completed a ground-water study in an area of about 9,000 square miles in northwest Ohio. During this study approximately 80 wells were drilled, pump tested, and logged with geophysical equipment to determine the significant hydrologic factors controlling the occurrence and quality of ground water. According to Norris and Fidler (1971, p. B229), "The principal objective was to determine whether, and in what areas, ground water is available for large-scale municipal or industrial use in northwest Ohio."

Norris and Fidler (1969) reported early in the study that the natural gamma log was a good basis for locating the contact between the dolomites of the Bass Islands Group and the underlying Lockport Dolomite. Norris and Fidler (1971) discussed the utility of the spontaneous-potential and singlepoint-resistance logs as adjuncts to the gamma log in stratigraphic correlations.

The objective of this study was to determine if usable relationships could be established between geophysical logs and quantitative hydrologic parameters. Selected wells were logged in the fall of 1968, and additional measurements were made in these and other wells in the spring of 1970. The locations of all wells discussed in the text and shown in the figures and table in this report are shown on figure 2 of Norris and Fidler (1971).

\section{METHOD OF STUDY}

Field tests in northwest Ohio of axially symmetrical and side-collimated gamma-gamma probes, neutron-epithermal neutron probes, and electrical resistivity tools indicated that the neutron and resistivity response could be related to inferred and known hydrologic values. The caliper and natural gamma logs gave borehole and lithologic information necessary for interpretation of the resistivity and neutron logs.

Normal logs measure the apparent resistivity, $R_{a}$, at borehole temperature, of a volume of rock surrounding the electrodes. In order to use logging-service-company departure curves and water-quality information determined from laboratory analyses, the $R_{a}$ values must be corrected to standard temperature, $25^{\circ} \mathrm{C}\left(77^{\circ} \mathrm{F}\right)$. The $R_{a}$ values at $11^{\circ} \mathrm{C}\left(52^{\circ} \mathrm{F}\right)$ in the Ohio wells were temperature corrected by use of the resistivity-salinity chart in Schlumberger (1969). Although the chart does not extend as high as the $R_{a}$ values measured, the slope of the constant-salinity lines remains the same, and a ratio between the resistivity at $52^{\circ} \mathrm{F}$ and at $77^{\circ} \mathrm{F}$ can be found to correct the measured $R_{a}$ values.

The resistivity of an aquifer when 100 -percent water saturated, $R_{o}$, is obtained from the temperature-corrected $R_{a}$ by suitable departure curves which take into account the effects of electrode spacing (distance AM), hole diameter, borehole-fluid resistivity $\left(R_{w}\right)$, depth of invasion, and bed thickness. For the Ohio work, an AM spacing of 64 inches was chosen to minimize borehole effects. Values of $R_{w}$ were calculated from laboratory determinations of specific conductance from water samples. The Ohio wells were drilled with air-rotary rigs so that the effects of mud invasion were minimized. Although gamma logs indicated that the Lockport Dolomite is a fairly homogeneous unit, intervals at least 50 feet thick were chosen for study to avoid thin-bed effects (Welex, 1962, p. 45).

Values for $\boldsymbol{R}_{o}$ determined independently from departure curves in Dakhnov (1959), Welex (1962), and Schlumberger (1956) were within 10 percent of each other.

The N-N (neutron-epithermal neutron) device is used for porosity measurements because it responds primarily to the amount of hydrogen present in the rocks. In relatively clean 
aquifers (little or no shale) the neutron log gives a measure of the amount of water-saturated porosity. Neutrons are emitted by a source in the probe, and some are backscattered by the aquifer and arrive at the detector. Each neutron detected results in a short electrical pulse. The number of pulses per second varies inversely with the porosity. With sufficient information about the borehole and environment, the number of pulses per second can be related to percentage porosity. The neutron $\log$ is perturbed by changes in borehole diameter, salinity of ground water, thin-bed effects, bound water in shales, and by water of crystallization. The Ohio wells averaged $9 \frac{1}{2}$ inches in diameter, and smooth sections for analysis were picked from caliper logs. The formation water in these wells was fresh, so corrections for salinity effects were not necessary. The gamma logs show that the Lockport Dolomite is a thick, homogeneous unit free of shale and clay and, therefore, thin beds and bound water in shales would not adversely affect the neutron logs. Gypsum, a common mineral with water of crystallization, has an apparent neutron porosity of about 49 percent; however, gypsum is not stable in this environment, and no gypsum beds were detected.

Scales were placed on $\mathrm{N}-\mathrm{N}$ logs at the end of each logging run with a pulse generator and nuclear counter. The pulse rate needed to simulate the lows and highs of each neutron log plus many points between the extremes was recorded. In this way any point on a neutron log could be scaled off in pulses per second.

\section{THE PROBLEM}

The resistivity of an aquifer decreases with increasing water content because, as a rule, only the water conducts electric current. The resistivity of completely saturated rock is dependent on water resistivity, porosity, and pore-space geometry. In water-saturated rocks with a simple geometry, such as the intergranular spaces in clean, clastic sediments, the resistivity, $R_{o}$, is proportional to the water resistivity, $R_{w}$, times an empirical constant of proportionality, $F$, as expressed in the formula

$$
R_{o}=R_{w} F
$$

$F$ is the formation resistivity factor or formation factor and represents the effects of porosity and pore geometry on resistivity. Work with porous sands in the Gulf coast led Archie (1.942) to develop the empirical relationship between resistivity and porosity, $R_{o}=R_{w} \bar{\phi}^{m}$, which was modified by subsequent workers to the form

$$
R_{o}=a R_{w} \phi^{m}
$$

$R_{o}$ and $R_{w}$ are resistivities of rock and water, $\phi$ is porosity in percent, and coefficient $a$ and exponent $m$ are values chosen to make the formula best fit the observed data. Since $R_{o} / R_{w}$ is defined as formation factor, the equation can be written
$F=a \phi^{-m}$. The value of coefficient $a$ ranges from less than 1 for rocks with intergranular porosity to slightly more than $\mathbf{l}$ for rocks with joint porosity; the value of exponent $m$, called the cementation exponent, is less than 2 for poorly sorted and cemented rocks and greater than 2 for well sorted and cemented rocks (Keller and Frischknecht, 1966).

For carbonate rocks the formula usually applied is $F=\phi^{-2}$, where coefficient $a$ is unity. According to Traugott (1970) the value of exponent $m$ ranges from 1.7 to 3.0 for dolomites. The use of the relationships between $R_{o}, R_{w}, \phi$ and $F$ for carbonate rocks is based on the assumption that they behave like granular rocks that are more or less cemented. For rocks with vugular porosity, common in limestone, the formulas may be invalid because a rock with a high ratio of vugular porosity to interconnecting porosity will have a higher resistivity than a rock of the same porosity having a low ratio.

No cores were taken from any of the Ohio wells penetrating the Silurian dolomites, hence no laboratory measurements of porosity and permeability are available. Answers to three questions regarding these rocks must be inferred, if possible, by other means. The questions are: (1) Do the dolomites behave like cemented granular rocks? (2) If they do, can a meaningful value for $F$ be determined? (3) To what extent can this $F$ be applied to estimates of water quality, porosity, and permeability? If both the neutron and electric logs are responding mainly to interconnected water-saturated porosity, the porosities determined from the logs should be in fairly close agreement. Furthermore, large differences in the porosities measured by the two logs might give evidence as to the validity of the method of study or imply adjustment of some assumed hydrologic parameters.

\section{RESULTS}

The neutron log deflection of various zones in the wells penetrating the Lockport Dolomite was compared with the apparent resistivity of these zones to determine the correspondence of the two logs. By use of a method described by Wyllie (1963, p. 120-124), neutron pulses per second for zones of different porosities are plotted on an arithmetical scale, and the corresponding apparent resistivity of each zone is plotted on a logarithmic scale. A straight line is then fitted through the data points, with the common point of minimum neutron deflection and minimum resistivity as the origin. Minimum neutron log deflection would occur at 100-percent porosity where all of the neutrons become thermalized and none are detected. In practice, some neutrons are always detected in a completely water-filled environment, so this count rate-65 pps (pulses per second) for the Ohio wells-is used rather than instrument zero where no radiation is detected at all. The apparent resistivity at 100-percent porosity is the resistivity of the borehole fluid, which averaged $8.8 \mathrm{ohm}-\mathrm{m}$ (ohm-meters) for the Ohio wells.

If many points from zones of similar lithologic character are plotted according to Wyllie's method, the points will be in a 
broad band lying between the limits imposed by the extreme values of $m$, the cementation exponent. Some points in water-saturated rocks will be entirely outside these limits because vugular porosity causes an inverse relation between the $\log$ responses. In petroleum studies, points that have an anomalously high apparent resistivity for a given neutron deflection may contain hydrocarbons. Figures 1 and 2 are graphs of neutron response and apparent resistivity for selected zones of the Lockport Dolomite made to determine the similarity of $\log$ response. When all zones of all porosities in the Ohio wells are plotted, they fall in a wedge-shaped pattern bounded by the dashed lines on the two figures. The solid lines fitted through the data points on figures 1 and 2 have approximately the same slope, although it is obvious by inspection that the points in figure 1 fall closer to the line than do those of figure 2 . To avoid anomalous $\log$ responses due to borehole diameter changes, all of the data points on figures 1 and 2 were chosen from sections of the wells that had smooth caliper logs. An examination of the side-collimated gammagamma $\log$ for these same zones showed no large deflections from the average line. The smoothness of the caliper and gamma-gamma logs plus the similarity of response of the neutron and resistivity logs was interpreted to indicate that both are responding to water-saturated porosity and, therefore, the carbonate sections chosen may behave somewhat like a cemented granular aquifer with no large volumes of vugular porosity.
$R_{a}$ values were determined for selected dolomite intervals both by fitting an average line through the resistivity logs and by adding and averaging discrete apparent resistivity values as read from the logs. Both methods yielded virtually the same average value. The values of $R_{a}, R_{o}$, and $R_{w}$ for various intervals, the $F$ computed from the $R_{o}$ and $R_{w}$ values, and the values of $\phi$ determined independently from $F$ and from the neutron $\log$ are shown in table 1 . The effects and magnitude of clay ion exchange and mineral-grain surface conductance of $R_{w}$ in the Lockport Dolomite wells are not known. However, chemical analyses of the dolomites (Stout, 1941) show the clay content to be fairly constant and small, generally less than 0.1 percent. In dolomites with a uniform clay content and texture, ion exchange and mineral-surface conductance would have a measurable, but as yet unknown, effect on all formation factors.

\section{WATER QUALITY}

Perhaps the simplest approach to studies of water quality in the Lockport Dolomite is the empirical method. To evaluate the applicability of the method described by Turcan (1966), formation factors were used to estimate water quality, and the results were compared with concentrations of dissolved solids measured in water samples. Figure 3, with data from 25 wells in the Lockport, shows a smooth progression of increasing specific conductance with increasing dissolved solids. If spe-

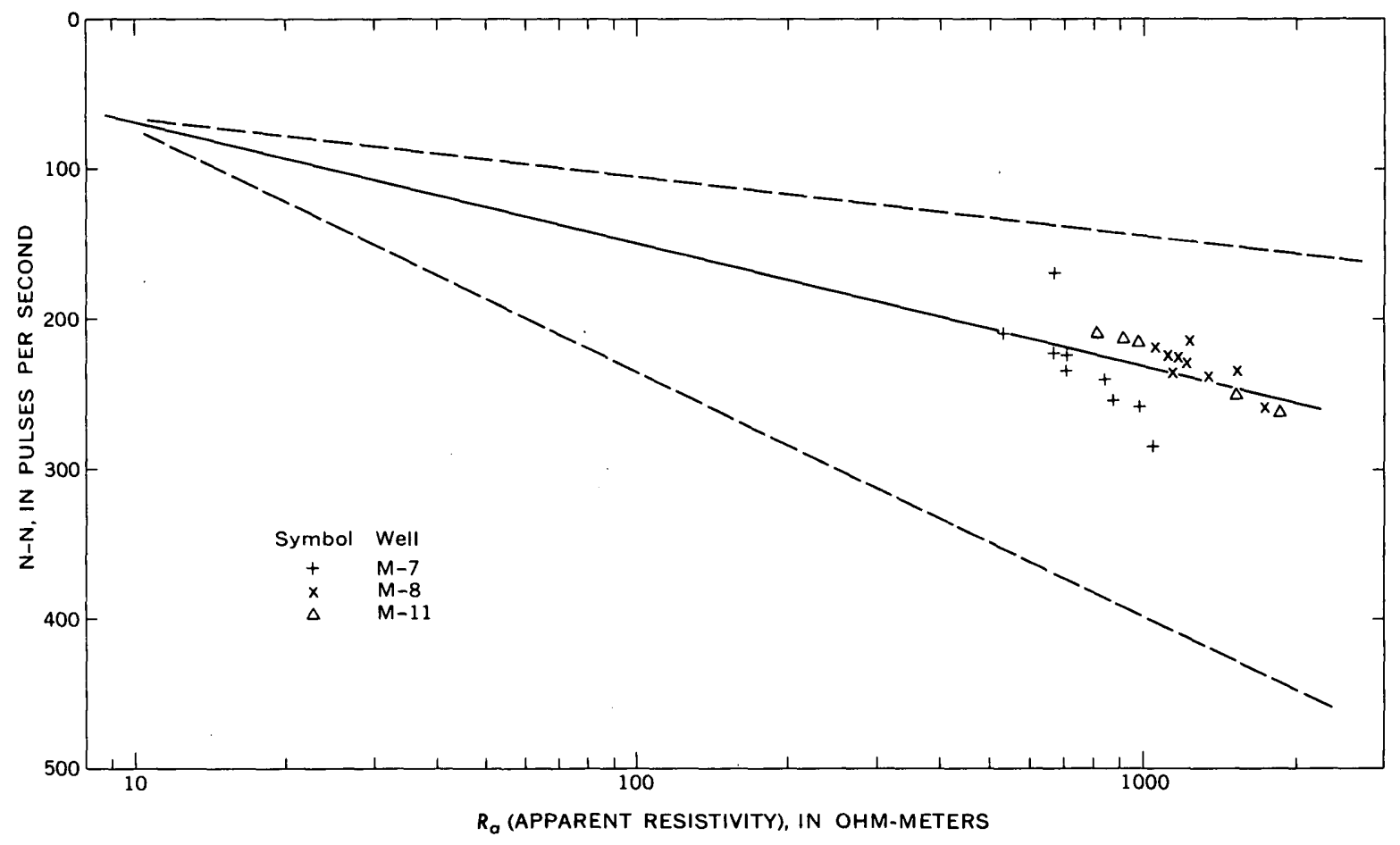

Figure 1.-Apparent resistivity and neutron deflection in wells M-7, M-8, and M-11. Dashed lines bound area into which would fall data points for all zones of all porosities in the Ohio wells. 


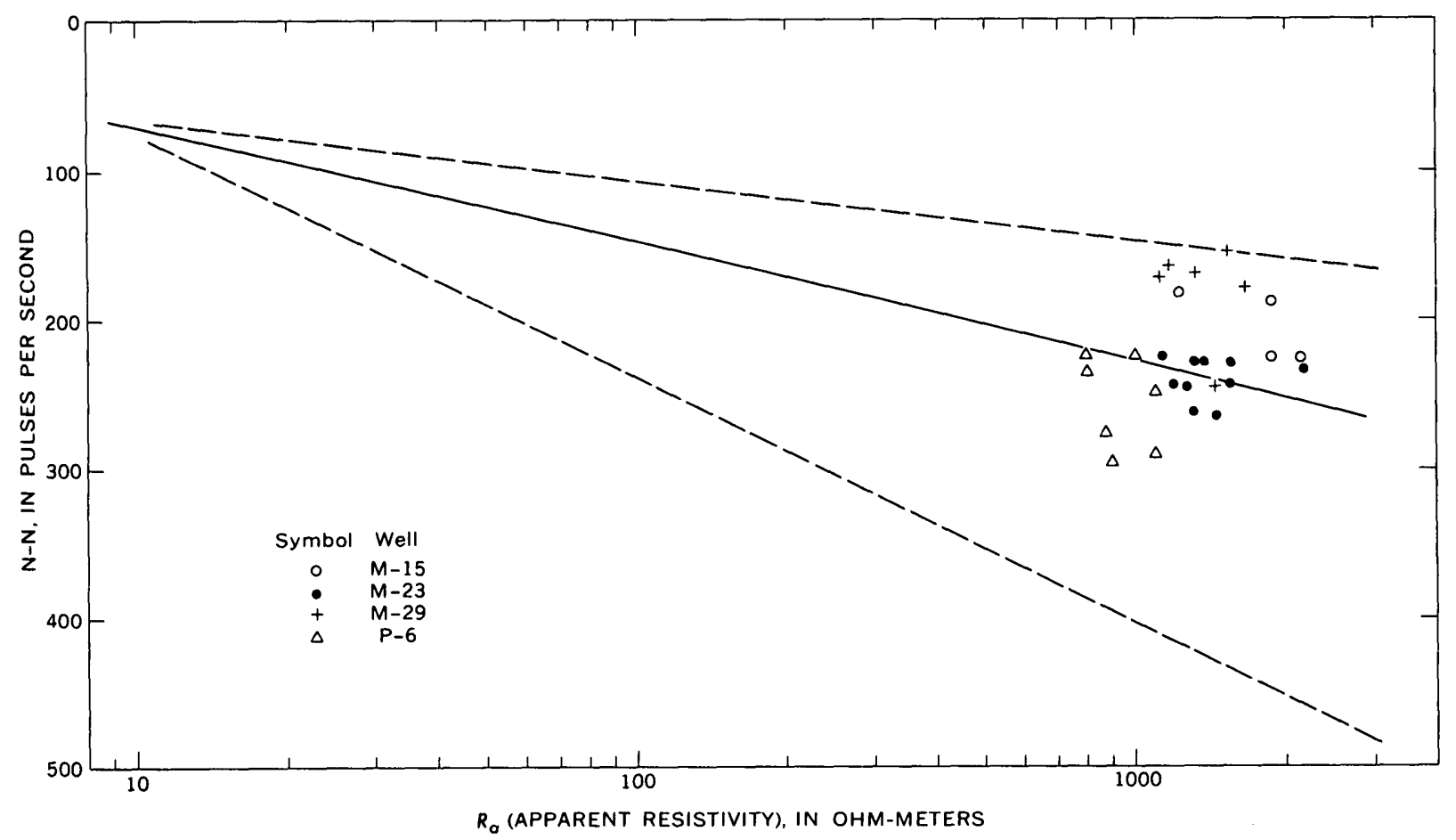

Figure 2.-Apparent resistivity and neutron deflection in wells M-15, M-23, M-29, and P.6. Dashed lines same as in figure 1.

Table 1.-Value of $\mathrm{R}_{\mathrm{a}}, \mathrm{R}_{\mathrm{o}}, \mathrm{R}_{\mathrm{W}}, \mathrm{F}$, and $\phi$ for wells in the Lockport Dolomite of Ohio

\begin{tabular}{|c|c|c|c|c|c|c|c|c|}
\hline $\begin{array}{l}\text { Well } \\
\text { No. }\end{array}$ & $\begin{array}{l}\text { Depth } \\
\text { interval } \\
\text { sampled } \\
\text { (feet) }\end{array}$ & $\begin{array}{c}R_{a} \text { at } \\
\text { borehole } \\
\text { temperature } \\
\text { (ohm-meters) }\end{array}$ & $\begin{array}{c}R_{a} \text { at } \\
25^{\circ} \mathrm{C} \\
\text { (ohm-meters) }\end{array}$ & $\begin{array}{c}R_{o} \text { from } \\
\text { Dakhnov }{ }^{1} \\
\text { (ohm-meters) }\end{array}$ & $\begin{array}{c}R_{w} \text { at } \\
25^{\circ} \mathrm{C} \\
\text { (ohm-meters) }\end{array}$ & $F$ & 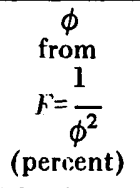 & $\begin{array}{c}\phi \\
\text { from } \\
\text { neutron logs } \\
\text { (fig. 5) } \\
\text { (percent) }\end{array}$ \\
\hline 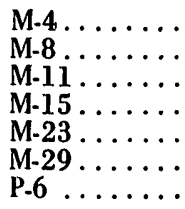 & $\begin{array}{l}160-250 \\
280-370 \\
360-410 \\
155-250 \\
180-280 \\
305-365 \\
330-400\end{array}$ & $\begin{array}{l}2,390 \\
1,775 \\
1,700 \\
2,400 \\
1,965 \\
1,910 \\
1,353\end{array}$ & $\begin{array}{r}1,690 \\
1,255 \\
1,204 \\
1,700 \\
1,387 \\
1,350 \\
\mathbf{9 5 7}\end{array}$ & $\begin{array}{r}1,230 \\
907 \\
890 \\
1,240 \\
1,020 \\
984 \\
699\end{array}$ & $\begin{array}{c}11.8 \\
10.3 \\
12.1 \\
10.7 \\
9.26 \\
8.2 \\
5.5\end{array}$ & $\begin{array}{r}104 \\
80 \\
74 \\
116 \\
110 \\
120 \\
127 \\
\end{array}$ & $\begin{array}{r}9.8 \\
11.2 \\
11.6 \\
9.3 \\
9.5 \\
9.1 \\
8.9\end{array}$ & $\begin{array}{r}10.7 \\
11.9 \\
11.4 \\
14.8 \\
10.0 \\
22.4 \\
8.1\end{array}$ \\
\hline & & & & & Average $=$ & 104 & & \\
\hline
\end{tabular}

${ }^{1}$ Dakhnov (1959, fig. 81).

cific conductance can be determined from legs, the corresponding dissolved solids at $25^{\circ} \mathrm{C}$ can be read from the graph. Similar graphs could be made for the dominant ions in order to estimate the concentrations of chemical constituents (Turcan, 1966).

The neutron and electric logs of M-7, a typical well penetrating the Lockport Dolomite, are shown in figure 4. Values for the 10-foot intervals between 220 and 320 feet, plotted on figure 1, show a similarity of response between the neutron and electric logs. The neutron $\log$ in figure 4 has a large excursion to the left, due to borehole enlargement, in the interval between 275 and 285 feet. Anomalous measurements of this type were discarded and not used for plotting data points on figures 1 and 2 . Several examples of the determina- tion of dissolved-solids content of water contained in the Lockport Dolomite aquifer by use of electric logs will help explain the method.

The average $R_{a}$ at borehole temperature for the interval from 220 to 320 feet, excluding the hole enlargement, is 1,075 ohm-m (from the 64-inch-normal curve for well M-7). Correcting this value for temperature and borehole conditions by use of any of the departure curves mentioned previously gives an $R_{o}$ of $553 \mathrm{ohm}-\mathrm{m}$. Using $F=104$, the average value for seven other wells (table 1), the $R_{w}$ is $5.3 \mathrm{ohm}-\mathrm{m}$ for well M-7. Using the relation specific conductance $=\frac{10,000}{R_{w}}$, a specific conductance of $1,885 \mu \mathrm{mhos} / \mathrm{cm}$ (micromhos per centimeter) is 


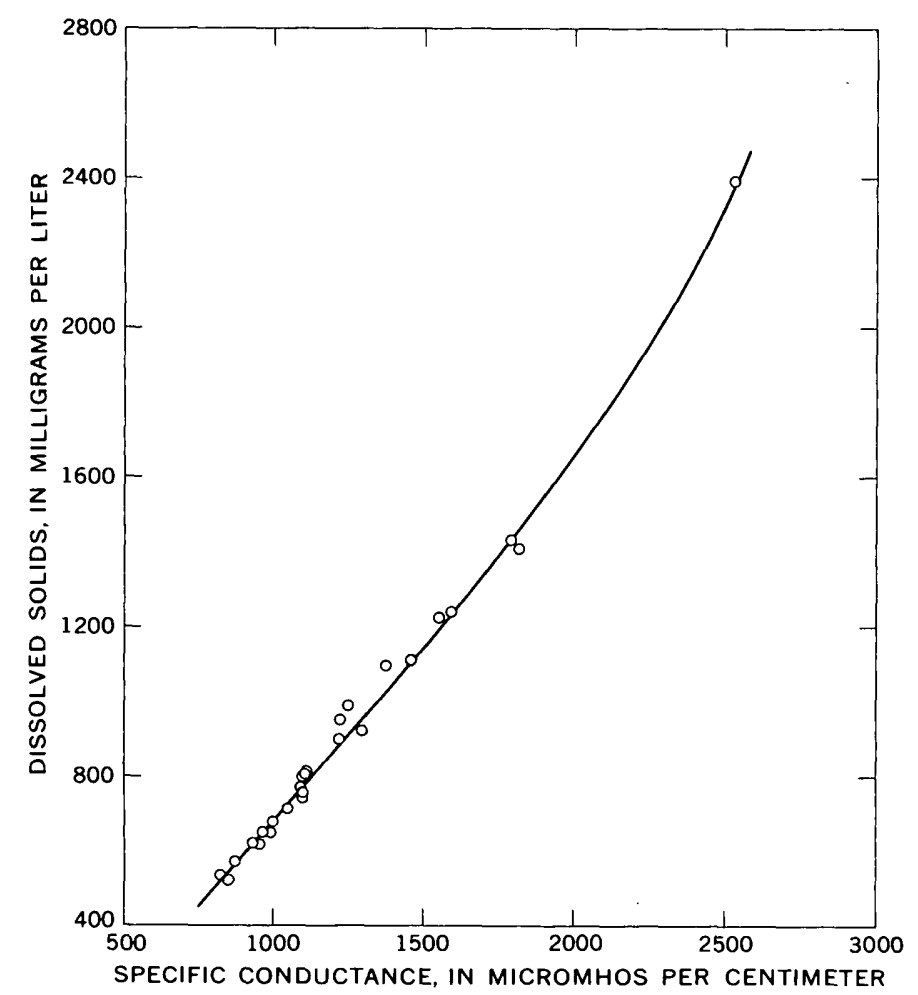

Figure 3.-Specific conductance and dissolved solids of water from 25 wells in Lockport Dolomite.

obtained for this water. Entering this value in figure 3 gives a dissolved-solids content of $1,540 \mathrm{mg} / 1$ (milligrams per liter). The specific conductance was $1,770 \mu \mathrm{mhos} / \mathrm{cm}$ and the dissolved solids $1,440 \mathrm{mg} / \mathrm{l}$, measured in water from the well. In another well, M-13, using an average $R_{o}$ of 705 ohm-m gives an $R_{w}$ of $6.8 \mathrm{ohm}-\mathrm{m}$. The log-derived specific conductance is $1,440 \mu \mathrm{mhos} / \mathrm{cm}$, and the dissolved-solids from figure 3 is $1,100 \mathrm{mg} / \mathrm{l}$. The actual laboratory-measured specific conductance was $1,370 \mu \mathrm{mhos} / \mathrm{cm}$ and the dissolved solids $1,090 \mathrm{mg} / \mathrm{l}$ for well M-13.

\section{POROSITY}

Ideally, porosity should be determined from laboratory analyses of rock cores; however, an approximate porosity calibration curve for the neutron $\log$ sometimes can be constructed by methods described by Wyllie $(1952,1963)$. Neutron logs are examined to find the widest dynamic range where the minimum neutron pulses-per-second count corresponds to the highest porosity and the maximum count corresponds to the lowest porosity. Ordinarily one can assume a porosity of $30-35$ percent in shales and 1-2 percent in dense limestone or anhydrite. The neutron deflection opposite the Lockport Dolomite's most dense bed, which also exhibited increasing $R_{o}$ with increasing neutron pulses per second, reached a maximum of 412 neutron pps. This bed was assumed to have a porosity of 1 percent. No representative
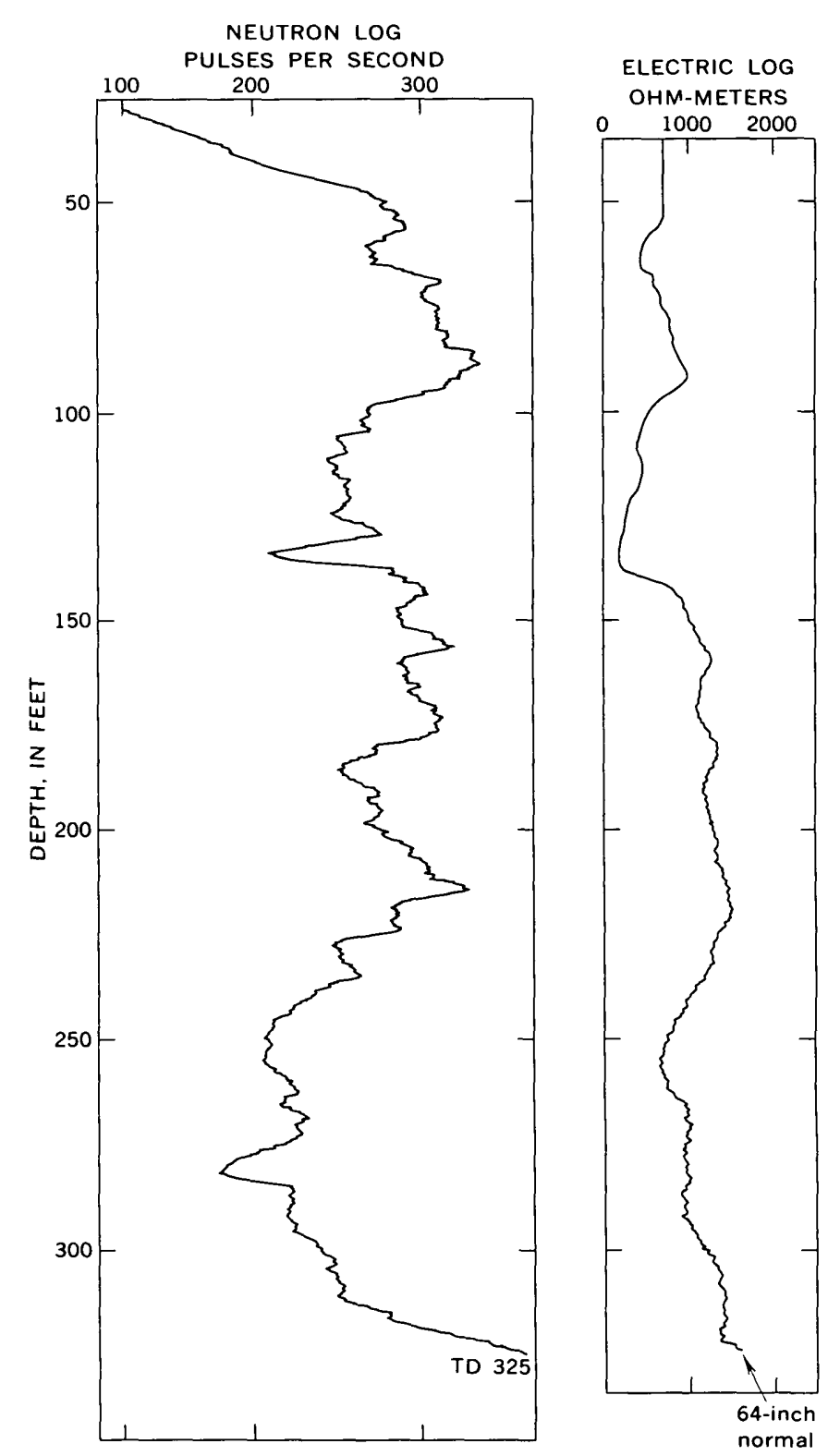

Figure 4.-Neutron and electric logs of well M-7.

shales were found on the gamma logs, so an alternative high porosity measurement was sought. Caliper logs of well M-13 showed a large cavity between the 176- and 188-foot levels, with a diameter in excess of 2 feet. The nuclear counter registered 65 neutron pps in this cavity, by far the lowest value measured in any well. It was assumed that the value of 65 pps approached but did not quite reach a porosity of 100 percent. With the approximate maximum and minimum neutron deflections determined, the neutron-porosity line in figure 5 was drawn. This line is constructed between the point at 4.12 pps representing the estimated 1-percent porosity and the point at 65 pps representing the estimated 100-percent porosity. The curve is virtually the same one that would result by drawing a straight line between equivalent points on Schlumberger chart C-18 (Schlumberger, 1966). In theory, any 


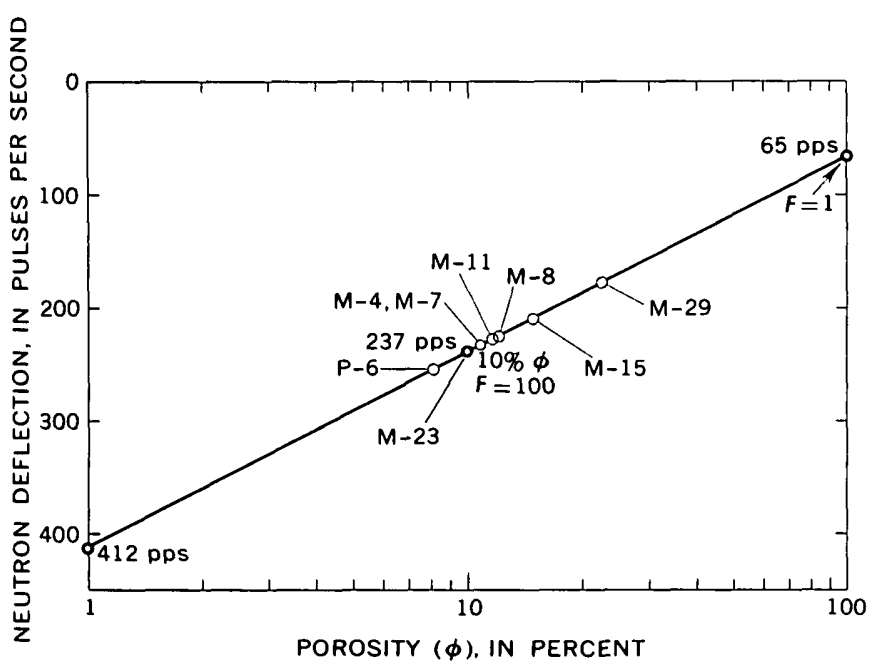

Figure 5.-Neutron-porosity relationship for wells in the Lockport Dolomite. $F$, formation factor.

neutron response in pulses per second in the Ohio wells is related to an equivalent porosity. The neutron porosities for the seven wells in table 1 and well M-7 were determined by plotting average neutron pulses per second on the calibration curve of figure 5 .

Two points on figure 5 are needed to establısh the position of the neutron-formation factor line in figure 6. For convenience the porosity values of 100 percent and 10 percent are used in the formula $F=\phi^{m}$, with exponent $m$ equal to 2 . When $\phi=1.00$ percent the value of $F$ is 1 , and when $\phi=10$ percent the value of $F$ is 100 . The 100-percent porosity value occurs at $65 \mathrm{pps}$ and $F=1$ on the scales in figure 6 , and the 10 -percent porosity value occurs at 237 pps and $F=100$, taken directly from the 10 -percent porosity point in figure 5 .
Drawing a line through these two points establishes the position of the neutron-formation factor line for an exponent $m$ of 2. Also drawn on figure 6 are dashed lines showing the same porosity points of 100 percent and 10 percent when the cementation exponent $m$ is equal to 3 and 1.7 , the limits of cementation suggested by Traugott (1970).

The well-data points on figure 6 are based on the formation factors from the resistivity values in table 1 and the corresponding average neutron pulses per second for these intervals. Also shown on figure 6 is the same information for well M-7. The porosity from the neutron $\log$ of M-7 is 10.7 percent and the porosity using a value for $F$ of 132 is 8.7 percent. Likewise, the two porosity columns in table 1 show, with two exceptions, fairly good agreement between the $\phi$ calculated from values of $F$ (from resistivity logs) and the $\phi$ derived from neutron logs (see figure 5). Two wells, M-15 and M-29, plot at higher values of $m$ on figure 6 than the rest of the Ohio wells, and their $F$-derived porosities depart markedly from the neutron porosities. If new values of $m$ are estimated from figure $6(m=2.5$ for $M-15$ and $m=3$ for M-29) the porosities from $F=\frac{1}{\phi^{m}}$ become 14.9 percent for M-15 and 20.3 percent for M-29. These values agree well with the neutron-derived porosities in table 1. Lacking other data, it is not possible to say which porosity method gives values closest to the actual porosity. A graph of neutron response and formation factor, as in figure 6 , is useful because once the neutron logs in several holes are calibrated with resistivity logs, formation factors can be estimated implicitly from neutron logs in other holes in the same hydrologic environment.

Without data from core samples to determine the upper and lower porosity limits of the neutron deflection, the value of this neutron calibration method is severely limited because

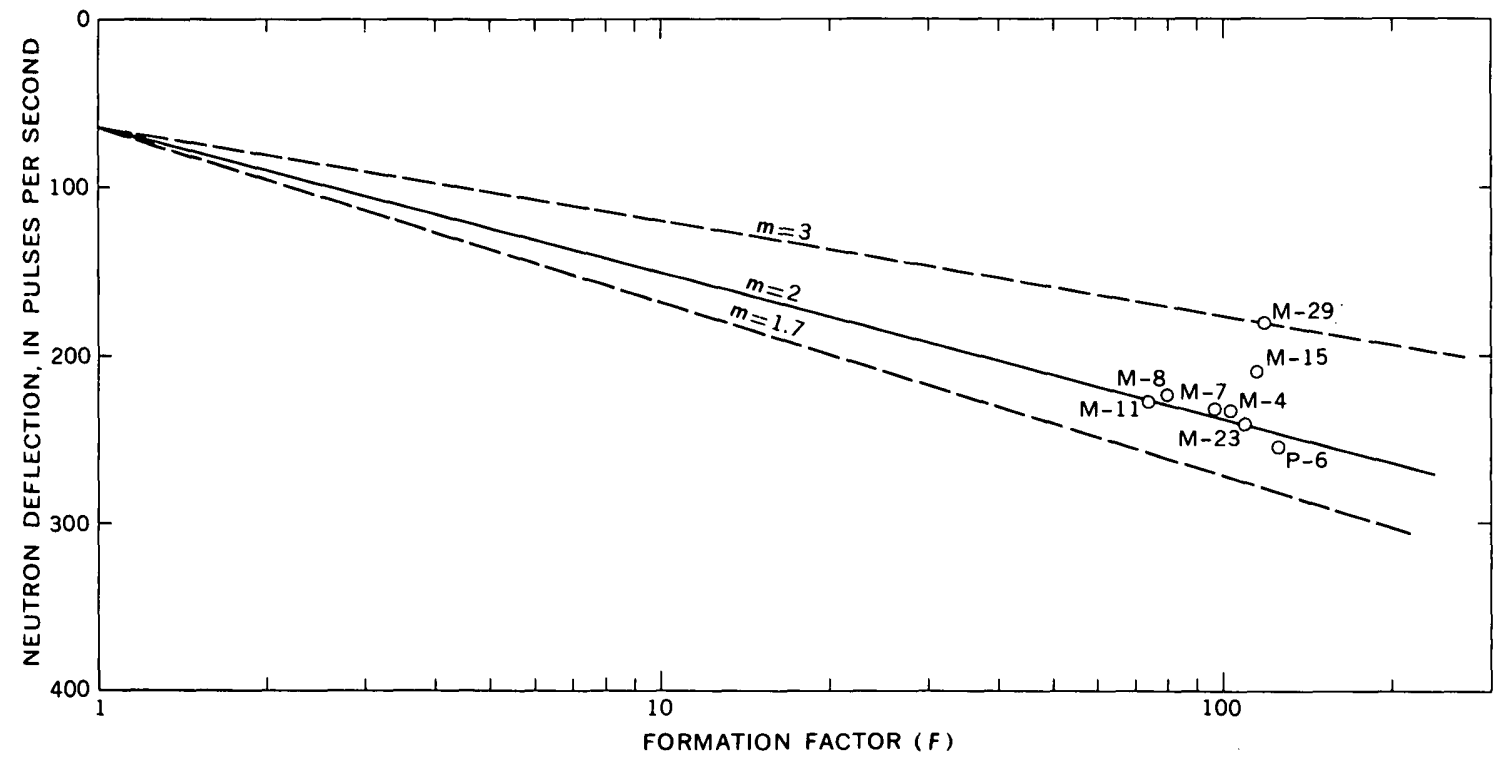

Figure 6.-Neutron-formation factor relationship for wells in the Lockport Dolomite. $m$, cementation exponent. 
many assumptions are made. The method may have some merit when applied to zones exhibiting good linearity between neutron and resistivity response, a smooth borehole, and a uniform lithology undisturbed by radical departures in bulk density. Archie (1952) discussed many of the problems related to porosity determinations in carbonate rocks, not the least of which is his "geometrical problem." According to Archie (1952, p. 287)

One of the most difficult problems involves an analysis of thin, porous layers imbedded between layers of low porosity. This condition is the rule rather than the exception for limestone since few limestones are known where the porosity is uniform over a vertical interval of a few feet or more.

In spite of these difficulties, a relationship between $F$ and $\phi$ for carbonates can be established in some instances. The relationship is similar to that for sandstones except that greater variation occurs owing to the greater heterogeneity of limestone pore geometry. Archie also showed several plots of the relationship between $F$ and $\phi$ for compact crystalline limestone over the porosity range from 5 to 30 percent. Perhaps the porosity range shown in table 1 for selected intervals in the Lockport Dolomite is in the right order of magnitude.

\section{PERMEABILITY}

Permeabilities of carbonate rocks determined from the methods described by Croft (1971) may give an inaccurate picture of the permeabilities of the more productive zones. Generally the most permeable sections of carbonate aquifers occur along joints, fractures, and bedding planes that have been enlarged by ground-water solution. Because the borehole enlarges at these places, the geophysical logs are severely affected and give inconclusive measurements. For this reason, the caliper tool is frequently needed to find hole enlargements, which usually are related to high permeability in carbonate rocks. Packer tests and borehole flowmeter studies will help verify permeable zones located from a study of caliper logs.

Geophysical studies of the Ohio test wells showed that, except for those within the high-yield area of Norris and Fidler (1971), many wells penetrate relatively uniform, dense dolomite with little variation in hole size. Although many dolomite zones in these low-yield wells simulate cemented clastic rocks, permeability estimations are difficult owing to the variability of carbonate porosity. One of Croft's figures, a graph of $F$ and permeability adapted from Alger (1966), is based on sand samples of constant porosity. The well-data points in figure 5 show the range in porosities in the dolomite intervals that satisfy the various criteria described previously. When all types of dolomite porosity are included (vugular, joint, solutional, intergranular) the log-derived porosities range from 1 percent to nearly 40 percent.

A graph of $F$ and permeability measured on cores of known porosities would be the best method to establish the relation- ship for $F$ values determined from logs. Several graphs would result, each curve relating $F$ and permeability at a given porosity. Tentative plots of log-derived $F$ and permeabilities from pumping tests in the Ohio wells indicate that several permeability values can be found at the same $F$ value, depending on the estimated percentage and type of porosity of the dolomite zone analyzed.

In the absence of core-derived values, no useful relationship between $F$ and permeability could be established owing to the wide range in pore geometry possible in any well penetrating the dolomite.

\section{CONCLUSIONS}

This study of the Lockport Dolomite indicates that within limits, for carefully chosen sections, water quality can be determined from resistivity curves, and an estimate of porosity can be made by analysis of neutron-epithermal neutron logs in conjunction with the resistivity curve. However, straight-line relationships between formation factor and permeability could not be established because of complex pore geometry in highly permeable sections of the aquifer and because of the great variability in porosity in those sections that could be considered somewhat comparable to cemented clastic rocks.

Geophysical logs of carbonate rocks are more difficult to analyze than those of clastic rocks. For this reason additional tests are planned for other carbonate aquifers in the continuing belief that a useful relationship can be found. The use of other methods to obtain porosity is strongly endorsed. Not only should cores be cut and analyzed but the acousticvelocity $\log$ and the side-collimated gamma-gamma logs should also be used to determine porosity independently of the neutron-resistivity studies. Focused-resistivity devices would be useful to obtain $R_{o}$ for thin, highly resistive beds. With these alternatives, the user of empirical methods derived from neutron-electric log analysis will have an independent means to check his results.

\section{REFERENCES}

Alger, R. P., 1966, Interpretation of electric logs in fresh water wells in unconsolidated formations, in Soc. Prof. Well Log Analysts, Logging Symposium, 7th Ann., Tulsa, Okla., May 1966, Trans.: Houston, Tex., Soc. Prof. Well Log Analysts, p. CCI-CC25.

Archie, G. E., 1942, The electrical resistivity $\log$ as an aid in determining some reservoir characteristics: Am. Inst. Mining Metall. Engineers, Trans., v. 146, p. 54-62.

- 1952, Classification of carbonate reservoir rocks and petrophysical considerations: Am. Assoc. Petroleum Geologists Bull., v. 36, no. 2, p. 278-298.

Croft, M. G., 1971, A method of calculating permeability from electric logs, in Geological Survey Research 1971: U.S. Geol. Survey Prof. Paper 750-B, p. B265-B269.

Dakhnov, V. N., 1959, Geophysical well logging [translated from Russian edition, 1962, by G. V. Keller]: Colorado School Mines Quart., v. 57, no. 2, 445 p. 
Keller, G. V., and Frischknecht, F. C., 1966, Electrical methods in geophysical prospecting, v. 10 of International series of monographs in electromagnetic waves: New York, Pergamon Press, $519 \mathrm{p}$.

Norris, S. E., and Fidler, R. E., 1969, Correlation of carbonate rock units in northwest Ohio by natural gamma logging, in Geological Survey Research 1969: U.S. Geol. Survey Prof. Paper 650-B, p. B158-B161.

1971, Availability of ground water from limestone and dolomite aquifers in northwest Ohio and its relation to geologic structure, in Geological Survey Research 1971: U.S. Geol. Survey Prof. Paper 750-B, p. B229-B235.

Schlumberger Well Surveying Corporation, 1956, Log interpretation charts: Tulsa, Okla., Schlumberger Well Surveying Corp., Oklahoma Division.

1966, Log interpretation charts: Houston, Tex., Schlumberger Well Surveying Corp.

Schlumberger Limited, 1969, Log interpretation charts: Houston, Tex., Schlumberger Well Services.
Stout, Wilber, 1941, Dolomites and limestones of western Ohio: Ohio Div. Geol. Survey Bull. 42, 4th ser., 468 p.

Traugott, M. 0., 1970, Log evaluation of a heterogeneous carbonate reservoir, Cato San Andres Field, in Soc. Prof. Well Log Analysts, Logging Symposium, 11th Ann, Los Angeles, Calif., May 1970, Trans: Houston, Tex., Soc. Prof. Well Log Analysts, p. E1-E9.

Turcan, A. N., Jr., 1966, Calculation of water quality from electrical logs--theory and practice: Louisiana Geol. Survey and Dept. Public Works Water Resources Pamph. 19, 23 p.

Welex, A division of Halliburton Company, 1962, Charts for the interpretation of well logs (Welex Bull. A 133): Houston, Tex., Welex, A Division of Halliburton Company, $72 \mathrm{p}$.

Wyllie, M. R. J., 1952, Procedures for the direct employment of neutron log data in electric log interpretation: Geophysics, v. 17, no. 4 , p. $790-805$.

1963, The fundamentals of well log interpretation, $3 \mathrm{~d}$ ed. revised: New York, Academic Press, 238 p. 


\title{
RECONNAISSANCE OF GROUND-WATER SUPPLIES FROM BEDROCK IN THE METLAKATLA PENINSULA, ANNETTE ISLAND, ALASKA
}

\author{
By MELVIN V. MARCHER, Oklahoma City, Okla.
}

\author{
Work done in cooperation with the Federal Aviation Administration
}

\begin{abstract}
Bedrock in the western part of Annette Island, herein referred to as the Metlakatla peninsula, consists of igneous and metamorphic rocks that yield water only from fractures. A test well, 362 feet deep, obtained water between 305 and 362 feet. Initial production of the well was $100 \mathrm{gpm}$ (gallons per minute), but results from a 12-hour recovery test suggested that this rate probably could not be maintained because of hydrologic boundaries. When the well was pumped continuously at a rate of $35 \mathrm{gpm}$ for more than 3 months, the water level declined 125 feet at an average rate of 0.6 foot per day to about 115 feet below sea level. Chemical analyses show that ground water is a sodium bicarbonate type. During pumping of the test well, the chloride content of the water increased from 75 to $222 \mathrm{mg} / \mathrm{l}$ (milligrams per liter) indicating that salt water was entering the aquifer.
\end{abstract}

Although annual precipitation in southeastern Alaska is as much as 269 inches, the igneous and metamorphic rocks underlying most of the region generally yield only small amounts of water. This report describes the results of a project to develop ground-water supplies from bedrock on Annette Island. Some of the conclusions derived from the project are applicable to other areas because the climate, topography, and geology of the island are typical of much of southeastern Alaska.

As a major part of the project, five small-diameter holes were drilled to determine the subsurface distribution of fracture zones and, where possible, to test the water-yielding capabilities of each zone. Drill hole 5 had the greatest potential as a source of water and, therefore, was redrilled as a test well. Each water-bearing zone in this well was tested for yield, a water sample collected for chemical analysis, and, upon completion of drilling, a 12-hour recovery test was made.

Interbedded gravel, sand, silt, and clay interpreted as raised beach deposits, which may be potential sources of ground water, were studied in some detail and are described more fully in a companion paper (Marcher, 1971) (p. D202-D205, this chapter).

\section{GENERAL SETTING}

Annette Island is in extreme southeastern Alaska (fig. 1). The western part of the island, an area of about 20 square miles herein referred to as the Metlakatla peninsula, is mostly a swampy, heavily vegetated lowland generally less than 200 feet above sea level.

Annette Island lies in the Wrangell-Revillagigedo belt of metamorphic rocks (Buddington and Chapin, 1929, p. 181-183). Mapping by Berg (1969) shows that bedrock in the Metlakatla peninsula is chiefly schist, gneiss, and hornfels. These rocks are locally mixed and in part gradational with, foliated granitic rocks, which, in turn, grade into foliated quartz diorite and diorite. An area of about 1.5 square miles in the vicinity of Yellow Hill is underlain by dunite and pyroxenite. Sedimentary rocks include muck, glacial till, and raised beach deposits.

\section{GROUND WATER IN BEDROCK}

\section{Bedrock fractures}

The number, spacing, attitude, size, and interconnection of fractures such as joints and faults control the occurrence, storage, and movement of ground water in bedrock in the Metlakatla peninsula. Observations, mainly along the beach, showed a wide variety in the degree and type of jointing. For example, in some areas three sets of uniform, well-developed joints in coarse-grained dioritic rocks intersect to produce sharply defined trihedral blocks. Elsewhere, similar rocks are rather thoroughly fractured but the fractures do not follow any discernible pattern. Measurements showed that the major sets of joints strike between N. $15^{\circ}$ E. and N. $15^{\circ} \mathrm{W}$. Other sets strike N. $25^{\circ}-35^{\circ}$ E. and N. $55^{\circ}-65^{\circ}$ W. Of 63 measurements of joint dips, about 47 percent dip at angles greater than $80^{\circ}$, and nearly 95 percent dip at angles greater than $45^{\circ}$.

A 23-foot drill core taken from drill hole 4 from a depth of 


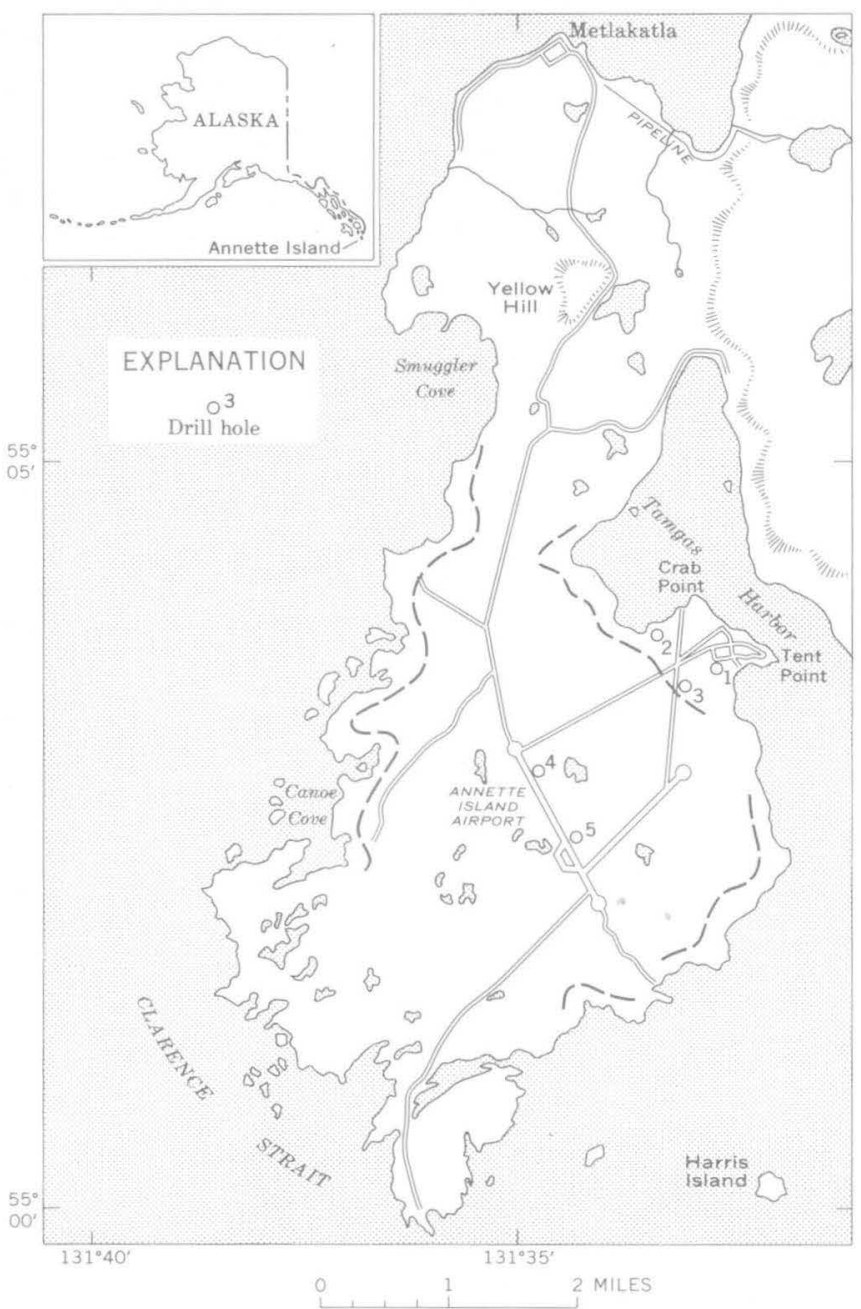

Figure 1.-Map of Metlakatla peninsula, Annette Island, Alaska, showing location of drill holes.

47-70 feet provided information on shallow subsurface joints. This core showed about 70 joints for an average of about three per foot. The width of these joints ranges from a hairline to about one-sixteenth inch, and many were partly or completely healed with quartz. Where the fractures were not fairly well healed, the core broke and the width of the fractures could not be determined. Because most of the fractures had been healed or were very narrow, the test hole did not yield a significant amount of water.

Highly fractured ultrabasic rocks south of Yellow Hill provide openings for seeps and small springs. Other small seeps issue from fractured rocks along the west side of the peninsula; these seeps undoubtedly go dry in the summer.

Rocks penetrated in the interval above 305 feet in the test well were nearly free of fractures, but zones of fractured rock were indicated below this depth by the difficulty experienced in maintaining a straight and round hole. Furthermore, the increase in well yield and reduction in drawdown described in the summary of test pumping suggest that the abundance of fractures increases with depth. The interval between 305 and 362 feet in the test well is interpreted as a fault zone because normally the number of fractures decreases with depth. Even though a fault zone may yield the major supply of ground water to the well, most recharge to the faults probably takes place through overlying jointed rock.

\section{Test drilling and pumping}

Results of test drilling and yield tests are summarized as follows:

Drill hole 1 reached a total depth of 295 feet and was abandoned because brackish water was obtained at that depth. A water-bearing zone, between 86 and 126 feet, was tested by pumping with air for 12 hours at a rate of one third gpm (gallon per minute).

Drill hole 2 reached a total depth of 113 feet. A waterbearing zone between 94 and 96 feet was tested by pumping with air at a rate of one-half gpm that increased to $1 \mathrm{gpm}$ after 30 hours.

Drill hole 3 reached a total depth of 215 feet. A waterbearing zone between 92 and 95 feet was pumped with air at a rate of two-thirds gpm for 4 hours but did not increase in yield.

Drill hole 4 reached a depth of 104 feet, but no water was obtained.

Drill hole 5 was drilled using a core drill to a depth of 305 feet. The hole was then redrilled for a test well to a depth of 362 feet using a 6 -inch churn drill. The results of testing the various water-bearing zones in this well are summarized below.

\section{Depth \\ (feet) \\ Summary of testing}

$70-90 \ldots$. Pumped with air $1 / 2 \mathrm{gpm}$ for 8 hours. Cemented in after pumping.

$109-121 \ldots$. . Pumped with air $2 / 3$ gpm for 8 hours. Cemented in after pumping.

$183-209 \ldots$. . Pumped with air $2 / 3$ gpm for 8 hours. Cemented in after pumping.

$272-282 \ldots$. . Pumped with air $12 / 3$ gpm for 8 hours. Cemented in after pumping.

297-305 .... Pumped with air $8 \mathrm{gpm}$ for 24 hours.

$305-313 \ldots \ldots$. Pumped with air $12 \frac{1}{2}$ gpm for 16 hours with 130 feet drawdown. Static level 10 feet.

$313-320 \ldots$. . . Pumped 16 hours at $30 \mathrm{gpm}$ with 94 feet of drawdown. Static level 13 feet.

$321-326 \ldots$. . Pumped 72 hours at $37 \mathrm{gpm}$ with drawdown of 80 feet. Static level 23 feet.

$332-336 \ldots$. . Pumped 23 hours at $37 \mathrm{gpm}$ with drawdown of 67 feet. Static level 23 feet.

Fresh ground water beneath Annette Island is in contact with sea water. Excessive lowering of the water table in a pumping well may cause salt water to enter and contaminate the aquifer. To forestall such a possibility, drawdown in the well must be carefully controlled.

To estimate the amount of drawdown after pumping the production well for an extended period of time and to estimate the long-term yield, a 12-hour recovery test was run. Analysis of the test data indicates that impermeable boundaries are present in the vicinity of the well and that the initial 
yield of $100 \mathrm{gpm}$ could not be maintained without excessive drawdown.

Subsequent to the recovery test a pump was installed in the well and operated almost continuously at a rate of $35 \mathrm{gpm}$ for more than 3 months. Water-level measurements made during this period, plotted against time, are shown in figure 2 . Examination of the drawdown curve shows that from a level of 127 feet shortly after pumping started, the water level declined to 206 feet after 100 days of pumping. Total drawdown from static level was 125 feet.

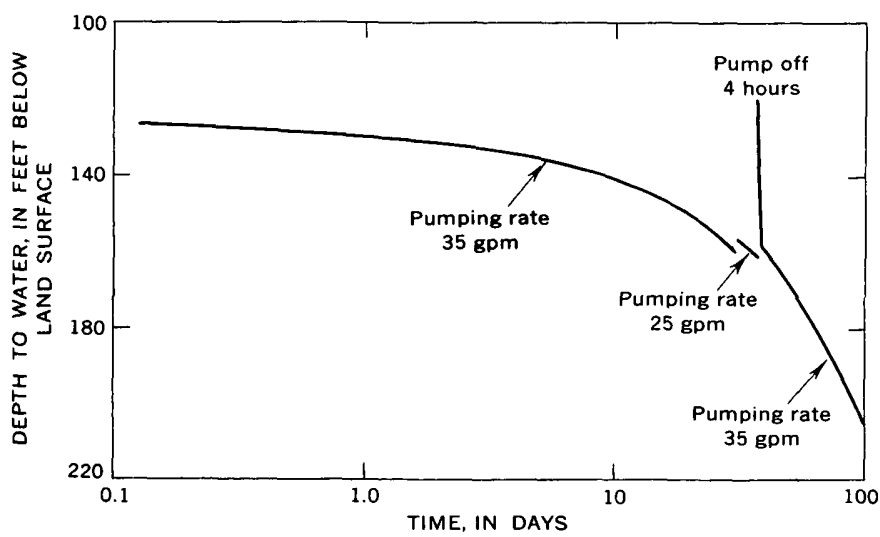

Figure 2.-Drawdown in the test well after pumping 100 days. Water level at start of pumping was 81 feet.
During the 3-month pumping period, the rate of drawdown was far in excess of that estimated on the basis of the test. Apparently the water-yielding zones are separated from one another and from surface recharge by considerable thicknesses of unfractured rock so that when they are drained of their stored water, replenishment takes place slowly. Hydrologic boundaries undoubtedly are present, because the fracture zones are not continuous and because the degree of fracturing along individual zones differs from place to place.

\section{Chemical quality}

At least one sample of water for chemical analysis was collected from each drill hole except number 4, and samples from four of the water-bearing zones in the test well were analyzed to determine variations in chemical quality with depth. Several samples were collected from the completed well after different periods of pumping and analyzed to determine changes in chemical quality that would indicate salt-water intrusion. The results of the analyses are given in table 1.

By plotting the results of the chemical analyses according to a method devised by Stiff (1951, p. 15-16), the gross chemical characteristics of the water can be compared as shown in figure 3.

Table 1.-Chemical analyses of ground water from Metlakatla peninsula, Annette Island, Alaska

[All analyses made by U.S. Geological Survey. Results in milligrams per liter except where indicated]

\begin{tabular}{|c|c|c|c|c|c|c|c|c|c|c|c|}
\hline $\begin{array}{c}\text { Source } \\
\text { of } \\
\text { water }\end{array}$ & $\begin{array}{c}\text { Date } \\
\text { of } \\
\text { collection }\end{array}$ & $\begin{array}{c}\text { Silica } \\
\left(\mathrm{SiO}_{2}\right)\end{array}$ & $\begin{array}{l}\text { Iron } \\
(\mathrm{Fe})\end{array}$ & $\begin{array}{l}\text { Calcium } \\
\text { (Ca) }\end{array}$ & $\begin{array}{l}\text { Magne- } \\
\text { sium } \\
(\mathrm{Mg})\end{array}$ & $\begin{array}{l}\text { Sodium } \\
\text { (Na) }\end{array}$ & $\begin{array}{l}\text { Potas- } \\
\text { ium } \\
(\mathrm{K})\end{array}$ & $\begin{array}{c}\text { Bicar- } \\
\text { bonate } \\
\left(\mathrm{HCO}_{3}\right)\end{array}$ & $\begin{array}{c}\text { Carbon- } \\
\text { ate } \\
\left(\mathrm{CO}_{3}\right)\end{array}$ & $\begin{array}{l}\text { Sulfate } \\
\left(\mathrm{SO}_{4}\right)\end{array}$ & $\begin{array}{l}\text { Chloride } \\
\text { (Cl) }\end{array}$ \\
\hline $\begin{array}{r}\text { Drill hole } 1 \\
\mathbf{3} \\
\mathbf{5} \\
\text { Test well . }\end{array}$ & 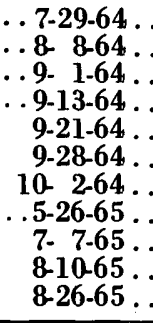 & $\begin{array}{lr}. & 2.7 \\
\therefore & 7.7 \\
\therefore & 20 \\
\therefore & 31 \\
\therefore & 25 \\
\therefore & 15 \\
\therefore & 15 \\
\therefore & 17 \\
\therefore & 18 \\
\therefore & 17 \\
. & 16 \\
\end{array}$ & $\begin{array}{l}0.43 \\
.60 \\
.40 \\
.73 \\
.27 \\
.25 \\
.04 \\
.29 \\
.02 \\
.00 \\
.2 \\
\end{array}$ & $\begin{array}{c}12 \\
6.4 \\
12 \\
7.2 \\
1.6 \\
1.6 \\
.8 \\
.0 \\
.0 \\
.0 \\
4\end{array}$ & $\begin{array}{r}14 \\
.5 \\
1.2 \\
3.2 \\
1.9 \\
2.4 \\
1.9 \\
7.1 \\
4.4 \\
3.9 \\
2.6 \\
\end{array}$ & $\begin{array}{r}720 \\
220 \\
200 \\
89 \\
105 \\
193 \\
200 \\
235 \\
276 \\
300 \\
300 \\
\end{array}$ & $\begin{array}{r}2.2 \\
.8 \\
.3 \\
1.7 \\
1.0 \\
6.7 \\
.6 \\
8.5 \\
9.2 \\
9.0 \\
8.8\end{array}$ & $\begin{array}{l}471 \\
551 \\
558 \\
235 \\
215 \\
404 \\
451 \\
493 \\
480 \\
487 \\
502 \\
\end{array}$ & $\begin{array}{r}24 \\
12 \\
0 \\
4 \\
12 \\
11 \\
17 \\
30 \\
22 \\
19 \\
18\end{array}$ & $\begin{array}{c}327 \\
7.2 \\
4.8 \\
6.1 \\
7.2 \\
3.8 \\
4.3 \\
6.7 \\
25 \\
16 \\
23 \\
\end{array}$ & $\begin{array}{c}642 \\
9.2 \\
5.7 \\
12 \\
14 \\
24 \\
42 \\
74 \\
125 \\
155 \\
172\end{array}$ \\
\hline $\begin{array}{c}\text { Source } \\
\text { of } \\
\text { water }\end{array}$ & $\begin{array}{c}\text { Date } \\
\text { of } \\
\text { collection }\end{array}$ & $\begin{array}{l}\text { Fluo- } \\
\text { ride } \\
\text { (F) }\end{array}$ & $\begin{array}{l}\text { Nitrate } \\
\left(\mathrm{NO}_{3}\right)\end{array}$ & $\begin{array}{c}\text { Dissolved } \\
\text { solids } \\
\text { (calcu- } \\
\text { lated) }\end{array}$ & $\begin{array}{c}\text { Hard- } \\
\text { ness } \\
\text { as } \\
\mathrm{CaCO}_{3}\end{array}$ & $\begin{array}{l}\text { Specific } \\
\text { conduct- } \\
\text { ance } \\
\text { (micro- } \\
\text { mhos) at } \\
25^{\circ} \mathrm{C}\end{array}$ & $\begin{array}{c}\mathrm{pH} \\
\text { (pH } \\
\text { units) }\end{array}$ & $\begin{array}{c}\text { Color } \\
\text { (Pt-Co } \\
\text { scale } \\
\text { units) }\end{array}$ & & Rema & \\
\hline $\begin{array}{r}\text { Drill hole } \mathbf{1} \\
\mathbf{2} \\
\mathbf{3} \\
\mathbf{5}\end{array}$ & $\begin{array}{r}7-29-64 \\
8-8-64 \\
9-1-64 \\
9-13-64 \\
9-21-64 \\
9-28-64 \\
10-2-64 \\
5-26-65 \\
7-7-65 \\
8-10-65\end{array}$ & $\begin{array}{rr}. & 1.2 \\
. & 1.1 \\
. & .1 \\
. & .1 \\
. & .1 \\
. & .2 \\
. & .2 \\
.2 & .2 \\
. & .2 \\
.3\end{array}$ & $\begin{array}{r}0.2 \\
.3 \\
.8 \\
.6 \\
1.2 \\
1.0 \\
.9 \\
.3 \\
.2 \\
.1\end{array}$ & $\begin{array}{r}\mathbf{1 , 9 7 0} \\
\mathbf{3 3 7} \\
\mathbf{5 2 0} \\
\mathbf{2 6 0} \\
\mathbf{2 8 7} \\
\mathbf{4 6 3} \\
\mathbf{5 0 6} \\
\mathbf{5 9 2} \\
\mathbf{7 0 5} \\
\mathbf{7 5 0}\end{array}$ & $\begin{array}{l}86 \\
18 \\
35 \\
31 \\
12 \\
14 \\
10 \\
29 \\
18 \\
16\end{array}$ & $\begin{array}{r}3,260 \\
859 \\
830 \\
434 \\
449 \\
758 \\
859 \\
958 \\
1,190 \\
1,290\end{array}$ & $\begin{array}{l}8.4 \\
8.3 \\
8.2 \\
8.4 \\
9.0 \\
9.0 \\
9.0 \\
8.9 \\
8.7 \\
8.7\end{array}$ & $\begin{array}{r}45 \\
50 \\
30 \\
30 \\
10 \\
10 \\
10 \\
12 \\
5 \\
5\end{array}$ & \multirow{2}{*}{\multicolumn{3}{|c|}{$\begin{array}{l}\text { Water from 86-126-foot zone. } \\
\text { Water from 94-96-foot zone. } \\
\text { Water from 92-95-foot zone. } \\
\text { Water from 109-121-foot zone. } \\
\text { Water from 183-209-foot zone. } \\
\text { Water from 272-282-foot zone. } \\
\text { Water from 297-305-foot zone. } \\
\text { After pumping 72 hours. } \\
\text { After pumping 730 hours. } \\
\text { After pumping about } 1,550 \\
\text { hours. } \\
\text { After pumping about } 1,900 \\
\text { hours. }\end{array}$}} \\
\hline . & $8-25-65$ & .2 & .1 & 782 & 21 & 1,355 & 8.6 & 10 & & & \\
\hline
\end{tabular}




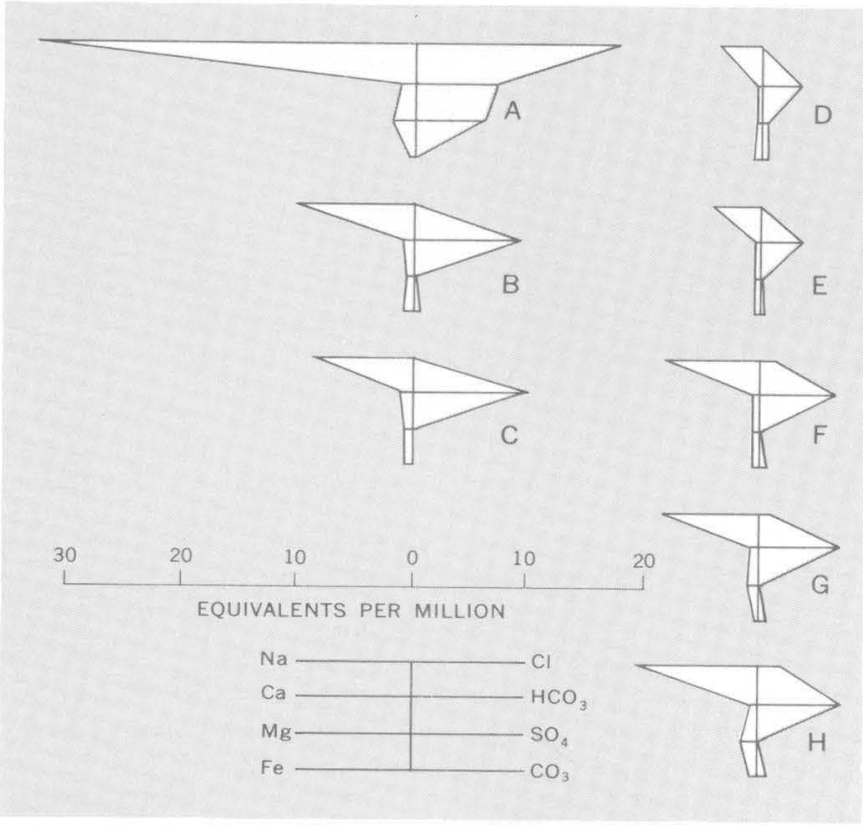

Figure 3.-Chemical characteristics of ground water from Metlakatla peninsula. A, drill hole $1 ; \mathrm{B}$, drill hole 2 ; $\mathrm{C}$, drill hole $3 ; \mathrm{D}$, drill hole 5 , 109-121 feet; E, drill hole 5, 183-209 feet; F, drill hole 5, 272-282 feet; G, drill hole 5, 297-305 feet; H, test well, composite of all producing zones.

Samples from drill holes 2 and 3 and the composite sample from the test well show that the water is a sodium bicarbonate type.

The high sodium, magnesium, sulfate, and chloride contents in water from drill hole 1 suggest admixture of sea water with normal ground water.

During drilling of the test well, samples were collected from water-bearing zones at depths of 109-121, 183-209, 272-282, and 297-305 feet. These samples were collected after the hole had been pumped to remove all drilling fluids, thereby assuring a representative water sample. After each sample was collected, the water-bearing zone was sealed with cement and drilling continued. Thus, each sample from above 305 feet represents water from a single fracture zone. Samples from below a depth of 305 feet are a composite of all water-bearing zones penetrated by the well.

Chemical analyses show that the concentration of some constituents changed little with depth (table 1). Other constituents, particularly sodium and bicarbonate, increased rather markedly with depth. These increases are presumably the result of the water being in contact with the rock longer as it slowly moves downward or incomplete flushing of sea water from deeper crevices.

Because of the potential hazard of salt-water intrusion with progressive lowering of the water level in the test well during pumping, samples were collected intermittently between April and October 1965 and tested for chloride content. Figure 4

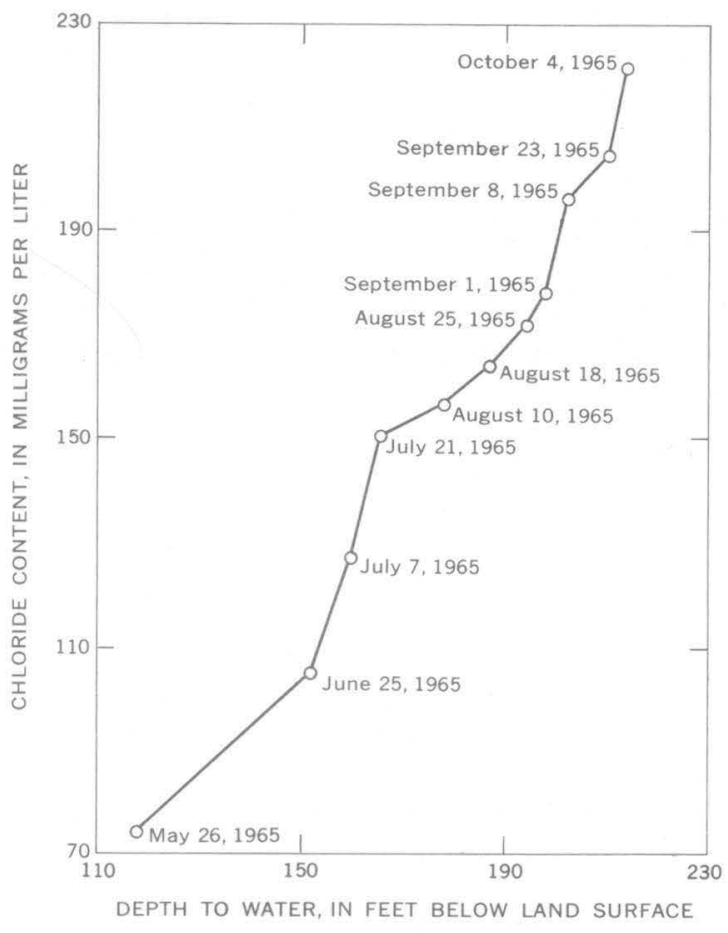

Figure 4.-Increase of chloride content of water in test well with increasing drawdown.

shows that the average chloride content increase was about 15 $\mathrm{mg} / \mathrm{l}$ for every 10 feet of drawdown.

\section{CONCLUSIONS}

Four out of five drill holes produced small amounts of water from bedrock in the Metlakatla peninsula; geologically similar terranes in southeastern Alaska also might be expected to provide small supplies. Fractured zones at depths of less than 150 feet are more likely to provide a continuing supply of water because recharge can take place more rapidly. Although the test well drilled during this study cannot be pumped continuously at a rate of $35 \mathrm{gpm}$, it will provide that amount intermittently. However, drawdown must be carefully controlled to prevent encroachment of salt water. Additional supplies may be available from fracture zones, which can be located only by test drilling.

\section{REFERENCES}

Berg, H. C., 1969, Preliminary geologic map of Annette Island, Alaska: U.S. Geol. Survey open-file rept., 1 sheet.

Buddington, A. F., and Chapin, Theodore, 1929, Geology and mineral deposits of southeastern Alaska: U.S. Geol. Survey Bull. 800, 398 p.

Marcher, M. V., 1971, Raised beach deposits and their ground-water potential in the southern part of the Metlakatla peninsula, Annette Island, Alaska, in Geological Survey Research 1971: U.S. Geol. Survey Prof. Paper 750-D, p. D202-D205.

Stiff, H. A., Jr., 1951, The interpretation of chemical water analysis by means of patterns: Jour. Petroleum Technology, v. 3, no. 10, sec. 1, p. $15-16$; sec. 2 , p. 3 . 


\title{
RAISED BEACH DEPOSITS AND THEIR GROUND-WATER POTENTIAL IN THE SOUTHERN PART OF THE METLAKATLA PENINSULA, ANNETTE ISLAND, ALASKA
}

\author{
By MELVIN V. MARCHER, Oklahoma City, Okla.
}

Work done in cooperation with the Federal Aviation Administration

\begin{abstract}
Interbedded layers of gravel and sand on the Metlakatla peninsula are interpreted as raised beach deposits derived largely from marine, glaciomarine, and glacial deposits reworked by waves and tidal currents. Such deposits and similar deposits elsewhere in southeastern Alaska may be potential sources of small ground-water supplies.
\end{abstract}

Ground-water supplies in bedrock of southeastern Alaska, which are described in a companion paper (Marcher, 1971) (p. D198-D201, this chapter), may be difficult and costly to locate. Thus, in some parts of the region the search for ground water is most logically directed toward locating alluvial or similar deposits sufficiently thick and permeable to store and yield water. Layers of gravel and sand that make up ancient beach deposits in some areas may be potential sources of water. These deposits are also potential sources of aggregate materials in a region where bedrock is almost every where at or near the surface.

As part of a project to locate water supplies on the Metlakatla peninsula, the raised beach deposits were studied briefly. Drill holes, scattered surface exposures, and excavations near Crab Point provide information on the thickness, stratigraphy, and general lithology of the deposits. Size analyses of surface samples and differential thermal analysis of a clay sample were made in the laboratories of the U.S. Geological Survey, Denver, Colo.

\section{DISTRIBUTION AND THICKNESS}

In regard to the inferred distribution of the raised beach deposits, L. A. Yehle reports (written commun., Nov. 1970) as follows:

** a 1:20,000 scale topographic map of the southern part of Metlakatla peninsula prepared in 1940 by the U.S. Geological Survey *** shows several levels of benches or terraces ***. Altitudinally, the lowest cluster of levels is up to about 30 to 35 feet above msl (mean sea level) and many others have their inner margin about 25 feet above msl. An intermediate cluster of bench or terrace levels is between about 50 and 55 feet above msl. A much less well developed, and higher, cluster of levels is between about 95 and 110 feet above msl. Between all these clusters of levels there are other scattered benches or terraces.

Yehle also notes (written commun., Nov. 1970) as follows:

At Metlakatla town, Dick Lemke and I noted sand and gravel underlying the ground surface up to an altitude of at least 50 feet above mean sea level. These (presumably) wave and tidal currentworked materials well may extend to slightly higher altitudes. In the central part of town there is a hint of a very minor break-in slope at about 35 feet above msl. In the western part of town this altitude is at the lower margin of a more prominent break-in slope. However, in the latter area, no data on materials are available.

Drill-hole records and scattered outcrops along streams in the southern part of the peninsula show that at least some of the benches noted by Yehle are underlain by raised beach deposits. The highest known raised beach deposits underlie a terrace at the 50-foot level at the site of drill hole 3 . The deposits are absent at higher levels in at least part of the area as shown by the logs of drill holes 4 and 5 (95 and 115 feet above sea level, respectively); both drill holes passed directly from muck into bedrock.

Drill-hole logs (table 1) show that raised beach deposits are as much as $\mathbf{5}$ feet thick. Exposures near the modern beach and in stream banks near the narrow part of the peninsula show that the deposits are at least 10-12 feet thick in this part of the area. Similar thicknesses were seen in construction excavations near Tent and Crab Points and in nearby surface outcrops.

\section{LITHOLOGY}

Drill-hole $\operatorname{logs}$ and surface exposures show the general lithology and stratigraphy of the raised beach deposits and indicate that lateral changes in lithology take place over short 
Table 1.-Driller's logs of drill holes penetrating raised beach deposits [Logs provided by A. J. Lappi, Federal Aviation Administration]

\begin{tabular}{|c|c|c|}
\hline & $\begin{array}{l}\text { ickness } \\
\text { (feet) }\end{array}$ & $\begin{array}{l}\text { Depth } \\
\text { (feet) }\end{array}$ \\
\hline \multicolumn{3}{|c|}{ Drill hole $1-$ Altitude 10 feet (altimeter) } \\
\hline $\begin{array}{l}\text { Rock fill } \\
\text { Muskeg and muck } \ldots \ldots \ldots \ldots \ldots \ldots \ldots \ldots \ldots \ldots \ldots \\
\text { Brown gravel and sand, some silty clay } \\
\text { (some water). } \\
\text { Granite }\end{array}$ & $\begin{array}{l}3 \\
4 \\
4 \\
\end{array}$ & $\begin{array}{l}0-3 \\
3-7 \\
7-11\end{array}$ \\
\hline
\end{tabular}

Drill hole 2-Altitude 15 feet (altimeter)

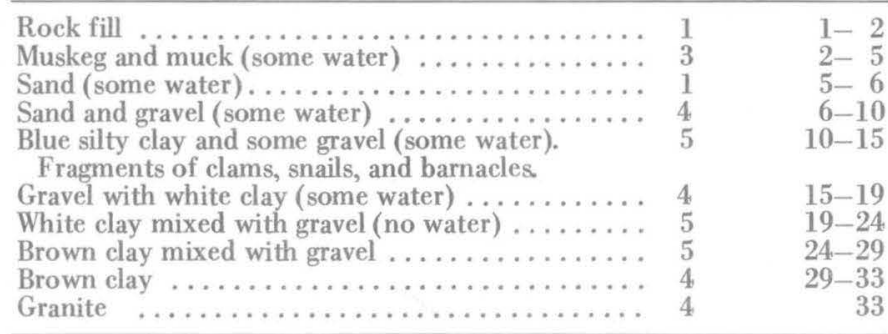

Granite $\ldots \ldots \ldots \ldots \ldots \ldots \ldots \ldots \ldots \ldots, 4 \ldots \ldots \ldots \ldots, 33$

Drill hole 3-Altitude 50 feet (altimeter)

Rock fill ..................... 2

Muskeg and muck (some water) ........... 6

Gravel (some water) $\ldots \ldots \ldots \ldots \ldots \ldots \ldots \ldots \ldots$

Blue silty clay $\ldots \ldots \ldots \ldots \ldots \ldots \ldots \ldots \ldots \ldots \ldots$

Blue silty clay mixed with gravel $\ldots \ldots \ldots \ldots \ldots \ldots$

Hardpan mixed with gravel ............ 8

Clay and some gravel ............... 3

Hardpan mixed with gravel (some water) ....... 4

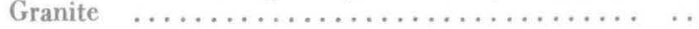

distances. At locality 21-5 (fig. 1) raised beach deposits, about 10 feet thick, exposed about 40 feet above tide level, consist mainly of interbedded layers and lenses of gravel, sand, silt, and clay containing cobbles up to 8 inches in diameter. Visual estimation indicates that about two-thirds of the gravel and cobbles are subangular and about one-third are subrounded to rounded. The upper 2 feet of the exposure is heavily stained by iron oxide and organic matter; within this interval a few layers less than 1 inch thick are weakly cemented by iron oxide. Size analysis of a grab sample from this locality shows that about 50 percent of the sample is larger than $4 \mathrm{~mm}$ (millimeters) in diameter (fig. 2). The particle-size distribution curve (fig. 2) shows that sorting is poor.

At locality 35-1 the raised beach deposits consist of 4-6 feet of sandy gravel overlying silty and clayey bluish-gray sand of unknown thickness. Analysis of a sample (35-1A) from the gravel shows that sorting is poor and that about 55 percent of the sample is larger than $4 \mathrm{~mm}$; the median particle size is between 5 and $6 \mathrm{~mm}$. The larger particles are subangular to well rounded; perhaps 30-50 percent subangular. Analysis of a sand sample (35-1B) from this locality shows that the sand has a sorting coefficient of 1.7 , indicating that it is well sorted. About 50 percent of the sample is in the fine and very fine size range; the medium size is $0.075 \mathrm{~mm}$.

The stratigraphic sequence at locality 36-1 consists of an unknown thickness of bluish-gray clay overlain by about 6 feet

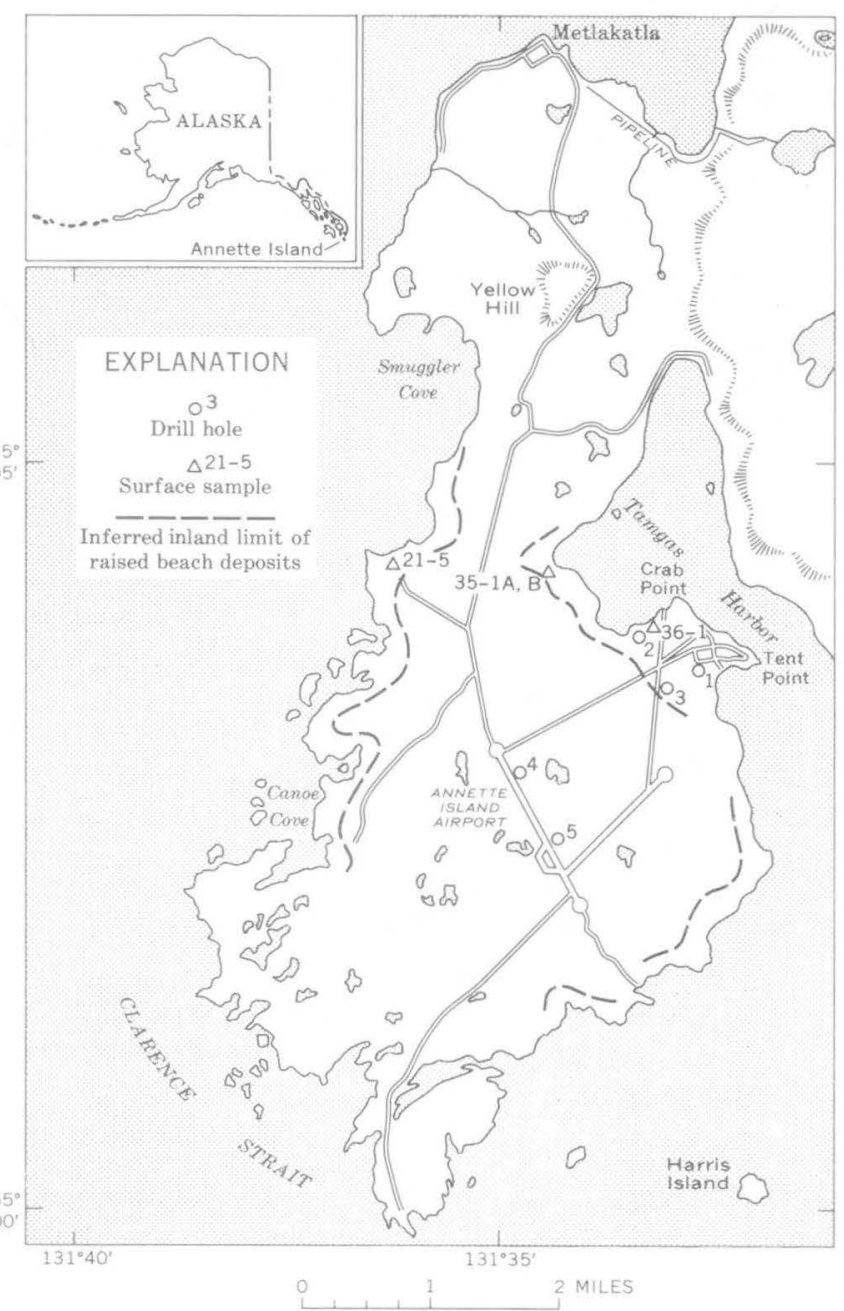

Figure 1.-Map of the Metlakatla peninsula, showing location of drill holes and surface samples, and inferred limit of raised beach deposits.

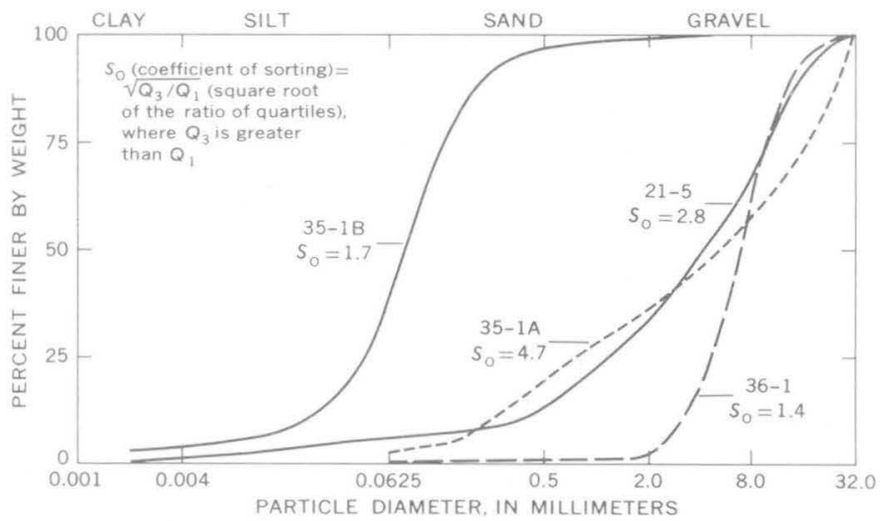

Figure 2.-Particle-size distribution of surface samples from raised beach deposits. See figure 1 for sample localities. 
of gravel which, in turn, is overlain by about 4 feet of organically rich muck. Near the middle of the gravel layer is a wedge of silty peat containing fragments of partly lignitized wood as much as 2 feet long. The gravel at this locality, in contrast to that of the other localities, is well sorted, as shown by a sorting coefficient of 1.4 , and most of the particles are subrounded to well rounded. About 80 percent of the sample is larger than $4 \mathrm{~mm}$, and the mediun size is about $7 \mathrm{~mm}$.

Differential thermal analysis of a clay sample from locality 36-1 shows that the clay is illite, a common constituent of both marine and glacial deposits (Grim, 1955, p. 484).

\section{ORIGIN}

The origin of the deposits herein referred to as raised beaches is reflected in their beltlike pattern of distribution and stratigraphy. Based on Chapin's suggestion (1918, p. 99) that the Metlakatla peninsula is a wave-cut bench, raised beach deposits are logically expected in this area. A more complex origin was postulated by Buddington (1927, p. 51) who suggested that the peninsula is largely the product of subaerial erosion and glaciation subsequently modified by marine erosion between successive uplifts. Periods of stable sea level would allow time for the accumulation of beach deposits, and uplift would preserve such deposits by removing them from the zone of wave erosion.

At least part of the raised beach deposits is derived by wave and tidal current erosion of marine or glaciomarine deposits. Indication of marine origin is provided by fossils, such as fragments of clams, snails, and barnacles in samples of silty clay from drill hole 2 at a depth of 11-14 feet. However, the clay contained no microfossils. Similar silty clay was penetrated in drill holes 1 and 3 , but no samples were collected; hence, the presence or absence of fossils in the deposits at these sites is not known.

Modern beach deposits on the Metlakatla peninsula appear to consist of both locally derived and exotic fragments. The older raised beach deposits, however, apparently consist of material derived mainly from glaciomarine and glacial deposits that have been reworked by wave and tidal current action. Modern beach gravel on Prince of Wales Island has been described by Sainsbury $(1961$, p. 332) who points out that the gravel is rounded and unstriated and that most of the rock-flour matrix has been removed. Sainsbury further states that typical glacial deposits could probably be found at shallow depth beneath many of the beaches. Material described in the logs of drill holes in Metlakatla peninsula suggests glacial material such as the hardpan noted in drill hole 3. However, no striated or faceted rock particles were recovered during test drilling nor were any noted in surface outcrops.

Information on uplift required to elevate the raised beach deposits above the zone of wave erosion, thus preserving them, is provided by Twenhofel $(1952$, p. 523-548) who reviewed and summarized the literature relating to shoreline changes along the Pacific coast of Alaska. Most of his evidence for uplift is based on fossil-bearing marine deposits, commonly derived from glacial and glaciomarine material and very similar to those in the Metlakatla peninsula. Twenhofel describes deposits that have been elevated from a few to several hundred feet above sea level and cites evidence obtained by previous workers to show that uplift has amounted to 500 feet or perhaps more in the Portland Canal and Juneau areas.

Hicks and Shofnos (1965, p. 3315-3320) present sea-level data to show that nearly all southeastern Alaska is rising. The center of uplift is in the vicinity of Glacier Bay about 320 miles north of Annette Island. At Ketchikan, only 15 miles north of Annette Island, uplift amounts to about 3 centimeters per century. Uplift on nearby Gravina Island has been as much as $\mathbf{8 0}$ feet as shown by marine fossils in blue clay and gravel at that altitude (Chapin, 1918, p. 99). Uplift can take place suddenly and dramatically as shown by more than 7 feet of uplift associated with the Alaskan earthquake of March 27, 1964 (Grantz and others, 1964, p. 4).

\section{WATER-SUPPLY POTENTIAL}

With average precipitation of 117 inches fairly well distributed throughout the year, the raised beach deposits on Metlakatla peninsula should receive nearly continuous recharge. However, the several feet of overlying muck are poorly permeable; thus the rate of recharge may be rather slow.

During an extended dry period the beach deposits at higher altitudes would drain first. Therefore, the most favorable sites for ground water from these deposits are in low areas but above the tidal range to eliminate the danger of contamination by salt water. Infiltration galleries in the raised beach deposits beside or beneath streams would probably be the best means of development. Horizontal galleries in trenches reaching bedrock and perpendicular to the direction of ground-water flow would intercept the greatest amount of water and would, therefore, provide the greatest yield. Methods of installing and maintaining infiltration galleries for developing shallow ground-water supplies have been described by Feulner (1964).

No analyses of water from the raised beach deposits were made during the study of the Metlakatla peninsula, but the chemical quality is probably good. Because the raised beach deposits are near the surface, they are subject to pollution; thus the area around an infiltration gallery would have to be protected. Dark color derived from decomposition of vegetation in the muskeg and muck may be a problem, although the color might be eliminated by special treatment.

\section{REFERENCES}

Buddington, A. F., 1927, Abandoned marine benches in southeastern Alaska: Am. Jour. Sci., 5th ser., v. 13, p. 45-52.

Chapin, Theodore, 1918, The structure and stratigraphy of Gravina and Revillagigedo Islands, Alaska: U.S. Geol. Survey Prof. Paper 120-D, p. 83-100. 
Feulner, A. J., 1964, Galleries and their use for development of shallow ground-water supplies, with special reference to Alaska: U.S. Geol. Survey Water-Supply Paper 1809-E, p. E1-E16.

Grantz, Arthur, Plafker, George, and Kachadoorian, Reuben, 1964, Alaska's Good Friday earthquake, March 27, 1964: U.S. Geol. Survey Circ. 491, 35 p.

Grim, R. E., 1955, Properties of clay, in Recent Marine Sediments-a symposium: Soc. Econ. Paleontologists and Mineralogists Spec. Pub. 4, p. 466-495.

Hicks, S. D., and Shofnos, William, 1965, The determination of land emergence from sea level observations in southeastern Alaska: Jour.
Geophys. Research, v. 70, p. 3315-3320.

Marcher, M. V., 1971, Reconnaissance of ground-water supplies from bedrock in the Metlakatla peninsula, Annette Island, Alaska, in Geological Survey Research 1971: U.S. Geol. Survey Prof. Paper 750-D, p. D198-D201.

Sainsbury, C. L., 1961, Geology of part of the Craig C-2 quadrangle and adjoining areas, Prince of Wales Island, southeastern Alaska: U.S. Geol. Survey Bull. 1058-H, p. 299-362.

Twenhofel, W. S., 1952, Recent shoreline changes along the Pacific coast of Alaska: Am. Jour. Sci., v. 250, no. 7, p. 523-548. 


\title{
COASTAL GROUND-WATER FLOW NEAR PONCE, PUERTO RICO
}

\author{
By G. D. BENNETT and E. V. GIUSTI, San Juan, P.R.
}

Work done in cooperation with the Puerto Rico Department of Public Works

\begin{abstract}
Electric-analog techniques were used to simulate groundwater flow in the alluvium on the south coast of Puerto Rico near Ponce. The flow simulations were taken in a vertical plane, using analog models of Teledeltos conducting paper. Anisotropy was simulated by distortion of the coordinates, and the fresh-water-sea-water interface was determined by trial and error cutting of the model. Models having an anisotropy, or ratio of lateral to vertical permeability, of 1,000 gave results that agreed well with field conditions. Two simulations were performed-one corresponding to high water-table conditions and one corresponding to low water-table conditions. The flow pattern in the aquifer oscillates seasonally between these two extremes, giving rise to a wide transition zone between fresh water and sea water.
\end{abstract}

The alluvium of the southern coastal plain of Puerto Rico forms a water-table aquifer of considerable economic importance. An investigation recently was conducted to determine the effects of a proposed floodway in the Rio Bucaná, near Ponce, on this aquifer. During the course of this investigation, steady-state electric-analog experiments were carried out in order to study the pattern of ground-water flow, in a vertical section, in the vicinity of the coast. This paper summarizes the results of these experiments.

\section{LOCATION AND HYDROLOGIC CHARACTERISTICS OF THE AREA}

The area shown in figure 1 was divided by N. E. McClymonds (written commun., 1971) into the indicated physiographic subregions. The area of the present study, enclosed by the heavy line in figure 1 , occupies parts of two of these physiographic subregions-the coastal plain and the coastal flats. Line NS is the section along which the analog simulations of flow in a vertical plane were taken.

Both the coastal plain and the coastal flats are areas of alluvium. McClymonds estimates the thickness of alluvium as 30-100 feet at the north edge of the coastal plain, increasing to $300-400$ feet near the shore. Data for the area near the coast are limited, however; the actual depth of alluvium in this vicinity is uncertain.

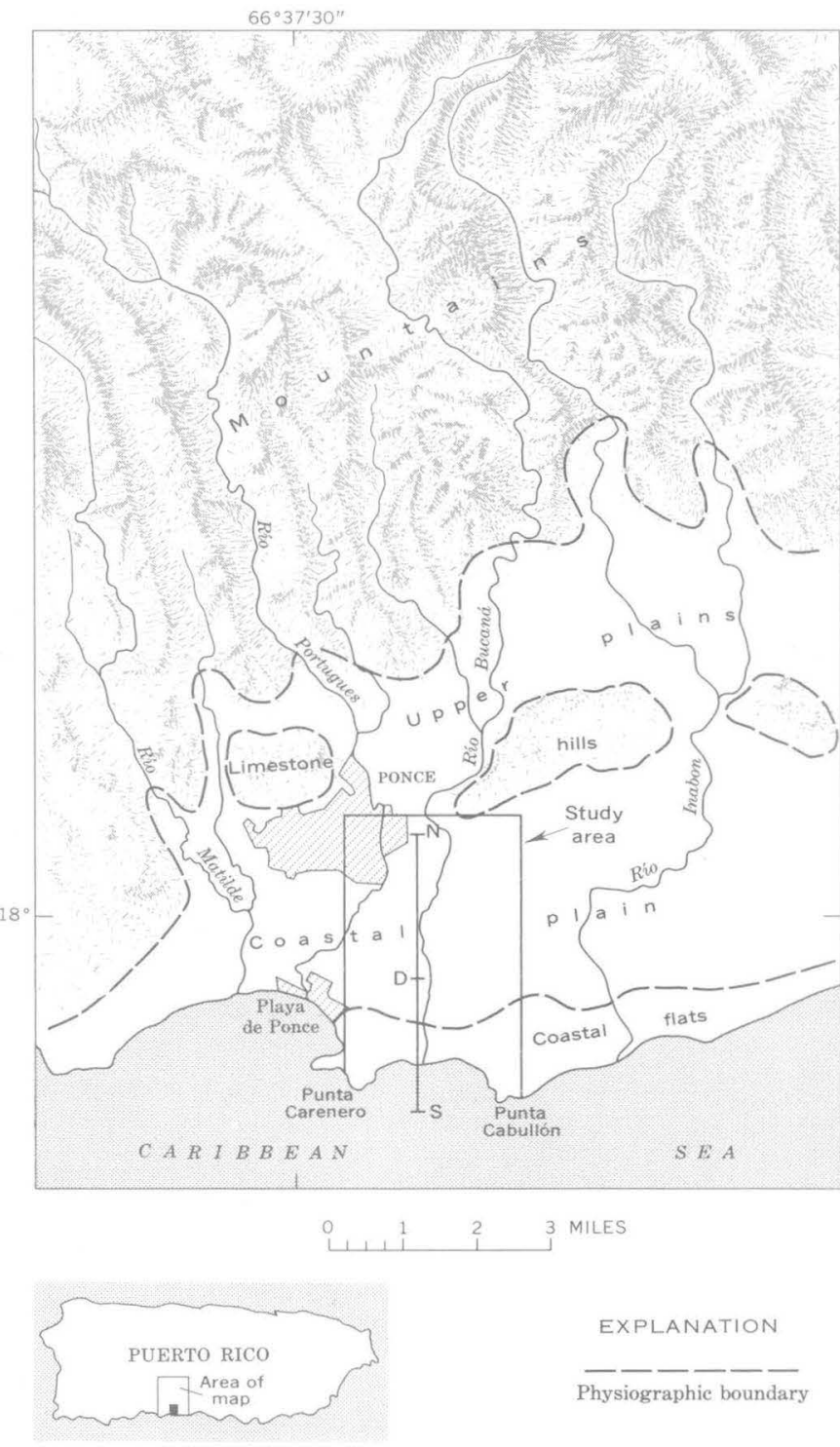

Figure 1.-Location and physiographic setting of study area, and section line (NS) of analog simulation. D, approximate boundary between net areal inflow (to the north) and net areal outflow. 
Except for the urban areas of Ponce, the coastal plain is largely devoted to sugarcane agriculture. Intensive irrigation is practiced, utilizing both surface water and ground water. Near the coast an extensive system of surface drains has been installed. This system provides both agricultural drainage and drainage of coastal swamps.

Areal recharge to the aquifer in the coastal plains and coastal flats occurs through the return flow of irrigation water, through infiltration of precipitation, and intermittently, during intervals of high flow, through seepage from the river. Areal discharge occurs through pumpage, flow into drains, direct evapotranspiration from the water table, and drainage to the river. In the northern part of the study area, from point $\mathrm{N}$ to the vicinity of point $D$ in figure 1 , recharge exceeds discharge, giving rise to a small net areal inflow. In the southern part of the area, from point $D$ to the shore in figure 1 , discharge exceeds recharge, creating a net areal outflow.

The areas designated as upper plains in figure 1 are regions of thin alluvial cover. Numerous storage reservoirs and canals have been constructed in these areas to serve the irrigation network. Seepage from these works and from the rivers causes the upper plains to be a recharge zone for the ground-water system. The prevailing direction of ground-water flow is to the south.

Limestone hills lie west, northwest, and northeast of Ponce, partly separating the coastal plain from the upper plains. The hydrologic significance of the limestone hills is not entirely clear; the limestone generally is low in permeability, but undoubtedly does transmit some ground water to the coastal alluvium. The bedrock surface immediately beneath the coastal alluvium also is probably limestone. If there is ground-water flow at depth within the bedrock, it occurs only in the northern part of the study area and is small relative to the flow in the alluvium. In this study, therefore, the bedrock surface was treated as an impervious base.

North of the upper plains, the topography is mountainous. Elevations reach 1,500 feet within a few miles of the edge of the plains. The mountains are of volcanic origin, and, except in a very shallow weathered zone, permeability is extremely small. Regional ground-water movement is negligible. Rainfall in this area is consumed in evapotranspiration or runs off. Annual precipitation is high in the mountains, which thus constitute a low-permeability area of heavy runoff. As this runoff enters the upper plains, it provides recharge to the ground-water system through seepage from streams and irrigation works.

In the mountains approximately 13 miles north of the coast, precipitation is about 100 inches per year. Annual precipitation decreases steadily to about 45 inches at the north edge of the upper plains and to about 35 inches at the shore. The precipitation is seasonal, both in the plains and in the mountains to the north. Heavy precipitation occurs from August through October and in May. Thus the recharge due to direct precipitation on the alluvium and that due to runoff from the mountains are both seasonal.

The aquifer is narrow. The north edge of the coastal plain is about 3 miles from the shore, and the north edge of the upper plains ranges from 5 to 9 miles from the shore. The small size of the aquifer is reflected in its storage capacity. Thus, water levels rise rapidly during wet periods and decline rapidly during dry periods. Changes in water level of 10-20 feet between rainy and dry seasons are common.

\section{CHARACTERISTICS OF THE ALLUVIUM}

The alluvial material ranges from clay to gravel. In the study area, the range from clay to medium sand predominates, although coarse sand and gravel is represented. The alluvium exhibits hydrologic properties typical of a stratified anisotropic unconfined aquifer. The average lateral hydraulic conductivity of the alluvium within the study area, as determined by a pumping test, is approximately 33 feet per day. The specific yield of the alluvium, as estimated by water-budget studies in an area some distance to the east, is about 0.15 .

\section{ANALOG TECHNIQUE}

The analog models were constructed of Teledeltos conducting paper. Figure 2 illustrates schematically their essential

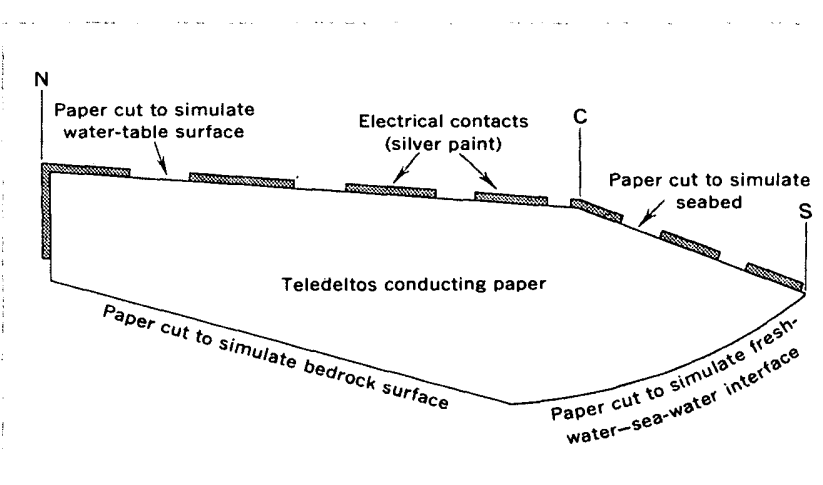

Figure 2-Essential features of Teledeltos paper analog. Point $\mathrm{C}$ corresponds to coastline.

components. The bedrock was assumed to be impermeable, and the lower left edge of each model was therefore cut to simulate a seaward dipping bedrock surface. The lower right (seaward) edge of each model was cut by trial and error during the course of the experiments to simulate a fresh-water-seawater interface, as determined using the relations of Hubbert (1940). The technique, somewhat similar to that described by Muskat (1937, p. 480-499) for the analog simulation of brine coning beneath oil wells, is explained more fully below.

Point $\mathrm{C}$ on figure 2 corresponds to the coastline. To the left of point $C$, the upper edge of the model was cut to simulate 
the shape of the water table; to the right of point $\mathrm{C}$, the upper edge was cut to simulate the seabed. Contacts of silver paint along the edge of the paper were used for input and output. To the left of point $\mathrm{C}$, each contact along the upper edge of the paper represented an interval along the water table. To the right of point $\mathrm{C}$, each contact represented an interval along the seabed, which forms an outflow face for the aquifer. A single contact was painted along the left vertical edge of the model. This contact provided an input to simulate ground-water inflow to the coastal sediments from the upper plains. In effect, the use of this contact introduced the assumption that equipotentials, or lines of constant head, are vertical toward the north edge of the coastal plain.

The potentials of contacts to the left of point $\mathrm{C}$ were adjusted in proportion to the average water-table elevation in the interval represented by the contact. The potentials of contacts to the right were adjusted in proportion to the equivalent fresh-water head represented by the column of sea water above the point simulated by the contact. For example, at a depth of 40 feet, the fresh-water head at the seabed, measured above sea level as datum, would be approximately 1 foot. A piezometer filled with fresh water and inserted to the seabed at this point would show a level approximately 1 foot above sea level. The relation used to compute fresh-water heads along the seabed is

$$
h_{f d}=\frac{\rho_{s}-\rho_{f}}{\rho_{f}} d,
$$

where $h_{f d}$ is the fresh-water head at a point on the seabed where the sea depth is $d, \rho_{s}$ is the density of sea water, $\rho_{f}$ is the density of fresh water, and sea level is taken as the head datum.

Figure 3 shows, schematically, the form of head distribution obtained by using this relation. The lowest head occurs just at the shoreline, on the water table, where $h_{f}=\mathbf{0}$, that is, where fresh-water head is just at sea level. Head increases both to landward and to seaward. It follows that the fresh-water discharge area generally will be distributed both to landward and to seaward of the shoreline, rather than solely to seaward, as is sometimes assumed.
The interface relation given by Hubbert (1940), which is used to compute the position of the transition to sea water at depth, is equivalent to equation 1 . Taking sea level as the head datum, it may be written

$$
h_{f i}=\frac{\rho_{s}-\rho_{f}}{\rho_{f}} d_{i}
$$

where now $h_{f i}$ is the fresh-water head at a point on the interface which is located at a depth $d_{i}$ below sea level. The other terms are as already defined.

Equation 2, like equation 1, is a statement of the fresh-water head distribution that must prevail in a region of static salt water. The assumption that the salt water is static is an approximation, as is the treatment of the fresh-water-seawater transition zone as a sharp interface. As the techniques were intended to yield only the general features of the flow pattern, these approximations were acceptable. In order to simulate the interface, preliminary experiments were conducted during which potentials were measured throughout the lower part of the model; head values were calculated from these potentials, and a trial position of the interface was computed from equation 2 . The model was cut slightly to seaward of this trial interface position, and the procedure repeated, until a lower boundary satisfying equation 2 was obtained. This trial procedure served also to fix the seaward limit of the model, which was taken as the intersection of the interface with the seabed.

The Teledeltos paper was of uniform conductivity and could not simulate heterogeneity of the aquifer. The effects of stratification were partly accounted for by assuming the aquifer to be uniformly anisotropic and simulating this anisotropy through the method of distortion of coordinates (Muskat, 1937, p. 225-227). This technique involves application of the equation

$$
\frac{\overline{\Delta x}}{\overline{\Delta z}}=\sqrt{\frac{K_{z}}{K_{x}}}
$$

where $\frac{\overline{\Delta x}}{\overline{\Delta z}}$ is the ratio of length to depth for a rectangular

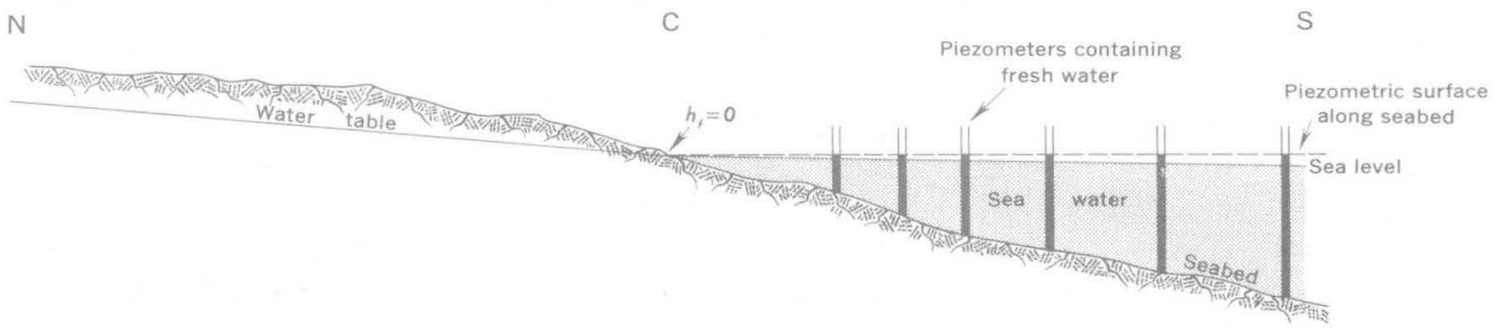

Figure 3.-Distribution of fresh-water head along seabed. 
section of the model representing a square section of the anisotropic aquifer, $K_{z}$ is the average vertical hydraulic conductivity of the aquifer, and $K_{x}$ is the average lateral hydraulic conductivity of the aquifer.

Initially, a model was constructed using an anisotropy, $\frac{K_{x}}{K_{z}}$, of 100 . The results of this model failed to agree with field data. The depth of fresh water near the coast, as yielded by the model, was less than that which was known to occur. At the same time, the fresh-water heads at depth near the coast as given by the model were less than those observed in deep wells. The anisotropy, $\frac{K_{x}}{K_{z}}$ was accordingly increased to 1,000 , and the experiments repeated. Agreement with field data for this anisotropy was good, both with respect to fresh-water heads and depth of fresh water near the coast. The anisotropy of 1,000 was therefore used in the remaining experiments.

Two analog simulations were carried out-one representing high water-table conditions, corresponding to the rainy season, and one representing low water-table conditions corresponding to dry conditions.

\section{EXPERIMENTAL RESULTS}

Figure $4 A$ shows a flownet derived from a model representing high water-table conditions, and figure $4 B$ shows a flownet derived from a model representing low water-table conditions. The vertical exaggeration in the figures was arbitrarily chosen for purposes of illustration and is not the same as that used in the models to simulate anisotropy.

The division point between recharge and discharge areas is located at point $\mathrm{D}$ on figure $4 A$ and slightly north of point $\mathrm{D}$ on figure $4 B$. The flow at the division point in figure $4 A$ is about 13 cubic feet per day per foot of aquifer normal to the section, and in figure $4 B$ about 6.5 cubic feet per day.

In each flownet, approximately 60 percent of the flow enters the modeled area as ground-water inflow at point $\mathrm{N}$, representing recharge in the upper plains of the Rio Bucaná. A large part of this recharge probably occurs as leakage from the extensive network of artificial lakes and irrigation canals.

In the flownet of figure $4 A$, the areal discharge per unit width between $\mathrm{D}$ and the coast-that is, the vertical discharge through a strip 1 foot wide, extending along the water table from point $\mathrm{D}$ to the shore-is approximately 8 cubic feet per

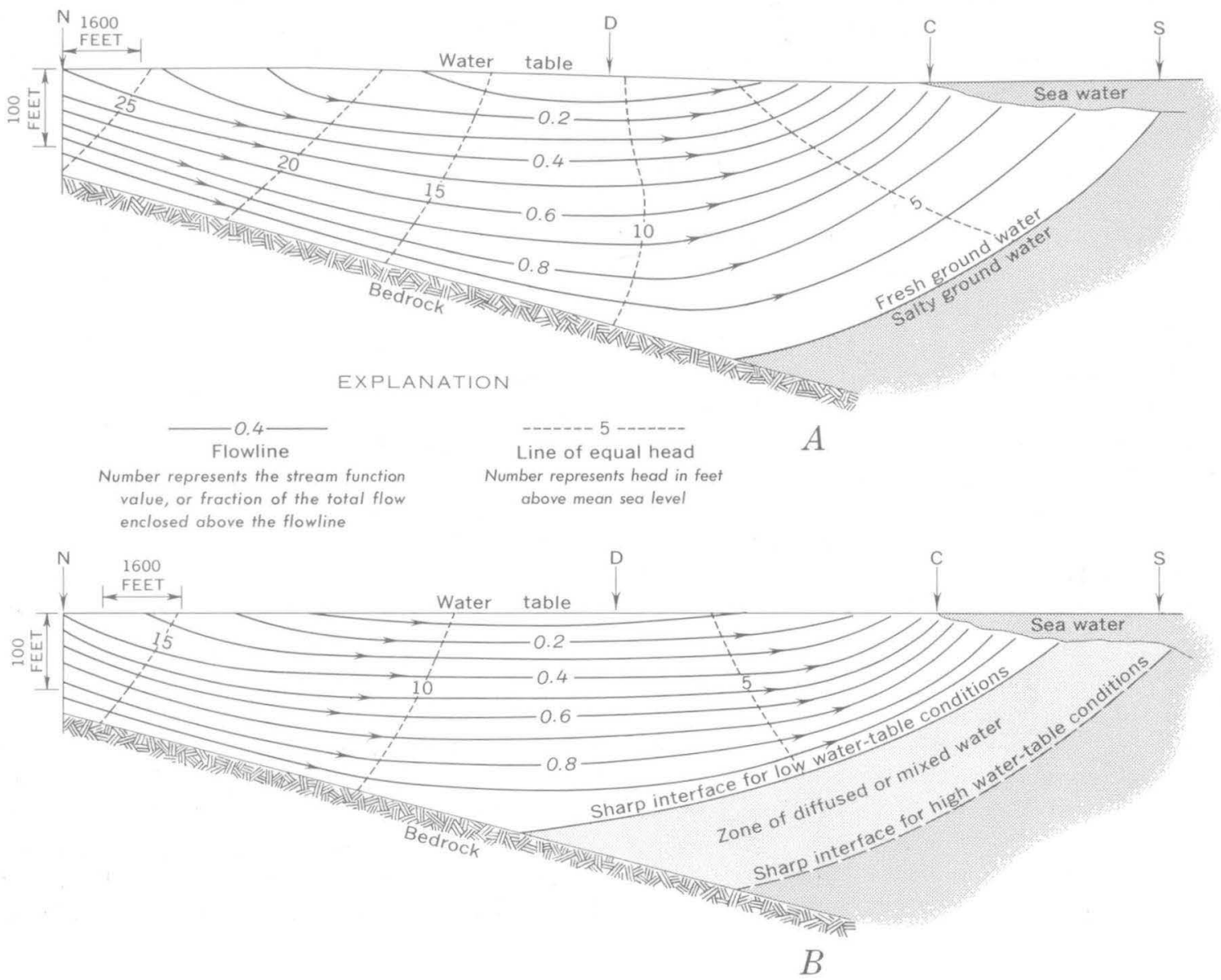

Figure 4.-Flownets in vertical sections along line NS representing: $A$, high water-table conditions; $B$, low water-table conditions. 
day. The corresponding discharge in the flownet of figure $4 B$ is about 3 cubic feet per day. In figure $4 A$, the direct discharge to the sea per unit width-that is, the discharge through a strip 1 : foot wide extending along the seabed, from the shore to point $\mathrm{S}$-is about 5 cubic feet per day. The corresponding discharge in figure $4 B$ is approximately 3.5 cubic feet per day. The relatively high variation in the areal discharge from the coastal flats is in agreement with the field situation. Three of the mechanisms of discharge in this area-flow into drains, evapotranspiration from the water table, and flow into the river-decrease in the dry season as the water table falls.

Some characteristics of the flow patterns in figure 4 deserve mention. The lines of equal head are not vertical. The head at depth, in the vicinity of the transition to sea water, is substantially higher than that vertically above at the water table. It follows that use of the Ghyben-Herzberg relation (Herzberg, 1901) to determine the depth of fresh water near the coast, on the basis of water-table elevations, will yield estimates that are too low. This behavior is generated by the anisotropy which was set at $\frac{K_{x}}{K_{z}}=1,000$. In the preliminary model simulating the anisotropy of $\frac{K_{x}}{K_{z}}=100$, the lines of equal head were more nearly vertical, and agreement with the Ghyben-Herzberg prediction was reasonable. Figure 4 shows that wells near the coast, screened between 100 feet and 200 . feet below land surface, should flow during the wet season, even though the aquifer is unconfined, and should cease flowing during the dry season. This behavior has been observed in numerous deep wells in the coastal area.

The distance offshore to which fresh water extends may depend in part on the configuration of the coastline. To the east and west of the line of section, in the vicinities of Punta Cabullón and Punta Carenero, the shoreline extends some $2,000 \mathrm{ft}$ farther seaward than it does along the line of section. In these areas, the fresh water may terminate much closer to the shoreline than figure 4 indicates.

The lighter shaded area in figure $4 B$ represents the zone between the interface corresponding to the low water table and that corresponding to the high water table. This zone is characterized by seasonal advance and retreat of the saline front in response to the seasonal fluctuations of water table and should be a zone of diffused or mixed water. Normally, zones of this type, generated by advance and retreat of the saline front, are attributed to the action of tides-that is, to fluctuations in head on the seaward side-having periods measured in hours. Here, the cause is primarily a head fluctuation on the landward side, which has a period measured in months. The tidal effect, by comparison, is relatively small, as tides in the Caribbean Sea in the vicinity are generally less than 1 foot in amplitude.

\section{FACTORS AFFECTING THE WATER-QUALITY DISTRIBUTION IN THE FIELD}

The processes of dispersion undoubtedly cause the actual zone of diffusion to be wider than that shown on figure $4 B$. The hypothesis proposed by Cooper (1964) suggests that the zone of diffusion normally should extend seaward of the sharp boundary determined by using interface mechanics. On this basis, the interface for the low water-table condition, shown in figure $4 B$, should represent the seaward limit of uncontaminated fresh water. The zone of diffusion should extend seaward from this line to a position somewhere beyond the sharp interface determined for the high water-table condition.

Field evidence shows that water quality at shallow depths near the coast is poor, ranging from 1,000 to 5,000 milligrams per liter in dissolved solids. The poor-quality water near the surface is probably due to evaporative discharge processes and to shallow periodic penetration of salt water from the sea and river mouth generated by the small tidal oscillation. At greater depths water of better quality is obtained; whereas at still greater depths, between 150 and 250 feet, quality deteriorates again as the zone of diffusion between fresh water and sea water is entered. In preference in the sharp interface shown in figure 4 , the transition to sea water at depth can be illustrated by a series of chloride concentration lines, shown schematically in figure 5 . The lines reverse and bend landward near

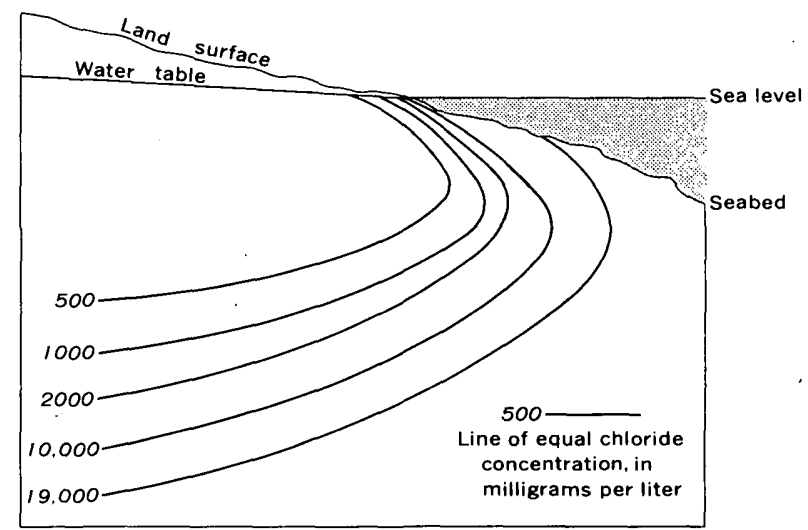

Figure 5.-General form of vertical water-quality distribution near the coast.

the surface, reflecting the shallow poor-quality water described above. The fresh-water body enclosed by the chloride lines thus has the form of a wedge protruding into the salt water. Along the upper and lower edges of this wedge the flow has characteristics of variable density, and in these areas simulation of the flow system by the analog is necessarily poor. 


\section{LIMITATIONS OF THE TECHNIQUE}

The analog technique employed in this study exhibits numerous limitations in addition to those associated with its inability to simulate variable-density flow and its treatment of the transition to sea water as a sharp interface.

The Teledeltos paper models can simulate only equilibrium conditions. They can give an accurate representation of the flow pattern only if the time derivative of head, $\frac{\partial h}{\partial t}$, is zero throughout the aquifer. The flow system in the aquifer is certainly nonequilibrium, to the extent that it oscillates between the conditions shown in figure 4; however, because these conditions represent the maximum and minimum points, respectively, of the head oscillation, $\frac{\partial h}{\partial t}$ should approximate zero at these times. Errors in the flow patterns of figure 4 due to nonequilibrium effects should therefore be small.

The Teledeltos paper models cannot, as noted earlier, simulate heterogeneity. The aquifer exhibits heterogeneity in stratification, which is partly represented by the anisotropy of the model. The aquifer also shows evidence of heterogeneity in the map view, and this was not simulated in any way in the models. The flow pattern in the aquifer also is three dimensional, whereas the models are two dimensional. Because of these shortcomings, the analog results should be taken as a first approximation to field conditions, rather than as a detailed representation.

\section{REFERENCES}

Cooper, H. H., 1964, A hypothesis concerning the dynamic balance of fresh water and salt water in a coastal aquifer, in Sea water in coastal aquifers: U.S. Geol. Survey Water-Supply Paper 1613-C, p.1-11.

Herzberg, Alexander, 1901, Die Wasserversorgung einiger Nordseebader [The water supply on parts of the North Sea Coast]: Munich, Jour. Gasbeleucht. und Wasserversorg, v. 44, p. 815-819, 842-84.4.

Hubbert, M. K., 1940, The theory of ground-water motion: Jour. Geology, v. 48, no. 8, pt. 1, p. 785-944.

Muskat, Morris, 1937, The flow of homogeneous fluids through porous media: New York, McGraw Hill Book Co., 763 p. 


\title{
BASE FLOW AS AN INDICATOR OF AQUIFER CHARACTERISTICS IN THE COASTAL PLAIN OF DELAWARE
}

\author{
By RICHARD H. JOHNSTON, Dover, Del.
}

Work done in cooperation with the Delaware Geological Survey

\begin{abstract}
Base flow (considered to be entirely ground-water discharge) constitutes an estimated 75-90 percent of the streamflow in the Coastal Plain of central and southern Delaware. In several small basins, a correlation has been established between base flow and the hydraulic diffusivity (transmissivity/storage coefficient, $T / S$ ) of the water-table aquifer. Small basins of high hydraulic diffusivity drain rapidly during the period of ground-water recharge (winter and early spring) and are characterized by above-average winter base flow. On the other hand, above-average base flow after prolonged periods of no recharge (streamflow at 90 percent duration for example) does not indicate high hydraulic diffusivity. In fact, small basins where the diffusivity is high may have lower discharge after extended dry periods than do basins where the diffusivity is lower.
\end{abstract}

The Coastal Plain of southern and central Delaware is drained by tranquil streams which are characterized by moderate rises in stage after heavy rains and prolonged, slowly diminishing base flow during extended dry periods. Separation of the streamflow hydrographs for several of these streams indicates that they derive 75-90 percent of their flow from ground-water discharge. Consequently, streamflow is influenced markedly by the hydraulic characteristics of the water-table aquifer.
Four small streams, located within a radius of about 15 miles, have been studied for comparison of base flow with aquifer properties. The principal characteristics of these basins are listed in table 1. These are natural-flow streams having similar basin characteristics except for aquifer properties. Average annual precipitation on the basins is about 46 inches. Forest covers 40 to 55 percent of the land, and the remainder is used primarily for agriculture. Urbanization is almost nil. Surface storage is negligible and regulation nonexistent except for Sowbridge Branch, which is occasionally regulated during periods of heavy overland runoff. Withdrawals of ground water and surface water are almost insignificant compared to stream runoff and evapotranspiration.

Thomas and Benson (1970) concluded from a study of basins throughout the United States that those basin characteristics which are most directly related to streamflow are drainage-basin size, mean annual precipitation, forest cover, snowfall, and surface storage. Of these five basin parameters, four (mean annual precipitation, forest cover, snowfall, and surface storage) are very similar in the four basins. The only dissimilarity exists in drainage-basin size; the area of the basins ranging from 2.8 square miles for Beaverdam Branch to 75.4

Table 1.-Characteristics of the Beaverdam Branch, Nanticoke River, Sowbridge Branch, and Stockley Branch drainage basins in Delaware ${ }^{1}$

\begin{tabular}{|c|c|c|c|c|}
\hline Basin characteristics & $\begin{array}{c}\text { Beaverdam } \\
\text { Branch at } \\
\text { Houston }\end{array}$ & $\begin{array}{l}\text { Nanticoke } \\
\text { River near } \\
\text { Bridgeville }\end{array}$ & $\begin{array}{c}\text { Sowbridge } \\
\text { Branch near } \\
\text { Milton }\end{array}$ & $\begin{array}{c}\text { Stockley } \\
\text { Branch at } \\
\text { Stockley }\end{array}$ \\
\hline 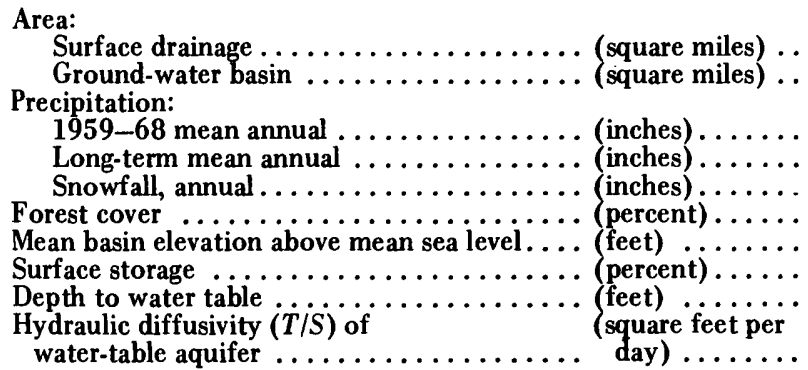 & $\begin{array}{c}2.83 \\
2.85 \\
40 \\
45 \\
16 \\
43 \\
55 \\
0 \\
2-11\end{array}$ & $\begin{array}{l}75.4 \\
72.5 \\
41 \\
45 \\
17 \\
40 \\
50 \\
1.7 \\
8-13 \\
4.6 \times 10^{4}\end{array}$ & $\begin{array}{l}41 \\
47 \\
16 \\
54 \\
38 \\
4 \\
9-15 \\
2.5 \times 10^{4}\end{array}$ & $\begin{array}{l}42 \\
47 \\
15 \\
51 \\
46 \\
0.4 \\
0-11 \\
3.9 \times 10^{4}\end{array}$ \\
\hline
\end{tabular}

\footnotetext{
${ }^{1}$ Data in part from Forest and Walker (1970).
} 
square miles for the Nanticoke River. Even so, all four may be considered as small basins. Because of the similar characteristics, runoff and evapotranspiration are nearly identical in the four basins. During the 10-year period 1959-68, precipitation averaged 40-42 inches annually, runoff averaged 16-17 inches annually, and evapotranspiration averaged 23-25 inches annually.

The water-table aquifer in the four basins consists of fine- to coarse-grained Pleistocene sand with minor gravel lenses. Underlying the Pleistocene deposits are less permeable beds of Miocene sand generally separated from the water-table aquifer by confining beds of sandy clay. Locally, small head differences exist between the Pleistocene and Miocene aquifers. However, leakage of water between the two aquifers is considered to be very small in comparison with the discharge from the water-table aquifer.

Traditionally, the area contributing to a stream has been assumed to be the surface drainage area determined by planimetering topographic maps. However, during periods of base flow (when the flow is ground-water discharge), the contributing area is the ground-water basin as determined from water-table contour maps. In the flat Coastal Plain of Delaware with its permeable surficial sand, the surface drainage basin and the ground-water basin do not necessarily coincide and serious errors may ensue by assuming that they do. For this study, the areas of the ground-water basins were determined by planimetering water-table contour maps prepared by J. K. Adams, D. H. Boggess, O. J. Coskery, and C. F. Davis (see U.S. Geol. Survey Hydrol. Inv. Atlases listed in References). Surface drainage areas and ground-water-basin areas are listed in table 1.

Base flow (which is considered to be entirely ground-water discharge) was determined by separation of the streamflow hydrographs for the 10-year period 1959-68. Base-flow recession curves prepared in the manner described by Riggs (1963) were utilized in separation of the hydrographs. During 5 of the 10 years, the streamflow hydrographs display one continuous base-flow recession from May to October, with superimposed short periods of direct runoff. During the winter, the streamflow hydrographs are characterized by a series of short, "stair-stepping" recession curves produced as the streams respond to pulses of ground-water recharge. Consecutively higher base flows follow each recharge pulse. During the winter, rating curves of ground-water stage versus base flow were used to estimate base flow during periods when the separation of overland runoff from base flow was in question.

During periods of overland runoff, the amount of water moving from the streams into the aquifer and reentering the streams later is either negligible or nonexistent. Three streams have been monitored to determine the relation of groundwater stage to stream stage by installation of piezometers adjacent to the stream. During 1970, only one stream (not listed in table 1) showed a period when the stream stage was higher than the ground-water stage in the adjacent water-table aquifer. In general, periods when water moves from the stream into the water-table aquifer, if they do occur, are so short that they would have negligible effect on the base flow values computed for the 10-year period.

The hydraulic diffusivity (transmissivity/storage coefficient, $T / S$ ) of the water-table aquifer was estimated by analysis of ground-water level recessions using the method of Rorabaugh (1960) and by the response of water levels to recharge using the method of Stallman and Papadopulos (1966). Transmissivities $(T)$ were estimated from specific-capacity data and converted to hydraulic diffusivity using values of storage coefficient $(S)$ ranging from 0.11 to 0.15 . The estimated mean hydraulic diffusivity for the four basins is listed in table 1 .

Figure 1 shows that the relationship of hydraulic diffusivity $(T / S)$ to mean winter base flow, mean annual base flow, and flow at 90 -percent duration. The figure indicates that (1) winter base flow varies directly with the $\log _{10}$ of hydraulic diffusivity, (2) the mean annual base flow is about the same regardless of hydraulic diffusivity, and (3) low base flow (flow at 90 -percent duration) varies inversely with the $\log _{10}$ of hydraulic diffusivity. High winter base flow may therefore be used to identify areas of above-average transmissivity. On the other hand, a relatively low base flow at 90 -percent duration is

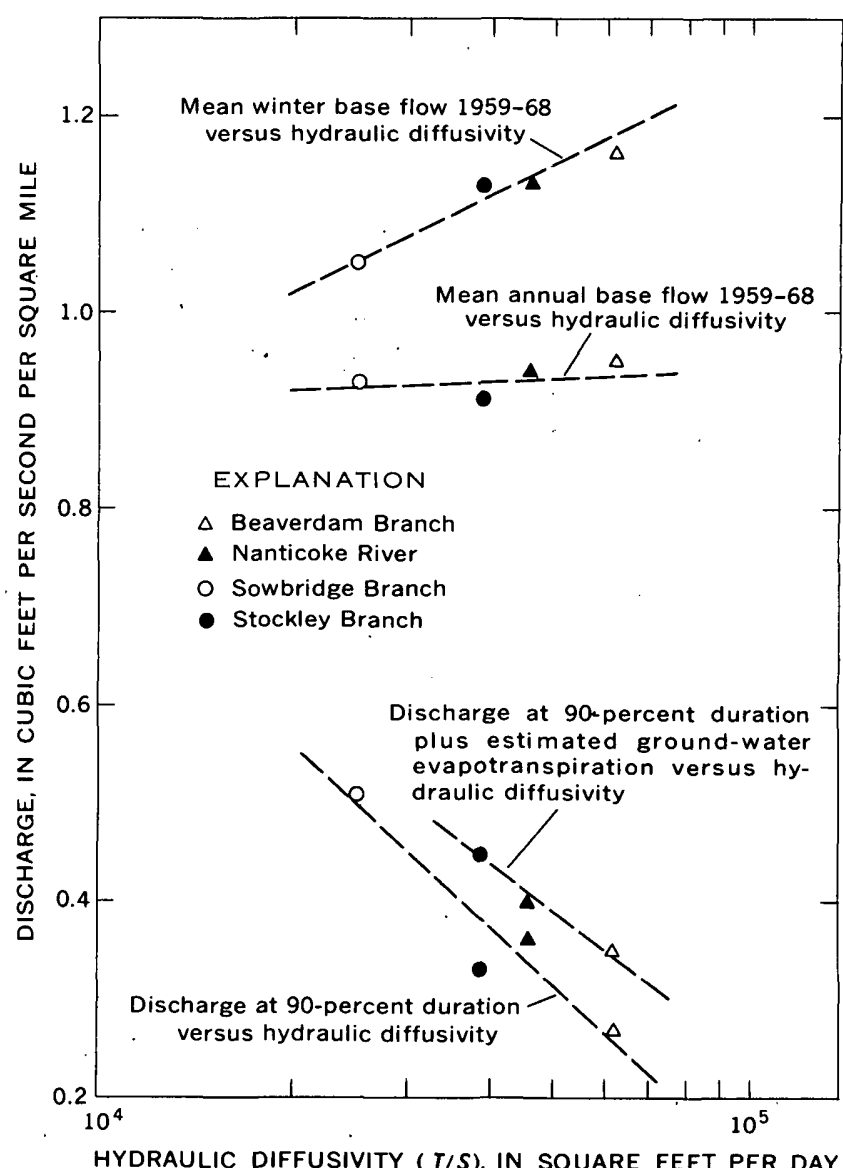

Figure 1.-Relationship between hydraulic diffusivity $(T / S)$ of the water-table aquifer and the base flow of streams. 
also an indication of above-average transmissivity in the Coastal Plain of Delaware. The significance of these different relationships will be discussed later in this report.

Very low base flows normally occur during the late summer and early fall months when ground-water evapotranspiration may substantially reduce streamflow. In order to compensate for possible differences in evapotranspiration rates, the actual streamflow at 90 -percent duration has been adjusted to the flow which would have occurred if there were no ground-water evapotranspiration. Rating curves of ground-water stage versus base flow during summer and winter months were used for this purpose. The streamflow at 90 -percent duration (corrected for ground-water evapotranspiration) is considered to be the equivalent of the base flow during winter having the same ground-water stage. By use of this method it was possible to correct the streamflow at 90 -percent duration in three of the four basins as shown in the lower graphs in figure 1 .

The relationships shown in figure 1 may apply only to relatively small basins having a range of hydraulic diffusivity from $10^{4}$ to $10^{5}$ square feet per day. The relationships do not apply, for example, to the Piedmont region of northern Delaware, where the crystalline rocks have very low transmissivity and where basin characteristics may differ greatly from those listed in table 1 .

Rorabaugh (1960) has shown that ground-water levels decline exponentially with time after a critical time elapses. The time required to drain a unit thickness of water-table aquifer varies directly with the square of the distance $\left(a^{2}\right)$ from the stream to the ground-water divide and inversely with $T / S$. Thus small basins with high hydraulic diffusivity drain rapidly, small basins with lower diffusivity drain more slowly, and large basins with lower diffusivity drain much more slowly. In the small Coastal Plain basins of Delaware it is often difficult to estimate accurately the distance (a) to groundwater divides. However, these distances are similar in the four basins. If it is assumed that $a^{2}$ is constant, the relationships shown in figure 1 are readily explained. During the winter and early spring when recharge occurs, the areas of high hydraulic diffusivity drain rapidly after each pulse of recharge, and high base flow is maintained. However, during the summer and early fall when recharge is very small or nonexistent, the areas of high diffusivity are characterized by below-average base flow, owing to their prolonged drainage at rates greater than those in areas of low diffusivity.

In some areas, high flow at 90 -percent duration has been interpreted as an indication of high transmissivity. For example, LaSala (1968) shows that streams in western New York which drain basins underlain by thick and extensive sand and gravel deposits have much higher flow at 90-percent duration than do streams draining basins underlain by less permeable fine-grained deposits. However, in the Coastal Plain of Delaware, high flow at 90-percent duration does not indicate basins of high transmissivity, as is shown by the lower curves in figure 1. A large number of base-flow measurements were made in Delaware in September 1968 as part of the
Delmarva hydrology study (unpublished data provided by $\mathrm{K}$. R. Taylor). These measurements, made at 80- to 95-percent duration, were compared with a map showing transmissivity of the water-table aquifer in Delaware. No correlation between areas of high transmissivity and above-average base flow was evident. In fact, many areas of very high transmissivity were characterized by extremely low flow.

Basins in which there is substantial recharge to, or discharge from deep artesian aquifers will not indicate the same relation of base flow to hydraulic diffusivity as those shown in figure 1. However, the curves in figure 1 are useful in identifying such basins. In particular, the fact that mean annual base flow is about the same, regardless of hydraulic diffusivity, provides a very useful tool.

For example, Beaverdam Creek near Milton, Del., ${ }^{1}$ probably has the highest base flow of any stream in Delaware during both the winter recharge periods and extended periods of very low flow. Mean base flow during 1970 (a year of slightly below-average precipitation) was 1.65 cubic feet per second per square mile. Ground-water gain along the stream is very large, as determined from seepage runs and temperature studies (Hollyday, 1970).

An exploratory hole drilled in this basin disclosed a thick (132 foot) section of Pleistocene sand and gravel. A subsequent pumping test yielded a transmissivity of $1.3 \times 10^{4}$ square feet per day and an estimated hydraulic diffusivity of $9.5 \times 10^{4}$ square feet per day. Furthermore, the Pleistocene deposits are separated from permeable sand strata in the Miocene Manokin aquifer by a thin (18-foot) confining bed (clayey silt) which may be breached elsewhere in the basin. The head is apparently higher in the Manokin than in the overlying water-table aquifer; however, the exact head difference is unknown. The hydrogeologic setting thus indicates possible upward leakage from the Manokin aquifer.

The exceptionally high base flow of Beaverdam Creek is therefore probably due to (1) the highly permeable Pleistocene sand and gravel, which drain rapidly to the stream, particularly during the winter and spring recharge, and (2) constant upward leakage from the Manokin aquifer, which contributes to base flow year round. If these conclusions are valid, the difference between the mean annual base flow of Beaverdam Creek and the mean annual base flow of the streams in figure 1 (a relatively constant figure) is a measure of the upward leakage from the Manokin aquifer.

Acknowledgments. - On the surface-water aspects of this study, the writer benefited from informal discussions and unpublished data provided by Philip Pfannebecker, R. H. Simmons, and K. R. Taylor, of the U.S. Geological Survey. Thanks are also due to K. D. Woodruff, J. C. Miller, and Boris Bilas, of the Delaware Geological Survey, who provided fieid assistance during the ground-water phase of the study.

\footnotetext{
${ }^{1}$ A different stream from Beaverdam Branch listed in table 1 and figure 1 .
} 


\section{REFERENCES}

Adams, J. K., and Boggess, D. H., 1964a, Water-table, surìace-drainage, and engineering soils map of the Hickman area, Delaware: U.S. Geol. Survey Hydrol. Inv. A tlas HA-100, scale 1:24,000.

- 1964b, Water-table, surface-drainage, and engineering soils map of the Ellendale quadrangle, Delaware: U.S. Geol. Survey Hydrol. Inv. Atlas HA-101, scale 1:24,000.

- 1964c, Water-table, surface-drainage, and engineering soils map of the Harbeson quadrangle, Delaware: U.S. Geol. Survey Hydrol. Inv. Atlas HA.108, scale 1:24,000.

Adams, J. K., Boggess, D. H., and Coskery, O. J., 1964, Water-table, surface-drainage, and engineering soils map of the Seaford East quadrangle, Delaware: U.S. Geol. Survey Hydrol. Inv. A tlas HA-106, scale 1:24,000.

Boggess, D. H., and Adams, J. K., 1964a, Water-table, surface-drainage, and engineering soils map of the Greenwood quadrangle, Delaware: U.S. Geol. Survey Hydrol. Inv. Atlas HA-99, scale 1:24,000.

1964b, Water-table, surface-drainage, and engineering soils map of the Seaford West area, Delaware: U.S. Geol. Survey Hydrol. Inv. Atlas HA.105, scale 1:24,000.

Boggess, D. H., Adams, J. K., and Coskery, O. J., 1964, Water-table, surface-drainage, and engineering soils map of the Milton quadrangle, Delaware: U.S. Geol. Survey Hydrol. Inv. Atlas HA-102, scale $1: 24,000$.

Boggess, D. H., Adams, J. K., and Davis, C. F., 1964, Water-table, surface-drainage, and engineering soils map of the Georgetown quadrangle, Delaware: U.S. Geol. Survey Hydrol. Inv. Atlas HA-107, scale 1:24,000.

Davis, C. F., and Boggess, D. H., 1964, Water-table, surface-drainage, and engineering soils map of the Harrington quadrangle, Delaware: U.S. Geol. Survey Hydrol. Inv. Atlas HA-136, scale 1:24,000.

Forrest, W. E., and Walker, P. N., 1970, A proposed stream-flow program for Maryland and Delaware: U.S. Geol. Survey open-file rept., $41 \mathrm{p}$.

Hollyday, E. F., 1970, Use of infrared radiometry in measuring ground-water inflow to streams, Delmarva Peninsula, Maryland and Delaware, in Hydrology and oceanography, second annual earth resources aircraft program status review, v. 3: Natl. Aeronautics and Space Adm. Manned Spacecraft Center, Houston, Tex., p. 44-1 to 44-14.

LaSala, A. M., Jr., 1968, Ground-water resources of the Erie-Niagara basin, New York: New York Water Resources Comm., Basic Planning Rept. ENB-3, 114 p.

Riggs, H. C., 1963, The base-flow recession curve as an indicator of ground water: Internat. Assoc. Sci. Hydrology Pub. 63, p. 352-363.

Rorabaugh, M. I., 1960, Use of water levels in estimating aquifer constants in a finite aquifer: Internat. Assoc. Sci. Hydrology Pub. 52, p. 314-323.

Stallman, R. W., and Papadopulos, I. S., 1966, Measurement of hydraulic diffusivity of wedge-shaped aquifers drained by streams: U.S. Geol. Survey Prof. Paper 514, 50 p.

Thomas, D. M., and Benson, M. A., 1970, Generalization of streamflow characteristics from drainage-basin characteristics: U.S. Geol. Survey Water-Supply Paper 1975, 55 p. 


\title{
ASSOCIATION AND DISSOCIATION OF A HUMIC ACID FRACTION AS A FUNCTION OF pH
}

\author{
By R. L. WERSHAW and D. J. PINCKNEY, Denver, Colo.
}

\begin{abstract}
A humic acid fraction isolated by gel-permeation chromatography forms stable aggregates of a variety of sizes in solution. The concentrations of the various molecular sizes are a function of $\mathrm{pH}$. At $\mathrm{pH} 7$ the system is monodisperse, consisting of particles having a radius of gyration of $9.1 \mathrm{~A}$.
\end{abstract}

Molecular weights of less than 1,000 to greater than $2,000,000$ have been reported for humic acids and their salts, and the humic acid samples used have in general been found to be polydisperse (Bailly and Margulis, 1968; Flaig and Beutelspacher, 1968; Mehta and others, 1963; Piret and others, 1960; Rashid and King, 1970). We have measured a number of different particle sizes of both fractionated and unfractionated samples of sodium humate dissolved in water (Wershaw and others, 1967; 1970). In the work reported here we have found that a sodium humate fraction isolated by gel-permeation chromatography is polydisperse when dissolved in distilled water or in buffers of $\mathrm{pH} 6$ or less and $\mathrm{pH} 8$ or greater, and monodisperse at $\mathrm{pH}$ 7. These results indicate that this fraction of sodium humate forms stable colloidal aggregates made up of smaller particles of a single molecular size. The relative concentrations of the different aggregate sizes are a function of $\mathrm{pH}$.

Acknowledgments. -We thank M. G. Buchanan and R.W. Hendricks of Oak Ridge National Laboratory, and James Lake, of the University of Wisconsin, for providing programs that were used in correcting for slit collimation effects.

\section{EXPERIMENTAL SECTION}

The sodium humate in this study was extracted from a North Carolina soil and was prepared as outlined previously (Wershaw and Burcar, 1967). It was fractionated on a Sephadex G-50 chromatographic column $4 \mathrm{~cm}$ in diameter and $25 \mathrm{~cm}$ long; $10 \mathrm{ml}$ of a 1-percent solution of sodium humate was put on the column and eluted with distilled water at a flow rate of $3.5 \mathrm{ml} / \mathrm{minute}$. The five sharp, well-separated bands which were obtained by this procedure were collected and lyophilized. For this study we have chosen to work with the second fraction (fraction 2) that was eluted from the column, because previous studies indicated that particles of several different sizes were present in the water solution of this fraction. Fraction 2 was about 25 percent of the unfractionated material.

All of the particle size measurements were made with a Kratky low-angle X-ray scattering goniometer on 0.5 -percent solutions of fraction 2 in the buffers listed in table 1 . The entrance slit was $0.150 \mathrm{~mm}$, and the detector slit was 0.300 $\mathrm{mm}$; copper $K \alpha$ radiation was used, and monochromatization was obtained with a nickel filter and a pulse-height analyzer. Slit collimation correlations were applied to the data, using the procedure outlined by Hendricks and Schmidt (1967).

Table 1.-Composition of buffer solutions for particle-size measurements in fraction 2

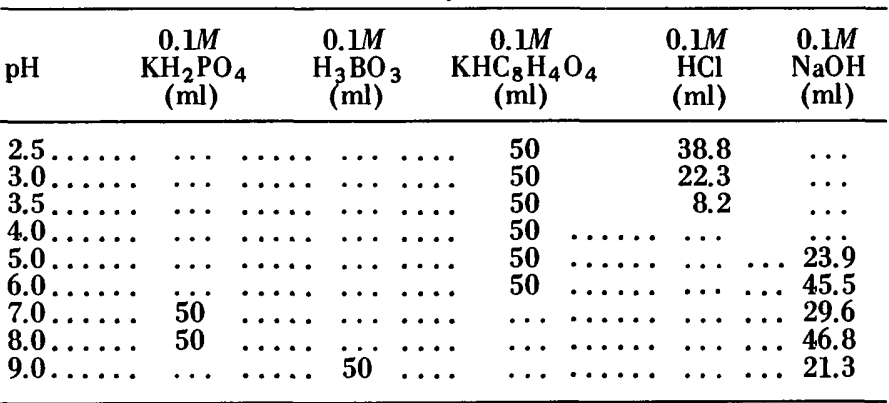

\section{RESULTS AND DISCUSSION}

In figure 1 the logarithms of the scattered intensities are plotted against $h^{2}$ which is defined by $h=\frac{4 \pi \sin \theta}{\lambda}$, where $2 \theta$ is the scattering angle and $\lambda=1.54 \mathrm{~A}$, for fraction 2 in different buffers. The curves have been separated along the ordinate in order to show their shapes more clearly. Guinier (1939) has shown that, for a group of identical particles suspended in a medium of electron density different from the particles, a straight line will be obtained in such a plot. The radius of gyration of these particles may then be calculated from the slope of the line. In a polydisperse system the Guinier plot will 


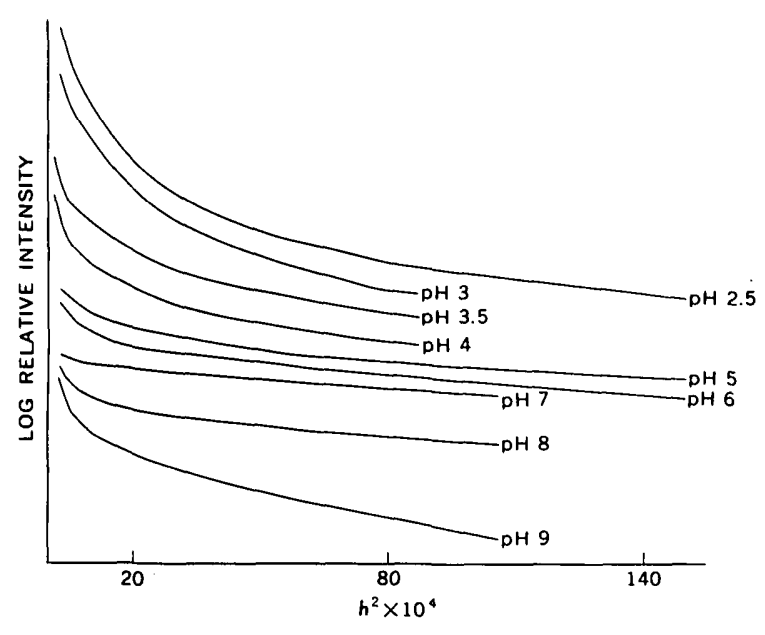

Figure 1.-Log of scattered intensity versus $h^{2}$ (Guinier curves) for 0.5-percent solutions of fraction 2 from $\mathrm{pH} 2.5$ to $\mathrm{pH}$ 9. The curves have been separated along the ordinate.

not be a straight line but a curve that is concave up (Beeman and others, 1957).

In figure 1 the Guinier plots of the scattering of the solutions of $\mathrm{pH} \mathrm{2.5-4}$ are concave up, indicating that the systems are polydisperse; however, at $\mathrm{pH} 7$ practically the entire Guinier curve is a straight line, indicating that the solution is monodisperse. At $\mathrm{pH}$ values of 8 and 9 the curves are also those of polydisperse systems. The particles at $\mathrm{pH} 7$ have a radius of gyration of $9.1 \mathrm{~A}$. Particles as large as $103 \mathrm{~A}$ in radius of gyration have been measured in fraction 2 dissolved in water.

In figure 2 the curves for $\mathrm{pH}$ values of 4 and less have been plotted against the same ordinate so that they are in correct

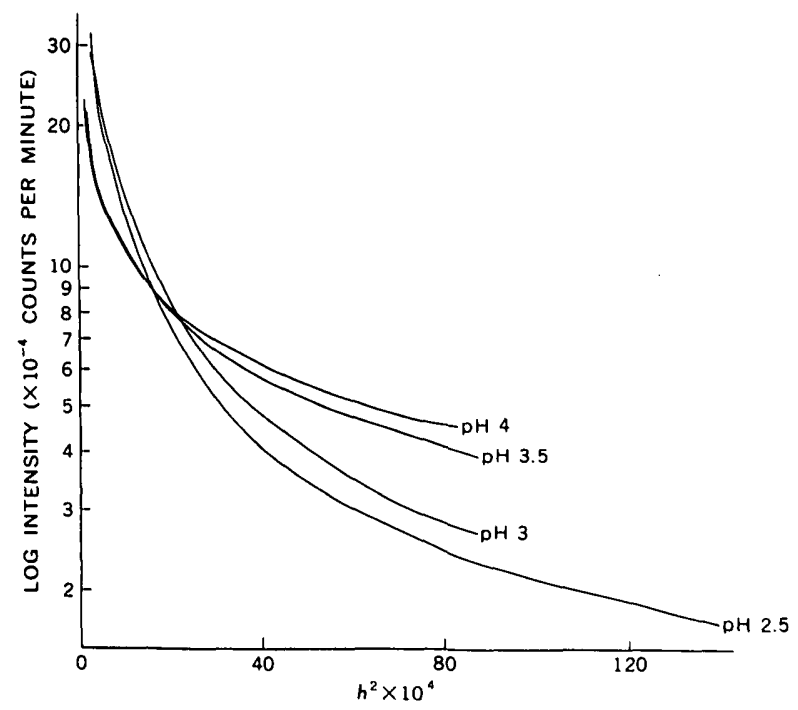

Figure 2-Log of scattered intensity versus $h^{2}$ (Guinier curves) for 0.5 -percent solutions of fraction 2 from $\mathrm{pH} 2.5$ to $\mathrm{pH} 4$. positions relative to one another. It will be noted that the relative scattered intensities in the region of small $h$ values decrease with increasing $\mathrm{pH}$ and that in the region of large values of $h$ the relative scattered intensities increase with increasing $\mathrm{pH}$. The high slope of the part of the Guinier curve at low $h$ values is due mainly to the large particles in the system, whereas the low slope at higher values of $h$ is caused mainly by the smaller particles. Therefore, the curves in figure 2 show a decreasing concentration of large particles and an increasing concentration of small particles with increasing $\mathrm{pH}$.

\section{CONCLUSIONS}

By studying this humic acid fraction in its dissociated state in a buffer we should be able to obtain a much more fundamental understanding of the chemical and physical properties of this material, both as a solid phase and as a dispersed phase in water. A study of the binding mechanism of the particles one to another is of prime importance. Although the particles which associate to form agglomerates appear to be approximately the same size, they may not be chemically identical; this difference may play a role in the polymerization. In studying this material we should follow the example of those who have been so successful in elucidating the chemistry of proteins which also form stable associations in solution.

\section{REFERENCES}

Bailly, J. R., and Margulis, Henri, 1968, Etude de quelques acides humiques sur gel de dextrane: Plant and Soil, v. 29, no. 3, p. 343.

Beeman, W. W., Kaesberg, P., Anderegg, J. W., and Webb, M. B., 1957, Size of particles and lattice defects: Handbuch der Physik, v. 32, p. $321-442$

Flaig, W. A. J., and Beutelspacher, H., 1968, Investigations of humic acids with the analytical ultracentrifuge: Isotopes and Radiation in Soil Organic-Matter Studies, Internat. Atomic Energy Agency, p. 23-30.

Guinier, Andre, 1939, Diffraction of X-rays of very small anglesApplication to the study of ultramicroscopic phenomenon: Annals Physics, v. 12, p. 161.

Hendricks, R. W., and Schmidt, P. W., 1967, Calculation of weighting functions for collimation corrections in small-angle $\mathrm{X}$-ray scattering: Acta Physica Austriaca, v. 26, no. 2-3, p. 97-121.

Mehta, N. C., Dubach, P., and Deuel, H., 1963, Untersuchungen uber die molekulargewichtsverteilung von huminstoffen durch gelfiltration an Sephadex: Zeitschr. Pflanzenernahrung Düngung, Bodenkunde 102 , p. 128-137.

Piret, E. L., White, R. G., Walther, H. C., and Madden, A. J., 1960, Some physico-chemical properties of peat humic acids: Royal Dublin Soc. Sci. Proc., v. 1A, p. 69-79.

Rashid, M. A., and King, L. H., 1970, Major oxygen-containing functional groups present in humic and fulvic acid fractions isolated from contrasting marine environments: Geochim. et Cosmochim. Acta, v. 34, p. 193-201.

Wershaw, R. L., Burcar, P. J., Sutula, C. L., and Wiginton, B. J., 1967, Sodium humate solution studied with small-angle X-ray scattering: Science, v. 157, no. 3795, p. 1429-1431. 
Wershaw, R. L., and Burcar, P. J., 1967, Physical-chemical properties of naturally occurring polyelectrolytes-I. Sodium humate: 3d Ann. Am. Water Resources Conf. Proc., p. 351-364.
Wershaw, R. L., Heller, S. J., and Pinckney, D. J., 1970, Measurement of the molecular size of a sodium humate fraction: Advances in X-ray Analysis, v. 13, p. 609-617. 


\title{
METHOD OF RATING FLOW IN A STORM SEWER
}

\author{
By G. E. SEABURN, Mineola, N.Y. \\ Work done in cooperation with the New York State Department of \\ Environmental Conservation, Nassau County Department of Public Works, \\ Suffolk County Department of Environmental Control, and the \\ Suffolk County Water Authority
}

\begin{abstract}
Accurate flow measurements in storm-sewer systems are required for many hydrologic studies and are generally difficult to obtain. One approach is to use a theoretical rating curve between stage and discharge developed by using the critical-flow relationship and the Bernoulli equation. To verify this curve, a rating curve for the local storm-sewer system was developed from flow measurements of water supplied by nearby fire hydrants. Three methods were used to measure flow: volumetric, current-meter, and critical-flow measurements. The field-determined rating curve and the theoretical rating curve are nearly identical for the range of the field tests. Instantaneous discharges exceeding the field rating curve were evaluated by using the extension of the theoretical rating curve.
\end{abstract}

Many hydrologic studies in urban areas require measurement of flow in storm sewers. These measurements commonly are difficult, however, because storm sewers generally are not conducive to flow measurement.

In a study of the hydrologic effects of recharge basins on Long Island, N. Y. (see fig. 1), accurate measurement of the amount of runoff entering a recharge basin by way of the storm sewers posed such a difficult problem that choosing basins for study was almost solely dictated by the ease with which flow could be measured.

This report is one of several being prepared as part of a comprehensive study of recharge basins by the U.S. Geological Survey in cooperation with state and local agencies. It describes the methods used to calibrate and measure inflow through storm sewers to one recharge basin, the Deer Park basin, on Long Island. Two other recharge basins used in this study, the Westbury and Syosset recharge basins, were rated earlier by a somewhat different approach (Seaburn, 1970). The three recharge basins were named by the author after the village in which they are located to distinguish them from the many other basins in the area.

Inflow to both the Westbury and the Syosset recharge basins is measured by recording water stage behind a $V$-notch weir

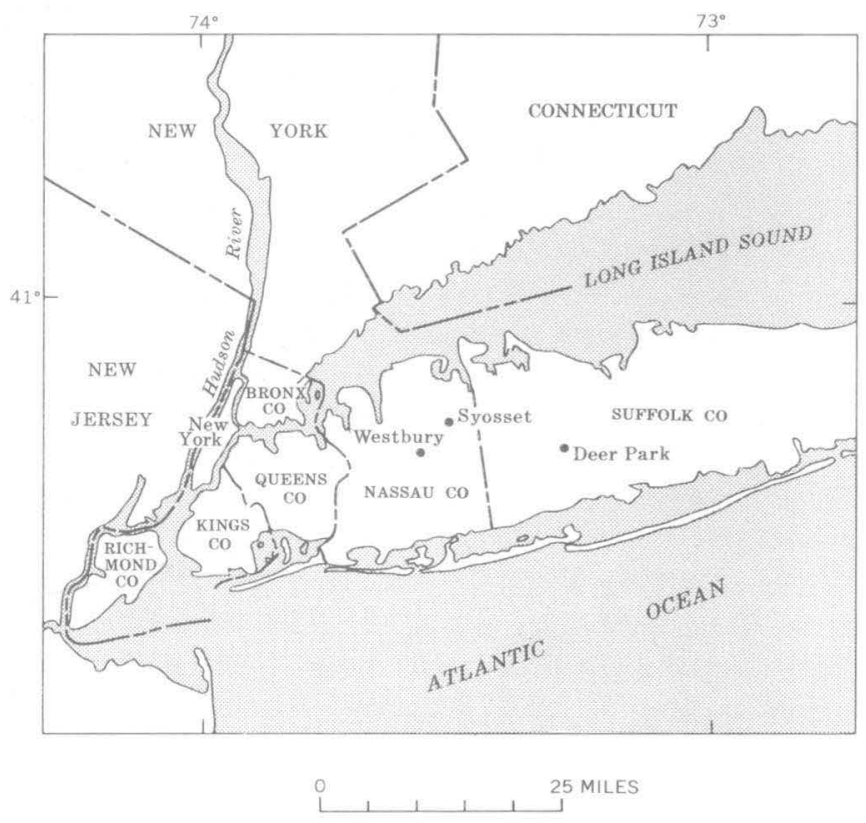

Figure 1.-Westbury, Syosset, and Deer Park recharge basins and general geographic features of Long Island, N.Y.

inside the inflow pipe leading into the basin. The weirs were field rated with water from nearby fire hydrants, using methods similar to those described in a later paragraph. The major reason for using $V$-notch weirs at these basins was to increase the sensitivity of stage measurements at low flows, which are expected frequently from the relatively small drainage areas (15 acres and 28.8 acres, respectively). However, the major disadvantage of this method is that debris tends to collect on or behind the weirs. This problem has caused considerable loss of record and has required constant maintenance to keep the weirs clean. 
In choosing a third recharge basin for use in this study an effort was made to avoid basins requiring an artificial flow control that would tend to catch debris.

\section{DESCRIPTION OF TEST BASIN}

The Deer Park recharge basin (fig. 1) drains a residential area of 118 acres. An extensive sewering system (see fig. 2) collects and delivers storm runoff from two subareas to the basin for disposal by infiltration through moderately to highly permeable sand and gravel deposits typical of most of Long Island. A wide range of flows from this comparatively large drainage area was expected, and an accurate method of measuring the flow throughout this range was needed. The storm-sewer system provided a convenient structure for measuring these flows without the need for an artificial flow control. A description of this arrangement, which is in no way unique, follows.

Water from the two drainage subareas passes through the storm sewers into the last precast-concrete manhole before entering the recharge basin. The dead-storage space below the invert of the outflow pipe is sufficiently large to dissipate the energy of the inflow and establish subcritical flow before the water passes into the outflow pipe. Figure 3, a schematic view of a water-level profile through the manhole and the outlet pipe, shows the dead-storage space as well as the location of the water-level recorder in the manhole. The hydraulically steep slope of the outflow pipe from the manhole drops about 1 foot in 20 feet. Water flowing through the manhole at subcritical velocities and discharging into the outflow at supercritical velocities must pass through critical flow at the pipe entrance. Because of this fact, the entrance of the outflow pipe acts as a flow control and eliminates the need for an artificial control.

\section{THEORETICAL RATING CURVE}

The section of water in the plane of the pipe entrance, called the control section, is defined as the section where critical flow occurs as the discharge passes from subcritical to supercritical. Critical flow is defined as the condition for which the Froude number is equal to unity or, more commonly, the condition at which the specific energy is a minimum for a given discharge (Chow, 1959, p. 42). Critical depth $\left(d_{C}\right)$, the depth of a given flow when the specific energy is a minimum, occurs in the control section.

The following relationship describes the flow through the control section from subcritical (in the manhole) to supercritical flow (in the outflow pipe):

$$
Q=\sqrt{g \frac{A^{3}}{T}},
$$

where $Q$ is inflow, in cubic feet per second; $A$ and $T$ are the cross-sectional area and the water-surface width in the control section, in square feet and feet, respectively; and $g$ is acceleration due to gravity, in feet per second per second. Because $A$ and $T$ describe the configuration of the cross section as a function of critical depth $\left(d_{C}\right)$, equation 1 can be solved for the inflow, $Q$, at various depths at the control section.

Measurements of stage are made at the water-level recorder near the wall opposite the outflow pipe in the manhole (fig. $3)$. Therefore, critical depth $\left(d_{C}\right)$ at the entrance to the pipe must be adjusted to reflect the flow depth $\left(d_{R}\right)$ at the recorder location. This adjustment was made by using the principle of conservation of energy (more commonly, Bernoulli's equation; Chow, 1959, p. 40):

$$
d_{C}+\frac{Q^{2}}{2 g A^{2} C}+Z_{C}+h_{L}=d_{R}+\frac{Q^{2}}{2 g A_{R}^{2}}+Z_{R}
$$

where subscript $C$ refers to the control section and subscript $R$ refers to a section at the water-level recorder; $d$ is the depth of flow, in feet; $Z$ is the altitude of the bottom of the channel, in feet; $h_{L}$ is the energy loss from section $R$ to $C$, in feet; and $Q$, $A$, and $g$ have been defined previously. (Refer to figure 3 for the location of sections $R$ and $C$.) Energy losses, $h_{L}$, are assumed negligible within this short reach. Under steady flow conditions and using values of $d_{C}, A_{C}$, and $Q$ developed from equation 1 , the author solved equation 2 for values of $d_{R}$ and established a stage-inflow relationship for flow in the manhole. This relationship is shown as the solid line in figure 4 .

\section{METHODS USED TO FIELD RATE THE FLOW SYSTEM}

Field measurements verified the stage-inflow relationship shown in figure 4. A rectangular channel 18 inches wide and 10 feet long was built on the apron of the outlet pipe in the recharge basin. This flume is shown in figure 5 . A $2 \times 4$-inch wooden board nailed to the flume outlet served as a weir to impound water and establish subcritical flow in the channel.

Public-supply water from nearby fire hydrants was used to rate the system. The maximum discharge available from two fire hydrants was about 1.7 cfs (cubic feet per second) or about $770 \mathrm{gpm}$ (gallons per minute) as determined by volumetric measurement. This flow created a stage of 0.56 foot at the water-level recorder.

A series of calibration tests were run to determine inflow and corresponding stage. Three methods of flow measurements were used: (1) Current-meter measurements, (2) volumetric measurements, and (3) critical-flow measurements. Currentmeter measurements were made by using a pygmy current meter and streamflow measuring procedures described by Corbett and others (1962). Volumetric measurements were made by recording the time required to fill a 5.5-cubic-foot rectangular container. Critical depth was measured above the 


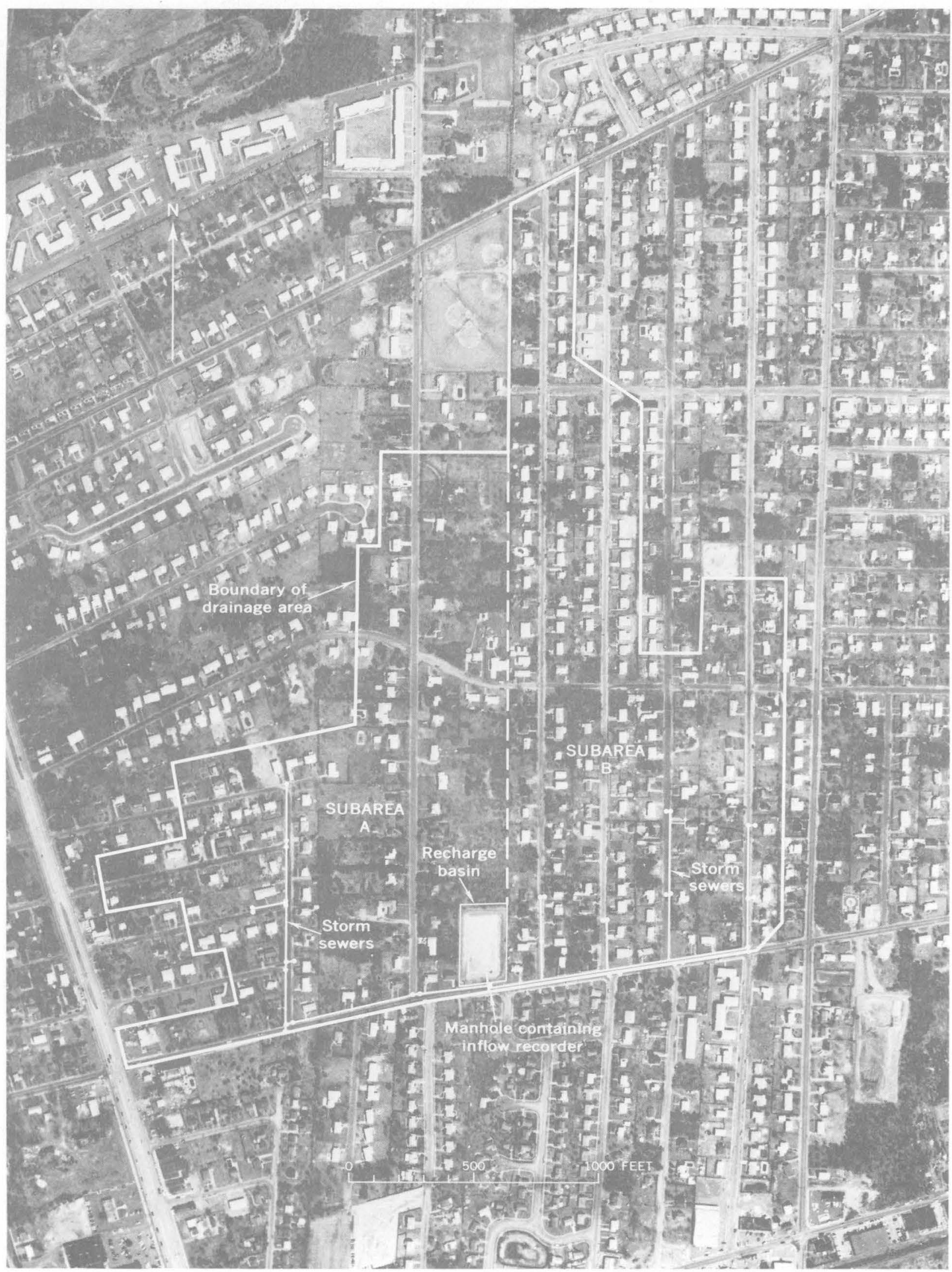

Figure 2.-Aerial view of Deer Park recharge basin and its drainage area. 


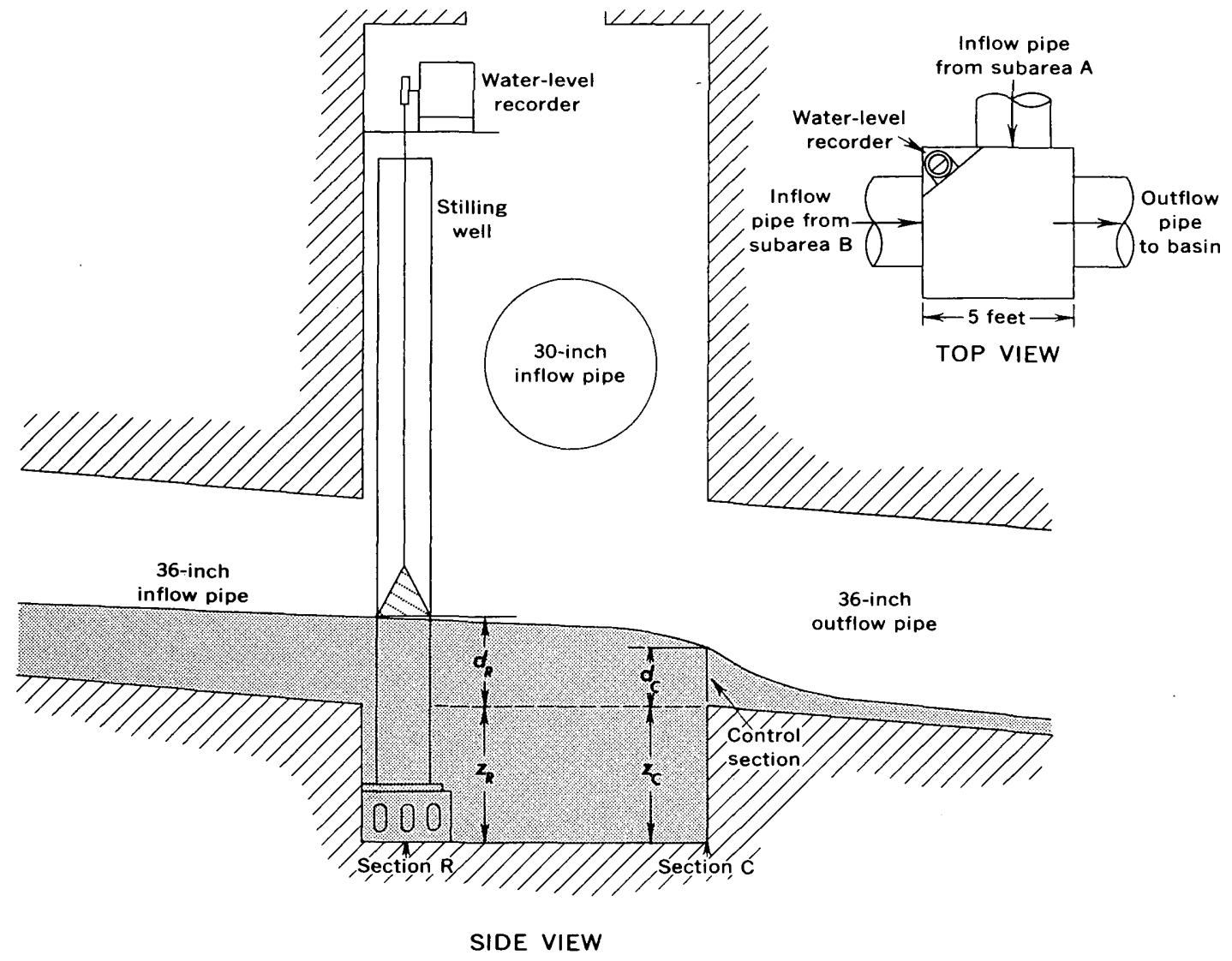

Figure 3.-Diagram showing the water-level profile in manhole and pipes and the water-level recorder.

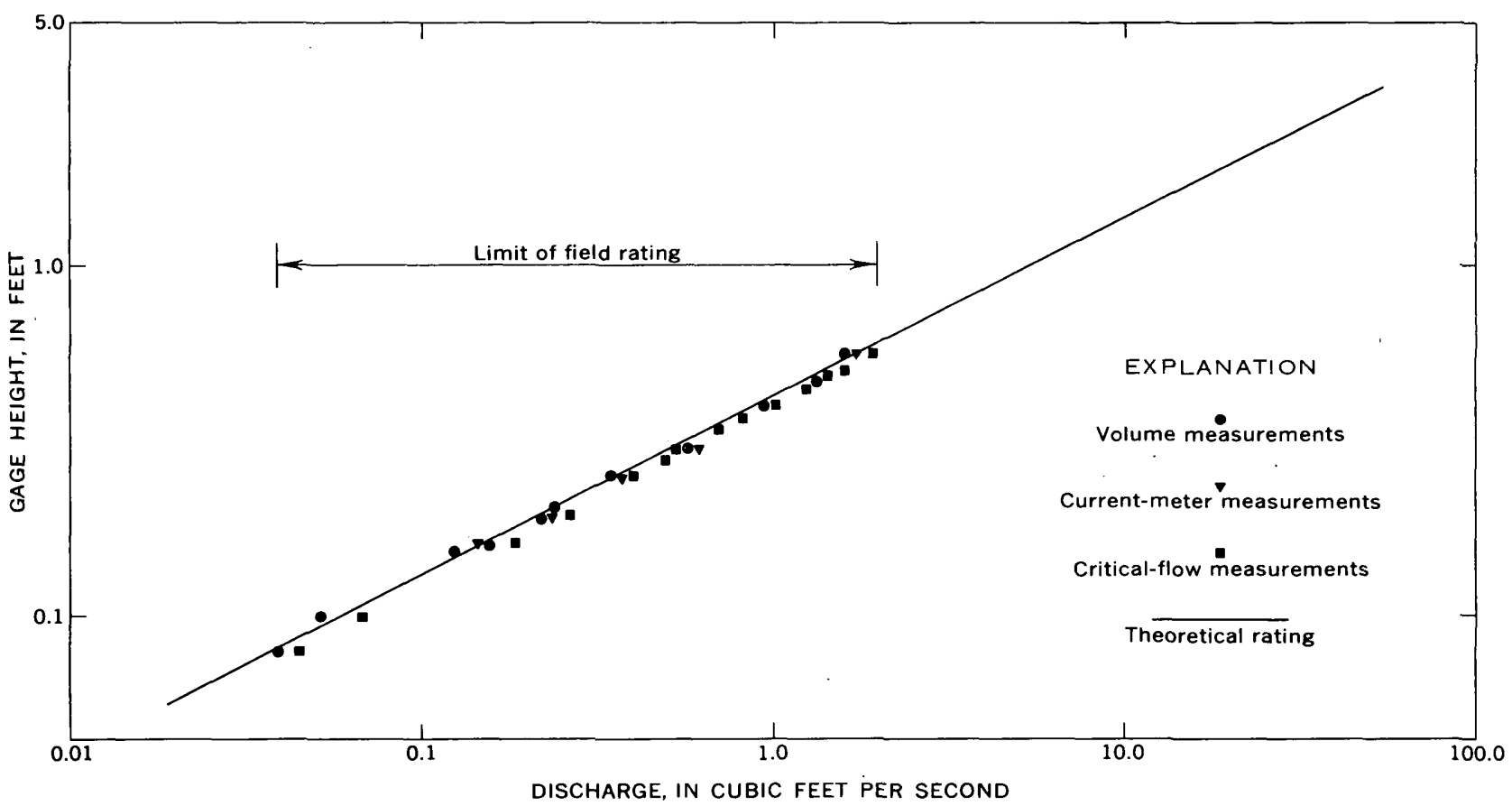

Figure 4.-Rating curve developed for Deer Park recharge basin. 


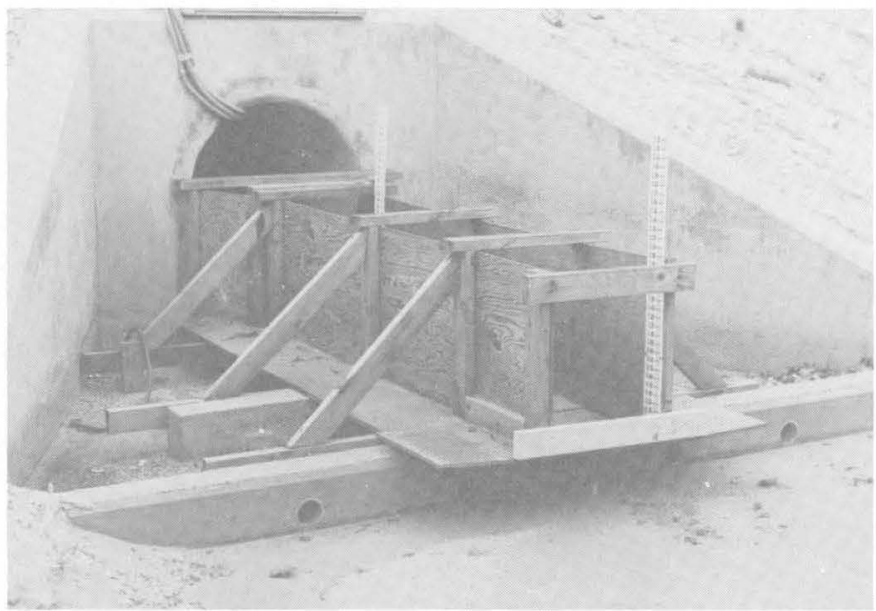

Figure 5.-Flume used to field rate flow into Deer Park recharge basin.

weir at the outlet of the flume and was used in equation 1 to compute inflow. Each field-determined value of inflow and corresponding stage were plotted on figure 4.

The nearly identical slopes of the two rating curves indicate that field conditions approach those conditions assumed by the theoretical relationship and expressed by equation 2 . Because the curves are in close agreement, instantaneous discharges that exceed the field rating can be evaluated confidently by using the theoretical rating curve. For practical purposes, the rating curve was extended to about $50-60 \mathrm{cfs}$, corresponding to a gage height of 3.5-4 feet at the recorder. Extending the rating curve farther is unwarranted except for hurricane conditions.

Low-flow sensitivity, which was initially considered secondary in importance to reliable and continuous inflow measurements at Deer Park, has proven adequate. For example, a flow of $1 \mathrm{cfs}$ creates a stage measurement at the recorder of 0.40 foot. An equivalent flow at Westbury and Syosset creates a stage of 0.74 and 0.82 foot, respectively. Flows as small as $0.01 \mathrm{cfs}$ can be measured easily at Deer Park. This precision is similar to that attained at the other basins.

\section{SUMMARY}

From March to December 1970, measurements of the inflow from 17 of 27 storms at the Westbury recharge basin and 16 of 28 storms at the Syosset basin were affected by debris interference at some time throughout the inflow event. Interference usually occurred during recession when velocities were not large enough to carry debris over the weirs. The flow-measuring equipment at these basins required considerable maintenance.

At the same time, the equipment at the Deer Park basin required maintenance only to keep the sediment buildup in the dead storage to a minimum, and the equipment has operated successfully during 34 of 36 storms. No data were obtained during two storm-caused failures of the recorder.

The close agreement of theoretical and field rating curves and consistent and reliable operation of the inflow recorder make the flow-monitoring scheme developed at the Deer Park recharge basin far superior to the schemes developed at the Westbury and Syosset recharge basins.

\section{REFERENCES}

Chow, V. T., 1959, Open-channel hydraulies: New York, McGraw-Hill Book Co., 680 p.

Corbett, D. M., and others, 1962, Stream-gaging procedure-A manual describing methods and practices of the Geological Survey: U.S. Geol. Survey Water-Supply Paper 888, 245 p.

Seaburn, G. E., 1970, Preliminary results of hydrologic studies at two recharge basins on Long Island, N.Y.: U.S. Geol. Survey Prof. Paper 627-C, 17 p., 15 figs. 



\section{SUBJECT INDEX}

[For major headings such as "Economic geology," "Geochemistry," "Ground water," see under State names or refer to table of contents]

\section{A}

Age determinations, calc-alkalic plutons, Washington $\ldots . .$. lunar mare materials ......... plutonic rocks, Alaska ........ Santander massif, Colombia . . tonalite-granodiorite plutons, Washington .........

Alaska, barite, Seward Peninsula ... glacial geology, Ray Mountains ground water, southeastern

part . . . . . 198,202 petrology, St. Lawrence Island

Allegheny Group, Pennsylvania, paleocurrent studies ....

Analog techniques, use in coastal ground-water flow study .

Analyses. See specific types: Chemical, Flame photometric, $X$-ray diffraction, X-ray fluorescence.

Antarctica, mineralogy, central part Antelope Valley Limestone, California and Nevada, paleontology.......$\ldots \ldots$.

Apollo 11 and 12 landing sites, comparison of materials .

Appalachian region, systematic pattern of Triassic dikes ....

Aquifers, coastal, electric-analog studies ............ contamination, Long Island, N.Y. ........... correlation of hydraulic diffusivity and base flow ..... fractured bedrock, Annette Island, Alaska .........

Arizona, mineralogy, Mohave County ............

Atomic powerplant, computation of reaeration coefficients in nearby estuary .......

\section{B}

Barite deposit, Seward Peninsula, Alaska .............

Base flow, as indicator of aquifer characteristics .........

Beach deposits, as source of ground water, Annette Island, Alaska .............

Beckler Peak stock, Washington, age determinations ........

Bedrock, as source of ground water, Annette Island, Alaska . .

\begin{abstract}
Page
\end{abstract}
D34

138

68

44

39

1

122

68

115

206
Bell Aerosystems shipborne gravimeter, comparison with LaCoste-Romberg gravimeter ............

Brazil, economic geology, Tocantins complex ............

Brevard fault zone, southeastern United States, areal geology $\ldots \ldots \ldots \ldots \ldots$.

\section{C}

California, paleontology, eastern part .............

Carter Caves Sandstone, Kentucky, stratigraphy..$\ldots \ldots \ldots$

Cenozoic, Washington, geochronology $\ldots \ldots \ldots \ldots \ldots$.

See also Quaternary, Tertiary.

Chemical analyses, ground water, Louisiana ...........

pallasite, Antarctica ........

Chicot aquifer, Louisiana, quality of water ..............

Chromitite, Brazil, economic potential..$\ldots \ldots \ldots \ldots$.

Colombia, geochronology, Santander massif ........

Colorado, economic geology, eastern Elk Mountains ........

oil shale, northwestern part ... structural geology, Eagle basin

Computer applications, development of solar position diagrams

Conemaugh Formation, Pennsylvania, paleocurrent studies

Connecticut, estuarine studies, Haddam Neck ...........

Pleistocene geology, northwestern part ............

Copper, disseminated, eastern Elk Mountains, Colo. ......

Cretaceous, Alaska, petrology .....

Washington, geochronology ..

Cyprus, isotope studies, southern part $\ldots \ldots \ldots \ldots \ldots$

\section{D}

Delaware, ground water-surface water relationships, coastal plain .........

Detergents, in water, southern Nassau County, N.Y. age

Dikes, systematic pattern, Appalach ian region ...........

Dissolved oxygen, computation of, in estuary ...........

Dolomite, well logging, Ohio water wells ..............

Doughnut Formation, Utah, stratigraphy...$\ldots \ldots \ldots$.

Drainage basins, correlation of base flow and hydraulic diffu. sivity $\ldots \ldots \ldots \ldots \ldots$

Drainage changes, preglacial Kentucky River, Kentucky . .

Dunes, growth and movement studies, New Mexico .......

Page

D84

108

\section{E}

Eagle basin, Colorado, structural geology ............

Echinoderms, Ordovician, California and Nevada ...........

Eocene, Colorado, oil shale .......

Equipment. See Instruments and equipment.

Estuary, Connecticut River, computation of reaeration coefficients .............

Evaporation, contributing effect on lake levels ...........

Fault, age determination, Washington .................

Fission-track ages, plutons, Washington ....................

Flame photometric analysis, igneous rocks, Cyprus ........

Flow, ground-water, simulation by analog techniques ...... storm sewer, method of rating See also Base flow.

\section{G}

Geochronology. See Age determinations.

Glacial deposits, Connecticut, river diversion by $\ldots \ldots \ldots$

Granodiorite, disseminated sulfides in, eastern Elk Mountains, Colo. ............. 


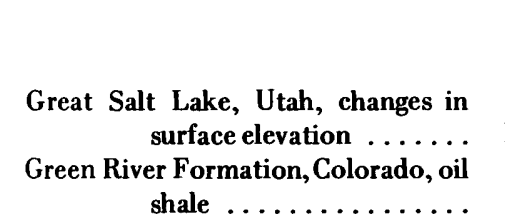

H

Harmotome, sodic, Arizona ..... Henderson Gneiss, North Carolina, petrology ..........

Housatonic River, Connecticut, glacial diversion ..........

Humbug Formation, Utah, stratigraphy $\ldots \ldots \ldots \ldots$.

Humic acid, effect of $\mathrm{pH}$ on association and dissociation ...

Hydraulic diffusivity, aquifers, correlation to base flow ......

\section{I}

Indiana, glacial geology, southeastern part ............

Instruments and equipment, computer-generated solar position diagrams ...... stable-platform sea gravimeters

Iron, in ground water, Louisiana ...

\section{K}

Kentucky, glacial geology, northeastern part ........... stratigraphy, northeastern part

\section{L}

LaCoste-Romberg shipborne gravimeter, comparison with Bell Aerosystems gravimeter .............

Lacustrine tuffs, Arizona, sodic harmotome in .........

Lakes. See Great Salt Lake.

Lockport Dolomite, Ohio, ground water .............

Long Island, N.Y., method of rating flow in storm sewers ....

Louisiana, quality of water, southwestern part .........

Lunar mare materials, from various sites, comparison .....

\section{M}

Mare materials, from various sites on moon, comparison .....

Mesozoic. See Cretaceous, Jurassic, Triassic.

Meteorite, Antarctica, mineralogy . .

Methods and techniques, computation of reaeration coeffi-

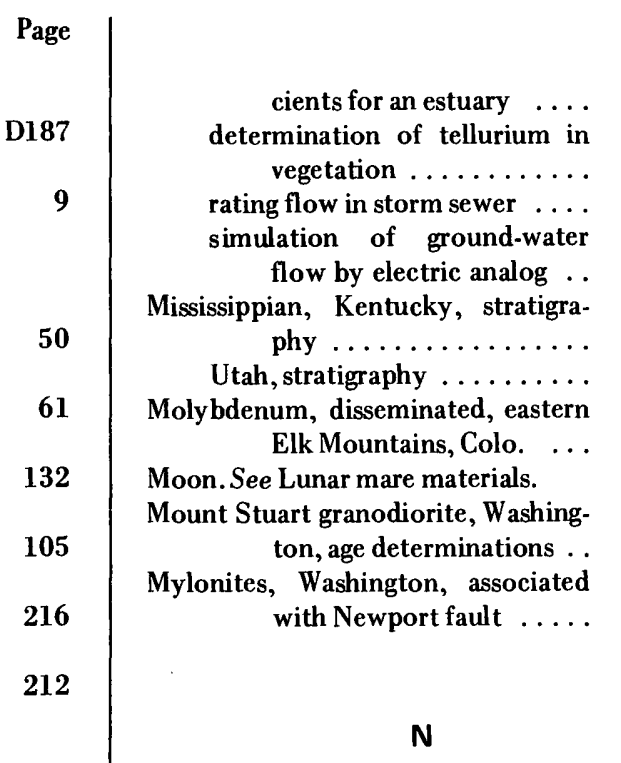

Neutron well log, use in estimating formation porosity .....

Nevada, paleontology, western part . New Mexico, sedimentation, White Sands National Monument

New York, hydrologic techniques, Long Island .......... quality of water, southern Nassau County ...........

Newport fault, northeastern Washington .............

Nickel-iron, in pallasite from Antarctica ..............

North Carolina, petrology, western part $\ldots \ldots \ldots \ldots \ldots$

\section{o}

Ohio, ground water, northwestern part $\ldots \ldots \ldots \ldots \ldots$

Oil shale, assays of, Colorado ......

Olivine, in pallasite from Antarctica

Ordovician, California and Nevada, paleontology ........

Oxidation potential, relation to iron in ground water ........

Oxygen, dissolved, computation of, in estuary $\ldots \ldots \ldots \ldots$

\section{$\mathbf{P}$}

Paleocurrent studies, Allegheny and Conemaugh Formations, Pennsylvania .........

Paleozoic, North Carolina, petrology See also Mississippian, Ordovician, Pennsylvanian, Permian, Silurian.

Pallasite, Antarctica, mineralogy ... Pennsylvania, quality of water, south-central part ..... sedimentology, central part ...
Pennsylvanian, Pennsylvania, paleocurrent studies ....... D115

Utah, stratigraphy ....... 105

Permian, Colorado, structural geology ...............

$\mathrm{pH}$, effect on association and dissociation of a humic acid ....

Phosphate, in water, southern Nassau County, N.Y. ........

Photography, aerial, use of solar position diagrams ......

Placer deposits, Brazil, potential platinum in ...........

Platinum, Brazil, potential in chromitite $\ldots \ldots \ldots \ldots \ldots$

Pleistocene, Alaska, glacial geology . Connecticut, river diversion by glacial deposits .......

Kentucky-Indiana, glacial geology .............

Louisiana, quality of water ...

Pliocene, Arizona, mineralogy . . . . .

Plutonic rocks, age determinations, Alaska ............. petrology, North Carolina ....

Potassium-argon age, granitic plutonic rocks, Alaska .....

plutons, Washington ...... 34, 39

Santander massif, Colombia ..

Precambrian, Alaska, barite deposit .

Puerto Rico, ground water, coast near Ponce ..........
Quaternary.See Pleistocene.

\section{$\mathbf{R}$}

Ray Mountains, Alaska, glacial geology $\ldots \ldots \ldots \ldots \ldots$

Reaeration coefficients, in an estuary, computation .....

Resistivity well log, use in estimating water quality $\ldots \ldots \ldots$.

Round Valley Limestone, Utah, stratigraphy $\ldots \ldots \ldots \ldots$.

Rubidium-strontium age, Santander massif, Colombia .....

190

105

\section{S}

Sand dunes, growth and movement studies, New Mexico ....

Santander massif, Colombia, geochronology ..........

Shale oil, potential yields of, Colorado ..............

Silurian, Ohio, ground water ...... Sinuk River barite deposit, Alaska, geochemistry ........

Skykomish-Stillaguamish areas, Washington, age determinations ............ 
Sodium humate, effect of $\mathrm{pH}$ on association and dissociation ..............

Solar position diagrams, computergenerated ...........

South America. See Brazil, Colombia.

Specific conductance, relation to ground-water levels in wells ...............

$\mathrm{Sr}^{87} / \mathrm{Sr}^{86}$, determined for Troodos massif, Cyprus ........

Storm sewers, flow measurements in

Stream diversion, Connecticut, by glacial deposits ........

Streams, contamination, Long Island, N.Y. ...........

Sulfides, disseminated, eastern Elk Mountains, Colo. ......

Sun. See Solar position diagrams.

Tellurium, determination in vegetation
V

Vegetation, determination of tellurium in .............

Tertiary, Washington, geochronology ............... Washington, probable date of Newport fault ......... See also Eocene, Pliocene.

Triassic, eastern United States, areal geology .............

Troodos massif, Cyprus, isotope studies .............

Tuffs, lacustrine, sodic harmotone in

\section{U}

Ultramafic rock, Brazil, potential platinum in ..........

Utah, changes in surface elevation, Great Salt Lake ........ stratigraphy, rorthern part ... of Great Salt Lake ......

Well logging, resistivity and neutron, Ohio water wells .......

Wells Formation, Utah, stratigraphy White Sands National Monument, N. Mex., sand-dune studies .

Wissahickon Formation, Pennsylvania, quality of water ...

Page

\section{W}

Wasatch Formation, Colorado, oil shale $\ldots \ldots \ldots \ldots \ldots$

D9

\section{$\mathbf{x}$}

$\mathrm{X}$-ray diffraction analysis, pallasite, Antarctica ...........

$\mathrm{X}$-ray fluoresence analysis, igneous rocks, Cyprus ........ 


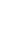




\section{AUTHOR INDEX}

A

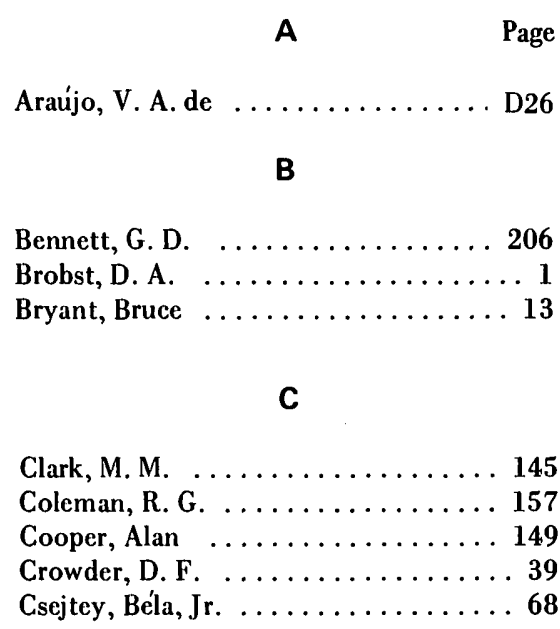

D

Douglass, J. R. 108

E

Engels, J. C. 34,39

Englund, K. J. 99

\section{$\mathbf{F}$}

Fayard, L. D. 182

Ford, A. B.

Frecman, V. L.

56 80

\section{G}

Giusti, E. V.

Goldsmith, Richard
206

44

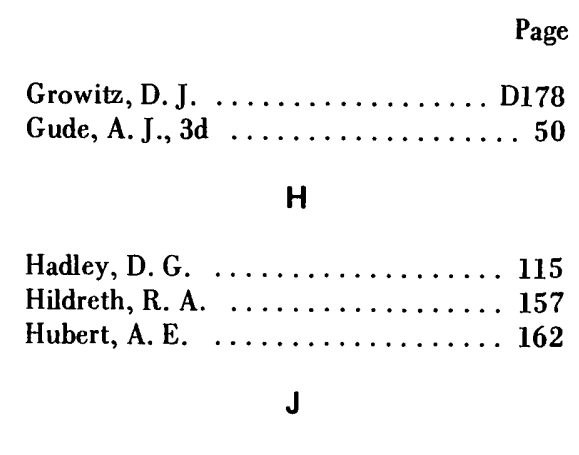

Johnston, R. H. . . . . . . . 212

\section{K}

King, P. B. . . . . . . . . . . 8 84

Koch, Ellis

171

$\mathbf{L}$

Lloyd, O. B., Jr. 178

\section{M}

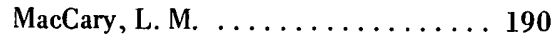

McKay, E.J. ................ 9

McKee, E. D. ............. 108

Marcher, M. V. ......... 198, 202

Marvin, R. F. . ............ 44

Mehnert, H. H. . . . . . . . . . 44

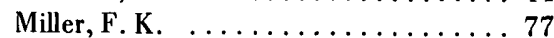

Miller, T. P. . . . . . . . . . . . 68

Motta, Jorge $\ldots \ldots \ldots \ldots \ldots \ldots \ldots 26$

Mullens, T. E. ............. 105

\section{$\mathbf{N}$}

Nelson, A. E.

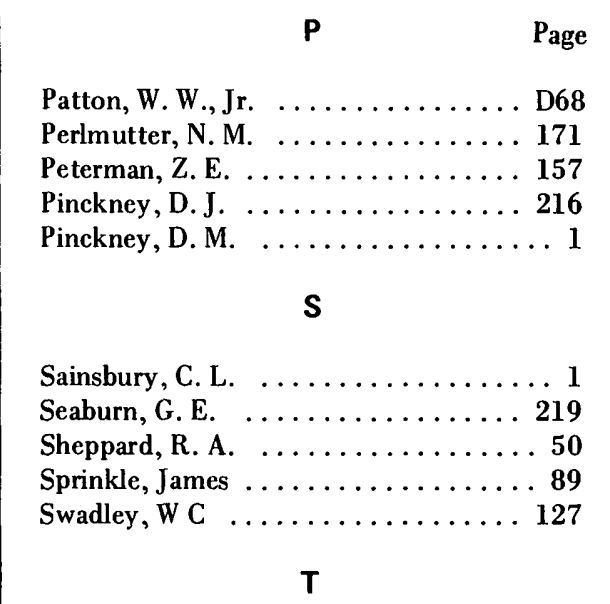

Tabor, R.W. . . .

Trask, N. J. . . . . . . . . . 138

\section{V}

von Huene, Roland 149

\section{W}

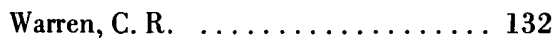

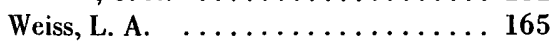

Wershaw, R. L. . . . . . . . . 216

Whitaker, G. L. . . . . . . . . . 187

White, R. W. . . . . . . . . . 26

Windolph, J. F., Jr. ........... 99

\section{$\mathbf{Y}$}

Yeats, R. S. . . . . . . . . . . . 34

Yeend, Warren $\ldots \ldots \ldots \ldots \ldots \ldots \ldots 122$ 